Mariana Capela Lombardi Moreto

\title{
O PRECEDENTE JUdicial no Sistema Processual Brasileiro
}

\author{
TESE DE DOUTORADO \\ Orientador: Professor Titular José Ignacio Botelho de Mesquita
}

Faculdade de Direito da Universidade de São Paulo Departamento de Direito Processual Civil 
Mariana Capela Lombardi Moreto

\section{O PRECEDENTE JUdicial no Sistema Processual Brasileiro}

Tese de Doutorado apresentada ao Departamento de Direito Processual Civil da Faculdade de Direito da Universidade de São Paulo, como exigência parcial para a obtenção do título de Doutor no Curso de Pós-Gradução Stricto Sensu, sob orientação do Professor Titular José Ignacio Botelho de Mesquita. 
BANCA EXAMINADORA: 
Ao Junior, теи amor. 


\section{AGRADECIMENTOS}

Ao Prof. José Ignacio Botelho de Mesquita, agradeço pelas lições de vida e de direito; pela inestimável orientação ao longo do mestrado e do doutorado; pelo exemplo e incentivo, sem os quais eu não teria chegado tão longe; pelos reiterados votos de confiança; e, acima de tudo, pela amizade. Aos Profs. WALter PIVA Rodrigues e SusAnA HENRIQUES DA COSTA, agradeço pelas lições de processo civil, iniciadas há uma década, ainda nos bancos da graduação, e pelas importantes e cuidadosas observações feitas durante o exame de qualificação, sem as quais certamente este trabalho seria menos rico (espero ter atendido às expectativas!). Aos meus pais, FÁtima MARTins CAPELA LOMBARDi e ANTONIO VICENTE LOMBARDI, agradeço pelo apoio incondicional, desde sempre. À minha irmã, GABRIELA CAPELA LOMBARDI, agradeço pelo laço inquebrantável que nos une. Ao meu marido, José RoberTo MORETO JunIOR, agradeço por estar ao meu lado nos momentos de felicidade e de tormento, para sempre. Aos colegas e amigos IARA Ferfoglia Gomes Dias Vilardi e Rodolfo da Costa Manso Real Amadeo, agradeço pelas dicas na reta final do trabalho e pelas indicações bibliográficas, que trouxeram novas luzes a esta tese. À FACULDADE DE DIREITO DO LARGO DE SÃO FRANCISCO, agradeço pelos doze anos de acolhida e por me permitir realizar mais este sonho. Obrigada! 
"O direito é um todo harmônico que há de ser apreciado em seu conjunto." (in GUIMARÃES, Mário, O juiz e a função jurisdicional, 1958, p. 326) 


\section{$\underline{\text { ÍNDICE }}$}

IMPORTÂNCIA E DELIMITAÇÃO DO TEMA............................................ 12

1. INTRODUÇÃ

1.1 Definição de precedente judicial e de jurisprudência ............................................. 19

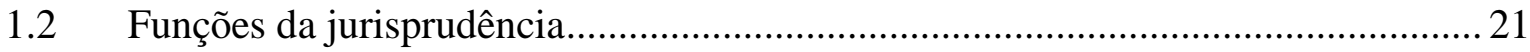

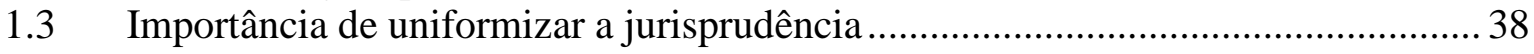

1.3.1 Garantia de maior isonomia e segurança jurídica................................... 38

1.3.2 Diminuição do tempo do litígio (duração razoável do processo?) ............ 47

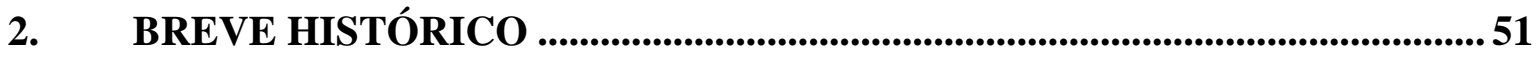

2.1 Façanhas e sentenças da Cúria Régia................................................................. 51

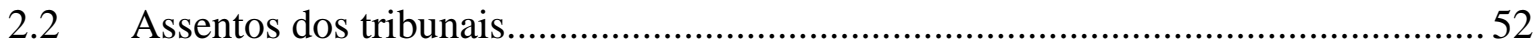

2.2.1 Assentos do Tribunal da Relação do Rio de Janeiro e da Casa da

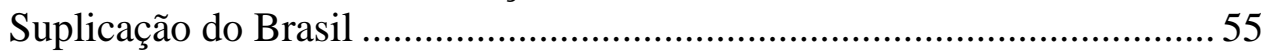

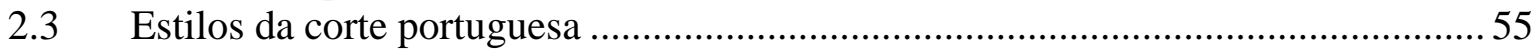

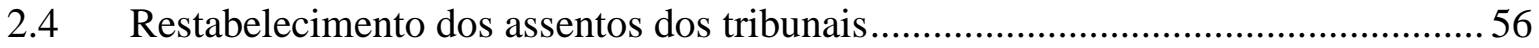

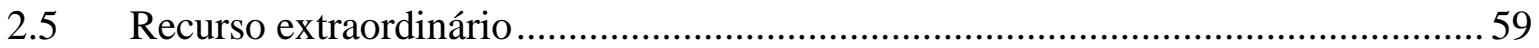

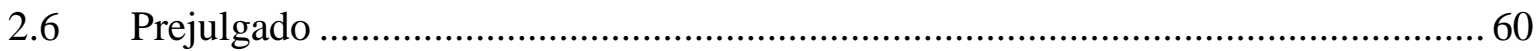

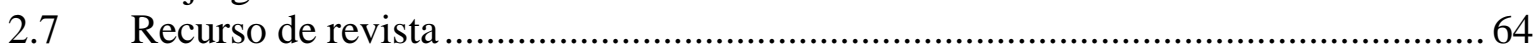

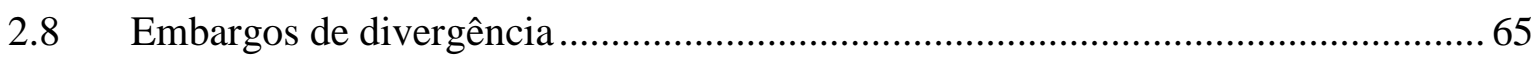

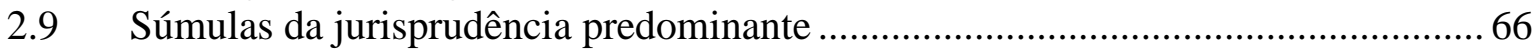

2.10 Representação para interpretação de lei ou ato normativo .................................... 70

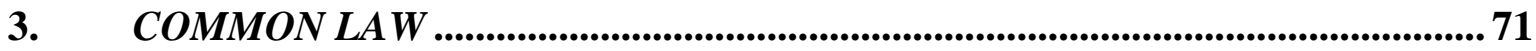

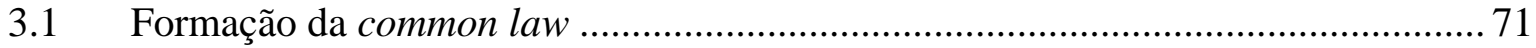

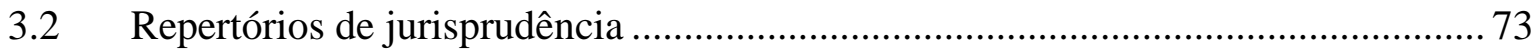

3.3 Eficácia vinculante do precedente judicial e teoria do stare decisis......................... 75

3.4 Exceções à teoria do stare decisis...................................................................... 78

4. CRESCENTE VALORIZAÇÃO DO PRECEDENTE JUDICIAL .................. 81

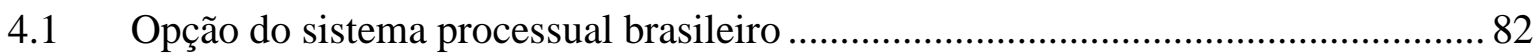

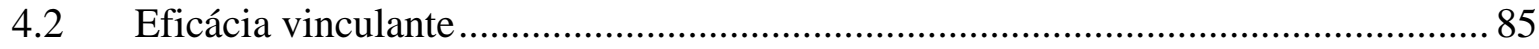

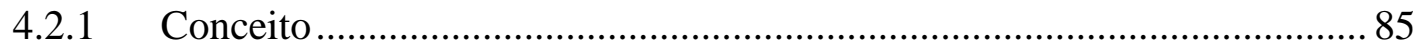

4.2.2 Controle de constitucionalidade concentrado ......................................... 89

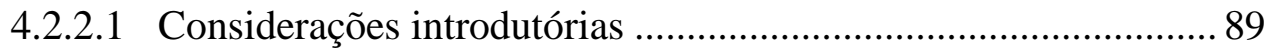

4.2.2.2 Breve histórico e regulamentação.............................................. 91

4.2.2.3 Competência e quórum para o julgamento ................................. 93

4.2.2.4 Medida cautelar .................................................................... 94

4.2.2.5 Eficácia erga omnes, efeitos vinculantes e irrecorribilidade .......95 95

4.2.2.6 Intervenção de terceiros ........................................................ 100

4.2.2.7 Modulação dos efeitos .......................................................... 100

4.2.2.8 A denominada "coisa julgada inconstitucional"....................... 101

4.2.2.9 Percepções gerais................................................................. 102 


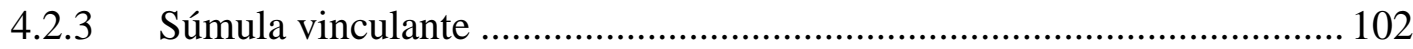

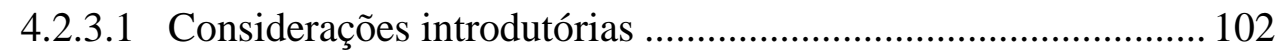

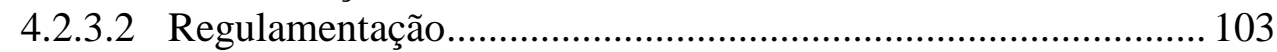

4.2.3.3 Legitimação e intervenção de terceiros .................................... 106

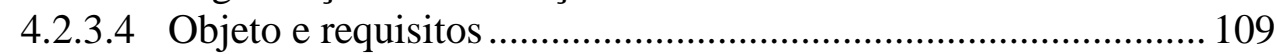

4.2.3.5 Procedimento de elaboração, revisão e cancelamento.................. 113

4.2.3.6 Mecanismos de impugnação........................................................ 117

4.2.3.7 Efeitos e modulação dos efeitos ............................................. 123

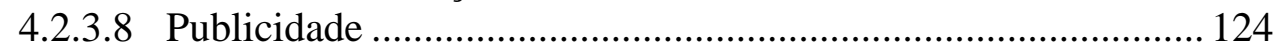

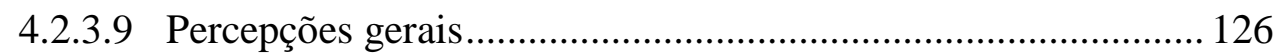

4.2.3.10 Respostas às críticas ............................................................. 128

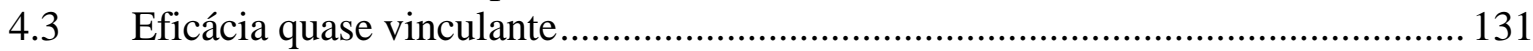

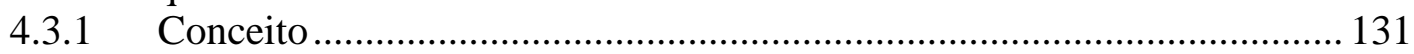

4.3.2 Ampliação dos poderes do relator …………………………………...... 133

4.3.2.1 Art. 38, da Lei $n^{\circ} 8.038 / 1990$................................................ 135

4.3.2.2 Art. 557, caput e $\S 1^{\circ}$, do CPC.................................................. 137

4.3.2.3 Art. 544, § 4 , II, "b" e "c", do CPC......................................... 147

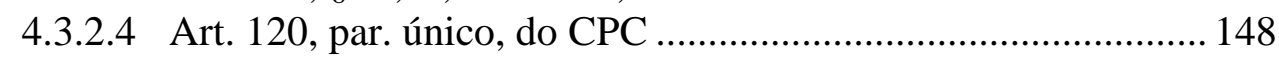

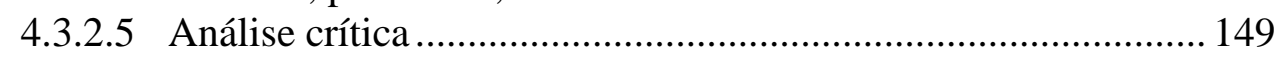

4.3.3 Ampliação dos poderes do juiz de primeiro grau ...................................... 154

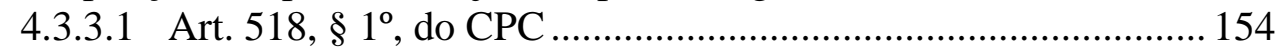

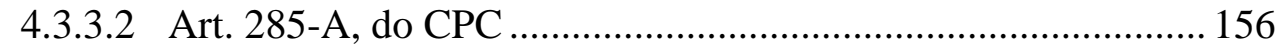

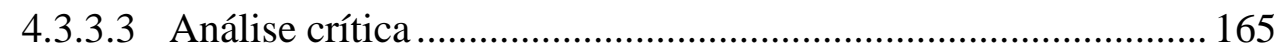

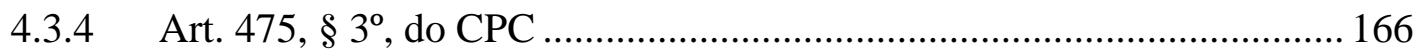

4.3.5 Art. 481, par. único, do CPC ……………………………………........ 167

4.3.6 Recurso extraordinário e repercussão geral ............................................... 169

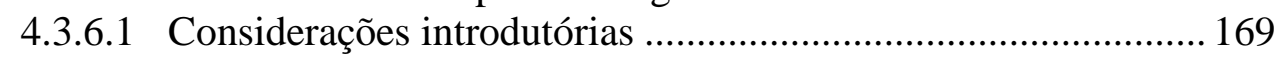

4.3.6.2 Regulamentação....................................................................... 173

4.3.6.3 Conceito, presunção legal e demonstração da repercussão

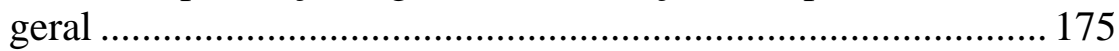

4.3.6.4 Competência para a apreciação da repercussão geral.................. 178

4.3.6.5 Momento e procedimento para a apreciação da repercussão

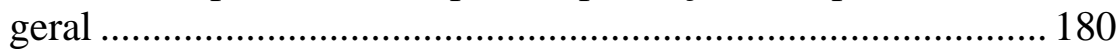

4.3.6.6 Irrecorribilidade da decisão preliminar e efeitos para o futuro . 182

4.3.6.7 Multiplicidade de recursos sobre a mesma controvérsia ............ 183

4.3.6.8 Intervenção de terceiros............................................................ 187

4.3.6.9 Outras questões relevantes...................................................... 192

4.3.7 Recurso especial e recursos repetitivos ................................................... 194

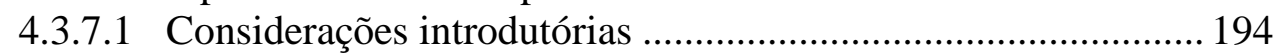

4.3.7.2 Regulamentação...................................................................... 195

4.3.7.3 Conceito ...................................................................................... 197

4.3.7.4 Seleção do recurso paradigma e suspensão dos demais

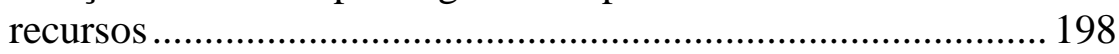

4.3.7.5 Competência e momento para o julgamento do recurso

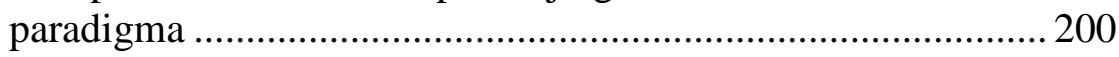

4.3.7.6 Efeitos sobre os recursos sobrestados.......................................201

4.3.7.7 Intervenção de terceiros.......................................................... 203

4.3.7.8 Outras questões relevantes.................................................... 204

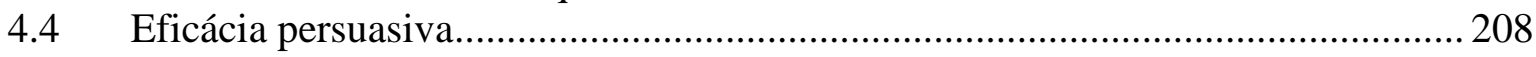

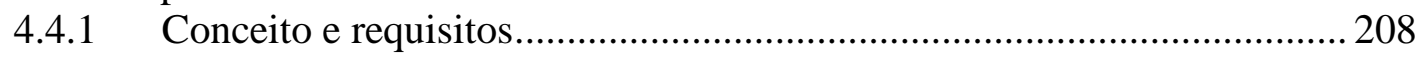




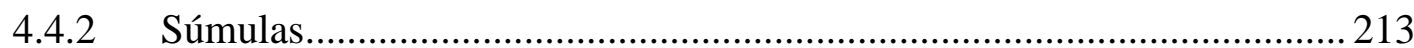

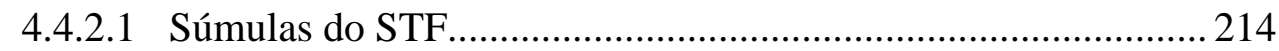

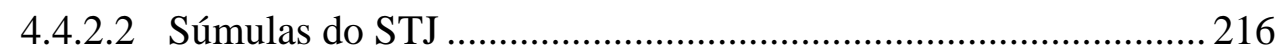

4.5 Adequada utilização dos precedentes judiciais e da jurisprudência: inspiração nas técnicas oriundas da common law ............................................................... 220

5. OUTROS MEIOS DE UNIFORMIZAÇÃO DE JURISPRUDÊNCIA .......... 226

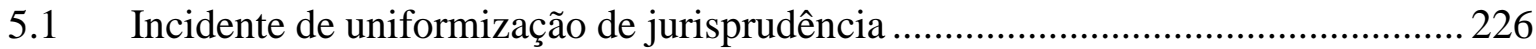

5.2 Incidente de assunção de competência .............................................................. 234

5.2.1 Confronto com o incidente de uniformização de jurisprudência.............. 237

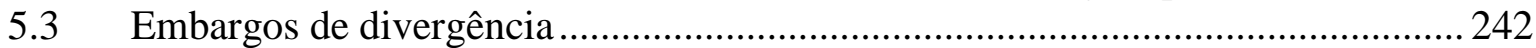

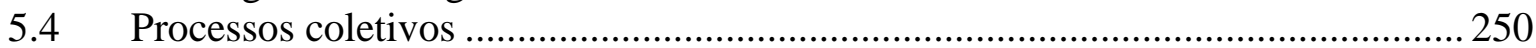

5.5 O problema dos Juizados Especiais Estaduais e Federais .................................. 253

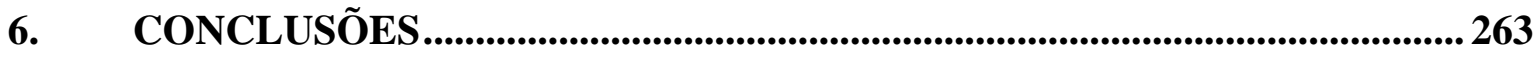

Bibliografia $\quad 273$

Resumo $\quad 306$

Abstract $\quad 307$

Riassunto $\quad 308$ 


\section{ABREVIATURAS}

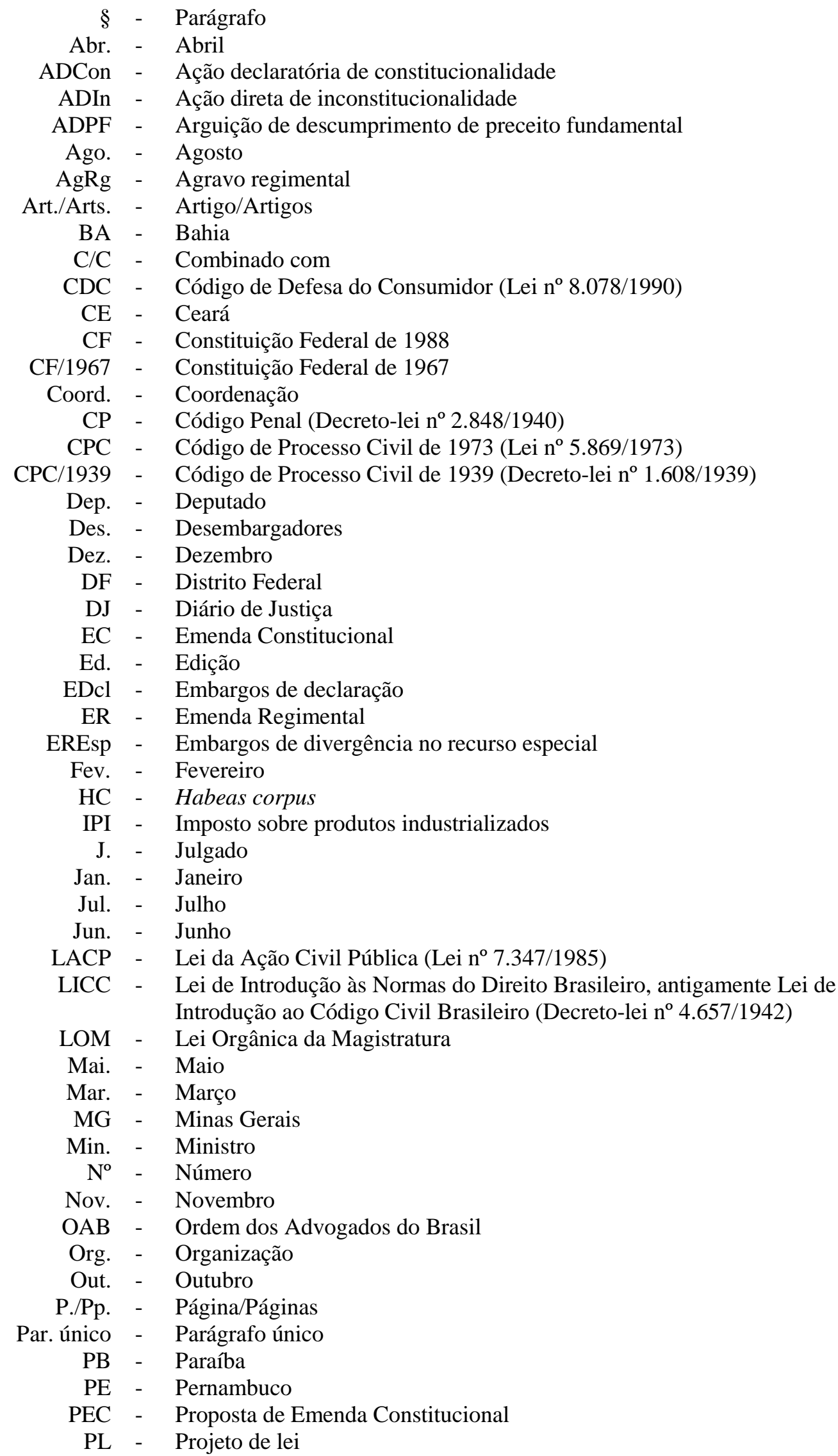


PR - Paraná

Prof./Profs. - Professor/Professores

PSV - Proposta de Súmula Vinculante

QO - Questão de ordem

RC - Reclamação Constitucional

Rcl - Reclamação

RE - Recurso extraordinário

Rel. - Relator

Resol. - Resolução

REsp - Recurso especial

Rev. - Revisão

RITJSP - Regimento Interno do Tribunal de Justiça do Estado de São Paulo

RISTF - Regimento Interno do Supremo Tribunal Federal, atualizado até a ER n ${ }^{\circ}$ $46 / 2011$

RISTJ - Regimento Interno do Superior Tribunal de Justiça, atualizado até a ER n ${ }^{\circ}$ $13 / 2011$

RJ - Rio de Janeiro

RS - Rio Grande do Sul

Set. - Setembro

Ss. - Seguintes

STF - Supremo Tribunal Federal

STJ - Superior Tribunal de Justiça

TJSP - Tribunal de Justiça do Estado de São Paulo

Trad. ital. - Tradução para o italiano

Trad. port. - Tradução para o português

V. - Vide

Vol. - Volume

Vs. - Versus 


\section{IMPORTÂNCIA E DELIMITAÇÃO DO TEMA}

A discussão acerca do papel que o precedente judicial exerce em determinado sistema jurídico é tema de grande relevância prática e científica no ramo do direito processual, já que o precedente constitui, desde há muito, uma das fontes de direito $^{1}$, ao lado da lei, do costume, da doutrina e dos princípios gerais. Nessa medida, hoje dificilmente se ignora a importância fundamental do precedente judicial na experiência jurídica, qualquer que seja o sistema em foco ${ }^{2}$.

Para CRUZ E TUCCI, nos dias atuais, "a produção jurisprudencial, antecipando-se, em muitas situações, à própria lei, tem granjeado relevância vital como fator de complementação e aperfeiçoamento das mais diversificadas legislações"3. A afirmativa é bastante precisa: frequentemente a jurisprudência assume posição de vanguarda, antecipando-se à norma positivada ${ }^{4}$. É o caso da correção monetária dos ${ }^{1}$ Para Ross, "por 'fontes do direito', (...) entender-se-á o conjunto de fatores ou elementos que exerçam
influência na formulação do juiz da regra na qual ele funda sua decisão; acresça-se que esta influência pode
variar - desde aquelas fontes que conferem ao juiz uma norma jurídica já elaborada que simplesmente tem
que aceitar até aquelas outras que lhe oferecem nada mais do que idéias e inspiração para ele mesmo (o
juiz) formular a regra que necessita" (in Ross, Alf, Direito e justiça, 2000, p. 103). LIMONGI FRANÇA critica
o termo "fontes de direito" ao se referir a lei, costume, doutrina etc., pois "não se trata propriamente de
fontes do direito, de fatôres que dão origem ao direito, mas, de modo menos impróprio, de meios técnicos, de
modos, de formas de cujo recurso, a autoridade constituída ou o próprio povo que aquela representa, em
reconhecendo a conveniência de certo princípio jurídico, lança mão para externá-lo, erigindo-o em regra de
direito" (in LIMONGI FRANÇA, Rubens, Jurisprudência - Seu caráter de forma de expressão de Direito, in
Repertório Enciclopédico do Direito Brasileiro, vol. 30, p. 274). V., acolhendo a teoria de LIMONGI FRANÇA,
VIGLIAR, José Marcelo Menezes, Uniformização de jurisprudência - Segurança jurídica e dever de
uniformizar, 2003, pp. 51 e ss. V., sobre o assunto, MusCARI, Marco Antonio Botto, Súmula vinculante,
1999, pp. 24/31. Não nos aprofundaremos nessa discussão devido aos estreitos limites deste trabalho.

${ }^{2}$ In TARUfFo, Michele, Precedente e giurisprudenza, in Rivista Trimestrale di Diritto e Procedura Civile, ano 61, $\mathrm{n}^{\circ} 3$, 2007, p. 709. V., no mesmo sentido, FERRO, Marcelo Roberto, A jurisprudência como forma de expressão de direito, in Revista de Direito Civil, Imobiliário, Agrário e Empresarial, n 51, 1990, p. 89.

${ }^{3}$ In CRUZ E TUCCI, José Rogério, Precedente judicial como fonte de direito, 2004, p. 28. No mesmo sentido, PEREIRA DOS SANTOS aponta que a jurisprudência prepara as reformas legislativas (in PEREIRA DOS SANTOS, Carlos Maximiliano, Hermenêutica e aplicação do direito, 2007, p. 146) e CARLIN afirma que, ao adaptar o texto da lei à realidade social, a jurisprudência serve "como uma nova proposta ou sugestão à reforma" (in CARLIN, Volnei Ivo, O papel do juiz na sociedade moderna, in Revista de Processo, $\mathrm{n}^{\circ}$ 45, 1987, p. 248). FERNANDEZ, por sua vez, explica que "el legislador demora en la sanción de leyes porque le parece que muchos hechos de la realidad social no están todavía maduros para darles protección jurídica, de modo que la ley generalmente llega tarde, cuando la costumbre, los usos sociales y la jurisprudencia superaron las necesidades no satisfechas por el legislador" (in FERNANDEZ, Alberto Vicente, Funcion creadora del juez, 1980, p. 42).

${ }^{4}$ ASCARELLI aborda o assunto nos seguintes termos: "Talvez a diferença entre direito legislado e sua aplicação nos tribunais seja particularmente acentuada em duas hipoteses. Quando a lei está em vigor ha muitos anos, é frequente o caso de a jurisprudência tê-la interpretado, integrando-a, modificando-a, até torna-la irreconhecivel. Deixando de parte o sistema inglês, baseado, como é sabido, em principios diferentes dos que dominam em outros países acerca do valor do precedente judicial, basta recordar a obra 
débitos oriundos de decisão judicial, que, mesmo antes da promulgação da lei que a determinou, já era admitida na prática pelos tribunais superiores ${ }^{5}$; o mesmo se diga sobre a trajetória dos direitos da concubina (reconhecimento à indenização previdenciária no caso de morte do segurado etc. $)^{6}$, entre tantos outros exemplos ${ }^{7}$.

Por vezes, o movimento inverso também ocorre: alguns institutos legais passam a ser desprezados pelos tribunais até perderem toda a sua imperatividade. É o que se passou, por exemplo, com a superação cultural do crime de adultério, finalmente excluído da redação do art. 1.521, do atual Código Civil ${ }^{8}$.

Via de regra, nos sistemas de common law, provenientes do direito inglês ${ }^{9}$, em que prevalece o direito casuístico, o precedente judicial assume função diferente daquela que exerce nos sistemas de civil law, provenientes da Europa continental, de tradição romano-germânica, em que predomina o direito codificado ${ }^{10}$. Nem por isso se pode dizer que o precedente judicial é pouco importante para os países de civil law, embora, sem dúvida, assuma papel muito mais central nos países de common law, onde os

da jurisprudência francesa sôbre o código napoleônico. É frequente, então, não só a conquista de novas soluções ou a elaboração de novos institutos, mas, tambem, a elaboração de novos principios gerais. A doutrina e a jurisprudência, nesses casos, preparam a nova legislação." (in ASCARELLI, Tullio, Problemas das sociedades anônimas e direito comparado, 1945, pp. 9/10). V., no mesmo sentido, TARUFFO, Michele, Institutional factors influencing precedents, in Interpreting precedents: a comparative study, 1997, pp. $456 / 457$.

${ }^{5}$ In AZEVEDo, Luiz Carlos de, Função da jurisprudência nos conflitos entre a lei natural e a lei positiva, in Revista Trimestral de Jurisprudência dos Estados, nº 34, 1985, p. 45.

${ }^{6}$ In CRUZ E TuCCI, José Rogério, Precedente judicial como fonte de direito, 2004, p. 288.

7 V., invocando a obra de RECASÈNS SICHES, em que são trazidos diversos exemplos de inovações substanciais impostas ao direito francês a partir de criações jurisprudenciais, CARVALHO, Ivan Lira de, Decisões vinculantes, in Revista Forense, vol. 343, 1998, pp. 520/521. V., citando vários outros exemplos ocorridos no Brasil, FAGUNDES, Miguel Seabra, Contribuição da jurisprudência à evolução do direito brasileiro, in Revista Forense, vol. 126, 1949, pp. 19/24 e MONTEIRO, Washington de Barros, Da jurisprudência, in Revista Forense, vol. 202, 1963, p. 374.

${ }^{8}$ In CRUZ E TuCCI, José Rogério, Precedente judicial como fonte de direito, 2004, p. 289.

${ }^{9}$ Segundo COUTURE, "rara fortuna ésta de los ingleses de poseer la mejor justicia del mundo. Y mucho más rara todavía, la de constituir un pueblo que tiene conciencia de poseerla." (in COUTURE, Eduardo Juan, La justicia inglesa, in Estudios de derecho procesal civil, tomo I, 1978, p. 145).

${ }^{10}$ Sobre a origem dos sistemas de common law e civil law, confira-se o ensinamento de SOARES: "No sentido amplo, Common Law quer referir-se por um lado ao sistema da família dos direitos que receberam a influência do direito da Inglaterra (onde vicejam os contrastes apontados entre Common Law $v$. Equity Law $e$ Common Law $v$. Statute Law) e de outro lado, o sistema da família dos direitos romano-germânicos, que igualmente se denominam Civil Law, conforme apelação que os doutrinadores daquele sistema costumam conferir a essa última." (in SOARES, Guido Fernando Silva, Common Law - Introdução ao direito dos EUA, 1999, p. 47). 
tribunais são os protagonistas na edição das normas gerais obrigatórias, que regulam e conferem equilíbrio às relações jurídicas ${ }^{11}$.

Nas exatas palavras de SOARES, “a questão é de método: enquanto no nosso sistema a primeira leitura do advogado e do juiz é a lei escrita e, subsidiariamente, a jurisprudência, na Common Law o caminho é inverso: primeiro os cases e, a partir da constatação de uma lacuna, vai-se à lei escrita" ${ }^{\prime 12}$. Essa feição mostra que, na common law, o case law é a regra, ao passo que o statute law é a exceção, de função meramente integrativa, secundária e complementar ${ }^{13}$.

Dadas essas premissas, nesse sistema, o precedente judicial tem, em regra, papel vinculante, coercitivo (binding authority). É o judge-made law, que se funda no princípio do stare decisis ${ }^{14}$, segundo o qual a decisão cria direito, impondo aos juízes o dever funcional de seguirem em casos sucessivos a orientação adotada anteriormente em caso análogo.

11 In LimONGI FRANÇA, Rubens, Jurisprudência - Seu caráter de forma de expressão de Direito, in Repertório Enciclopédico do Direito Brasileiro, vol. 30, p. 281. V., no mesmo sentido, BARTOLETTO, Luiz Carlos, Analogia, jurisprudência e princípios gerais do direito, in Revista de Direito Civil, Imobiliário, Agrário e Empresarial, no 72, 1995, p. 30 e FERRO, Marcelo Roberto, A jurisprudência como forma de expressão de direito, in Revista de Direito Civil, Imobiliário, Agrário e Empresarial, no 51, 1990, p. 89. ROSS assume posição um pouco mais cética e, em sentido contrário, afirma que "não é fácil decidir em que medida os juízes ingleses e norteamericanos - em harmonia com a doutrina da 'força obrigatória' atribuem, na realidade, maior importância ao precedente em suas decisões do que seus colegas da Europa continental, o que não pode ser tomado por pressuposto" (in Ross, Alf, Direito e justiça, 2000, p. 113). E o autor assim prossegue: "seria possível supor que os juízes do continente europeu não se sentem responsáveis pela evolução do direito em medida idêntica aos seus colegas angloamericanos, estando, sim, inclinados a deixar nas mãos do legislador qualquer tentativa de reforma, ao menos naquelas esferas jurídicas que tradicional e regularmente estão submetidas à legislação", concluindo que "se assim fosse, resultaria que, contrariamente ao que proclama a ideologia oficial, o juiz estaria, de fato, menos disposto a afastar-se dos precedentes" (in idem, ibidem, p. 117).

${ }^{12}$ In SoAReS, Guido Fernando Silva, Common Law - Introdução ao direito dos EUA, 1999, p. 39. V., em sentido semelhante, afirmando que há duas técnicas diferentes no desenvolvimento do direito, ASCARELLI, Tullio, Problemas das sociedades anônimas e direito comparado, 1945, p. 68.

${ }^{13}$ Ressalte-se que, a despeito da aversão natural da common law ao direito legislado, mesmo nesse sistema não se nega a supremacia formal que a lei possui sobre as decisões do Judiciário. V., nesse sentido, GoRON, Lívio Goellner, A jurisprudência como fonte de direito: a experiência anglo-americana, in Revista de Direito Constitucional e Internacional, $\mathrm{n}^{\circ}$ 47, 2004, p. 289.

${ }^{14}$ Stare decisis é termo remanescente da expressão latina "stare decisis et non quieta movere", que, ao pé da letra, significa "que as coisas permaneçam firmes e imodificadas, em razão das decisões". V., nesse sentido, SoARES, Guido Fernando Silva, Common Law - Introdução ao direito dos EUA, 1999, p. 35. V., sobre as diferenças entre civil law e common law no que diz respeito à existência da doutrina formal do stare decisis, CAPPELLETTI, Mauro, The judicial process in comparative perspective, 1989, pp. 51/52. 
No sistema de civil law, pelo contrário, o precedente judicial interpreta em geral papel de cunho persuasivo, de valor moral (persuasive authority). A jurisprudência, especialmente aquela emanada dos tribunais superiores, possui a função de orientar e de nortear a interpretação da lei pelos juízos inferiores, mas não necessariamente obriga que se adote o mesmo entendimento ${ }^{15}$.

LIMONGI FRANÇA explica que os ordenamentos de civil law podem ser separados em quatro grupos, em relação às disposições que trazem sobre a jurisprudência como forma de expressão de direito: o primeiro é o daqueles que negam de modo absoluto a possibilidade dessa prerrogativa (Código Austríaco e Prussiano); o segundo é o daqueles que são omissos com relação à matéria (Código de Napoleão, Italiano, Alemão, Japonês e Chinês); o terceiro é o daqueles que a mencionam de modo parcialmente negativo, para dizer que a jurisprudência não pode revogar a lei (Código Espanhol, Argentino e Uruguaio); e o quarto é o daqueles que a ela se referem de modo positivo, reconhecendolhe papel de coadjuvante na interpretação das leis (Código Suíço e Soviético) ${ }^{16}$.

Os membros de cada um desses grupos possuem características peculiares que os diferenciam dos demais ${ }^{17}$. Em comum entre eles está o fato de, pelo menos em regra, a jurisprudência não surtir efeitos vinculantes - tanto que não são raros os casos em

\footnotetext{
${ }^{15}$ LIMONGI FRANÇA afirma que a não vinculação das decisões é tradição herdada do direito romano, a qual se justifica por quatro razões: em primeiro lugar, em suas decisões, o magistrado não aplica o direito segundo fórmula matemática pura e simples, mas atende a circunstâncias fáticas de ordem moral, social, psicológica e política que diferem das circunstâncias do caso seguinte; em segundo lugar, deve prevalecer a multissecular, trabalhada e complexa doutrina da coisa julgada, cujos princípios resguardam os direitos de terceiros que não integram a lide; em terceiro lugar, conhece-se a sobrecarga de serviço atribuída aos juízes e tribunais, sendo que decisões pouco meditadas estão longe de constituir expressão inatacável do direito; por último, por excesso de trabalho e por vezes por comodismo, magistrados e advogados tendem a se basear em máximas judiciárias sem avaliar seu respectivo valor intrínseco, gerando um círculo vicioso que contribui para o aviltamento da própria jurisprudência (in LIMONGI FRANÇA, Rubens, Jurisprudência - Seu caráter de forma de expressão de Direito, in Repertório Enciclopédico do Direito Brasileiro, vol. 30, pp. 284/285).

${ }^{16}$ In Limongi FrançA, Rubens, Jurisprudência - Seu caráter de forma de expressão de Direito, in Repertório Enciclopédico do Direito Brasileiro, vol. 30, p. 279.

${ }^{17}$ Até por isso, jamais existiu um modelo homogêneo e unitário de processo civil de civil law (in TARUFFO, Michele, Observações sobre os modelos processuais de civil law e de common law, in Revista de Processo, $\mathrm{n}^{\mathrm{o}} 110,2003$, p. 149). Seja na história dos últimos dois séculos, seja na história atual, é possível reconhecer a presença de no mínimo três modelos diferenciados: o modelo austro-alemão, o modelo franco-italiano e o modelo espanhol; logo, quando se fala em um iceberg de civil law, realiza-se um nível de abstração excessivo, em que se colhem poucos traços comuns, de caráter geral (in TARUFFO, Michele, Icebergs do common law e civil law? Macrocomparação e microcomparação processual e o problema da verificação da verdade, in Revista de Processo, $\mathrm{n}^{\circ}$ 181, 2010, p. 168). O mesmo ocorre com o sistema de common law: os sistemas inglês e norte-americano já eram historicamente distintos por várias razões, mas a divisão entre eles tornou-se tão profunda e radical nos últimos anos que agora eles não são nem mais comparáveis (in idem, ibidem, pp. 168/169).
} 
que questões jurídicas análogas geram decisões opostas, somente porque proferidas por diferentes sujeitos ou órgãos judicantes, dando ensejo ao fenômeno da "jurisprudência lotérica"18.

Apesar das diferenças entre os sistemas de civil law e de common law, cada vez maior tem sido a interação entre eles ${ }^{19}$, sendo possível identificar um movimento migratório rumo a um direito de "meio-termo" ${ }^{20}$ : ao mesmo tempo em que os países de common law têm feito uso, em certos casos, do papel persuasivo da jurisprudência (referindo-se, por vezes, até mesmo a decisões reiteradas de cortes de outros países ${ }^{21}$ ), e adotado textos codificados ${ }^{22}$, os países de civil law têm, em algumas situações, dotado o

\footnotetext{
${ }^{18}$ In CAMBI, Eduardo, Jurisprudência lotérica, in Revista dos Tribunais, vol. 786, 2001, p. 111.

${ }^{19}$ V., no mesmo sentido, AsCARELl, Tullio, Problemas das sociedades anônimas e direito comparado, 1945, pp. 45 e 91/92, CAPPELLETTI, Mauro, Juízes legisladores?, 1993, pp. 123/124, CHIARLONI, Sergio, Un mito rivisitato: note comparative sull'autorità del precedente giurisprudenziale, in Rivista di Diritto Processuale, ano 56, $\mathrm{n}^{\circ}$ 3, 2001, p. 615, GoRON, Lívio Goellner, A jurisprudência como fonte de direito: a experiência anglo-americana, in Revista de Direito Constitucional e Internacional, $\mathrm{n}^{\circ}$ 47, 2004, pp. 294/295, NOGUEIRA, Gustavo Santana, Jurisprudência vinculante no direito norte-americano e no direito brasileiro, in Revista de Processo, $\mathrm{n}^{\circ}$ 161, 2008, pp. 102/103 e TARUFFO, Michele, Precedente e giurisprudenza, in Rivista Trimestrale di Diritto e Procedura Civile, ano 61, n 3, 2007, p. 709.
}

${ }^{20} \mathrm{~V}$., nesse sentido, com fundamento na lição de BARBosa Moreira, VigLiar, José Marcelo Menezes, Uniformização de jurisprudência - Segurança jurídica e dever de uniformizar, 2003, pp. 166/167.

${ }^{21}$ V., sobre o assunto, observação de SOARES: "Até fins do século passado, alguns cases ingleses eram citados nos EUA; hoje, conforme constaram os autores norte-americanos consultados para este trabalho, nenhuma influência a Common Law inglesa exerce nos EUA. Contrariamente, é do conhecimento do autor que, na Inglaterra, pelo menos em matéria de responsabilidade civil extracontratual (torts), tem havido, com alguma freqüência, invocação do leading case Babcock v. Jackson nos julgados ingleses (responsabilidade civil por acidente com automóvel)." (in SOARES, Guido Fernando Silva, Common Law - Introdução ao direito dos EUA, 1999, p. 53). V., sustentando que, quando a invocação é de decisão de juízo estrangeiro, a hipótese é de utilização de exemplo, e não de precedente, LOPES, Raquel Cardoso, Uniformização da jurisprudência, in Revista Forense, vol. 390, 2007, p. 575. V., em sentido semelhante, explicando ainda que o exemplo informa, mas não sugere, e muito menos impõe, uma decisão conforme, TARUFFO, Michele, Precedente e giurisprudenza, in Rivista Trimestrale di Diritto e Procedura Civile, ano 61, $\mathrm{n}^{\circ}$ 3, 2007, pp. $721 / 722$.

${ }^{22}$ É o caso da própria Inglaterra, que em 1999 editou um Código de Processo Civil escrito, cuja versão integral está disponível em <http://www.justice.gov.uk/civil/procrules_fin/menus/rules.htm>, acesso em 07/01/2012. A propósito do assunto, MANCUSO também faz menção ao Uniform Commercial Code, de alto prestígio nos Estados Unidos, e ao advento, nesse país, em 2005, do Class Action Fairness Act (in MANCUSO, Rodolfo de Camargo, Súmula vinculante: perguntas e respostas, in Direito civil e processo - Estudos em homenagem ao Professor Arruda Alvim, 2007, p. 1.465). V., afirmando que o direito inglês atribui atualmente importância cada vez maior à lei, DAVID, René, O direito inglês, 1997, p. 11. V., sustentando que na common law é cada vez maior a importância do statutory law, CuNHA, Sérgio Sérvulo da, Nota breve sobre o efeito vinculante, in Revista de Informação Legislativa, $\mathrm{n}^{\circ} 129,1996, \mathrm{p} .10$. V., invocando que, no mundo moderno, o sistema de common law "precisa tomar em consideração a política legislativa expressa ou implícita numa multidão de dispositivos legais pertinentes", RE, Edward D., Stare decisis, in Revista de Informação Legislativa, n 122, 1994, p. 285. 
precedente judicial de eficácia vinculante, ou quase vinculante ${ }^{23}$. As influências mútuas demonstram que o momento é de desconstrução de paradigmas ${ }^{24}$.

Assim, abstraídas as peculiaridades de cada um, "constata-se realmente que, considerado o valor, in abstrato, dos precedentes judiciais, a influência destes é deveras similar em ambos os sistemas: de fato, enquanto naqueles países que seguem o modelo da common law, a força vinculante dos anteriores julgados tem-se tornado mais flexível, nos dos ordenamentos codificados é incontestável a difusa e constante tendência de os juízes aterem-se aos precedentes na fundamentação da ratio decidendi" ${ }^{25}$.

O presente trabalho propõe-se a analisar de forma sistemática e crítica o papel e a influência do precedente judicial no ordenamento jurídico brasileiro, à luz das mais recentes reformas introduzidas na legislação constitucional e processual com o duplo objetivo de conferir maior valor ao precedente e de uniformizar a jurisprudência, sob a (pretensa) justificativa de garantir maior isonomia e segurança jurídica aos jurisdicionados. A bem da verdade, são duas faces de uma mesma moeda, pois, ao dotar o precedente de maior valor, atinge-se a uniformização, e vice-versa.

\footnotetext{
${ }^{23}$ V., afirmando que na atualidade a tarefa do juiz da civil law está muito próxima da exercida pelo juiz da common law, MARINONI, Luiz Guilherme, A transformação do civil law e a oportunidade de um sistema precedentalista para o Brasil, disponível em <http://marinoni.adv.br>, acesso em 16/09/2011, p. 3. Mas a tendência não é de hoje. Em livro datado de 1945, AsCARELLI já fazia alusão ao fenômeno: "Ao lado da legislação, é indispensável examinar a jurisprudência: o direito é, na realidade dos fatos, aquele que, dia a dia, é aplicado e seguido. Com frequência entre o direito que está na lei e o direito vivo aplicado quotidianamente pela jurisprudência, ha uma diferença, suscetivel de ser bastante acentuada. Isso é verdadeiro, não só no sistema inglês, em que a jurisprudência adquire, como é sabido, particular importância, com o reconhecimento do valor normativo do precedente jurisprudencial, mas tambem nos sistemas de base romanista. A diferença pratica entre esses dois sistemas é, a esse respeito, menor do que a teórica, pois, na realidade, mesmo nos sistemas de base romanista, a jurisprudência adota máximas constantes, que só dificilmente podem ser overruled, para usarmos o têrmo inglês." (in ASCARELLI, Tullio, Problemas das sociedades anônimas e direito comparado, 1945, p. 9). V., no mesmo sentido, fazendo referência especificamente ao crescente papel do precedente no direito brasileiro, MANCUSO, Rodolfo de Camargo, A jurisprudência, dominante ou sumulada, e sua eficácia contemporânea, in Aspectos polêmicos e atuais dos recursos cíveis de acordo com a Lei $n^{\circ}$ 9.756/98, 1999, pp. 523/527. V., ainda, TARUFFO, Michele, Institutional factors influencing precedents, in Interpreting precedents: a comparative study, 1997, pp. 459/460.

${ }^{24}$ In PARENTE, Eduardo de Albuquerque, Jurisprudência: da divergência à uniformização, 2006, p. 18. É dentro desse contexto, mas levando em consideração fatores mais amplos, que TARUFFO afirma que as diferenças fundamentais traçadas entre os dois tipos de ordenamento "se mostram há tempos superadas e já incapazes de fornecer conhecimentos acatáveis", ensejando verdadeira crise dos modelos tradicionais (in TARUFFO, Michele, Observações sobre os modelos processuais de civil law e de common law, in Revista de Processo, $\mathrm{n}^{\circ} 110,2003$, p. 143).

${ }^{25}$ In CRUZ E TUCCI, José Rogério, Precedente judicial como fonte de direito, 2004, p. 26.
} 
Para tanto, dividiremos o trabalho em seis capítulos: o primeiro fará uma introdução ao tema, tratando de aspectos gerais que decorrem do estudo do precedente judicial e da jurisprudência; o segundo fará uma breve abordagem histórica do assunto; o terceiro examinará questões de direito comparado, com vistas a traçar as principais características do sistema de common law, com foco no direito inglês; o quarto e o quinto cuidarão do tema central da tese, analisando cuidadosamente o precedente judicial conforme a sua eficácia (vinculante, quase vinculante e persuasiva), e os demais meios de uniformização de jurisprudência; o sexto exporá nossas conclusões sobre o tema. 
SUMÁRIO. 1.1 Definição de precedente judicial e de jurisprudência. 1.2 Funções da jurisprudência. 1.3 Importância de uniformizar a jurisprudência. 1.3.1 Garantia de maior isonomia e segurança jurídica. 1.3.2 Diminuição do tempo do litígio (duração razoável do processo?).

\subsection{Definição de precedente judicial e de jurisprudência}

Alguns autores utilizam o termo "precedente judicial" como sinônimo de “jurisprudência”. Outros, como KELSEN, o utilizam como sinônimo de decisão judicial vinculante para subsequentes casos idênticos ${ }^{26}$. No título desta tese, optamos pelo emprego daquela locução de forma proposital, mas a definimos de forma diversa.

Toda decisão judicial proferida por autoridade judiciária constitui precedente judicial. Ainda que seja dissonante de todas as demais e assuma posicionamento isolado em relação à matéria de fundo, a decisão proferida por autoridade judiciária é um precedente judicial. O fato de poder ser alterada por decisão posterior, mediante recurso, não retira dela essa característica. Para que a decisão seja considerada um precedente judicial, basta que seja proferida por autoridade judiciária, portanto ${ }^{27}$.

O sentido do termo "jurisprudência" é um pouco diferente, na medida em que pressupõe um mínimo de constância e de uniformização, que se forma a partir da existência de algumas decisões reiteradas num mesmo sentido ${ }^{28}$. De certa forma, pode-se

\footnotetext{
${ }^{26}$ In KELSEN, Hans, Teoria pura do direito, 1999, p. 278.

${ }^{27}$ De maneira similar, SOARES explica que na common law "precedent é a única ou várias decisões de um appellate court, órgão coletivo de segundo grau, que obriga sempre o mesmo tribunal ou os juízes que lhe são subordinados" (in SOARES, Guido Fernando Silva, Common Law - Introdução ao direito dos EUA, 1999, p. 40). A diferença é que no Brasil o precedente não necessariamente possui efeito vinculante, nem necessariamente provém de órgão colegiado. V., em sentido semelhante ao nosso, PARENTE, Eduardo de Albuquerque, Jurisprudência: da divergência à uniformização, 2006, p. 5.

${ }^{28} \mathrm{~V}$., em sentido semelhante, sustentando que "a jurisprudência não é, pois, a decisão isolada de um tribunal: é uma espécie de consolidação do saber difuso, um certo consenso interpretativo, progressivo e inacabado do ordenamento", CUNHA, Sérgio Sérvulo da, Nota breve sobre o efeito vinculante, in Revista de Informação Legislativa, $\mathrm{n}^{\circ}$ 129, 1996, p. 7. V., afirmando que "jurisprudência no sentido técnico do termo é o entendimento majoritário esposado pelos Tribunais, após reiteradas decisões sobre a mesma matéria", TOSTES, Natacha Nascimento Gomes, Uniformização de jurisprudência, in Revista de Processo, $\mathrm{n}^{\circ}$ 104, 2001, p. 198. V., em sentido parecido, BUZAID, Alfredo, Uniformização da jurisprudência, in Revista da Ajuris - Associação dos Juízes do Rio Grande do Sul, no 34, 1985, p. 190 e VIGLIAR, José Marcelo Menezes,
} 
dizer que o conjunto de precedentes judiciais, em determinado sentido, é chamado de jurisprudência $^{29}$. É como SOARES explica: um único caso isolado não constitui jurisprudência, da mesma maneira que uma única andorinha não faz verão ${ }^{30}$.

Embora sem dúvida as sentenças de primeiro grau também formem jurisprudência, muitas vezes fornecendo até melhor contribuição para o direito, preferimos utilizar o vocábulo para designar o pronunciamento constante e uniforme dos tribunais apenas, já que esse é o sentido em que é mais utilizado ${ }^{31}$.

Assim, a jurisprudência representa a tendência dos tribunais de julgar de um ou outro jeito. O precedente judicial, por outro lado, não necessariamente expressa orientação uniforme; pode constituir entendimento isolado do prolator da decisão, contrário ao resto da jurisprudência sobre o assunto em questão.

Uniformização de jurisprudência - Segurança jurídica e dever de uniformizar, 2003, p. 63. V., em sentido diverso, sustentando que a decisão isolada proferida pelo STF, em sessão plenária, ou pelo STJ, em sessão da Corte Especial, também constitui jurisprudência, RoSAS, Roberto, Jurisprudência. Uniformização. Súmula, in Direito processual: inovações e perspectivas - estudos em homenagem ao Ministro Sálvio de Figueiredo Teixeira, 2003, p. 385 e idem, Da súmula à súmula vinculante, in Revista dos Tribunais, vol. 879, 2009, pp. $43 / 44$.

${ }^{29}$ LIMONGI FRANÇA distingue cinco significados diversos de jurisprudência: o primeiro é um conceito lato, que abrange toda a ciência do direito, teórica ou prática, elaborada por jurisconsultos ou magistrados; o segundo está ligado à etimologia do vocábulo (juris + prudentia), consistente no conjunto das manifestações dos jurisconsultos (prudentes) diante de questões jurídicas concretas a eles apresentadas; o terceiro, de doutrina jurídica, teórica, prática ou de dupla natureza, abrange o complexo das indagações, estudos e trabalhos feitos pelos juristas sem o objetivo de resolver imediatamente problemas concretos atuais; o quarto envolve as manifestações dos juízes e tribunais sobre as lides e negócios submetidos à sua autoridade, implicando uma técnica especializada e um rito próprio, imposto por lei; e o quinto - significado com o qual mais nos identificamos - diz respeito ao conjunto de pronunciamentos pelo Poder Judiciário, num determinado sentido, sobre certo objeto, de modo constante, reiterado e pacífico (in LIMONGI FRANÇA, Rubens, Jurisprudência - Seu caráter de forma de expressão de Direito, in Repertório Enciclopédico do Direito Brasileiro, vol. 30, pp. 273/274).

${ }^{30}$ In SoARES, Guido Fernando Silva, Common Law - Introdução ao direito dos EUA, 1999, p. 51. V., no mesmo sentido, afirmando que "uma decisão isolada não constitui jurisprudência", PEREIRA DOS SANTOS, Carlos Maximiliano, Hermenêutica e aplicação do direito, 2007, p. 151. V., reportando-se a esse aspecto quantitativo, TARUFFO, Michele, Precedente e giurisprudenza, in Rivista Trimestrale di Diritto e Procedura Civile, ano 61, no 3,2007 , p. 711.

${ }^{31}$ In PEREIRA dos SANTOS, Carlos Maximiliano, Hermenêutica e aplicação do direito, 2007, pp. 152/153. V., sustentando que as decisões de primeiro grau, mesmo que reiteradas e pacíficas, não formam propriamente jurisprudência, porque "tais decisões estariam sujeitas a, no mínimo, mais um grau de jurisdição, que poderiam substituí-las (em suas essências) por outras que se tornariam então as definitivas", VIGLIAR, José Marcelo Menezes, Uniformização de jurisprudência - Segurança jurídica e dever de uniformizar, 2003, p. 75. 
Nem sempre o termo "jurisprudência" foi empregado com o sentido acima, sendo nítida a mutação semântica havida desde a Roma antiga ${ }^{32}$. Em muitos momentos da história, foi utilizado como sinônimo de ciência do direito (prudentia $=$ ciência, iuris $=$ do direito) ou dos pareceres ou opiniões dos prudentes (jurisconsultos romanos) às consultas que lhes eram formuladas ${ }^{33}$.

O presente trabalho visa a examinar não só o papel da jurisprudência no ordenamento jurídico pátrio, mas, de forma ainda mais ampla, o papel do próprio precedente judicial. Logo, quando nos referimos a um ou a outro, o fazemos de forma deliberada e intencional, tendo em mente os conceitos mencionados acima.

\subsection{Funções da jurisprudência}

Ao longo da história, diversos autores se debruçaram sobre o estudo das funções da jurisprudência.

MARCEl NASt, Professor da Universidade de Estrasburgo, identificou três funções precípuas: uma função automática de aplicação da lei; uma função de adaptação, para fins de harmonização da lei com as ideias contemporâneas e as necessidades modernas; e uma função de criação, para fins de preenchimento das lacunas da lei ${ }^{34}$.

\footnotetext{
32 In Velasco, Ignacio Maria Poveda, Direito, jurisprudência e justiça no pensamento clássico (grecoromano), in Revista da Faculdade de Direito da Universidade de São Paulo, no 101, 2006, pp. 21/22. V., no mesmo sentido, AzEVEDO, Luiz Carlos de, Função da jurisprudência nos conflitos entre a lei natural e a lei positiva, in Revista Trimestral de Jurisprudência dos Estados, $\mathrm{n}^{\circ}$ 34, 1985, pp. 41/42, BARTOLETTO, Luiz Carlos, Analogia, jurisprudência e princípios gerais do direito, in Revista de Direito Civil, Imobiliário, Agrário e Empresarial, no 72, 1995, pp. 27/28, CRUZ E TUCCI, José Rogério, Precedente judicial como fonte de direito, 2004, pp. 9/10, nota de rodapé no 1, FERRO, Marcelo Roberto, A jurisprudência como forma de expressão de direito, in Revista de Direito Civil, Imobiliário, Agrário e Empresarial, n 51, 1990, pp. 90/91, MANCUSO, Rodolfo de Camargo, Divergência jurisprudencial e súmula vinculante, 2007, pp. 30/38 e SANCHES, Sydney, Uniformização da jurisprudência, 1975, pp. 1/4. V., sobre a diferença do conceito entre gregos e romanos, FERRAZ Junior, Tércio Sampaio, Introdução ao estudo do direito - técnica, decisão, dominação, 1994, p. 62. V., ainda, sobre o nascimento do vocábulo "jurisprudência" na mitologia grega, LuIZ, Elton, O nascimento da jurisprudência, in Revista da Faculdade de Direito Cândido Mendes, $\mathrm{n}^{\circ} 9$, 2004, pp. 35/43.

${ }^{33}$ In Moreira Alves, José Carlos, Direito romano, 2007, p. 12.

${ }^{34}$ In PEREIRA DOS SANTOS, Carlos Maximiliano, Hermenêutica e aplicação do direito, 2007, p. 146.
} 
No Brasil, LimOngI FRANÇA concluiu serem cinco as funções da jurisprudência: interpretar a lei; vivificar a lei; humanizar a lei; suplementar a lei; e rejuvenescer a lei.

Quanto ao primeiro ponto, o autor explica que a lei é um preceito geral e que, ao aplicá-la ao caso concreto, o magistrado deve repassar o significado de cada um dos termos que a integram, para o correto enquadramento da espécie. Esse trabalho normalmente é realizado de antemão pela doutrina, mas como dificilmente existe uniformidade de opiniões e o juiz deve julgar de acordo com o seu próprio convencimento, a ele cabe a adoção de uma orientação, seja ela original ou não.

Quanto ao segundo ponto, uma vez publicada no diário oficial e iniciado seu termo de vigência, a lei é apenas mais um preceito que passa a integrar o sistema jurídico - "como uma roupagem, um molde, um protótipo, sem atuação efetiva $e$ própria"35. Surgida a controvérsia, caberá ao Poder Judiciário interpretar os preceitos jurídicos cotejando-os ao caso concreto, emprestando-lhes o dinamismo que os torna atuantes, vivificando, portanto, a lei.

A propósito do terceiro ponto, como dito, a lei é ordem de caráter geral, impessoal. Ao aplicá-la, cabe ao magistrado arredondar as suas arestas e adaptar a rigidez de seus mandamentos às irregularidades e especificidades naturais do caso concreto, sem, é claro, distorcer-lhe as feições. Ao fazê-lo, o juiz deve sempre atender aos fins sociais a que a lei se dirige e às exigências do bem comum.

Em relação ao quarto ponto, sobressai o poder criador do juiz, em face das inevitáveis lacunas da lei. Como na ausência de texto expresso aplicável não pode se eximir de julgar, tampouco rejeitar o pedido do autor com fundamento exclusivo nessa circunstância, em casos tais o magistrado deve recorrer à analogia, ao costume e aos princípios gerais de direito, suplementando efetivamente a lei. Porém, tal poder não é ilimitado e o magistrado não pode jamais afastar-se dessas três balizas.

${ }^{35}$ In Limongi FrAnÇA, Rubens, Jurisprudência - Seu caráter de forma de expressão de Direito, in Repertório Enciclopédico do Direito Brasileiro, vol. 30, p. 292. 
Por fim, quanto ao quinto ponto, cabe à jurisprudência, sem comprometer a essência do preceito legal, adaptá-lo à realidade social e às transformações da vida cotidiana. Cabe a ela ainda fornecer os elementos de reelaboração constante do sistema jurídico, para que este permaneça sempre ordenado à utilidade comum ${ }^{36}$.

Em época um pouco mais recente, FERRO também escreveu sobre o assunto, ressaltando ter a jurisprudência duas funções mediatas: o alcance da igualdade e da segurança. Para tanto, a jurisprudência deve se valer de dois meios imediatos, quais sejam, a interpretação e a humanização da lei ${ }^{37}$.

Quanto ao primeiro ponto, o autor esclarece que, em princípio, a interpretação não acrescenta nada à lei; busca-se apenas o seu verdadeiro sentido, adaptando-o, quando o caso, às necessidades do momento. Daí surgiriam duas espécies de poderes: o poder conservador e o poder criador da jurisprudência.

Por meio do poder conservador, o juiz interpreta a lei nova em cotejo com a antiga. Assim, resguarda tudo aquilo que era bom e que não é incompatível com o novo ordenamento, ou corrige e adapta, às necessidades atuais, um texto defeituoso ou ultrapassado. Já o poder criador, excepcional, revela-se nos casos de omissão da lei, visando ao preenchimento de lacunas. Isso porque o juiz não pode se negar a prestar atividade jurisdicional sob o argumento de que a lei é obscura ou omissa. Em casos tais, deve se valer da analogia, dos costumes e dos princípios gerais de direito.

Ainda, FERRO ressalta a perfeita integração existente entre o trabalho do juiz e o do legislador. Aquele não se limita à aplicação automática da lei, mas "procura adaptála aos interesses da comunidade, funcionando como um intermediário entre a letra morta dos Códigos e a vida real",38.

\footnotetext{
${ }^{36}$ In Limongi FrançA, Rubens, Jurisprudência - Seu caráter de forma de expressão de Direito, in Repertório Enciclopédico do Direito Brasileiro, vol. 30, pp. 291/293.

${ }^{37}$ In FerRo, Marcelo Roberto, A jurisprudência como forma de expressão de direito, in Revista de Direito Civil, Imobiliário, Agrário e Empresarial, nº 51, 1990, p. 95.

${ }^{38}$ In FerRo, Marcelo Roberto, A jurisprudência como forma de expressão de direito, in Revista de Direito Civil, Imobiliário, Agrário e Empresarial, nº 51, 1990, p. 97.
} 
Quanto ao segundo ponto, referente à humanização da lei, FERRO explica que a norma, que é geral e impessoal, deve ser adaptada para o caso concreto, de acordo com as peculiaridades de cada espécie ${ }^{39}$. Esse trabalho deve guardar limites, evitando-se a aplicação puramente sentimental da lei ${ }^{40}$.

Não obstante reconheça as importantes funções da jurisprudência, FERRO aponta alguns inconvenientes decorrentes de sua aplicação. $O$ primeiro consistiria no desprestígio do Poder Legislativo, já que a preponderância da jurisprudência determina, de certa forma, a crise da lei; o segundo, no seu manuseio inconsequente e automático pelos magistrados (e, acrescentamos nós, pelos advogados), sem a realização da devida análise crítica.

Trata-se esta última de ponderação extremamente relevante, pois, por mais remansosa que seja a jurisprudência, é necessário que o intérprete faça o cotejo entre a tese jurídica por ela sugerida e o caso concreto, à luz da melhor doutrina e dos princípios gerais de direito. O pior erro é o daqueles que, por incompetência ou comodismo, lidam com a jurisprudência de forma não criteriosa ${ }^{41}$.

${ }^{39} \mathrm{~V}$., em sentido parecido, afirmando que "o juiz realiza, na grande maioria dos casos, um trabalho de adaptação da lei ao caso concreto", MELlo, Pedro Thaumaturgo Soriano de, Um estudo sobre a eqüidade e o poder criador do juiz, in Revista do Tribunal Regional do Trabalho da $8^{a}$ Região, nº 50, 1993, p. 100.

40 PEREIRA DOS SANTOS adverte para os perigos do magistrado que se deixa guiar pelo sentimento, ressaltando que o papel da judicatura é manter o equilíbrio dos interesses e, dentre estes, distinguir os legítimos dos ilegítimos (in PEREIRA DOS SANTOS, Carlos Maximiliano, Hermenêutica e aplicação do direito, 2007, pp. 68/69).

${ }^{41}$ Nesse sentido, irretocável é a crítica de PEREIRA DOS SANTOS: "Em virtude da lei do menor esforço e também para assegurarem os advogados o êxito e os juízos inferiores a manutenção das suas sentenças, do que muitos se vangloriam, preferem, causídicos e magistrados, às exposições sistemáticas de doutrina jurídica, os repositórios de jurisprudência. Basta a consulta rápida a um índice alfabético para ficar um caso liquidado, com as razões na aparência documentadas cientificamente. Por isso, os repertórios de decisões em resumo, simples compilações, obtêm esplêndido êxito de livraria. Há verdadeiro fanatismo pelos acórdãos: dentre os freqüentadores dos pretórios, são muitos os que se rebelam contra uma doutrina; ao passo que rareiam os que ousam discutir um julgado, salvo por dever de ofício, quando pleiteiam a reforma do mesmo. Citado um aresto, a parte contrária não se atreve a atacá-lo de frente; prefere ladeá-lo, procurar convencer de que não se aplica à hipótese em apreço, versara sobre caso diferente. No Brasil, até quando o Judiciário invade a esfera de atuação do Congresso, ou se afasta, por outra forma, dos cânones constitucionais, surge sempre forte corrente, entre os mais doutos, que pleiteia o respeito à exegese ocasional; embora em assunto da própria competência o Legislativo nada tenha com a opinião dos juízes e seja também certo que um só julgado não constitui jurisprudência. Quando a lei é nova, ainda os seus aplicadores atendem à teoria, compulsam tratados, apelam para o Direito comparado; desde, porém, que aparecem decisões a propósito da norma recente, volta a maioria ao trabalho semelhante à consulta a dicionários. 'Copiam-se, imitam-se, contam-se os precedentes; mas de pesá-los não se cuida'. Desprezam-se os trabalhos diretos sobre os textos; prefere-se a palavra dos profetas às tábuas da lei. O processo é erradíssimo. Os julgados constituem bons auxiliares de exegese, quando manuseados criteriosamente, criticados, comparados, examinados à luz dos princípios, com os livros de doutrina, com as exposições sistemáticas do Direito em punho. A jurisprudência, só por si, isolada, não tem valor decisivo, absoluto. 
Ainda em época recente, MANCUSO abordou o tema, sustentando que "nos Estados de Direito e em situações de normalidade, a jurisprudência, mormente quando potencializada em Súmulas ou enunciados, exerce papel relevantíssimo, atuando em mais de um plano: a) opera como uma segura diretriz para o Poder Judiciário, funcionando com importante subsídio para a subsunção dos fatos ao Direito, na medida em que sinaliza a interpretação predominante em casos análogos; b) contribui para a consecução da ordem jurídica justa, ou isonômica, ensejando que casos semelhantes recebam respostas judiciárias qualitativamente uniformes; c) complementa a formação da convicção do magistrado, seja atuando como fator de atualização do Direito Positivo, seja como elemento moderador entre o fato e a fria letra da lei”, ${ }^{2}$.

As opiniões doutrinárias mencionadas acima nos remetem a algumas reflexões acerca das funções da jurisprudência. O assunto é complexo e comporta inúmeras divagações; entretanto, tratando-o de forma direta e objetiva, identificamos duas importantes funções na jurisprudência, que praticamente se confundem, já que a segunda decorre da primeira: a primeira é a de interpretar a lei, delimitando o alcance do texto legal; a segunda é a de adequar a lei no tempo, de acordo com as necessidades da realidade social presentes no momento de aplicação da lei.

Com efeito, é forçoso concordar com o papel interpretativo do precedente judicial. Na medida em que consistem em preceitos gerais e impessoais, as leis, por natureza, são amplas e abstratas, de modo que as decisões judiciais - principalmente quando reiteradas e uniformes, formando jurisprudência - passam a guiar as orientações

Basta lembrar que a formam tanto os arestos brilhantes, como as sentenças de colégios judiciários onde reinam a incompetência e a preguiça." (in PEREIRA DOS SANTOS, Carlos Maximiliano, Hermenêutica e aplicação do direito, 2007, pp. 148/149). No mesmo sentido, corretíssima é a censura de LIMONGI FRANÇA: "O êrro não está em consultá-los [os arestos], se devidamente ponderados e relacionados com os altos princípios que a Doutrina, através de séculos de verdadeiro sacrifício de uma classe de abnegados, conseguiu edificar, e que constituem a própria garantia de estabilidade do Direito. $O$ êrro, sim, está na voracidade, na glutoneria pantagruélica, revelada em razões e sentenças, com a qual, causídicos e magistrados, constantemente se atiram à mal posta mesa do banquete aresteiro, na avidez incontida de dar ao caso concreto a solução mais rápida, com menor possibilidade numérica de ser reformada." (in LIMONGI FRANÇA, Rubens, Jurisprudência - Seu caráter de forma de expressão de Direito, in Repertório Enciclopédico do Direito Brasileiro, vol. 30, p. 289). V., em sentido semelhante, ao tratar dos perigos da interpretação vinculante em abstrato introduzida pela EC nº 7/1969, BOTELHO DE MESQUITA, José Ignacio, $O$ princípio da liberdade na prestação jurisdicional, in Teses, estudos e pareceres de processo civil, vol. 2, 2005, p. 47.

${ }^{42}$ In MANCUSO, Rodolfo de Camargo, Divergência jurisprudencial e súmula vinculante, 2007, pp. 48/49. 
futuras, sobre a forma correta de se interpretar o texto legal, delimitando-o de acordo com o propósito para o qual a norma foi emitida ${ }^{43}$ e, consequentemente, eliminando a dose de indeterminação nele contida.

Isso ocorre porque a lei não contém a decisão do problema; a norma resulta do processo hermenêutico do intérprete, a quem cabe atribuir significação ao texto da lei ${ }^{44}$. Consoante afirma GUIMARÃES, "por mais sábio que seja o legislador, por mais previdente ou por mais casuísta, não poderá nunca prever tôda a variedade de relações sôbre as quais vai recair a lei" 45 . Mas como ressalta GRAU, "nem por isso ela é menos correta, porque a culpa não está na lei, nem no legislador, mas sim na natureza das coisas" ${ }^{46}$.

Logo, de um mesmo texto legal sempre ${ }^{47}$, ou quase sempre ${ }^{48}$, é possível extrair soluções bastante diferentes - para GARCIA, segundo estudos realizados, a aplicação combinada dos vários métodos hermenêuticos (gramatical, histórico, teleológico, sistemático etc. ${ }^{49}$ ) é capaz de conduzir a cento e quarenta e quatro entendimentos diferentes

${ }^{43}$ KARAN explica a questão nos seguintes termos: "O essencial na obra do legislador não é o texto da lei, mas é o pensamento dos valores que a lei visa. Assim, o recomendável, na obra do juiz, não é o apego incondicional ao texto da lei, mas o prevalecimento daqueles valores, daqueles bens que o legislador tinha em mente ao elaborar a lei que o juiz tem de levar em conta no seu julgamento do caso concreto." (in KARAN, Munir, A função judicial, in Revista de Processo, no 42, 1986, p. 182). V., nesse sentido, ao tratar da "lógica do razoável" de RECASÈnS SICHES, SOBRINHO, Elício de Cresci, O juiz criador do direito e a interpretação razoável, in Revista da Ajuris - Associação dos Juízes do Rio Grande do Sul, $\mathrm{n}^{\circ}$ 50, 1990, $\mathrm{p}$. 29. V., defendendo posicionamento semelhante, MELlo, Pedro Thaumaturgo Soriano de, Um estudo sobre a eqüidade e o poder criador do juiz, in Revista do Tribunal Regional do Trabalho da $8^{a}$ Região, $\mathrm{n}^{\circ}$ 50, 1993, p. 100.

${ }^{44}$ Segundo COUTURE, "o intérprete é um intermediário entre o texto e a realidade; a interpretação consiste em extrair o sentido, desenterrar o conteúdo, que o texto encerra com relação à realidade" (in COUTURE, Eduardo Juan, Interpretação das leis processuais, 1956, p. 13).

${ }^{45}$ In GUIMARÃES, Mário, O juiz e a função jurisdicional, 1958, p. 332.

${ }^{46}$ In GRAU, Eros Roberto, Eqüidade, razoabilidade e proporcionalidade, in Revista do Advogado, no 78 , 2004, p. 28.

${ }^{47}$ Para THEODORO JUNIOR, "todas as leis de direito são de certa forma dotadas de certa imprecisão, cujo grau pode variar, mas cuja presença nunca poderá ser evitada. O que varia é, pois, o volume da indeterminação, nunca a sua presença." (in THEODORO JUNIOR, Humberto, Repercussão geral do Recurso Extraordinário (Lei $\left.n^{o} 11.418\right)$ e Súmula Vinculante do Supremo Tribunal Federal (Lei $\left.n^{o} 11.417\right)$, in Revista IOB de Direito Civil e Processual Civil, no 48, 2007, p. 106).

${ }^{48}$ ROMANI entende que "o ordenamento jurídico apresenta um complexo de normas, algumas delas de enunciado literal tão exato e preciso que não permite qualquer outro tipo de raciocínio que não aquele determinado no texto legal, impedindo a faculdade do julgador de interpretá-lo e questionar sobre a conveniência da sua aplicação, pois que deve obediência ao princípio da legalidade" (in RoMANI, Dagoberto, O juiz, entre a lei e o direito, in Revista dos Tribunais, vol. 633, 1988, p. 235).

${ }^{49}$ COUTURE, com fundamento na lição de SAVIGNY, menciona a existência de quatro processos para a interpretação das leis: gramatical, lógico, histórico e sistemático (in COUTURE, Eduardo Juan, Interpretação das leis processuais, 1956, pp. 15/16). Em seguida, o autor afirma que os quatro métodos referidos "não 
da mesma proposição normativa ${ }^{50}$-, cabendo ao juiz fazer prevalecer no caso concreto uma ou outra tese jurídica ${ }^{51}$. Nos dizeres de SILVA, "para o intérprete contemporâneo, as leis pressupõem sempre riqueza de significado e flexibilidade de sentido" ${ }^{\circ 2}$, justamente porque são sempre gerais.

Por vezes nem é o caso de a lei ser tão ampla e abstrata (embora essas características sejam inerentes à sua natureza), pois em algumas situações a interpretação conferida pelos tribunais pode desafiar a sua (aparente) literalidade ${ }^{53}$. Por exemplo, a Lei n 8.245, de 18 de outubro de 1991 (“Lei de Locação"), prevê em seu art. 51, caput, que, preenchidas determinadas condições, "nas locações de imóveis destinados ao comércio, o locatário terá direito a renovação do contrato, por igual prazo" (destaque nosso). Não obstante a lei fale em "igual prazo", dando a entender que o contrato deve ser renovado pelo mesmo prazo do contrato renovando, a jurisprudência, inclusive a do $\mathrm{STJ}^{54}$, é unânime no sentido de que a renovação não pode ultrapassar o prazo de cinco anos ${ }^{55}$.

bastam, por si sós, para a obra interpretativa; reunidos, porém, cumprem-na em grande parte. Se algo existe para se acrescentar a essa união de gramática, lógica, história e sistema, é a idéia de atualidade na vigência do Direito. O fenômeno de interpretação não tende a revelar o pensamento do legislador, mas sim a extensão da eficácia atual da norma." (in idem, ibidem, p. 22).

${ }^{50}$ In GARCIA, Dínio de Santis, Efeito vinculante dos julgados da Corte Suprema e dos Tribunais Superiores, in Revista dos Tribunais, vol. 734, 1996, p. 41.

${ }^{51}$ In CAMBI, Eduardo, Jurisprudência lotérica, in Revista dos Tribunais, vol. 786, 2001, p. 110 e CARLIN, Volnei Ivo, Jurisprudência como função substitutiva do legislador, in Seqüência: estudos jurídicos e políticos, $\mathrm{n}^{\circ} 16,1988$, pp. 33/34.

${ }^{52}$ In Silva, Wilma Nogueira de Araújo Vaz da, O papel do juiz na criação do direito, in Revista do Tribunal Superior do Trabalho, 1987, p. 148. Apesar de existir uma multiplicidade de possibilidades interpretativas de cada texto jurídico, há limites que impedem que ao interpretá-lo se desnature seu sentido e seu alcance; a interpretação judicial deve ser sempre razoável (in PERNíA, Hermann Petzold, Subsunción, hermenéutica y argumentación em derecho, disponível em <http://carloscolmenares.com/userfiles/SUBSUNCION\%20\%20 HERMENEUTICA\%20Y\%20ARGUMENTACION\%20EN\%20DERECHO.pdf>, acesso em 25/08/2011, p. $8)$.

${ }^{53} \mathrm{~V}$., afirmando que "na aplicação do direito surgem, de contínuo, dúvidas e incertezas, ainda quando a norma legal seja explícita", BUZAID, Alfredo, Uniformização da jurisprudência, in Revista da Ajuris Associação dos Juízes do Rio Grande do Sul, no 34, 1985, p. 193. V., no mesmo sentido, confirmando que "vemos diariamente se acalorarem nos Tribunais e nos foros debates sobre textos de 'clareza meridiana' $e$ os próprios juízes discutem e afinal decidem sobre a verdadeira exegese de normas aparentemente perfeitas", KARAN, Munir, A função judicial, in Revista de Processo, n 42, 1986, p. 181.

${ }^{54}$ Confira-se nesse sentido: REsp n ${ }^{\circ}$ 1.042.440/SP; REsp no 962.945/MG; REsp no 693.729/MG; REsp no 267.129/RJ; REsp no 195.971/MG; REsp nº 182.713/RJ; REsp n 170.589/SP.

${ }^{55}$ Fica comprovado, assim, o que em meados do século passado dizia GuIMARÃES: “A lei - lemos algures êste pensamento - é, por vêzes, como as águas paradas de um lago que ocultem, no fundo, cipós e ninhos de serpentes. Na sua tranqüilidade pode enganar, com precipícios ocultos, os intérpretes descuidadosos." (in GUIMARÃES, Mário, O juiz e a função jurisdicional, 1958, p. 326). 
De casos como esse se extrai, a nosso ver, a segunda função da jurisprudência, que é a de adequar a lei no tempo, adaptando-a à realidade social presente no momento da aplicação da lei - sempre atendendo aos fins sociais a que a lei se dirige e às exigências do bem comum (art. $5^{\circ}$, da LICC) ${ }^{56}$. Nas precisas palavras de NÉRI DA SILVEIRA, "se a interpretação das leis e a construção do Direito não podem negar ou violar os limites, expressamente demarcados, da fonte principal, legislativa, indiscutível é, todavia, que imensos domínios se abrem à adaptação dos textos legislativos, tantas vezes inadequados à época e às exigências vitais da sociedade, para os que sabem ver a função social e conciliadora da justiça viva, da justiça dinâmica",57.

Irrepreensíveis também são as ponderações de BotelHO DE MESQUITA sobre o tema em discussão: "Não há exagero algum em comparar a lei, quando entra em vigor, a fruto que ainda é verde no momento em que nasce. A vida humana incide sobre a lei como os raios do sol sobre o fruto apenas gerado. No contato com o caso concreto, a lei mostra as suas virtudes e os seus defeitos. É tarefa dos juízes realçar aquelas e minimizar estes. Do desempenho dessa atividade é que se revela e se torna atuante o

\footnotetext{
${ }^{56} \mathrm{~V}$., no mesmo sentido, CARLIN, Volnei Ivo, O papel do juiz na sociedade moderna, in Revista de Processo, $\mathrm{n}^{\mathrm{o}} 45,1987$, p. 248 e LIEBMAN, Enrico Tullio, A força criativa da jurisprudência e os limites impostos pelo texto da lei, in Revista de Processo, $\mathrm{n}^{\circ}$ 43, 1986, p. 60. Sobre o mesmo assunto, invocando a lição de PERELMAN, FREITAS ensina que há duas interpretações que se opõem: a estática, que se esforça em encontrar a vontade do legislador que sancionou o texto legal; e a dinâmica, que, como convém, interpreta o texto em função do bem comum ou da equidade (in FREITAS, Juarez, Hermenêutica jurídica: o juiz só aplica a lei injusta se quiser, in Revista da Ajuris - Associação dos Juízes do Rio Grande do Sul, $\mathrm{n}^{\circ}$ 40, 1987, p. 42). V., no mesmo sentido, KARAN, Munir, A função judicial, in Revista de Processo, no 42, 1986, p. 183. AzEVEDO, por sua vez, com supedâneo na lição de CABRAL DE MONCADA, distingue a jurisprudência em: jurisprudência dos conceitos; e jurisprudência dos interesses, ou dos valores legais. A primeira consiste na interpretação da lei pelo critério logicista; preserva o culto da lei e representa a vontade última do legislador. Já pela segunda, disseminada amplamente por IHERING, o juiz vai além da dedução lógica dos conceitos, perquirindo sobre o real interesse do legislador, sempre levando em consideração os fins e os valores pertencentes ao meio social (in AZEVEDO, Luiz Carlos de, Função da jurisprudência nos conflitos entre a lei natural e a lei positiva, in Revista Trimestral de Jurisprudência dos Estados, no 34, 1985, p. 42). SOBRINHO também menciona a classificação acima em texto sobre o poder criador do juiz (in SoBRINHO, Elício de Cresci, O juiz criador do direito e a interpretação razoável, in Revista da Ajuris - Associação dos Juízes do Rio Grande do Sul, $\mathrm{n}^{\circ} 50$, 1990, p. 26). V., também, CruZ E TucCI, José Rogério, Precedente judicial como fonte de direito, 2004, pp. 214/216 e FERRAZ JUNIOR, Tércio Sampaio, Introdução ao estudo do direito - técnica, decisão, dominação, 1994, pp. 80/82.

${ }^{57}$ In NÉRI DA SILVEIRA, José, A função do juiz, in Revista da Ajuris - Associação dos Juízes do Rio Grande do Sul, $\mathrm{n}^{\circ}$ 54, 1992, p. 47. Em sentido semelhante, SANCHES declara que "a interpretá-lo [o direito positivo], deve o juiz entender a moral da época em que elaborado e aquela em que deverá aplicá-lo, à busca de solução que se mostre compatível com as novas circunstâncias, sem refugir à inspiração da norma que interpreta" (in SANCHES, Sydney, O juiz e os valores dominantes: o desempenho da função jurisdicional em face dos anseios sociais por justiça, in Revista dos Tribunais, vol. 669, 1991, p. 238), da mesma forma que SILVA afirma que "na aplicação da lei, há necessidade de atualizar-se o seu conteúdo, cabendo ao intérprete o complexo papel de reavaliação e recriação" (in SILVA, Wilma Nogueira de Araújo Vaz da, O papel do juiz na criação do direito, in Revista do Tribunal Superior do Trabalho, 1987, p. 148).
} 
sentido mais justo do comando jurídico contido na norma legal, dando lugar, não raro, à formulação de um novo comando extraído do anterior. A norma que daí resulta é o produto de uma construção jurisprudencial. Na sua gênese, apresenta-se como resultado da pressão dos fatos sobre a lei que sobre eles incide. É a lei recebendo de volta a força que projetou sobre os fatos."

Como se vê, aquilo que os tribunais aplicam no dia-a-dia não é exatamente a lei em si, mas a particular interpretação que conferem à lei ${ }^{59}$; nitidamente, não vale a máxima da escola da exegese, de acordo com a qual, "para um Estado que tem uma legislação, a jurisprudência dos Tribunais não é senão a própria lei" ${ }^{60}$. Para tanto, devem estar atentos aos fatos e ao tempo em que vivem, não bastando o conhecimento puramente técnico do direito para que se resolvam os conflitos ${ }^{61}$. Encontra-se portanto absolutamente superada a concepção de MONTESQUIEU, de que o juiz, inanimado, é la bouche de la loi ${ }^{62}$.

Nessa linha, para o advogado, mais importante do que conhecer o texto seco da lei é conhecer o que os tribunais, especialmente os superiores, dizem que ela $\operatorname{diz}^{63}$. A

\footnotetext{
${ }^{58}$ In Botelho DE Mesquita, José Ignacio, A súmula da jurisprudência predominante no Supremo Tribunal Federal, in Teses, estudos e pareceres de processo civil, vol. 2, 2005, p. 218. V., em sentido semelhante, afirmando que "toda lei nova é como um sapato novo que se vai amoldando ao pé através das variadas interpretações - disparatadas umas, parciais outras - que recebe", CunHA, Sérgio Sérvulo da, Nota breve sobre o efeito vinculante, in Revista de Informação Legislativa, $\mathrm{n}^{\circ}$ 129, 1996, p. 7.

${ }^{59}$ V., nesse sentido, VASCONCELOS, Arnaldo, Sobre a jurisprudência, in Revista da Faculdade de Direito de Fortaleza, no 29, 1988, p. 145. V., defendendo posicionamento idêntico, afirmando que "não existe lei sem interpretação" e que "a lei é sempre a lei mais a sua interpretação", BotelHO DE MESQUITA, José Ignacio, As novas tendências do direito processual: uma contribuição para o seu reexame, in Teses, estudos e pareceres de processo civil, vol. 1, 2005, p. 304. V., de forma mais ampla, afirmando que "los hechos, la historia, no son nada si no se los interpreta" e que "por la interpretación el mundo de la cultura habla, y con más claridad y fuerza en la medida que el intérprete lo estimula con su talento", FERNANDEZ, Alberto Vicente, Funcion creadora del juez, 1980, p. 71.

${ }^{60}$ In GARCEZ Neto, Martinho, Função criadora da Jurisprudência, in Revista da EMERJ, n 19,2002 , pp. $46 / 47$.

${ }^{61}$ In NÉRI DA SIlveIRA, José, A função do juiz, in Revista da Ajuris - Associação dos Juízes do Rio Grande do Sul, n' 54, 1992, p. 46.

${ }^{62}$ V., no mesmo sentido, TARUFFO, Michele, Senso comum, experiência e ciência no raciocínio do juiz, in Revista Forense, vol. 355, 2001, p. 118. BOTELHO DE MESQUITA explica que o juiz inanimado é apenas uma metáfora e que o que MONTESQUIEU defendia outra coisa não era senão o princípio da independência do juiz (in BOTELHO DE MESQuITA, José Ignacio, As novas tendências do direito processual: uma contribuição para o seu reexame, in Teses, estudos e pareceres de processo civil, vol. 1, 2005, pp. 281/283).

${ }^{63}$ Segundo TARUFFO, "la ricerca e l'uso del precedente giurisprudenziale sono ormai il ferro del mestiere quotidiano del giurista pratico" (in TARUFFO, Michele, Precedente e giurisprudenza, in Rivista Trimestrale di Diritto e Procedura Civile, ano 61, $\mathrm{n}^{\circ}$ 3, 2007, p. 711). V., do mesmo autor, Institutional factors influencing precedents, in Interpreting precedents: a comparative study, 1997, p. 457. V., em sentido semelhante, afirmando que, "no final, o estudo da produção judicial pode ser até mais importante do que a legislativa no panorama de hoje", PARENTE, Eduardo de Albuquerque, Jurisprudência: da divergência à
} 
uma, porque, por melhor conhecedor que seja da produção legislativa, somente tendo esse panorama completo é que o advogado consegue aconselhar bem seu cliente, assessorandoo adequadamente a respeito de suas reais chances de êxito ${ }^{64}$; a duas, porque o precedente possui poderoso papel persuasivo quando mencionado nas peças processuais (hoje em dia, muito mais que a doutrina, em geral ${ }^{65}$ ), sendo capaz inclusive de influenciar julgamentos ${ }^{66}$.

Também por parte dos magistrados é importante o conhecimento da interpretação conferida à lei pelos tribunais a que se encontram funcionalmente subordinados (especialmente pelos tribunais superiores), permitindo-se a aplicação uniforme da norma e garantindo-se isonomia entre os jurisdicionados.

uniformização, 2006, pp. 74/75. V., nessa mesma linha, sustentando que "a interpretação que os Tribunais fazem do Direito Positivo resulta, na ordem prática, tão ou até mais importante do que a própria norma legal em si", MANCUSO, Rodolfo de Camargo, Divergência jurisprudencial e súmula vinculante, 2007, p. 44. Isso porque, como CERNICCHIARO observa: "Os tribunais, notadamente o Supremo Tribunal Federal, quanto à Constituição da República, e o Superior Tribunal de Justiça, relativamente à legislação infraconstitucional, ao firmar entendimento, dizem o Direito. Certo, pode ser modificado. Ter-se-á, pois, sucessão (ideológica) de lei no tempo. Se assim não for entendido, estar-se-á fazendo mero raciocínio formal de hermenêutica. A grande missão do Judiciário (dar justiça-conferir expressão axiológica à lei) não pode ser reduzida a mero jogo de xadrez, vazio de significado!" (in CERNICCHIARO, Luiz Vicente, Jurisprudência, in Revista da Procuradoria Geral do INSS, no 3, 1999, p. 24). V., ainda, VIGLIAR, José Marcelo Menezes, Uniformização de jurisprudência - Segurança jurídica e dever de uniformizar, 2003, p. 68.

${ }^{64}$ Em sentido semelhante, MARINONI afirma que, ao contrário do advogado de common law, o advogado de civil law é obrigado a advertir seu cliente de que determinada lei pode, conforme o juiz sorteado para analisar o caso, ser interpretada em seu favor ou não (in MARINONI, Luiz Guilherme, Princípio da segurança dos atos jurisdicionais, disponível em <http://marinoni. adv.br>, acesso em 16/09/2011, p. 5). Mas isso não significa que o advogado não deva se insurgir contra a jurisprudência que considere equivocada, defendendo ponto de vista próprio, conforme ressalva já feita acima.

${ }^{65}$ LiMONGI FRANÇA afirma que, a partir do momento em que assume a feição de expressão do direito positivo, o que se dá por meio do preenchimento de alguns requisitos, a jurisprudência se coloca num plano superior ao da investigação científica (in LIMONGI FRANÇA, Rubens, Jurisprudência - Seu caráter de forma de expressão de Direito, in Repertório Enciclopédico do Direito Brasileiro, vol. 30, p. 288). No mesmo sentido, GARCEZ NETO sustenta que a jurisprudência hoje merece preferência sobre a doutrina e que o antagonismo que, a princípio, pareceu existir entre elas encontra-se superado, pois " a doutrina tomou a seu cargo justificar as soluções definitivamente admitidas pela jurisprudência" (in GARCEZ NETO, Martinho, Função criadora da Jurisprudência, in Revista da EMERJ, $\mathrm{n}^{\mathrm{o}}$ 19, 2002, pp. 49/50). No entanto, compartilhamos do entendimento de STRECK, no sentido de que importa, sim, o que a doutrina pensa (in STRECK, Lenio Luiz, Crise de paradigmas - Devemos nos importar, sim, com o que a doutrina diz, disponível em <http://www.leniostreck.com.br/site/wp-content/uploads/2011/10/10.pdf>, acesso em 03/12/2011). V., abordando o mesmo tema, idem, Regra ou princípio - Ministro equivoca-se ao definir presunção da inocência, in Consultor Jurídico, disponível em <http://www.conjur.com.br/2011-nov17/ministro-fux-presuncao-inocencia-regra-nao-principio>, acesso em 03/12/2011, p 1. Afinal, "a ninguém se arroga o patrimônio exclusivo do saber, muito menos aos juízes do STF e do STJ" (in RosAS, Roberto, Jurisprudência. Uniformização. Súmula, in Direito processual: inovações e perspectivas - estudos em homenagem ao Ministro Sálvio de Figueiredo Teixeira, 2003, p. 396).

$66 \mathrm{~V}$., no mesmo sentido, PARENTE, Eduardo de Albuquerque, Jurisprudência: da divergência à uniformização, 2006, p. 26. 
Não por simples coincidência, CHARles Evan Hughes, ex-ministro da Suprema Corte norte-americana, afirmou, em discurso proferido em Nova York em 3 de maio de 1907, quando ainda era governador daquele Estado, que: "we are under a Constitution, but the Constitution is what the judges say it is, and the judiciary is the safeguard of our liberty and of our property under the Constitution".

Exatamente no mesmo sentido, o italiano CHIOvendA escreveu que "giuridicamente la volontà concreta della legge è ciò che il giudice afferma essere la volontà concreta della legge" 67 , o que demonstra que nesse particular aspecto a realidade é a mesma para os países de common law e de civil law, a despeito da distinta valoração que cada um dos dois sistemas atribui ao precedente judicial e à jurisprudência.

Da mesma forma, o venezuelano PERNÍA aduziu com bastante propriedade que "el sentido de las normas jurídicas generales es aquél que le atribuyen los jueces u otros funcionarios encargados de aplicarlas concretamente (pero en especial los primeros), por lo que la eficacia de tales normas depende de la interpretación que los mismos - conforme a sus creencias, concepciones e intereses y bajo la influencia de un determinado ambiente histórico-social - les den" ${ }^{, 68}$.

Já no Brasil merece destaque a lição de GRAU, para quem “(...) $a$ interpretação é atividade que se presta a transformar disposições (textos, enunciados) em normas; as normas resultam da interpretação, dizendo o que os intérpretes dizem que elas dizem. O intérprete dotado de poder suficiente para criar as normas jurídicas é o juiz."69.

Dadas essas premissas, é possível sustentar que, ao julgar, o juiz exerce certo poder criador, já que o processo hermenêutico não é mecânico ou estático, tampouco exige subserviência ao texto literal da lei ${ }^{70}$. Esse poder fica ainda mais evidente nos casos

\footnotetext{
${ }^{67}$ In CHIOVENDA, Giuseppe, Istituzioni di diritto processuale civile, vol. 1, 1935, p. 39.

${ }^{68}$ In PERNíA, Hermann Petzold, El juez y la interpretación de la ley, in Revista de la Facultad de Ciencias Juridicas y Politicas, ${ }^{\circ}$ 69, 1988, p. 68.

${ }^{69}$ In GRAU, Eros Roberto, Sobre a produção legislativa e a normativa do direito oficial: o chamado 'efeito vinculante', in Revista da Escola Paulista da Magistratura, vol. 1, n 3, 1997, p. 68.

${ }^{70}$ V., em sentido semelhante, ASCARELLI, Tullio, Problemas das sociedades anônimas e direito comparado, 1945, p. 74, BARBOSA MoReIRA, José Carlos, O juiz e a cultura da transgressão, in Temas de direito processual, $7^{a}$ série, 2001, pp. 259/260, CARLIN, Volnei Ivo, Jurisprudência como função substitutiva do legislador, in Seqüência: estudos jurídicos e políticos, nº 16, 1988, pp. 31/37, CAZETTA JúnIOR, José Jesus, A
} 
em que a lei é omissa, quando o juiz, por força do princípio da indeclinabilidade da jurisdição, deve se pautar na analogia, nos costumes e nos princípios gerais de direito (chamados de mecanismos de integração da ordem jurídica) para dar sua resposta ao pedido do autor (arts. 126, do $\mathrm{CPC}^{71}$, e $4^{\mathrm{o}}$, da LICC) ${ }^{72}$.

ineficácia do precedente no sistema brasileiro de jurisdição constitucional (1891-1993): contribuição ao estudo do efeito vinculante, Tese (Doutorado), 2004, p. 40, COUTURE, Eduardo Juan, Interpretação das leis processuais, 1956, p. 35, FERNANDEZ, Alberto Vicente, Funcion creadora del juez, 1980, p. 71, FreItAS, Juarez, Hermenêutica jurídica: o juiz só aplica a lei injusta se quiser, in Revista da Ajuris - Associação dos Juízes do Rio Grande do Sul, $\mathrm{n}^{\circ}$ 40, 1987, pp. 43/44, GALGANO, Francesco, L'efficacia vincolante del precedente di Cassazione, in Contratto e Impresa, $\mathrm{n}^{\circ}$ 3, 1999, p. 893, GARCEZ NeTO, Martinho, Função criadora da Jurisprudência, in Revista da EMERJ, $\mathrm{n}^{\circ}$ 19, 2002, p. 51, GRAU, Eros Roberto, Eqüidade, razoabilidade e proporcionalidade, in Revista do Advogado, $\mathrm{n}^{\circ} 78$, 2004, p. 28, LEAL, Pastora do Socorro Teixeira, A vinculação da interpretação judicial: aspectos constitucionais, in Revista de Direito Constitucional e Internacional, $\mathrm{n}^{\circ} 43,2003$, p. 211, LIEBMAN, Enrico Tullio, A força criativa da jurisprudência e os limites impostos pelo texto da lei, in Revista de Processo, ${ }^{\circ}$ 43, 1986, p. 59, NOBRE JÚNIOR, Edilson Pereira, $O$ direito processual brasileiro e o efeito vinculante das decisões dos tribunais superiores, in Revista de Processo, $\mathrm{n}^{\circ}$ 105, 2002, p. 88, PARENTE, Eduardo de Albuquerque, Jurisprudência: da divergência à uniformização, 2006, p. 19, PERNíA, Hermann Petzold, El juez y la interpretación de la ley, in Revista de la Facultad de Ciencias Juridicas y Politicas, $\mathrm{n}^{\circ}$ 69, 1988, p. 64, Rosas, Roberto, Jurisprudência. Uniformização. Súmula, in Direito processual: inovações e perspectivas - estudos em homenagem ao Ministro Sálvio de Figueiredo Teixeira, 2003, p. 391, SANTOS, Francisco Cláudio de Almeida, Atividade jurisdicional: princípios gerais aplicáveis, in Revista de Processo, $\mathrm{n}^{\circ}$ 58, 1990, pp. 147/148, SOBRINHO, Elício de Cresci, O juiz criador do direito e a interpretação razoável, in Revista da Ajuris - Associação dos Juízes do Rio Grande do Sul, nº 50, 1990, p. 26, TARUFFO, Michele, Senso comum, experiência e ciência no raciocínio do juiz, in Revista Forense, vol. 355, 2001, p. 118, idem, Legalidade e justificativa da criação judiciária do direito, in Revista da Esmape - Escola Superior da Magistratura de Pernambuco, $\mathrm{n}^{\circ}$ 14, 2001, p. 431, VIGLIAR, José Marcelo Menezes, Uniformização de jurisprudência Segurança jurídica e dever de uniformizar, 2003, pp. 169 e ss., MALLET, Estevão, A jurisprudência sempre deve ser aplicada retroativamente?, in Revista do Advogado, $\mathrm{n}^{\circ}$ 86, 2006, p. 26, MELlo, Pedro Thaumaturgo Soriano de, Um estudo sobre a eqüidade e o poder criador do juiz, in Revista do Tribunal Regional do Trabalho da $8^{a}$ Região, no 50, 1993, pp. 95/102 e SiLVA, Wilma Nogueira de Araújo Vaz da, O papel do juiz na criação do direito, in Revista do Tribunal Superior do Trabalho, 1987, pp. 154/161 - os três últimos analisando o tema também sob a perspectiva do direito do trabalho. Merece destaque, ainda, a lição de CAPPELLETTI, no seguinte sentido: “(...) even when bound to apply a pre-existing law (which is not always the case), the judge is inevitably both an interpreter and a lawmaker. It could not be otherwise, since interpretation always implies a degree of discretion and choice, hence of creativity, a degree which is especially high in certain areas such as constitutional adjudication (...) and adjudication dealing with 'social' and 'diffuse' rights (...)." (in CAPPELLETTI, Mauro, The judicial process in comparative perspective, 1989, pp. 53/54). V., do mesmo autor, Juízes legisladores?, 1993, pp. 20/23. V., criticando decisão do TJDFT, em que a lei foi aplicada "literalmente, de maneira fria e impessoal, ignorando circunstâncias novas", em oposição ao quanto aqui preconizado, CoElHo, Luiz Carlos Galvão, A função supletiva do juiz em casos de omissão da lei, in Revista de Processo, n 45, 1987, pp. 236/239.

${ }^{71}$ Sobre o art. 126, do CPC, a redação primitiva do Código dava a entender que o juiz poderia aplicar as normas legais ou os mecanismos de integração alternativamente, afastando a vinculação do juiz à lei. A redação, que contrariava toda a tradição jurídica brasileira, foi corrigida antes que o Código entrasse em vigor, pela Lei $\mathrm{n}^{\circ} 5.925$, de $1^{\mathrm{o}}$ de outubro de 1973 (in GRECO FILHO, Vicente, Direito processual civil brasileiro, vol. 1, 2000, p. 31).

${ }^{72} \mathrm{~V}$., asseverando que existe uma hierarquia entre a analogia, o costume e os princípios gerais de direito, uma vez que tanto o CPC (art. 126) quanto a LICC (art. $4^{\circ}$ ) se referem a tais realidades na mesma ordem, ARRUda Alvim, José Manoel de, As normas processuais civis, in A norma jurídica, 1980, p. 60. 
Que fique claro que de maneira nenhuma estamos a negar a teoria dualista do ordenamento jurídico, inspirada no Iluminismo e nos valores da Revolução Francesa ${ }^{73}$ e defendida por CHIOVENDA e LIEBMAN $^{74}$, a qual, entende que o direito é preexistente à sentença e que a atividade judicial, portanto, apenas reconhece o direito já concretizado ${ }^{75}$. De fato, o intérprete não cria a norma, o intérprete a expressa; "ela (a norma) preexiste, potencialmente, no invólucro do texto, invólucro do enunciado" "76. Mas ainda assim, ao julgar, o juiz leva em consideração não só os limites traçados pelo texto da lei (e, por vezes, pela analogia, pelos costumes e pelos princípios gerais de direito), como também a realidade social presente no momento da ocorrência dos fatos e do julgamento, exsurgindo daí certo poder criador.

Todos esses fatores influenciam a atividade hermenêutica, que contém em si determinada margem de flexibilização - não houvesse essa margem, os textos legais seriam sempre interpretados da mesma forma e no mesmo sentido, o que está longe de ser real.

E não é só isso; o magistrado carrega seus valores pessoais, suas ideologias, seus pontos de vista, sua história, suas máximas de experiência ${ }^{77}$, de maneira que isso tudo

73 In MARINONI, Luiz Guilherme, Princípio da segurança dos atos jurisdicionais, disponível em <http://marinoni.adv.br>, acesso em 16/09/2011, p. 34.

${ }^{74} \mathrm{~V}$., afirmando que "a lei é eficaz e obrigatória independentemente de uma sentença que lhe determine a aplicação", LIEBMAN, Enrico Tullio, A força criativa da jurisprudência e os limites impostos pelo texto da lei, in Revista de Processo, no 43, 1986, p. 60.

75 À teoria dualista contrapõe-se a teoria unitária do ordenamento jurídico, defendida por CARNELUTTI, segundo a qual o processo e o direito material se fundiriam em uma só unidade e a produção de direitos subjetivos, obrigações e concretas relações jurídicas entre sujeitos seria obra da sentença e não da ocorrência de fatos previstos em normas gerais. DINAMARCO ilustra a preexistência de direitos e obrigações ao processo e à sentença a partir dos seguintes exemplos: “a) a constituição do devedor em mora e fluência de juros a partir de momentos anteriores à sentença que declara a existência da obrigação principal; b) a extinção do direito subjetivo material por prescrição antes da sentença que o reconheça como potencialmente existente; c) a sentença de acolhimento da demanda de investigação de paternidade, colocando o autor como ocupante da situação familiar devida desde o momento em que nascera (se morto o pai antes da sentença, nem por isso o filho assim declarado fica privado de seu quinhão na herança); d) a aquisição do domínio por usucapião, que se consuma no momento em que implementado o requisito do tempus, sendo admissível sua dedução em defesa apesar de não amparado o possuidor por qualquer prévio reconhecimento judicial da prescrição aquisitiva que alega (Súmula 237 STF); e) a admissibilidade da reivindicação do bem sobre o qual exercera posse ad usucapionem por tempo suficiente, tendo-a perdido o possuidor sem ainda haver obtido sentença que declarasse o usucapião a seu favor." (in DINAMARCO, Cândido Rangel, Instituições de direito processual civil, vol. 1, 2004, p. 133).

${ }^{76}$ In GRAU, Eros Roberto, Sobre a produção legislativa e a normativa do direito oficial: o chamado 'efeito vinculante’, in Revista da Escola Paulista da Magistratura, vol. 1, nº 3, 1997, p. 71.

${ }^{77}$ V., sobre esse assunto, SOBRINHO, Elício de Cresci, O juiz e as máximas da experiência, in Revista do Tribunal de Justiça do Estado do Pará, n 46, 1988, pp. 82/96. V., abordando o tema de forma ainda mais 
também influencia as decisões judiciais. Vale lembrar: por mais que não exerça outros cargos e funções (art. 95, par. único, I, da CF), não se dedique a atividade políticopartidária (art. 95, par. único, III, da CF) etc., o juiz é imparcial, mas jamais neutro, porquanto é absolutamente impossível dissociar por completo o homem do profissional ${ }^{78}$, pela própria condição da natureza humana ${ }^{79}$. Nas sábias palavras de Ross: "no cumprimento de sua missão o juiz se acha sob a influência da tradição cultural porque é um ser humano de carne e osso e não um autômato, ou melhor, porque o juiz não é um mero fenômeno biológico, mas também um fenômeno cultural" ${ }^{\prime 2}$.

Embora esse poder criador seja em certa medida semelhante ao do legislador, com ele não se equipara nem se confunde, já que, além de não gerar normas de caráter geral e impessoal, não é amplo, tampouco ilimitado ${ }^{81}$; antes, não deve ser contrário

ampla, TARUFFO, Michele, Senso comum, experiência e ciência no raciocínio do juiz, in Revista Forense, vol. 355, 2001, pp. 101/118.

${ }^{78}$ V., nesse sentido, PERNíA, Hermann Petzold, El problema de la subsunción y la argumentación jurídica, disponível em <http://www.grupologosula.org/dikaiosyne/art/dik017.pdf>, acesso em 25/08/2011, p. 4. É nesse contexto que COUTURE afirma que "todo intérprete é, embora não o queira, um filósofo e um político da lei" (in CoUTURE, Eduardo Juan, Interpretação das leis processuais, 1956, p. 23). É também vendo as coisas dessa perspectiva que CALAMANDREI explica que “(...) ao julgar, a intuição e o sentimento têm frequentemente maior lugar do que à primeira vista parece. Não foi sem razão que alguém disse que sentença derivava de sentir." (in CALAMANDREI, Piero, Eles, os juízes, vistos por um advogado, 1971, p. 145). SANCHES professa entendimento semelhante: "A consciência jurídica de cada juiz depende de sua formação técnica e filosófica, no sentido mais amplo, abrangendo-lhe a cultura jurídica, a visão política, econômica, social, moral, e, até eventualmente religiosa (se professar religião). E como essa formação se dá com enorme diversidade entre as pessoas, oriundas das mais distintas classes econômicas e sociais, é inevitável que, mesmo juízes independentes, que só decidem de acordo com sua consciência jurídica, cheguem, apesar disso, a conclusões parcial ou totalmente divergentes." (in SANCHES, Sydney, O juiz e os valores dominantes: o desempenho da função jurisdicional em face dos anseios sociais por justiça, in Revista dos Tribunais, vol. 669, 1991, p. 239). V., ainda, no mesmo sentido, FERNANDEZ, Alberto Vicente, Funcion creadora del juez, 1980, p. 71 e VIGLIAR, José Marcelo Menezes, Uniformização de jurisprudência Segurança jurídica e dever de uniformizar, 2003, p. 153.

${ }^{79}$ In GRECO FILHO, Vicente, O juiz e a lei, in EDP: Estudos de Direito Público, no 1, 1987, p. 48.

${ }^{80}$ In Ross, Alf, Direito e justiça, 2000, p. 126.

${ }^{81}$ V., nesse sentido, ASCARELl, Tullio, Problemas das sociedades anônimas e direito comparado, 1945, p. 80, BARbosa MoreIRA, José Carlos, O juiz e a cultura da transgressão, in Temas de direito processual, $7^{\mathrm{a}}$ série, 2001, p. 260, CRUZ, José Raimundo Gomes da, A jurisprudência ante a Constituição de 1988, in Revista de Direito Civil, Imobiliário, Agrário e Empresarial, no 54, 1990, p. 96, GALGANO, Francesco, L'efficacia vincolante del precedente di Cassazione, in Contratto e Impresa, $\mathrm{n}^{\circ} 3$, 1999, p. 894 e LEAL, Pastora do Socorro Teixeira, A vinculação da interpretação judicial: aspectos constitucionais, in Revista de Direito Constitucional e Internacional, $n^{\circ} 43,2003$, p. 215. Bastante oportunas são as considerações de LIEBMAN sobre o assunto: "A distinção entre legislação e jurisdição reside, ao que me parece, na qualidade do objeto a respeito do qual o legislador e o juiz são chamados a pronunciar-se: problemas abstratos para o legislador; problemas concretos para o juiz, com a natural conseqüência de que o ato legislativo resolve e é eficaz para uma série de casos futuros, enquanto o ato jurisdicional põe fim a uma controvérsia concreta e é eficaz só em relação a esta. Assim se estabelece claramente a distinção entre ambas as funções, e o juiz, enquanto tem a tarefa de decidir casos concretos com atos eficazes exclusivamente em relação àquele caso isoladamente considerado, nada tem de legislador, mesmo que o seu ato possa ser até certo ponto criativo." 
à lei e, na ausência desta, não deve jamais ofender os três mecanismos de integração da ordem jurídica - analogia, costumes e princípios gerais de direito - mencionados acima ${ }^{82}$.

Como não poderia deixar de ser, há quem sustente que a lei é um mero referencial e que, do confronto entre a lei e o justo, este deve prevalecer ${ }^{83}$. Assim como Botelho DE Mesquita, porém, pensamos que "liberdade de interpretação da lei não é liberdade de interpretação contra a lei" ${ }^{, 44}$ e que, ainda que dura, a lei deve ser observada. O juiz deve sempre interpretá-la com justiça, buscando a melhor decisão possível, mas sem jamais negar a sua aplicação ${ }^{85}$. É inclusive para controlar a legalidade das decisões

(in LieBman, Enrico Tullio, A força criativa da jurisprudência e os limites impostos pelo texto da lei, in Revista de Processo, $\mathrm{n}^{\circ}$ 43, 1986, p. 59).

${ }^{82}$ In LIMONGI FRANÇA, Rubens, Jurisprudência - Seu caráter de forma de expressão de Direito, in Repertório Enciclopédico do Direito Brasileiro, vol. 30, pp. 281/282. V., mencionando que, ao lado da lei, a consciência jurídica também funciona como limite ao exercício da função jurisdicional, CARVALHO, Ivan Lira de, Decisões vinculantes, in Revista Forense, vol. 343, 1998, p. 525. V., nesse mesmo sentido, afirmando que "o único compromisso que têm os juízes é com a lei e a própria consciência", MONTEIRO, Washington de Barros, Da jurisprudência, in Revista Forense, vol. 202, 1963, p. 374.

${ }^{83}$ In Carvalho, Amílton Bueno de, A lei, o juiz, o justo, in Revista da Ajuris - Associação dos Juízes do Rio Grande do Sul, nº 39,1987 , pp. 132/152.

${ }^{84}$ In BotelHo DE MESQUITA, José Ignacio, Da ação civil, in Teses, estudos e pareceres de processo civil, vol. 1, 2005, p. 78. Tratando do princípio da legalidade, o autor ainda esclarece que "um processo cujo desfecho seja impossivel de prever porque dependa exclusivamente da vontade do magistrado é uma garantia apenas na aparência, o que talvez seja pior do que não ter garantia nenhuma com que contar" (in BOTELHO DE MESQUITA, José Ignacio, As novas tendências do direito processual: uma contribuição para o seu reexame, in Teses, estudos e pareceres de processo civil, vol. 1, 2005, p. 292). GUIMARÃES defende posicionamento parecido, ao dispor que: "Deverá o juiz obedecer à lei, ainda que dela discorde, ainda que lhe pareça injusta. É um constrangimento que o princípio da divisão dos poderes impõe ao aplicador." (in GUIMARÃES, Mário, O juiz e a função jurisdicional, 1958, p. 330).

${ }^{85}$ V., nesse sentido, SANCHES, Sydney, $O$ juiz e os valores dominantes: o desempenho da função jurisdicional em face dos anseios sociais por justiça, in Revista dos Tribunais, vol. 669, 1991, p. 239. Nas sempre sábias palavras de GUIMARÃEs: "Dentro dêsse critério, pode o juiz colaborar com o legislador, melhorando, lapidando, valorizando a lei. Não lhe será lícito, porém, assestar baterias contra ela. Não poderá ir para o norte quando o texto legal, certa ou erradamente, lhe haja indicado o sul." (in GUIMARÃES, Mário, O juiz e a função jurisdicional, 1958, p. 332). V., em sentido semelhante, ALMEIDA, Cynthia Rach de, Do impedimento do juiz julgar contra a lei, in Revista Forense, vol. 308, 1989, pp. 287/288, AsCARELLI, Tullio, Problemas das sociedades anônimas e direito comparado, 1945, pp. 77/80, BARBOSA MOREIRA, José Carlos, O juiz e a cultura da transgressão, in Temas de direito processual, $7^{\mathrm{a}}$ série, 2001, p. 260, BOTELHO DE MESQUTTA, José Ignacio, As novas tendências do direito processual: uma contribuição para o seu reexame, in Teses, estudos e pareceres de processo civil, vol. 1, 2005, p. 304, Delgado, José Augusto, Poderes, deveres e responsabilidade do Juiz, in Revista de Processo, no 42, 1986, p. 42, FAGUNDES, Miguel Seabra, Contribuição da jurisprudência à evolução do direito brasileiro, in Revista Forense, vol. 126, 1949, pp. 18/19, FREITAS, Juarez, Hermenêutica jurídica: o juiz só aplica a lei injusta se quiser, in Revista da Ajuris - Associação dos Juizes do Rio Grande do Sul, no 40, 1987, p. 52, Liebman, Enrico Tullio, A força criativa da jurisprudência e os limites impostos pelo texto da lei, in Revista de Processo, $\mathrm{n}^{\circ}$ 43, 1986, p. 60, NÉRI DA SILVEIRA, José, A função do juiz, in Revista da Ajuris - Associação dos Juízes do Rio Grande do Sul, ${ }^{\circ} 54,1992$, p. 44 e TOSTES, Natacha Nascimento Gomes, Uniformização de jurisprudência, in Revista de Processo, $\mathrm{n}^{\circ}$ 104, 2001, p. 198. 
judiciais que serve a obrigação de motivá-las, prevista no art. 93, IX, da $\mathrm{CF}^{86}$ - embora a motivação tenha sido inutilizada, pelo uso cada vez mais frequente da motivação aparente, que o preceito constitucional não conseguiu coibir ${ }^{87}$.

Embora se inclua entre os autores "negativistas", que atribuem pouco ou nenhum valor à jurisprudência como forma de expressão do direito ${ }^{88}$, ao tratar do costume como fonte subsidiária, BEVILAQUA traduz com perfeição o espírito da jurisprudência, conforme segue: "A pratica judiciaria tem por ponto de partida uma sentença, que teve a ventura de provocar imitações. Para proferir o seu julgamento, o magistrado, deante de uma lei deficiente, ou de um preceito legal, que o desenvolvimento da cultura tornou antiquado, absurdo ou injusto, procurou, no acervo de idéas e sentimentos que a educação e o commercio da vida depositaram no seu espirito, os elementos para formular a regra juridica exigida pelo caso sujeito à sua apreciação. Umas vezes ser-lhe-ão auxílio bastante os preceitos da hermeneutica; outras vezes terá de remontar aos principios geraes do direito, e até ao patrimonio mental e emocional dominante no momento histórico e no grupo social, a que pertence. Proferida a sentença, calou no animo dos interessados, provocou applausos dos contemporaneos, porque correspondia à idéa e ao sentimento de justiça das pessôas esclarecidas ou tambem do povo, e, assim lançou o germen de um direito novo, que se affirmará pela reproducção de outras sentenças, que seguirão a trilha aberta por força da imitação e por preguiça mental, mas, principalmente, porque sentirão os juizes, que as proferirem, ser a decisão, que firmou precedente, a expressão do direito latente, funccionando como órgão legislativo o juiz, que o revelou. Assim se estabelece o costume, e a regularidade com que é observado mostra que, como a

\footnotetext{
86 V., nesse sentido, BotelHo DE MesquitA, José Ignacio, O princípio da liberdade na prestação jurisdicional, in Teses, estudos e pareceres de processo civil, vol. 2, 2005, p. 39.

${ }^{87}$ In Botelho De Mesquita, José Ignacio, A revisão do Código de Processo Civil, in Revista do Advogado, $\mathrm{n}^{\circ} 75$, São Paulo, abr. 2004, p. 65, nota de rodapé no 11.

88 In LIMONGI FRANÇA, Rubens, Jurisprudência - Seu caráter de forma de expressão de Direito, in Repertório Enciclopédico do Direito Brasileiro, vol. 30, p. 282. Mas BEVILAQUA reconhece a insuficiência da lei para fornecer solução a todos os conflitos que emergem da vida em sociedade: "A fonte immediata do direito é a lei. Esta, porém, por mais que se alarguem as suas generalizações, por mais que se espiritualize, jamais poderá comprehender a infinita variedade de phenomenos sociaes, que emergem da elaboração constante da vida e vêm pedir garantias ao direito. Desta insufficiencia da lei para dar expressão juridica a todas as necessidades sociaes, que a reclamam, para traduzir o matiz da vida organizada em sociedade, resulta, em primeiro logar, que é forçoso manter, a seu lado, as fontes subsidiarias do direito, que o revelem quando ella fôr omissa, e, em segundo logar, que é indispensavel applicar à lei os processos logicos da analogia e da interpretação, para que os seus dispositivos adquiram a necessaria extensão e flexibilidade." (in BeVILAQUA, Clovis, Theoria geral do direito civil, 1929, pp. 26/27).
} 
lei, elle é a manifestação da mesma força, que organiza a sociedade e dirige aos seus destinos. $" 89$.

A partir do quanto exposto, é inevitável concluir que, "no decurso contínuo da aplicação judicial, torna-se necessário um processo constante de interpretação ou de complementação das normas por parte dos Tribunais (especialmente as mais altas instâncias) ${ }^{, 90}$.

Tal processo é deveras importante e conta com o esforço conjunto da comunidade jurídica em geral, já que a elaboração jurisprudencial não é trabalho exclusivo dos tribunais ${ }^{91}$. São especialmente os causídicos, apoiados na lição da doutrina, que no cotidiano forense criam e aprimoram teses jurídicas e sugerem aos tribunais a adoção de uma ou de outra interpretação, dando ensejo à formação dos precedentes judiciais e, depois, à consolidação da jurisprudência. Estabelece-se, assim, um diálogo constante entre os operadores do direito ${ }^{92}$.

Como o direito é dinâmico e a lei é estática, com o passar do tempo aumenta a distância entre um e outro ${ }^{93}$. A jurisprudência cuida de aproximá-los novamente, permitindo que ambos evoluam e se renovem sem que seja necessária a alteração dos textos legais, a não ser, é claro, nas hipóteses de mudança brusca de orientação ${ }^{94}$. Não

\footnotetext{
${ }^{89}$ In BeVILAQUA, Clovis, Theoria geral do direito civil, 1929, pp. 32/33.
}

${ }^{90}$ In Gustin, Moacyr Barbosa de Sousa, Da Jurisprudência como ciência compreensiva: a dialética do compreender mediante o interpretar, in Revista de Informação Legislativa, nº 125, 1995, p. 210.

91 V., nesse sentido, FAGUNDES, Miguel Seabra, Contribuição da jurisprudência à evolução do direito brasileiro, in Revista Forense, vol. 126, 1949, p. 24.

92 V., no mesmo sentido, referindo-se a texto de Francesco Galgano, Cruz E TuCCI, José Rogério, $O$ diálogo do Dr. Theotonio com a jurisprudência, in Revista do Advogado, $\mathrm{n}^{\circ}$ 81, 2005, pp. 71/72. V., em sentido semelhante, BotelHo DE MESQuitA, José Ignacio, A súmula da jurisprudência predominante no Supremo Tribunal Federal, in Teses, estudos e pareceres de processo civil, vol. 2, 2005, pp. 217/218.

93 V., nesse sentido, Silva, Wilma Nogueira de Araújo Vaz da, O papel do juiz na criação do direito, in Revista do Tribunal Superior do Trabalho, 1987, p. 149. Em sentido parecido, FERNANDEZ afirma que: "La historia demuestra que las necesidades de la vida humana no tardaron en producir el conflicto entre la justicia y la ley. Este conflicto aparece en mayor o menor grado en todas las culturas; pero, indudablemente, el desarrollo de una cultura da nacimiento a problemas nuevos en el ámbito del derecho." (in FERNANDEZ, Alberto Vicente, Funcion creadora del juez, 1980, p. 15).

${ }^{94}$ V., nesse sentido, VASCONCELOS, Arnaldo, Sobre a jurisprudência, in Revista da Faculdade de Direito de Fortaleza, no 29, 1988, pp. 145/147. PEREIRA DOS SANTOS também enxerga na jurisprudência o papel de "grande renovadora do Direito", na medida em que "extirpa, erradica idéias dominantes e retrógradas, apura, depura, corrige e consolida as que têm fundo de ciência e de utilidade geral" (in PEREIRA DOS SANTos, Carlos Maximiliano, Hermenêutica e aplicação do direito, 2007, p. 147). Em sentido semelhante, MARCATO sustenta que "a realidade social é mutável e, em que pese a imutabilidade do teor literal da norma 
poderia ser mais correta a assertiva de FAGUNDES, no sentido de que, "em muitos casos, melhor atende aos simultâneos reclamos da estabilidade social e da sua evolução, o critério de adaptação gradativa através dos arestos, que o da legislação abundante, responsável pela desconfiança da consistência do direito",95.

\section{Importância de uniformizar a jurisprudência}

\subsubsection{Garantia de maior isonomia e segurança jurídica}

Ao exercer seu direito de ação, o autor visa a obter do Estado uma tutela jurisdicional com vistas a solucionar conflito existente no plano de direito material. Com isso, tem interesse na prolação de uma sentença, a qual, após o trânsito em julgado, se tornará imune a impugnações, colocando fim definitivamente ao litígio, qualquer que seja o seu resultado ${ }^{96}$.

O Estado, na qualidade de criador da ordem jurídica, não é indiferente em relação a ela. A bem da verdade, é ele o primeiro interessado na sua realização. Assim, uma vez que o julgamento do Estado interpõe-se entre o exercício do direito de ação e a prestação da atividade jurisdicional, tem ele o escopo primordial de eliminar a incerteza jurídica, concedendo ou não a tutela requerida pelo autor ${ }^{97}$.

jurídica já interpretada anteriormente, ocorre naturalmente a evolução da jurisprudência em consonância com essas mutações sociais, impondo-se, em conseqüência, a revisão das teses jurídicas fixadas - mesmo porque seria absurda a cristalização da orientação original, cerceando a liberdade de movimento e de expansão" (in MARCATO, Antonio Carlos, Incidente de uniformização de jurisprudência, in Apontamentos de direito processual civil, 1996, p. 20).

95 In FAGUndes, Miguel Seabra, Contribuição da jurisprudência à evolução do direito brasileiro, in Revista Forense, vol. 126, 1949, p. 18.

96 Como já tivemos a oportunidade de expor em trabalho anterior: "Até meados do século passado, confrontavam-se duas posições metodológicas a propósito do objetivo do processo. Uma delas, idealizada por CHIOVENDA, entendia que a jurisdição teria a finalidade de atuar a vontade concreta da lei, realizando o direito na prática. Já a outra, defendida por CARNELUTTI, afirmava que o escopo do processo seria a justa composição da lide, haja vista a insuficiência do direito material para tal fim. Em época mais recente, sobreveio, no Brasil, a teoria de DINAMARCo, segundo a qual o sistema processual deve ser observado pelo ângulo 'externo e metajurídico', investigando-se os 'substratos sociais, políticos e culturais que legitimam sua própria existência e o exercício da jurisdição pelo Estado’ (DINAMARCO, Cândido Rangel, Instituições de direito processual civil, vol. 1, 2004, pp. 125/126). Assim, para o referido autor, 'o escopo de pacificar pessoas mediante a eliminação de conflitos com justiça é, em última análise, a razão mais profunda pela qual o processo existe e se legitima na sociedade' (idem, ibidem, p. 128)." (in LOMBARDI, Mariana Capela, Da coisa julgada civil - limites subjetivos e extensão a terceiros, Dissertação (Mestrado), 2008, pp. 9/10, nota de rodapé $\mathrm{n}^{\mathrm{o}} 5$ ).

${ }^{97}$ In Botelho De Mesquita, José Ignacio, Da ação civil, in Teses, estudos e pareceres de processo civil, vol. 1, 2005, p. 99. 
Ocorre que, como já exposto, o nosso sistema jurídico permite - ou ao menos convive com a virtualidade de que isso ocorra - que situações jurídicas análogas sejam julgadas de maneiras diferentes, a depender da interpretação conferida à lei aplicável pelo sujeito ou órgão prolator da decisão ${ }^{98}$. A lei, por sua própria natureza, é geral, abstrata e impessoal; muitas vezes, é integrada ainda por conceitos juridicamente indeterminados e por cláusulas gerais ${ }^{99}$. Natural, portanto, que dê ensejo a interpretações diversas e a leituras até mesmo contraditórias ${ }^{100}$.

A possibilidade de interpretação controvertida da lei é expressamente conhecida, tanto que a Súmula-STF n 343 não admite ação rescisória por ofensa a literal disposição de lei (art. 485, V, do CPC) quando a decisão rescindenda se tiver baseado em texto legal de interpretação controvertida nos tribunais ${ }^{101}$; na mesma linha, a Súmula-STF n 400 não admite recurso extraordinário com fundamento em violação a dispositivo da Constituição (ou à letra de tratado ou lei federal ${ }^{102}$ ) quando a decisão tiver dado razoável interpretação à lei, ainda que não seja a melhor.

98 V., no mesmo sentido, MANCUSO, Rodolfo de Camargo, Divergência jurisprudencial e súmula vinculante,
2007, p. 25. Como bem pondera KARAN, “o Direito tem por objeto uma realidade contingente e a absoluta
singularidade da pessoa humana, não podendo ter métodos iguais aos das ciências exatas" (in KARAN,
Munir, A função judicial, in Revista de Processo, no 42,1986, p. 179).
99 V., esmiuçando o assunto, MARINONI, Luiz Guilherme, O precedente na dimensão da igualdade,
disponível em <http://marinoni.adv.br>, acesso em 16/09/2011, pp. $11 / 18$ e PARENTE, Eduardo de
Albuquerque, Jurisprudência: da divergência à uniformizaçâa, 2006, pp. $46 / 52$. V., denominando essas
normas de "normas elásticas", GALGANO, Francesco, L'efficacia vincolante del precedente di Cassazione, in Contratto e Impresa, $\mathrm{n}^{\circ} 3,1999$, pp. 890/891.

${ }^{100}$ COUTURE também constata a dificuldade a que nos reportamos: "E não ocorre apenas o fato de que as palavras têm significações variáveis e ondulantes, naturalmente imprecisas, que tornam virtualmente impossível uma obra exata de interpretação; ocorre, além disso, que a lei se exprime não só em palavras como também em conceitos. Nêles, combinaçães quase misteriosas de vocábulos, os possíveis significados são ilimitados. À incerteza natural de cada têrmo se junta a incerteza natural de suas combinações recíprocas." (in COUTURE, Eduardo Juan, Interpretação das leis processuais, 1956, p. 17).

${ }^{101}$ O Supremo Tribunal Federal tem entendido que o enunciado dessa súmula não se aplica a questões constitucionais (in YARSHELl, Flávio Luiz, A Reforma do Judiciário e a promessa de "duração razoável do processo", in Revista do Advogado, $\mathrm{n}^{\circ} 75,2004$, p. 29). CAMBI caracteriza a vedação à ação rescisória nessa situação como "kafkaniana" (in CAMBI, Eduardo, Jurisprudência lotérica, in Revista dos Tribunais, vol. 786, 2001, p. 111). DINAMARCO retrata como cínico um sistema que permite decisões desiguais para casos substancialmente iguais e depois impede a rescisão do julgado sob o argumento de que fora proferido em meio a uma jurisprudência vacilante nos tribunais (in DINAMARCO, Cândido Rangel, Decisões vinculantes, in Revista de Processo, $\mathrm{n}^{\circ}$ 100, 2000, p. 171). V., tratando amplamente do assunto, artigo de nossa co-autoria, BotelHo De Mesquita et. al., Balanço de uma polêmica: a Súmula-STF 343, in Direito processual civil, vol. 2, 2011, pp. 343/368.

102 A Súmula-STF no 400 foi editada em 1964, sob a égide da Constituição Federal de 1946, e ainda permanece em vigor. Apesar de não ter sido formalmente cancelada pelo Supremo Tribunal Federal, entendemos que o enunciado não se coaduna com os valores atualmente presentes no nosso ordenamento. V., 
Mas “o fato de o sistema 'tolerar' decisões diferentes acerca de situações absolutamente idênticas não significa que este fenômeno seja desejável" ${ }^{\text {103 }}$. Pelo contrário, a situação que se forma beira o insuportável, na medida em que provoca nos jurisdicionados insegurança jurídica. Não é crível que, apesar de a lei ser igual para todos, para o mesmo conflito jurídico uns possam obter tutela jurisdicional e outros não, a depender da sorte (ou do azar) da parte na distribuição dos respectivos processos ${ }^{104}$. Tratase praticamente de uma piada de mau gosto ${ }^{105}$. Toda essa incerteza gera desconfiança em relação ao Poder Judiciário e à administração da justiça em geral, culminando em séria perda de autoridade ${ }^{106}$.

Essa situação se fez ainda mais evidente após a promulgação da Constituição de 1988 (a chamada "Constituição cidadã”), que disseminou na população a ideia de cidadania ${ }^{107}$. Consciente o povo da titularidade de seus direitos, aumentaram os litígios de conotação individual e coletiva, inclusive para a satisfação de pretensões que há duas ou três décadas não se pensava serem tuteláveis (ex.: danos morais, direitos do

criticando a Súmula-STF no 400, a qual considera "surpreendente", com inegável razão, NEGRÃO, Theotonio, O novo recurso extraordinário: perspectivas na Constituição de 1988, in Revista do Advogado, $\mathrm{n}^{\circ}$ 81, 2005 , pp. 15/16. WAMBIER noticia que a sua incidência vem sendo, felizmente, cada vez mais frequentemente afastada pelo STJ (in WAMBIER, Teresa Arruda Alvim, Os princípios constitucionais da legalidade e da isonomia, como inspiradores da compreensão de algumas recentes alterações do direito positivo Constituição Federal e CPC, in Revista do Advogado, $\mathrm{n}^{\circ}$ 88, 2006, p. 189). FERNANDES, por outro lado, afirma que é comum encontrar na jurisprudência mais atual do STF a aplicação do enunciado em matéria constitucional (in FERNANDES, Sérgio Ricardo de Arruda, A influência da jurisprudência dos tribunais no julgamento realizado na instância revisora, in Revista de Direito do Tribunal de Justiça do Estado do Rio de Janeiro, $\mathrm{n}^{\circ}$ 67, 2006, p. 64, nota de rodapé $\mathrm{n}^{\circ} 7$ ).

${ }^{103}$ In MedinA, José Miguel Garcia, WAMBIER, Luiz Rodrigues e WAMBIER, Teresa Arruda Alvim, A súmula vinculante, vista como meio legítimo para diminuir a sobrecarga de trabalho dos tribunais brasileiros, in Revista do Advogado, no 92, 2007, p. 13. V., exatamente no mesmo sentido, WAMBIER, Teresa Arruda Alvim, Os princípios constitucionais da legalidade e da isonomia, como inspiradores da compreensão de algumas recentes alterações do direito positivo - Constituição Federal e CPC, in Revista do Advogado, $\mathrm{n}^{\circ}$ 88, 2006, p. 189.

${ }^{104} \mathrm{O}$ sorteio do julgador deveria ser um modo de se aperfeiçoar o princípio do juiz natural, ao invés de se tornar fonte de incertezas (in PARENTE, Eduardo de Albuquerque, Jurisprudência: da divergência à uniformização, 2006, p. 35, nota de rodapé $\left.\mathrm{n}^{\circ} 11\right)$.

105 In MARINONI, Luiz Guilherme, A transformação do civil law e a oportunidade de um sistema precedentalista para o Brasil, disponível em <http://marinoni.adv.br>, acesso em 16/09/2011, p. 5.

106 Afinal, "a confiança é a medida da autoridade" (in BotELHO DE MESQUITA, José Ignacio, A crise do Judiciário e o processo, in Teses, estudos e pareceres de processo civil, vol. 1, 2005, p. 256).

${ }^{107} \mathrm{~V}$., afirmando que o volume crescente de processos é problema grave que aflige todos os países nesse novo século, TARZIA, Giuseppe, La durata del processo civile e la tutela dei deboli, in Rivista di Diritto Processuale, ano 60, $\mathrm{n}^{\mathrm{o}}$ 2, 2005, p. 317. 
consumidor) ${ }^{108}$, gerando verdadeira "inclusão judicial"109 e impulsionando, com isso, o choque entre decisões conflitantes.

$\mathrm{Na}$ apresentação de livro que trata do assunto em foco, CARMONA obtempera com razão: "Conviver com a divergência torna-se, nos dias que correm, completamente insuportável. A afirmação, à primeira vista politicamente incorreta, faz todo o sentido para os operadores do direito e para todos aqueles que acreditam na função educativa do processo: sempre que os tribunais discordam sobre a interpretação da lei, sempre que os órgãos fracionários das cortes dissentem quanto à aplicação da lei, sempre que os juízes destoam dos tribunais aos quais, funcionalmente, estão subordinados, instaura-se uma crise, que acaba afetando, direta ou indiretamente, toda a sociedade. Cumpre ao Estado, portanto, na busca de um processo que pretenda cumprir, entre outros escopos, o educativo, estimular os meios de sanar esta verdadeira perturbação que o dissenso tende a provocar." 110.

E o problema não é de hoje. Como será visto mais adiante, há mais de século se cogita no Brasil de instrumentos voltados à uniformização da jurisprudência, sendo possível localizar nos mais diversos tribunais do país precedentes antigos exaltando preocupação com o assunto. Em voto de vinte anos atrás, o Min. SÁlvio DE FiGUEIREDO TEIXEIRA já alertava para os males da situação decorrente da discrepância de entendimentos entre os tribunais: “(...) perante jurisprudência incerta, ninguém está seguro do seu direito" $" 111$.

Logo, ao mesmo tempo em que aos juízes deve ser garantida a liberdade de interpretarem os textos legais, tal liberdade não deve ser absoluta, porque isso daria ensejo

\footnotetext{
${ }^{108}$ In CRUZ E TUCCI, José Rogério, O problema da lentidão da justiça e a questão da súmula vinculante, in Revista do Advogado, $\mathrm{n}^{\circ}$ 75, 2004, p. 75. V., no mesmo sentido, CARVAlHO, Ivan Lira de, Decisões vinculantes, in Revista Forense, vol. 343, 1998, p. 524, NOBRE JÚNIOR, Edilson Pereira, O direito processual brasileiro e o efeito vinculante das decisões dos tribunais superiores, in Revista de Processo, $\mathrm{n}^{\circ}$ 105, 2002, $\mathrm{p}$. 64 e TOSTES, Natacha Nascimento Gomes, Uniformização de jurisprudência, in Revista de Processo, $\mathrm{n}^{\circ}$ 104, 2001, p. 215.

109 In DONOSO, Denis, Um novo princípio contraditório. Análise da constitucionalidade das técnicas de massificação de soluções e da escalada da importância do precedente judicial, in Revista Dialética de Direito Processual, $\mathrm{n}^{\circ}$ 73, 2009, p. 25.

${ }^{110}$ In CARMONA, Carlos Alberto, Apresentação, in PARENTE, Eduardo de Albuquerque, Jurisprudência: da divergência à uniformização, 2006, p. ix.

${ }^{111}$ STJ, Quarta Turma, REsp no 14.945-MG, rel. Min. SÁLVIO DE FIGUEIREDO TEIXEIRA, j. 17/03/1992.
} 
a arbitrariedades e, consequentemente, à proliferação da dita jurisprudência lotérica, de todo indesejável e nociva ao sistema. Acima de tudo, a ordem jurídica deve ser coerente e, como é óbvio, não é ela formada apenas pelas leis, mas também pelas decisões judiciais ${ }^{112}$.

Como com defende TOSTES, ela própria integrante da magistratura de carreira estadual fluminense, "a independência do magistrado deve ser utilizada para reverter-se em prol da população, cujo destino está em suas mãos, e não para ser fonte que jorra vaidade pessoal, com a satisfação íntima de que: 'sou integrante do grupo do eu sozinho, e decido como eu quero, porque sou independente","113.

Sobressai daí a contribuição primordial da uniformização da jurisprudência, qual seja, garantir entendimento uniforme sobre o texto da lei. A conclusão é redundante, mas é importante que seja dita.

Deve-se ter em mente que a uniformização é não só um direito do jurisdicionado, mas acima de tudo um dever do Estado, que serve essencialmente ao seu próprio interesse em manter o império de suas leis e o respeito às suas instituições ${ }^{114}$. Ainda que o pensamento aqui esposado não esteja livre de críticas ${ }^{115}$, nos parece que o Poder Judiciário, embora formado por inúmeros sujeitos, compõe uma estrutura única, que deve ter visão uniforme sobre determinados temas. Afinal, "antes jurisprudência errada, mas uniforme, do que jurisprudência incerta. Diante de jurisprudência uniforme cada um

\footnotetext{
${ }^{112}$ In MARINONI, Luiz Guilherme, Precedentes obrigatórios, disponível em <http://marinoni.adv.br〉, acesso em 16/09/2011, p. 2.

${ }^{113}$ In TOSTES, Natacha Nascimento Gomes, Uniformização de jurisprudência, in Revista de Processo, $\mathrm{n}^{\circ}$ 104, 2001, p. 197.

${ }^{114}$ In Botelho DE MESQUITA, José Ignacio, A súmula da jurisprudência predominante no Supremo Tribunal Federal, in Teses, estudos e pareceres de processo civil, vol. 2, 2005, p. 217.

115 BARBOSA MOREIRA, por exemplo, já teve dúvidas sobre "em que medida é realmente desejável que um órgão superior fixe o entendimento a ser adotado de maneira uniforme pelos outros órgãos judiciais na aplicação deste ou daquele texto legal". Segundo o autor: "De certas normas todos reconhecem com facilidade que devem ser aplicadas do mesmo modo em todo o território nacional; entre elas, sem dúvida, em linha de princípio, as normas constitucionais. Já com relação a outras, pode mostrar-se mais aconselhável dar espaço à porção menor ou maior de flexibilidade interpretativa, capaz de levar em conta variáveis regionais ou locais, cuja luz também se justifique uma variação nas soluções. É o que sucede, por exemplo, com disposições legais que se valham de conceitos jurídicos indeterminados - como 'bons costumes', 'conduta desonrosa', 'elevado valor' e outros cuja concretização se sujeite à influência de fatores culturais dificilmente redutíveis à uniformidade, sobretudo em país com as dimensões e as desigualdades do nosso." (in BARBOSA MOREIRA, José Carlos, Súmula, jurisprudência, precedente: uma escalada e seus riscos, in Revista Síntese de Direito Civil e Processual Civil, no 35, 2005, p. 15).
} 
sabe com o que se pode contar; perante jurisprudência incerta, ninguém está seguro do seu direito." 116 .

Nesse contexto, o juiz deve deixar de lado sua vaidade e satisfação pessoal e, com humildade, conscientizar-se de que faz parte de uma estrutura hierarquicamente organizada. Nessa toada, possui o dever de seguir o entendimento dos tribunais a que se encontra funcionalmente subordinado, sob pena de impor ao jurisdicionado uma espécie de sanção ${ }^{117}$. Mesmo que com isso tenha que sacrificar suas convicções pessoais, ou suas convicções sociais (como a política e a religiosa) ${ }^{118}$, deve, na medida do possível, acompanhar o entendimento prevalecente em prol da unicidade de interpretação ${ }^{119}$.

Defendendo posicionamento idêntico, o Min. Humberto Gomes DE BARROS, em determinado julgamento, ressaltou o papel atribuído ao Superior Tribunal de Justiça na interpretação da lei federal, conforme se observa do seguinte trecho: "Tenho em mim a firme convicção de que o Superior Tribunal de Justiça foi concebido para um escopo especial: orientar a aplicação da lei federal e unificar-lhe a interpretação, em todo o Brasil. Se assim ocorre, é necessário que sua jurisprudência seja observada, para se manter firme e coerente. Assim sempre ocorreu em relação ao Supremo Tribunal Federal, de quem o STJ é sucessor, nesse mister. Em verdade, o Poder Judiciário mantém sagrado compromisso com a justiça e a segurança. Se deixarmos que nossa jurisprudência varie ao sabor das convicções pessoais, estaremos prestando um desserviço a nossas instituições. Se nós - os integrantes da Corte - não observarmos as decisões que ajudamos a formar, estaremos dando sinal, para que os demais órgãos judiciários façam o mesmo. Estou certo

\footnotetext{
116 In RoSAS, Roberto, Jurisprudência. Uniformização. Súmula, in Direito processual: inovações $e$ perspectivas - estudos em homenagem ao Ministro Sálvio de Figueiredo Teixeira, 2003, p. 387.

117 V., nesse sentido, Vigliar, José Marcelo Menezes, Uniformização de jurisprudência - Segurança jurídica e dever de uniformizar, 2003, p. 34.

118 V., nesse sentido, VigliaR, José Marcelo Menezes, Uniformização de jurisprudência - Segurança jurídica e dever de uniformizar, 2003, p. 42.

${ }^{119} \mathrm{~V}$., em sentido semelhante, arguindo que "o juiz que contraria a posição de tribunal superior, ciente de que a este cabe a última palavra, pratica ato que, ao atentar contra a lógica do sistema, significa desprezo ao Poder Judiciário e desconsideração para com os usuários do serviço jurisdicional”, MARINONI, Luiz Guilherme, A transformação do civil law e a oportunidade de um sistema precedentalista para o Brasil, disponível em <http://marinoni.adv.br>, acesso em 16/09/2011, p. 4.
} 
de que, em acontecendo isso, perde sentido a existência de nossa Corte. Melhor será extingui-la." ${ }^{120}$.

Assim, ainda que não seja factível eliminar-se plenamente a dúvida interpretativa, se pode e se deve minimizar, na medida do possível, as divergências interpretativas acerca dos textos de lei, colaborando-se para a proteção da previsibilidade, indispensável à segurança jurídica ${ }^{121}$.

Não por isso, evidentemente, o magistrado deve sentir-se proibido de manifestar em seus votos e decisões suas razões particulares, seus pontos de vista. Pelo contrário, é até saudável que o faça, para fornecer subsídios para a revisão do pensamento prevalecente, se for o caso ${ }^{122}$. O próprio STJ já decidiu que “o juiz que, ressalvando entendimento pessoal, segue a jurisprudência do Tribunal, não incorre em contradição, nem prejudica a unanimidade do julgamento; apenas subordina seu ponto de vista, vencido, à orientação prevalente, nisso contribuindo para a estabilidade da jurisprudência, que é do Tribunal, e não do juiz,"123.

Outrossim, é importante que fique claro que não se reprime aqui o magistrado que, após examinar o caso posto sob a sua apreciação, percebe que a hipótese é diversa daquelas que deram origem aos precedentes, que portanto não se aplicam ao caso sub judice. Tampouco se reprime o magistrado que procura nova interpretação com o fim de fazer evoluir o direito. Pelo contrário, o debate é sempre bem-vindo, com o propósito de incentivar o desenvolvimento do direito e a adequada percepção de seus institutos. Nesse sentido, os tribunais devem sempre estar preocupados em rever seus posicionamentos, modificando-os quando alterados os fatores que deram causa à formação dos precedentes judiciais que os abrigam ${ }^{124}$.

\footnotetext{
${ }^{120}$ STJ, Corte Especial, AgRg nos EREsp n ${ }^{\circ}$ 228.432/RS, rel. Min. Humberto Gomes De Barros, j. $01 / 02 / 2002$.

121 In MARINONI, Luiz Guilherme, Princípio da segurança dos atos jurisdicionais, disponível em <http://marinoni.adv.br>, acesso em 16/09/2011, p. 6.

${ }^{122}$ In TOSTES, Natacha Nascimento Gomes, Uniformização de jurisprudência, in Revista de Processo, $\mathrm{n}^{\circ}$ 104, 2001, p. 212.

${ }^{123}$ STJ, Segunda Turma, EDcl em REsp no 20.979/PE, rel. Min. ARI PARGENDLER, j. 16/05/1996.

${ }^{124}$ In CAMBI, Eduardo, Jurisprudência lotérica, in Revista dos Tribunais, vol. 786, 2001, p. 119.
} 
O que se pretende evitar é que, mantido o contexto histórico, cultural, político, social e econômico, os jurisdicionados fiquem à mercê de entendimentos diversos, muitas vezes antagônicos, fundados em razões de ordem meramente subjetiva do julgador, comprometendo a unidade do direito ${ }^{125}$. Combate-se, assim, o juiz revolucionário, que mesmo ciente do entendimento pacificado insiste em dissentir dele, prestando verdadeiro desserviço à comunidade ${ }^{126}$.

A passagem de CALAMANDREI sobre o assunto é clássica e elucida todas as questões a respeito do tratamento a ser conferido ao tema: "Si deve in secondo luogo ricordare che, cuando si parla dei vantaggi derivanti dalla unità del diritto obiettivo nello Stato si intende sempre riferirsi alla unità nello spazio, non già alla unità nel tempo. Uniformità del diritto non vuol dire immobilità del diritto, il quale, come tutte le manifestazioni dello spirito umano, si svolge ininterrottamente attraverso un continuo divenire. Il principio della uniformità del diritto obiettivo si deve pertanto inevitabilmente riportare a un determinato momento storico (...)."127 (destaque nosso).

Concordamos também com o que, no Brasil, propõe BOTELHO DE MESQUITA: “A divergência na interpretação da lei não é, em si mesma, nenhum mal. Basta considerar que a evolução da jurisprudência se processa mercê de interpretações novas que se contrapõem às antigas. O que é um mal é a decisão errônea ou a divergência que não corresponda a nenhuma evolução dos fatos que presidiram a criação da norma interpretada.". E assim prossegue o referido autor, ao abordar em tópico subsequente o assunto das interpretações sumuladas: "O que se visa a impedir é que prospere a divergência fundada em erro ou em razões de ordem meramente subjetiva; não a evolução

\footnotetext{
${ }^{125} \mathrm{~V}$., afirmando que "o problema da uniformização da jurisprudência não se confunde, pois, com o da evolução do direito interpretado pelos tribunais", BUZAID, Alfredo, Uniformização da jurisprudência, in Revista da Ajuris - Associação dos Juízes do Rio Grande do Sul, no 34, 1985, p. 192. V., no mesmo sentido, MARCATO, Antonio Carlos, Incidente de uniformização de jurisprudência, in Apontamentos de direito processual civil, 1996, p. 20.

${ }^{126}$ V., no mesmo sentido, Tostes, Natacha Nascimento Gomes, Uniformização de jurisprudência, in Revista de Processo, $\mathrm{n}^{\circ}$ 104, 2001, p. 197.

${ }^{127}$ In CALAMANDreI, Piero, La cassazione civile, vol. 2, 1920, pp. 51/52. V., no mesmo sentido, inclusive invocando a lição do mestre italiano, BUZAID, Alfredo, Uniformização da jurisprudência, in Revista da Ajuris - Associação dos Juízes do Rio Grande do Sul, no 34, 1985, p. 212.
} 
ordenada da jurisprudência, ditada pela modificação das circunstâncias objetivas que presidiram a criação da súmula." ${ }^{28}$.

Na década de 1950, GUIMARÃES formulava alerta em sentido muito parecido, que, de tão atual, parece ter sido concebido para os dias de hoje: "Manter quanto possível a jurisprudência, será obra de boa política judiciária, porque inspira no povo confiança na Justiça. Não concebem os leigos que o certo na decisão de hoje se repute errado na sentença de amanhã. Mas não devemos erigi-la em tabu. Não devemos fechar os tribunais à penetração de idéias novas. (...) Recapitulando e resumindo: acate a magistratura a jurisprudência, mas não se escravize a ela. Acolha as doutrinas novas, quando convier, sem exageros, também." ${ }^{129}$.

Uma vez uniformizada a jurisprudência e dificultada a dissensão por parte desses magistrados "rebeldes", a tendência é que se elimine, ainda que não por completo, o descompasso entre as leis e as situações da vida, tornando o direito previsível (criando legítimas expectativas e induzindo comportamentos ${ }^{130}$ ) e não um jogo de azar, em que se pode tanto ganhar quanto perder. Nessa medida, concordamos quando MARINONI afirma que "apenas o sistema que privilegia os precedentes pode garantir a coerência do direito, a previsibilidade e a igualdade"131.

E, quanto maior a coerência do direito, a previsibilidade e a isonomia entre os jurisdicionados, maior a segurança jurídica, a qual - nunca é demais lembrar - constitui "uma das finalidades mais relevantes de qualquer sistema jurídico, em todos os tempos e

\footnotetext{
${ }^{128}$ In Botelho De MesquitA, José Ignacio, Uniformização da jurisprudência (esboço de substitutivo ao Projeto de Lei 3.804/93), in Teses, estudos e pareceres de processo civil, vol. 2, 2005, pp. 240/241.

${ }^{129}$ In GUIMARÃES, Mário, O juiz e a função jurisdicional, 1958, pp. 327/328.

${ }^{130}$ Conforme MARINONI, "o cidadão deve saber, na medida do possível, não apenas os efeitos que as suas ações poderão produzir, mas também como os terceiros poderão reagir diante delas. Note-se, contudo, que a previsibilidade das conseqüências oriundas da prática de conduta ou ato pressupõe univocidade em relação à qualificação das situações jurídicas, o que torna esses elementos indissociavelmente ligados." (in MARINONI, Luiz Guilherme, Princípio da segurança dos atos jurisdicionais, disponível em <http://marinoni.adv.br>, acesso em 16/09/2011, p. 3).

${ }^{131}$ In MARINONI, Luiz Guilherme, Precedentes obrigatórios, disponível em <http://marinoni.adv.br>, acesso em 16/09/2011, p. 3.
} 
nos mais diferentes povos" ${ }^{\prime 132}$. Consequentemente, maior também a confiança depositada no Poder Judiciário, incrementando-se o prestígio das instituições judiciárias em geral.

\subsubsection{Diminuição do tempo do litígio (duração razoável do processo?)}

Nossa principal preocupação é com a garantia de maior isonomia e segurança jurídica aos jurisdicionados, como exposto no tópico anterior. Não se pode ignorar, porém, que a jurisprudência, quando uniformizada, tende a diminuir o tempo de duração dos litígios ${ }^{133}$ - indicado, por essa expressão, o intervalo de tempo entre a propositura da ação e a sua duração ${ }^{134}$-, proporcionando maior celeridade no trâmite dos $\operatorname{processos}^{135}$.

A garantia da tutela jurisdicional tempestiva encontra hoje previsão explícita na Constituição Federal, com a inclusão do inciso LXXVIII ("a todos, no âmbito judicial e administrativo, são assegurados a razoável duração do processo e os meios que garantam a celeridade de sua tramitação") em seu art. $5^{\circ}$, pela EC n ${ }^{\circ} 45 / 2004^{136}$. Longe de constituir novidade no ordenamento ${ }^{137}$, a alteração constitucional trouxe conscientização

132 In MALlET, Estevão, A jurisprudência sempre deve ser aplicada retroativamente?, in Revista do Advogado, n 86, 2006, p. 28. V., em sentido semelhante, CAZETTA JúNIOR, José Jesus, A ineficácia do precedente no sistema brasileiro de jurisdição constitucional (1891-1993): contribuição ao estudo do efeito vinculante, Tese (Doutorado), 2004, p. 43.

${ }^{133}$ V., amplamente sobre o tempo de duração dos litígios e questões análogas, CRUZ E TuCCI, José Rogério, Tempo e processo: uma análise empírica das repercussões do tempo na fenomenologia processual (civil e penal), 1997, DUARTE, Ricardo Quass, O tempo inimigo no processo civil brasileiro, 2009, PEREIRA JUNIOR, Ricardo, $O$ desafio moderno e o Judiciário: ordem jurídica, tempo, espaço e atuação da justiça, Tese (Doutorado), 2010, entre outros.

${ }^{134}$ In VigORITI, Vincenzo, Notas sobre o custo e a duração do processo civil na Itália, in Revista de Processo, $\mathrm{n}^{\circ} 43,1986$, p. 145.

135 V., em sentido semelhante, VIGLIAR, José Marcelo Menezes, Uniformização de jurisprudência Segurança jurídica e dever de uniformizar, 2003, p. 162.

${ }^{136}$ Dentro do ideal de buscar a razoável duração do processo e a celeridade de sua tramitação, a EC $\mathrm{n}^{\circ}$ 45/2004 implementou três importantes medidas no art. 93, da CF: a primeira foi a inclusão do inciso XII, proibindo férias coletivas nos juízos e tribunais de segundo grau, funcionando, nos dias em que não houver expediente forense normal, juízes em plantão permanente; a segunda foi a inclusão do inciso XV, determinando a distribuição imediata de processos, em todos os graus de jurisdição; a terceira foi a inclusão da alínea "e" no inciso II, estipulando que não será promovido o juiz que, injustificadamente, retiver autos em seu poder além do prazo legal, não podendo devolvê-los ao cartório sem o devido despacho ou decisão. V., tratando das alterações acima, YARSHELl, Flávio Luiz, A Reforma do Judiciário e a promessa de “duração razoável do processo", in Revista do Advogado, no 75, 2004, pp. 30/31.

137 A Convenção Americana sobre Direitos Humanos (Pacto de São José da Costa Rica), de 1969, incorporada na ordem jurídica brasileira pelo Decreto n 678/1992, já dispunha no art. 8.1 que "toda pessoa tem direito a ser ouvida com as devidas garantias e dentro de um prazo razoável por um juiz ou tribunal competente, independente e imparcial, instituído por lei anterior, na defesa de qualquer acusação penal 
geral no sentido de que a razoável duração do processo e a celeridade na sua tramitação são direitos de todos os cidadãos ${ }^{138}$. Finalmente chegou a hora de o tempo do processo "tomar o seu efetivo lugar dentro da ciência processual, pois este não pode deixar de influir sobre a elaboração dogmática preocupada com a construção do processo justo ou com aquele destinado a realizar concretamente os valores e os princípios contidos na Constituição da República"139.

Atualmente, portanto, tem-se a exata noção de que o acesso à ordem jurídica justa só é realmente possível a partir de um processo rápido, sem desperdício de tempo e sem dilações indevidas. Ao lado da efetividade do resultado, é imperioso que a decisão do processo seja tempestiva ${ }^{140}$ - e também para esse fim, a nosso ver, contribui a jurisprudência uniforme.

Não somos ingênuos e alienados a ponto de crer que a jurisprudência uniforme é suficiente para garantir o alcance da tão almejada duração razoável do

contra ele formulada, ou para a determinação de seus direitos e obrigações de ordem civil, trabalhista fiscal ou de qualquer outra natureza". O art. 37, caput, da CF, por força da alteração introduzida pela EC $\mathrm{n}^{\circ}$ 19/1998, também já erigia a eficiência como um dos princípios basilares da administração pública - a propósito do assunto, MORAES qualifica o princípio da eficiência como "o que impõe a persecução do bem comum, por meio do exercício de suas competências de forma imparcial, neutra, transparente, participativa, eficaz, sem burocracia e sempre em busca da qualidade, primando pela adoção dos critérios legais e morais necessários para a melhor utilização possível dos recursos públicos, de maneira a evitar desperdícios e garantir uma maior rentabilidade social" (in MORAES, Alexandre de, Consumidor e direito à prestação jurisdicional eficiente e célere, in Revista do Advogado, $\mathrm{n}^{\circ}$ 89, 2006, p. 14). Segundo CRUZ E TUCCI, a garantia do due process (art. $5^{\circ}$, LIV, da $\mathrm{CF}$ ) também já pressupunha o direito ao rápido desfecho do litígio ou da persecutio criminis (in CRUZ E TUCCI, José Rogério, Ineficiência da administração da justiça e dano moral, in Questões práticas de processo civil, 1998, pp. 105/106).

${ }^{138}$ Mesmo antes da alteração constitucional, CRUZ E TUCCI defendia a ideia de que são "perfeitamente indenizáveis os danos material e moral originados da excessiva duração do processo, desde que o diagnóstico da morosidade tenha como causa primordial o anormal funcionamento da administração da justiça" (in CRUZ E TUCCI, José Rogério, Ineficiência da administração da justiça e dano moral, in Questões práticas de processo civil, 1998, p. 107). Segundo o autor, "o grande volume de trabalho que pesa sobre determinados órgãos do Poder Judiciário pode servir para escusar os juízes e tribunais de toda a responsabilidade pessoal decorrente do atraso na prolação das decisões, mas não suprime, à evidência, a responsabilidade objetiva do Estado pelo anormal funcionamento do serviço judiciário" (in idem, ibidem, p. 105). Nessa mesma linha, LUCON noticia que "a Itália introduziu o processo justo em sua Constituição e aprovou lei prevendo a possibilidade de os cidadãos italianos pleitearem indenizações perante as Cortes italianas pela demora injustificada no processo" (in LuCON, Paulo Henrique dos Santos, Duração razoável e informatização do processo nas recentes reformas, in Direito civil e processo - Estudos em homenagem ao Professor Arruda Alvim, 2007, p. 1.399).

139 In MARINONI, Luiz Guilherme, Tutela antecipatória, julgamento antecipado e execução imediata da sentença, 2002, p. 16.

140 In GAJARDONI, Fernando da Fonseca, O princípio constitucional da tutela jurisdicional sem dilações indevidas e o julgamento antecipadíssimo da lide (artigo 285-A do CPC), in As grandes transformações do processo civil brasileiro - Homenagem ao Professor Kazuo Watanabe, 2009, p. 1.001. 
processo. De fato, o nosso Poder Judiciário padece de outros males igualmente graves falta de investimento no setor, má gestão administrativa e orçamentária ${ }^{141}$, ausência de preparo e treinamento adequado dos profissionais etc. - que mesmo a jurisprudência uniforme não consegue atacar ${ }^{142}$. Com inegável senso de realidade, BOTELHO DE MESQUITA assevera que "o de que o Poder Judiciário carece urgentemente é de recursos materiais e humanos para atender devidamente à demanda de seus serviços"143.

Além disso, há dados concretos de que os processos judiciais nos Estados Unidos, vistos como o ambiente natural por excelência dos precedentes judiciais vinculantes (e portanto uniformes), não são exatamente um modelo de celeridade ${ }^{144}$.

De todo modo, é fato que a jurisprudência uniforme pode sim ajudar na diminuição do tempo dos litígios ${ }^{145}$. Além de ser mais rápido para o magistrado proferir uma decisão com base em entendimento consolidado, os recursos contra essa decisão são obstados já no limiar (vide, por exemplo, a redação dos arts. 518, par. único, e 557, caput, do CPC, que permitem o não recebimento e a negativa de seguimento a recurso de

\footnotetext{
${ }^{141}$ V., sobre os problemas de gestão do Judiciário, PINHEIRO, Armando Castelar, Reforma do Judiciário: observações de um economista, in Revista do Advogado, $\mathrm{n}^{\circ} 75,2004, \mathrm{p}$. 22 . E o problema não é de hoje: em texto datado de 1964, LEAL esclarece que "o Supremo Tribunal, com admirável espírito de coesão, está cônscio da urgência de se aparelhar melhor para o exato desempenho de sua tarefa" (in LEAL, Victor Nunes, Atualidade do Supremo Tribunal, in Revista de Direito Administrativo, $\mathrm{n}^{\circ} 78,1964$, p. 453).
}

${ }^{142}$ V., em sentido semelhante, PARENTE, Eduardo de Albuquerque, Jurisprudência: da divergência à uniformização, 2006, pp. 16/17 e VILARDI, Iara Ferfoglia Gomes Dias, Súmula vinculante: razões e conseqüências de sua implementação no sistema de direito brasileiro, Dissertação (Mestrado), 2008, p. 171 esta última tratando do tema sob a perspectiva da súmula vinculante. Afinal, "a aceleração do curso dos processos é (...) aspecto que não comporta soluções meramente legislativas" (in BOTELHO DE MESQUITA, José Ignacio, As novas tendências do direito processual: uma contribuição para o seu reexame, in Teses, estudos e pareceres de processo civil, vol. 1, 2005, p. 299). BARBOSA MOREIRA aborda o tema sob uma perspectiva ainda mais ampla: "pode-se dizer com propriedade que a crise da Justiça reflete a crise do direito material: as normas civis, penais, administrativas, tributárias - quiçá constitucionais - é que não estão conseguindo manter a comunidade dentro das fronteiras da licitude. Escorre do terreno substancial a lama que obstrui os canais do processo. Nem de longe me passa pela cabeça insinuar que a isso se reduz o conjunto de causas da situação atual. Todo fenômeno de proporções consideráveis decorre de uma conjugação de fatores, em geral imbricados e entrelaçados uns nos outros. Quis apenas assinalar, com minhas observações precedentes, uma linha de derivação que não deixa de ter sua importância." (in BARBOSA MOREIRA, José Carlos, O juiz e a cultura da transgressão, in Temas de direito processual, $7^{\mathrm{a}}$ série, 2001, p. 258).

${ }^{143}$ In Botelho DE MesquitA, José Ignacio, A crise do Judiciário e o processo, in Teses, estudos e pareceres de processo civil, vol. 1, 2005, p. 262.

${ }^{144}$ In BARBosA MOREIRA, José Carlos, Súmula, jurisprudência, precedente: uma escalada e seus riscos, in Revista Síntese de Direito Civil e Processual Civil, no 35, 2005, pp. 13/14.

145 V., em sentido semelhante, MORAES, Alexandre de, Consumidor e direito à prestação jurisdicional eficiente e célere, in Revista do Advogado, no 89, 2006, p. 17. 
apelação em confronto com súmula do STJ ou do STF), evitando-se o desenvolvimento de incidentes processuais inúteis.

Há inclusive quem afirme que, ao reduzir ao mínimo os inconvenientes da incerteza do direito, a jurisprudência uniforme diminui a reprodução de demandas contrárias a teses jurídicas já pacificadas, pois de antemão faz saber qual será o entendimento vitorioso $^{146}$. Supondo ser correta essa assertiva, a tendência é que, com a distribuição de menos processos, se diminua o acúmulo de trabalho dos magistrados de primeiro e segundo graus também, tornando mais célere o julgamento dos litígios em todas as instâncias, de um modo geral.

${ }^{146}$ In PEReIRA DOS SANTOS, Carlos Maximiliano, Hermenêutica e aplicação do direito, 2007, p. 147. 


\section{BREVE HISTÓRICO}

SuMÁRIO. 2.1 Façanhas e sentenças da Cúria Régia. 2.2 Assentos dos tribunais. 2.2.1 Assentos do Tribunal da Relação do Rio de Janeiro e da Casa da Suplicação do Brasil. 2.3 Estilos da corte portuguesa. 2.4 Restabelecimento dos assentos dos tribunais. 2.5 Recurso extraordinário. 2.6 Prejulgado. 2.7 Recurso de revista. 2.8 Embargos de divergência. 2.9 Súmulas da jurisprudência predominante. 2.10 Interpretação em abstrato pelo STF.

\section{Façanhas e sentenças da Cúria Régia}

Do ponto de vista da produção jurídico-literária europeia, os séculos VIII a XI (primeira metade) ficaram conhecidos como "séculos mudos", uma vez que nessa época nada de relevante se criou ou se desenvolveu ${ }^{147}$. A unidade jurídica deixada pelos romanos foi completamente fracionada pelos visigodos, surgindo comunidades espalhadas pelo campo, dentro das quais se criaram direitos costumeiros, de aplicação local, em que o costume prevalecia sobre qualquer outra fonte jurídica.

Na Península Ibérica ${ }^{148}$, tornou-se comum o julgamento por façanhas (no direito espanhol, faciendas ou fazañas), de acordo com a solução observada em um caso exemplar, considerado paradigma. A força vinculante desse caso paradigma decorria basicamente de dois elementos: autoridade do prolator da decisão e exemplaridade do caso em si. As façanhas eram transmitidas às gerações seguintes oralmente ou por meio de anotações feitas pelos juízes responsáveis pelos julgamentos ${ }^{149}$.

Com o passar do tempo, a partir da época da Reconquista, o monarca passou a recuperar o poder real. Instalou-se a Cúria Régia, que o assistia em questões administrativas, legislativas e de justiça, funcionando com competência recursal e com competência originária em certas causas relevantes. As decisões da Cúria Régia, que

\footnotetext{
${ }^{147}$ In AZEVEDO, Luiz Carlos de e CRUZ E TUCCI, José Rogério, Lições de história do processo civil lusitano, 2009, p. 159.

${ }^{148} \mathrm{~V}$., afirmando que "no puede ponerse en duda que las fuentes españolas, en especial las posteriores al Renacimiento, inspiraron todo el proceso del nuevo mundo", COUTURE, Eduardo Juan, Trayectoria y destino del derecho procesal civil hispanoamericano, in Estudios de derecho procesal civil, tomo I, 1978, p. 305.

${ }^{149}$ In AZEVEDO, Luiz Carlos de e CRUZ E TUCCI, José Rogério, Lições de história do processo civil lusitano, 2009, pp. 159/160.
} 
muitas vezes apenas confirmavam formalmente a vigência de costumes, traçavam os limites da orientação jurisprudencial e possuíam força vinculante ${ }^{150}$.

\section{Assentos dos tribunais}

Originalmente, no direito português, a interpretação autêntica das leis constituía prerrogativa exclusiva do monarca, que assim o fazia por meio da publicação de leis interpretativas ou em Relação, quando proferia decisões ao presidir julgamentos da Casa da Suplicação (que era o tribunal supremo) ou da Casa do Cível.

Em razão das diversas funções que assumiram, os monarcas posteriormente declinaram de tal privilégio, que passou, com D. MANUEL, ao tribunal superior do reino. A alteração fez parte do movimento de progressiva restrição da liberdade doutrinal dos juristas, que concentravam em suas mãos boa parte da atividade político-administrativa da época $^{151}$.

Os desembargadores das duas Relações, reunidos em "Mesa Grande”, por convocação do regedor ou do governador, passaram a proferir assentos, tomados por maioria de votos, sempre que houvesse dúvida sobre a interpretação das ordenações e das leis extravagantes, com eficácia vinculante para casos semelhantes e futuros. A competência do monarca manteve-se apenas nos casos em que subsistia dificuldade interpretativa sobre determinado texto normativo ${ }^{152}$.

CAZETTA JÚNIOR esclarece que "por meio desses assentos - que favoreciam a segurança e a certeza na aplicação do direito por meio de uma resolução autoritária realizava-se a interpretação autêntica das leis" ${ }^{\prime 153}$. Para tanto, os assentos eram inseridos

\footnotetext{
${ }^{150}$ In AzEVEDO, Luiz Carlos de e CRUZ E TUCCI, José Rogério, Lições de história do processo civil lusitano, 2009, pp. 160/161.

${ }^{151}$ In CAZetta Júnior, José Jesus, Assentos da Casa da Suplicação, in Revista do Advogado, nº 84, 2005, p. 82.

${ }^{152}$ In CAZetta Júnior, José Jesus, Assentos da Casa da Suplicação, in Revista do Advogado, nº 84, 2005, pp. 83/84.

${ }^{153}$ In CAZETta Júnior, José Jesus, Assentos da Casa da Suplicação, in Revista do Advogado, nº 84, 2005, p. 84. V., em sentido semelhante, AzEVEdo, Luiz Carlos de e CRUZ E TuCCI, José Rogério, Lições de história do processo civil lusitano, 2009, p. 167.
} 
em um livro, batizado de Livro dos Assentos ou Livro Verde e, mais tarde, de Livro dos Assentos da Relação ${ }^{154}$.

As interpretações conferidas pelos assentos fizeram surgir uma espécie de "legislação jurisprudencial". O magistrado que deixasse de observar o entendimento neles fixado ficava sujeito a sanções funcionais e corria o risco até de ser suspenso ${ }^{155}$. Mas se tratava de uma atribuição do próprio rei, delegada a um órgão especializado, e não de uma manifestação do Poder Judiciário, como a que fazem os tribunais nos dias de hoje ${ }^{156}$.

A interpretação com eficácia vinculante foi regulamentada pelo Alvará de 10 de dezembro de 1518 e, mais tarde, pelas Ordenações Manuelinas (Livro V, Título 58, § $1^{\circ}$ ), que assim diziam: "E assim vemos por bem, que quando os Desembargadores que forem no despacho d'algum feito, todos, ou algum delles tiverem alguma duvida em alguma Nossa Ordenaçam do entendimento della, vam com a dita duvida ao Regedor, o qual na Mesa grande com os Desembargadores que lhe bem parecer a determinará, $e$ segundo o que hi for determinado se poerá a sentençã. E se na dita Mesa forem isso mesmo em duvida, que ao Regedor pareça que he bem de No-lo fazer saber, pera a Nós loguo determinarmos, No-lo fará saber, pera Nós nisso Provermos. E os que em outra maneira interpretarem Nossas Ordenações, ou derem sentenças em algum feito, tendo algum delles duvida no entendimento da dita Ordenaçam, sem hirem ao Regedor como dito he, seram suspensos atee nossa Mercê. E a determinaçam que sobre o entendimento da dita Ordenaçam se tomar, mandará o Regedor escrever no livrinho pera despois nom viir em duvida."157.

De 1518 a 1581, a prerrogativa de emitir assentos era única e exclusivamente da Casa da Suplicação. Em 1582, foi implementada em Portugal reforma

\footnotetext{
${ }^{154}$ In AzEVEDO, Luiz Carlos de e CRUZ E TuCCI, José Rogério, Lições de história do processo civil lusitano, 2009, pp. 164/167.

${ }^{155}$ In BARBosa MoreIRA, José Carlos, Súmula, jurisprudência, precedente: uma escalada e seus riscos, in Revista Síntese de Direito Civil e Processual Civil, no 35, 2005, p. 5 e MANCuso, Rodolfo de Camargo, A jurisprudência, dominante ou sumulada, e sua eficácia contemporânea, in Aspectos polêmicos e atuais dos recursos cíveis de acordo com a Lei $n^{\circ}$ 9.756/98, 1999, pp. 523/524.

156 In LIMONGI FRANÇA, Rubens, Jurisprudência - Seu caráter de forma de expressão de Direito, in Repertório Enciclopédico do Direito Brasileiro, vol. 30, p. 278, citando lição de BORGES CARNEIRO.

157 In RosAS, Roberto, Jurisprudência. Uniformização. Súmula, in Direito processual: inovações $e$ perspectivas - estudos em homenagem ao Ministro Sálvio de Figueiredo Teixeira, 2003, p. 388.
} 
nos tribunais superiores, mantendo-se uma Relação no Norte (a Casa da Suplicação) e criando-se outra no Sul (a Casa do Cível, mais tarde Relação do Porto) - basicamente, competia-lhes o julgamento, em última instância, dos pleitos judiciais, sendo cada qual competente por diferentes comarcas e ouvidorias. A partir daí, a Casa do Cível passou a ter competência autônoma e ampla, inclusive para proferir assentos.

Em momento subsequente, também as Relações ultramarinas, de Goa, da Bahia e do Rio de Janeiro, adquiriram a prerrogativa de emitir assentos, reforçando o caráter jurisprudencial do direito.

As Ordenações Filipinas reiteraram o entendimento das Ordenações anteriores, dispondo o seguinte no Livro I, Título $\mathrm{V}, \S 5^{\circ}$ : “E havemos por bem, que quando os Desembargadores, que forem no despacho de algum feito, todos ou algum dêles tiverem alguma dúvida em alguma nossa ordenação do entendimento dela, vão com a dúvida ao Regedor, o qual na Mesa grande com os Desembargadores, que lhe bem parecer, a determinará, e segundo o que aí fôr determinado, se porá a sentença. E a determinação, que sôbre o entedimento da dita ordenação se tomar, mandará o Regedor escrever no Livro da Relação, para depois não vir em dúvida. E os que em outra maneira interpretarem nossas Ordenações, ou deram sentenças em algum feito, tendo algum dêles dúvida no entendimento da Ordenação, sem ir ao Regedor, será suspenso até nossa mercê." ${ }^{158}$.

A prática de emitir assentos normativos perdurou em Portugal até 1993, quando $\mathrm{o}$ art. $2^{\mathrm{o}}$, do Código Civil, foi declarado inconstitucional pelo Tribunal Constitucional, por meio do Acórdão $n^{\circ} 810$, de 7 de dezembro daquele ano ${ }^{159}$. Entendeuse, basicamente, que os assentos usurpariam competência reservada ao Poder Legislativo, e desvirtuariam as funções do Poder Judiciário ${ }^{160}$.

\footnotetext{
${ }^{158}$ In AZEVEDO, Álvaro Villaça, Os assentos no direito processual civil, in Justitia - Órgão do Ministério Público de São Paulo, nº 74, 1971, p. 119.

${ }^{159} \mathrm{~V}$., amplamente sobre o assunto, NeVES, António Castanheira, O problema da constitucionalidade dos assentos: comentário ao Acórdão $n^{o} 810 / 93$ do Tribunal Constitucional, 1994. Apesar dessa ruptura, persistem ainda na Constituição portuguesa três hipóteses em que as decisões do Tribunal Constitucional possuem força obrigatória geral; as três dizem respeito ao controle (abstrato e concreto) da constitucionalidade ou legalidade das leis praticado pelo Tribunal Constitucional (in CRUZ E TUCCI, José Rogério, Precedente judicial como fonte de direito, 2004, p. 253).

${ }^{160}$ In GARCIA, Dínio de Santis, Efeito vinculante dos julgados da Corte Suprema e dos Tribunais Superiores, in Revista dos Tribunais, vol. 734, 1996, p. 44.
} 
O Tribunal da Relação do Rio de Janeiro foi criado em 1751, com competência territorial que abrangia o sul do Brasil. O tribunal passou a tirar assentos normativos, mas a Lei da Boa Razão, de 18 de agosto de 1769, estabeleceu que apenas a Casa da Suplicação de Lisboa era competente para fazê-lo com força de lei. Para que os assentos alcançassem valor normativo, era necessária, assim, a aprovação da Casa da Suplicação, eliminando-se a possibilidade de assentos contraditórios.

Com a transformação da Relação do Rio de Janeiro em Casa da Suplicação para o Brasil, por ocasião da vinda da família real para o Brasil, em 1808, outorgou-se competência à nova corte para emitir assentos interpretativos, no âmbito de sua jurisdição, com a mesma eficácia daqueles emitidos pela Casa de Suplicação de Lisboa ${ }^{161}$.

Proclamada a Independência, tal competência foi deferida ao Supremo Tribunal de Justiça, instituído pela Constituição do Império, de $1824^{162}$. A extinção do instituto deu-se com a República ${ }^{163}$.

\subsection{Estilos da corte portuguesa}

Tanto as Ordenações Afonsinas, quanto as Ordenações Manuelinas, incluíram os estilos da corte entre as fontes de direito. Referidos estilos não eram escritos, mas tinham a eficácia reconhecida pelo seu uso renovado. Consistiam basicamente na jurisprudência constante e uniforme da Casa da Suplicação ou da Casa do Cível - as duas mais elevadas cortes de justiça do reino.

\footnotetext{
${ }^{161}$ In Rosas, Roberto, Do assento e do prejulgado à Súmula do STF, in Revista dos Tribunais, vol. 404, 1969, p. 19.

162 In AzEVEDO, Luiz Carlos de e CRUZ E TUCCI, José Rogério, Lições de história do processo civil lusitano, 2009 , pp. $173 / 175$.

${ }^{163}$ In NOBRE JÚNIOR, Edilson Pereira, O direito processual brasileiro e o efeito vinculante das decisões dos tribunais superiores, in Revista de Processo, n 105, 2002, p. 78.
} 
Para que fosse considerado estilo e tivesse eficácia vinculante, o posicionamento judicial deveria obedecer a três requisitos, de acordo com a praxe forense: estar em consonância com as leis do reino; ser suficientemente antigo, tendo pelo menos dez anos; e ser uniforme, tendo sido confirmado em pelo menos duas ou três decisões ${ }^{164}$.

Sob a vigência das Ordenações Filipinas, D. FILIPE II aprovou, em 1605, o Regimento da Casa da Suplicação, o qual regulamentou a imperatividade dos estilos ${ }^{165}$.

\subsection{Restabelecimento dos assentos dos tribunais}

O primeiro diploma legal no Brasil a regular o processo civil e a organização judiciária foi o Regulamento $\mathrm{n}^{\circ} 737$, de 25 de novembro de 1850 . Não havia nele qualquer previsão a respeito de precedentes judiciais.

Como naquela época o país não possuía acervo jurisprudencial próprio, o Decreto $\mathrm{n}^{\circ}$ 2.684, de 23 de outubro de 1875, cuidou de dar "força de lei no Imperio a assentos da Casa da Supplicação de Lisboa e competencia ao Supremo Tribunal de Justiça para tomar outros". Ao que tudo indica, pretendia-se iniciar imediatamente a unificação jurisprudencial, com o consequente restabelecimento da segurança jurídica da sociedade ${ }^{166}$.

Com efeito, constou do art. $1^{\circ}$, do referido decreto, que: "Os assentos tomados na Casa da Supplicação de Lisboa, depois da creação da do Rio de Janeiro até á época da Independencia, á excepção dos que estão derogados pela legislação posterior, têm força de lei em todo o Imperio. As disposições desta lei não prejudicam os casos julgados contra ou conforme os ditos assentos.”. Já do art. $2^{\circ}$, constou que: “Ao Supremo Tribunal de Justiça compete tomar assentos para intelligencia das leis civis, commerciaes e criminaes, quando na execução dellas occorrerem duvidas manifestadas por julgamentos

\footnotetext{
${ }^{164}$ In FERRAZ JUNIOR, Tércio Sampaio, Introdução ao estudo do direito - técnica, decisão, dominação, 1994, p. 244.

${ }^{165}$ In AZEVEDO, Luiz Carlos de e CruZ E TUCCI, José Rogério, Lições de história do processo civil lusitano, 2009, pp. 168/169.

${ }^{166}$ In AZEVEDO, Álvaro Villaça, Os assentos no direito processual civil, in Justitia - Órgão do Ministério Público de São Paulo, nº 74, 1971, p. 121.
} 
divergentes havidos no mesmo Tribunal, Relações e Juizos de primeira instancia nas causas que cabem na sua alçada.".

$\mathrm{O}$ art. $2^{\circ}$, em seus $\S \S 1^{\circ}$ e $2^{\circ}$, ainda estabeleceu que: os assentos seriam tomados, sendo consultadas previamente as Relações; os assentos seriam registrados em livro próprio, remetidos ao Governo Imperial e a cada uma das Câmaras Legislativas, numerados e incorporados à coleção das leis de cada ano; os assentos seriam obrigatórios provisoriamente, até que fossem derrogados pelo Poder Legislativo ${ }^{167}$.

Os assentos, com eficácia vinculante, vigeram no Brasil até o advento da República ${ }^{168}$, mas o ideal de uniformização não desapareceu com eles. Segundo BUZAID, "esta tendência de política legislativa assinala a preocupação dos juristas em evitar que continuem os dissídios jurisprudenciais, que são fontes de inquietação para as partes e de descrédito para o Judiciário"169.

O projeto de Constituição apresentado pelo Instituto dos Advogados Brasileiros em 1946, de autoria do jurista HAROLDO VALLADÃo, tentou ressuscitar a figura dos assentos. Segundo o projeto, o recurso extraordinário deveria ser interposto quando ocorresse divergência na interpretação definitiva de lei federal entre dois tribunais, ou entre um deles e o STF. Fixada pelo STF a interpretação da lei, pela forma e nos termos determinados no regimento interno, dela seria tomado assento que os tribunais e juízes deveriam observar ${ }^{170}$.

A proposta foi rejeitada pela Constituinte de 1946, mas HAROLDO VALLADÃo insistiu, criando em 1964 o anteprojeto de Lei Geral de Aplicação das Normas Jurídicas, que previa a resolução unificadora da jurisprudência do Supremo Tribunal Federal, nos seguintes termos: “Art. $7^{\circ}$ - O Supremo Tribunal Federal, no exercício das atribuições que lhe confere o art. 101, III, d, da Constituição Federal, uma vez fixada a interpretação da lei federal pelo Tribunal Pleno, em três acórdãos, por maioria absoluta

\footnotetext{
${ }^{167}$ In RIBAS, Antonio Joaquim, Consolidação das leis do processo civil, 1915, p. 303.

${ }^{168}$ In CRUZ E TUCCI, José Rogério, Eficácia do precedente judicial na história do direito brasileiro, in Revista do Advogado, $\mathrm{n}^{\circ}$ 78, 2004, pp. 43/44.

${ }^{169}$ In BuZAID, Alfredo, Uniformização da jurisprudência, in Revista da Ajuris - Associação dos Juízes do Rio Grande do Sul, no 34, 1985, p. 196.

170 In VILARDI, Iara Ferfoglia Gomes Dias, Súmula vinculante: razões e conseqüências de sua implementação no sistema de direito brasileiro, Dissertação (Mestrado), 2008, p. 62.
} 
(Constituição Federal, art. 200), torna-la-á pública, na forma e nos termos determinados no Regimento, em Resolução que os tribunais e os juízes deverão observar enquanto não modificada segundo o mesmo processo, ou por disposição constitucional ou legal superveniente" ${ }^{, 171}$.

A resolução teria caráter vinculante e seria tomada quando houvesse no pleno três acórdãos, julgados por maioria absoluta, no mesmo sentido. O caráter vinculante cessaria no caso de modificação do entendimento pelo mesmo procedimento, ou por disposição constitucional ou legal superveniente ${ }^{172}$. Como explica VILARDI, "para o jurista, a necessidade de vinculação do precedente era medida de rigor, pois, 'sem tal medida o texto constitucional é um simples saco sem fundo, e, em vez de uniformizar a jurisprudência, torna-se inútil, falha espetacularmente, servirá apenas de ponto de apoio para novos e intermináveis recursos extraordinários... É um verdadeiro divertissment judiciário' (Valladão, 1982: 333)",173.

A proposta acabou não vingando, mas poucos anos mais tarde veio a lume nova tentativa de restabelecer a figura dos assentos com força de lei. Com efeito, o anteprojeto do Código de Processo Civil atualmente em vigor, publicado em abril de 1964, suprimia o recurso de revista e os embargos de divergência e previa, nos arts. 516 a 520, procedimento de uniformização de jurisprudência que reavivava o mecanismo dos antigos assentos, em substituição ao prejulgado ${ }^{174}$.

Segundo o anteprojeto, resolvido o incidente de uniformização de jurisprudência, a decisão sobre a tese jurídica, tomada pela maioria absoluta dos membros do tribunal, culminava com a edição de assento pelo presidente, o qual, quarenta e cinco

\footnotetext{
${ }^{171}$ In CUNHA, Sérgio Sérvulo da, Nota breve sobre o efeito vinculante, in Revista de Informação Legislativa, $\mathrm{n}^{\circ} 129,1996$, p. 8.

${ }^{172}$ In Botelho De Mesquita, José Ignacio, A súmula da jurisprudência predominante no Supremo Tribunal Federal, in Teses, estudos e pareceres de processo civil, vol. 2, 2005, p. 226 e CRUZ E TUCCI, José Rogério, Eficácia do precedente judicial na história do direito brasileiro, in Revista do Advogado, no 78, 2004, p. 47.

173 In VILARDI, Iara Ferfoglia Gomes Dias, Súmula vinculante: razões e conseqüências de sua implementação no sistema de direito brasileiro, Dissertação (Mestrado), 2008, pp. 62/63.

${ }^{174}$ In SANCHES, Sydney, Uniformização da jurisprudência, 1975, pp. 16/17. V., examinando as disposições do anteprojeto que cuidavam de reintroduzir os assentos, AZEVEDO, Álvaro Villaça, Os assentos no direito processual civil, in Justitia - Órgão do Ministério Público de São Paulo, no 74, 1971, pp. 129/131. O autor conclui que "é essa a melhor instituição que se possa almejar na unificação da jurisprudência" e que "a implantação dos assentos no Anteprojeto Buzaid é para nós grande conquista” (in idem, ibidem, p. 142).
} 
dias após a publicação oficial, ganhava força de lei perante todo o território nacional, enquanto não modificada por decisão proferida pelo mesmo mecanismo. O incidente poderia ser suscitado e processado perante o Supremo Tribunal Federal ou perante tribunal estadual, conforme cuidasse da interpretação de lei federal ou estadual, respectivamente.

$\mathrm{Na}$ Exposição de Motivos, Alfredo BUZAID consignou que: “ $O$ Anteprojeto toma em alta consideração o problema da uniformidade da jurisprudência, procurando dar-lhe uma solução diversa da que fôra adotada tradicionalmente no Brasil. Reconhece que a divergência de julgados constitui um mal, gerando profunda instabilidade nas relações jurídicas, criando um clima de insegurança e despertando no ânimo dos litigantes certa decepção ao verem que a justiça do caso concreto fica à sorte da distribuição dos feitos." ${ }^{175}$.

A proposta também não teve êxito em função das repetidas objeções à constitucionalidade de seu texto e versão diferente do incidente de uniformização de jurisprudência, sem eficácia vinculante, foi aprovada no Código de BUZAID ${ }^{176}$, conforme será tratado mais adiante.

\section{$2.5 \quad$ Recurso extraordinário}

Com a promulgação da Constituição de 1891, fruto do início da República, foram extintos os assentos e teve lugar uma nova estrutura judiciária no país: criou-se o Supremo Tribunal Federal e, com ele, introduziu-se o recurso extraordinário, inspirado no writ of error do direito norte-americano.

O recurso extraordinário, cabível na hipótese de divergência jurisprudencial entre tribunais distintos a propósito da interpretação conferida às leis federais, tinha por escopo principal a manutenção da uniformidade na aplicação do direito pátrio ${ }^{177}$. Essa

\footnotetext{
${ }^{175}$ In MUSCARI, Marco Antonio Botto, Súmula vinculante, 1999, p. 16.

${ }^{176}$ In BARBOSA MOREIRA, José Carlos, Súmula, jurisprudência, precedente: uma escalada e seus riscos, in Revista Síntese de Direito Civil e Processual Civil, $\mathrm{n}^{\circ}$ 35, 2005, p. 7, BotelHo DE MesquITA, José Ignacio, A súmula da jurisprudência predominante no Supremo Tribunal Federal, in Teses, estudos e pareceres de processo civil, vol. 2, 2005, p. 222 e CRUZ E TUCCI, José Rogério, Eficácia do precedente judicial na história do direito brasileiro, in Revista do Advogado, $\mathrm{n}^{\mathrm{o}} 78,2004$, pp. 47/48.

${ }^{177}$ In CRUZ E TUCCI, José Rogério, Eficácia do precedente judicial na história do direito brasileiro, in Revista do Advogado, no 78, 2004, pp. 44/45.
} 
função permaneceu até 1988, quando, com a criação do Superior Tribunal de Justiça, foi concebido o recurso especial.

A Constituição Federal de 1946 previu expressamente o cabimento do recurso extraordinário quando a decisão recorrida desse à lei interpretação diversa daquela conferida pelo STF e por outros tribunais, não limitados, como ocorria na Constituição de 1934, aos de Apelação de Estados e do Distrito Federal ou dos Territórios.

A Constituição Federal de 1967 introduziu a expressão "negar vigência" à lei, para o fim de restringir os casos de cabimento do apelo ${ }^{178}$.

A Emenda Constitucional $\mathrm{n}^{\circ} 1$, de 17 de outubro de 1969, incluiu dispositivo atribuindo competência ao STF para regular o cabimento do recurso extraordinário nos casos de violação à Constituição, lei ou tratado, e de divergência jurisprudencial. Nessa toada, o art. 308, do RISTF, que entrou em vigor em 15 de outubro de 1970, regulamentou o art. $119, \S 1^{\circ}$, da CF, estipulando os casos em que não era cabível recurso extraordinário, excluindo de tais hipóteses os casos de ofensa à Constituição ou discrepância manifesta da jurisprudência predominante no Supremo Tribunal Federal ${ }^{179}$.

Atualmente, compete ao Supremo Tribunal Federal julgar, mediante recurso extraordinário, as causas decididas em única ou última instância, quando a decisão recorrida: contrariar dispositivo da Constituição; declarar a inconstitucionalidade de tratado ou lei federal; julgar válida lei ou ato de governo local contestado em face da Constituição; ou julgar válida lei local contestada em face de lei federal (art. 102, III, "a", "b", "c" e "d", respectivamente).

\section{Prejulgado}

Também com o intuito de uniformizar o direito, a Lei $\mathrm{n}^{\circ} 17$, de 20 de novembro de 1891, do Estado de Minas Gerais, previu o prejulgado, em seu art. 22:

\footnotetext{
${ }^{178}$ In Botelho DE MESQUITA, José Ignacio, A súmula da jurisprudência predominante no Supremo Tribunal Federal, in Teses, estudos e pareceres de processo civil, vol. 2, 2005, p. 223.

${ }^{179}$ In CÔRTES, Osmar Mendes Paixão, A experiência brasileira com a vinculação das decisões judiciais e a atual súmula vinculante introduzida pela EC 45/2004, in Direito civil e processo - Estudos em homenagem ao Professor Arruda Alvim, 2007, p. 1.384.
} 
"Quando ocorrer manifesta contradição entre decisões definitivas, no Tribunal da Relação, sobre questões de direito, o Presidente, ex officio, ou a requerimento do Procurador Geral, no interesse da lei e uniformidade da jurisprudência, sujeitará de novo a espécie ao Tribunal e comunicará a decisão ao Governo, em relatório circunstanciado, para ser presente ao Poder Legislativo." ${ }^{180}$.

O Decreto $\mathrm{n}^{\circ}$ 16.273, de 20 de dezembro de 1923, em seu art. 103 e respectivos parágrafos, também admitiu o mecanismo do prejulgado, restrito à Corte de Apelação do Distrito Federal: “Quando a lei receber interpretação diversa nas Câmaras de Apelação Cível ou Criminal, ou quando resultar da manifestação dos votos de uma Câmara, em caso sub judice, que se terá de declarar uma interpretação diversa, deverá a Câmara divergente representar, por seu Presidente, ou Presidente da Corte, para que este, incontinenti, faça a reunião das duas Câmaras, conforme a matéria for cível ou criminal. $\S 1^{\circ}$. Reunidas as Câmaras, e submetida a questão à sua deliberação o vencido, por maioria, constitui decisão obrigatória para o caso em apreço e norma aconselhável para os casos futuros, salvo relevantes motivos de direito, que justifiquem renovar-se idêntico procedimento de instalação das Câmaras Reunidas. $\S 2^{\circ}$. O acórdão será subscrito por todos os membros das Câmaras Reunidas e, na sessão que se seguir, a Câmara, que tenha provocado o procedimento uniformizador, aplicando o vencido aos feitos em debate, decidirá a causa, ressalvado aos membros das Câmaras, que se tenham mantido em divergência, a faculdade de fazer referência não motivada aos seus votos, exarado no referido acórdão." ${ }^{181}$.

Cada câmara tinha um livro especial, espécie de repositório oficial, denominado de "livro dos prejulgados", onde constavam as ementas dos acórdãos das câmaras reunidas. Na primeira semana de cada trimestre, o secretário da corte devia providenciar para que fosse feita, sob sua direta e pessoal inspeção, a permuta de inscrições entre os livros de prejulgados das câmaras de idêntica jurisdição por matéria. As normas para a confecção desses livros eram estabelecidas pelo presidente do tribunal, que determinava sobre eles a necessária inspeção, bem como a sua disponibilização ao público.

\footnotetext{
${ }^{180}$ In RoSAS, Roberto, Do assento e do prejulgado à Súmula do STF, in Revista dos Tribunais, vol. 404, 1969, p. 19 e idem, Jurisprudência. Uniformização. Súmula, in Direito processual: inovações e perspectivas - estudos em homenagem ao Ministro Sálvio de Figueiredo Teixeira, 2003, p. 388.

181 In RosAS, Roberto, Jurisprudência. Uniformização. Súmula, in Direito processual: inovações $e$ perspectivas - estudos em homenagem ao Ministro Sálvio de Figueiredo Teixeira, 2003, p. 389.
} 
O prejulgado da Corte de Apelação do Distrito Federal foi extinto na Reforma Judiciária de 1926, mas foi restabelecido em seguida pelo art. $7^{\circ}$, do Decreto $\mathrm{n}^{\circ}$ 19.408, de 18 de novembro de $1930^{182}$, “destinado a uniformizar a jurisprudência das câmaras".

Em São Paulo, o Código de Processo Civil e Comercial do Estado também previu o mecanismo do prejulgado, com o objetivo de garantir a uniformidade de interpretação da lei. Segundo o respectivo art. 1.126: “Quando ao relator parecer que já existe divergência entre as Câmaras, proporá, depois da revisão do feito, que o julgamento da causa se efetue em sessão conjunta. Decidida a questão de direito, a Câmara a que pertencer a causa, passará imediatamente a julgá-la. À parte não se dará, então, o recurso do art. 1.119." ${ }^{183}$.

Alguns anos depois, a Lei $\mathrm{n}^{\mathrm{o}}$ 319, de 25 de novembro de 1936, previu em seu art. $2^{\circ}$ o prejulgado com validade para todo o país. As regras foram reformuladas para permitir que qualquer juiz integrante de turma julgadora o invocasse ao reconhecer a ocorrência, ou a possibilidade de ocorrência, de divergência entre câmaras ou turmas sobre matéria que impactasse no julgamento de caso concreto, provocando o pronunciamento prévio do pleno.

No âmbito da Lei no 319/1936, o prejulgado possuía eficácia vinculante horizontal, pois, se uma das turmas desrespeitasse a regra de direito nele estabelecida, era cabível a interposição de recurso de revista, previsto no art. $1^{\circ}$ da lei e respectivos parágrafos.

À semelhança dos diplomas acima referidos, a Consolidação das Leis do Trabalho previu em seu art. $902, \S 1^{\circ}$, com a redação dada pelo Decreto-lei $n^{\circ} 8.737$, de 19 de janeiro de 1946, o prejulgado com força vinculante para os Tribunais Regionais do Trabalho, as Juntas de Conciliação e Julgamento e os juízes de direito investidos na

\footnotetext{
${ }^{182}$ Foi esse mesmo Decreto que criou a Ordem dos Advogados do Brasil, então "Ordem dos Advogados Brasileiros".

183 In RoSAS, Roberto, Jurisprudência. Uniformização. Súmula, in Direito processual: inovações e perspectivas - estudos em homenagem ao Ministro Sálvio de Figueiredo Teixeira, 2003, p. 388.
} 
jurisdição trabalhista. Examinando caso abstrato sobre matéria controvertida, o Tribunal Superior do Trabalho emitia seu posicionamento, fixando a regra que deveria ser observada em todos os julgados subsequentes, de forma vinculante, garantida a possibilidade de o TST revogar o prejulgado na hipótese de nova interpretação.

A autoridade do prejulgado trabalhista foi reafirmada pelo Decreto-lei $\mathrm{n}^{\circ}$ 229, de 28 de fevereiro de 1967, que, ao alterar por meio de seu art. 28 a redação do art. 894 da CLT, previa que seria negado seguimento a embargos para o pleno se a decisão embargada estivesse em consonância com prejulgado ou jurisprudência uniforme do mesmo tribunal. Muito se discutiu sobre a constitucionalidade do instituto, tendo em 12 de maio de 1977 o STF declarado a sua inconstitucionalidade, ao acolher representação da Procuradoria-Geral da Justiça. O instituto foi revogado pela Lei $\mathrm{n}^{\mathrm{o}} 7.033$, de 5 de outubro de 1982, que excluiu definitivamente a referência ao prejulgado ${ }^{184}$.

O Código Eleitoral, introduzido pela Lei no 4.737, de 15 de julho de 1965, também previu o prejulgado, dando-lhe roupagem de precedente judicial ${ }^{185}$, ao estabelecer em seu art. 263 que, "no julgamento de um mesmo pleito eleitoral, as decisões anteriores sôbre questões de direito constituem prejulgados para os demais casos, salvo se contra a tese votarem dois terços dos membros do Tribunal”. A disposição permanece em vigor até os dias de hoje, "mas este não tem obtido no Brasil a adesão pretendida pelos doutrinadores, pois sua força vinculativa encontra a oposição dos julgados prolatados por decisão única" ${ }^{" 186}$.

Com o advento do Código de Processo Civil de 1939, uma vez restaurada a competência exclusiva da União para legislar em matéria processual, foi mantido, no art. 861, o instituto do prejulgado: a requerimento de qualquer de seus juízes, a câmara, ou turma julgadora, poderia promover o pronunciamento prévio das câmaras reunidas sobre a

184 In ANDRADE, Dárcio Guimarães de, Uniformização de jurisprudência, in Revista Trimestral de Jurisprudência dos Estados, nº 179, 2000, p. 61.

185 In VILARDI, Iara Ferfoglia Gomes Dias, Súmula vinculante: razões e conseqüências de sua implementação no sistema de direito brasileiro, Dissertação (Mestrado), 2008, p. 61.

186 In Rosas, Roberto, Jurisprudência. Uniformização. Súmula, in Direito processual: inovações e perspectivas - estudos em homenagem ao Ministro Sálvio de Figueiredo Teixeira, 2003, p. 395. No julgamento do REsp Eleitoral $n^{\circ}$ 9.936/RJ, em 1993, sob a relatoria do Min. SEPúlVEDA PERTENCE, o Tribunal Superior Eleitoral chegou inclusive a concluir pela inconstitucionalidade do prejulgado eleitoral (in NOBRE JÚNIOR, Edilson Pereira, $O$ direito processual brasileiro e o efeito vinculante das decisões dos tribunais superiores, in Revista de Processo, $\mathrm{n}^{\mathrm{o}}$ 105, 2002, p. 79). 
interpretação de qualquer norma jurídica, se reconhecesse que sobre ela ocorria, ou poderia ocorrer, divergência de interpretação entre câmaras ou turmas. Foi abolida, porém, a possibilidade de interposição de recurso de revista contra decisão que o desrespeitasse, fazendo com que o prejulgado deixasse de possuir eficácia vinculante ${ }^{187}$.

\section{7}

\section{Recurso de revista}

O recurso de revista foi inicialmente previsto na Lei $\mathrm{n}^{\circ} 319$, de 25 de novembro de 1936 , em seu art. $1^{\circ}$ e respectivos parágrafos.

O referido diploma legal dispunha que cabia o recurso para o pleno das decisões finais da Corte de Apelação, ou de quaisquer de suas câmaras ou turmas, em duas hipóteses: quando contrariassem ou divergissem de outra decisão, também final, da mesma corte, ou de alguma de suas câmaras ou turmas, sobre a mesma espécie ou sobre idêntica relação de direito; ou, quando proferidas por alguma ou algumas das câmaras, ou turmas, contrariassem interpretação da mesma lei, ou mesmo ato, adotada pela mesma corte.

No julgamento do recurso, a corte fixava a interpretação ou a norma que se deveria observar na espécie, de forma definitiva. O único recurso cabível a partir de então era o extraordinário, nos casos em que a Constituição Federal permitisse.

No Código de Processo Civil de 1939 o recurso de revista foi novamente previsto, entre os arts. 853 e 860 .

Era cabível a sua interposição para as câmaras cíveis reunidas, nos casos em que duas ou mais câmaras, ou turmas, entre si, divergissem, em suas decisões finais, quanto ao modo de interpretar o direito em tese. $\mathrm{O}$ recurso ainda era extensivo à decisão final de qualquer das câmaras, ou turmas, que contrariasse outro julgado, também final, das câmaras reunidas.

${ }^{187}$ In CRUZ E TUCCI, José Rogério, Eficácia do precedente judicial na história do direito brasileiro, in Revista do Advogado, $\mathrm{n}^{\mathrm{o}} 78,2004$, pp. 45/47. 
Não era lícito alegar que uma interpretação divergia de outra, quando depois a mesma câmara ou turma que a adotou, ou as câmaras reunidas, firmassem jurisprudência uniforme no sentido da interpretação contra a qual se pretendia reclamar.

No julgamento do recurso, o tribunal deveria examinar, preliminarmente, se a divergência se manifestou quanto à interpretação do direito em tese, fixando, em caso afirmativo, a interpretação que se deveria observar na espécie, decidindo-a em definitivo.

Para NEGRÃO, "o recurso de revista correspondia, mais ou menos, ao que hoje se chama de uniformização da jurisprudência, mas com outra disciplina, muito melhor, a meu ver (e que hoje encontra correspondente nos embargos de divergência perante os Tribunais Superiores), e é uma pena que tenha sido substituído pelo incidente de uniformização de jurisprudência" ${ }^{\prime 188}$.

Segundo BUZAID, o que levou o legislador a eliminar o recurso de revista do subsequente Código de Processo Civil "foi o fato de que a divergência jurisprudencial não pode constituir fundamento para impugnação. $O$ seu fundamento é o estado de sucumbimento, isto é, o gravame produzido à parte pelo órgão judiciário. Ora, a circunstância de um aresto haver contrariado entendimento que outra Câmara, Turma ou Tribunal Pleno deu ao mesmo preceito legal pode ser lamentável, mas não é fundamento autônomo de recurso." 189 .

\subsection{Embargos de divergência}

Em tendo o STF considerado incabível a interposição de recurso de revista diante de divergência intramuros, a Lei ${ }^{\circ}$ 623, de 19 de fevereiro de 1949, criou os embargos de divergência, determinando a inclusão do par. único ao art. 833, do Código de Processo Civil de 1939, com a seguinte redação: "além de outros casos admitidos em lei, serão embargáveis, no Supremo Tribunal Federal, as decisões das Turmas, quando divirjam entre si, ou de decisão tomada pelo Tribunal Pleno". O instituto, que já era

\footnotetext{
${ }^{188}$ In NEGRÃO, Theotonio, O novo recurso extraordinário: perspectivas na Constituição de 1988, in Revista do Advogado, $\mathrm{n}^{\circ} 81,2005$, p. 10.

${ }^{189}$ In BUZAID, Alfredo, Uniformização da jurisprudência, in Revista da Ajuris - Associação dos Juízes do Rio Grande do Sul, no 34, 1985, p. 213.
} 
previsto no Regimento Interno do STF (art. 309) ${ }^{190}$, basicamente possuía a mesma finalidade do recurso de revista, mas era restrito ao Supremo Tribunal Federal.

Em 28 de agosto de 1963, quando ainda vigoravam a Constituição Federal de 1946 e o Código de Processo Civil de 1939, foi aprovada Emenda Regimental, idealizada pelo Min. Victor NUnES LEAL (com o apoio decisivo de outros ministros, dentre eles, Gonçalves de Oliveira, Pedro Chaves e Evandro Lins E Silva ${ }^{191}$ ), que permitiu que o Supremo Tribunal Federal, pelo voto da maioria absoluta de seus membros, editasse súmulas da jurisprudência dominante, resumindo em enunciados as teses jurídicas que verdadeiramente refletissem o pensamento da corte. Frustradas as tentativas de restabelecer os assentos com força de lei, até então a uniformização da jurisprudência era feita exclusivamente pelo recurso de revista, pelo prejulgado, pelo recurso extraordinário e pelos embargos de divergência.

A ideia foi chegar num meio-termo entre a dureza implacável dos antigos assentos e a virtual inoperância dos $\operatorname{prejulgados}^{192}$, para estabilizar a jurisprudência e tornar de imediato conhecimento as decisões do STF. Além de repertório oficial da jurisprudência predominante do Supremo, as súmulas passaram a funcionar como método de trabalho, já que seus enunciados configuravam obstáculos para o julgamento de recursos, com vistas a ordenar e facilitar a tarefa judicante, especialmente nos casos repetitivos ${ }^{193}$ : "Por tudo isso, dizia o prefácio da primeira edição da Súmula que a sua finalidade 'não é somente proporcionar maior estabilidade à jurisprudência, mas também facilitar o trabalho dos advogados e do Tribunal, simplificando o julgamento das questões

\footnotetext{
${ }^{190}$ In SANCHES, Sydney, Uniformização da jurisprudência, 1975, pp. 16/17.

${ }^{191}$ In RosAs, Roberto, Da súmula à súmula vinculante, in Revista dos Tribunais, vol. 879, 2009, p. 42.

192 V., nesse sentido, RosAS, Roberto, Do assento e do prejulgado à Súmula do STF, in Revista dos Tribunais, vol. 404, 1969, p. 20.

${ }^{193}$ É fato notório que quem mais contribui para a existência e para a pendência de casos repetitivos nos acervos judiciários é o próprio Estado, em seus diversos níveis federativos. V., nesse sentido, DINAMARCO, Cândido Rangel, Decisões vinculantes, in Revista de Processo, n 100, 2000, p. 168, ViGLIAR, José Marcelo Menezes, Uniformização de jurisprudência - Segurança jurídica e dever de uniformizar, 2003, p. 44 e TEIXEIRA, Sálvio de Figueiredo, As tendências brasileiras rumo à jurisprudência vinculante, in Revista do Instituto dos Advogados de São Paulo, $\mathrm{n}^{\circ}$ 2, 1998, p. 148. Este último enumera medidas adotadas pelo Executivo, no final da década de 1990, no sentido de valorizar as decisões judiciais e diminuir sua presença em juízo (in idem, ibidem, pp. 148/150).
} 
freqüentes. Por isso, a emenda ao Regimento (...) atribui à Súmula outros relevantes efeitos processuais', como fossem: negar-se provimento ao agravo para subida de recurso extraordinário, não se conhecer do recurso extraordinário, não se conhecer dos embargos de divergência e rejeitar os infringentes, sempre que o pedido do recorrente contrariasse a jurisprudência compreendida na Súmula, ressalvado o procedimento de revisão da própria Súmula. Mais que isso, poderia o relator, em tal hipótese, mandar arquivar o recurso extraordinário, ou o agravo de instrumento, facultado à parte prejudicada interpor agravo regimental contra o despacho." 194.

Seu idealizador costumava dizer que o instituto da súmula da jurisprudência predominante era subproduto de sua falta de memória: "juiz calouro, com a agravante da falta de memória, tive que tomar, nos primeiros anos, numerosas notas, e bem assim

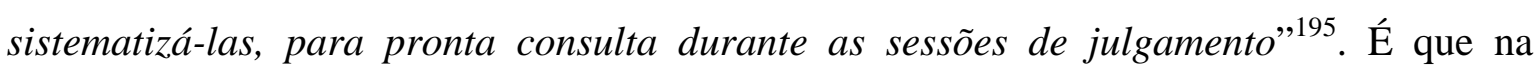
inexistência de método próprio para identificar as matérias que já não convinha discutir de novo, salvo se sobreviesse motivo relevante, o hábito dos ministros era de se reportarem cada qual à sua memória, testemunhando, para os colegas mais novatos, qual era a jurisprudência assentada na corte.

Ao permitirem o discernimento das hipóteses que se repetiam com frequência daquelas que mais raramente eram submetidas ao STF, as súmulas inauguraram uma espécie de "princípio da relevância às avessas". Estabeleceu-se que os casos repetitivos, então considerados sem relevância jurídica, deviam ser julgados de forma segura, mas rápida, abolindo-se as formalidades e os desdobramentos protelatórios e evitando "as questiúnculas estéreis, do dia a dia, as saborosas controvérsias úteis aos desvãos dos entendimentos humanos, porém, inúteis" $"$ "196. Foi nesse contexto, então, que as súmulas passaram a adquirir colaterais efeitos de natureza processual ${ }^{197}$. Às partes inconformadas, reservava-se somente o uso do agravo regimental, que permitia a alegação

\footnotetext{
${ }^{194}$ In LEAL, Victor Nunes, Passado e futuro da súmula do STF, in Revista de Direito Administrativo, $\mathrm{n}^{\circ} 145$, 1981, p. 8 .

${ }^{195}$ In LEAL, Victor Nunes, Passado e futuro da súmula do STF, in Revista de Direito Administrativo, $\mathrm{n}^{\circ} 145$, 1981, p. 14.

${ }^{196}$ In RoSAS, Roberto, Do assento e do prejulgado à Súmula do STF, in Revista dos Tribunais, vol. 404, 1969, p. 21.

${ }^{197}$ In LEAL, Victor Nunes, Passado e futuro da súmula do STF, in Revista de Direito Administrativo, $\mathrm{n}^{\circ} 145$, 1981, pp. $14 / 15$.
} 
da não aplicabilidade da súmula para o caso concreto ou a alegação de argumentos novos para pedir a sua revisão ${ }^{198}$.

Ainda que oficialmente dirigidas a facilitar o trabalho dos advogados na localização dos precedentes e a atenuar a sobrecarga de trabalho do Supremo Tribunal Federal, as súmulas surgiram como reação do STF ao processo de debilitação pelo qual estava passando, causado, alegadamente, pelas instituições liberais previstas na Constituição de 1946 e pela já então considerável quantidade de processos a serem julgados - cerca de sete mil por ano, um "fardo asfixiante"199.

Sua aceitação, como sói ocorrer com a maioria dos institutos jurídicos, não se deu de forma pacífica, tendo gerado de início amplas discussões em torno de sua natureza, abrangência e efeitos. Os principais motivos de resistência encontrados em alguns setores da advocacia e até mesmo da magistratura diziam respeito ao caráter quase normativo dos enunciados e ao suposto impedimento da evolução da jurisprudência.

LEAL retrucava as críticas demonstrando que as súmulas não eram imutáveis: "É um instrumento flexível, que simplifica o trabalho da Justiça em todos os graus, mas evita a petrificação, porque a Súmula regula o procedimento pelo qual pode ser modificada. Ela não estanca o fluxo criador da jurisprudência, nem impede a sua adaptação às condições emergentes. Apenas exige, para ser alterada, mais aprofundado esfôrço dos advogados e juízes. Deverão êles procurar argumentos novos, ou aspectos inexplorados nos velhos argumentos, ou realçar as modificações operadas na própria realidade social e econômica. Com essa precaução, a Súmula substitui a loteria judiciária das maiorias ocasionais pela perseverança esclarecida dos autênticos profissionais do direito." 200 . Nem poderia ser de outra forma, já que ele mesmo reconhecia que "firmar a jurisprudência, de modo rígido, não seria um bem, nem mesmo seria viável. A vida não pára, nem cessa a criação legislativa e doutrinária do direito. Mas vai uma enorme diferença entre a mudança, que é freqüentemente necessária, e a anarquia jurisprudencial,

\footnotetext{
${ }^{198}$ In BOTELHO DE MESQUITA, José Ignacio, A súmula da jurisprudência predominante no Supremo Tribunal Federal, in Teses, estudos e pareceres de processo civil, vol. 2, 2005, pp. 220/224.

${ }^{199}$ In LeAL, Victor Nunes, Atualidade do Supremo Tribunal, in Revista de Direito Administrativo, ${ }^{\circ}$ 78, 1964, p. 455.

${ }^{200}$ In LEAL, Victor Nunes, Atualidade do Supremo Tribunal, in Revista de Direito Administrativo, $\mathrm{n}^{\circ} 78$, 1964, pp. 458/459.
} 
que é descalabro e tormento. Razoável e possível é o meio-têrmo, para que o Supremo Tribunal possa cumprir o seu mister de definir o direito federal, eliminando ou diminuindo os dissídios de jurisprudência."201 . Com o tempo, os temores de estratificação da jurisprudência arrefeceram e foram contrariados pela receptividade do Supremo em rediscutir, e modificar, quando era o caso, os enunciados da Súmula.

Em sessão plenária de 13 de dezembro de 1963 foram aprovadas as primeiras trezentas e setenta súmulas do Supremo Tribunal Federal, as quais começaram a vigorar no início do ano judiciário de 1964. O primeiro adendo (Súmulas-STF no 371-404) foi aprovado em 3 de abril de 1964; o segundo adendo (Súmulas-STF no 405-438), em $1^{\circ}$ de junho de 1964; o terceiro adendo (Súmulas-STF nº 439-472), em 1º de outubro de 1964; o quarto adendo (Súmulas-STF no 473-551), em 8 de dezembro de 1969; e o quinto adendo (Súmulas-STF nº 552-600), em 15 de dezembro de 1976.

O primeiro longo interregno, da edição do terceiro para o quarto adendo, deveu-se à mudança do regime político, quando se passou a questionar se seria mantida a inovação da súmula. Só com a Constituição de 1967 é que se teve certeza de que as súmulas poderiam prosseguir ${ }^{202}$. Mais tarde, as súmulas de jurisprudência predominante tornaram-se corriqueiras e, com a promulgação do Código de Processo Civil de 1973, os demais tribunais do país passaram a ter competência para editarem as suas próprias (art. 479, do CPC) $)^{203}$.

Ainda que nenhuma disposição legal conferisse a seus enunciados eficácia vinculante, na prática as súmulas exerciam - e ainda exercem, até hoje, como será visto mais adiante - enorme influência nos julgamentos, tanto nos tribunais quanto em primeiro $\operatorname{grau}^{204}$.

\footnotetext{
${ }^{201}$ In LEAL, Victor Nunes, Atualidade do Supremo Tribunal, in Revista de Direito Administrativo, ${ }^{\circ}$ 78, 1964, p. 455.

${ }^{202}$ In LEAL, Victor Nunes, Passado e futuro da súmula do STF, in Revista de Direito Administrativo, $\mathrm{n}^{\circ} 145$, 1981, p. 14.

${ }^{203}$ In LEAL, Victor Nunes, Passado e futuro da súmula do STF, in Revista de Direito Administrativo, $\mathrm{n}^{\circ} 145$, 1981, pp. 1/2.

${ }^{204}$ In BARBOSA MOREIRA, José Carlos, Súmula, jurisprudência, precedente: uma escalada e seus riscos, in Revista Síntese de Direito Civil e Processual Civil, nº 35, 2005, p. 6.
} 
A Emenda Constitucional $\mathrm{n}^{\circ}$ 7, de 13 de abril de 1977, exacerbou ao extremo o poder do Supremo Tribunal Federal, ao atribuir-lhe competência para a interpretação em abstrato de qualquer lei ou ato normativo federal ou estadual, mediante iniciativa do Procurador-Geral da República e com efeito vinculante para todos os juízes e tribunais do país (art. 119, I, “l”, da CF de 1967) ${ }^{205}$. O instituto, denominado de "representação para interpretação de lei ou ato normativo", dava ensejo a atividade judicial de natureza preventiva, porquanto ocorria antes da instauração da ação judicial.

A Emenda $n^{\circ} 7$ ao RISTF de 1970, publicada em 23 de agosto de 1978, reiterou a regra acima, ao dispor que as decisões tomadas mediante representação do Procurador-Geral teriam força vinculante, "implicando sua não-observância negativa de vigência do texto interpretado" ${ }^{206}$. É curioso notar que, embora não recepcionado pela Constituição de 1988, o instituto continua previsto no atual RISTF, publicado em 7 de outubro de 1980, nos arts. 179 a 187.

O instituto, criado simultaneamente ao instrumento de avocação de causas pelo STF e à arguição de relevância para a admissão do recurso extraordinário (todos considerados instrumentos autoritários), recebeu a crítica da doutrina mais abalizada na época, não obstante tenha permanecido em vigor por longos anos. BOTELHO DE MESQUITA, por exemplo, em tese originalmente apresentada e aprovada na VIII Conferência Nacional da Ordem dos Advogados do Brasil, realizada em Manaus entre 18 e 22 de maio de 1980, propôs a supressão desse "instrumento redutor da liberdade, e a criação, em seu lugar, de meios aptos à uniformização da jurisprudência"207.

\footnotetext{
${ }^{205}$ In BotelHo DE MESQuiTA, José Ignacio, A súmula da jurisprudência predominante no Supremo Tribunal Federal, in Teses, estudos e pareceres de processo civil, vol. 2, 2005, pp. 223/224.

${ }^{206}$ In CÔRTES, Osmar Mendes Paixão, A experiência brasileira com a vinculação das decisões judiciais e a atual súmula vinculante introduzida pela EC 45/2004, in Direito civil e processo - Estudos em homenagem ao Professor Arruda Alvim, 2007, p. 1.384.

${ }^{207}$ In Botelho DE Mesquita, José Ignacio, O princípio da liberdade na prestação jurisdicional, in Teses, estudos e pareceres de processo civil, vol. 2, 2005, pp. 45/47.
} 


\section{COMMON LAW}

SUMÁRIO. 3.1 Formação da common law. 3.2 Repertórios de jurisprudência. 3.3 Eficácia vinculante do precedente judicial e teoria do stare decisis. 3.4 Exceções à teoria do stare decisis.

\subsection{Formação da common law}

Após a queda do Império Romano do Ocidente, o direito europeu permaneceu em todo o continente, e também na Inglaterra, com características muito parecidas, predominando um sistema de regras não escritas, baseado nos costumes locais. Foi na passagem do século XII para o século XIII que a comunidade europeia foi alvo de sensível transformação, que se fez notar também no campo do direito.

Antes que o ensino do direito romano-canônico começasse a se espalhar, a Inglaterra, como resultado da invasão normanda e até mesmo em razão da sua posição geográfica, deu início a um processo de centralização das fontes de produção do direito, unindo regiões que até então eram autônomas e independentes. Esse direito comum e uniforme administrado pelo Estado passou a substituir, de forma progressiva, os sistemas jurídicos fragmentários que vigiam até então.

Quando o direito romano-canônico passou a assumir autoridade perante os tribunais canônicos e laicos, já era muito tarde para que o direito inglês se fizesse "seduzir" por tais reflexões jurídicas ${ }^{208}$. Na época, estava ele sob o forte domínio de advogados e juízes, que, formando um grupo homogêneo e compacto, controlavam a prática jurídica e a preparação para o exercício da profissão. Esse grupo detinha não só as habilidades necessárias para o mister, mas também o monopólio do conhecimento jurídico, extraído essencialmente das decisões judiciais preexistentes ${ }^{209}$.

\footnotetext{
${ }^{208}$ In CRUZ E TUCCI, José Rogério, Precedente judicial como fonte de direito, 2004, pp. 149/150.

209 In CAZETTA JÚNIOR, José Jesus, A ineficácia do precedente no sistema brasileiro de jurisdição constitucional (1891-1993): contribuição ao estudo do efeito vinculante, Tese (Doutorado), 2004, p. 69.
} 
Como o direito inglês constitui o protótipo em que diversos direitos se inspiraram, convém basear-se nele para o estudo da common law ${ }^{210}$ - embora seja difícil, quiçá impossível, traduzir por completo seu espírito em trabalho tão modesto como o presente. Seu período de formação é comumente apontado pela doutrina entre 1066 e o início da dinastia Tudor, em $1485^{211}$.

A preocupação do sistema inglês sempre foi a de garantir a certeza do direito, evitando julgamentos contraditórios em casos análogos. Daí porque desde a sua formação a common law mostrou ser um sistema de case law, embora de início não houvesse regra alguma impondo efeito vinculante ao precedente judicial ${ }^{212}$. O direito era entendido como fruto moral, racional, econômico, histórico, experimental, que encontrava na lei apenas uma de suas manifestações ${ }^{213}$.

Sobressai também a sua natureza essencialmente contenciosa e procedimental. Isso porque, desde os primórdios, assim como o direito romano das legis actiones, o direito da common law em geral se realiza na experiência concreta, prática, vivida perante os tribunais: "la common law era ed è opera dei giudici, che non la derivano semplicemente dal custom ma la creano risolvendo controversie ed applicando e riformulando le regole in funzione delle peculiarità dei casi concreti" ${ }^{214}$. Mesmo a

\footnotetext{
${ }^{210}$ Nesse sentido: "O direito inglês é o direito aplicado na Inglaterra e no País de Gales. Não é o direito dos países de língua inglesa ou de Commonwealth nem o do Reino Unido ou da Grã-Bretanha. Os direitos de Commonwealth às vezes são próximos do direito inglês, mas, em outros casos, podem ser bastante diferentes. $O$ direito da Irlanda do Norte e o da Ilha de Man são bastante próximos do direito inglês, mas o da Escócia é muito diverso, como também o é o das ilhas anglo-normandas. O domínio territorial limitado em que se aplica o direito inglês não constitui, porém, o critério com base no qual convém julgar seu valor e seu interesse. Comparável ao que foi o direito romano para os países do continente europeu e para inúmeros países extra-europeus, o direito inglês está na origem da maioria dos direitos dos países de língua inglesa, tendo exercido uma influência considerável sobre o direito de vários países que sofreram, numa época de sua história, a dominação britânica. Esses países podem ter se emancipado da Inglaterra e seu direito pode ter adquirido ou conservado características próprias. Mas a marca inglesa muitas vezes permanece profunda nesses países, afetando a maneira de conceber o direito, os conceitos jurídicos utilizados, os métodos e o espírito dos juristas. Assim, o direito inglês, superando amplamente o domínio estrito de sua aplicação territorial, constitui o protótipo em que numerosos direitos se inspiraram; é por seu estudo que convém começar todo e qualquer estudo dos direitos pertencentes à 'família de common law'." (in DAVID, René, O direito inglês, 1997, pp. VII/VIII).

${ }^{211}$ In CRUZ E TUCCI, José Rogério, Precedente judicial como fonte de direito, 2004, p. 151 e Goron, Lívio Goellner, A jurisprudência como fonte de direito: a experiência anglo-americana, in Revista de Direito Constitucional e Internacional, ${ }^{\circ}$ 47, 2004, pp. 285/286.

${ }^{212}$ In CRUZ E TUCCI, José Rogério, Precedente judicial como fonte de direito, 2004, pp. 153/154.

${ }^{213}$ In AsCARelli, Tullio, Problemas das sociedades anônimas e direito comparado, 1945, p. 60.

${ }^{214}$ In TARUFFO, Michele, Il giudice e la "Rule of Law", in Rivista Trimestrale di Diritto e Procedura Civile, ano 53, n 3, 1999, p. 937.
} 
educação jurídica sempre foi centrada no estudo das decisões judiciais preexistentes, despontando daí seu caráter fundamentalmente prático. Não existem no direito da common law regras materiais, mas técnicas processuais, destinadas a pôr fim aos litígios ${ }^{215}$.

No final do século XVIII e início do século XIX, já era nítida a diferença do continente europeu em relação à Inglaterra, tanto na arquitetura institucional, quanto no pensamento jurídico. Embora tenha predominado por bastante tempo na common law teoria em sentido contrário, naquela época já havia sido amplamente difundida a consciência de que o direito não era simplesmente declarado, mas produzido pelos tribunais $^{216}$.

\subsection{Repertórios de jurisprudência}

No decorrer dos anos, as decisões judiciais no direito inglês foram sendo catalogadas em livros, denominados de statute books, que nada mais eram do que compilações dos costumes da corte. Os statute books eram utilizados como referência pelos juízes por ocasião da prolação das decisões, quando adaptavam a ratio do caso julgado para o caso concreto. Também eram usados com escopo acadêmico, com vistas a auxiliar o ensino jurídico nas universidades.

Para FERREIRA DA SILVA, é "fácil perceber que um sistema fundado sobre a autoridade de decisões prévias carece de um arsenal bastante grande e fiel onde se armazenem, de forma concreta, as decisões objeto de referência". De tal forma prossegue o autor -, “à medida em que se aperfeiçoavam os repositórios de decisões também evoluía a doutrina do precedente" 217.

Ao longo da história da common law, essas publicações passaram por três grandes etapas. De 1283 a 1535 desenvolveu-se a fase dos denominados Year Books, que

\footnotetext{
${ }^{215}$ In DAVID, René, O direito inglês, 1997, pp. 7/8 e GoRON, Lívio Goellner, A jurisprudência como fonte de direito: a experiência anglo-americana, in Revista de Direito Constitucional e Internacional, $\mathrm{n}^{\circ}$ 47, $2004, \mathrm{p}$. 286.

216 In CAZETTA JÚNIOR, José Jesus, A ineficácia do precedente no sistema brasileiro de jurisdição constitucional (1891-1993): contribuição ao estudo do efeito vinculante, Tese (Doutorado), 2004, p. 72.

${ }^{217}$ In FERREIRA DA SILVA, Luis Renato, A regra do precedente no direito inglês, in Revista de Direito Civil, Imobiliário, Agrário e Empresarial, nº 75, 1996, p. 49.
} 
consistiam em repositórios de jurisprudência, contendo trechos selecionados dos argumentos dos litigantes e das decisões judiciais. Referidas anotações eram feitas, geralmente em francês, por advogados e estudantes que assistiam aos julgamentos. Tais anuários eram bastante organizados e vinham catalogados por assunto e em ordem alfabética.

Por volta da metade do século XVI, em período que perdurou até meados do século XIX, as compilações então existentes foram substituídas pelos Law Reports, de caráter privado, feitos por juízes para o seu próprio uso. Esses repertórios transcreviam textualmente o caso e a respectiva decisão. A coleção do Chief-Justice EDWARD COKE (Coke's Reports), de 1600, dividida em 11 volumes, foi a mais famosa, tanto que o seu autor ficou conhecido como o fundador da teoria moderna do precedente judicial ${ }^{218}$.

A terceira e última grande etapa teve início em 1865 , com a criação do General Council of Law Reporting, e se estende até os dias atuais. Apesar de ainda existirem publicações particulares, trata-se de repositórios oficiais, que, nessa qualidade, conferem maior confiabilidade e idoneidade às citações ${ }^{219}$.

A forma como se estruturaram essas publicações fez com que o direito jurisprudencial inglês, assim como o direito anglo-americano em geral, formasse um corpo perfeitamente orgânico. A jurisprudência da civil law, pelo contrário, é integrada por julgados esparsos e, mesmo quando constantes num determinado sentido, não se enxerga neles um conjunto próprio de princípios ${ }^{220}$.

Mesmo hoje, o sistema inglês dispõe de excelentes instrumentos de pesquisa, inclusive eletrônicos, sendo que as decisões da House of Lords são disponibilizadas na íntegra no site do órgão (<http://www.parliament.the-stationeryoffice.co.uk>) logo depois dos julgamentos. Nos Estados Unidos, também são bastante

\footnotetext{
${ }^{218}$ In CRUZ E TUCCI, José Rogério, Precedente judicial como fonte de direito, 2004, p. 155. V., para uma breve biografia de Sir EDWARD COKE, YoshIKAWA, Eduardo Henrique de Oliveira, Origem e evolução do devido processo legal substantivo: o controle da razoabilidade das leis do século XVII ao século XXI, 2007, pp. $27 / 36$.

${ }^{219}$ In FERREIRA DA SILVA, Luis Renato, A regra do precedente no direito inglês, in Revista de Direito Civil, Imobiliário, Agrário e Empresarial, nº 75, 1996, pp. 49/50.

${ }^{220}$ In LimOngi FrançA, Rubens, Jurisprudência - Seu caráter de forma de expressão de Direito, in Repertório Enciclopédico do Direito Brasileiro, vol. 30, p. 285.
} 
utilizados como fontes de consulta os serviços de empresas privadas, assim como o próprio site da Suprema Corte $(<\mathrm{http}: / / \mathrm{www} \text {.supremecourt.gov }>)^{221}$.

Quando da formação do direito inglês, os juízes não tinham por base um sistema de regras preestabelecidas. Conforme muito bem aponta GORON, "aos magistrados do Reino cabia não somente aplicar, mas sobretudo revelar o direito que devia ser aplicado, retirando-o das convicções da população",222.

Nessa toada, não havia uma regra que obrigasse a vinculação ao precedente $^{223}$; havia apenas a tradição de respeitar as decisões da mesma corte ou das cortes hierarquicamente superiores.

Foi no século XIX que o precedente judicial na common law passou a assumir eficácia vinculante (binding precedent). No julgamento do caso Beamisch vs. Beamisch, conduzido em 1861 por Lord CAMPBELL, restou estabelecido que a House of Lords estaria obrigada a acatar sua própria autoridade nos julgamentos ${ }^{224}$. O entendimento foi reiterado em 1895 no caso Bradford vs. Pickles e foi definitivamente reconhecido em 1898 no caso London Tramways Company vs. London County Council ${ }^{225}$. Consolidou-se então na Inglaterra a moderna teoria do stare decisis (que, portanto, não nasceu junto com a common law e com ela não se confunde ${ }^{226}$ ), concebida por Sir BARON PARKE J., segundo a qual o precedente passa a assumir força obrigatória ${ }^{227}$. Costuma ser dito que essa regra propicia uma quádrupla vantagem: igualdade, segurança, economia e respeitabilidade ${ }^{228}$.

${ }^{221}$ In TOSTES, Natacha Nascimento Gomes, Uniformização de jurisprudência, in Revista de Processo, $\mathrm{n}^{\circ}$ 104, 2001, pp. 201/202.

${ }^{222}$ In GoRON, Lívio Goellner, A jurisprudência como fonte de direito: a experiência anglo-americana, in Revista de Direito Constitucional e Internacional, n ${ }^{\circ}$ 47, 2004, p. 286.

${ }^{223}$ In FERRAZ JUNIOR, Tércio Sampaio, Introdução ao estudo do direito - técnica, decisão, dominação, 1994, p. 243.

${ }^{224}$ In CRUZ E TUCCI, José Rogério, Precedente judicial como fonte de direito, 2004, p. 158.

${ }^{225}$ In CRUZ E TUCCI, José Rogério, Precedente judicial como fonte de direito, 2004, p. 161.

${ }^{226}$ In MARINONI, Luiz Guilherme, Precedentes obrigatórios, disponível em <http://marinoni.adv.br>, acesso em 16/09/2011, p. 3.

${ }^{227}$ Ross avalia a doutrina do stare decisis de maneira bastante cética, afirmando categoricamente que a mesma não passa de uma ilusão: "Trata-se de uma ideologia mantida por certas razões com o intuito de ocultar aos seus propugnadores e aos demais a função criadora de direito detida pelos juízes, e transmitir a 
Segundo CAZETTA JÚNIOR, a força vinculante dos precedentes para os juízes tem seu centro de gravidade no princípio da universalização, de acordo com o qual casos similares devem ser tratados de forma análoga, sendo que, "a esse princípio ético se associam outros fins políticos: (1) tornar os julgamentos racionais e previsíveis; (2) proteger a confiança que as decisões anteriores tenham gerado, inclusive quanto à imparcialidade do sistema judiciário; (3) permitir que os Tribunais focalizem, gradualmente, questões novas" ${ }^{229}$. Assim, no geral, o afastamento da regra só é possível nas hipóteses em que fatos relevantes se coloquem entre a situação presente e a situação que deu origem ao precedente, diferenciando os casos.

Na hipótese de descumprimento, aplica-se o contempt of court. Aquele que viola uma decisão da corte torna-se culpado por contumácia e corre o risco de ser preso ${ }^{230}$.

Essencialmente, o efeito vinculante das decisões depende da posição hierárquica do prolator da decisão. O julgamento normalmente vincula a própria corte (eficácia interna ou horizontal) e os órgãos hierarquicamente inferiores (eficácia externa ou (vertical $)^{231}$.

O precedente judicial não deve ser automaticamente aplicado; antes, os elementos objetivos do caso que gerou o precedente e a regra jurídica que sustenta a decisão (ratio decidendi ${ }^{232}$ ) devem ser cotejados com o caso concreto.

impressão falaciosa de que estes apenas aplicam o direito existente, o qual pode ser determinado em virtude de um conjunto de regras objetivas como indica a doutrina de stare decisis." (in Ross, Alf, Direito e justiça, 2000, p. 115).

${ }^{228}$ In Dinamarco, Cândido Rangel, Decisões vinculantes, in Revista de Processo, $\mathrm{n}^{\circ}$ 100, 2000, p. 169. V., sustentando sua tese nesse quadrinômio, VIGLIAR, José Marcelo Menezes, Uniformização de jurisprudência - Segurança jurídica e dever de uniformizar, 2003.

${ }^{229}$ In CAZETTA JÚNIOR, José Jesus, A ineficácia do precedente no sistema brasileiro de jurisdição constitucional (1891-1993): contribuição ao estudo do efeito vinculante, Tese (Doutorado), 2004, p. 74.

${ }^{230}$ In DAVID, René, O direito inglês, 1997, p. 19.

${ }^{231}$ In CRUZ E TuCCI, José Rogério, Precedente judicial como fonte de direito, 2004, p. 170.

${ }^{232}$ Nos Estados Unidos, não se fala em ratio decidendi, mas em holding (in CAZETTA JúNIOR, José Jesus, $A$ ineficácia do precedente no sistema brasileiro de jurisdição constitucional (1891-1993): contribuição ao estudo do efeito vinculante, Tese (Doutorado), 2004, p. 80). 
Nas palavras de CRUZ E TUCCI, a ratio decidendi “(...) constitui a essência da tese jurídica suficiente para decidir o caso concreto (rule of law). É essa regra de direito (e, jamais, de fato) que vincula os julgamentos futuros inter alia. Sob o aspecto analítico, três são os elementos que a integram: a) a indicação dos fatos relevantes (statement of material facts); b) o raciocínio lógico-jurídico da decisão (legal reasoning); $e$ c) o juízo decisório (judgement). Cumpre esclarecer que a ratio decidendi não é pontuada ou individuada pelo órgão julgador que profere a decisão. Cabe aos juízes, em momento posterior, ao examinarem-na como precedente, extrair a 'norma legal' (abstraindo-a do caso) que poderá ou não incidir na situação concreta. (...) Como regra necessária à decisão, não se confunde com o obiter dictum, vale dizer, passagem da motivação do julgamento que contém argumentação marginal ou simples opinião, prescindível para o deslinde da controvérsia. $O$ obiter dictum, assim considerado, não se presta para ser invocado como precedente vinculante em caso análogo, mas pode perfeitamente ser referido como argumento de persuasão."233.

Como se vê, na ratio decidendi encontram-se os motivos determinantes da decisão. Já o obiter dictum lida com os fatos marginais, secundários, mencionados na decisão para o fim exclusivo de enriquecimento do julgado. A precisa fixação do que constitui um e outro é de extrema relevância, pois é apenas a ratio decidendi que assume caráter vinculante para o futuro e é com ela que deve ser comparado o caso novo em apreciação. O que consta da esfera do obiter dictum, por sua vez, surte efeitos meramente persuasivos.

Essa comparação é feita de forma relativamente flexível, porque o juiz, ao interpretar o precedente, pode fazê-lo de forma restritiva (restrictive distinguishing), ampliativa (ampliative distinguishing) ou analógica, nos chamados cases of first impression, quando, ao se deparar com a questão pela primeira vez, tem de criar a solução adequada ao caso concreto ${ }^{234}$.

\footnotetext{
${ }^{233}$ In CRUZ E TUCCI, José Rogério, Precedente judicial como fonte de direito, 2004, pp. 175/177.

${ }^{234}$ In CRUZ E TUCCI, José Rogério, Precedente judicial como fonte de direito, 2004, p. 175 e Goron, Lívio Goellner, A jurisprudência como fonte de direito: a experiência anglo-americana, in Revista de Direito Constitucional e Internacional, nº 47, 2004, p. 292.
} 
Diz-se que a técnica das distinções é fundamental no direito inglês, pois é ela que permite a sua evolução, apesar de a regra do precedente conferir-lhe certa rigidez $^{235}$. Ainda assim o sistema não é totalmente imune a críticas. Para Goron, “(...) $a$ common law vem sofrendo uma crise de consideráveis proporções em face das exigências do Estado Social que foi implementado no pós-guerra. O processo tradicional de elaboração do Direito de base jurisprudencial, lastreado no uso, adaptação e superação gradual de precedentes judiciais, não consegue atender eficientemente às atuais demandas por rápidas e profundas transformações sociais." ${ }^{236}$.

Em qualquer caso, o juiz deve sempre justificar os motivos de aplicação ou de rejeição de um precedente, levando em consideração não apenas o caso concreto, posto sob a sua apreciação, mas também a repercussão prática que a sua decisão gerará para todo o ordenamento.

\subsection{Exceções à teoria do stare decisis}

O fato de o precedente ser dotado de eficácia vinculante não significa que a tese jurídica que ele encerra deva ser aplicada nos julgamentos futuros de casos análogos sem qualquer exceção. Para permitir a evolução natural do direito, as cortes superiores podem, excepcionalmente, substituir os precedentes que entenderem ultrapassados ou superados, desarrazoados ou errôneos ${ }^{237}$, mediante procedimento de overruling, que pode ocorrer de forma expressa (express overruling) ou tácita (implied overruling). $\mathrm{Na}$ civil law ocorre algo parecido, quando a corte declara abandonar um precedente para seguir outro, mediante revirement jurisprudencial ${ }^{238}$.

Trata-se, enfim, de "mecanismo utilizado para que se reconheça a existência de fundamento para o abandono do precedente anteriormente estabelecido, por haverem sido alteradas as razões que autorizaram a sua edição"239.

\footnotetext{
${ }^{235}$ In DAVID, René, O direito inglês, 1997, p. 14.

${ }^{236}$ In GoRON, Lívio Goellner, A jurisprudência como fonte de direito: a experiência anglo-americana, in Revista de Direito Constitucional e Internacional, nº 47, 2004, p. 293.

${ }^{237}$ In RE, Edward D., Stare decisis, in Revista de Informação Legislativa, no 122, 1994, p. 285.

${ }^{238}$ In LOPES, Raquel Cardoso, Uniformização da jurisprudência, in Revista Forense, vol. 390, 2007, p. 573.

239 In Tostes, Natacha Nascimento Gomes, Uniformização de jurisprudência, in Revista de Processo, $\mathrm{n}^{\circ}$ 104, 2001, p. 212.
} 
Em 1966, mais especificamente em 26 de julho, a House of Lords, por intermédio de seu Lord Chancellor (Lord GARDINER), anunciou oficialmente, por meio do Practice Statement, que poderia, quando entendesse oportuno ou conveniente, para evitar uma injustiça no caso concreto, anular ou superar seus próprios precedentes ${ }^{240}$ : "Their Lordships regard the use of precedent as an indispensable foundation upon which to decide what is the law and its application to individual cases. It provides at least some degree of certainty upon which individuals can rely in the conduct of their affairs, as well as a basis for orderly development of legal rules. Their Lordships nevertheless recognise that too rigid adherence to precedent may lead to injustice in a particular case and also unduly restrict the proper development of the law. They propose, therefore, to modify their present practice and, while treating former decisions of this House as normally binding, to depart from a previous decision when it appears right to do so. In this connection they will bear in mind the danger of disturbing retrospectively the basis on which contracts, settlements of property and fiscal arrangements have been entered into and also the especial need for certainty as to the criminal law. This announcement is not intended to affect the use of precedent elsewhere than in this House." ${ }^{241}$. Antes disso, suas decisões só poderiam ser alteradas por ato do Parlamento editando regulamentação específica sobre a matéria e anulando a decisão anterior ${ }^{242}$.

Na Criminal Division da Court of Appeal a regra do precedente é constantemente mitigada, chegando alguns autores a afirmar que as decisões proferidas nesse âmbito constituem exceções ao stare decisis.

Há, ainda, importantes decisões judiciais que fixaram exceções à regra do stare decisis. Em 1944, decisão exarada pela Civil Division da Court of Appeal no caso Young vs. Bristol Aeroplane Co. Ltd. estabeleceu três exceções à regra do precedente: “On

\footnotetext{
${ }^{240}$ In GoRON, Lívio Goellner, A jurisprudência como fonte de direito: a experiência anglo-americana, in Revista de Direito Constitucional e Internacional, $\mathrm{n}^{\circ}$ 47, 2004, p. 291 e NoGUEIRA, Gustavo Santana, Jurisprudência vinculante no direito norte-americano e no direito brasileiro, in Revista de Processo, $\mathrm{n}^{\circ} 161$, 2008, p. 105. V., mencionando que o Practice Statement diminuiu a rigidez do stare decisis na Inglaterra, CAPPELLETTI, Mauro, The judicial process in comparative perspective, 1989, p. 52. V., do mesmo autor, Juizes legisladores?, 1993, p. 122.

241 Disponível em <http://sixthformlaw.info/02_cases/mod2/cases_precedent_hol.htm\#Practice Statement (Judicial Precedent) [1966] HL>, acesso em 05/11/2011.

${ }^{242}$ In FERREIRA DA SILVA, Luis Renato, A regra do precedente no direito inglês, in Revista de Direito Civil, Imobiliário, Agrário e Empresarial, nº 75, 1996, p. 54.
} 
a careful examination of the whole matter we have come to the clear conclusion that this court is bound to follow previous decisions of its own as well as those of courts of coordinate jurisdiction. The only exceptions to this rule (two of them apparent only) are those already mentioned which for convenience we here summarize: (1.) The court is entitled and bound to decide which of two conflicting decisions of its own it will follow. (2.) The court is bound to refuse to follow a decision of its own which, though not expressly overruled, cannot, in its opinion, stand with a decision of the House of Lords. (3.) The court is not bound to follow a decision of its own if it is satisfied that the decision was given per incuriam." 243 .

Em 1968, decisão proferida novamente pela Court of Appeal, no caso Boys vs. Chaplin, determinou que a decisão tomada em uma interlocutory appeal, "where legal points are rarely fully argued ${ }^{, 244}$, não tem a prerrogativa de vincular a Court of Appeal.

Já em 1977, por ocasião do julgamento do caso Worcester Works Finance Ltd. vs. Cooden Engineering Co. Ltd., estabeleceu-se que decisão proferida pela Court of Appeal perde sua eficácia vinculante se desaprovada pelo Privy Council. A exceção encerra uma peculiaridade pois as decisões tomadas por um e por outro tribunal não são vinculantes entre si, na medida em que atuam em campos diversos ${ }^{245}$.

\footnotetext{
${ }^{243}$ Disponível em <http://www.justis.com/data-coverage/iclr-s4420113.aspx>, acesso em 05/11/2011.

244 Disponível em <http://sixthformlaw.info/02_cases/mod2/cases_precedent_coa.htm\#Boys v Chaplin [1968] CA>, acesso em 05/11/2011.

${ }^{245}$ V., a respeito de tais decisões judiciais e das demais exceções, FERREIRA DA SILVA, Luis Renato, A regra do precedente no direito inglês, in Revista de Direito Civil, Imobiliário, Agrário e Empresarial, nº 75, 1996, pp. $54 / 56$.
} 


\section{CRESCENTE VALORIZAÇÃO DO PRECEDENTE JUDICIAL}

SUMÁRIO. 4.1 Opção do sistema processual brasileiro. 4.2 Eficácia vinculante. 4.2.1 Conceito. 4.2.2 Controle de constitucionalidade concentrado. 4.2.2.1 Considerações introdutórias. 4.2.2.2 Breve histórico e regulamentação. 4.2.2.3 Competência e quórum para o julgamento. 4.2.2.4 Medida cautelar. 4.2.2.5 Eficácia erga omnes, efeitos vinculantes e irrecorribilidade. 4.2.2.6 Intervenção de terceiros. 4.2.2.7 Modulação dos efeitos. 4.2.2.8 A denominada "coisa julgada inconstitucional”. 4.2.3 Súmula vinculante. 4.2.3.1 Considerações introdutórias. 4.2.3.2 Regulamentação. 4.2.3.3 Legitimação e intervenção de terceiros. 4.2.3.4 Objeto e requisitos. 4.2.3.5 Procedimento de elaboração, revisão e cancelamento. 4.2.3.6 Mecanismos de impugnação. 4.2.3.7 Efeitos e modulação dos efeitos. 4.2.3.8 Publicidade. 4.2.3.9 Percepções gerais. 4.2.3.10 Respostas às críticas. 4.3 Eficácia quase vinculante. 4.3.1 Conceito. 4.3.2 Ampliação dos poderes do relator. 4.3.2.1 Art. 38, da Lei $n^{o}$ 8.038/1990. 4.3.2.2 Art. 557, caput e $\S 1^{o}$, do CPC. 4.3.2.3 Art. 544, § 4', II, "b” e “c”, do CPC. 4.3.2.4 Art. 120, par. único, do CPC. 4.3.2.5 Análise crítica. 4.3.3 Ampliação dos poderes do juiz de primeiro grau. 4.3.3.1 Art. 518, \$ $1^{o}$, do CPC. 4.3.3.2 Art. 285-A, do CPC. 4.3.3.3 Análise crítica. 4.3.4 Art. 475, § $3^{o}$, do CPC. 4.3.5. Art. 481, par. único, do CPC. 4.3.6 Recurso extraordinário e repercussão geral. 4.3.6.1 Considerações introdutórias. 4.3.6.2 Regulamentação. 4.3.6.3 Conceito, presunção legal e demonstração da repercussão geral. 4.3.6.4 Competência para a apreciação da repercussão geral. 4.3.6.5 Momento e procedimento para a apreciação da repercussão geral. 4.3.6.6 Irrecorribilidade da decisão preliminar e efeitos para o futuro. 4.3.6.7 Multiplicidade de recursos sobre a mesma controvérsia. 4.3.6.8 Intervenção de terceiros. 4.3.6.9 Outras questões relevantes. 4.3.7 Recurso especial e recursos repetitivos. 4.3.7.1 Considerações introdutórias. 4.3.7.2 Regulamentação. 4.3.7.3 Conceito. 4.3.7.4 Seleção do recurso paradigma e suspensão dos demais recursos. 4.3.7.5 Impugnação da seleção e desistência do recurso paradigma. 4.3.7.6 Competência e momento para o julgamento do recurso paradigma. 4.3.7.7 Efeitos sobre os recursos sobrestados. 4.3.7.8 Intervenção de terceiros. 4.4 Eficácia persuasiva. 4.4.1 Conceito e requisitos. 4.4.2 Súmulas. 4.4.2.1 Súmulas do STF. 4.4.2.2 Súmulas do STJ. 4.5 Adequada utilização dos precedentes judiciais e da jurisprudência: inspiração nas técnicas oriundas da common law. 
Com relação a seus diferentes graus de jurisdição, o sistema processual brasileiro é estruturado como uma pirâmide: na base encontram-se os juízos de primeiro grau; no meio, os tribunais locais (estaduais) ou regionais (federais); e no topo, os tribunais superiores. Por tribunais superiores deve-se entender o Supremo Tribunal Federal (órgão de cúpula do Poder Judiciário), o Superior Tribunal de Justiça, o Tribunal Superior do Trabalho, o Tribunal Superior Eleitoral e o Superior Tribunal Militar, mas, para efeitos do nosso estudo, faremos referência apenas aos dois primeiros, que compõem a justiça comum, já que os três últimos fazem parte da justiça especializada, cujo exame foge dos limites deste trabalho.

Em função dessa estrutura piramidal, entendemos que a jurisprudência emanada dos tribunais superiores, assim como aquela emanada dos tribunais locais ou regionais nos limitados casos em que funcionam como última instância (nos temas relativos a direito estadual ou municipal), deveria surtir efeitos vinculantes. Naturalmente, há questões que extrapolam o âmbito de atuação do Supremo Tribunal Federal, não havendo motivos para restringir o instituto da súmula vinculante - ainda mais com todos os limites impostos ao seu objeto, como se verá a seguir - a esse tribunal.

Ainda assim, a regra não deveria se aplicar a toda jurisprudência. Somente do entendimento suficientemente discutido e maturado, representado por diversas decisões anteriores, é que deveria emergir essa espécie de efeito - no caso de direito novo, por exemplo, a divergência é saudável e deve ser suportada até a efetiva consolidação de entendimento em um sentido ou em outro pelo tribunal superior ${ }^{246}$. Uma vez consolidado o entendimento, então, o tribunal superior deveria emitir súmula de jurisprudência, com eficácia vinculante - até porque "uniformização sem efeito vinculante é o mesmo que uniformização sem efeito uniformizante" ${ }^{247}$.

\footnotetext{
${ }^{246}$ Sobre o assunto, ASCARELLI pondera que: "Quando, ao contrário, a lei é recente e fruto de uma ordem de idéias, distinta da do direito vigente no momento de sua decretação, pode verificar-se um fenomeno oposto, isto é, a tendência para interpretar a nova lei com os velhos principios. Pode acontecer, então, que, em lugar de ser a doutrina a preparar o caminho para uma nova legislação, seja a legislação a preparar o caminho para uma nova doutrina." (in ASCARELLI, Tullio, Problemas das sociedades anônimas e direito comparado, 1945, p. 10).

${ }^{247}$ In BotelHo DE MESQuiTA, José Ignacio, Uniformização da jurisprudência (esboço de substitutivo ao Projeto de Lei 3.804/93), in Teses, estudos e pareceres de processo civil, vol. 2, 2005, p. 240. O autor
} 
O raciocínio sempre brilhante de BARBOSA MOREIRA encaixa-se como uma luva no que diz respeito à necessidade, ou à conveniência, de os entendimentos consolidados serem registrados em súmula, sendo de se supor que os entendimentos que não alcançaram esse status permanecem ainda instáveis: "As teses prevalecentes, de maneira tranqüila, na jurisprudência de um tribunal, é de supor que hajam sido incorporadas à respectiva Súmula. Quanto às que ainda não o foram, o que se presume é que o terreno permanece instável, sem o grau de consolidação suficiente para que salte aos olhos, bem definido, o perfil da paisagem. Incorreria em excesso de afoiteza quem se precipitasse a cortar cerce evolução em curso, que a rigor não se sabe aonde conduzirá. Tenha-se em mente que, às vezes, sucessivas decisões tomadas numa única sessão bastam para converter em majoritária, no tribunal, tese a cujo favor, até então, falava número menor de precedentes. $" 248$.

Essa súmula, na medida em que vinculante, deveria surtir efeitos sobre todos os órgãos do Poder Judiciário, inclusive sobre os tribunais superiores, independentemente da matéria de especialização de cada um deles. Apenas na hipótese de eventual conflito é que deveria prevalecer internamente aquela do próprio tribunal superior que a emitiu, até, evidentemente, que os enunciados conflitantes fossem uniformizados - e deveria existir mecanismo para esse fim. Por exemplo, uma súmula do STJ deveria ser aplicável perante todos os demais juízos e tribunais; na hipótese de conflito com uma súmula do TST, porém, no STJ e nos órgãos a ele subordinados prevaleceria aquela, e no TST e nos demais juízos trabalhistas prevaleceria esta, até que se buscasse a uniformização entre elas, por mecanismo dirigido a esse fim $^{249}$. E, claro, na hipótese de conflito com

prossegue afirmando que: “(...) compreende-se que todas as interpretações sumuladas, e não apenas algumas delas, devam ter efeito vinculante. A opção, conseqüentemente, não pode ser entre atribuir ou não efeito vinculante à uniformização, mas entre uniformizar ou não uniformizar a jurisprudência." (in idem, ibidem, pp. 240/241).

248 In BARBOSA MOREIRA, José Carlos, Algumas inovações da Lei 9.756 em matéria de recursos civis, in Aspectos polêmicos e atuais dos recursos cíveis de acordo com a Lei $n^{o}$ 9.756/98, 1999, p. 325. V., no mesmo sentido, ARENHART, Sérgio Cruz, A nova postura do relator no julgamento dos recursos, in Revista de Processo, $\mathrm{n}^{\circ}$ 103, 2001, pp. 48/49. Em sentido semelhante, para justificar a criação das súmulas da jurisprudência predominante, LEAL afirmou, dentre outros motivos, que "era imprescindível distinguir os precedentes que exprimem nosso entendimento firme daqueles outros em que a nossa jurisprudência ainda se acha em vias de fixação" (in LEAL, Victor Nunes, Atualidade do Supremo Tribunal, in Revista de Direito Administrativo, $\mathrm{n}^{\circ} 78,1964$, p. 456).

${ }^{249}$ Esses conflitos são essencialmente hipotéticos, pois como muito bem ressalta ARENHART, invocando a lição de JOSÉ MigUel GARCIA MEDINA, "não haverá caso em que se possa invocar a jurisprudência ou as súmulas de um tribunal para solucionar tema afeto ao outro, já que, qualquer exame que um faça sobre 
súmula do STF, prevaleceria sempre esta, o que significa dizer que não teriam validade súmulas emitidas em contrariedade com os postulados do tribunal supremo ${ }^{250}$.

Em países como a França, os juízes de primeiro grau tendem a respeitar e a seguir as decisões da Corte de Cassação, apesar de o precedente judicial - exceto os provenientes da Assemblée Plénière ${ }^{251}$ - não ser dotado de eficácia vinculante. É uma questão de ordem psicológica, de tradição cultural. O mesmo ocorre na Alemanha, especialmente após a transformação do Tribunal da Câmara Imperial no Bundesgerichthof - $B G H$, em que, apesar de os precedentes não obrigarem, o juiz só se afasta da orientação consagrada pelos tribunais em raras exceções ${ }^{252}$. O mesmo se aplica à Itália ${ }^{253}$.

No Brasil, por outro lado, não é difícil encontrar decisões que destoam do entendimento dos tribunais superiores. Nas palavras de MARINONI, "o atual sistema brasileiro padece da tirania de alguns juízes que gostariam de poder impor as suas concepções morais sobre a Lei, a Constituição e a Democracia" ${ }^{\text {254 }}$. Exceto nas hipóteses de precedentes vinculantes, alguns (não se pode generalizar, jamais) de nossos julgadores sentem-se livres e confortáveis para decidirem como bem quiserem, mesmo que para isso tenham que ignorar posicionamento de corte superior. Infelizmente, a prática, nada benéfica, arraigou-se em nossa tradição jurídica.

matéria atinente ao outro constituirá intromissão indevida na competência desta Corte" (in ARENHART, Sérgio Cruz, A nova postura do relator no julgamento dos recursos, in Revista de Processo, $\mathrm{n}^{\circ}$ 103, 2001, $\mathrm{p}$. 46). O autor ressalva que em duas hipóteses será cabível a invocação, pelo STJ, de súmula do STF: a primeira dirá respeito às súmulas anteriores à Constituição Federal, época em que o STF também fazia a análise da legislação infraconstitucional; e a segunda guardará relação com a interpretação de regras infraconstitucionais tendo por base algum princípio constitucional. De resto, na resolução de questões federais propriamente ditas, o STJ sempre será a última instância, já que não haverá tribunal superior ao mesmo para julgar tais questões (in idem, ibidem, p. 46).

${ }^{250}$ A Súmula-STF no 401, editada em 1964, ao dispor que "não se conhece do recurso de revista, nem dos embargos de divergência, do processo trabalhista, quando houver jurisprudência firme do Tribunal Superior do Trabalho no mesmo sentido da decisão impugnada, salvo se houver colisão com a jurisprudência do Supremo Tribunal Federal", já reconhecia a prevalência dos entendimentos do STF sobre os entendimentos do TST, por exemplo.

${ }^{251}$ In CRUZ E TuCCI, José Rogério, Precedente judicial como fonte de direito, 2004, p. 251.

${ }^{252}$ In CRUZ E TUCCI, José Rogério, Precedente judicial como fonte de direito, 2004, pp. 220/230.

${ }^{253}$ In CRUZ E TUCCI, José Rogério, Precedente judicial como fonte de direito, 2004, pp. 254/257 e PARENTE, Eduardo de Albuquerque, Jurisprudência: da divergência à uniformização, 2006, p. 14.

${ }^{254}$ In MARINONI, Luiz Guilherme, Precedentes obrigatórios, disponível em <http://marinoni.adv.br>, acesso em 16/09/2011, p. 5. 
Dessa forma, pensamos que conferir eficácia vinculante a todas as súmulas dos tribunais superiores (e dos tribunais locais ou regionais quando funcionem como última instância) - que poderiam ser revistas e canceladas a qualquer tempo, uma vez observados procedimento e quórum específicos - seria a melhor opção, com vistas à uniformização da jurisprudência e ao consequente alcance da coerência interna do sistema como um todo.

Todavia, não foi esse o caminho seguido pelo legislador pátrio. Embora a EC n ${ }^{\circ} 45 / 2004$ tenha introduzido a súmula com efeitos vinculantes, somente as editadas pelo STF em consonância com os requisitos previstos no art. 103-A, do CF, assumem essa feição. Também de efeitos vinculantes são dotadas as sentenças proferidas em sede de controle de constitucionalidade concentrado.

De resto, o nosso sistema prevê precedentes que produzem efeitos quase vinculantes, ou meramente persuasivos. Não se pode negar, porém, que alterações legislativas têm sido introduzidas com o fim de conferir maior valor aos precedentes judiciais, de forma geral. É de tais alterações que se passa a cuidar a seguir.

\subsection{Eficácia vinculante}

\subsubsection{Conceito}

Efeito vinculante é o efeito que vincula, que liga, que conecta - e que nessa medida torna o objeto sobre o qual recai de observância obrigatória, como se lei fosse algum sujeito, ou alguns sujeitos. Embora à primeira vista assim não pareça, o efeito vinculante não recai sobre toda a decisão judicial, ou sobre o seu dispositivo, mas tãosomente sobre os seus motivos determinantes (ou sobre a ratio decidendi, para empregar o termo oriundo do direito inglês). Quando se fala então em efeitos vinculantes de uma decisão judicial, ou de uma súmula, está-se a fazer referência aos efeitos vinculantes de seus motivos determinantes.

Historicamente, o efeito vinculante foi introduzido no ordenamento brasileiro pela Emenda Constitucional $\mathrm{n}^{\circ}$ 7/1977, a qual, regulando o instituto, já mencionado, da representação do Procurador-Geral da República ao Supremo Tribunal 
Federal para interpretação em tese de leis ou atos normativos federais ou estaduais, previa que "a partir da data da publicação da ementa do acórdão no Diário Oficial da União, a interpretação nele fixada terá força vinculante, implicando sua não-observância negativa de vigência do texto interpretado". O Regimento Interno do Supremo Tribunal Federal, ao disciplinar a representação interpretativa, em seu art. 187, também estabelecia que " $a$ partir da publicação do acórdão, por suas conclusões e ementa, no Diário de Justiça da União, a interpretação nele fixada terá força vinculante para todos os efeitos" ${ }^{255}$.

Mais recentemente, o efeito vinculante encontrou guarida na Emenda Constitucional $n^{\circ} 3$, de 17 de março de 1993, que, ao incluir o $\S 2^{\circ}$ ao art. 102, atribuiu o referido efeito às decisões definitivas proferidas pelo Supremo Tribunal Federal nas ações declaratórias de constitucionalidade ${ }^{256}$. A Lei $\mathrm{n}^{\circ}$ 9.868/1999 estendeu o efeito vinculante às decisões definitivas proferidas pelo Supremo Tribunal Federal nas ações diretas de inconstitucionalidade, tendo o $\S 2^{\circ}$ do art. 102, da CF, com a redação conferida pela $\mathrm{EC} \mathrm{n}^{\circ}$ 45/2004, finalmente contemplado no bojo constitucional essa extensão.

Segundo MEndes, trata-se o efeito vinculante de instituto jurídico importado do direito alemão ${ }^{257}$, "que tem por objetivo outorgar maior eficácia às decisões proferidas por aquela Corte Constitucional, assegurando força vinculante não apenas à parte dispositiva da decisão, mas também aos chamados fundamentos ou motivos determinantes (tragende Gründe), 258 .

255 In MENDES, Gilmar Ferreira, O efeito vinculante das decisões do Supremo Tribunal Federal nos processos de controle abstrato de normas, disponível em <http://jus.com.br/revista/texto/108/o-efeitovinculante-das-decisoes-do-supremo-tribunal-federal-nos-processos-de-controle-abstrato-de-normas >, 1999, acesso em 08/10/2011.

${ }^{256}$ V., sobre as razões para a adoção do novo instituto, bem como sobre os fatores propulsores e inibidores do efeito vinculante, DINIZ, Antonio Carlos de Almeida, A recepção do instituto de efeito vinculante pelo direito brasileiro, in Revista de Direito Constitucional e Internacional, no 39, 2002, pp. 219/221.

${ }^{257}$ V., afirmando, em texto voltado ao exame do efeito vinculante, que o Brasil tem se mostrado um habitual importador de dispositivos legislativos estrangeiros, DINIZ, Antonio Carlos de Almeida, A recepção do instituto de efeito vinculante pelo direito brasileiro, in Revista de Direito Constitucional e Internacional, $\mathrm{n}^{\circ}$ 39, 2002, p. 210.

258 In MENDES, Gilmar Ferreira, O efeito vinculante das decisões do Supremo Tribunal Federal nos processos de controle abstrato de normas, disponível em <http://jus.com.br/revista/texto/108/o-efeitovinculante-das-decisoes-do-supremo-tribunal-federal-nos-processos-de-controle-abstrato-de-normas $>, 1999$, acesso em 08/10/2011. V., em sentido semelhante, afirmando que "o instituto processual da força de lei, conquanto implique em eficácia geral ou erga omnes, só assegura obediência à parte dispositiva da decisão no controle abstrato de normas, ao passo que o efeito vinculante possui o condão de vincular os órgãos estatais também aos chamados fundamentos determinantes, ou seja, a ratio decidendi da interpretação fixada pelo tribunal", DINIZ, Antonio Carlos de Almeida, A recepção do instituto de efeito vinculante pelo 
A explicação acima foi refutada, com vantagem, por BOTELHO DE MESQuiTA. Consoante o renomado processualista, em primeiro lugar, é inadmissível que a interpretação de instituto inserido na Constituição brasileira só se faça possível a partir de lei de outro estado soberano. Em segundo lugar, a lei brasileira dispõe exatamente no sentido oposto, afirmando que os motivos não fazem coisa julgada, mesmo que importantes para se determinar o alcance da parte dispositiva da sentença. Em terceiro lugar, se julgada procedente ADIn ou ADCon, a extensão do efeito vinculante aos motivos da sentença nada acrescentaria à força vinculante da sua parte dispositiva; o efeito vinculante só teria utilidade no caso de ser negada a declaração pretendida, pois é na fundamentação que se encontraria a conclusão oposta à demandada. Mas, em quarto lugar, essa utilidade deixa de existir se se atribui a essas decisões caráter dúplice ou ambivalente $^{259}$.

Após examinar atentamente o efeito vinculante das decisões do Tribunal Constitucional Federal alemão, bem como os efeitos da sentença e a coisa julgada no direito brasileiro, o autor concluiu que “(...) não há nenhum interesse prático na atribuição de efeito vinculante às decisões de mérito que julguem procedentes as ações de inconstitucionalidade ou de constitucionalidade. Sua eficácia erga omnes já torna vinculante a declaração da Corte não só para o requerente e quaisquer autoridades, tribunais ou órgãos constitucionais da União e dos Estados, como para quaisquer terceiros, os particulares inclusive." ${ }^{260}$. Por outro lado, supondo que a ADIn e a ADCon não são ações dúplices, e que o julgamento de improcedência da ADIn terá como fundamento a conclusão de que a lei em causa é compatível com a Constituição, da mesma forma que o julgamento de improcedência da ADCon terá como fundamento a conclusão de que a lei em causa é incompatível com a Constituição, tais conclusões não adquirirão a autoridade da coisa julgada, nem terão força de lei. Porém, tornar-se-ão de observância

direito brasileiro, in Revista de Direito Constitucional e Internacional, $\mathrm{n}^{\circ} 39,2002$, p. 212, nota de rodapé $\mathrm{n}^{\circ}$ 10 .

259 In Botelho DE Mesquita, José Ignacio, O desmantelamento do sistema brasileiro de controle de constitucionalidade, in Teses, estudos e pareceres de processo civil, vol. 2, 2005, p. 262.

${ }^{260}$ In Botelho DE MesquitA, José Ignacio, $O$ desmantelamento do sistema brasileiro de controle de constitucionalidade, in Teses, estudos e pareceres de processo civil, vol. 2, 2005, p. 267. 
obrigatória pelos demais órgãos do Poder Judiciário e do Poder Executivo, em função justamente do dito efeito vinculante ${ }^{261}$.

Não pretendemos nos alongar no assunto pois senão teríamos que tratar da diferenciação entre efeitos da sentença e coisa julgada, que é matéria complexa e que demanda muito mais do que poucas linhas ${ }^{262}$. O que é necessário compreender aqui é que a sentença de procedência proferida em ADIn e ADCon extrapola as partes da demanda, atingindo a todos, em caráter obrigatório; também no caso de improcedência, sua motivação atinge os demais órgãos do Poder Judiciário e do Poder Executivo, em função justamente do dito efeito vinculante.

A eficácia vinculante das súmulas (vinculantes) do $\mathrm{STF}$, que se opera "em relação aos demais órgãos do Poder Judiciário e à administração pública direta e indireta, nas esferas federal, estadual e municipal" (art. 103-A, caput, da CF), por sua vez, torna os motivos determinantes de seus enunciados de observância obrigatória a tais sujeitos $^{263}$, como se lei fosse. Tanto é parecido o efeito vinculante das súmulas do STF com o efeito vinculante das decisões proferidas em ADIn e ADCon que o constituinte fez questão de disciplinar os institutos um em seguida do outro (a ADIn e a ADCon estão previstas nos arts. 102 e 103, da CF; a súmula vinculante está prevista no art. 103-A, da $\mathrm{CF}$, que imediatamente sucede o referido art. 103).

\footnotetext{
261 In Botelho De MesquitA, José Ignacio, $O$ desmantelamento do sistema brasileiro de controle de constitucionalidade, in Teses, estudos e pareceres de processo civil, vol. 2, 2005, p. 269. Para o autor, a técnica também é útil para os casos de interpretação conforme (art. 28, par. único, da Lei no 9.868/1999), “em que, demandada a inconstitucionalidade de uma lei ou ato normativo, a Corte julga que a norma não é inconstitucional desde que interpretada de determinado modo", pois "a chamada interpretação conforme fica confinada à motivação do acórdão que, no dispositivo, concluirá simplesmente que a norma não é inconstitucional e pronunciará a improcedência da ADIN" (in idem, ibidem, p. 270).

262 Tanto que constituiu o cerne de nossa dissertação de mestrado, já mencionada alhures, em que tratamos dos limites subjetivos e da extensão a terceiros da coisa julgada civil.

${ }^{263}$ V., no mesmo sentido, afirmando que "a eficácia obrigatória dos precedentes é, em termos mais exatos, a eficácia obrigatória da ratio decidendi”, MARINONI, Luiz Guilherme, Coisa julgada erga omnes e eficácia vinculante, disponível em <http://marinoni.adv.br>, acesso em 16/09/2011, p. 24. V., em sentido semelhante, CAZETTA JÚNIOR, José Jesus, A ineficácia do precedente no sistema brasileiro de jurisdição constitucional (1891-1993): contribuição ao estudo do efeito vinculante, Tese (Doutorado), 2004, p. 45.
} 


\subsubsection{Controle de constitucionalidade concentrado}

\subsubsection{Considerações introdutórias}

A Constituição Federal de 1988 é considerada rígida, na medida em que, dotada de estabilidade especial, seu conteúdo só pode ser alterado pelo procedimento constitucionalmente fixado, que é distinto do processo legislativo ordinário ${ }^{264}$. A rigidez da Constituição atesta a superioridade hierárquica das normas nela inseridas, de forma que as normas infraconstitucionais que a contrariem materialmente, ou que forem editadas em desconformidade com o procedimento formal nela previsto, padecem do vício de inconstitucionalidade ${ }^{265}$.

Como todo e qualquer instituto jurídico, o controle de constitucionalidade pode ser classificado de diversas maneiras, a depender do aspecto levado em consideração. Assim, o controle pode ser: preventivo ou repressivo; judiciário ou político; difuso ou concentrado; e principal ou incidental. Embora esses diferentes critérios relacionem-se entre si, para efeitos do nosso estudo ficaremos restritos à análise do controle de constitucionalidade concentrado (mais especificamente da ação direta de inconstitucionalidade - ADIn e da ação declaratória de constitucionalidade - ADCon, que são os principais meios de controle concentrado), o qual atribui a órgão(s) específico(s) competência para julgar a questão da compatibilidade da norma com a Constituição Federal (no caso, o STF), e é feito normalmente por via principal ${ }^{266}$.

Isso porque, ao contrário do controle de constitucionalidade preventivo (normalmente controle interno do Poder Legislativo, via Comissão de Constituição e Justiça, e controle exercido pelo Presidente da República por meio do veto, nos termos do

\footnotetext{
${ }^{264}$ In FerreIRA FILHO, Manoel Gonçalves, Curso de direito constitucional, 1999, pp. 13/14.

${ }^{265}$ In RAMOS, Elival da Silva, $O$ controle de constitucionalidade, in Estudos em homenagem à Professora Ada Pellegrini Grinover, 2005, pp. 206/207.

${ }^{266}$ O nosso sistema prevê casos, de cunho excepcional, de controle concentrado (um único juízo) diante do controle incidental (caso concreto). É a hipótese da ação direta de inconstitucionalidade interventiva (ADIn interventiva) e da arguição de descumprimento de preceito fundamental (ADPF). Em ambos os casos, o julgamento é reservado a um único órgão (o STF), o que demonstra tratar-se de controle concentrado; contudo, faz-se a análise de uma situação concreta, a qual justifica a intervenção ou atesta o descumprimento de um preceito fundamental. Logo, trata-se de controle concentrado, em que a inconstitucionalidade consubstancia questão incidental. V., nesse sentido, DELlORE, Luiz Guilherme Pennacchi, Evolução do controle de constitucionalidade das leis: rumo ao controle concentrado?, 2007, pp. 54/55.
} 
art. $66, \S 1^{\circ}$, da $\mathrm{CF}$ ), e do controle de constitucionalidade difuso (que assim como o concentrado também é repressivo, contrapondo-se ao controle preventivo), o controle de constitucionalidade concentrado, ao gerar efeitos erga omnes e vinculantes, configura, ainda que de maneira reflexa, importante instrumento de uniformização da jurisprudência ${ }^{267}$. Tanto é assim que a ação declaratória de constitucionalidade foi introduzida no ordenamento com o nítido propósito de centralizar no STF as decisões sobre a constitucionalidade das leis e atos normativos federais ${ }^{268}$. Antes da sua implementação, os tribunais manifestavam convencimentos diversos a propósito da constitucionalidade ou não dos mesmos textos legislativos, o que fazia com que fosse mantida vasta, e indesejável, divergência jurisprudencial ${ }^{269}$.

\footnotetext{
${ }^{267}$ Com efeito, se proveniente de controle de constitucionalidade difuso, feito em caráter incidental, visando à solução de um caso concreto, a declaração de inconstitucionalidade da lei ou ato normativo em regra não extrapola as fronteiras do processo em que a decisão foi emitida, surtindo efeitos apenas entre as partes. V., nesse sentido, BARBOSA MOREIRA, José Carlos, El control judicial de la constitucionalidad de las leyes en el Brasil: un bosquejo, in Temas de direito processual, $6^{\text {a }}$ série, 1997, p. 186. Nesse caso, não há que se falar em efeito vinculante, nem em coisa julgada de espécie alguma, inter partes ou erga omnes, acerca da questão de constitucionalidade, tendo em vista que a declaração incidental de inconstitucionalidade não integra a parte dispositiva da decisão (que é a única que faz coisa julgada), importando na resolução de questão meramente prejudicial. V., nesse sentido, GRINOVER, Ada Pellegrini, $O$ controle difuso da constitucionalidade e a coisa julgada erga omnes das ações coletivas, in Revista do Advogado, $\mathrm{n}^{\circ}$ 89, 2006, p. 8, PORTO, Sérgio Gilberto, Coisa julgada civil, 2006, pp. 115/117, RAmos, Elival da Silva, O controle de constitucionalidade, in Estudos em homenagem à Professora Ada Pellegrini Grinover, 2005, p. 212 e ZAVASCKI, Teori Albino, Eficácia das sentenças na jurisdição constitucional, 2001, p. 30. Assim, como a decisão constituirá precedente com eficácia meramente persuasiva, qualquer outro órgão judicial poderá enfrentar novamente a questão, em outro processo, emitindo decisão em um sentido ou em outro. Não estamos considerando aqui, evidentemente, a hipótese do art. 52, X, da CF, que outorga competência ao Senado Federal para suspender, mediante resolução, a execução de uma lei acoimada de inconstitucional por uma decisão definitiva do STF proferida incidenter tantum, pois "a própria suspensão de execução pelo Senado, tal como compreendida e praticada no âmbito federal, dá sinais evidentes de superação ou obsolescência" (in MENDES, Gilmar Ferreira, Direitos fundamentais e controle de constitucionalidade (estudos de direito constitucional), 2004, p. 384).
}

${ }^{268}$ A ADIn é cabível para declarar a inconstitucionalidade de lei ou ato normativo federal ou estadual, ao passo que a ADCon é cabível para declarar a constitucionalidade de lei ou ato normativo federal apenas, conforme redação do art. 102, I, "a", da CF.

${ }^{269}$ Para CRUZ E TUCCI, "observa-se, assim, que a primordial razão política inspiradora do Legislativo federal foi, sem dúvida, a de instituir um mecanismo destinado a subordinar o desfecho de demandas em curso perante juízos inferiores - monocráticos e colegiados - à decisão do Excelso Pretório" (in CRUZ E TUCCI, José Rogério, Limites subjetivos da eficácia da sentença e da coisa julgada civil, 2006, p. 337). V., em sentido semelhante, BARBosa MoreIRA, José Carlos, El control judicial de la constitucionalidad de las leyes en el Brasil: un bosquejo, in Temas de direito processual, $6^{\mathrm{a}}$ série, 1997, pp. 190/191 e DELLORE, Luiz Guilherme Pennacchi, Evolução do controle de constitucionalidade das leis: rumo ao controle concentrado?, 2007, p. 115. Merece destaque também a percuciente observação de BOTELHO DE MESQUITA, no sentido de que "por meio dessa inovação, recuperou o Presidente da República o poder de opor-se à declaração incidental de inconstitucionalidade e de antecipar-se à declaração de inconstitucionalidade por via principal, com a prerrogativa - que logo mais lhe seria gentilmente outorgada - de dispor de medida cautelar para suspender os julgamentos em curso, nos quais se estivesse questionando a constitucionalidade da lei ou ato normativo objeto da ADCON" (in BOTELHO DE MESQUITA, José Ignacio, O desmantelamento do sistema brasileiro de controle de constitucionalidade, in Teses, estudos e pareceres de processo civil, vol. 2, 2005, p. 260). V., defendendo a ideia de que a ADCon serviu apenas para a "sofisticação do modelo concentrado de constitucionalidade", "mediante uma 'germanização' despropositada", SILVA NETO, 
Mesmo em relação ao controle concentrado, não nos ocuparemos de todas as questões que emergem de seu estudo, como as que tocam os limites subjetivos da coisa julgada, a natureza dúplice ou ambivalente da ADIn e da ADCon etc., porque, além de serem estranhas ao tema central do trabalho, em oportunidade anterior já nos debruçamos sobre elas ${ }^{270}$.

\subsubsection{Breve histórico e regulamentação}

O controle de constitucionalidade jurisdicional repressivo foi implantado no Brasil com a primeira Constituição republicana, de $1891^{271}$. Adotando como paradigma o sistema americano, de início, o controle era apenas difuso e incidental, com efeitos inter partes, outorgando-se a qualquer órgão do Poder Judiciário competência para conhecer e julgar, incidente e prejudicialmente, a questão da inconstitucionalidade.

A partir de 1934, passou-se a admitir, ainda que de forma bastante limitada, o controle concentrado, por via principal, advindo, em tal contexto, a ação direta com finalidade interventiva, em que a declaração de inconstitucionalidade figura como pressuposto da intervenção federal ou estadual.

Francisco da Cunha e, O controle difuso: uma forma de humanização do controle de constitucionalidade das leis, in Revista de Direito Constitucional e Internacional, $\mathrm{n}^{\circ}$ 59, 2007, p. 140. V., também sobre o assunto, MACHADO, Hugo de Brito, Ação declaratória de constitucionalidade, in Revista dos Tribunais, vol. 697, 1993, pp. 34/36 e SLAIBI FILHO, Nagib, Ação declaratória de constitucionalidade, 1994, pp. 1/12.

${ }^{270}$ V., tratando do tema sob outra óptica, dissertação de mestrado de nossa autoria, LOMBARDI, Mariana Capela, Da coisa julgada civil - limites subjetivos e extensão a terceiros, Dissertação (Mestrado), 2008, pp. $148 / 167$.

${ }^{271}$ V., sobre a evolução do controle de constitucionalidade no Brasil, BARBOSA MOREIRA, José Carlos, El control judicial de la constitucionalidad de las leyes en el Brasil: un bosquejo, in Temas de direito processual, 6 ${ }^{\text {a }}$ série, 1997, pp. 184/185, CRUZ E TUCCI, José Rogério, Limites subjetivos da eficácia da sentença e da coisa julgada civil, 2006, pp. 333/336, MENDES, Gilmar Ferreira, Direitos fundamentais e controle de constitucionalidade (estudos de direito constitucional), 2004, pp. 189/216, MOREIRA ALVES, José Carlos, A evolução do controle da constitucionalidade no Brasil, in As garantias do cidadão na justiça, 1993, pp. 1/14, RAmos, Elival da Silva, O controle de constitucionalidade, in Estudos em homenagem à Professora Ada Pellegrini Grinover, 2005, pp. 213/215 e SiLVA NeTo, Francisco da Cunha e, O controle difuso: uma forma de humanização do controle de constitucionalidade das leis, in Revista de Direito Constitucional e Internacional, $\mathrm{n}^{\circ}$ 59, 2007, pp. 136/140. Segundo CAZETTA JÚNIOR, apesar de o controle, em teoria, ser tão velho quanto a República, a história acidentada desta, com uma triste sucessão de Constituições e golpes de estado, aliada a uma fraqueza congênita do Poder Judiciário, não permitiu que o instituto prosperasse; segundo o autor, "por isso mesmo, durante muitos anos este instituto foi, com boa vontade, uma espada de papel" (in CAZETTA JÚNIOR, José Jesus, A ineficácia do precedente no sistema brasileiro de jurisdição constitucional (1891-1993): contribuição ao estudo do efeito vinculante, Tese (Doutorado), 2004, p. 27). 
Em 1965, em pleno regime militar, por meio da EC nº 16 à Constituição de 1946, foi amplamente alargado o campo do controle de constitucionalidade por via principal $^{272}$. Além de mantida a ação direta interventiva, foi introduzida no nosso sistema, como instrumento de controle do Legislativo pelo Executivo ${ }^{273}$, a então chamada representação por inconstitucionalidade, que deu origem à ação declaratória de inconstitucionalidade genérica, por meio da qual se atribuiu ao STF competência para processar e julgar representação do Procurador-Geral da República contra inconstitucionalidade de lei ou ato de natureza normativa, tanto federal, quanto estadual.

Igualmente dispunha o art. 114, I, “l”, da Constituição de 1967, cuja redação foi posteriormente alterada pela EC n 7/1977 (o famigerado "pacote de abril"), que inseriu também a representação interpretativa, para a interpretação de lei ou ato normativo federal ou estadual, em abstrato, e a denominada "arguição de relevância da questão federal", a qual constitui o cerne da atual repercussão geral da questão constitucional $^{274}$.

A Constituição de 1988 manteve a mesma orientação em seu art. 102, I, “a”, substituindo a representação por inconstitucionalidade pela ADIn e ampliando o rol de legitimados a agir ${ }^{275}$. Segundo BotelHo DE MESQUITA, “graças a essa providência, a iniciativa da declaração de inconstitucionalidade em abstrato deixou de constituir instrumento de ação política do Executivo contra o Legislativo para, bem ao contrário, passar a constituir um instrumento oponível não só contra atos normativos do Poder

\footnotetext{
${ }^{272}$ A doutrina costuma dizer que somente a partir da $\mathrm{EC} \mathrm{n} \mathrm{n}^{\circ}$ 16/1965 é que o sistema brasileiro passou a ser efetivamente misto, com a inclusão de uma ação típica de controle concentrado e abstrato (in DELLORE, Luiz Guilherme Pennacchi, Evolução do controle de constitucionalidade das leis: rumo ao controle concentrado?, 2007, p. 183). V., no mesmo sentido, MoReIRA Alves, José Carlos, A evolução do controle da constitucionalidade no Brasil, in As garantias do cidadão na justiça, 1993, p. 4.

273 In Botelho DE Mesquita, José Ignacio, O desmantelamento do sistema brasileiro de controle de constitucionalidade, in Teses, estudos e pareceres de processo civil, vol. 2, 2005, p. 258.

${ }^{274}$ In CRUZ E TUCCI, José Rogério, Limites subjetivos da eficácia da sentença e da coisa julgada civil, 2006, p. 334 e SouZA, Bernardo Pimentel, Apontamentos sobre a repercussão geral no recurso extraordinário, in Direito civil e processo - Estudos em homenagem ao Professor Arruda Alvim, 2007, p. 1.230.

${ }^{275}$ A esse propósito, a EC n ${ }^{\circ}$ 45/2004, alterando a redação do art. 103, da CF, unificou a legitimação para a propositura da ADIn e da ADCon. Hoje o rol de legitimados consiste no seguinte: o Presidente da República; a Mesa do Senado Federal; a Mesa da Câmara dos Deputados; a Mesa de Assembleia Legislativa ou da Câmara Legislativa do Distrito Federal; o Governador de Estado ou do Distrito Federal; o Procurador-Geral da República; o Conselho Federal da Ordem dos Advogados do Brasil; partido político com representação no Congresso Nacional; e confederação sindical ou entidade de classe de âmbito nacional.
} 
Executivo, inclusive as medidas provisórias, como também contra atos legislativos que, a despeito de inconstitucionais, houvessem sido aprovados pelo Congresso Nacional mediante o beneplácito, ou por força de pressão, do Palácio do Planalto"276.

A EC nº 3/1993, finalmente, pelas circunstâncias eminentemente políticas já relatadas acima, introduziu no art. 102, I, da CF, a ADCon, destinada a declarar a constitucionalidade de lei ou ato normativo federal. Curiosamente, a própria constitucionalidade do instrumento chegou a ser questionada, dando ensejo à ADCon $\mathrm{n}^{\mathrm{o}} 1$ 1/DF, a qual declarou constitucional a figura da ação declaratória de constitucionalidade, por maioria de votos, restando vencido o Min. MARCO Aurélio ${ }^{277}$. A despeito de a ADCon ter sido inserida no ordenamento em 1993, seu procedimento somente foi regulamentado em 1999, pela Lei ${ }^{\circ}$ 9.868, de 10 de novembro daquele ano, que disciplina, também, o procedimento da tradicional ação direta de inconstitucionalidade. O RISTF, por sua vez, cuida do assunto nos arts. 169 a 178.

\subsubsection{Competência e quórum para o julgamento}

No que tange à ADIn, a inconstitucionalidade da lei é declarada se seis ou mais ministros do STF (maioria absoluta) votam em tal sentido, sendo necessário o quórum mínimo de oito ministros na sessão (art. 22, da Lei n ${ }^{\circ}$ 9.868/1999, e art. 123, par. único, do

\footnotetext{
276 In Botelho De Mesquita, José Ignacio, O desmantelamento do sistema brasileiro de controle de constitucionalidade, in Teses, estudos e pareceres de processo civil, vol. 2, 2005, p. 259.

${ }^{277}$ V., fazendo menção ao acórdão proferido no julgamento da ADCon $\mathrm{n}^{\circ}$ 1-1/DF, BARBOSA MoREIRA, José Carlos, El control judicial de la constitucionalidad de las leyes en el Brasil: un bosquejo, in Temas de direito processual, 6 a série, 1997, p. 191 e RAMOS, Elival da Silva, O controle de constitucionalidade, in Estudos em homenagem à Professora Ada Pellegrini Grinover, 2005, p. 215. A ADCon foi bastante criticada por ter tido origem na antiga avocatória (v., discorrendo amplamente sobre esse instituto, MANCUSO, Rodolfo de Camargo, Divergência jurisprudencial e súmula vinculante, 2007, pp. 297/307), prevista na EC no 7/1977 e revogada pela atual Constituição, por meio da qual o STF podia, mediante pedido do Procurador-Geral da República, avocar qualquer causa, processada perante qualquer juízo ou tribunal, em nome do perigo de grave lesão à ordem, à saúde, à segurança ou às finanças públicas (in CôRTES, Osmar Mendes Paixão, $A$ experiência brasileira com a vinculação das decisões judiciais e a atual súmula vinculante introduzida pela EC 45/2004, in Direito civil e processo - Estudos em homenagem ao Professor Arruda Alvim, 2007, p. 1.385). A ADCon também foi censurada por, no início, ter sido atribuída a um seleto grupo de "quatro escolhidíssimos legitimados": o Presidente da República, as Mesas do Senado e da Câmara dos Deputados e o Procurador-Geral da República (in BoTELHO DE MESQuITA, José Ignacio, O desmantelamento do sistema brasileiro de controle de constitucionalidade, in Teses, estudos e pareceres de processo civil, vol. 2, 2005, p. 260). V., fazendo referência à ADCon, afirmando que "a solução da Emenda Constitucional n" $3 / 1993$ saiu desfigurada, só tendo sido corrigida com a Emenda Constitucional no 45/2004”, MARTINS, Ives Gandra da Silva, Reflexões sobre o controle concentrado de constitucionalidade, in Revista do Advogado, $\mathrm{n}^{\circ}$ 99, 2008, p. 58. É curioso notar que IVES GANDRA DA SILVA MARTINS foi quem, com GILMAR FERREIRA MENDES, formulou a proposta de emenda constitucional que deu origem à ADCon.
} 
RISTF); não atingido esse voto, nos termos dos arts. 23, caput, e 24, da Lei nº 9.868/1999, e do art. 173, caput, do RISTF, a lei é declarada constitucional. Julgada a ação, o órgão responsável pelo ato normativo é comunicado do resultado (art. 25, da Lei no 9.868/1999, e art. 125, caput, do RISTF), fazendo-se desnecessária a realização de comunicação de tal teor ao Senado Federal. O procedimento da ADCon é bastante semelhante e a declaração de constitucionalidade da norma depende também do voto da maioria absoluta dos ministros do STF.

\subsubsection{Medida cautelar}

Tanto na ADIn quanto na ADCon, admite-se a propositura de medida cautelar, a ser concedida por decisão da maioria absoluta dos membros do tribunal (arts. 10, caput, e 21, caput, da Lei $\mathrm{n}^{\circ}$ 9.868/1999). O objeto da cautelar, na ADCon, consiste "na determinação de que os juízes e os Tribunais suspendam o julgamento dos processos que envolvam a aplicação da lei ou do ato normativo objeto da ação até seu julgamento definitivo".

De forma parecida, a arguição de descumprimento de preceito fundamental - ADPF (outra modalidade de controle de constitucionalidade concentrado, prevista no $\S$ $1^{\circ}$ do art. 102, da CF, e regulada pela Lei $\mathrm{n}^{\circ}$ 9.882, de 3 de dezembro de 1999) admite a concessão de liminar, a qual "poderá consistir na determinação de que juízes e tribunais suspendam o andamento de processo ou os efeitos de decisões judiciais, ou de qualquer outra medida que apresente relação com a matéria objeto da argüição de descumprimento de preceito fundamental, salvo se decorrentes da coisa julgada" (art. $5^{\circ}$, § $3^{\circ}$, da Lei $\mathrm{n}^{\circ}$ 9.882/1999, o qual se encontra atualmente suspenso por força da ADIn $n^{\circ}$ 2.231/DF, proposta pelo Conselho Federal da Ordem dos Advogados do Brasil, ainda pendente de julgamento ${ }^{278}$ ). Fica claro, de toda forma, que o objetivo dos dispositivos mencionados "é resguardar a uniformidade de tratamento perante o texto objeto de deliberação pelo Supremo",279.

${ }^{278}$ A íntegra da Lei $\mathrm{n}^{\circ}$ 9.882/1999 é objeto da ADIn $\mathrm{n}^{\circ}$ 2.231. Andamento disponível em <http://www. stf.jus.br/portal/processo/verProcessoAndamento.asp>, acesso em 08/01/2012.

${ }^{279}$ In PARENTE, Eduardo de Albuquerque, Jurisprudência: da divergência à uniformização, 2006, p. 87. 


\subsubsection{Eficácia erga omnes, efeitos vinculantes e irrecorribilidade}

No que diz respeito aos efeitos que as sentenças proferidas em ADIn e ADCon produzem, o art. 28, par. único, da Lei no 9.868/1999, disciplina que "a declaração de constitucionalidade ou de inconstitucionalidade, inclusive a interpretação conforme a Constituição e a declaração parcial de inconstitucionalidade sem redução de texto, têm eficácia contra todos e efeito vinculante em relação aos órgãos do Poder Judiciário e à Administração Pública federal, estadual e municipal". Nos mesmos moldes vem redigido o art. 102, § $2^{\circ}$, da CF, de acordo com o qual "as decisões definitivas de mérito, proferidas pelo Supremo Tribunal Federal, nas ações diretas de inconstitucionalidade e nas ações declaratórias de constitucionalidade produzirão eficácia contra todos e efeito vinculante, relativamente aos demais órgãos do Poder Judiciário e à administração pública direta e indireta, nas esferas federal, estadual e municipal", conforme a redação conferida pela EC $n^{\circ} 45 / 2004^{280}$.

Como se vê, as decisões proferidas em ADIn e ADCon são oponíveis aos demais órgãos do Poder Judiciário e à administração pública direta e indireta, nas esferas federal, estadual e municipal, sem a necessidade de qualquer ato de suspensão pelo Senado Federal. Ao extrapolarem o âmbito da demanda, essas decisões funcionam como um precedente vinculante, atingindo, de forma cogente, não só as partes do processo, mas também terceiros. Assim, embora imediatamente o objetivo de ambos os mecanismos de controle seja a declaração da constitucionalidade ou inconstitucionalidade da norma, mediatamente seu propósito é a uniformização da jurisprudência, de cima para baixo na estrutura judiciária ${ }^{281}$.

Na ADCon, a existência de tal propósito exsurge da redação da própria lei, já que o art. 14, III, da Lei nº 9.868/1999, exige que da petição inicial conste indicação da "existência de controvérsia judicial relevante sobre a aplicação da disposição objeto da

\footnotetext{
${ }^{280}$ Como já exposto, até a $\mathrm{EC} \mathrm{n}{ }^{\circ} 45 / 2004$, a Constituição atribuía eficácia vinculante apenas às decisões proferidas em ADCon. Quanto à ADIn, o assunto era tratado somente na Lei $n^{\circ}$ 9.868/1999, que igualmente mencionava a ADCon. Embora muitos tenham se insurgido contra o fato de a lei regulamentar a questão de maneira distinta da CF, ao julgar a RC $n^{\circ} 1.880 / \mathrm{SP}$, em 06/11/2002, o STF concluiu pela constitucionalidade do par. único do art. 28, da Lei $\mathrm{n}^{\circ}$ 9.868/99, sob o fundamento de que a ADCon consubstanciaria uma ADIn com "sinal trocado", tendo ambas caráter dúplice e efeitos semelhantes.

${ }^{281}$ In PARENTE, Eduardo de Albuquerque, Jurisprudência: da divergência à uniformização, 2006, p. 85.
} 
ação declaratória"282. Ou seja, inexistindo “controvérsia judicial relevante", entendida esta como a controvérsia passível de gerar instabilidade e insegurança jurídica, a declaração de constitucionalidade da norma não se justifica e a petição inicial, nessa condição, deve ser indeferida liminarmente (art. 15, caput, da Lei $\mathrm{n}^{\circ}$ 9.868/1999), por faltar-lhe requisito essencial. Em 1994, ao julgar a ADCon $n^{\circ}$ 1-1/DF, que tratou da constitucionalidade da própria ação declaratória de constitucionalidade, o Min. MoREIRA AlvES, então relator, consignou o seguinte, corroborando o entendimento acima: "Esta Corte, no julgamento do incidente de inconstitucionalidade da Emenda Constitucional $n^{o} 3 / 93$ que instituiu a presente ação declaratória de constitucionalidade, estabeleceu, como uma das condições dessa ação, a necessidade de demonstração da existência de controvérsia judicial séria sobre a norma ou as normas cuja declaração de constitucionalidade é pretendida. Assim sendo, a delimitação do objeto da ação declaratória de constitucionalidade não se adstringe aos limites do objeto fixado pelo autor, mas estes estão sujeitos ainda aos lindes da controvérsia judicial que o autor tem que demonstrar. (...)”.

A opção assumida pelo nosso sistema, de dotar as sentenças da ADIn e da ADCon de eficácia vinculante, com vistas a proporcionar uniformização, parece absolutamente correta, pois não faria sentido que os efeitos do controle realizado em abstrato pelo STF ficassem restritos à própria demanda e fossem efêmeros no tempo, ensejando manifestações contraditórias dos demais tribunais do país, hierarquicamente subordinados a ele.

Por ocasião do julgamento da famigerada ADCon $\mathrm{n}^{\circ} 1-1 / \mathrm{DF}$, o Min. FRANCISCO REZEK expôs entendimento justamente nessa linha: "Insiste-se em que um dos aspectos sedutores do nosso sistema é o livre convencimento do Juiz ante o caso concreto e sua prerrogativa de dizer o direito conforme sua consciência, à revelia, se necessário, do que tenham dito tribunais a ele superiores. Isso faz algum sentido na medida em que é ilimitado o índice de variedade das situações concretas: não há um processo igual a outro no âmbito do confronto entre interesses individuais. Mas pergunto-me se há algum respeito pelo interesse público em abonar-se essa forma de rebeldia a decisões de cortes superiores. Houve uma época - membros mais antigos deste Tribunal o recordam - em

282 Trata-se de consequência que decorre da própria presunção de constitucionalidade das normas (in Dellore, Luiz Guilherme Pennacchi, Evolução do controle de constitucionalidade das leis: rumo ao controle concentrado?, 2007, p. 115). 
que determinado Tribunal de Justiça, numa prestigiosa unidade da Federação, dava-se crônica e assumidamente a desafiar a jurisprudência do Supremo a respeito de um tema sumulado (um tema, por sinal, menor: a representatividade da ofendida em caso de crimes contra os costumes). O Supremo tinha posição firme, constante e unânime a tal respeito, $e$ certo Tribunal de Justiça, porque pensava diferentemente, dava-se à prática de decidir nos termos de sua própria convicção, valorizando a chamada liberdade de convencimento, própria de todo juiz ou tribunal. Resultado: todas essas decisões eram, mediante recurso, derrubadas por esta casa. Aquilo que deveria acabar na origem, à luz da jurisprudência do Supremo, só acabava aqui, depois de um lamentável dispêndio de recursos financeiros, de tempo e de energia, num Judiciário já congestionado e com tempo mínimo para cuidar de coisas novas. E quando acontecia de a jurisprudência do Supremo acabar não prevalecendo, e de a decisão do tribunal rebelde encontrar seu momento de glória? Quando o réu, porque assistido por advogado relapso, ou porque carente de outros meios, não apresentava recurso... Só nessa circunstância infeliz a rebeldia contra a jurisprudência do Supremo dava certo. Pelo contrário, parece-me uma situação imoral, com que a consciência jurídica não deveria, em hipótese alguma, contemporizar. De modo que me pergunto: faz sentido não ser vinculante uma decisão da Suprema Corte do país? Não estou falando, naturalmente, de fatos concretos, cada um com seu perfil, reclamando o esforço hermenêutico da lei pelo juiz que conhece as características próprias do caso. Estou me referindo a hipótese de pura análise jurídica. Tem alguma seriedade a idéia de que se devam fomentar decisões expressivas de rebeldia? A que serve isso? Onde está o interesse público em que esse tipo de política prospere? Vejo como sábio e bem-vindo aquilo que diz o $\S 2^{\circ}$ do art. 102, por força da Emenda $n$. 3, e a única coisa que lamento é que isso não tenha sido, desde o início, a regra pertinente à ação direta declaratória de inconstitucionalidade".

O mesmo se diga a propósito da ADPF, cujo objeto precípuo é evitar ou reparar lesão a preceito fundamental, resultante de ato do Poder Público. Além de o art. 10, $\S 3^{\circ}$, da Lei no 9.882/1999, prever que, na hipótese de procedência do pedido, “a decisão terá eficácia contra todos e efeito vinculante relativamente aos demais órgãos do Poder Público", o art. $1^{\circ}$, par. único, I, dessa mesma lei, dispõe que a arguição caberá também "quando for relevante o fundamento da controvérsia constitucional sobre lei ou ato 
normativo federal, estadual ou municipal, incluídos os anteriores à Constituição" ${ }^{283}$. Por isso, há quem ressalte a utilidade do instituto por "permitir a antecipação de decisões sobre controvérsias constitucionais relevantes, evitando que elas venham a ter um desfecho definitivo após longos anos, quando muitas situações já se consolidaram ao arrepio da 'interpretação autêntica' do Supremo Tribunal Federal’284.

Dois exemplos recentes e emblemáticos do papel uniformizador do STF no julgamento de ADIn e ADPF são aqueles referentes à interrupção de gravidez na hipótese de feto anencéfalo (ADPF $n^{\circ} 54 / \mathrm{DF}$, rel. Min. MARCO AURÉLIO) ${ }^{285}$ e à união estável homoafetiva (ADIn no 4.227/DF e ADPF no 132/RJ, rel. Min. AYRES BRITTO). Devido aos limites deste estudo, não cabe aqui discorrer sobre cada um dos processos. O fato é que ambos os casos indicam a importância dos mecanismos de controle de constitucionalidade concentrado, conduzidos pelo STF, na uniformização da jurisprudência. Sem dúvida, as duas questões colocadas no cerne dos processos acima são da mais alta relevância e o tratamento diferenciado a respeito de cada uma delas pelos diferentes tribunais do país é gerador de intensa insegurança jurídica. Tanto que na ADPF $n^{\circ}$ 54/DF o Min. NeLson JoBIM expôs "ser fundamental que o Tribunal coloque, definitivamente, uma solução ao problema para evitar que tenhamos soluções contraditórias em todo o território nacional".

Assim, uma vez proferida decisão definitiva em sede de controle de constitucionalidade, todos os órgãos judiciais e da administração pública direta e indireta, assim como quaisquer terceiros, devem acatar o quanto decidido pelo Supremo. Aliás, no caso de procedência de ADIn (ou de improcedência de ADCon, admitindo-se o caráter dúplice da ação), a consequência sequer poderia ser outra, porque “(...) a norma tida como inconstitucional é posta fora do ordenamento de direito positivo, e não haverá nenhum

\footnotetext{
${ }^{283} \mathrm{Na}$ ADIn no 2.231/DF, já mencionada, também foi deferida medida liminar para, com relação ao art. $1^{\circ}$, par. único, I, da Lei no 9.882/1999, excluir de sua aplicação controvérsia constitucional concretamente já posta em juízo.

${ }^{284}$ In MENDES, Gilmar Ferreira, Argüição de descumprimento de preceito fundamental (art. 102, $\S 1^{\circ}, C F$ ), disponível em <http://jus.com.br/revista/texto/235/arguicao-de-descumprimento-de-preceito-fundamental-art102-1o-cf>, 1999, acesso em 08/10/2011.

285 V., abordando o caso, PARENTE, Eduardo de Albuquerque, Jurisprudência: da divergência à uniformização, 2006, pp. 88/89.
} 
órgão constitucional, autoridade ou tribunal que disponha de competência para fazer com que essa mesma norma retorne ao ordenamento jurídico" 286.

A intenção da regra, claramente, é fazer com que o STF, na qualidade de guardião da Constituição, tenha a última palavra no que tange à declaração da constitucionalidade ou inconstitucionalidade das leis ou atos normativos. Até por isso, segundo o art. 26, da Lei $\mathrm{n}^{\circ}$ 9.868/1999, a decisão que declara a constitucionalidade ou a inconstitucionalidade de lei ou ato normativo mediante ADIn ou ADCon é irrecorrível, ressalvada a oposição de embargos de declaração, não podendo, igualmente, ser objeto de ação rescisória. O art. 12, da Lei n ${ }^{\circ}$ 9.882/1999, também dispõe que a decisão que julgar procedente ou improcedente o pedido em ADPF é irrecorrível, não podendo ser objeto de ação rescisória.

Isso não significa, porém, que, em permanecendo a norma no ordenamento (na hipótese de ADIn julgada improcedente, por exemplo), não possa o STF tornar a decidir a respeito de sua constitucionalidade ou inconstitucionalidade, mesmo em sentido diverso, se ajuizada novamente a ação por outros legitimados concorrentes ou, ainda que pelo mesmo legitimado, com fundamento em nova causa de pedir ${ }^{287}$. Essa abertura é vital, porquanto evita o engessamento do sistema, na mesma medida em que a possibilidade de revisão ou cancelamento da súmula vinculante o faz, como será visto a seguir. Os dois casos mencionados acima, de interrupção de gravidez na hipótese de feto anencéfalo e de união estável homoafetiva, são exemplos claros de que avanços científicos e alterações sociais e culturais por vezes demandam a revisitação de temas que até determinado momento encontravam-se, aparentemente, assentados.

\footnotetext{
286 In Botelho De MesquitA, José Ignacio, O desmantelamento do sistema brasileiro de controle de constitucionalidade, in Teses, estudos e pareceres de processo civil, vol. 2, 2005, p. 267. V., no mesmo sentido, GuASQUE, Luiz Fabião, A inconstitucionalidade das leis, in Revista dos Tribunais, vol. 689, 1993, p. 99.

${ }^{287}$ V., afirmando que a corte constitucional de um país deve ser operante e que as interpretações do ordenamento jurídico devem ser tão dinâmicas quanto as mudanças fáticas e jurídicas da sociedade, SANTOS, Alberto Senna, Coisa julgada e o controle de constitucionalidade da norma, in Revista de Processo, $\mathrm{n}^{\circ} 141$, 2006, pp. 110/114.
} 
Justamente em razão dos amplos efeitos gerados pelo julgamento da ADIn e da ADCon, o relator, considerando a relevância da matéria e a representatividade dos postulantes, poderá, por despacho irrecorrível, admitir a manifestação de órgãos ou entidades (art. $7^{\circ}, \S 2^{\circ}$, da Lei $\mathrm{n}^{\mathrm{o}}$ 9.868/1999 ${ }^{288}$ ). Pessoalmente, entendemos que, comprovada a representatividade temática, o relator deveria ser obrigado a admitir a manifestação dos postulantes, porque toda matéria será relevante, independentemente do assunto tratado, se se considerar a extensão dos efeitos gerados pela sentença proferida nesses mecanismos de controle de constitucionalidade.

Reiteramos o entendimento em relação à ADPF, na medida em que do art. $6^{\circ}, \S \S 1^{\circ}$ e $2^{\circ}$, da Lei $n^{\circ} 9.882 / 1999$, consta respectivamente que, "se entender necessário, poderá o relator ouvir as partes nos processos que ensejaram a argüição, requisitar informações adicionais, designar perito ou comissão de peritos para que emita parecer sobre a questão, ou ainda, fixar data para declarações, em audiência pública, de pessoas com experiência e autoridade na matéria" e que "poderão ser autorizadas, a critério do relator, sustentação oral e juntada de memoriais, por requerimento dos interessados no processo".

\subsubsection{Modulação dos efeitos}

Dependendo da hipótese sub judice, ao declarar a inconstitucionalidade de lei ou ato normativo, e tendo em vista razões de segurança jurídica ou de excepcional interesse social, poderá o Supremo Tribunal Federal, por maioria de dois terços de seus membros, restringir os efeitos daquela declaração ou decidir que ela só tenha eficácia a partir de seu trânsito em julgado ou de outro momento que venha a ser fixado, excepcionado a regra de produção de efeitos ex tunc e o princípio da nulidade absoluta da

\footnotetext{
${ }^{288}$ A Mensagem no 1.674 , de 10 de novembro de 1999, que vetou o art. 18, § 2º da Lei n $^{\circ}$ 9.868/1999 (o qual previa, em relação à ADCon, que "o relator, considerando a relevância da matéria e a representatividade dos postulantes, poderá, por despacho irrecorrível, admitir, observado o prazo estabelecido no parágrafo anterior, a manifestação de outros órgãos ou entidades"), consignou como razão de veto restar "assegurada, todavia, a possibilidade de o Supremo Tribunal Federal, por meio de interpretação sistemática, admitir no processo da ação declaratória a abertura processual prevista para a ação direta no $\S 2^{o}$ do art. $7^{o}$. . Daí se extrai que o art. $7^{\circ}, \S 2^{\circ}$, da Lei $n^{\circ}$ 9.868/1999, também é aplicável à ADCon, embora topologicamente encontre-se no capítulo II da lei, que versa exclusivamente sobre a ADIn.
} 
lei inconstitucional (art. 27, da Lei ${ }^{\circ}$ 9.868/1999, e art. 11, da Lei $n^{\circ}$ 9.882/1999 ${ }^{289}$ ). Tratase de hipótese de modulação da eficácia temporal da declaração de inconstitucionalidade, a qual vem sendo constantemente aplicada pelo $\mathrm{STF}^{290}$, a despeito da rejeição que sofreu, e ainda sofre, por parte da doutrina ${ }^{291}$.

\subsubsection{A denominada "coisa julgada inconstitucional"}

O campo de incidência dos efeitos vinculantes das sentenças proferidas em ADIn é tão largo que admite até mesmo a oposição de impugnação ao cumprimento de sentença ou de embargos à execução de sentença já transitada em julgado, que tenha considerado constitucional norma declarada posteriormente inconstitucional, nos termos dos arts. 475-L, $\S 1^{\circ}$, e 741, par. único, do CPC. Isso porque ambos os dispositivos consideram inexigível o título judicial fundado em lei ou ato normativo posteriormente declarados inconstitucionais pelo Supremo Tribunal Federal, independentemente do exercício de ação rescisória ${ }^{292}$. Trata-se do que a doutrina convencionou chamar de "coisa julgada inconstitucional".

Naturalmente, transitando em julgado sentença que tenha considerado constitucional norma declarada posteriormente inconstitucional, admite-se também a propositura de ação rescisória, com fundamento no art. 485, V, do CPC, por violação a "literal disposição de lei”, entendida essa em sentido amplo, para compreender as normas

\footnotetext{
${ }^{289}$ V., defendendo a inconstitucionalidade dos dois dispositivos, MARTINS, Ives Gandra da Silva, Reflexões sobre o controle concentrado de constitucionalidade, in Revista do Advogado, $\mathrm{n}^{\circ}$ 99, 2008, pp. 55/57.

${ }^{290}$ Até no controle difuso o STF já decidiu que é possível, excepcionalmente, alterar a data da produção dos efeitos da decisão que declara norma inconstitucional, como se confere do trecho da seguinte ementa: “(...) 7. Inconstitucionalidade, incidenter tantum, da lei local que fixou em 11 (onze) o número de Vereadores, dado que sua população de pouco mais de 2600 habitantes somente comporta 09 representantes. 8. Efeitos. Princípio da segurança jurídica. Situação excepcional em que a declaração de nulidade, com seus normais efeitos ex tunc, resultaria grave ameaça a todo sistema legislativo vigente. Prevalência do interesse público para assegurar, em caráter de exceção, efeitos pro futuro à declaração incidental de inconstitucionalidade. (...)" (STF, Pleno, RE no 197.917/SP, rel. Min. MAURícIO CORRÊA, j. 24/03/2004).

${ }^{291}$ Há, inclusive, duas ações diretas de inconstitucionalidade - ADIn n ${ }^{\circ} 2.154$, ajuizada pela Confederação Nacional das Profissões Liberais, e ADIn $n^{\circ} 2.258$, ajuizada pelo Conselho Federal da OAB - pendentes de julgamento que questionam de modo expresso a adequação do art. 27, da Lei nº 9.868/1999.

292 Assim como Dellore, entendemos que os dispositivos são inconstitucionais, "tendo em vista que (i) a Constituição protege a coisa julgada que restou formada no processo anteriormente julgado e (ii) a alteração realizada no CPC foi desacompanhada de qualquer permissão constitucional para que a coisa julgada fosse afastada" (in DELLORE, Luiz Guilherme Pennacchi, Evolução do controle de constitucionalidade das leis: rumo ao controle concentrado?, Dissertação (Mestrado), 2007, pp. 144/145). V., no mesmo sentido, tratando do antigo art. 741, par. único, do CPC, YARSHELl, Flávio Luiz, Ação rescisória: juízos rescindente e rescisório, 2005, p. 255.
} 
infraconstitucionais (lei ordinária, lei complementar, decreto, medida provisória etc.) e as normas constitucionais ${ }^{293}$.

\subsubsection{Percepções gerais}

Diante do exposto, é possível sustentar que as sentenças proferidas em sede de controle de constitucionalidade concentrado, especialmente em ADIn e ADCon, constituem os precedentes vinculantes por excelência do nosso sistema e, nessa medida, proporcionam, ainda que de forma reflexa, a uniformização da jurisprudência da forma mais correta e precisa possível, que é aquela que é feita de cima para baixo, do STF para os demais órgãos. Não à toa, diz-se que o controle de constitucionalidade concentrado, ao surtir efeitos vinculantes, foi o precursor do caminho posteriormente trilhado pela súmula vinculante.

\subsubsection{Súmula vinculante}

\subsubsection{Considerações introdutórias}

Para a introdução da súmula vinculante no ordenamento brasileiro, algumas propostas foram discutidas em paralelo. Foi a proposta de emenda constitucional de autoria do Sen. Ronaldo Cunha Lima (PEC n 54/1995) que, após treze anos de tramitação, prosperou, dando ensejo à súmula vinculante do Supremo Tribunal Federal.

O instituto foi implementado através do art. $8^{\circ}$ da Emenda Constitucional $\mathrm{n}^{\circ}$ 45, de 30 de dezembro de 2004, que acrescentou à Constituição Federal o art. 103-A, logo

\footnotetext{
${ }^{293}$ BotelHo DE MESQUiTA examina o assunto detidamente e conclui que, na hipótese de transitar em julgado sentença que considera inconstitucional determinada lei, "no caso da superveniente declaração de constitucionalidade, a ação rescisória teria que vir a ser obrigatoriamente julgada procedente por força não só da eficácia de coisa julgada erga omnes, como também do efeito vinculante da declaração" (in BOTELHO DE MESQUITA, José Ignacio, Conflito entre a intangibilidade da coisa julgada e outro princípio constitucional. Um falso problema, in Coisa julgada, 2004, p. 110). Com relação à hipótese inversa, obtempera o autor que "a parte que se julgue prejudicada por sentença fundada em norma que considere inconstitucional poderá sempre demandar a rescisão da sentença, haja ou não precedente declaração de sua inconstitucionalidade. Se houver, tanto melhor, pois o êxito estará garantido; mas, se não houver, isto não constituirá impedimento à admissibilidade nem ao julgamento de procedência da rescisória." (in idem, ibidem, p. 111). V., no mesmo sentido, fazendo referência inclusive à lição reproduzida acima, PARENTE, Eduardo de Albuquerque, Jurisprudência: da divergência à uniformização, 2006, p. 85.
} 
em seguida ao art. 103, que prevê a ação direta de inconstitucionalidade e a ação declaratória de constitucionalidade, cujas decisões também surtem efeitos vinculantes.

Na definição de SHIMURA, "trata-se de mais outra forma de uniformização de jurisprudência, agora com força obrigatória em relação a determinados entes ou pessoas, com o escopo de prevenir litígios, conferir celeridade e previsibilidade na outorga da tutela jurisdicional nas hipóteses repetitivas, evitando a multiplicação e a eternização dos processos" ${ }^{294}$. A percepção é correta, tanto que a existência de divergência sobre a matéria a ser sumulada constitui requisito para a edição de súmula vinculante, restando nítido, portanto, o seu propósito uniformizador.

\subsubsection{Regulamentação}

Como dito acima, a súmula vinculante está prevista na Constituição Federal em seu art. 103-A, redigido nos seguintes termos:

“Art. 103-A. O Supremo Tribunal Federal poderá, de ofício ou por provocação, mediante decisão de dois terços dos seus membros, após reiteradas decisões sobre matéria constitucional, aprovar súmula que, a partir de sua publicação na imprensa oficial, terá efeito vinculante em relação aos demais órgãos do Poder Judiciário e à administração pública direta e indireta, nas esferas federal, estadual e municipal, bem como proceder à sua revisão ou cancelamento, na forma estabelecida em lei.

$\S 1^{o}$ A súmula terá por objetivo a validade, a interpretação e a eficácia de normas determinadas, acerca das quais haja controvérsia atual entre órgãos judiciários ou entre esses e a administração pública que acarrete grave insegurança jurídica e relevante multiplicação de processos sobre questão idêntica.

$\S 2^{o}$ Sem prejuízo do que vier a ser estabelecido em lei, a aprovação, revisão ou cancelamento de súmula poderá ser provocada por aqueles que podem propor a ação direta de inconstitucionalidade.

\footnotetext{
${ }^{294}$ In SHIMURA, Sérgio, A súmula vinculante como mecanismo de tutela coletiva, in Direito civil e processoEstudos em homenagem ao Professor Arruda Alvim, 2007, p. 900.
} 
$\S 3^{\circ}$ Do ato administrativo ou decisão judicial que contrariar a súmula aplicável ou que indevidamente a aplicar, caberá reclamação ao Supremo Tribunal Federal que, julgando-a procedente, anulará o ato administrativo ou cassará a decisão judicial reclamada, e determinará que outra seja proferida com ou sem a aplicação da súmula, conforme o caso."

Como já prenunciava o $§ 2^{\circ}$ acima, em 19 de dezembro de 2006 foi editada a Lei $\mathrm{n}^{\circ} 11.417$, com o intuito de regulamentar o artigo em referência, alterar a Lei $\mathrm{n}^{\circ}$ 9.784, de 29 de janeiro de 1999, disciplinando a edição, a revisão e o cancelamento de enunciado de súmula vinculante pelo Supremo Tribunal Federal, especialmente do ponto de vista procedimental, e dar outras providências.

Como também já prenunciava o art. 10, da Lei no $11.417 / 2006$, que prevê que "o procedimento de edição, revisão ou cancelamento de enunciado de súmula com efeito vinculante obedecerá, subsidiariamente, ao disposto no Regimento Interno do Supremo Tribunal Federal", o próprio Regimento Interno do Supremo Tribunal Federal passou a regulamentar a súmula vinculante, nos arts. 354-A a 354-G, introduzidos recentemente, por força da Emenda Regimental n 46, de 6 de julho de 2011.

E a regulamentação não parou por aí. A súmula vinculante também veio regulada pelas Resoluções-STF n ${ }^{\circ} 381$, de 29 de outubro de 2008, e 388, de 5 de dezembro de 2008. A primeira simplesmente institui nova classe processual, denominada de "Proposta de Súmula Vinculante (PSV)", para o processamento de proposta de edição, revisão ou cancelamento de súmula vinculante (art. 1 , da Resol.-STF nº 381/2008); a segunda disciplina o processamento de proposta de edição, revisão e cancelamento de súmulas (vinculantes ou não) e dá providências correlatas.

Por fim, a EC n 45/2004 disciplinou em seu art. $8^{\circ}$ que "as atuais súmulas do Supremo Tribunal Federal somente produzirão efeito vinculante após sua confirmação por dois terços de seus integrantes e publicação na imprensa oficial’. A norma é válida e permanece em vigor, apesar de não ter sido refletida no texto constitucional.

Dessas considerações introdutórias já é possível perceber a ausência de sistematização na regulamentação da súmula vinculante. Trata-se de figura processual 
introduzida no ordenamento há pouco mais de sete anos e já existem nada menos do que seis diplomas (CF, EC no 45/2004, Lei n ${ }^{\circ}$ 11.417/2006, RISTF, Resol.-STF n ${ }^{\circ}$ 381/2008 e Resol.-STF no 388/2008) regulamentando-a, o que demonstra certa pulverização de normas - de todo indesejada - a seu respeito.

A rigor, a novidade sequer necessitava ter sido prevista em sede constitucional. Aparentemente, assim optou o constituinte por razões mais políticas do que técnicas, pois a súmula vinculante faz parte de um "pacote" maior, integrando um propósito reformista amplo acerca da estrutura do Poder Judiciário e de outras questões pura ou predominantemente processuais, denominado de "Reforma do Poder Judiciário" ou "Reforma da Justiça"295. Além do mais, a introdução via Emenda Constitucional tende a conferir ao instituto uma maior legitimidade, facilitando a sua aceitação pela comunidade jurídica $^{296}$.

Em tendo sido essa a opção adotada, melhor seria se o legislador tivesse sido mais cauteloso na edição das normas. A regra do art. 8º da EC n ${ }^{\circ}$ 45/2004, por exemplo, poderia ter sido incorporada ao texto constitucional sem nenhum problema, o que já descartaria um diploma na regulamentação da súmula vinculante. É lógico que a matéria não poderia vir inteiramente tratada na Constituição, já que por sua própria natureza o texto constitucional é mais enxuto, fugindo de sua atribuição a disposição acerca de particularidades do procedimento. Assim, era esperado que em seguida fosse editada lei ordinária regulamentando a edição, a revisão e o cancelamento da súmula vinculante, da mesma forma que era esperado que, ao lado da lei ordinária, o Regimento Interno dispusesse sobre outros detalhes atinentes à organização interna da instituição ${ }^{297}$ (sem, é claro, usurpar os limites da autorização constitucional ${ }^{298}$ ). Porém, a nosso ver, algumas

\footnotetext{
295 Segundo BARBOSA MoreirA, as regras mais relevantes da EC n ${ }^{\circ}$ 45/2004 podem ser distribuídas em quatro grupos ou categorias: modificações estruturais do Poder Judiciário e do Ministério Público; alterações de competência; disposições sobre a disciplina jurídica da magistratura (ingresso na carreira, promoção, remoção, férias, número de juízes em cada unidade jurisdicional etc.); normas de caráter pura ou predominantemente processual, incluídas as referentes a aspectos do funcionamento dos órgãos judiciais (in Barbosa Moreira, José Carlos, A emenda constitucional $n^{\circ} 45$ e o processo, in Revista Forense, vol. 383, 2006, p. 182).

${ }^{296}$ In PARENTE, Eduardo de Albuquerque, Jurisprudência: da divergência à uniformização, 2006, pp. 92/93.

${ }^{297}$ V., no mesmo sentido, Dinamarco, Cândido Rangel, Decisões vinculantes, in Revista de Processo, $\mathrm{n}^{\circ}$ 100, 2000, p. 183.

${ }^{298}$ Dispõe o art. 96, I, “a”, da CF, que “compete privativamente: aos tribunais: eleger seus órgãos diretivos e elaborar seus regimentos internos, com observância das normas de processo e das garantias processuais das
} 
questões - como, por exemplo, aquelas inseridas nos arts. 354-E e 354-F, do RISTF - já poderiam ter sido disciplinadas via lei ordinária, assim como a introdução da Emenda Regimental n $n^{\circ} 46 / 2011$ já poderia ter contemplado todos os pontos das Resoluções do STF n $381 / 2008$ e 388/2008, descartando-se mais dois diplomas, e solucionando-se a dúvida acerca da revogação (ou não-recepção) da Resol.-STF no 388/2008, na parte em que conflita com os arts. 354-A a 354-G, do RISTF - embora pareça natural que isso tenha ocorrido, como se verá adiante.

\subsubsection{Legitimação e intervenção de terceiros}

$\mathrm{O}$ art. 103, $\S 2^{\circ}$, da $\mathrm{CF}$, previu que, "sem prejuizo do que vier a ser estabelecido em lei, a aprovação, revisão ou cancelamento de súmula poderá ser provocada por aqueles que podem propor a ação direta de inconstitucionalidade".

Em seguida, como expressamente autorizava a disposição acima, a Lei $n^{\circ}$ 11.417/2006, em seu art. $3^{\circ}$, expandiu esse rol, ao nominar expressamente os seguintes legitimados a propor a edição, a revisão ou o cancelamento de súmula vinculante: o Presidente da República; a Mesa do Senado Federal; a Mesa da Câmara dos Deputados; o Procurador-Geral da República; o Conselho Federal da Ordem dos Advogados do Brasil; o Defensor Público-Geral da União; partido político com representação no Congresso Nacional; confederação sindical ou entidade de classe de âmbito nacional; a Mesa de Assembleia Legislativa ou da Câmara Legislativa do Distrito Federal; o Governador de Estado ou do Distrito Federal; os Tribunais Superiores, os Tribunais de Justiça de Estados ou do Distrito Federal e Territórios, os Tribunais Regionais Federais, os Tribunais Regionais do Trabalho, os Tribunais Regionais Eleitorais e os Tribunais Militares ${ }^{299}$.

Logo, além dos legitimados à propositura de ação direta de inconstitucionalidade, a Lei $n^{\circ}$ 11.417/2006 conferiu também ao Defensor Público-Geral da União e aos Tribunais Superiores, Tribunais de Justiça de Estados ou do Distrito

partes, dispondo sobre a competência e o funcionamento dos respectivos órgãos jurisdicionais e administrativos".

${ }^{299}$ Há quem sustente que, nos mesmos termos da ADIn e da ADC, o STF deverá exigir em relação a alguns legitimados pertinência temática. V., sobre o assunto, CARDOSO, Oscar Valente, Súmulas vinculantes $e$ desvinculação da jurisprudência, in Revista Dialética de Direito Processual, $\mathrm{n}^{\circ}$ 77, 2009, p. 76. A exigência nos parece correta, para evitar que os legitimados proponham a edição, a revisão e o cancelamento de súmulas vinculantes a torto e a direito, em relação a matérias que não lhes digam o menor respeito. 
Federal e Territórios, Tribunais Regionais Federais, Tribunais Regionais do Trabalho, Tribunais Regionais Eleitorais e Tribunais Militares a possibilidade de proporem a edição, a revisão ou o cancelamento de súmula com efeitos vinculantes.

A Lei $\mathrm{n}^{\mathrm{o}}$ 11.417/2006 ainda fez outra relevante ressalva, autorizando o Município a propor a edição, a revisão ou o cancelamento de enunciado de súmula vinculante, não de maneira autônoma, independentemente de processo em andamento, como os demais, mas incidentalmente ao curso de processo em que seja parte, sem suspendê-lo ${ }^{300}$ (art. $3^{\circ}, \S 1^{\text {o }}$, da Lei no $\left.11.417 / 2006\right)$.

De maneira geral, tais alterações introduzidas pela lei ordinária nos parecem benéficas, especialmente no que diz respeito à possibilidade de outros tribunais, além do STF, poderem propor a edição, a revisão ou o cancelamento de súmula com efeitos vinculantes. Com efeito, por vezes tais tribunais possuem até mais sensibilidade que o STF para perceber quais matérias demandam regulamentação via súmula vinculante, ou quais súmulas devem ser revisadas ou canceladas, já que estão mais próximos da população e julgam mais casos que o tribunal supremo e, com isso, enxergam com mais facilidade os desvios na interpretação das leis, e as dúvidas a propósito de sua validade e eficácia. $\mathrm{O}$ relatório do Dep. MAURícIO RANDS, relator do projeto que deu origem à Lei $\mathrm{n}^{\circ}$ 11.417/2006, fez observação exatamente nesse sentido: "A ampliação do rol de legitimados para pleitear a edição, revisão e cancelamento de enunciados da súmula vinculante, tal qual proposta no projeto, é de todo recomendável, pois democratiza o instituto e afasta dele a pecha de autoritarismo. Com efeito, é extremamente salutar a iniciativa de legitimar os tribunais, os procuradores-gerais de justiça e os defensores públicos-gerais, pois são eles os personagens mais próximos dos jurisdicionados e da realidade pulsante dos fatos, de modo que terão melhores condições de iniciar um movimento pela modificação da jurisprudência sumulada pelo Supremo." ${ }^{301}$.

\footnotetext{
${ }^{300}$ Essa parte da regra é consentânea com o art. $6^{\circ}$, da Lei $n^{\circ} 11.417 / 2006$, que dispõe que a proposta de edição, revisão ou cancelamento de enunciado de súmula vinculante não autoriza a suspensão dos processos em que se discuta a mesma questão. Diversamente, admite-se a concessão de medida cautelar e liminar para a suspensão dos processos em curso até o julgamento, respectivamente, de ADCon e de ADPF (art. 21, da Lei $\mathrm{n}^{\mathrm{o}} 9.868 / 1999$, e art. $5^{\circ}, \S 3^{\circ}$, da Lei $\left.\mathrm{n}^{\circ} 9.882 / 1999\right)$; na hipótese de julgamento de recursos especiais repetitivos, também se determina o sobrestamento dos demais recursos até o julgamento daquele(s) representativo(s) da controvérsia (art. 543-B, $\S 1^{\circ}$, do CPC).

${ }^{301}$ In CÔRTES, Osmar Mendes Paixão, A experiência brasileira com a vinculação das decisões judiciais e a atual súmula vinculante introduzida pela EC 45/2004, in Direito civil e processo - Estudos em homenagem ao Professor Arruda Alvim, 2007, p. 1.393.
} 
A propósito da possibilidade de participação de amicus curiae, o art. $3^{\circ}, \S$ $2^{\circ}$, da Lei $n^{\circ} 11.417 / 2006$, estabeleceu que, no procedimento de edição, revisão ou cancelamento de enunciado da súmula vinculante, o relator poderá admitir, por decisão irrecorrível, a manifestação de terceiros na questão, nos termos do Regimento Interno do Supremo Tribunal Federal. A alteração, no geral, também parece positiva pois, dependendo da matéria a ser regulada pela súmula, é enriquecedor o debate com outros membros da sociedade, para opinarem ou prestarem informações sobre a matéria controvertida. Além do que, ao emitir efeitos vinculantes, a súmula age como se lei fosse, sendo recomendável enorme cautela em relação a tudo que a envolve.

Justamente por isso, há um ponto que nos incomoda com relação a tal questão: dada a magnitude dos efeitos da súmula vinculante, mais correto seria se a lei falasse que o relator deverá admitir a intervenção de terceiros, ao invés de "poderá admitir a intervenção de terceiros" (destaque nosso). Da forma como está redigida, a lei deixa totalmente sob a discricionariedade do relator a admissão ou não do amicus curiae.

Concordamos que não se deve abrir a todos tal possibilidade (não é nada disso o que pregamos), pois isso teria o condão de tumultuar o processo de edição, revisão ou cancelamento de súmula. Para restringir o rol de "legitimados a intervir", poder-se-ia, por exemplo, exigir uma espécie de pertinência temática, tal como ocorre nas ações coletivas. Pensamos que essa seria uma boa solução para evitar manifestações impertinentes e, ao mesmo tempo, retirar do crivo único e exclusivo do relator a decisão sobre a admissão do amicus curiae. Embora hoje tenhamos atingido um estágio em que o relator é dotado de poderes amplíssimos, sentimos que seria prudente agir, com relação a esse assunto, com certo temperamento.

Por fim, vale lembrar que, entre as atribuições do relator, encontra-se a de "convocar audiência pública para ouvir o depoimento de pessoas com experiência e autoridade em determinada matéria, sempre que entender necessário o esclarecimento de questões ou circunstâncias de fato, com repercussão geral ou de interesse público relevante" (art. 21, XVII, do RISTF). Evidentemente, esse procedimento também deve ser observado no caso de edição, revisão ou cancelamento de súmula. 


\subsubsection{Objeto e requisitos}

$\mathrm{O}$ art. 103-A, caput, da $\mathrm{CF}$, restringe o objeto da súmula vinculante a matéria constitucional, a respeito da qual já tenham sido proferidas reiteradas decisões. $\mathrm{O} \S$ $1^{\circ}$, por sua vez, complementa e especifica a regra do caput ao falar em normas acerca das quais haja controvérsia atual entre órgãos judiciários ou entre esses e a administração pública que acarrete grave insegurança jurídica e relevante multiplicação de processos sobre questão idêntica.

Logo, não é toda e qualquer norma que pode ser objeto de súmula vinculante, mas apenas norma constitucional (ou norma ordinária, examinada à luz da Constituição Federal, como se verá a seguir), já reiteradamente apreciada, a respeito da qual haja controvérsia atual entre órgãos judiciários ou entre esses e a administração pública - controvérsia essa capaz de acarretar grave insegurança jurídica e relevante multiplicação de processos sobre questão idêntica.

Do nosso ponto de vista, essa parte final do $\S 1^{\circ}$ sequer seria necessária, porquanto redundante. Afinal, qualquer controvérsia a propósito de norma jurídica, especialmente de norma constitucional ou de norma ordinária em confronto com a Constituição, é suficiente para acarretar grave insegurança jurídica e relevante multiplicação de processos sobre questão idêntica. O que importa é que de tais requisitos sobressaem os objetivos primordiais da súmula vinculante, quais sejam, garantir maior segurança jurídica e diminuir os processos repetitivos sobre matéria idêntica, mediante a uniformização de interpretação de norma constitucional até então de sentido controverso como já exposto alhures, a Constituição de 1988 possibilitou o acesso ao Poder Judiciário a um número maior de pessoas e causas, impulsionando a crise numérica de recursos no STF e uma avalanche de pretensões homogêneas (ex.: planos econômicos, questões previdenciárias) $)^{302}$.

Aliás, por controvérsia atual, deve-se entender aquela ainda não superada, representada por diversas decisões conflitantes. Inclusive, quanto mais diversificados os órgãos prolatores de tais decisões, do ponto de vista regional, melhor. Embora o requisito

\footnotetext{
${ }^{302}$ In GRINOVER, Ada Pellegrini, Mudanças estruturais no processo civil brasileiro, in Revista IOB de
} Direito Civil e Processual Civil, no 44, 2006, p. 48. 
não se encontre disposto em lugar nenhum, tampouco sua ausência seja impedimento para a edição de súmula vinculante, trata-se de meio de garantir que a controvérsia efetivamente reflete discussão nacional, e não regional, e de que serão considerados todos os aspectos relevantes acerca do tema.

O exemplo invocado por PARENTE é bastante representativo dessa questão. Segundo o autor, em determinadas regiões do país, especialmente nas menos centrais, há muito menos demandas que tratam de forma específica, ou com a complexidade necessária, de algumas matérias (ex.: fiscais), em comparação com os grandes polos industriais. Ocorre que tais processos tendem a chegar primeiro nos tribunais superiores, pois nessas regiões a quantidade de feitos é menor e a estrutura judiciária é mais enxuta, tornando o trâmite dos processos mais célere. Tendo isso em mente, não seria razoável que o STF gerasse precedentes vinculantes com base somente em processos oriundos dessas regiões, porquanto nesses locais dificilmente terão sido aprofundados todos os aspectos relevantes da matéria - não por falta de aptidão dos advogados e magistrados, mas simplesmente porque são regiões de menor complexidade industrial, social e jurídica, e que demandam, portanto, discussões mais superficiais. Independentemente do conhecimento dos julgadores a respeito do direito estrito, o fato é que determinadas questões sequer poderão ser abordadas pelo STF, em função da limitação das decisões prévias à causa de pedir da demanda e da ausência do requisito do prequestionamento ${ }^{303}$. Assim, no momento de aprovação da súmula, é de todo recomendável que os ministros tenham essa percepção e façam a devida ponderação, com vistas a confirmar se foram esgotados todos os aspectos relevantes que poderiam emergir da matéria, ou se a discussão reflete apenas controvérsia local, a recomendar o amadurecimento do tema nos demais tribunais do país.

Esse aspecto remete a outro ponto ainda mais importante: é necessário que a matéria a ser sumulada também esteja madura dentro do próprio STF, e já tenha sido exaustivamente debatida, a ponto de os magistrados sentirem-se realmente seguros a emitirem enunciado com eficácia vinculante ${ }^{304}$. O caput do art. 103-A, da CF, é bastante

\footnotetext{
${ }^{303}$ In PARENTE, Eduardo de Albuquerque, Jurisprudência: da divergência à uniformização, 2006, p. 59.

${ }^{304}$ V., afirmando que, em função desse requisito, as súmulas vinculantes, em regra, "serão formuladas a partir das questões processuais de massa ou homogêneas, envolvendo matérias previdenciárias, administrativas, tributárias ou até mesmo processuais, suscetíveis de uniformização e padronização", GRINOVER, Ada Pellegrini, Mudanças estruturais no processo civil brasileiro, in Revista IOB de Direito Civil e Processual Civil, $\mathrm{n}^{\circ}$ 44, 2006, p. 50. V., em sentido semelhante, sustentando que as súmulas
} 
claro nesse sentido, ao prever que a súmula vinculante poderá ser editada “(...) após reiteradas decisões (...)". O intuito dessa regra é fazer com que as súmulas vinculantes reflitam entendimento efetivamente consolidado dentro da corte, evitando que os enunciados sofram revisão ou sejam cancelados $\operatorname{logo} \mathrm{em}_{\text {seguida }}{ }^{305}$ em razão de eventual descuido na sua edição - como ocorreu, mais ou menos, com a Súmula Vinculante no 30, cuja publicação foi suspensa um dia após a sua aprovação, para melhor exame, em razão de questão de ordem levantada pelo Min. José ANTONIO DiAS TOFFOLI no início da sessão plenária do STF de 04/02/2010. Nada mais constrangedor, para dizer o mínimo...

Apesar da importância desse requisito, que a nosso ver deveria valer para todas as súmulas em geral, constata-se que nem todas as súmulas vinculantes emitidas pelo STF refletem a jurisprudência do tribunal. É o caso, por exemplo, da Súmula Vinculante $\mathrm{n}^{\circ}$ 11 ("só é lícito o uso de algemas em casos de resistência e de fundado receio de fuga ou de perigo à integridade física própria ou alheia, por parte do preso ou de terceiros, justificada a excepcionalidade por escrito, sob pena de responsabilidade disciplinar, civil e penal do agente ou da autoridade e de nulidade da prisão ou do ato processual a que se refere, sem prejuízo da responsabilidade civil do Estado"), cuja edição baseou-se em um único precedente do STF $\left(\mathrm{HC}^{\circ}\right.$ 91.952/SP), julgado na sessão anterior à aprovação da súmula, conforme se extrai dos debates que lhe deram origem ${ }^{306}$.

Tal desrespeito é absurdo, na medida em que a norma, além de estar inserida no próprio caput do art. 103-A, da CF, tem toda razão de $\operatorname{ser}^{307}$. Não é crível que o STF emita verbetes vinculantes sem a devida reflexão. E essa reflexão decorre muito mais

vinculantes "incidirão sobre matéria tributária, previdenciária, consumerista, de servidores públicos, de conflitos de massa e outros temas de larga repercussão, onde a questão jurídica predomine sobre a matéria de fato e diga respeito a um número importante de sujeitos ou de situações", MANCUSO, Rodolfo de Camargo, Súmula vinculante: perguntas e respostas, in Direito civil e processo - Estudos em homenagem ao Professor Arruda Alvim, 2007, p. 1.465.

305 Afinal, "una corte che, sulla stessa questione, cambiasse ogni giorno opinione, avrebbe ben scarsa autorevolezza e violerebbe qualunque principio di uguaglianza dei cittadini di fronte alla legge" (in TARUFFo, Michele, Precedente e giurisprudenza, in Rivista Trimestrale di Diritto e Procedura Civile, ano 61, no 3, 2007, p. 719).

306 Os debates estão disponíveis em <http://www.stf.jus.br/arquivo/cms/jurisprudenciaSumulaVinculante/ anexo/DJE_11.11.2008.pdf>, acesso em 29/09/2011.

${ }^{307}$ V., afirmando que a exigência é lógica, pois "se o tribunal busca dar à sociedade segurança jurídica, deve ter posição consolidada sobre o assunto, com a concordância da maioria de seus integrantes", CÔRTES, Osmar Mendes Paixão, A experiência brasileira com a vinculação das decisões judiciais e a atual súmula vinculante introduzida pela EC 45/2004, in Direito civil e processo - Estudos em homenagem ao Professor Arruda Alvim, 2007, p. 1.389. 
da prática do que da teoria, já que é na experiência forense, na análise de casos concretos, que os vícios das normas aparecem, recomendando a edição de enunciados que as complementem, para o fim de esclarecer seu verdadeiro sentido, ou de dispor sobre sua validade e eficácia.

Lamentavelmente, há quem discorde dessa opinião, sustentando que o texto constitucional prevê duas hipóteses distintas de edição de súmula vinculante: "aquela em que decorra de reiteradas decisões sobre matéria constitucional, com o que o verbete passará a representar a consolidação da inteligência dos Tribunais sobre a matéria; e aquela que objetiva eliminar divergência dentro do Poder Judiciário ou entre este e a Administração Pública em geral" ${ }^{308}$. Não podemos concordar com essa posição até mesmo por uma questão de técnica legislativa: o $\S 1^{\circ}$ do art. 103-A, da CF, complementa o texto do caput, ao exigir outros requisitos para a edição de súmula vinculante, mas não cria outra hipótese além dele. É assim que os textos legais funcionam: o caput contém a regra geral e os parágrafos trazem complementos ou exceções a essa regra geral. Tivesse o legislador a intenção de criar duas hipóteses distintas, as teria disciplinado em artigos diferentes, ou em parágrafos diferentes, mas não uma no caput e a outra no respectivo parágrafo ${ }^{309}$.

Sobre o fato de a súmula vinculante poder versar exclusivamente sobre matéria constitucional, logo que o art. 103-A, da $\mathrm{CF}$, entrou em vigor, houve quem entendesse que a regra do caput deveria ser interpretada de forma ampla, em conjunto com a regra do $\S 1^{\circ}$, com o intuito de permitir ao STF a emissão de súmula vinculante tratando também de regras ordinárias, examinadas à luz da Constituição ${ }^{310}$. De fato, foi essa a orientação seguida, como se confere do teor das trinta e duas súmulas vinculantes editadas até o momento, nem todas versando sobre matéria puramente constitucional.

$\mathrm{O}$ art. 354-E, do RISTF, inovou em relação ao texto constitucional ao prever que "a proposta de edição, revisão ou cancelamento de súmula vinculante poderá

\footnotetext{
${ }^{308}$ In MARTINs, Ives Gandra da Silva, Duas hipóteses para súmulas vinculantes, in Revista Jus Vigilantibus, disponível em <http://jusvi.com/artigos/36441>, 2008, acesso em 02/11/2011.

${ }^{309}$ V., nesse sentido, CARDOSO, Oscar Valente, Súmulas vinculantes e desvinculação da jurisprudência, in Revista Dialética de Direito Processual, no 77, 2009, p. 82.

${ }^{310}$ V., defendendo essa orientação, PARENTE, Eduardo de Albuquerque, Jurisprudência: da divergência à uniformização, 2006, pp. 96/97. V., no mesmo sentido, MEDINA, José Miguel Garcia, WAMBIER, Luiz Rodrigues e WAMBIER, Teresa Arruda Alvim, A súmula vinculante, vista como meio legítimo para diminuir a sobrecarga de trabalho dos tribunais brasileiros, in Revista do Advogado, nº 92, 2007, p. 10.
} 
versar sobre questão com repercussão geral reconhecida, caso em que poderá ser apresentada por qualquer Ministro logo após o julgamento de mérito do processo, para deliberação imediata do Tribunal Pleno na mesma sessão". Assim, criou mais uma hipótese a autorizar a edição, a revisão ou o cancelamento de súmula vinculante, a saber, a questão com repercussão geral reconhecida.

Dessa inovação, duas questões surgem. A primeira diz respeito à possibilidade - na verdade, à constitucionalidade - de norma regimental prever outra hipótese autorizadora de edição, revisão ou cancelamento de súmula vinculante que não está prevista na Constituição. A segunda diz respeito ao sentido da expressão "questão com repercussão geral reconhecida".

Quanto ao primeiro ponto, em princípio nos parece que a norma é constitucional, na medida em que não conflita com a regra originalmente prevista. Além disso, o próprio texto da Constituição já previa a possibilidade de vir a ser regulamentado por lei ordinária (art. 103-A, § 2 , da CF), que, por sua vez, também já dispunha sobre a possibilidade de vir a ser complementada, subsidiariamente, por norma regimental (art. 10, da Lei $\left.n^{\circ} 11.417 / 2006\right)$.

Quanto ao segundo ponto, nos parece que a expressão em discussão deve ser interpretada à luz da "repercussão geral das questões constitucionais" que aparece no art. 102, III, $\S 3^{\circ}$, da $\mathrm{CF}$, como requisito de admissibilidade do recurso extraordinário. Assim, serão consideradas de repercussão geral reconhecida as questões sobre as quais o STF já se manifestou, em sentido positivo, por ocasião do julgamento de recurso extraordinário. Tais questões podem ser facilmente identificadas por meio de consulta ao site do tribunal ${ }^{311}$.

\subsubsection{Procedimento de elaboração, revisão e cancelamento}

O procedimento de elaboração, revisão e cancelamento da súmula vinculante está previsto no Regimento Interno do Supremo Tribunal Federal. Embora a

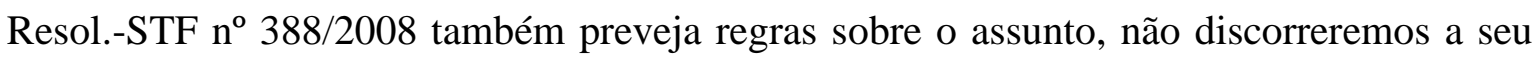

311 Informações sobre temas que tiveram a repercussão geral reconhecida encontram-se disponíveis em <http://www.stf.jus.br/portal/jurisprudenciaRepercussao/listarProcesso.asp>, acesso em 05/11/2011. 
respeito, pois tudo indica que esse procedimento foi substituído por aquele do Regimento Interno, implementado em momento posterior pela Emenda Regimental $n^{\circ} 46 / 2011^{312}$. Isso porque os arts. 354-A a 354-G, do RISTF, são posteriores à Resol.-STF nº 388/2008, e as resoluções do STF servem justamente para "complementar o Regimento Interno ou o Regulamento da Secretaria e resolver os casos omissos, bem assim para complementar a legislação relativa ao funcionalismo, ou regular sua aplicação", conforme descrição constante do art. 363, I, do RISTF. Assim, em tendo o próprio Regimento Interno passado a regular o assunto, a Resolução tornou-se desnecessária e obsoleta. A única disposição da referida Resol.-STF n ${ }^{\circ}$ 388/2008 que parece permanecer em vigor é a inserida em seu art. $3^{\circ}$, no sentido de que "a manifestação de eventuais interessados e do Procurador-Geral da República dar-se-á em sessão plenária, quando for o caso", na medida em que não conflita com qualquer regra regimental.

Em suma, restou estabelecido no Regimento Interno que, recebendo proposta de edição, revisão ou cancelamento de súmula vinculante, a Secretaria Judiciária a autuará e registrará ao presidente, para apreciação, no prazo de cinco dias, quanto à adequação formal da proposta (art. 354-A, do RISTF). Verificado o atendimento dos requisitos formais, a Secretaria Judiciária publicará edital no site do tribunal e no DJ eletrônico, para ciência e manifestação de interessados no prazo de cinco dias (sem

312 Os procedimentos do RISTF e da Resol.-STF nº 388/2008 são um pouco diferentes, conforme demonstrado abaixo, em ordem:

\begin{tabular}{|c|c|}
\hline RISTF & Resolução-STF n⿳ 388/2008 \\
\hline 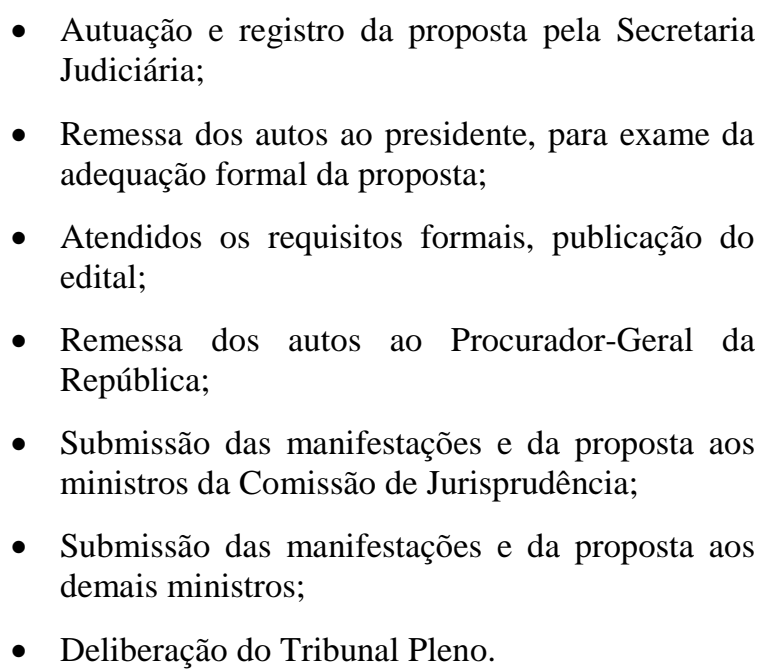 & $\begin{array}{l}\text { - Registro e autuação da proposta pela Secretaria } \\
\text { Judiciária; } \\
\text { - Publicação do edital; } \\
\text { - Remessa dos autos à Comissão de Jurisprudência, } \\
\text { para exame da adequação formal da proposta; } \\
\text { - Atendidos os requisitos formais, submissão das } \\
\text { manifestações e da proposta aos demais ministros } \\
\text { e ao Procurador-Geral da República; } \\
\text { - Remessa dos autos ao ministro presidente; } \\
\text { - Deliberação do Tribunal Pleno. }\end{array}$ \\
\hline
\end{tabular}


prejuízo da eventual manifestação oral de tais interessados na sessão plenária, conforme a regra do art. $3^{\circ}$, da Resol.-STF $n^{\circ} 388 / 2008$, mencionada acima), encaminhando a seguir os autos ao Procurador-Geral da República (art. 354-B, do RISTF) ${ }^{313}$.

Devolvidos os autos com a manifestação do Procurador-Geral da República, o presidente submeterá as manifestações e a proposta de edição, revisão ou cancelamento de súmula aos ministros da Comissão de Jurisprudência, em meio eletrônico, para que se manifestem no prazo comum de quinze dias; decorrido o prazo, a proposta, com ou sem manifestação, será submetida, também por meio eletrônico, aos demais ministros, pelo mesmo prazo comum (art. 354-C, do RISTF). Decorrido tal prazo, o presidente submeterá a proposta à deliberação do Tribunal Pleno, mediante inclusão em pauta (art. 354-D, do RISTF).

Na sessão plenária, a edição, a revisão e o cancelamento de enunciado de súmula com efeito vinculante dependerão de decisão tomada por dois terços dos membros do Supremo Tribunal Federal, nos termos do art. 103-A, caput, da CF, e do art. $2^{\circ}$, $\S 3^{\circ}$, da Lei ${ }^{\circ} 11.417 / 2006$.

Como se vê, o procedimento não encerra qualquer complexidade e é feito de maneira a permitir a ciência e a manifestação dos interessados, contando com a participação efetiva do Procurador-Geral da República e de todos os ministros do STF. O mais importante disso tudo é que o procedimento para a revisão e o cancelamento da súmula é exatamente idêntico ao procedimento para a sua edição, o que por um lado evita a possibilidade de mudanças constantes, e por outro afasta a tão temida estagnação do enunciado $^{314}$, já que, apesar de vinculante, ele não é "inscrito em pedra" e, portanto, pode ser revisitado sempre que as alterações sociais, ou então o simples surgimento de exegese mais adequada, recomendarem.

\footnotetext{
${ }^{313}$ Essa regra está em consonância com o art. $2^{\circ}, \S 2^{\circ}$, da Lei $n^{\circ} 11.417 / 2006$, que prevê que o ProcuradorGeral da República, nas propostas que não houver formulado, manifestar-se-á previamente à edição, revisão ou cancelamento de enunciado de súmula vinculante. Conciliando as duas regras, nos parece que, se a proposta partir do Procurador-Geral da República, não é necessária nova manifestação dele, de modo que, após a publicação do edital e a manifestação dos interessados, os autos devem ser remetidos diretamente ao presidente da corte.

314 V., em sentido semelhante, CARDOSO, Oscar Valente, Súmulas vinculantes e desvinculação da jurisprudência, in Revista Dialética de Direito Processual, nº 77, 2009, p. 78.
} 
Afinal, como muito bem ponderado por CAMBI antes mesmo da implementação da súmula vinculante no nosso ordenamento, “(...) as súmulas nem sempre são corretas nem, muito menos, infalíveis ou inalteráveis, devendo estar abertas a mecanismos que permitam a possibilidade de modificação dos posicionamentos jurídicos, no curso do tempo e da história. Exemplo disso é a Súm. 84 do STJ, que revogou o entendimento consagrado na Súm. 621 do STF, passando a admitir a oposição de embargos de terceiro, fundados em alegação de posse advinda do compromisso de compra e venda do imóvel, ainda que desprovido do registro. Com efeito, a previsão de meio capaz de rever ou de cancelar a súmula é indispensável à manutenção da independência dos Juízes, à permanente evolução e atualização do direito, bem como ao necessário controle das opiniões e entendimentos dos Tribunais Superiores." $" 315$.

$\mathrm{O}$ art. $5^{\circ}$, da Lei $\mathrm{n}^{\circ}$ 11.417/2006, segue essa mesma linha, ao estabelecer que, revogada ou modificada a lei em que se fundou a edição de enunciado de súmula vinculante, o Supremo Tribunal Federal, de ofício ou por provocação, procederá à sua revisão ou cancelamento, conforme o caso. Considerando que a súmula vinculante sempre diz respeito a determinada norma, natural que seu enunciado seja cancelado, ou no mínimo adaptado, de acordo com as novas circunstâncias, no caso de revogação ou modificação da norma que deu ensejo à edição da súmula vinculante ${ }^{316}$.

Vale ressaltar que, para que as atuais súmulas do STF transformem-se em súmulas vinculantes, basta confirmação nesse sentido por parte de dois terços dos integrantes da corte e sua publicação na imprensa oficial, conforme regra do art. $8^{\circ}$, da EC $n^{\circ} 45 / 2004$.

Se, por qualquer motivo, for recusada a aprovação, a revisão ou o cancelamento da súmula vinculante, ou se não for atingido o quórum mínimo para fazê-lo, nada impede que a mesma proposta seja levada novamente à apreciação dos ministros, em nova sessão. A lei sequer estabelece a necessidade de intervalo mínimo entre uma sessão e

\footnotetext{
${ }^{315}$ In CAMBI, Eduardo, Jurisprudência lotérica, in Revista dos Tribunais, vol. 786, 2001, p. 115.

${ }^{316} \mathrm{~V}$., em sentido semelhante, afirmando que "a súmula vinculante é o produto final (e potencializado) da iterativa interpretação, pelo STF, de um dado contexto normativo que lhe é subjacente, e assim, é natural que, alterado ou extinto esse contexto, a súmula, por simetria, venha a ser alterada ou extinta", MANCUSO, Rodolfo de Camargo, Súmula vinculante: perguntas e respostas, in Direito civil e processo - Estudos em homenagem ao Professor Arruda Alvim, 2007, p. 1.470.
} 
outra, devendo ser reiterada a iniciativa quando o tribunal sentir que a tese ventilada na proposta possui chances de êxito ${ }^{317}$.

\subsubsection{Mecanismos de impugnação}

$\mathrm{O} \S 3^{\circ}$, do art. 103-A, da $\mathrm{CF}$, prevê que, "do ato administrativo ou decisão judicial que contrariar a súmula aplicável ou que indevidamente a aplicar, caberá reclamação ao Supremo Tribunal Federal que, julgando-a procedente, anulará o ato administrativo ou cassará a decisão judicial reclamada, e determinará que outra seja proferida com ou sem a aplicação da súmula, conforme o caso"318.

$\mathrm{O}$ art. $7^{\circ}$, da Lei $\mathrm{n}^{\circ} 11.417 / 2006$, complementa a regra, ao estabelecer que, "da decisão judicial ou do ato administrativo que contrariar enunciado de súmula vinculante, negar-lhe vigência ou aplicá-lo indevidamente caberá reclamação ao Supremo Tribunal Federal, sem prejuizo dos recursos ou outros meios admissíveis de impugnação" (destaque nosso). Do $\S 1^{\circ}$ do referido artigo ainda consta que, "contra omissão ou ato da administração pública, o uso da reclamação só será admitido após esgotamento das vias administrativas", havendo quem sustente a inconstitucionalidade desse dispositivo, por limitar o acesso ao Judiciário e violar o art. $5^{\circ}, \mathrm{XXXV}$, da $\mathrm{CF}^{319}$. Já o $\S 2^{\circ}$ praticamente reproduz a segunda parte do art. 103-A, $\S 3^{\circ}$, da $\mathrm{CF}^{320}$.

${ }^{317}$ In CÔRTES, Osmar Mendes Paixão, A experiência brasileira com a vinculação das decisões judiciais e a atual súmula vinculante introduzida pela EC 45/2004, in Direito civil e processo - Estudos em homenagem ao Professor Arruda Alvim, 2007, p. 1.393.

${ }^{318}$ Vê-se que nesse caso específico o STF passa a exercer a função de cassação, como aquela desempenhada, por exemplo, pelas Cortes de Cassação italiana ou francesa. V., sobre ambas, BuZAID, Alfredo, Uniformização da jurisprudência, in Revista da Ajuris - Associação dos Juízes do Rio Grande do Sul, $\mathrm{n}^{\circ} 34$, 1985, pp. 202/210. Tratando do modelo francês, MARINONI esclarece que "a Cassação foi instituída unicamente para cassar a interpretação incorreta, não para estabelecer a interpretação correta ou para decidir em substituição à decisão prolatada pelo juiz ordinário" (in MARINONI, Luiz Guilherme, Os precedentes na dimensão da segurança jurídica, disponível em <http://marinoni.adv.br〉, acesso em 16/09/2011, p. 11).

${ }^{319}$ V., sobre o assunto, CARDOSO, Oscar Valente, Súmulas vinculantes e desvinculação da jurisprudência, in Revista Dialética de Direito Processual, nº 77, 2009, p. 77.

${ }^{320}$ No âmbito administrativo, a Lei no $11.417 / 2006$ também implementou alterações, ao determinar a inclusão de novos dispositivos na Lei $n^{\circ} 9.784$, de 29 de janeiro de 1999, a qual regula o processo administrativo da Administração Pública Federal. Com efeito, ao art. 56 da Lei $n^{\circ} 9.784 / 1999$ foi acrescido o respectivo $\S 3^{\circ}$, com a seguinte redação: "se o recorrente alegar que a decisão administrativa contraria enunciado da súmula vinculante, caberá à autoridade prolatora da decisáo impugnada, se não a reconsiderar, explicitar, antes de encaminhar o recurso à autoridade superior, as razões da aplicabilidade ou inaplicabilidade da súmula, conforme o caso". Acrescentou-se à referida lei, também, os arts. 64-A ("se o recorrente alegar violação de enunciado da súmula vinculante, o órgão competente para decidir o recurso explicitará as razões da aplicabilidade ou inaplicabilidade da súmula") e 64-B ("acolhida pelo Supremo Tribunal Federal a 
Do exame de tais dispositivos, a ideia que imediatamente nos ocorre é que em certo sentido a súmula vinculante acabou por assumir maior força que a própria lei, já que contra a decisão que desafia aquela é cabível reclamação ao Supremo Tribunal Federal, para a preservação de sua competência e garantia da autoridade de suas decisões,

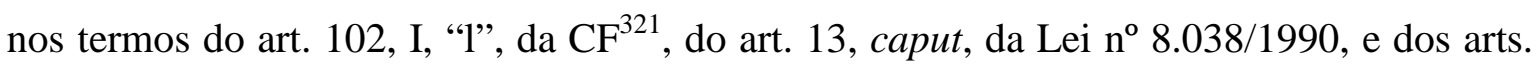
156, caput, do RISTF; já contra a decisão que desafia a letra pura e simples da lei não é cabível reclamação constitucional.

Consoante a Súmula-STF n ${ }^{\circ}$ 734, "não cabe reclamação quando já houver transitado em julgado o ato judicial que se alega tenha desrespeitado decisão do Supremo Tribunal Federal". Nessa medida, em não sendo sucedâneo de ação rescisória, a reclamação só será cabível se houver recurso ainda pendente de julgamento. Assim, havendo, por exemplo, apelação em curso, caso esta seja provida para reformar ou anular a sentença antes que a reclamação seja apreciada no STF, esta ficará prejudicada, por perda de objeto, já que não será possível cassar uma sentença que não mais subsiste no ordenamento. Da mesma forma, se a reclamação for provida pelo STF antes do julgamento do recurso de apelação, este perderá o seu objeto, já que o tribunal a quo não poderá julgar recurso contra sentença antes cassada pelo $\mathrm{STF}^{322}$.

Pode ocorrer, porém, de o julgamento tomado em primeiro lugar não reconhecer a violação à súmula vinculante e determinar a manutenção da decisão tal como lançada. Nesse caso, o recurso ou a reclamação ainda não julgados ficarão prejudicados? A questão é tormentosa e deve ser bem ponderada. Foi provavelmente imaginando essa situação que, tratando en passant do assunto, BARBOSA MOREIRA asseverou que " $a$ tramitação paralela do recurso e da reclamação será capaz, sem dúvida, de gerar

reclamação fundada em violação de enunciado da súmula vinculante, dar-se-á ciência à autoridade prolatora e ao órgão competente para o julgamento do recurso, que deverão adequar as futuras decisões administrativas em casos semelhantes, sob pena de responsabilização pessoal nas esferas cível, administrativa e penal").

${ }^{321} \mathrm{O}$ art. 105, I, "f”, da CF, prevê o cabimento de reclamação no âmbito do STJ, também para a preservação de sua competência e garantia da autoridade de suas decisões. V., sobre a evolução e os antecedentes históricos da reclamação, LuCON, Paulo Henrique dos Santos, Evolução da reclamação constitucional e seu emprego para assegurar a autoridade dos precedentes, artigo no prelo, 2011, pp. 2/5 e MARINONI, Luiz Guilherme e MITIDIERO, Daniel, Repercussão geral no recurso extraordinário, 2008, pp. 45/46.

${ }^{322}$ In MANCUSO, Rodolfo de Camargo, Súmula vinculante: perguntas e respostas, in Direito civil e processo - Estudos em homenagem ao Professor Arruda Alvim, 2007, p. 1.465. 
problemas práticos (...),323. Assim, imaginemos a primeira situação: o recurso de apelação é improvido, antes do julgamento da reclamação, e determina a manutenção da sentença por não reconhecer a ocorrência de violação a súmula vinculante. Nesse caso, a reclamação ficará prejudicada por perda do objeto, não porque a questão da súmula já foi apreciada, mas porque a reclamação versa sobre decisão que não mais subsiste no ordenamento - o acórdão do tribunal substitui a sentença de primeiro grau (art. 512, do CPC) ${ }^{324}$. Nada impede, porém, que a parte prejudicada mova nova reclamação, dessa vez questionando o acórdão.

Agora imaginemos a situação inversa: a reclamação é julgada improcedente, determinando-se a manutenção da sentença, por entender o STF que não ocorreu no caso sub judice violação a súmula vinculante. A rigor, ao julgar a apelação, o tribunal continua livre para decidir em um sentido ou em outro; porém, em tomando conhecimento da decisão da reclamação, é recomendável que acompanhe a decisão do STF, ainda que com ela não concorde - o tribunal pode até consignar isso expressamente no acórdão, explicando que se curva à decisão do STF em prol da unicidade de interpretação. Caso assim não o faça, o tribunal estará comprando uma batalha inglória, da qual fatalmente sairá vencido, pois a parte prejudicada poderá mover nova reclamação ao STF, que muito provavelmente será julgada nos mesmos termos da reclamação anterior.

Cumpre lembrar que o procedimento da reclamação comporta a concessão de liminar para a suspensão do processo ou do ato impugnado, para evitar dano irreparável (art. 14, II, da Lei no 8.038/1990 e art. 158, do RISTF).

Uma vez provido o recurso interposto ou julgada procedente a reclamação, tanto o texto constitucional quanto o texto da lei ordinária determinam que o ato administrativo seja anulado ou que a decisão judicial seja cassada, ordenando-se a prática

\footnotetext{
${ }^{323}$ In BARBOSA MoreIRA, José Carlos, A emenda constitucional no 45 e o processo, in Revista Forense, vol. 383, 2006, pp. 185/186.

${ }^{324} \mathrm{O}$ efeito substitutivo do recurso "faz com que a decisão do juízo ad quem, qualquer que seja ela, substitua a decisão recorrida. O efeito vem expressamente previsto pelo art. 512 do CPC, que prevê que 'o julgamento proferido pelo tribunal substituirá a sentença ou a decisão recorrida, no que tiver sido objeto de recurso'. Assim, ainda que a decisão do tribunal confirme a decisão recorrida sem nada alterar em sua essência, por esse efeito, uma vez julgado o recurso, não mais existirá a decisão recorrida, mas apenas a do tribunal." (in ARENHART, Sérgio Cruz e MARINONI, Luiz Guilherme, Curso de processo civil: processo de conhecimento, vol. 2, 2007, p. 526). V., amplamente sobre o assunto, CINTRA, Antonio Carlos de Araújo, Sobre os limites objetivos da apelação civil, Tese (Livre Docência), 1986, pp. 90/102.
} 
de outro ato ou a prolação de outra decisão, com ou sem a aplicação da súmula, conforme o caso. O art. 17, da Lei $\mathrm{n}^{\circ}$ 8.038/1990, vai no mesmo sentido ao dispor que, “julgando procedente a reclamação, o Tribunal cassará a decisão exorbitante de seu julgado ou determinará medida adequada à preservação de sua competência". Redação semelhante possui o art. 161, III, do RISTF ${ }^{325}$. Por óbvio, a não aplicação da súmula será possível em duas situações: se o STF optar por cancelar o seu enunciado; ou se o órgão julgador do recurso ou da reclamação entender que o caso sub judice não se encaixa na hipótese da súmula.

Aliás, aqui importa deixar claro que o juiz que não aplica a súmula vinculante por entender que o caso concreto não se subsume à hipótese por ela contemplada não se confunde com aquele que se recusa a aplicá-la por não concordar com o seu conteúdo, ou mesmo com a sua obrigatoriedade. Este - o magistrado "rebelde", de que já falamos - deve inclusive se sujeitar a penalidades administrativas, civis e penais, por ferir, conscientemente, regra cogente, a que está sujeito por disposição constitucional e legal. A hipótese parece tão grave quanto a do juiz de inferior instância que recebe uma ordem de tribunal que lhe é superior e deixa de lhe dar cumprimento ao argumento de que não concorda com o seu conteúdo ${ }^{326}$. Ainda que a Lei $n^{\circ} 11.417 / 2006$ tenha previsto tais sanções apenas para hipótese específica, direcionando-as à autoridade administrativa que mesmo depois de julgada procedente a reclamação pelo STF insiste em não adequar à súmula vinculante as futuras decisões administrativas em casos semelhantes (conforme art. 64-B, da Lei n 9.784/1999), parece possível, e recomendável, alargar o dispositivo para todos os casos em que o magistrado agir com dolo ou culpa ${ }^{327}$.

\footnotetext{
${ }^{325}$ Nos incisos I e II do art. 161, do RISTF, estão previstas, respectivamente, a possibilidade de, julgando procedente a reclamação, o Plenário ou a Turma avocar o conhecimento do processo em que se verifique usurpação de sua competência; ou ordenar que lhe sejam remetidos, com urgência, os autos do recurso para ele interposto.

${ }^{326}$ V., sustentando que nessa hipótese estará o magistrado agindo criminosamente, cometendo prevaricação, nos termos do art. 319, do CP, CARVALHO, Ivan Lira de, Decisões vinculantes, in Revista Forense, vol. 343, 1998, p. 527.

${ }^{327}$ V., em sentido semelhante ao nosso, MARINONI, Luiz Guilherme, Coisa julgada erga omnes e eficácia vinculante, disponível em <http://marinoni.adv.br>, acesso em 16/09/2011, p. 31 e SHIMURA, Sérgio, $A$ súmula vinculante como mecanismo de tutela coletiva, in Direito civil e processo - Estudos em homenagem ao Professor Arruda Alvim, 2007, p. 908. Mas o entendimento tem seus opositores. V., afirmando que não há qualquer sanção ao sujeito ou órgão jurisdicional que deixa de aplicar o enunciado, CARDOSO, Oscar Valente, Súmulas vinculantes e desvinculação da jurisprudência, in Revista Dialética de Direito Processual, $\mathrm{n}^{\mathrm{o}} 77$, 2009, p. 78, LimA, Ronaldo Cunha, Harmonizar a jurisprudência, in Revista da Procuradoria Geral do INSS, 1998, p. 11 e MANCUSO, Rodolfo de Camargo, Súmula vinculante: perguntas e respostas, in Direito civil e processo - Estudos em homenagem ao Professor Arruda Alvim, 2007, p. 1.463. Este último ainda lembra que o substitutivo $n^{\circ} 13$ à PEC no 96-A/1992 chegou a prever que "o descumprimento das decisões
} 
No mesmo sentido, também parece possível, e recomendável, aplicar-se multa por litigância de má-fé à parte que postula e recorre contra o enunciado de súmula vinculante, por aplicação analógica do art. 17, I, do CPC, o qual reputa litigante de má-fé aquele que deduzir pretensão ou defesa contra texto expresso de $1 \mathrm{ie}^{328}$. Entendimento em sentido contrário apenas incentivaria o desrespeito à súmula vinculante.

Uma importante questão a respeito da qual todos os textos que regulamentam a súmula vinculante silenciam é a do cabimento ou não de ação rescisória contra a decisão judicial transitada em julgado que contraria enunciado de súmula vinculante, nega-lhe vigência ou aplica-o indevidamente. Para nós a questão não é nem um pouco complexa e a resposta é positiva - ou seja, cabe ação rescisória contra decisão que viola súmula vinculante. Poder-se-ia argumentar que o rol do art. 485, do CPC, é taxativo e que, por não contemplar expressamente tal hipótese, incabível seria a propositura de ação rescisória. A verdade é que, ao contrário do que poderia parecer à primeira vista, o artigo efetivamente contempla a hipótese em apreço. Está ela prevista no inciso V, que reconhece a possibilidade de rescisão da sentença quando "violar literal disposição de lei".

Reconhecemos que a afirmação pode causar perplexidade nos mais conservadores. Não surtirá esse efeito, porém, se se partir da premissa de que a súmula vinculante age sobre a lei, ao conferir diretrizes sobre como interpretá-la, ou sobre em que medida considerá-la válida ou inválida, eficaz ou ineficaz, como dito acima. Nessa medida, a violação da súmula vinculante nada mais é do que a violação da própria lei.

Como já visto acima, com o intuito de regular o art. 485, V, do CPC, o Supremo Tribunal Federal editou, em sessão plenária de 13 de dezembro de 1963, súmula de jurisprudência predominante que recebeu o no 343 , no sentido de que "não cabe ação

sumuladas pelo STF e pelo STJ, por agente político ou por agente público, é motivo para a perda do cargo e responsabilização pelos danos patrimoniais provocados, decretação de indisponibilidade dos bens, sem prejuízo das demais sanções previstas em lei" (projetado § $5^{\circ}$ ao art. 111, da CF) (in idem, ibidem, p. 1.463).

${ }^{328} \mathrm{~V}$., muito antes da introdução da súmula vinculante, defendendo a imposição dos ônus da litigância de má-fé às partes que insistem em não se submeter à jurisprudência vencedora nos tribunais superiores, e, em especial, à Administração Pública, BUENo FILHO, Edgard Silveira, Os precedentes no direito brasileiro, in Revista dos Tribunais, vol. 716, 1995, p. 26. V., em sentido oposto, DIAS, Luiz Claudio Portinho, Recurso contra decisão em consonância com jurisprudência assente das Cortes Superiores: litigância de má-fé?, in Revista da Procuradoria Geral do INSS, ${ }^{\circ}$ 4, 1999, pp. 44/46. 
rescisória por ofensa a literal disposição de lei, quando a decisão rescindenda se tiver baseado em texto legal de interpretação controvertida nos tribunais". A contrario sensu, portanto, cabe ação rescisória por ofensa a literal disposição de lei, quando a decisão rescindenda se tiver baseado em texto legal de interpretação uniforme nos tribunais. Evidentemente, se há súmula vinculante a respeito da matéria, encontra-se ela devidamente uniformizada (a súmula vinculante, inclusive, é o meio mais eficaz de uniformizar entendimento, pois faz isso de forma cogente). Logo, cabe ação rescisória por desrespeito a súmula vinculante com fundamento no art. $485, \mathrm{~V}$, do $\mathrm{CPC}^{329}$.

Considere-se, ainda, que o art. $7^{\circ}$, da Lei $n^{\circ} 11.417 / 2006$, fala no cabimento de "outros meios admissiveis de impugnação" e a ação rescisória nada mais é do que um meio de impugnação. Esse artigo, aliás, nos remete ainda a outro assunto, que diz respeito à possibilidade ou não de se opor impugnação e embargos à execução - mais dois meios de impugnação previstos no CPC - com fundamento em súmula vinculante.

Novamente a resposta é positiva, pois os arts. 475-L, $\S 1^{\circ}$, e 741, par. único, do CPC, com a redação introduzida pela Lei $n^{\circ} 11.232$, de 22 de dezembro de 2005, preveem que, para efeito do disposto no inciso II do caput dos artigos (impugnação e embargos fundados na inexigibilidade do título), considera-se também inexigível o título judicial fundado em lei ou ato normativo declarados inconstitucionais pelo Supremo Tribunal Federal, ou fundado em aplicação ou interpretação da lei ou ato normativo tidas pelo Supremo Tribunal Federal como incompatíveis com a Constituição Federal. Por meio de súmula vinculante é impossível que o STF declare inconstitucional lei ou ato normativo, já que é previsto procedimento específico para esse fim; por outro lado, é perfeitamente possível que, por meio de súmula vinculante, o STF interprete lei ou ato normativo, à luz da Constituição. Logo, o cumprimento ou a execução da sentença judicial contrária a súmula vinculante poderão ser desafiados por impugnação ou embargos à execução fundados na inexigibilidade do título.

\footnotetext{
${ }^{329} \mathrm{~V}$., em sentido semelhante ao nosso, sustentando o cabimento de ação rescisória com fundamento no art. 485, V, do CPC, por considerar a súmula vinculante equiparável à literal disposição de lei, CiANCI, Mirna, Súmula vinculante. Os meios processuais de controle da vinculação (Lei 11.417/2006, art. $7^{\circ}$ ), in Direito civil e processo - Estudos em homenagem ao Professor Arruda Alvim, 2007, pp. 1.365/1.366. V., em sentido parecido, Medina, José Miguel Garcia, WAMBIER, Luiz Rodrigues e WAMBIER, Teresa Arruda Alvim, A súmula vinculante, vista como meio legítimo para diminuir a sobrecarga de trabalho dos tribunais brasileiros, in Revista do Advogado, no 92, 2007, pp. 19/20.
} 
Embora por meio do exercício acima seja possível chegar à conclusão de que são cabíveis ação rescisória, impugnação ao cumprimento de sentença e embargos à execução com fundamento em violação a súmula vinculante, melhor seria se o legislador tivesse regulado expressamente tais assuntos, evitando qualquer sorte de dúvida e consequente divergência de interpretação - que é justamente o que a súmula vinculante objetiva prevenir e remediar.

\subsubsection{Efeitos $e$ modulação dos efeitos}

Como já asseverado, a súmula vinculante, por sua própria natureza, surte efeitos vinculantes, em relação aos demais órgãos do Poder Judiciário e à administração pública direta e indireta, nas esferas federal, estadual e municipal ${ }^{330}$ (art. 103-A, caput, da $\mathrm{CF}$ ), como se lei fosse. Em regra, esses efeitos passam a surtir imediatamente, tão logo publicada a súmula vinculante no órgão oficial.

O Supremo Tribunal Federal, porém, novamente "por decisão de 2/3 (dois terços) dos seus membros, poderá restringir os efeitos vinculantes ou decidir que só tenha eficácia a partir de outro momento, tendo em vista razões de segurança jurídica ou de excepcional interesse público", conforme regra constante do art. $4^{\circ}$, da Lei n ${ }^{\circ}$ 11.417/2006.

Ao dispor que o STF poderá "restringir os efeitos vinculantes" da súmula, a regra está a se referir a restrição temporal, e não a restrição em relação aos sujeitos que a ela se subordinam - esses nunca mudam e são sempre aqueles referidos no caput do art. 103-A, da $\mathrm{CF}^{331}$. Nessa medida, é permitido ao STF, se "razões de segurança jurídica ou de excepcional interesse público" recomendarem, determinar que a súmula surta efeitos a partir de um momento determinado (à semelhança da vacatio legis), ou não abranja certas

\footnotetext{
330 Segundo DINAMARCO, "está mais que patente a intenção de inibir aos entes estatais as notórias e reiteradas condutas de invasão do patrimônio dos particulares com acintoso desrespeito aos precedentes dos mais variados tribunais do País" (in Dinamarco, Cândido Rangel, Decisões vinculantes, in Revista de Processo, $\mathrm{n}^{\mathrm{o}}$ 100, 2000, p. 168).

${ }^{331}$ V., em sentido oposto, sustentando que, "por razões de segurança jurídica ou de excepcional interesse público, pode ser restringida a eficácia vinculativa da súmula a pessoas ou regiões", com fundamento no art. $4^{\mathrm{o}}$, da Lei $\mathrm{n}^{\mathrm{o}}$ 11.417/2006, MedinA, José Miguel Garcia, WAMBIER, Luiz Rodrigues e WAMBIER, Teresa Arruda Alvim, A súmula vinculante, vista como meio legítimo para diminuir a sobrecarga de trabalho dos tribunais brasileiros, in Revista do Advogado, n 92, 2007, p. 17. V., nesse mesmo sentido, SHIMURA, Sérgio, A súmula vinculante como mecanismo de tutela coletiva, in Direito civil e processo - Estudos em homenagem ao Professor Arruda Alvim, 2007, p. 905.
} 
situações. Foi exatamente o que aconteceu, por exemplo, com relação à Súmula Vinculante $\mathrm{n}^{\circ} 8$ ("são inconstitucionais o parágrafo único do artigo $5^{\circ}$ do Decreto-lei $n^{\circ} 1.569 / 1977 e$ os artigos 45 e 46 da Lei $n^{o}$ 8.212/1991, que tratam de prescrição e decadência de crédito tributário"), a qual teve seus efeitos modulados, para ressalvar que os contribuintes não terão direito à restituição dos créditos pagos que passaram a ser considerados prescritos, exceto se a apresentação de seus requerimentos administrativos ou o ajuizamento de suas ações judiciais tenham sido feitos até a data do julgamento dos REs $n^{\circ}$ 556.664/RS, 559.882/RS, 559.943/RS e 560.626/RS ${ }^{332}$.

Essa concepção tem origem na Lei $n^{\circ}$ 9.868, de 10 de novembro de 1999, que dispõe sobre o processamento e julgamento da ação direta de inconstitucionalidade e da ação declaratória de constitucionalidade perante o Supremo Tribunal Federal, e na Lei $\mathrm{n}^{\mathrm{o}}$ 9.882, de 3 de dezembro de 1999, que disciplina a ação de descumprimento de preceito fundamental. Como já demonstrado acima, ambas possuem disposições bastante similares a essa regra, denominada de "modulação" ou "limitação temporal" dos efeitos da decisão.

A prática já foi alvo (e, a bem da verdade, ainda é) de bastante crítica por parte da comunidade jurídica, mas vem sendo reiteradamente aplicada pelo STF. A rigor, se o efeito vinculante da súmula equipara-se ao efeito vinculante das ações proferidas em ação direta de inconstitucionalidade, não há por que não se admitir tais efeitos prospectivos, ou a modulação dos efeitos, em relação à súmula vinculante, considerando ainda que, por conveniência social, pode ser essencial a limitação temporal dos efeitos da súmula, para não atingir situações jurídicas em curso, por exemplo ${ }^{333}$.

\subsubsection{Publicidade}

Nos termos do art. 354-G, do RISTF, a proposta de edição, revisão ou cancelamento de súmula tramitará sob a forma eletrônica, e as informações correspondentes ficarão disponíveis aos interessados no site do STF. Essa disposição já constava da Resol.-STF no 388/2008, cujo art. $4^{\circ}$ dispunha que "a proposta de edição,

\footnotetext{
${ }^{332}$ In CARDOSO, Oscar Valente, Súmulas vinculantes e desvinculação da jurisprudência, in Revista Dialética de Direito Processual, no 77, 2009, pp. 76/77.

${ }^{333}$ V., no mesmo sentido, CôRTES, Osmar Mendes Paixão, A experiência brasileira com a vinculação das decisões judiciais e a atual súmula vinculante introduzida pela EC 45/2004, in Direito civil e processo Estudos em homenagem ao Professor Arruda Alvim, 2007, p. 1.394.
} 
revisão ou cancelamento de súmula tramitará sob a forma eletrônica e as informações correspondentes ficarão disponíveis aos interessados no sítio do STF”. Apesar de a regra estar em vigor desde a data da publicação da referida Resolução, em 10 de dezembro de 2008, a ferramenta só foi efetivamente disponibilizada ao público em 6 de março de $2009^{334}$, o que demonstra um atraso de quase três meses pelo STF na implementação da medida, que ele próprio aprovou. Não obstante, a fórmula hoje funciona bem e é muito fácil localizar no site do tribunal página voltada às Propostas de Súmula Vinculante, embora a mesma não pareça ser atualizada com a frequência desejável ${ }^{335}$.

Também para conferir a devida publicidade, dessa vez ao enunciado final aprovado, o art. $2^{\circ}, \S 4^{\circ}$, da Lei $n^{\circ} 11.417 / 2006$, determina que no prazo de dez dias após a sessão em que editar, rever ou cancelar enunciado de súmula com efeito vinculante, o Supremo Tribunal Federal publique, em seção especial do Diário da Justiça e do Diário Oficial da União, o enunciado respectivo. Tais enunciados também constam do site do STF, em página de simples acesso ${ }^{336}$, facilitando ainda mais seu conhecimento por parte da comunidade jurídica.

E não basta que o próprio enunciado seja disponibilizado: o teor da proposta de súmula aprovada, que deve constar do acórdão, conterá cópia dos debates que lhe deram origem, integrando-o, e constarão das publicações dos julgamentos no DJ eletrônico (art. 354-F, do RISTF). A iniciativa merece aplausos pois indiretamente destaca a necessidade de que seja feito o exame cuidadoso de todos os debates que deram ensejo à edição da súmula vinculante, antes de se cogitar da sua aplicação. Na medida em que não é uma fórmula matemática, a súmula vinculante não prescinde da realização de atividade hermenêutica e o histórico dos debates serve justamente para auxiliar o intérprete nesse exercício $^{337}$.

\footnotetext{
${ }^{334}$ Conforme notícia disponível em <http://www.stf.jus.br/portal/cms/verNoticiaDetalhe.asp?idConteudo= 104123>, acesso em 29/09/2011.

335 Em consulta à referida página (<http://www.stf.jus.br/portal/cms/verTexto.asp?servico=jurisprudencia PropostaSumulaVinculante >) em 29/09/2011, fomos surpreendidos com mensagem que dizia que a última atualização havia sido feita há quase um mês, em 30/08/2011, às 14:06:42.

336 Conforme o seguinte endereço eletrônico: <http://www.stf.jus.br/portal/cms/verTexto.asp?servico= jurisprudenciaSumulaVinculante>, acesso em 29/09/2011.

${ }^{337}$ MANCuSO faz afirmação no mesmo sentido, mas ressalva, com razão, que a interpretação da súmula vinculante não pode ter o mesmo elastério da interpretação da lei, porque ela já constitui o extrato de reiterados julgamentos do STF sobre uma dada matéria, tendo o tema sido exaustivamente debatido, até se alcançar um consenso estratificado (in MANCUSO, Rodolfo de Camargo, Súmula vinculante: perguntas $e$
} 
Diante de tudo o quanto exposto, somos favoráveis ao mecanismo da súmula vinculante, introduzido pela $\mathrm{EC} \mathrm{n}^{\circ}$ 45/2004. Como já se disse no início deste trabalho, a uniformização da jurisprudência é medida de rigor para garantir maior isonomia entre os jurisdicionados, maior segurança jurídica e, incidentalmente, maior celeridade ao trâmite dos processos. A súmula vinculante é capaz de proporcionar isso tudo, na medida em que uniformiza, à força e de maneira obrigatória, o entendimento sobre a norma a que diz respeito, a propósito de sua validade, interpretação ou eficácia.

O que nos preocupa é que a matéria vem tratada de forma um pouco difusa, porquanto espalhada por seis diplomas diferentes (CF, EC n ${ }^{\circ}$ 45/2004, Lei $n^{\circ} 11.417 / 2006$, RISTF, Resol.-STF n 381/2008 e Resol.-STF n 388/2008), o que está longe do ideal, ainda mais para um instituto tão recente. Nessa medida, o legislador deve redobrar a atenção sempre que for complementar ou alterar qualquer norma que lhe diga respeito, de forma a manter a harmonia entre todas elas. Da mesma forma, os operadores do direito devem estar atentos a todos os diplomas, para aplicarem o instituto corretamente, compreendendo-o em todas as suas facetas.

respostas, in Direito civil e processo - Estudos em homenagem ao Professor Arruda Alvim, 2007, p. 1.464). V., afirmando que "evidentemente, as súmulas, passando a ter efeito vinculante, devem passar a ser elaboradas com muito mais critério e de forma a não gerar, na medida do possível, problemas interpretativos mais complexos do que gerados pela própria norma constitucional de que derivam", reconhecendo, portanto, que a súmula vinculante também deve, no geral, ser interpretada, MEDINA, José Miguel Garcia, WAMBIER, Luiz Rodrigues e WAMBIER, Teresa Arruda Alvim, A súmula vinculante, vista como meio legítimo para diminuir a sobrecarga de trabalho dos tribunais brasileiros, in Revista do Advogado, no 92, 2007, p. 10. V., ainda no mesmo sentido, SHIMURA, Sérgio, A súmula vinculante como mecanismo de tutela coletiva, in Direito civil e processo - Estudos em homenagem ao Professor Arruda Alvim, 2007, p. 903 e STRECK, Lenio Luiz, O efeito vinculante das súmulas e o mito da efetividade: uma crítica hermenêutica, in Revista do Instituto de Hermenêutica Jurídica, vol. 1, no 3, 2005, p. 94. LEAL, idealizador das súmulas da jurisprudência predominante, prevê solução drástica para evitar a indesejável interpretação das súmulas: "Cuidando ainda da Súmula como método de trabalho - aspecto em relação ao qual seria até indiferente o conteúdo dos seus enunciados - é oportuno mencionar que estes não devem ser interpretados, isto é, esclarecidos quanto ao seu correto significado. O que se interpreta é a norma da lei ou do regulamento, e a Súmula é o resultado dessa interpretação, realizada pelo Supremo Tribunal. A Súmula deve, pois, ser redigida tanto quanto possível com a maior clareza, sem qualquer dubilidade [dubiedade], para que não falhe ao seu papel de expressar a inteligência dada pelo Tribunal. Por isso mesmo, sempre que seja necessário esclarecer algum dos enunciados da Súmula, deve ser ele cancelado, como se fosse objeto de alteração, inscrevendo-se o seu novo texto na Súmula com outro número." (in LEAL, Victor Nunes, Passado e futuro da súmula do STF, in Revista de Direito Administrativo, no 145, 1981, p. 11). Mas constata que "nem sempre - a nosso ver, infelizmente - tem sido essa prática seguida no Supremo Tribunal. Mais de uma vez. tem havido interpretação de súmula, com acréscimo ou supressão de palavras, conservando-se o mesmo número." (in idem, ibidem, p. 12). 
Além disso, percebe-se que essas normas que regulam a súmula vinculante são omissas sobre questões importantes. Chama-se a atenção especialmente para a punição daqueles que deliberadamente violarem os enunciados de súmula vinculante, bem como para o cabimento de ação rescisória contra a decisão judicial transitada em julgado que não a aplicar quando deveria, ou que a aplicar mal. Já demonstramos acima que tanto a punição - do magistrado "rebelde" e da parte litigante de má-fé - quanto a rescisória são perfeitamente cabíveis, com fundamento em regras que hoje constam do ordenamento jurídico. Todavia, para evitar interpretações em sentido diverso, seria de todo recomendável que o legislador disciplinasse esses dois aspectos de maneira expressa.

Evidentemente, para se tornarem efetivas, não basta que as regras estejam disciplinadas expressamente no texto legal. Exige-se, acima de tudo, uma tomada de consciência por parte da comunidade jurídica, principalmente pelos magistrados, a quem cumpre zelar pelo ordenamento e dar um bom exemplo aos demais. Deve-se evitar, a todo custo, o que ocorreu, por exemplo, com relação ao requisito da existência de repetidas decisões anteriores sobre a norma objeto da súmula, previsto claramente no art. 103-A, caput, do $\mathrm{CF}$, o qual foi sumariamente ignorado por ocasião da edição da Súmula Vinculante $\mathrm{n}^{\mathrm{o}} 11$ - e, possivelmente, por ocasião da edição de outras ${ }^{338}$.

Aliás, a esse propósito, é importante que o STF obedeça a esse requisito de forma bastante criteriosa, e não somente para cumprir formalmente o texto constitucional, apenas para que depois não se cogite de vício na elaboração da súmula vinculante. Com efeito, a Constituição Federal fala em "reiteradas decisões", o que não deixa de ser um critério bastante subjetivo. Duas, três, quatro decisões a rigor são reiteradas decisões, mas esses números ainda parecem baixos para estampar um entendimento efetivamente debatido e consolidado, que é o que no fundo a Constituição exige. Nesse sentido, muito mais do que se preocupar com o alcance de um número qualquer de decisões na mesma direção, o STF deve cuidar de examinar o entendimento que se pretende sumular de forma pormenorizada, com vistas a verificar se ele reflete posicionamento devidamente

\footnotetext{
${ }^{338}$ V., de forma semelhante, criticando a frustrante falta de cautela e zelo do Supremo Tribunal Federal na edição das Súmulas Vinculantes n ${ }^{\circ} 2$ e 3, VILARDI, Iara Ferfoglia Gomes Dias, Súmula vinculante: razões e conseqüências de sua implementação no sistema de direito brasileiro, Dissertação (Mestrado), 2008, pp. $143 / 169$.
} 
consolidado, recomendando que passe a surtir efeitos vinculantes a partir de então. Para tanto, não basta que a maioria qualificada do tribunal, ou mesmo a unanimidade dos membros que o compõem, tenha votado favoravelmente à edição da súmula; é necessário que o entendimento tenha sido também maturado com o tempo. Para tanto, impossível fugir do requisito da existência de reiteradas decisões sobre a matéria.

Também é importante ressaltar que o STF deve zelar para que seja observado estritamente o procedimento previsto no RISTF, ainda que por vezes se sinta tentado a saltar alguma etapa, com vistas a acelerar o trâmite das coisas ou a desburocratizar o processo de edição da súmula vinculante. Regras existem para serem cumpridas, de modo que todas as formalidades devem ser seguidas à risca, para que depois não se suscite a nulidade da súmula pela ocorrência de vício formal na sua elaboração.

O mesmo se diga quanto aos procedimentos de revisão e cancelamento das súmulas vinculantes, que devem ser estimulados e devidamente observados sempre que se verificar a alteração dos fatores que ensejaram a formação dos enunciados.

Apesar das críticas acima, um aspecto em especial deve ser objeto de adulação, a saber, a previsão constante do art. 354-F, do RISTF, no sentido de que o teor da proposta de súmula aprovada, que deve constar do acórdão, conterá cópia dos debates que lhe deram origem, integrando-o, e constarão das publicações dos julgamentos no DJ eletrônico. Como já adiantado acima, a iniciativa é merecedora de aplausos pois ressalta que, além da leitura do enunciado, deve ser feita também a leitura dos debates que culminaram na edição do enunciado, para que se chegue ao seu verdadeiro sentido e se identifique os seus motivos determinantes. Infelizmente, a leitura apenas das súmulas, e por vezes somente das ementas dos acórdãos, é prática que se arraigou na nossa cultura e que deve ser combatida.

\subsubsection{Respostas às críticas}

Apesar de ser capaz de garantir maior isonomia, maior segurança jurídica e diminuição do tempo do litígio, na medida em que uniformiza o entendimento sobre determinada norma de forma cogente e obrigatória, a súmula vinculante não está livre de censura. Pelo contrário, ainda são muitos os opositores ao instituto. Basicamente, as 
críticas feitas são três: engessamento da jurisprudência; quebra da independência e da liberdade hermenêutica dos juízes; e pouco valor prático no desafogamento dos tribunais superiores $^{339}$.

Quanto ao primeiro argumento, referente ao suposto engessamento da jurisprudência, é ele absolutamente falacioso. A experiência anglo-saxônica está aí para mostrar que a jurisprudência vinculante não engessa o ordenamento, tampouco impede a sua evolução ${ }^{340}$. Enquanto naquele ordenamento se aplica o método de overruling, no sistema jurídico brasileiro são previstas válvulas de escape que permitem a revisão e o cancelamento da súmula vinculante, devendo, para tanto, ser observado o mesmo procedimento que é seguido para a sua edição, exigindo-se igualmente quórum de dois terços dos membros do tribunal.

BARBosa MoreIRA diz que "as incessantes mutações da sociedade são captadas mais depressa e mais intensamente pelos órgãos judiciais de nível inferior, convocados a lidar antes dos outros com os conflitos de interesses que as novas condições sociais, políticas, econômicas e culturais vão desenhando" ${ }^{341}$. Essa particularidade não é ignorada pelo sistema da súmula vinculante, pois até mesmo os Tribunais de Justiça de Estados ou do Distrito Federal e Territórios, os Tribunais Regionais Federais, os Tribunais

\footnotetext{
${ }^{339}$ In LIMA, Ronaldo Cunha, Harmonizar a jurisprudência, in Revista da Procuradoria Geral do INSS, 1998, p. 10. Há quem suscite críticas mais profundas, como é o caso de LEAL, para quem a eficácia vinculante não é compatível com o sistema constitucional vigente, por supostamente violar os seguintes preceitos constitucionais: princípio do estado de direito; princípio democrático; princípio da separação dos poderes; princípio da independência judicial; princípio da legalidade e da reserva legal; princípio do pluralismo político; princípio do acesso à justiça; princípio do devido processo legal; dever de motivar as decisões judiciais; garantia do contraditório e da ampla defesa; e princípio federativo (in LEAL, Pastora do Socorro Teixeira, A vinculação da interpretação judicial: aspectos constitucionais, in Revista de Direito Constitucional e Internacional, no 43, 2003, pp. 267/268).

${ }^{340}$ Nas palavras de CAMBI, "exemplo típico desse fenômeno é o que ocorreu nos Estados Unidos, cuja Constituição vigora desde 1787, mas já foi interpretada pela Suprema Corte de maneiras diferentes, conforme as circunstâncias históricas, culturais, políticas, sociais e econômicas; com relação à segregação racial, por exemplo, a posição da jurisprudência modificou-se, pelo menos, três vezes: i) em 1857, em Dred Scott v. Sandford, a Suprema Corte afirmou que os escravos não poderiam ser considerados cidadãos norteamericanos, sendo tutelados, constitucionalmente, pelo direito de propriedade; ii) em 1896, em Plessy v. Ferguson, consolidou-se a doutrina do Separate but Equal (isto é, não havia violação da Constituição desde que os Estados tratassem igualmente brancos e negros, o que, na prática, significava que deveria haver, v.g., um ônibus distinto para transportar cada uma das raças); iii) em 1954, em Brown v. Board of Education, iniciou-se o final da aplicação da doutrina do Separate but Equal, quando se considerou que ela não poderia ter aplicação nas escolas públicas." (in CAMBI, Eduardo, Jurisprudência lotérica, in Revista dos Tribunais, vol. 786, 2001, pp. 119/120).

${ }^{341}$ In BARBosA MoReIRA, José Carlos, Súmula, jurisprudência, precedente: uma escalada e seus riscos, in Revista Síntese de Direito Civil e Processual Civil, no 35, 2005, p. 14.
} 
Regionais do Trabalho, os Tribunais Regionais Eleitorais e os Tribunais Militares, por conta da disposição constante do art. $3^{\circ}$, XI, da Lei $n^{\circ} 11.417 / 2006$, podem propor a revisão e o cancelamento de enunciados com eficácia vinculante.

No que se refere ao segundo argumento, quanto à suposta quebra da independência e da liberdade hermenêutica dos juízes, antes de mais nada há que se ressaltar que o princípio do livre convencimento motivado e da persuasão racional (art. 131, do CPC) diz muito mais com os fatos e com as provas da demanda, do que com o direito em si. Assim, na medida em que as súmulas vinculantes versam somente sobre questões de direito, não se retira do juiz a liberdade de exame das questões de fato, que envolvem a análise e a valoração das provas, tampouco a formulação do juízo de adequação da aplicabilidade ou não da súmula ao caso $s u b$ judice $e^{342}$. A propósito desse último aspecto, o magistrado deve averiguar com calma se o caso em análise se enquadra na hipótese da súmula; se entender que a ratio decidendi de um e de outro são diferentes, deve descartar a sua utilização para aquele caso concreto, como feito pelos ingleses mediante o método de distinguishing.

Ainda que assim não fosse, já demonstramos que o magistrado integra uma estrutura única, harmônica, e em prol dessa unicidade de entendimento deve sacrificar suas convicções pessoais. Nesse sentido, fazemos coro à lição de PARENTE: "Se isso resvala na livre convicção individual, são opções do sistema que, por óbvio, em muitos momentos, devem prescindir de algumas alternativas em favor de outras. Esse é um modo de ver o fenômeno processual de cima para baixo, mediante interpretações finais e obrigatórias dos Tribunais Superiores. A atuação destes redunda em benefício para o Estado, o litigante e a comunidade no geral, eliminando, na medida do possível, a insegurança (e o arbítrio) decorrente de entendimentos livres, diferenciados e conflitantes. Definir um entendimento em sua abstração e generalidade para preservar a eficácia do legislado (ou do direito como um todo) e obrigar tanto quanto a lei, em termos de expectativas socialmente compartilhadas, sobrepõe-se ao interesse subjetivo dos contendores e à liberdade interpretativa do juiz",343.

\footnotetext{
${ }^{342}$ V., no mesmo sentido, CAMBI, Eduardo, Jurisprudência lotérica, in Revista dos Tribunais, vol. 786, 2001, p. 114, PARENTE, Eduardo de Albuquerque, Jurisprudência: da divergência à uniformização, 2006, pp. 43/44 e SHIMURA, Sérgio, A súmula vinculante como mecanismo de tutela coletiva, in Direito civil e processo Estudos em homenagem ao Professor Arruda Alvim, 2007, p. 903.

${ }^{343}$ In PARENTE, Eduardo de Albuquerque, Jurisprudência: da divergência à uniformização, 2006, p. 43.
} 
A propósito do assunto, é ainda curiosa (e verdadeira) a observação de MARINONI, conferida com supedâneo na lição de CAPPELLETTI, no sentido de que, "de forma acrítica, ao mesmo tempo em que se vê na obrigatoriedade dos precedentes um atentado contra a liberdade do juiz, celebra-se o duplo grau de jurisdição como garantia de justiça. Os juízes pensam que exercem poder quando julgam como desejam, mas não percebem que não têm poder para decidir (sozinhos) sequer uma ação de despejo fundada em falta de pagamento ou uma ação ressarcitória derivada de acidente de trânsito, e, além disto, que as suas sentenças, em regra, não interferem na vida dos litigantes." ${ }^{344}$.

Quanto ao terceiro argumento, a respeito do pouco valor prático que a súmula vinculante traz para o desafogamento dos tribunais superiores, fazemos menção ao quanto já exposto no item "1.3.2" acima. Em suma, ainda que o instituto não seja capaz de solucionar todas as mazelas que atrasam a solução dos litígios e que não possibilite o alcance da almejada duração razoável do processo, é inegável que ao menos um pouco ele tende a contribuir para a aceleração do trâmite processual, em todas as instâncias ${ }^{345}$. Além do que, mesmo que não haja diminuição do tempo dos processos, a certeza jurídica que a súmula vinculante proporciona já vale o investimento ${ }^{346}$.

\subsection{Eficácia quase vinculante}

\subsubsection{Conceito}

A eficácia quase vinculante é intermediária, localizada entre os dois extremos formados pela eficácia vinculante e pela eficácia persuasiva. Ao contrário desta, ela vincula, é obrigatória; mas nem sempre, como aquela - somente em determinadas situações, para determinados fins. É por isso que se fala em eficácia quase vinculante: ela vincula, mas com restrições.

\footnotetext{
${ }^{344}$ In MARINONI, Luiz Guilherme, Os precedentes na dimensão da segurança jurídica, disponível em <http:// marinoni.adv.br>, acesso em 16/09/2011, p. 12.

${ }^{345}$ V., no mesmo sentido, MEdina, José Miguel Garcia, WAMBIER, Luiz Rodrigues e WAMBIER, Teresa Arruda Alvim, A súmula vinculante, vista como meio legítimo para diminuir a sobrecarga de trabalho dos tribunais brasileiros, in Revista do Advogado, $\mathrm{n}^{\circ}$ 92, 2007, p. 8 e RosAS, Roberto, Da súmula à súmula vinculante, in Revista dos Tribunais, vol. 879, 2009, p. 47.

${ }^{346}$ In PARENTE, Eduardo de Albuquerque, Jurisprudência: da divergência à uniformização, 2006, p. 28.
} 
Em outras palavras, pode-se dizer que o precedente quase vinculante é o precedente de eficácia persuasiva que, em determinadas situações, e para determinados fins, assume eficácia vinculante. Por exemplo: as súmulas da jurisprudência predominante do STJ, em regra, possuem eficácia meramente persuasiva; no caso de recurso cuja tese jurídica as viole, porém, elas assumem eficácia vinculante, para autorizar o relator a obstar o seguimento do recurso (art. 557, caput, do CPC). Da mesma maneira, a jurisprudência dominante do STF, em regra, possui eficácia persuasiva; mas na hipótese de decisão recorrida contrária a ela, ela assume eficácia vinculante, para autorizar o relator a dar monocraticamente provimento ao recurso (art. 557, $\S 1^{\circ}$, do CPC), e assim por diante.

Mesmo quando persuasiva assumindo a força de vinculante, essa eficácia é bastante restrita, pois não extrapola em nenhuma medida o fim específico para o qual prevista. Por exemplo, na hipótese do art. 557, $\S 1^{\circ}$, do CPC, vista acima, caso o relator não faça uso de sua prerrogativa de dar monocraticamente provimento ao recurso e mandeo à mesa, não estará o colegiado obrigado a dar provimento ao recurso com fundamento na jurisprudência dominante aplicável ao caso. Isso porque, para o colegiado, a jurisprudência dominante surtirá, normalmente, efeitos meramente persuasivos. A parte prejudicada até poderá recorrer contra a decisão de mérito do colegiado; mas não poderá alegar que por ele foi violado o art. 557, $\S 1^{\circ}$, do $\mathrm{CPC}$, ou desrespeitada jurisprudência dominante de observância supostamente obrigatória.

Diferentemente da eficácia persuasiva e vinculante, que são amplamente reconhecidas e corriqueiramente referidas pela doutrina, a eficácia quase vinculante é conceito novo que consideramos apropriado para fazer referência a fenômeno também relativamente recente, que vem permeando nosso direito processual civil. A ideia será desenvolvida mais adiante, ao tratarmos da ampliação dos poderes do relator e do juiz de primeiro grau, e de outras situações pontuais previstas em nossa legislação.

O conceito pode gerar surpresa à primeira vista, mas não é de todo estranho. TARUFFO, em sua teoria do precedente (que aborda o assunto sob quatro aspectos, ou dimensões, quais sejam, institucional, objetiva, estrutural e da eficácia), já previa cinco diferentes graus de eficácia. No grau máximo, estaria a obrigação absoluta de seguir o precedente, que assumiria eficácia vinculante para todos os casos sucessivos e análogos. 
Nos graus intermediários, estariam as seguintes eficácias, em escala descendente: binding, em que o precedente deve ser seguido, salvo exceções expressamente previstas; defeasibily binding, em que o precedente deve ser seguido, a não ser que haja boas razões para não fazê-lo, o que obrigaria o juiz a justificar a sua escolha; e weakly binding, em que se espera, genericamente, que o precedente seja seguido. Por último, no grau inferior, estaria a situação em que o juiz é completamente livre para seguir ou não o precedente, não possuindo qualquer vinculação em relação à decisão anterior, tampouco a obrigação de justificar sua opção caso escolha afastar-se dela ${ }^{347}$.

\subsubsection{Ampliação dos poderes do relator}

No limiar da década de 1990, teve início movimento, que se estende até hoje, no sentido de ampliar os poderes do relator - tanto o desembargador de tribunal, quanto o ministro de tribunal superior - e dos magistrados em geral ${ }^{348}$. As alterações introduzidas na legislação processual com o intuito de criar o precedente judicial quase vinculante inserem-se justamente nesse contexto, ao permitirem ao relator que julgue recursos monocraticamente, sem submetê-los ao crivo do colegiado ${ }^{349}$.

É certo que o sistema processual sempre conviveu com decisões monocráticas dos relatores. Basta imaginar, por exemplo, as liminares concedidas por decisão singular em recursos ou ações originárias de competência dos tribunais. Nos últimos tempos, porém, principalmente em função da grande quantidade de recursos pendentes de julgamento e da morosidade do Judiciário ${ }^{350}$, passou-se a admitir decisões

\footnotetext{
${ }^{347}$ V., abordando a teoria de TARUFFO, sob o aspecto da "dimensão da eficácia”, LOPES, Raquel Cardoso, Uniformização da jurisprudência, in Revista Forense, vol. 390, 2007, pp. 572/573.

${ }^{348}$ V., amplamente sobre o assunto, TEIXEIRA, Guilherme Silveira, A ampliação dos poderes do juiz nas recentes reformas processuais e a necessidade de equilíbrio entre segurança e efetividade do processo, Dissertação (Mestrado), 2006, entre outros.

${ }^{349}$ Conforme DINAMARCO: "O notório e angustiante congestionamento do Poder Judiciário vem conduzindo o processo civil brasileiro por tentativas e caminhos novos que incluem o reforço dos poderes do relator, em associação com meios e modos de valorizar os precedentes judiciários consolidados." (in DINAMARCO, Cândido Rangel, $O$ relator, a jurisprudência e os recursos, in Aspectos polêmicos e atuais dos recursos cíveis de acordo com a Lei $n^{\circ} 9.756 / 98,1999$, p. 128). É nesse contexto que "uma decisão singular, proferida em Gabinete, substitui, quando a lei ou o regimento autorizam, os complicados e lentos processamentos perante câmaras, grupos, turmas etc." (in idem, ibidem, p. 129).

${ }^{350}$ Nos dizeres de CARNEIRO, “a 'ampliação dos poderes do relator' parte inclusive de uma constatação prática: na grande maioria das vezes, o voto do relator revela-se como condutor do colegiado, em solução de consenso" (in CARNEIRO, Athos Gusmão, Poderes do relator e agravo interno - artigos 557, 544 e 545 do CPC, in Revista Síntese de Direito Civil e Processo Civil, nº 6, 2000, p. 26).
} 
exclusivas do relator, sem qualquer interferência do revisor ou do terceiro julgador, não apenas sobre questões preliminares ou incidentais, mas para o próprio julgamento do recurso $^{351}$. Nas palavras de RODRIGUES, "flagrante, pois, a mitigação do princípio que se convencionou rotular de 'colegialidade das decisões' que, como é sabido, se insere na garantia fundamental do duplo grau de jurisdição, pois, inerente a esta garantia sempre esteve ligada a idéia de um direito ao julgamento por órgão fracionário, é bem verdade, mas, na forma de um Colegiado" 352.

O Supremo Tribunal Federal foi o pioneiro nesse movimento, tendo o seu regimento interno, em 1963, sob a liderança histórica do Min. ViCTOR NunES LEAL, passado a contemplar na competência do relator o poder de "mandar arquivar o recurso extraordinário ou o agravo de instrumento indicando o correspectivo número de Súmula" (art. 15, IV) ${ }^{353}$. A técnica foi buscada para o "notório, antigo e angustiante problema da sobrecarga da Corte Suprema brasileira, que já fora objeto de preocupações de Alfredo Buzaid na década dos anos cinqüenta",354.

Em 1951, ao cuidar da evolução histórica dos recursos, COUTURE já escrevia que "la tendencia de nuestro tiempo es la de aumentar los poderes de lo juez y disminuír el número de recursos: es el triunfo de una justicia pronta y firme sobre la necesidad de una justicia buena pero lenta" ${ }^{355}$. Assim, como caracterizado o nosso direito processual, ao relator reservam-se especialmente os processos com teses jurídicas já reiteradamente decididas pela corte, valorizando-se os precedentes judiciais; às pautas reservam-se os casos ainda não solucionados pelos tribunais, ou já solucionados mas ainda sem entendimento consolidado, e as ações de competência originária.

\footnotetext{
${ }^{351}$ V., nesse sentido, CARNEIRO, Athos Gusmão, Poderes do relator e agravo interno - artigos 557, 544 e 545 do CPC, in Revista Síntese de Direito Civil e Processo Civil, n ${ }^{\circ}$ 6, 2000, pp. 5/6 e Dellore, Luiz Guilherme Pennacchi, Evolução do controle de constitucionalidade das leis: rumo ao controle concentrado?, Dissertação (Mestrado), 2007, pp. 104/105.

${ }^{352}$ In RODRIGUES, Walter Piva, O princípio da colegialidade das decisões nos tribunais, in Revista Dialética de Direito Processual, $\mathrm{n}^{\circ}$ 1, 2003, p. 177.

353 In DinAMARCO, Cândido Rangel, O relator, a jurisprudência e os recursos, in Aspectos polêmicos e atuais dos recursos cíveis de acordo com a Lei $n^{\circ}$ 9.756/98, 1999, p. 129.

354 In DINAMARCO, Cândido Rangel, O relator, a jurisprudência e os recursos, in Aspectos polêmicos e atuais dos recursos cíveis de acordo com a Lei $n^{\circ}$ 9.756/98, 1999, p. 129.

${ }^{355}$ In COUTURE, Eduardo Juan, Fundamentos de derecho procesal, 1951, p. 248.
} 
Em 28 de maio de 1990 foi editada a Lei no 8.038, denominada de "Lei dos Recursos", instituindo normas procedimentais para determinados processos perante o Supremo Tribunal Federal e o Superior Tribunal de Justiça. Do art. 38 respectivo constou que "o Relator, no Supremo Tribunal Federal ou no Superior Tribunal de Justiça, decidirá o pedido ou o recurso que haja perdido seu objeto, bem como negará seguimento a pedido ou recurso manifestamente intempestivo, incabível ou, improcedente ou ainda, que contrariar, nas questões predominantemente de direito, Súmula do respectivo Tribunal".

A parte do dispositivo que nos interessa é a final, que trouxe para o plano legal uma espécie de "súmula impeditiva de recurso"356.

Como já visto, as súmulas (da jurisprudência dominante) foram criadas no âmbito do STF em 1963, por meio da edição de Emenda Regimental. Posteriormente estendidas para os demais tribunais do país, consistem em enunciados que resumem as teses jurídicas dominantes nos tribunais. Nessa qualidade, funcionam como precedentes de uniformização de jurisprudência e, a não ser que sejam observados os requisitos e o procedimento constantes do atual art. 103-A, da CF, possuem eficácia meramente persuasiva.

Na esteira do que já dispunha regra regimental, a Lei nº 8.038/1990 atribuiu às súmulas do STF e do STJ uma eficácia a mais, um plus, para autorizar (ou obrigar?) o relator a impedir o seguimento de pedidos e recursos, no âmbito do STF e do STJ, respectivamente, contrários aos seus enunciados. A aparente imperatividade da norma exsurge do termo utilizado pelo legislador: "o Relator (...) negará seguimento" (destaque nosso), ao invés de "o Relator (...) poderá negar seguimento". Esse aspecto será abordado de forma pormenorizada adiante, no item "4.3.2.5".

\footnotetext{
${ }^{356}$ Embora a "súmula impeditiva de recurso" propriamente dita seja aquela prevista no art. $518, \S 1^{\circ}$, do CPC, nos parece que é possível estender o conceito para todas as demais hipóteses legais em que a existência de súmula em conformidade com a decisão recorrida, ou em contrariedade com a tese jurídica sustentada no recurso, é capaz de abreviar o seu curso natural.
} 
Diz-se que a eficácia é quase vinculante, e não vinculante, pois neste caso a súmula vincula para fim específico, qual seja, obstar o seguimento de pedidos e recursos contrários a seus enunciados, e não de forma ampla e geral como a súmula prevista no art. 103-A, da CF. Na realidade, a súmula aqui tratada é aquela "comum", de eficácia persuasiva. Uma vez posta a situação prevista no art. 38, da Lei $n^{0}$ 8.038/1990, porém, ela assume nova feição, adquirindo uma força a mais para permitir a negativa de seguimento a pedidos e recursos contrários a seus postulados.

Apesar de norma regimental anterior ter autorizado o relator a arquivar recurso extraordinário ou agravo de instrumento com fundamento em súmula do STF, pode-se dizer que o artigo em referência inaugurou uma verdadeira revolução no sistema processual, pois, de maneira despretensiosa e sorrateira, atribuiu por meio de lei ordinária eficácia quase vinculante a todas as súmulas do STF e do STJ, cada qual no âmbito do próprio tribunal, não para torná-las de observância obrigatória pelas instâncias inferiores, mas para permitir a negativa de seguimento a pedidos e recursos perante os ditos tribunais superiores se contrários a seus enunciados.

A Lei $n^{\circ} 8.038 / 1990$ acabou por criar uma segunda espécie de súmula, não para se colocar ao lado da súmula da jurisprudência predominante, mas para substituí-la em determinadas situações. Trata-se quase de um modelo misto, híbrido, mais que persuasivo e menos que vinculante: a súmula não é vinculante o suficiente para se tornar de respeito obrigatório pelo relator e pelo colegiado, mas é vinculante o bastante para autorizar a negativa de seguimento, por decisão monocrática do relator, a pedidos ou recursos que a contrariem. É, portanto, quase vinculante.

De forma geral, entendemos que as alterações trazidas pelo art. 38, da Lei $n^{\circ}$ 8.038/1990, foram positivas para o ordenamento. Ainda que não tenham eficácia vinculante na forma do atual art. 103-A, da CF, as súmulas de jurisprudência do STF e do STJ devem mais que guiar e orientar decisões de maneira meramente persuasiva. Assim, nos parece bastante correta a iniciativa de autorizar seja obstado o seguimento de pedidos e recursos perante o STF e o STJ que contrariem os enunciados de súmulas dos respectivos tribunais. 
O legislador deveria até ter ousado mais, como posteriormente fez o legislador de 1998, autorizando o relator também a dar provimento a recurso interposto contra decisão contrária a súmula dos respectivos tribunais - a bem da verdade, do nosso ponto de vista, deveria até ter dado outro passo além, atribuindo eficácia vinculante a todas as súmulas do STF e do STJ, e dos demais tribunais superiores, mas isso já foi dito. Já que não foi essa a opção, a hipótese do art. 38, da Lei $n^{\circ}$ 8.038/1990, representa no geral alternativa satisfatória, até porque deixa traço da reverência que se deve prestar às súmulas do STF e do STJ.

\subsubsection{Art. 557, caput $e \S 1^{\circ}$, do CPC}

Por meio da Lei $\mathrm{n}^{\mathrm{o}}$ 9.756, de 17 de dezembro de $1998^{357}$, foi alterada a redação do art. 557, caput, do CPC, para constar que "o relator negará seguimento a recurso manifestamente inadmissível, improcedente, prejudicado ou em confronto com súmula ou com jurisprudência dominante do respectivo tribunal, do Supremo Tribunal Federal, ou de Tribunal Superior". A lei ainda previu o $\S 1^{\circ}$-A, para autorizar o relator a dar provimento ao recurso, "se a decisão recorrida estiver em manifesto confronto com súmula ou com jurisprudência dominante do Supremo Tribunal Federal, ou de Tribunal Superior".

Da simples análise dos dispositivos acima, verifica-se que o legislador seguiu o caminho inaugurado pelo art. 38, da Lei $\mathrm{n}^{\circ}$ 8.038/1990, abordado anteriormente, ampliando o alcance da súmula impeditiva de recurso e criando outro instituto semelhante a ela.

A propósito da redação do caput do artigo, três pontos essencialmente nos chamam a atenção. O primeiro deles é que a regra autoriza (ou determina?) a negativa de

\footnotetext{
${ }^{357}$ Originalmente, o art. 557, do CPC, possuía a seguinte redação: “Art. 557. Se o agravo for manifestamente improcedente, o relator poderá indeferi-lo por despacho. Também por despacho poderá convertê-lo em diligência se estiver insuficientemente instruído. Parágrafo único. Do despacho de indeferimento caberá recurso para o órgão a que competiria julgar o agravo.". A Lei $\mathrm{n}^{\circ}$ 9.139, de 30 de novembro de 1995, introduziu alterações no artigo, que passou a contar com o seguinte texto: "Art. 557. O relator negará seguimento a recurso manifestamente inadmissível, improcedente, prejudicado ou contrário à súmula do respectivo tribunal ou tribunal superior. Parágrafo único. Da decisão denegatória caberá agravo, no prazo de 5 (cinco) dias, ao órgão competente para o julgamento do recurso. Interposto o agravo a que se refere este parágrafo, o relator pedirá dia.". A redação conferida pela Lei $\mathrm{n}^{\circ}$ 9.756/1998 é a que se encontra em vigor.
} 
seguimento a recurso ${ }^{358}$ em conflito "com súmula ou com jurisprudência dominante" (destaque nosso). Aqui, portanto, a norma vai mais longe que a regra originalmente prevista na Lei ${ }^{\circ}$ 8.038/1990, autorizando a negativa de seguimento a recurso não só se estiver em conflito com súmula, mas também se estiver em conflito com jurisprudência dominante.

A alteração, no nosso entender, foi para pior. Enquanto a súmula é referência objetiva e não enseja maiores divagações, porquanto é facilmente identificada quando editada pelos tribunais, o termo "jurisprudência dominante" é de significado duvidoso, não tendo os operadores do direito, até o momento, chegado a um consenso a seu respeito ${ }^{359}$.

Segundo WAMBIER, a questão é seriíssima, “em razão da pouca probabilidade de que se tenha conhecimento, com base em levantamentos estatísticos confiáveis, daquela que seja a jurisprudência dominante num determinado Tribunal. Aliás, o problema é ainda maior, porque essa expressão - 'jurisprudência dominante' - é absolutamente fluida, indeterminada, sendo difícil para a parte recorrente quantificar a jurisprudência a ponto de saber, com desejável grau de probabilidade de acerto, se se trata ou não de 'dominante’.". Para o autor, “em resumo, é preciso esclarecer o que pode

\footnotetext{
${ }^{358}$ Para BARBOSA MOREIRA, a regra do art. 557, do CPC, abrange todos os recursos, inclusive a remessa necessária (Súmula-STJ $\mathrm{n}^{\circ} 253$ ), exceto o agravo interno previsto no respectivo $\S 1^{\circ}$ e os embargos de declaração, por haver previsão expressa de que seu julgamento ocorrerá em mesa (art. 537, do CPC) (in Barbosa Moreira, José Carlos, Comentários ao Código de Processo Civil, vol. 5, 2008, p. 681); CARNeIRO compartilha da mesma opinião (in CARNEIRO, Athos Gusmão, Poderes do relator e agravo interno - artigos 557, 544 e 545 do CPC, in Revista Sintese de Direito Civil e Processo Civil, no 6, 2000, pp. 9/10); VIVEIROS, por sua vez, ratifica o entendimento acima e acrescenta que a regra também não abrange os embargos infringentes (in VIVEIROS, Estefânia, Agravo interno no Superior Tribunal de Justiça e ampliação dos poderes do relator, in Universitas/Jus - Revista do Instituto de Ciências Jurídicas e Sociais do Centro Universitário de Brasília, $\mathrm{n}^{\circ}$ 7, 2001, p. 66). Concordamos com esse último posicionamento, embora o STJ já tenha se manifestado no sentido de que os embargos de declaração podem ser julgados monocraticamente pela sistemática do art. 557, do CPC (REsp n ${ }^{\circ}$ 259.764/PR).

359 Por exemplo, para ARENHART, para efeitos de aplicação do art. 557, do CPC, integra o conceito de jurisprudência dominante "a decisão, objeto de incidente de uniformização de jurisprudência, onde não se logrou atingir o quorum especial, exigido para a elaboração de uma súmula" (in ARENHART, Sérgio Cruz, $A$ nova postura do relator no julgamento dos recursos, in Revista de Processo, $\mathrm{n}^{\circ}$ 103, 2001, p. 49); para WAMBIER, no caso do direito federal, o referencial deve ser apenas o Superior Tribunal de Justiça (in WAMBIER, Luiz Rodrigues, Uma proposta em torno do conceito de jurisprudência dominante, in Revista de Processo, $\mathrm{n}^{\circ}$ 100, 2000, p. 83); já para DINAMARCO, “jurisprudência dominante será não somente aquela já estabelecida em incidentes de uniformização da jurisprudência mas também a que estiver presente em um número significativo de julgados, a critério do relator" (in DINAMARCO, Cândido Rangel, O relator, a jurisprudência e os recursos, in Aspectos polêmicos e atuais dos recursos cíveis de acordo com a Lei $n^{o}$ 9.756/98, 1999, p. 134). Particularmente, tendemos a concordar com essa última posição, conforme será exposto mais adiante, no item "4.4.1".
} 
estar contido na expressão 'jurisprudência dominante', tanto no tempo, quanto no espaço. Decisões recentes? Havidas em que período de tempo? Verificáveis após completa pesquisa em cada Tribunal? Ou em cada órgão fracionário?"360 . Em sentido semelhante, ARENHART observa que, “desde logo, seria possível se questionar: dominante em relação a quem? Em relação à câmara (ou turma)? Em relação ao tribunal? Em relação aos tribunais semelhantes (tribunais de justiça)? Dominante quando? Dominante frente a qual composição do tribunal? As dúvidas, diante de tão aberta definição, poderiam multiplicarse ao infinito (...) $)^{, 361}$.

Assim, a criação da "jurisprudência dominante impeditiva de recurso" (pensamos que podemos chamá-la assim, em alusão à "súmula impeditiva de recurso") abriria um leque de opções imenso ao relator, de todo indesejável para o ordenamento, na medida em que dotado de inegável subjetividade ${ }^{362}$. Tanto é assim que "é possível verificar divergências de ordem prática, com causas análogas sendo julgadas de forma monocrática com resultados diferentes, por relatores diferentes" 363 .

Justamente por isso, pensamos que, se a jurisprudência, mesmo que dominante, o que quer que isso signifique, não foi consolidada ainda a ponto de ser erigida ao status de súmula, não deve (ou ao menos não deveria) surtir efeitos mais que

${ }^{360}$ In WAMBIER, Luiz Rodrigues, Uma proposta em torno do conceito de jurisprudência dominante, in Revista de Processo, $\mathrm{n}^{\circ}$ 100, 2000, p. 82.

361 In ARENHART, Sérgio Cruz, A nova postura do relator no julgamento dos recursos, in Revista de Processo, $\mathrm{n}^{\mathrm{o}}$ 103, 2001, p. 47.

362 VIVEIROS ratifica a nossa preocupação: "Com efeito, a indicação objetiva no Código (CPC, art. 557) das hipóteses em que o relator poderá apreciar monocraticamente a controvérsia evita, no primeiro momento, que sejam extrapolados os poderes limítrofes que lhe foram outorgados pelo legislador. Ocorre que, não obstante ele tenha vinculado à lei as hipóteses permissivas de apreciação monocrática, o excesso de subjetivismo causa-nos aparente intranqüilidade. É a hipótese, v.g., da expressão 'jurisprudência dominante', ainda imatura quanto à fixação de sua extensão. O que muito nos conforta, por outro lado, é a possibilidade de a parte sempre poder provocar a manifestação do colegiado competente, na hipótese de irresignação pela decisão singular prolatada pelo relator." (in VIVEIROS, Estefânia, Agravo interno no Superior Tribunal de Justiça e ampliação dos poderes do relator, in Universitas/Jus - Revista do Instituto de Ciências Jurídicas e Sociais do Centro Universitário de Brasília, $\mathrm{n}^{\circ}$ 7, 2001, p. 63). A autora prossegue no seguinte sentido: “Tem-se, ademais, criticado a expressão 'jurisprudência dominante' por ser ela de cunho eminentemente subjetivo, conforme já noticiado, porque a lei silenciou a respeito dos parâmetros necessários à configuração do que seria 'dominante'. Tal lacuna refletiria diretamente na atuação do relator, que se pode utilizar para sustentação de sua decisão o entendimento de uma turma, mesmo que seja contrário a outra. Precisa então o relator, nessa hipótese, sentir-se seguro de que o resultado do julgamento monocrático seria o mesmo do colegiado, na hipótese de o recurso ser levado à apreciação desse órgão." (in idem, ibidem, p. 71).

${ }^{363}$ In DeLlore, Luiz Guilherme Pennacchi, Evolução do controle de constitucionalidade das leis: rumo ao controle concentrado?, 2007, p. 108. 
persuasivos. No item “4.1” trouxemos a lume importante lição de BARBOSA MOREIRA que corrobora esse entendimento.

Não bastasse o quanto exposto, o legislador, ao equiparar a jurisprudência dominante a súmula no que diz respeito aos efeitos que ambas devem gerar (ex.: negativa de seguimento a recurso), cria situação potencialmente paradoxal. Considere-se, por exemplo, a hipótese da existência de súmula bastante antiga e ultrapassada, mas ainda em vigor, em torno da qual vem se formando jurisprudência contrária, atualmente dominante no tribunal. Nessa situação, o relator deveria decidir com base em qual entendimento, no da súmula (ultrapassada) ou no da jurisprudência dominante (atual)?

A nosso ver, a despeito de formalmente restar preenchido o requisito da lei, em casos tais o relator não estaria autorizado a julgar o recurso monocraticamente, pois a solução não seria tão objetiva assim e, portanto, sujeitar-se-ia a confirmação ou retificação por seus pares. Explica-se: a lei permite ao relator que negue seguimento a recurso contrário a jurisprudência dominante ou súmula pois nesses casos a própria jurisprudência dominante ou súmula indicam o caminho a ser seguido; há pouco espaço para inovar, a resposta encontra-se "semipronta" no ordenamento ${ }^{364}$. Desse modo, não haveria por que tomar o tempo de outros dois magistrados, que muito provavelmente seguiriam esse entendimento "predeterminado". Na situação referida no parágrafo anterior, porém, a objetividade não se encontra presente. Na verdade há duas respostas "semiprontas" no ordenamento, mas elas são conflitantes entre si. Caberá ao relator, à luz das peculiaridades do caso concreto e do contexto em que se formaram os entendimentos contraditórios, optar entre um deles. É como se ele estivesse a inaugurar novo entendimento sobre o assunto, de modo tal que seria no mínimo conveniente submeter a decisão à apreciação mais ampla do colegiado.

\footnotetext{
${ }^{364}$ Conforme obtempera DINAMARCO, a possibilidade de o relator julgar monocraticamente fica "restrita a casos onde se prevê que os órgãos colegiados julgariam segundo critérios objetivos e temperada pela admissibilidade de agravo dirigido a eles" (in DINAMARCO, Cândido Rangel, O relator, a jurisprudência e os recursos, in Aspectos polêmicos e atuais dos recursos cíveis de acordo com a Lei $n^{\circ}$ 9.756/98, 1999, p. 131). V., em sentido semelhante, afirmando que o relator é um “'porta-voz avançado': o que ele diz, supõese que o diga 'antecipando' a decisão do colegiado", BARBOSA MOREIRA, José Carlos, Algumas inovações da Lei 9.756 em matéria de recursos civis, in Aspectos polêmicos e atuais dos recursos cíveis de acordo com a Lei $n^{\circ}$ 9.756/98, 1999, p. 324. V., na mesma linha, asseverando que "fica clara, pois, a opção da lei por manter o juiz natural do recurso em mãos do colegiado, limitando-se a delegar a função decisória da insurgência ao relator (sem necessária cooperação dos demais membros da corte) em casos em que a questão fosse de evidente solução", ARENHART, Sérgio Cruz, A nova postura do relator no julgamento dos recursos, in Revista de Processo, n 103, 2001, p. 43.
} 
Embora estejamos a tratar de situação muito mais hipotética do que prática, ela é perfeitamente possível de ocorrer, já que, no lapso que precede a revogação da súmula por entendimento contrário posterior, aquela convive necessariamente com este. $\mathrm{O}$ legislador deve estar atento a esse tipo de "constrangimento", sob pena de, ao conceber a solução de um problema, gerar outro. Nesse ponto, portanto, melhor seria se o artigo legal em tela tivesse feito referência tão-somente a súmula, excluindo a previsão referente a jurisprudência dominante.

O segundo ponto que nos chama a atenção referente ao caput do artigo é que a súmula ou jurisprudência dominante assumidas como paradigma devem ser provenientes “do respectivo tribunal, do Supremo Tribunal Federal, ou de Tribunal Superior" (destaque nosso). Aqui novamente amplia-se a regra original do art. 38, da Lei $\mathrm{n}^{\mathrm{o}} 8.038 / 1990$, permitindo-se que entendimento do respectivo tribunal barre o seguimento de recurso.

Novamente pensamos que a alteração foi para pior. Afinal, exceto nos limitados casos em que tribunal local ou regional funcionam como última instância, não é crível que súmula ou jurisprudência dominante deles provenientes sejam suficientes para impedir o seguimento de recurso. Como já se disse, o norte das decisões deve ser dado sempre pelos tribunais superiores, a quem cabe conferir uniformidade ao sistema. Não à toa, com a sabedoria que lhe é peculiar, TARUFFO esclarece que "le vere 'corti del precedente' sono le corti supreme, le cui decisioni si impongono a tutti gli organi giudiziari di grado inferiore ${ }^{365}$. Da forma como está redigido o caput do artigo, o relator poderia negar seguimento a recurso em conflito com jurisprudência do próprio tribunal, ainda que convergente com jurisprudência de tribunal superior. Isso parece pouco razoável, já que, na disputa entre uma e outra, a jurisprudência do tribunal superior deve sempre prevalecer. No mínimo deveria constar ressalva expressa nesse sentido.

VIVEIROS observa exatamente o mesmo problema, ao constatar que "essa alteração legislativa sob comento permite uma situação bastante peculiar que é a possibilidade de um relator de segundo grau negar seguimento, v.g., a uma apelação com

\footnotetext{
${ }^{365}$ In TARUFFO, Michele, Precedente e giurisprudenza, in Rivista Trimestrale di Diritto e Procedura Civile,
} ano $61, \mathrm{n}^{\mathrm{o}} 3,2007$, p. 718 . 
supedâneo em jurisprudência dominante do seu próprio tribunal, mesmo que essa prática se distancie do entendimento das Cortes superiores acerca do tema em julgamento" ${ }^{\circledR 66}$. BARBOSA MOREIRA também cuida do assunto, ao informar que "já decidiu o STJ que não é dado ao relator negar seguimento ao recurso, com apoio exclusivo na desarmonia entre a tese do recorrente e a jurisprudência do próprio tribunal, frustrando assim o controle do 'tribunal superior",367.

É claro que a uniformização interna é importante (e por isso defendemos com afinco os meios de uniformização de jurisprudência, em geral), mas pensamos que isso não é suficiente para proporcionar a certeza e a segurança jurídica de que necessitamos. O ideal - e é isso que buscamos - é que a jurisprudência seja uniforme em todos os tribunais do país; a orientação e o respectivo controle devem se dar, portanto, pelos tribunais superiores e, em especial, pelo STF.

Tanto deve ser assim que, no julgamento do REsp $\mathrm{n}^{\mathrm{o}} 193.189 / \mathrm{CE}^{368}$, o STJ decidiu que "a expressão 'jurisprudência dominante do respectivo tribunal' somente pode servir de base para negar seguimento a recurso quando o entendimento adotado estiver de acordo com a jurisprudência do Superior Tribunal de Justiça e do Supremo Tribunal Federal, sob pena de negar às partes o direito constitucional de acesso às vias extraordinárias". Exatamente no mesmo sentido foi o voto vencedor no REsp $\mathrm{n}^{\circ}$ $299.196 / \mathrm{MG}^{369}$. A interpretação nos parece perfeita, mas não é isso o que diz a lei ${ }^{370}$ tanto que no REsp $\mathrm{n}^{\mathrm{o}} 404.837 / \mathrm{RJ}^{371}$ decidiu-se que não viola o art. 557, do CPC, o julgamento monocrático tomado com base no entendimento pacífico do respectivo tribunal, ainda que em desacordo com orientação do STJ (embora depois o acórdão tenha

\footnotetext{
${ }^{366}$ In VIVEIROS, Estefânia, Agravo interno no Superior Tribunal de Justiça e ampliação dos poderes do relator, in Universitas/Jus - Revista do Instituto de Ciências Jurídicas e Sociais do Centro Universitário de Brasília, nº 7, 2001, p. 68.

${ }^{367}$ In BARBOsa Moreira, José Carlos, Comentários ao Código de Processo Civil, vol. 5, 2008, p. 682, nota de rodapé $n^{\circ} 50$.

${ }^{368}$ STJ, Segunda Turma, REsp no 193.189/CE, rel. Min. FrAnCIULli NETO, j. 20/06/2000.

${ }^{369}$ STJ, Segunda Turma, REsp no 299.196/MG, rel. Min. FRANCIULli NETO, j. 16/04/2002.

${ }^{370}$ A despeito da literalidade do texto, WAMBIER consigna que, "ao prever que possa o relator negar seguimento a recurso que confronte com a jurisprudência dominante do respectivo tribunal, a lei somente pode ter querido referir-se à hipótese de existir jurisprudência local que não colida com aquilo que também no Superior Tribunal de Justiça se tiver entendido como tal" (in WAMBIER, Luiz Rodrigues, Uma proposta em torno do conceito de jurisprudência dominante, in Revista de Processo, $\mathrm{n}^{\circ} 100,2000$, p. 84).

${ }^{371}$ STJ, Quinta Turma, REsp no 404.837/RJ, rel. Min. Felix Fischer, j. 26.3.2002.
} 
sido reformado, em embargos de divergência, oportunidade em que se consignou que "esta eg. Corte Especial assentou entendimento no sentido de que o Relator não pode decidir monocraticamente apoiado em Súmula do Tribunal local contrária à jurisprudência do STJ'). Diante da atecnia do legislador ${ }^{372}$, então, temos que contar com o bom-senso dos magistrados na interpretação e na aplicação da norma...

Uma terceira alteração em relação à regra original da Lei $n^{\circ}$ 8.038/1990 esta de mais difícil percepção - refere-se ao fato de o art. 557, caput, do CPC, mencionar que a súmula ou jurisprudência dominante assumidas como paradigma devem ser provenientes "do respectivo tribunal, do Supremo Tribunal Federal, ou de Tribunal Superior" (destaque nosso). À primeira vista o comando não se afasta daquele do art. 38, da Lei no 8.038/1990, pois este, ao mencionar "respectivos tribunais", está a se referir justamente ao STF e ao STJ (ambos tribunais superiores), já que a lei regula o processamento de recursos movidos exclusivamente perante essas duas cortes. A regra do art. 557, caput, do CPC, porém, amplia esse entendimento, ao estender a eficácia quase vinculante a súmulas de outros tribunais superiores, que não o STF e o STJ. Natural que assim fosse, porquanto o âmbito de atuação da norma aqui é o tribunal de segundo grau, situado hierarquicamente abaixo de todos os tribunais superiores.

Destarte, no que diz respeito à proveniência do paradigma, nos parece que o legislador andou bem ao ampliar a solução do art. 38, da Lei $\mathrm{n}^{\circ}$ 8.038/1990, para todos os tribunais superiores, dada a peculiaridade atinente ao âmbito de atuação da norma; por outro lado, exceto nos limitados casos em que funcionam como última instância, sequer deveria ter cogitado da possibilidade de se tomar como paradigma o posicionamento, mesmo que sumulado, de tribunais de segundo grau.

No que tange ao $\S 1^{\circ}-\mathrm{A}$, do art. 557, do $\mathrm{CPC}$, o que mais atrai nossa consideração diz com o fato de a regra autorizar o relator a dar provimento ao recurso, "se a decisão recorrida estiver em manifesto confronto com súmula ou com jurisprudência dominante do Supremo Tribunal Federal, ou de Tribunal Superior", ao invés de negar seguimento, como consta do caput e como já constava do art. 38, da Lei nº 8.038/1990.

\footnotetext{
${ }^{372}$ V., afirmando, como nós, que o legislador dedicou reduzida atenção ao instituto e que o texto legal inserido pela Lei no 9.756/1998 foi redigido com péssima técnica, ARENHART, Sérgio Cruz, A nova postura do relator no julgamento dos recursos, in Revista de Processo, n 103, 2001, p. 38.
} 
Aqui se cria, ao lado da "súmula impeditiva de recurso" (e da correlata "jurisprudência dominante impeditiva de recurso"), uma espécie de "súmula acolhedora de recurso" (e sua correlata "jurisprudência dominante acolhedora de recurso"), o que na nossa concepção não é de todo mal.

Em oposição à regra do caput, porém, só podem ser tomados como paradigma súmula ou jurisprudência dominante do STF ou de tribunal superior, sendo vedado portanto ao relator dar provimento a recurso, por decisão monocrática, com fundamento em súmula ou jurisprudência dominante do respectivo tribunal. Nesse ponto o legislador foi bem $^{373}$, mas teria ido ainda melhor se tivesse se referido tão-somente a súmula, excluindo a menção feita à jurisprudência dominante, como já exposto.

Aparentemente contrário à regra do caput, aqui o comando é de autorização, de modo que o provimento a recurso mediante decisão monocrática é faculdade do relator, e não dever - a norma diz que "o relator poderá dar provimento ao recurso" (destaque nosso). Em princípio, não há por que diferenciar a imperatividade dos casos, e a influência da jurisprudência em uma e outra hipótese, se a negativa de seguimento e o provimento a recurso são medidas igualmente graves, aptas por si só, em um caso e no outro, a colocar fim ao processo. $\mathrm{O}$ assunto será tratado com maior atenção adiante, no item "4.3.2.5".

A Lei $n^{\circ} 9.756 / 1998$ ainda incluiu os $\S \S 1^{\circ}$ e $2^{\circ}$ no art. 557, do CPC. O primeiro autoriza a interposição de agravo (denominado de "agravo interno") contra a decisão do relator, no prazo de cinco dias, ao órgão competente para o recurso, concedendo ao relator a possibilidade de se retratar; em não havendo a retratação, o relator apresentará o processo em mesa, proferindo voto, e, uma vez provido o agravo, o recurso terá seguimento. Já o segundo prevê que, em sendo manifestamente inadmissível ou infundado o agravo, o tribunal condenará o agravante a pagar ao agravado multa entre um e dez por cento do valor corrigido da causa, ficando a interposição de qualquer outro recurso condicionada ao depósito do respectivo valor.

\footnotetext{
${ }^{373}$ V., no mesmo sentido, VIVEIROS, Estefânia, Agravo interno no Superior Tribunal de Justiça e ampliação dos poderes do relator, in Universitas/Jus - Revista do Instituto de Ciências Jurídicas e Sociais do Centro Universitário de Brasília, no 7, 2001, p. 72.
} 
Na prática, parece que a celeridade visada pelo art. 557, do CPC, só será efetivamente alcançada se o vencido anuir à decisão singular, abstendo-se de provocar o colegiado mediante a interposição de agravo interno, já que “(...) a seqüência 'decisão do relator - agravo - julgamento colegiado', com eventuais ramificações, é obviamente mais complexa que o itinerário observado quando o relator se cinge a estudar o recurso e a levá-lo à apreciação do colegiado. Ensina a geometria, com efeito, que a reta é a menor distância entre dois pontos." ${ }^{374}$. De todo modo, tendo em vista as fragilidades do artigo - a saber, a possibilidade de julgamento monocrático com fundamento em jurisprudência dominante, o que quer que isso signifique, e a possibilidade de utilização de precedente de tribunal de segundo grau como paradigma -, é recomendável a manutenção desse meio de impugnação ${ }^{375}$, até porque o julgamento do agravo interno, em regra, demanda menos tempo e esforço do que o julgamento do recurso de origem, na medida em que a sua matéria é mais restrita ${ }^{376}$. Com efeito, na petição de agravo, o agravante deve impugnar exclusivamente as razões declinadas pelo relator por ocasião do julgamento monocrático, sem reiterar os fundamentos do recurso de origem, sob pena de esbarrar no óbice da Súmula-STJ no 182, aplicável por analogia ("é inviável o agravo do art. 545 do CPC que

\footnotetext{
${ }^{374}$ In BARBosa MOREIRA, José Carlos, Algumas inovações da Lei 9.756 em matéria de recursos civis, in Aspectos polêmicos e atuais dos recursos cíveis de acordo com a Lei $n^{\circ}$ 9.756/98, 1999, p. 328. V., em sentido semelhante, asseverando que as reformas introduzidas criaram mais um estágio na linha recursal, "autorizando, agora, um primeiro recurso examinado pelo relator da impugnação e, posteriormente, pelo colegiado a quem, originária e anteriormente, tocaria conhecer do tema”, ARENHART, Sérgio Cruz, A nova postura do relator no julgamento dos recursos, in Revista de Processo, $\mathrm{n}^{\circ}$ 103, 2001, p. 37. V., também nesse sentido, CARnEIRO, Athos Gusmão, Poderes do relator e agravo interno - artigos 557, 544 e 545 do CPC, in Revista Síntese de Direito Civil e Processo Civil, n 6, 2000, p. 14 e VIVEIROS, Estefânia, Agravo interno no Superior Tribunal de Justiça e ampliação dos poderes do relator, in Universitas/Jus - Revista do Instituto de Ciências Jurídicas e Sociais do Centro Universitário de Brasília, no 7, 2001, p. 64.

${ }^{375}$ Não que seja ele dos mais efetivos, pois, conforme a arguta observação de RODRIGUES, "é justo, todavia, ponderar sobre uma improvável vontade de revisar a decisão monocrática atacada já que há uma nítida acomodação que, entre componentes de Colegiados, acaba por se estabelecer, seja pela necessidade de dar velocidade à pauta, seja, enfim, por mero 'dever' de reciprocidade!' (in RoDRIGUES, Walter Piva, $O$ princípio da colegialidade das decisões nos tribunais, in Revista Dialética de Direito Processual, $\mathrm{n}^{\circ}$ 1, 2003, p. 177). Não sem razão, o autor conclui que "pode ser que os cidadãos corram o risco de ver desaparecer as razões de excelência que justificaram sempre, no correr dos tempos, a coexistência dos juízos monocráticos de primeiro grau e juízos colegiados de segundo grau como expressão máxima da necessidade de Justiça" (in idem, ibidem, p. 178).

376 BARBOSA MOREIRA acrescenta que o agravo interno, na hipótese em tela, "não era nem é eliminável", pois o juiz natural do recurso é o colegiado (in BARBOSA MOREIRA, José Carlos, Algumas inovações da Lei 9.756 em matéria de recursos civis, in Aspectos polêmicos e atuais dos recursos cíveis de acordo com a Lei $n^{o}$ 9.756/98, 1999, p. 324). V., no mesmo sentido, DINAMARCO, Cândido Rangel, O relator, a jurisprudência e os recursos, in Aspectos polêmicos e atuais dos recursos cíveis de acordo com a Lei $n^{\circ}$ 9.756/98, 1999, $\mathrm{p}$. 132. V., em sentido oposto, afirmando que "a inexistência de previsão expressa de recurso, da decisão do relator, na matéria que aqui interessa, em forma nenhuma viria a ferir regra ou princípio constitucional", mas que "indubitavelmente, a previsão do recurso (agravo) é recomendável, mesmo como forma de controle da atividade do relator", ARENHART, Sérgio Cruz, A nova postura do relator no julgamento dos recursos, in Revista de Processo, no 103, 2001, p. 41.
} 
deixa de atacar especificamente os fundamentos da decisão agravada"). Nos casos que nos interessam, por exemplo, a matéria ficaria limitada à conformidade ou não do recurso ou da decisão recorrida com súmula ou jurisprudência dominante.

Dessa forma, se o agravo interno for improvido, para o fim de manter a decisão monocrática do relator, a manifestação dos demais julgadores terá demandado menos tempo e esforço do que o julgamento do recurso de origem demandaria; terá sido atingida, assim, a finalidade da regra. Por outro lado, se o agravo interno for provido, para o fim de reformar a decisão monocrática do relator, determinando-se o seguimento do recurso em seus trâmites regulares, é porque não era mesmo o caso de julgamento monocrático. O colegiado então deverá se manifestar novamente, dessa vez sobre o recurso de origem em si, mas assim já seria se o recurso não tivesse sido julgado liminarmente pelo relator. O prejuízo então não terá sido tão grande.

Além do que, se imagina (ou ao menos se espera) que os casos de improvimento do agravo interno sejam mais numerosos que os casos de provimento, uma vez que quando da aplicação da regra do art. 557, do CPC, o relator, como já exposto, funciona como uma espécie de porta-voz dos membros do colegiado, devendo julgar como muito provavelmente seus pares julgariam.

Por força de sua própria natureza, não se aplica ao agravo interno, evidentemente, a disposição do art. 557, caput, do CPC. Seria de todo teratológica (e o agravo interno restaria completamente vazio de utilidade) a rejeição do agravo com fundamento nesse dispositivo, se o agravo visa justamente a corrigir decisão proferida com base no aludido artigo legal ${ }^{377}$.

A propósito do $\S 2^{\circ}$, do art. 557, do $\mathrm{CPC}$, apesar de o legislador ter sido pouco preciso ao exigir a interposição de agravo "manifestamente inadmissível ou infundado" para ensejar a aplicação da multa, o que poderia gerar um sem-número de discussões a respeito de seu significado, e a despeito dos inconvenientes que geralmente

\footnotetext{
377 V., nesse sentido, sustentando ainda que o referido agravo interno não constitui recurso, mas "meio integrativo da vontade do órgão colegiado do Tribunal”, ARRIBAS, Bruno Felipe da Silva Martin de, Decisão monocrática relatorial: análise do artigo 557 do Código de Processo Civil, in Revista da Esmape - Escola Superior da Magistratura de Pernambuco, no 20, 2004, pp. 116/117.
} 
acompanham esse tipo de sanção ${ }^{378}$, no geral consideramos positiva a regra, pois ela tem a vantagem de desencorajar os mal-intencionados, receosos que ficarão de serem apenados pecuniariamente.

\subsubsection{Art. 544, $\S 4^{o}$, II, " $\quad$ " $e$ "c c", do CPC}

A Lei $\mathrm{n}^{\circ}$ 12.322, de 9 de setembro de 2010, incluiu as alíneas "b" e "c" no art. 544, $\S 4^{\circ}$, II, do CPC, com o intuito de permitir ao relator (conforme a redação do $\S 4^{\circ}$, a saber, "no Supremo Tribunal Federal e no Superior Tribunal de Justiça, o julgamento do agravo obedecerá ao disposto no respectivo regimento interno, podendo o relator (...)", destaque nosso), no julgamento de agravo interposto contra decisão denegatória de seguimento de recurso especial ou extraordinário, conhecer do agravo para: negar-lhe seguimento, se manifestamente inadmissível, prejudicado ou em confronto com súmula ou jurisprudência dominante no tribunal (art. 544, § 4, II, "b", do CPC); e dar-lhe provimento, se o acórdão recorrido estiver em confronto com súmula ou jurisprudência dominante no tribunal (art. 544, § 4, II, “c”, do CPC).

Embora os dispositivos acima superem em qualidade a regra do art. 557, caput e $\S 1^{\circ}$, do CPC, pois só fazem referência a súmula ou jurisprudência do STF e do STJ, conforme se tratar de agravo contra decisão denegatória de seguimento de recurso extraordinário ou especial, respectivamente, pensamos que a menção a "jurisprudência dominante" não deveria ter sido incluída, pelos motivos já expostos no tópico anterior.

Vale mencionar que a mesma Lei $\mathrm{n}^{\circ}$ 12.322/2010 alterou a redação do art. 545, do CPC, para fazer constar que "da decisão do relator que não conhecer do agravo, negar-lhe provimento ou decidir, desde logo, o recurso não admitido na origem, caberá agravo, no prazo de 5 (cinco) dias, ao órgão competente, observado o disposto nos $\$ \S 1^{o} e$ $2^{\circ}$ do art. 557'. Reiteramos o quanto exposto no item anterior a propósito do agravo interno e da sanção de multa.

\footnotetext{
378 V., criticando a sanção pecuniária, por ser discriminatória em razão da fortuna, por se apoiar no valor da causa e por apenar o litigante e não o advogado, BARBOSA MOREIRA, José Carlos, Algumas inovações da Lei 9.756 em matéria de recursos civis, in Aspectos polêmicos e atuais dos recursos cíveis de acordo com a Lei $n^{\circ}$ 9.756/98, 1999, pp. 328/329. V., em sentido parcialmente semelhante, defendendo a constitucionalidade da multa exceto se imposta em face de pessoa que não tenha condições de, sem prejuízo ao seu sustento, arcar com o pagamento da sanção, ARENHART, Sérgio Cruz, A nova postura do relator no julgamento dos recursos, in Revista de Processo, $\mathrm{n}^{\circ}$ 103, 2001, pp. 56/57.
} 


\subsubsection{Art. 120, par. único, do CPC}

A mesma Lei no 9.756/1998, que implementou modificações no art. 557, do CPC, determinou a inclusão do par. único no art. 120, da lei processual, para estabelecer que, no caso de conflito de competência, havendo jurisprudência dominante do tribunal sobre a questão suscitada, o relator poderá decidir de plano o conflito, cabendo agravo (o dito agravo interno), no prazo de cinco dias, contado da intimação da decisão às partes, para o órgão recursal competente.

Aqui o legislador inovou ainda mais, pois, em todas as demais hipóteses tratadas acima, o julgamento monocrático era permitido com base em súmula, ou com base em súmula e jurisprudência dominante. Essa é a única hipótese do CPC em que se faz referência a jurisprudência dominante, mas não a súmula. Criou-se uma espécie de “jurisprudência dominante autorizadora de julgamento monocrático pelo relator".

A súmula, por sua própria natureza, é representativa de jurisprudência dominante e por isso, em princípio, encontra-se abrangida nesse conceito. Ainda, como diz o ditado popular, quem pode o mais, pode o menos; isto é, se o relator pode decidir sozinho com fundamento em jurisprudência dominante, a rigor também pode fazê-lo com fundamento em súmula. De toda forma, o mais correto seria que essa última hipótese estivesse expressamente contemplada na lei, senão no lugar daquela, o que seria ideal, no mínimo junto dela - embora daí decorresse potencial situação paradoxal, já enfrentada no item "4.3.2.2" acima.

O fato é que, ainda que a prerrogativa conferida pelo art. 120, par. único, do CPC, trate-se de faculdade e não de dever do relator, não deveria bastar a existência de jurisprudência dominante do próprio tribunal (que pode ser local, regional ou superior, dependendo de onde tramitar o conflito de competência) para permitir que ele julgasse sozinho o incidente, mediante decisão monocrática, por todos os motivos já expostos. Melhor seria se o legislador tivesse se referido a súmula de tribunal superior, e não a jurisprudência dominante do próprio tribunal. 
Para fins de sistematização da matéria, resumimos no quadro abaixo as alterações legislativas abordadas nos itens "4.3.2.1" a "4.3.2.4”:

\begin{tabular}{|c|c|c|c|c|c|}
\hline \multicolumn{6}{|c|}{ Ampliação dos poderes do relator } \\
\hline $\begin{array}{l}\text { Previsão } \\
\text { legal }\end{array}$ & $\begin{array}{l}\text { Âmbito de } \\
\text { atuação }\end{array}$ & $\begin{array}{l}\text { Dever ou } \\
\text { faculdade }\end{array}$ & $\begin{array}{c}\text { Providência, } \\
\text { mediante decisão } \\
\text { monocrática }\end{array}$ & Situação & Resultado \\
\hline $\begin{array}{l}\text { Art. } 38, \text { da } \\
\text { Lei } \mathrm{n}^{\circ} \\
8.038 / 1990\end{array}$ & $\begin{array}{c}\text { Recursos } \\
\text { perante o STF e } \\
\text { STJ }\end{array}$ & Dever & $\begin{array}{l}\text { Negar seguimento } \\
\text { a recurso }\end{array}$ & $\begin{array}{l}\text { Recurso contrário a } \\
\text { súmula do respectivo } \\
\text { tribunal (STF ou STJ) }\end{array}$ & $\begin{array}{l}\text { Súmula impeditiva de } \\
\text { recurso }\end{array}$ \\
\hline $\begin{array}{l}\text { Art. } 557 \text {, } \\
\text { caput, do } \\
\text { CPC }\end{array}$ & $\begin{array}{l}\text { Recursos em } \\
\text { geral }\end{array}$ & Dever & $\begin{array}{l}\text { Negar seguimento } \\
\text { a recurso }\end{array}$ & $\begin{array}{l}\text { Recurso contrário a } \\
\text { súmula ou jurisprudência } \\
\text { dominante do respectivo } \\
\text { tribunal (local ou } \\
\text { regional), do STF ou de } \\
\text { tribunal superior }\end{array}$ & $\begin{array}{l}\text { Súmula impeditiva de } \\
\text { recurso e jurisprudência } \\
\text { dominante impeditiva } \\
\text { de recurso }\end{array}$ \\
\hline $\begin{array}{l}\text { Art. 557, § } \\
1^{\circ}, \text { do CPC }\end{array}$ & $\begin{array}{l}\text { Recursos em } \\
\text { geral }\end{array}$ & Faculdade & $\begin{array}{l}\text { Dar provimento a } \\
\text { recurso }\end{array}$ & $\begin{array}{c}\text { Decisão recorrida } \\
\text { contrária a súmula ou } \\
\text { jurisprudência dominante } \\
\text { do STF ou de tribunal } \\
\text { superior } \\
\end{array}$ & $\begin{array}{c}\text { Súmula acolhedora de } \\
\text { recurso e jurisprudência } \\
\text { dominante acolhedora } \\
\text { de recurso }\end{array}$ \\
\hline $\begin{array}{l}\text { Art. } 544, \S \\
4^{\circ}, \text { II, "b", } \\
\text { do CPC }\end{array}$ & $\begin{array}{l}\text { AREsp e } \\
\text { ARExt }\end{array}$ & Faculdade & $\begin{array}{c}\text { Negar seguimento } \\
\text { a recurso }\end{array}$ & $\begin{array}{c}\text { Recurso contrário a } \\
\text { súmula ou jurisprudência } \\
\text { dominante do tribunal } \\
\text { (STF ou STJ) }\end{array}$ & $\begin{array}{c}\text { Súmula impeditiva de } \\
\text { recurso e jurisprudência } \\
\text { dominante impeditiva } \\
\text { de recurso } \\
\end{array}$ \\
\hline $\begin{array}{l}\text { Art. } 544, \S \\
4^{\circ}, \text { II, "c", } \\
\text { do CPC }\end{array}$ & $\begin{array}{l}\text { AREsp e } \\
\text { ARExt }\end{array}$ & Faculdade & $\begin{array}{l}\text { Dar provimento a } \\
\text { recurso }\end{array}$ & $\begin{array}{c}\text { Decisão recorrida } \\
\text { contrária a súmula ou } \\
\text { jurisprudência dominante } \\
\text { no tribunal (STF ou STJ) }\end{array}$ & $\begin{array}{c}\text { Súmula acolhedora de } \\
\text { recurso e jurisprudência } \\
\text { dominante acolhedora } \\
\text { de recurso }\end{array}$ \\
\hline $\begin{array}{l}\text { Art. } 120 \text {, } \\
\text { par. único, } \\
\text { do CPC }\end{array}$ & $\begin{array}{l}\text { Conflito de } \\
\text { competência }\end{array}$ & Faculdade & Decidir o conflito & $\begin{array}{l}\text { Existência de } \\
\text { jurisprudência dominante } \\
\text { do tribunal (local, } \\
\text { regional ou superior) } \\
\text { sobre a questão suscitada }\end{array}$ & $\begin{array}{c}\text { Jurisprudência } \\
\text { dominante autorizadora } \\
\text { de julgamento } \\
\text { monocrático }\end{array}$ \\
\hline
\end{tabular}

Após refletirmos detidamente sobre cada uma dessas alterações e de avaliálas individualmente e em conjunto, pensamos que o legislador, sob o pretexto de ampliar os poderes do relator e de conferir maior valor ao precedente judicial e à jurisprudência, acabou por tomar decisões precipitadas, sem a devida reflexão.

Acima de tudo, nos chama a atenção como as reformas legislativas introduziram inovações incoerentes entre si. Do ponto de vista da obrigatoriedade, algumas foram inseridas, ao menos aparentemente, como dever do relator, outras como faculdade; do ponto de vista da providência, uma foi inserida para negar seguimento a recurso, outras para negar seguimento e dar provimento a recurso, outra para decidir conflito de competência; do ponto de vista da espécie de paradigma, uma fala em súmula, outras falam em súmula ou jurisprudência dominante, outra fala em jurisprudência dominante; e, por 
fim, do ponto de vista da proveniência do paradigma, algumas falam em STF ou STJ, outra fala em STF e tribunal superior, outras falam em tribunal local/regional e tribunal superior.

As diferenças são gritantes. Independentemente da escolha adotada, acima de tudo, os critérios deveriam ser os mesmos em todos os casos, dando ensejo a um conjunto unitário, coerente e completo, como convém a um sistema ${ }^{379}$. Afinal, nas precisas palavras de GUIMARÃES, que inauguram o presente trabalho, "o direito é um todo harmônico que há de ser apreciado em seu conjunto" ${ }^{380}$.

A propósito dos critérios em si, desconsiderada uma peculiaridade ou outra, de maneira geral, nos parece que o mais correto seria se o legislador tivesse, em todos os casos, previsto a decisão monocrática como um dever do relator, para o fim de negar seguimento ou dar provimento a recurso, uma vez violada súmula proveniente de tribunal superior (ou de tribunal local ou regional nas limitadas hipóteses em que funcionam como última instância).

Ressalte-se que a obrigatoriedade, para se tornar efetiva, deveria ser passível de sanção ${ }^{381}$ e, no mínimo, estendida para o colegiado. Afinal, em sendo o relator integrante do colegiado, a regra deve ser a mesma para os dois; não faz sentido que a súmula e a jurisprudência dominante surtam efeitos vinculantes para um mas não para o outro.

No caso do art. 557, caput, do CPC, tal como redigido, mesmo sendo classificada como obrigatória a negativa de seguimento ao recurso por decisão monocrática do relator, não haverá qualquer consequência caso ele opte por enviar o recurso à mesa. $\mathrm{O}$

\footnotetext{
379 In CAZETTA JÚNIOR, José Jesus, A ineficácia do precedente no sistema brasileiro de jurisdição constitucional (1891-1993): contribuição ao estudo do efeito vinculante, Tese (Doutorado), 2004, p. 34. Infelizmente, não é assim que as coisas funcionam. Segundo esse mesmo autor, o ordenamento jurídico, além de se tratar de uma obra coletiva, é aperfeiçoado paulatinamente, refletindo a contínua influência de gerações sucessivas. Assim, os textos normativos têm muitos autores; e as várias contribuições não são contemporâneas. Surgem, então, duas dimensões férteis em incoerências: a primeira é sincrônica; a segunda é diacrônica (in idem, ibidem, pp. 34/35).

${ }^{380}$ In GUIMARÃES, Mário, O juiz e a função jurisdicional, 1958, p. 326.

${ }^{381}$ V., em sentido semelhante, afirmando que a conduta pretendida só se torna obrigatória - configurando uma prescrição ou comando - quando há, ao menos tacitamente, a ameaça de uma sanção, CAZETTA JÚNIOR, José Jesus, A ineficácia do precedente no sistema brasileiro de jurisdição constitucional (1891-1993): contribuição ao estudo do efeito vinculante, Tese (Doutorado), 2004, p. 34.
} 
mesmo se diga quanto à disposição do art. 38, da Lei $\mathrm{n}^{\circ}$ 8.038/1990. No máximo seria possível a interposição de agravo interno contra a ordem que determinou a submissão do recurso ao colegiado, o qual, no entanto, provavelmente seria rechaçado porquanto interposto contra despacho de mero expediente, sem conteúdo decisório. E mais: tal como redigida a lei, caso o colegiado entenda por dar provimento ao recurso, mesmo que fundado em tese jurídica conflitante com "súmula ou com jurisprudência dominante do respectivo tribunal, do Supremo Tribunal Federal, ou de Tribunal Superior", poderá fazêlo livremente, pois, em não estando mais presente a situação específica prevista no art. 557, caput, do CPC, tanto a súmula quanto a jurisprudência dominante surtirão sobre ele eficácia meramente persuasiva.

Como se vê, mesmo determinando em ambos os casos a negativa de seguimento a recurso pelo relator, tal obrigatoriedade é apenas aparente. Privilegiou-se muito mais o julgamento monocrático em si, concentrando poderes nas mãos do relator para o fim de conferir celeridade aos recursos, do que o julgamento conforme a súmula ou a jurisprudência dominante, para conferir uniformidade às decisões.

E se foi essa mesma a intenção do legislador - privilegiar o julgamento monocrático, e não o julgamento conforme a súmula ou a jurisprudência dominante -, deveria então simplesmente ter previsto autorização para o relator julgar monocraticamente, desde que a tese jurídica contida no recurso ou na decisão recorrida estivesse em conflito com súmula ou jurisprudência dominante (como é o caso dos arts. $557, \S 1^{\circ}, 544, \S 4^{\circ}$, II, “b” e “c", e 120, par. único, do $\mathrm{CPC}^{382}$ ). Da forma como redigidos, os arts. 38, da Lei $n^{\circ} 8.038 / 1990$, e 557, caput, do CPC, ficaram no meio do caminho; determinaram o julgamento monocrático conforme súmula ou jurisprudência dominante pelo relator, mas não previram nenhum meio de tornar a regra efetiva. Logo, conclui-se que as diretrizes neles estabelecidas são só aparentemente obrigatórias.

Percebendo essa incongruência, DiNAMARCO anota que: " $O$ caput $d o$ art. 557 diz que o relator negará seguimento ao recurso nos casos ali especificados. Essa

\footnotetext{
382 Conforme DinAMARCO, ao utilizar em tais artigos o verbo "poder", "o legislador quis deixar ao prudente arbítrio do próprio relator a opção entre julgar por si próprio, monocraticamente, ou encaminhar o caso ao colegiado" (in DINAMARCO, Cândido Rangel, O relator, a jurisprudência e os recursos, in Aspectos polêmicos e atuais dos recursos cíveis de acordo com a Lei $n^{\circ} 9.756 / 98,1999$, p. 132).
} 
redação, que insinua obrigatoriedade, vem da Reforma de 1995 e a nova lei limitou-se a reproduzi-la. Mas o emprego do advérbio manifestamente acaba por criar na prática a mesma situação, porque será dever do relator abster-se de julgar de plano sempre que não veja uma situação manifesta, isto é, límpida e indiscutível."383.

É curioso notar que, embora nesse ponto tenha deixado a desejar, o legislador foi muito além do que deveria ter ido quando atribuiu eficácia quase vinculante à jurisprudência dominante do tribunal de segundo grau. A nosso ver, dada a dificuldade na caracterização da jurisprudência dominante, a prerrogativa de surtir efeitos mais que persuasivos deveria ficar restrita a súmula. E não a qualquer súmula, mas a súmula de tribunal superior.

Todos pensavam que a grande revolução no sistema chegaria com a introdução da súmula vinculante, tão criticada por uns, e tão desejada por outros. Ledo engano... Tendo em vista o quanto exposto, quando da entrada em vigor da EC n ${ }^{\circ}$ 45/2004, o legislador ordinário já tinha ido muito mais longe, embora nem todos, num primeiro momento, tivessem se dado conta disso.

Em 1999, BARbosa Moreira já havia feito constatação nesse sentido: "Emenda constitucional, para estabelecer que as Súmulas, sob certas condições, passarão a vincular os outros órgãos judiciais? Ora, mas se já vamos além, e ao custo - muito mais baixo - de meras leis ordinárias (será que somente na acepção técnica da palavra?). O mingau está sendo comido pelas beiradas, e é duvidoso que a projetada emenda constitucional ainda encontre no prato o bastante para satisfazer seu apetite." ${ }^{384}$. Em texto mais recente, datado de 2005, o autor reiterou o entendimento: “(...) No que tange aos órgãos judiciais, dose nada desprezível do que se quis inovar com a Emenda Constitucional $n^{o} 45$ já vinha sendo paulatinamente inoculada, com mão de gato, por meio

\footnotetext{
383 In DinAMARCO, Cândido Rangel, O relator, a jurisprudência e os recursos, in Aspectos polêmicos e atuais dos recursos cíveis de acordo com a Lei $n^{\circ}$ 9.756/98, 1999, p. 132. V., em sentido semelhante, BARbosa MOREIRA, José Carlos, Algumas inovações da Lei 9.756 em matéria de recursos civis, in Aspectos polêmicos e atuais dos recursos cíveis de acordo com a Lei $n^{\circ}$ 9.756/98, 1999, p. 325. V., em sentido contrário, sustentando que, tanto em relação ao art. 557, do CPC, quanto em relação ao antigo art. 544, $\S 3^{\circ}$, do CPC, "não se pode imaginar que constitua a previsão mera faculdade do relator, e que ficaria a seu exclusivo alvitre julgar monocraticamente o recurso ou submetê-lo ao colegiado", ARENHART, Sérgio Cruz, A nova postura do relator no julgamento dos recursos, in Revista de Processo, $\mathrm{n}^{\circ}$ 103, 2001, p. 43.

${ }^{384}$ In BARBosa MoreIRA, José Carlos, Algumas inovações da Lei 9.756 em matéria de recursos civis, in Aspectos polêmicos e atuais dos recursos cíveis de acordo com a Lei $n^{\circ}$ 9.756/98, 1999, p. 329.
} 
de leis ordinárias que reformaram o CPC (...). Em certos aspectos, até se foi mais longe: várias das leis reformadoras atribuíram influência decisiva - bem pouco diversa, em perspectiva prática, da eficácia vinculante prevista no atual art. 103-A da Carta da República - a quaisquer proposições sumuladas e mesmo, em termos gerais, à jurisprudência 'predominante' ou 'dominante', ainda quando não entronizada em Súmula, nem emanada do STF.",385.

Em artigo datado de 2001, voltado à análise das alterações introduzidas pela Lei no 9.756/1998, ARENHART também observou que, "enquanto a doutrina se ocupa de ardorosamente debater o tão temido monstro (ou o tão esperado paladino) da súmula vinculante, recebe o aplicador do Direito, goela abaixo, remédio ainda mais pesado, que atribui vinculação mesmo a simples precedentes jurisprudenciais. Espera-se que o remédio não mate o paciente, mas o que mais admira é a completa falta de discussão em torno deste novos poderes conferidos ao relator." 386.

Em texto dirigido ao exame do art. $555, \S 1^{\circ}$, do $\mathrm{CPC}$, que será objeto do capítulo seguinte, BRAGHITTONI teceu consideração nessa mesma linha, afirmando que " $\mathrm{em}$ doses bastante suaves, quase homeopáticas, o legislador pretende inserir em nosso ordenamento, discretamente, a súmula vinculante" e que "os arts. 527 e 557, CPC, com a redação que a última reforma lhes deu, são os indícios mais eloqüentes nesse sentido"387.

Ao tratar do art. 557, do CPC, DELLORE também afirmou que "a norma é seguramente o cerne para a aplicação da súmula vinculante, abrindo o caminho para que viesse a alteração constitucional com a EC 45/04"388.

Não se pode fechar os olhos para a importância, cada vez mais crescente, do precedente judicial e da jurisprudência. Nem por isso eles podem ser regulados a torto e a

\footnotetext{
${ }^{385}$ In BARBOSA MOREIRA, José Carlos, Súmula, jurisprudência, precedente: uma escalada e seus riscos, in Revista Síntese de Direito Civil e Processual Civil, no 35, 2005, pp. 11/12.

386 In AREnhart, Sérgio Cruz, A nova postura do relator no julgamento dos recursos, in Revista de Processo, no 103, 2001, p. 58.

${ }^{387}$ In BraghitToni, Rogério Ives, Uniformização de jurisprudência e art. 555, §1 ${ }^{\circ}$, do Código de Processo Civil, in Revista do Instituto dos Advogados de São Paulo, no 15, 2005, p. 254.

${ }^{388}$ In DELlORE, Luiz Guilherme Pennacchi, Evolução do controle de constitucionalidade das leis: rumo ao controle concentrado?, Dissertação (Mestrado), 2007, p. 109.
} 
direito, como tem feito o legislador pátrio, sem a atenção devida em relação ao que isso impacta no ordenamento como um todo. Acima de tudo, o que propomos no presente trabalho é uma leitura conjunta e sistemática de todos os dispositivos que regulam a matéria.

\subsubsection{Ampliação dos poderes do juiz de primeiro grau}

$\mathrm{Na}$ onda das reformas que ampliaram os poderes do relator, outras tantas foram introduzidas na legislação processual civil com o intuito de ampliar os poderes também dos juízes de primeiro grau. Para efeitos do nosso estudo, interessam as que dizem respeito à criação de precedentes quase vinculantes, os quais, em determinadas condições, passaram a autorizar o juiz a deixar de receber recurso de apelação e a proferir sentença de improcedência antes mesmo da citação do réu. A seguir, passa-se a tratar dessas duas reformas.

\subsubsection{Art. 518, $\S 1^{o}$, do CPC}

A Lei $n^{\circ} 11.276$, de 7 de fevereiro de 2006, incluiu no art. 518, do CPC, o $\S$ $1^{\circ}$, que dispõe que "o juiz não receberá o recurso de apelação quando a sentença estiver em conformidade com súmula do Superior Tribunal de Justiça ou do Supremo Tribunal Federal ${ }^{, 389}$. Do exame de tal dispositivo, percebe-se que a regra do art. 38 , da Lei $\mathrm{n}^{\circ}$ 8.038/1990, foi praticamente reproduzida para estender ao juiz de primeiro grau os poderes atribuídos por aquele artigo ao relator no STF e no STJ, criando um novo requisito de admissibilidade recursal.

A proposição integrou o conjunto de projetos de lei decorrentes do "Pacto de Estado em Favor de um Judiciário mais Rápido e Republicano", assinado pelo chefe dos três Poderes em 15 de dezembro de 2004, e, conforme mencionado no parecer do relator na

\footnotetext{
${ }^{389}$ É oportuno informar que tramita perante a Câmara dos Deputados o PL n ${ }^{\circ} 1.795 / 2003$, de iniciativa do Dep. AloYsio NunES FERREIRA, cujo objetivo é incluir no CPC o art. 496-A, com a seguinte redação: "Não será admitido qualquer recurso contra decisão que esteja em conformidade com súmula de jurisprudência do Supremo Tribunal Federal ou de Tribunal Superior". O andamento do projeto pode ser conferido em <http://www.camara.gov.br/proposicoesWeb/fichadetramitacao?idProposicao=129993>, acesso em 08/01/2012.
} 
Câmara, o Dep. INALDO LEITÃO, “(...) representa, a nosso sentir, uma medida condizente com a adoção da súmula vinculante (...) ${ }^{\text {390 }}$.

A regra é bastante relevante, pois autoriza - embora aparentemente determine, já que o texto diz que "o juiz não receberá (...)" (destaque nosso)"391 - ao juiz que barre o recurso logo na origem, impedindo o acesso da parte interessada ao duplo grau de jurisdição. É claro que a parte ainda poderia recorrer de tal decisão via agravo de instrumento, mas, pela regra do art. 557, caput, do CPC, já tratado, o apelo dificilmente teria seguimento.

No geral, pensamos que a regra é positiva. Introduziu-se no ordenamento uma forma de obstar o seguimento do recurso logo na origem, à semelhança do que pode ser feito pelo relator, à luz do art. 557, caput, do CPC. De certa forma, estabelece-se que a sentença em conformidade com súmulas do STF e do STJ não necessita de revisão, pois a matéria já está pacificada, não sendo o recurso de apelação o meio adequado para a revisão do precedente ${ }^{392}$. Porém, justamente pelo fato de essa norma estar diretamente ligada à norma do referido art. $557^{393}$, o legislador deveria ter permitido que o paradigma utilizado fosse proveniente de qualquer tribunal superior, e não apenas do STF e do STJ, à semelhança do que dispõe aquele dispositivo legal, estabelecendo uma relação de continuidade entre elas. Mais uma vez se vê que a coerência não é o forte do nosso Código.

O $\S 2^{\circ}$ do art. 519, do CPC, faculta ao juiz, após a apresentação da resposta pelo apelado, "o reexame dos pressupostos de admissibilidade do recurso", entre os quais a rigor se enquadraria a conformidade com súmula do STF e do STJ, mas tal possibilidade parece de pouca utilidade para o caso em tela (tanto que a disposição já constava do CPC, como par. único do art. 519, quando o $\S 1^{\text {o }}$ foi incluído). Isso porque o ato de receber ou não o recurso é anterior ao ato de abrir vista à parte contrária (o próprio caput do artigo

\footnotetext{
${ }^{390}$ In DALL'AgNOL JunioR, Antonio Janyr, Admissão do recurso de apelação e súmulas (exegese do art. 518, § 1 $1^{o}$, do CPC), in Revista do Advogado, nº 85, 2006, pp. 182/183.

${ }^{391}$ Nesse ponto, reitera-se o quanto dito no item "4.3.2.5" acima.

392 In Dall'AgnOl Junior, Antonio Janyr, Admissão do recurso de apelação e súmulas (exegese do art. 518, $\S 1^{\circ}$, do CPC), in Revista do Advogado, nº 85, 2006, p. 185.

${ }^{393}$ V., em sentido semelhante, afirmando que "a correlação entre o art. 557 e o art. 518, $\$ 1{ }^{o}$ pode ser vislumbrada como os dois lados de uma moeda, no tocante à aplicação da súmula para agilizar os julgamentos", DELloRE, Luiz Guilherme Pennacchi, Evolução do controle de constitucionalidade das leis: rumo ao controle concentrado?, 2007, p. 147.
} 
aduz que "interposta a apelação, o juiz, declarando os efeitos em que a recebe, mandará dar vista ao apelado para responder"). Logo, se o recurso sequer será recebido, não será aberta vista à parte contrária, tampouco será apresentada resposta pelo apelado, de modo que não haverá oportunidade para o juiz reexaminar a conformidade ou não do recurso com as súmulas do STF e do STJ.

\subsubsection{Art. 285-A, do CPC}

De todas as alterações introduzidas na legislação com o propósito de alargar os poderes dos magistrados e de prestigiar o precedente judicial e a jurisprudência, aquela representada pelo art. 285-A, do CPC, é sem dúvida a que mais nos causa espanto. Não à toa, a norma gerou enorme polêmica nos círculos doutrinários, antes mesmo de vencidos os noventa dias de sua vacância, e ensejou a propositura, em 29 de março de 2006, de ação direta de inconstitucionalidade pelo Conselho Federal da Ordem dos Advogados do Brasil, à qual aderiu o Instituto Brasileiro de Direito Processual - IBDP na qualidade de amicus curiae, ainda pendente de julgamento junto ao STF (ADIn $n^{\text {o } 3.695)}$ (394. $^{3 .}$.

De tudo o que já se disse, fica claro que, do nosso ponto de vista, idealmente, apenas as súmulas (todas elas) dos tribunais superiores deveriam ter eficácia vinculante; nosso sistema, porém, optou por restringir tal eficácia a um número ainda menor de espécies, ou seja, às súmulas do STF editadas em conformidade com o art. 103$\mathrm{A}, \mathrm{da} \mathrm{CF}$, e às decisões proferidas em sede de controle de constitucionalidade concentrado, conferindo ainda eficácia quase vinculante a outros tantos paradigmas, em determinadas situações.

Até aí tudo bem, não fosse o fato de o legislador estender tal eficácia quase vinculante, em alguns casos, a mera jurisprudência dominante, e em outros, a paradigmas provenientes de tribunais locais ou regionais. Não contente, o legislador foi ainda mais

\footnotetext{
${ }^{394}$ Andamento disponível em <http://www.stf.jus.br/portal/processo/verProcessoAndamento.asp>, acesso em 08/01/2012. Para GAJARDONI, o verdadeiro motivo que ensejou a propositura da ação foi a "reserva de mercado da advocacia, abalada pela dispensa de contratação de advogado pelo réu vencedor na ação não apelada" (in GAJARDONI, Fernando da Fonseca, O princípio constitucional da tutela jurisdicional sem dilações indevidas e o julgamento antecipadíssimo da lide (artigo 285-A do CPC), in As grandes transformações do processo civil brasileiro - Homenagem ao Professor Kazuo Watanabe, 2009, p. 1.007). Ainda que esse tenha sido esse o mote propulsor da ação, o que não confirmamos, mas de que também não duvidamos, a novidade legislativa merece sim ser questionada e atacada.
} 
além e, por meio do art. 285-A, do CPC, conferiu eficácia quase vinculante a meros precedentes, oriundos de órgão de primeiro grau de jurisdição, mais especificamente do próprio juízo - caso a regra fosse ampliada para qualquer órgão de primeiro grau subordinado a um dado tribunal poderia se cogitar de um suposto propósito de uniformização interna, mas não é o caso.

Com efeito, consta do art. 285-A, caput, do CPC, fruto da Lei $\mathrm{n}^{\circ} 11.277$, de 7 de fevereiro de $2006^{395}$, que "quando a matéria controvertida for unicamente de direito $e$ no juízo já houver sido proferida sentença de total improcedência em outros casos idênticos, poderá ser dispensada a citação e proferida sentença, reproduzindo-se o teor da anteriormente prolatada". Os $\S \S 1^{\circ}$ e $2^{\circ}$ determinam, respectivamente, que: "se o autor apelar, é facultado ao juiz decidir, no prazo de 5 (cinco) dias, não manter a sentença e determinar o prosseguimento da ação"396, e "caso seja mantida a sentença, será ordenada a citação do réu para responder ao recurso".

Como se vê, o dispositivo acima faculta ao juiz de primeiro grau, ao receber a inicial, proferir sentença de plano, sem sequer determinar a citação do réu, se: a matéria de mérito ${ }^{397}$ for unicamente de direito; e no próprio juízo já houver sido proferida sentença de total improcedência em outros casos "idênticos"398. Nesse caso deverá reproduzir o teor

\footnotetext{
${ }^{395}$ Para PINTO, a Lei n ${ }^{\circ}$ 11.277/2006 é emblemática dos desideratos do legislador, de associar a modernidade cibernética à celeridade, simplicidade de formas e efetividade de resultados (in PINTO, José Augusto Rodrigues, Constitucionalidade e supletividade do artigo 285-A do CPC, in LTr: suplemento trabalhista, $\mathrm{n}^{\circ}$ 88, 2006, p. 371).

${ }^{396}$ Assim como faz o art. 296, caput, do CPC, o dispositivo amplia o rol do art. 463, do CPC, que dispõe que, "publicada a sentença, o juiz só poderá alterá-la: I-para lhe corrigir, de ofício ou a requerimento da parte, inexatidões materiais, ou lhe retificar erros de cálculo; II - por meio de embargos de declaração".

${ }^{397}$ O texto legal fala em "matéria controvertida" e não em "matéria de mérito", mas, a rigor, em não tendo o réu oferecido resistência aos pontos da petição inicial, de modo a convertê-los em questões, não há que se falar em controvérsia, ou em matéria controvertida, ainda. V., no mesmo sentido, criticando a falta de técnica do legislador, BONDIOLI, Luis Guilherme Aidar, O julgamento liminar de improcedência da demanda da ótica do réu (art. 285-A), in Direito civil e processo - Estudos em homenagem ao Professor Arruda Alvim, 2007, p. 1.324, nota de rodapé no 3, Burini, Bruno, O artigo 285-A do Código de Processo Civil, in Direito processual civil, 2007, pp. 182/183 e WAMBIER, Teresa Arruda Alvim, Anotações sobre princípio do contraditório como um dos fundamentos do processo civil contemporâneo, in Direito processual civil, 2007, p. 78.

${ }^{398}$ Ao falar em outros casos idênticos, o juiz certamente não quis se referir a ações idênticas (mesmas partes, mesma causa de pedir e mesmo pedido, cf. art. 301, § $2^{\circ}$, do CPC), senão teria que rejeitar a ação em razão da litispendência ou da coisa julgada. V., nesse sentido, GAJARDONI, Fernando da Fonseca, O princípio constitucional da tutela jurisdicional sem dilações indevidas e o julgamento antecipadíssimo da lide (artigo 285-A do CPC), in As grandes transformações do processo civil brasileiro - Homenagem ao Professor Kazuo Watanabe, 2009, pp. 1.015/1.016 e WAMBIER, Teresa Arruda Alvim, Anotações sobre princípio do
} 
da sentença adotada como paradigma, a qual funcionará praticamente como uma súmula vinculante de primeiro grau ${ }^{399}$, abrindo espaço para uma nova figura processual: a sentença emprestada $^{400}$.

A nosso ver, o legislador extrapolou todos os limites, chegando ao paroxismo $^{401}$. Há um sem-número de questões que não recomendam o julgamento de plano pelo juiz (exceto nas hipóteses do art. 295, do CPC, que dizem respeito a matérias preliminares $\left.^{402}\right)$.

Por exemplo, a lei simplesmente ignora a possibilidade de o réu, ao ser citado, reconhecer a procedência do pedido do autor, o que daria ensejo a resolução de mérito, nos termos do art. 269, II, do CPC. Embora se imagine que a situação não seja das mais comuns, a permissão é conferida pelo sistema do Código de Processo Civil e por isso deveria ser garantida por ele, em todas as suas proposições. Porém, enquanto se dá com uma mão, se tira com a outra. Configura-se quase uma antinomia, restando patente mais essa incoerência interna no sistema.

Ademais, parece que o alvo diretamente visado pela regra foi o de descongestionar o trânsito processual, fulminando processos alicerçados sobre teses jurídicas já repetidamente repelidas. Tal resultado, no entanto, só será efetivamente alcançado se o autor não apelar dessa sentença. Logo, a não ser que haja uma mudança radical na cultura dos recursos que impera em nossa sociedade - o que não prevemos, pelo

contraditório como um dos fundamentos do processo civil contemporâneo, in Direito processual civil, 2007, p. 78.

${ }^{399}$ In PINTO, José Augusto Rodrigues, Constitucionalidade e supletividade do artigo 285-A do CPC, in LTr: suplemento trabalhista, $\mathrm{n}^{\circ} 88,2006$, p. 371.

${ }^{400}$ In MEDINA, Paulo Roberto de Gouvêa, Sentença emprestada - uma nova figura processual..., in Revista de Processo, $\mathrm{n}^{\circ}$ 135, 2006, p. 153.

${ }^{401}$ A opinião não é só nossa. Também criticando o instituto, WAMBIER pondera que "o novo art. 285-A é uma demonstração eloqüente e lamentável da tentativa de resolver os grandes problemas estruturais do País (inclusive do processo) pela via da negativa de fruição de garantias constitucionais" (in WAMBIER, Teresa Arruda Alvim, Anotações sobre princípio do contraditório como um dos fundamentos do processo civil contemporâneo, in Direito processual civil, 2007, p. 74).

${ }^{402}$ Vale ressaltar que tramita perante o Senado Federal o PL n ${ }^{\circ}$ 134/2004, de iniciativa do Sen. PEDRO SimON, que altera os arts. 267, 269 e 295, do CPC, para autorizar o juiz a indeferir a inicial quando esta contrariar, em matéria exclusivamente de direito, súmula do STF. 
menos a curto e médio prazo ${ }^{403}$-, haverá mera transferência do problema do primeiro para o segundo grau de jurisdição ${ }^{404}$.

E se o autor tiver a sua apelação provida pelo tribunal, a situação se agravará ainda mais, pois o processo, após mobilizar o tribunal, retornará para mobilizar novamente o primeiro grau de jurisdição ${ }^{405}$. No caso, o instituto também não parece proporcionar celeridade, já que o autor terá a sua ação processada somente após aguardar anos a fio a decisão do tribunal. Poder-se-ia argumentar que essa hipótese, de fato desfavorável, ficaria restrita aos poucos casos em que o recurso de apelação do autor fosse provido. A verdade é que não se tem dados concretos para saber se essa situação é tão pouco recorrente assim, a ponto de justificar a opção feita pelo legislador à custa de outros princípios caríssimos ao processo civil.

Poder-se-ia argumentar, ainda, que a norma seria extremamente benéfica para o réu, que, na hipótese da prolação de sentença de improcedência, de plano ficaria protegido, sem passar pelos inconvenientes de ser citado em uma ação judicial e de ter de apresentar defesa ${ }^{406}$. Novamente o argumento cai por terra, pois o $\S 2^{\circ}$ manda que, interposto recurso de apelação pelo autor e mantida a sentença, o juiz ordene a citação do

\footnotetext{
${ }^{403}$ V., em sentido semelhante, asseverando que, historicamente, a prolação da sentença contra os interesses de qualquer das partes quase sempre gera a interposição de apelação, especialmente pelo sentimento de inconformismo que é próprio do ser humano, o qual parece ainda maior quando a perda processual ocorre logo depois da distribuição da primeira peça, MoNTENEGRO FILHO, Misael, Primeiras impressões a respeito do artigo 285-A. A criação do processo entre o autor e o magistrado, in Revista do Advogado, $\mathrm{n}^{\circ}$ 85, 2006, p. 192.

${ }^{404}$ V., exatamente no mesmo sentido, WAMBIER, Teresa Arruda Alvim, Anotações sobre princípio do contraditório como um dos fundamentos do processo civil contemporâneo, in Direito processual civil, 2007, p. 74. V., reconhecendo que "as vantagens vislumbradas pelo legislador atrelam-se à expectativa de que o pronunciamento liminar efetivamente coloque fim ao processo, convencendo o autor da inexistência do direito por ele alegado e desencorajando-o de levar o feito adiante, que, assim, encerrar-se-ia com o menor dispêndio de energia possível e sem a participação do réu", embora se posicione favoravelmente ao instituto, BONDIOLI, Luis Guilherme Aidar, O julgamento liminar de improcedência da demanda da ótica do réu (art. 285-A), in Direito civil e processo - Estudos em homenagem ao Professor Arruda Alvim, 2007, p. 1.324.

${ }^{405} \mathrm{~V}$., no mesmo sentido, embora se posicione favoravelmente ao instituto, PINTO, José Augusto Rodrigues, Constitucionalidade e supletividade do artigo 285-A do CPC, in LTr: suplemento trabalhista, $\mathrm{n}^{\circ}$ 88, 2006, p. 374.

${ }^{406} \mathrm{~V}$., nesse sentido, BONDIOLI, Luis Guilherme Aidar, O julgamento liminar de improcedência da demanda da ótica do réu (art. 285-A), in Direito civil e processo - Estudos em homenagem ao Professor Arruda Alvim, 2007, p. 1.323, BURINI, Bruno, O artigo 285-A do Código de Processo Civil, in Direito processual civil, 2007, p. 203 e GRINOVER, Ada Pellegrini, Mudanças estruturais no processo civil brasileiro, in Revista IOB de Direito Civil e Processual Civil, no 44, 2006, p. 51.
} 
réu para oferecer contrarrazões ${ }^{407}$. Como já se disse, "aqui, toda a aclamada celeridade atribuída ao feito é dissipada com a volta ao velho modelo"408. Assim, o argumento apenas prosperaria se fossem mínimos os casos em que o autor apelasse após receber sentença de improcedência, o que é bastante duvidoso, como já indicado acima.

Outras tantas críticas se colocam à figura processual criada pelo art. 285-A, do CPC, mas seu exame foge das pretensões do presente trabalho ${ }^{409}$. Nesta sede, o que interessa é que, para conferir efeito quase vinculante, nem mesmo súmula ou jurisprudência dominante a regra exige; basta que tenham sido proferidas duas (ou mais) sentenças de improcedência em casos idênticos. Diz-se duas pois o artigo fala em "outros casos idênticos", no plural, sem estabelecer um número mínimo de julgados ${ }^{410}$. Além disso, o referencial nem é tribunal superior, ou tribunal local ou regional, ou até mesmo comarca (o que já seria o cúmulo do absurdo), mas o próprio juízo.

É suficiente, portanto, que determinado juízo profira duas sentenças de improcedência em caso que alegue ser apenas de direito para que o magistrado fique indefinidamente autorizado a reproduzir o entendimento em outros "casos idênticos", sem a necessidade de sequer citar o réu, numa espécie de julgamento antecipadíssimo da

\footnotetext{
${ }^{407}$ V., afirmando que tecnicamente o caso é de intimação, não de citação, MoNTENEGRO FILHO, Misael, Primeiras impressões a respeito do artigo 285-A. A criação do processo entre o autor e o magistrado, in Revista do Advogado, no 85, 2006, pp. 193/194.

${ }^{408}$ In Burini, Bruno, O artigo 285-A do Código de Processo Civil, in Direito processual civil, 2007, p. 207.

409 Também foge das pretensões do presente trabalho o exame de outras áridas questões que exsurgem da sistemática implementada pelo art. 285-A, do CPC. Por exemplo, ao responder ao recurso do autor, o réu deve fazê-lo como se estivesse a apresentar contestação? Pode apresentar reconvenção, impugnação ao valor da causa ou invocar alguma espécie de intervenção de terceiros? Ainda que o autor opte por não recorrer da sentença, deve o réu ser cientificado da ação e de seu resultado, por aplicação analógica do art. 219 , $\S 6^{\circ}$, do CPC?

410 V., no mesmo sentido, GAJARDONI, Fernando da Fonseca, O princípio constitucional da tutela jurisdicional sem dilações indevidas e o julgamento antecipadíssimo da lide (artigo 285-A do CPC), in As grandes transformações do processo civil brasileiro - Homenagem ao Professor Kazuo Watanabe, 2009, p. 1.017 e WAMBIER, Teresa Arruda Alvim, Anotações sobre princípio do contraditório como um dos fundamentos do processo civil contemporâneo, in Direito processual civil, 2007, p. 77. V., em sentido diferente, sustentando que, apesar de a lei não estabelecer um número mínimo, deve-se pensar em número representativo de demandas similares julgadas num mesmo sentido, com vistas a evidenciar a firmeza do entendimento, BONDIOLI, Luis Guilherme Aidar, O julgamento liminar de improcedência da demanda da ótica do réu (art. 285-A), in Direito civil e processo - Estudos em homenagem ao Professor Arruda Alvim, 2007, p. 1.325 e BuRINI, Bruno, $O$ artigo 285-A do Código de Processo Civil, in Direito processual civil, 2007, pp. 201/203.
} 
$\operatorname{lide}^{411}$. Note-se que o artigo não exige que a sentença tenha transitado em julgado ${ }^{412}$ ou que tenha sido confirmada pelos tribunais competentes ${ }^{413}$; não há, portanto, um mínimo controle da qualidade, ou mesmo da legalidade da decisão, que são simplesmente presumidas pela lei processual.

Nessa linha de pensamento, como a lei não faz restrição a esse respeito, é possível que o juiz continue a reproduzir a sentença mesmo após a sua reforma pelo tribunal. Por vezes poderá fazê-lo por desconhecimento (já que após o julgamento da apelação pelo tribunal os autos normalmente demoram alguns meses para retornar ao primeiro grau), por outras por simples teimosia, com amparo no texto literal da lei, que não traça nenhum mecanismo para impedir essa teratológica situação. O resultado, enfim, é a possibilidade de o juiz continuar decidindo em sentido contrário ao de precedente, jurisprudência ou súmula dos tribunais competentes, e até mesmo dos tribunais superiores, o que vai de encontro a tudo que se defende neste trabalho.

Mesmo rendendo homenagens ao instituto, BONDIOLI reconhece que a tese jurídica a ser enfrentada para o julgamento da causa deve estar suficientemente amadurecida e solidificada e que tais requisitos não se satisfazem com a existência apenas no juízo de pronunciamentos uniformes em torno do tema. Segundo o autor, "elas [a maturidade e a solidez da tese jurídica] exigem também manifestações coincidentes $e$ reiteradas de outros órgãos julgadores, principalmente dos tribunais encarregados de dar a última palavra acerca do assunto em debate, que devem ser retratadas na sentença liminar" ${ }^{414}$. Há quem ainda vá além, como é o caso de WAMBIER, sustentando que " $a$

\footnotetext{
411 Ao se referir à nova figura processual, a doutrina já falou também em julgamento sumário do mérito, julgamento superantecipado, julgamento prima facie, julgamento in limine, julgamento de improcedência manifesta, julgamento liminar de ações repetitivas, resolução imediata etc.

412 BURINI alega que seria de se cogitar que o magistrado mais cauteloso aguardasse que os paradigmas transitassem em julgado para auferir com alto grau de probabilidade o acerto da interpretação, mas conclui que, em razão do tempo que o processo normalmente demora para ser definitivamente julgado, isso contrariaria o espírito criador da norma (in BURINI, Bruno, O artigo 285-A do Código de Processo Civil, in Direito processual civil, 2007, p. 196).

${ }^{413}$ V., criticando esse aspecto da norma, MONTENEGRO FILHO, Misael, Primeiras impressões a respeito do artigo 285-A. A criação do processo entre o autor e o magistrado, in Revista do Advogado, $\mathrm{n}^{\circ}$ 85, 2006, $\mathrm{p}$. 192.

${ }^{414}$ In BONDIOLI, Luis Guilherme Aidar, O julgamento liminar de improcedência da demanda da ótica do réu (art. 285-A), in Direito civil e processo - Estudos em homenagem ao Professor Arruda Alvim, 2007, p. 1.324. V., em sentido semelhante, afirmando que "parece extremamente conveniente rejeitar-se uma jurisprudência dominante de juízo em desconformidade com súmulas de tribunais superiores", BURINI, Bruno, O artigo 285-A do Código de Processo Civil, in Direito processual civil, 2007, p. 194.
} 
coincidência entre a orientação adotada pelo juízo de primeiro grau e o entendimento manifestado por tribunal que lhe seja hierarquicamente superior é, assim, pressuposto fundamental para a incidência do art. 285-A" ${ }^{\wedge 15}$. Concordamos em todos os aspectos com tais ponderações, exceto com a alegação de que as mesmas se encontram refletidas na norma legal ${ }^{416}$. Só nos resta contar com o bom-senso e com a benemerência esperados do julgador no momento de interpretá-la, e com a consolidação de entendimento jurisprudencial nesse sentido...

De mais a mais, como em primeiro grau, salvo raras exceções, não há especialização de juízos, é possível (e até esperado) que processos sobre a mesma matéria sejam distribuídos a diferentes juízos. Nessa situação, poderão ter seu curso normal ou interrompido precocemente, conforme já tenha sido proferida sentença de improcedência naquele juízo ou não. Irrompe daí inconveniente efeito colateral, que é o da pulverização de diretrizes jurisprudenciais entre os diferentes juízos ${ }^{417}$, criando verdadeiro "caos jurisprudencial ${ }^{418}$. Fica evidente a violação ao princípio da isonomia.

415 In WAMBIER, Teresa Arruda Alvim, Anotações sobre princípio do contraditório como um dos fundamentos do processo civil contemporâneo, in Direito processual civil, 2007, p. 77. V., em sentido semelhante, BuEno, Cássio Scarpinella Bueno, A nova etapa da reforma do Código de Processo Civil, vol. 2, 2007 , p. 57. Esse autor inclusive propõe, "em nome da leitura sistemática do processo civil a que insistentemente me refiro (...), uma interpretação do art. 285-A em que 'sentença do juízo' seja entendida simetricamente aos já referidos dispositivos de lei, isto é, como 'súmula ou jurisprudência dominante do respectivo tribunal, do Supremo Tribunal Federal, ou de Tribunal Superior', para empregar, aqui, o referencial amplo do caput do art. 557, na redação da Lei n. 9.756/1998. Até porque, também por força das premissas fundantes do meu pensamento sobre o direito processual civil, esta é a única forma de manter o art. 285-A afinado ao 'modelo constitucional do processo', observando-se de forma potencializada o princípio da isonomia a que fiz referência acima." (in idem, ibidem, p. 55). V., no mesmo sentido, LuCON, Paulo Henrique dos Santos, Duração razoável e informatização do processo nas recentes reformas, in Direito civil e processo - Estudos em homenagem ao Professor Arruda Alvim, 2007, p. 1.410.

${ }^{416}$ V., em sentido parecido com o nosso: "Em nenhum momento a norma em comento faz a exigência de que o julgado já prolatado e reproduzido por força do novo instituto esteja em consonância com o julgamento dos tribunais, em especial do Superior Tribunal de Justiça e do Supremo Tribunal Federal. Todos os comentaristas da norma, entretanto, com muita propriedade, vêm condicionando a prolação da sentença repetida a esta exigência, até para que o instituto atenda aos seus propósitos de desburocratização e celeridade." (in GAJARDONI, Fernando da Fonseca, O princípio constitucional da tutela jurisdicional sem dilações indevidas e o julgamento antecipadíssimo da lide (artigo 285-A do CPC), in As grandes transformações do processo civil brasileiro - Homenagem ao Professor Kazuo Watanabe, 2009, p. 1.014).

${ }^{417}$ V., fazendo alusão ao fenômeno, Burini, Bruno, O artigo 285-A do Código de Processo Civil, in Direito processual civil, 2007, p. 194.

${ }^{418}$ V., utilizando essa expressão, com fundamento na lição de TARUFFO, para se referir a situação em que há pulverização ou contrariedade plural entre decisões, por existirem orientações diferentes e incoerentes, LOPES, Raquel Cardoso, Uniformização da jurisprudência, in Revista Forense, vol. 390, 2007, p. 572. 
Isso sem contar que nem sempre haverá um entendimento consolidado dentro do próprio juízo. Há varas em que há mais de um juiz fixo (titular e auxiliar) e, em virtude do livre convencimento motivado (art. 131, do CPC), nada impede que cada um deles tenha entendimento diverso sobre o mesmo tema ${ }^{419}$.

Outro ponto digno de nota é que as sentenças proferidas em primeiro grau não possuem a mesma publicidade que os julgamentos proferidos pelos tribunais. Enquanto esses são recolhidos em repertórios de jurisprudência e na maioria das vezes ficam disponíveis na íntegra nos sites dos tribunais, que contam com avançados meios de busca, aquelas normalmente só são divulgadas entre as partes do processo. Como sustenta TARUFFO, "a judgement may actually become a precedent only when it is known not only by the parties to the single case but also to other courts, to lawyers and virtually to the general public" $" 420$. Tendo esse aspecto em mente, a situação preconizada pelo Código de Processo Civil atenta contra o princípio da segurança jurídica, pois o processo poderá ter desfecho desfavorável de forma supreendente, com fundamento em decisão anterior completamente desconhecida pelo autor da demanda ${ }^{421}$. Conforme ressalta MEDINA, "tudo se passa como se vigorasse, em primeiro grau de jurisdição, o sistema da súmula vinculante, sem súmula..."

\footnotetext{
${ }^{419}$ GAJARDONI recomenda que, em casos tais, melhor que não se permita a aplicação do dispositivo (in GAJARDONI, Fernando da Fonseca, O princípio constitucional da tutela jurisdicional sem dilações indevidas e o julgamento antecipadíssimo da lide (artigo 285-A do CPC), in As grandes transformações do processo civil brasileiro - Homenagem ao Professor Kazuo Watanabe, 2009, p. 1.012). Na nossa concepção, melhor que se revogue por completo o dispositivo, pois, na medida em que ele não exige um entendimento consolidado do juízo, ou bem ele vale para todas as situações, ou bem não vale para nenhuma.
}

${ }^{420}$ In TARUFFO, Michele, Institutional factors influencing precedents, in Interpreting precedents: a comparative study, 1997, p. 451.

${ }^{421}$ A respeito do assunto, para GAJARDONI, o fato de a norma processual determinar que as decisões paradigmas tenham sido proferidas no mesmo juízo objetiva dar racionalidade e previsibilidade à sistemática implantada, "permitindo ao jurisdicionado, por seus advogados, o prévio conhecimento do entendimento que naquela unidade judicial vem sendo adotado sobre determinado tema" (in GAJARDONI, Fernando da Fonseca, $O$ princípio constitucional da tutela jurisdicional sem dilações indevidas e o julgamento antecipadíssimo da lide (artigo 285-A do CPC), in As grandes transformações do processo civil brasileiro Homenagem ao Professor Kazuo Watanabe, 2009, p. 1.011). A observação acima só faz sentido no caso de comarca com vara única, hipótese em que seria um pouco mais fácil (embora, ainda assim, não tão fácil) ter conhecimento prévio sobre o entendimento do juízo. No caso de comarcas com mais de uma vara (como é o caso da Capital do Estado de São Paulo, por exemplo, em que só o foro central conta com quarenta e duas varas cíveis em primeiro grau, e em breve contará com cinquenta e sete, nos termos da Lei Complementar $\mathrm{n}^{\circ}$ 1.149, de 6 de outubro de 2011) é impossível antecipar o entendimento do juízo, já que a distribuição do processo é feita por sorteio e o juízo só é conhecido após o ajuizamento da ação.

${ }^{422}$ In Medina, Paulo Roberto de Gouvêa, Sentença emprestada - uma nova figura processual..., in Revista de Processo, no 135, 2006, p. 156. 
A propósito da discricionariedade criada pelo dispositivo, BARBOSA MOREIRA abordou muito bem o assunto e por isso tomamos a liberdade de reproduzir suas palavras: "Dificilmente se concebe incentivo maior à preguiça, ou, em termos menos severos, ao comodismo do julgador, que poderá valer-se da franquia para desvencilhar-se rapidamente do estorvo de novo processo, com a pura e simples baixa de um arquivo do computador. Dir-se-á que o texto projetado restringe a possibilidade às hipóteses em que não haja 'qualquer singularidade’ na causa agora ajuizada; mas a lei do menor esforço quase fatalmente induzirá o juiz menos consciencioso a enxergar identidade onde talvez não exista mais que vaga semelhança. A tentação da facilidade será forte demais, sobretudo quando grande a carga de trabalho que estiver assoberbando o magistrado. Em não poucos casos, ante a primeira impressão de déjà vu, a própria leitura da petição inicial corre o perigo de ver-se truncada, ou reduzida a sumária olhadela, desatenta a argumentos porventura novos que autor suscite. Não se poderá contar muito, por parte do juiz, com o empenho - tão desejável - numa reflexão constantemente renovada sobre as questões de direito que lhe incumbe enfrentar." ${ }^{423}$.

Por tudo isso, melhor seria se o legislador tivesse autorizado o julgamento de improcedência de plano com base em súmula dos tribunais superiores, e não com fundamento em sentenças anteriores do mesmo juízo. Afinal, como afirma BuENo, "se um dos grandes nortes das mais recentes reformas do Código de Processo Civil é racionalizar o acesso à Justiça, imperioso que o paradigma desta racionalização seja o mais duradouro, o mais seguro, o mais sólido, o mais uniforme possível, do ponto de vista sistemático. Não o menos duradouro, o menos seguro, o menos sólido, o menos uniforme, porque o mais passageiro, efêmero, até mesmo." ${ }^{\text {424 }}$. Mas, ainda assim, entendemos que, com exceção dos casos amparados pelo art. 295, do CPC, deveria sempre ser triangular a relação processual, com a citação do réu ${ }^{425}$. Nem mesmo a existência de súmula vinculante

\footnotetext{
${ }^{423}$ In BARBosa MoReIRA, José Carlos, Súmula, jurisprudência, precedente: uma escalada e seus riscos, in Revista Síntese de Direito Civil e Processual Civil, no 35, 2005, pp. 15/16.

${ }^{424}$ In BuEno, Cássio Scarpinella Bueno, A nova etapa da reforma do Código de Processo Civil, vol. 2, 2007, pp. $60 / 61$.

${ }^{425}$ Como demonstra RoDrigues, fazendo referência à tese de doutorado de LuIz CARLOS DE AZEVEDO, intitulada de "O direito de ser citado - perfil histórico", "um dos traços apontados pelo prestigiado Professor Azevedo é 'a presença sempre constante do ato citatório como condição indisponível à legitimidade do processo' a despeito das 'cíclicas mutações das idéias, conceitos e princípios por que tem passado a humanidade' (ob. cit. 32)" (in RoDRIGUES, Walter Piva, O direito de ser citado, in IOB - Repertório de Jurisprudência: civil, processual, penal e comercial, n 1, 1994, p. 19).
} 
do STF deveria ser suficiente para autorizar o referido julgamento antecipadíssimo da $\operatorname{lide}^{426}$.

\subsubsection{Análise crítica}

Para fins de sistematização da matéria, resumimos no quadro abaixo as alterações legislativas abordadas nos itens "4.3.3.1" e "4.3.3.2”:

\begin{tabular}{|c|c|c|c|c|c|}
\hline \multicolumn{6}{|c|}{ Ampliação dos poderes do juiz de primeiro grau } \\
\hline $\begin{array}{l}\text { Previsão } \\
\text { legal }\end{array}$ & $\begin{array}{l}\text { Âmbito de } \\
\text { atuação }\end{array}$ & $\begin{array}{l}\text { Dever ou } \\
\text { faculdade }\end{array}$ & $\begin{array}{c}\text { Providência, } \\
\text { mediante decisão } \\
\text { monocrática }\end{array}$ & Situação & Resultado \\
\hline $\begin{array}{l}\text { Art. 518, } \S \\
1^{\circ}, \text { do CPC }\end{array}$ & $\begin{array}{l}\text { Recurso de } \\
\text { apelação }\end{array}$ & Dever & $\begin{array}{l}\text { Não receber o } \\
\text { recurso }\end{array}$ & $\begin{array}{l}\text { Decisão recorrida em } \\
\text { conformidade com } \\
\text { súmula do STJ ou do STF }\end{array}$ & $\begin{array}{l}\text { Súmula impeditiva de } \\
\text { recurso }\end{array}$ \\
\hline $\begin{array}{l}\text { Art. 285- } \\
\text { A, do CPC }\end{array}$ & $\begin{array}{c}\text { Ação em } \\
\text { primeiro grau, } \\
\text { antes de } \\
\text { ordenada a } \\
\text { citação do réu }\end{array}$ & Faculdade & $\begin{array}{l}\text { Proferir sentença, } \\
\text { reproduzindo-se o } \\
\text { teor da } \\
\text { anteriormente } \\
\text { prolatada }\end{array}$ & $\begin{array}{c}\text { Matéria controvertida } \\
\text { unicamente de direito e } \\
\text { sentença anterior de total } \\
\text { improcedência proferida } \\
\text { pelo juízo em outros casos } \\
\text { idênticos }\end{array}$ & $\begin{array}{c}\text { Precedentes } \\
\text { autorizadores de } \\
\text { improcedência de plano }\end{array}$ \\
\hline
\end{tabular}

Da análise dos dispositivos acima, mais uma vez fica a impressão de que faltou ao legislador a devida reflexão. Novamente resta patente a incoerência interna do sistema preconizado pelo Código de Processo Civil.

Embora o art. 518, $\S 1^{\circ}$, do CPC, relacione-se diretamente com o art. 557, caput, do CPC, já que ambos visam ao mesmo fim - aquele para barrar o recurso de apelação logo na origem, este para barrar o recurso de apelação (ou outros recursos, como o agravo de instrumento, por exemplo) no tribunal, antes do julgamento pelo colegiado -, percebe-se que não há uma relação de continuidade entre eles. Já que o art. $518, \S 1^{\circ}$, do CPC, usa como paradigma súmula do STF e do STJ, e o art. 557, caput, do CPC, usa como paradigma súmula e jurisprudência dominante do respectivo tribunal, do STF e de tribunal superior, pode acontecer de um recurso de apelação ser devidamente recebido em primeiro grau, por estar em conformidade com súmula do STF e do STJ, mas ter seu seguimento negado pelo relator, por ser, por exemplo, contrário a jurisprudência dominante do

${ }^{426}$ V., em sentido semelhante ao nosso, sustentando, antes da edição da Lei $\mathrm{n}^{\circ} 11.277 / 2006$, que "ao contrário de algumas posições (inclusive projetos de lei), a aplicação da súmula vinculante não pode, de maneira alguma, ocorrer quando da análise da inicial" e que "talvez seja o caso de regra processual, não, como se pretende, para autorizar o indeferimento da inicial com aplicação da súmula, mas sim para vedar essa possibilidade (...)", PARENTE, Eduardo de Albuquerque, Jurisprudência: da divergência à uniformização, 2006, p. 104. 
respectivo tribunal. Não seria muito mais fácil, e lógico, se os critérios utilizados fossem os mesmos, impedindo-se desde logo a subida do recurso?

As fragilidades decorrentes do art. 285-A, do CPC, são ainda mais patentes, na medida em que o legislador, sem qualquer cautela, erigiu singelas sentenças de primeiro grau do próprio juízo ao status de paradigma apto a autorizar a prolação de sentença de improcedência de plano, mediante julgamento antecipadíssimo da lide, o que para nós não faz absolutamente nenhum sentido.

Por mais que devam ser introduzidas modificações na legislação com vistas a prestigiar o precedente judicial e a jurisprudência, tão essenciais para a aplicação uniforme do direito, o legislador deve antes de tudo ter uma visão geral do sistema, pensando em soluções que se compatibilizem não só com determinado problema específico, mas com o todo. É como o médico: não pode ele prescrever um remédio para tratar de uma gastrite, se o mesmo afetará o coração do paciente; a gastrite deve ser combatida, mas de forma que o resto do corpo permaneça em harmonia. Infelizmente o legislador pátrio não tem tido esse cuidado, como ficou claro dos tópicos anteriores.

Por fim, quanto à suposta obrigatoriedade constante da regra prevista no art. $518, \S 1^{\circ}$, do CPC, reiteramos o quanto exposto no item "4.3.2.5” acima.

\subsubsection{Art. 475, $\& 3^{\circ}$, do CPC}

Além das hipóteses já relatadas, a Lei $n^{\circ} 10.352$, de 26 de dezembro de 2001, criou mais uma de paradigma quase vinculante, conforme redação conferida ao $\S 3^{\circ}$, do art. 475, do CPC, ao estabelecer que não está sujeita à remessa necessária a sentença "fundada em jurisprudência do plenário do Supremo Tribunal Federal ou em súmula deste Tribunal ou do tribunal superior competente", mesmo que proferida contra a União, o Estado, o Distrito Federal, o Município, e as respectivas autarquias e fundações de direito público, ou que julgue procedentes, no todo ou em parte, os embargos à execução de dívida ativa da Fazenda Pública (as duas hipóteses de remessa necessária, previstas, respectivamente, no art. 475 , I e II, do CPC). 
Vê-se que o legislador criou mais um novo critério, ao se referir a “jurisprudência do plenário do Supremo Tribunal Federal” e a "súmula deste Tribunal ou do tribunal superior competente", o que é um contrassenso, já que a remessa necessária, para todos os efeitos, não passa de um recurso de apelação "obrigatório". Assim, se o recurso for manejado voluntariamente, aplicam-se os critérios do art. 518, $\S 1^{\circ}$, do CPC; por outro lado, se for o caso de remessa necessária, invocam-se os critérios, mais amplos, do art. $475, \S 3^{\circ}$, do CPC. De todo modo, uma vez no tribunal, aplicam-se para ambos os casos os critérios do art. 557, caput e $\S 1^{\circ}$, do CPC, e assim por diante.

Assim, nos parece que a regra deveria ser a mesma para os casos de remessa necessária e recurso voluntário e que, num caso e no outro, deveriam surtir efeitos quase vinculante apenas as súmulas dos tribunais superiores, pelos motivos exaustivamente expostos nos tópicos anteriores.

\subsubsection{Art. 481, par. único, do CPC}

Ao lado do controle de constitucionalidade concentrado, já tratado acima, o ordenamento jurídico brasileiro admite o controle de constitucionalidade difuso, feito por via incidental. Seu procedimento vem regulado no próprio Código de Processo Civil, nos arts. 480 a 482, em atendimento ao quanto disposto no art. 97, da CF, que consagra a denominada "cláusula de reserva de plenário nos tribunais" ("somente pelo voto da maioria absoluta de seus membros ou dos membros do respectivo órgão especial poderão os tribunais declarar a inconstitucionalidade de lei ou ato normativo do Poder Público").

A Lei $n^{\circ}$ 9.756/1998, de que já falamos por força das alterações implementadas nos arts. 557 e 120, do CPC, trouxe importante inovação em relação ao controle de constitucionalidade incidental, prevendo mais uma hipótese do que convencionamos chamar de precedente quase vinculante.

Com efeito, dita o procedimento que, arguida a inconstitucionalidade de lei ou de ato normativo do poder público, o relator, ouvido o Ministério Público, submeterá a questão à turma ou câmara, a que tocar o conhecimento do processo (art. 480, do CPC). Se a alegação for rejeitada, prosseguirá o julgamento; se for acolhida, será lavrado o acórdão, a fim de ser submetida a questão ao tribunal pleno (art. 481, caput, do CPC). Porém - e 
aqui está a inovação trazida pela Lei $n^{\circ}$ 9.756/1998 -, os órgãos fracionários dos tribunais não submeterão ao plenário, ou ao órgão especial, a arguição de inconstitucionalidade, quando já houver pronunciamento destes ou do plenário do Supremo Tribunal Federal sobre a questão (art. 481, par. único, do CPC).

Guardadas as devidas proporções, o dispositivo possui semelhanças com os mencionados arts. 557 e 120, do CPC. Enquanto aqueles admitem o julgamento monocrático pelo relator na hipótese de existência de determinados precedentes, o art. 481, par. único, do CPC, determina que o próprio órgão fracionário julgue a arguição de inconstitucionalidade quando já houver pronunciamento do plenário, ou do órgão especial, ou do plenário do Supremo Tribunal Federal sobre a questão.

O raciocínio do legislador foi o seguinte: se já houver decisão do pleno, ou do órgão especial, ou do plenário do STF, acerca da constitucionalidade ou inconstitucionalidade da lei, desnecessário movimentá-los a cada novo processo em que o tema é discutido. O objetivo da norma, claramente, é evitar a mobilização desnecessária da máquina judiciária - no caso, do pleno - quando já houver precedente de órgão hierarquicamente superior. Além da economia processual, o procedimento proporciona uniformização da jurisprudência a respeito da matéria, já que o dito precedente haverá de ser seguido.

A hipótese, novamente, é de precedente com eficácia quase vinculante ${ }^{427}$. Examinando o fenômeno, DeLlore leciona que: “Ora, estamos aqui tratando do controle difuso de constitucionalidade, em que, como é cediço, as decisões geram efeitos apenas inter partes. Assim, para que uma declaração de inconstitucionalidade reconhecida via controle difuso gere efeitos para além dos autos, prevê a Constituição que é necessária a manifestação do Senado Federal (CR, art. 52, X). E o art. 481, p.u. preceitua que, ainda sem a manifestação do Senado, mesmo tratando-se de controle difuso de

\footnotetext{
${ }^{427}$ Em sentido semelhante ao nosso, DinAmARCo sustenta que a hipótese é de eficácia vinculante: " $E$ isso significa, rigorosamente, dar eficácia vinculante aos pronunciamentos destes sobre questões constitucionais. Havendo já algum daqueles pronunciamentos superiores, aos órgãos fracionários não resta mais sequer competência para o juízo delibativo inerente ao incidente de inconstitucionalidade. Deve, simplesmente, aplicar a tese." (in DINAMARCO, Cândido Rangel, O relator, a jurisprudência e os recursos, in Aspectos polêmicos e atuais dos recursos cíveis de acordo com a Lei $n^{\circ} 9.756 / 98,1999$, p. 135). De fato, a hipótese é de eficácia vinculante; porém, como essa eficácia só se verifica se preenchidos determinados requisitos e para fim específico, preferimos chamá-la de eficácia quase vinculante, conforme definição exposta alhures.
} 
constitucionalidade, se um Tribunal superior (STJ ou STF, no caso) já houver se manifestado pela inconstitucionalidade, não haverá necessidade de manifestação plenária do Tribunal inferior. Temos aqui, claramente, uma decisão de controle difuso (inconstitucionalidade reconhecida pelo plenário de um Tribunal superior) gerando efeitos erga omnes ou, pelo menos, para além dos autos (para o plenário de um Tribunal inferior), em uma espécie de efeito vinculante. Trata-se, assim, de um claro abandono do clássico entendimento referente ao controle difuso." ${ }^{428}$.

Como se vê, ao atribuir eficácia à decisão do pleno, ou do órgão especial, ou do plenário do STF, acerca da constitucionalidade ou inconstitucionalidade da lei, para além do processo em que proferida, o CPC subverte o próprio sistema de controle de constitucionalidade, ao fazer com que uma decisão emitida em controle difuso vincule mais do que as próprias partes e surta efeitos para além dos autos, a despeito da não intervenção do Senado Federal.

A iniciativa parece bastante lógica e positiva, porquanto fundada na racionalidade, economia e celeridade ${ }^{429}$. Todavia, pensamos que deveria constar ressalva no sentido de que, na hipótese de divergência entre o julgamento paradigma do pleno, ou do órgão especial, do tribunal e o julgamento paradigma do plenário do STF, este deve prevalecer, sempre. A propósito do assunto, reiteramos as observações feitas quando examinamos o art. 557, do CPC.

\subsubsection{Recurso extraordinário e repercussão geral}

\subsubsection{Considerações introdutórias}

A mesma $\mathrm{EC} \mathrm{n} \mathrm{n}^{\circ} 45 / 2004$, que introduziu no ordenamento jurídico a súmula vinculante, acrescentou o $\S 3^{\circ}$ ao art. 102 , da CF, para o fim de incluir, entre os requisitos de admissibilidade do recurso extraordinário, a demonstração da repercussão geral das

\footnotetext{
${ }^{428}$ In DELlORE, Luiz Guilherme Pennacchi, Evolução do controle de constitucionalidade das leis: rumo ao controle concentrado?, Dissertação (Mestrado), 2007, p. 111.

${ }^{429}$ In DELlORE, Luiz Guilherme Pennacchi, Evolução do controle de constitucionalidade das leis: rumo ao controle concentrado?, Dissertação (Mestrado), 2007, p. 112.
} 
questões constitucionais discutidas no caso. Diz-se que a inovação decorreu da necessidade de diminuir o número e de acelerar a marcha dos recursos nos tribunais superiores ${ }^{430}$.

O novo requisito é de clara inspiração norte-americana ${ }^{431}$ - onde, na existência do writ of certiorari, "o julgamento pelo segundo grau de jurisdição (...) é direito da parte, no entanto, o terceiro grau, que seria o julgamento pela Suprema Corte, só ocorre quando esta entender que é de interesse nacional com a finalidade de fixar um precedente quanto ao ponto, destarte, não existe direito subjetivo para o julgamento pela Corte máxima norte-americana" ${ }^{432}$-, mas encontra antecedente similar no próprio direito brasileiro.

430 In CRUZ E TUCCI, José Rogério, Anotações sobre a repercussão geral como pressuposto de admissibilidade do Recurso Extraordinário (Lei $n^{\circ} 11.418 / 2006$ ), in Revista do Advogado, no 92, 2007, p. 24 e YARSHELl, Flávio Luiz, A Reforma do Judiciário e a promessa de "duração razoável do processo", in Revista do Advogado, $\mathrm{n}^{\circ} 75,2004$, p. 28 . V., em texto datado de 1996, sustentando que para a manutenção do número de juízes no STF a melhor solução seria "a da Corte Suprema americana, deixando ao próprio Tribunal a eleição dos casos que, no interesse da Nação, devam ser decididos", GARCIA, Dínio de Santis, Efeito vinculante dos julgados da Corte Suprema e dos Tribunais Superiores, in Revista dos Tribunais, vol. 734, 1996, p. 46.

${ }^{431}$ Embora outros países também pratiquem mecanismos semelhantes de seleção de causas a serem julgadas pelas cortes supremas. É o caso, por exemplo, da Alemanha, em que o recurso de revision, para ser julgado pelo tribunal supremo, deve ostentar uma "significação fundamental", e da Argentina, em que é vedado à corte suprema conhecer de recurso extraordinário "por falta de agravio suficiente o cuando las cuestiones planteadas resultaren insustanciales o carentes de trascendencia", nos termos do art. 280, do Codigo Procesal Civil y Comercial de la Nación Argentina (in MARINONI, Luiz Guilherme e MitidiERO, Daniel, Repercussão geral no recurso extraordinário, 2008, p. 21). V., no mesmo sentido, CouTo, Mônica Bonetti, Repercussão geral da questão constitucional: algumas notas reflexivas, in Direito civil e processo - Estudos em homenagem ao Professor Arruda Alvim, 2007, p. 1.375, nota de rodapé $n^{\circ} 2$. V., discorrendo sobre a diferença estrutural entre as cortes superiores dos países de civil e de common law e sobre a inexistência nos países de civil law do poder de selecionar os recursos que irão decidir, CAPPELLETTI, Mauro, The judicial process in comparative perspective, 1989, pp. 49/50. O mesmo autor anota que "the end result is that the higher courts of such civil law countries as France, Germany, and Italy must decide several thousands of appeals every year, most of them largely irrelevant for the clarification and evolution of the law" (in idem, ibidem, p. 50), e que, infelizmente, "when the decisions of the supreme court of a country run into the thousands, their quality, care, and ultimately their authority must suffer" (in idem, ibidem, p. 50). V., do mesmo autor, Juizes legisladores?, 1993, pp. 116/119. V., em sentido semelhante, afirmando que o enorme número de sentenças que a Corte de Cassação pronuncia por ano é um fenômeno gravemente patológico, que representa um dos maiores fatores de crise do sistema jurisdicional italiano, TARUFFO, Michele, Precedente $e$ giurisprudenza, in Rivista Trimestrale di Diritto e Procedura Civile, ano 61, $\mathrm{n}^{\circ}$ 3, 2007, p. 714. V., sustentando que o fato de a Corte de Cassação italiana pronunciar cerca de trinta mil decisões por ano transforma-a em "fonte di disorientamento per i giudici di merito", PISANI, Andrea Proto, Principio d'eguaglianza e ricorso per cassazione, in Revista de Processo, n $\mathrm{n}^{\circ}$ 191, 2011, p. 202.

432 In LOPES, Raquel Cardoso, Uniformização da jurisprudência, in Revista Forense, vol. 390, 2007, p. 575. V., em sentido semelhante, explicando que a seleção de recursos pela Suprema Corte norte-americana é feita de acordo com a oportunidade de criar um novo precedente, de proceder ao overruling daquele precedente que não se considera mais válido ou de solucionar conflito entre precedentes, TARUFFO, Michele, Precedente e giurisprudenza, in Rivista Trimestrale di Diritto e Procedura Civile, ano 61, n 3, 2007, p. 719 e idem, Institutional factors influencing precedents, in Interpreting precedents: a comparative study, 1997, p. 446. 
Tempo houve em que, sob a égide de outro regime constitucional, o recurso extraordinário, a priori incabível em algumas hipóteses, era admissível nessas mesmas hipóteses se acompanhado da arguição de relevância da questão federal ${ }^{433}$ (art. 119, III, "a" e “d”, e $\S 1^{\text {o }}$, da CF/1967, alterada pela EC no $1 / 1969$, c/c arts. 325, I a IX, e 327, § $1^{\text {o }}$, do RISTF, com a redação dada pela ER $n^{\circ} 2 / 1985^{434}$ ). Embora os institutos não se confundam, a ideia presente em ambos no sentido de estabelecer uma espécie de "filtro recursal" é mais ou menos a mesma, com vistas a permitir que o Supremo Tribunal Federal reserve a sua atenção e tempo ao trato de questões de maior dimensão, que impactem na vida econômica, social, política e jurídica do país, e não apenas de interesse restrito das partes do processo $^{435}$.

Paradoxalmente, como o requisito de admissibilidade diz respeito somente ao recurso extraordinário, haverá questões constitucionais “menos importantes" para o fim do recurso extraordinário, porquanto despidas de repercussão geral; mas não haverá questões federais "menos importantes" para o fim do recurso especial, como se tudo que constasse de lei federal fosse efetivamente relevante ${ }^{436}$. Nessa medida, desde já importa

${ }^{433}$ NEGRÃO critica a arguição de relevância, nos seguintes termos: “(...) Aí, então, foi criada a chamada argüição de relevância, que, de certa forma, foi uma experiência necessária, mas desastrosa para nossas instituições judiciárias, porque desapareceu, praticamente, a possibilidade de uniformização do Direito Federal. Tantas eram as dificuldades para que o recurso extraordinário chegasse ao Supremo Tribunal Federal, porque a argüição de relevância o impedia, que se verificou não ser mais possível manter-se aquela velha situação. Veio, portanto, a nova Constituição e criou o Superior Tribunal de Justiça, extinguiu a argüição de relevância - agora temos um Tribunal encarregado de unificar o Direito Federal, isto é, a legislação federal ordinária e as matérias chamadas infraconstitucionais - e atribuiu ao Supremo Tribunal Federal aquilo que não podia deixar de ser entregue a ele e que passou a ser a sua exclusiva função: a de interpretar o direito constitucional brasileiro. (...)" (in NEGRÃO, Theotonio, O novo recurso extraordinário: perspectivas na Constituição de 1988, in Revista do Advogado, nº 81, 2005, pp. 8/9).

${ }^{434} \mathrm{O}$ art. 327, $\S 1^{\circ}$, do RISTF, estabelecia que "entende-se relevante a questão federal que, pelos reflexos na ordem jurídica, e considerados os aspectos morais, econômicos, políticos ou sociais da causa, exigir a apreciação do recurso extraordinário pelo Tribunal".

${ }^{435}$ In BARBOSA MoreIRA, José Carlos, A emenda constitucional no 45 e o processo, in Revista Forense, vol. 383, 2006, pp. 184/185. V., estabelecendo as diferenças entre a arguição de relevância e a repercussão geral, MARINONI, Luiz Guilherme e MITIDIERO, Daniel, Repercussão geral no recurso extraordinário, 2008, pp. 30/31 e SoUZA, Bernardo Pimentel, Apontamentos sobre a repercussão geral no recurso extraordinário, in Direito civil e processo - Estudos em homenagem ao Professor Arruda Alvim, 2007, pp. 1.230/1.231. V., comparando a repercussão geral também com a transcendência do direito trabalhista (art. 896-A, da CLT, incluído pela Medida Provisória no 2.226/2001, com a seguinte redação: "o Tribunal Superior do Trabalho, no recurso de revista, examinará previamente se a causa oferece transcendência com relação aos reflexos gerais de natureza econômica, política, social ou jurídica”), PORTO, Sérgio Gilberto e USTÁRROZ, Daniel, A repercussão geral das questões constitucionais no recurso extraordinário (inovações procedimentais da Lei 11.418 e na Emenda Regimental 21 do STF), in Direito civil e processo - Estudos em homenagem ao Professor Arruda Alvim, 2007, p. 1.490.

436 In CRUZ E TUCCI, José Rogério, Anotações sobre a repercussão geral como pressuposto de admissibilidade do Recurso Extraordinário (Lei $n^{\circ}$ 11.418/2006), in Revista do Advogado, no 92, 2007, p. 25. $\mathrm{V}$., em sentido semelhante, afirmando que a relevância das disposições constitucionais parece residir em sua 
deixar claro que somos favoráveis à inclusão de filtro semelhante no $\mathrm{STJ}^{437}$, para a admissão do recurso especial ${ }^{438}$, até porque "se deve reconhecer às partes o direito a dois graus de jurisdição, não a três" ${ }^{439}$.

Pelo menos desde a previsão do recurso especial pela Constituição de 1988, o recurso extraordinário exprime outras preocupações primordiais que não a uniformização da jurisprudência ${ }^{440}$. Com a inclusão desse novo requisito de admissibilidade, a situação mudou de figura, já que o STF passou a não mais cuidar de questões particulares, de interesse restrito das partes, concentrando-se em questões de maior repercussão (de repercussão geral $)^{441}$. Ficou evidente o intuito de uniformizar, de cima para baixo, o entendimento a propósito de tais questões.

própria inserção constitucional, YARSHELL, Flávio Luiz, A Reforma do Judiciário e a promessa de "duração razoável do processo", in Revista do Advogado, n 75, 2004, pp. 28/29.

${ }^{437}$ V., defendendo a criação de filtro semelhante para a Corte de Cassação italiana, PISANI, Andrea Proto, Principio d'eguaglianza e ricorso per cassazione, in Revista de Processo, $\mathrm{n}^{\circ}$ 191, 2011, pp. 206/208.

${ }^{438}$ Exceto se interposto com fundamento na alínea "c" do permissivo constitucional, pois a simples existência de divergência jurisprudencial tornaria pressuposta a repercussão geral. V., sustentando que "o mesmo tratamento deve ser oferecido ao STJ, Corte que deve zelar pela uniformização do direito infraconstitucional", PORTO, Sérgio Gilberto e UstáRROZ, Daniel, A repercussão geral das questões constitucionais no recurso extraordinário (inovações procedimentais da Lei 11.418 e na Emenda Regimental 21 do STF), in Direito civil e processo - Estudos em homenagem ao Professor Arruda Alvim, 2007, p. 1.495.

${ }^{439}$ In GARCIA, Dínio de Santis, Efeito vinculante dos julgados da Corte Suprema e dos Tribunais Superiores, in Revista dos Tribunais, vol. 734, 1996, p. 46. Tanto que o recurso especial e o recurso extraordinário "têm em conta menos o direito subjetivo das partes do que a custódia do ordenamento jurídico" (in CUNHA, Sérgio Sérvulo da, Nota breve sobre o efeito vinculante, in Revista de Informação Legislativa, ${ }^{\circ}{ }^{129}, 1996$, p. 14). V., sobre os diversos graus de jurisdição na história e sobre o surgimento do princípio do duplo grau no Brasil, CINTRA, Antonio Carlos de Araújo, Sobre os limites objetivos da apelação civil, Tese (Livre Docência), 1986, pp. 11/15.

${ }^{440} \mathrm{~V}$., em sentido semelhante ao nosso, afirmando que "hoje, como antigamente, a alegação de diversidade de jurisprudência é desnecessária para justificar o cabimento do recurso extraordinário em matéria constitucional (embora facilitasse, no sistema anterior, o conhecimento do recurso pelo Supremo Tribunal Federal), mas é muito importante para ensejar o recurso especial, que tem como uma de suas finalidades precípuas, se não a mais importante, a uniformização da jurisprudência sobre as leis ordinárias federais", NEGRÃo, Theotonio, O novo recurso extraordinário: perspectivas na Constituição de 1988, in Revista do Advogado, $\mathrm{n}^{\circ}$ 81, 2005, p. 12.

${ }^{441} \mathrm{~V}$., em sentido semelhante, sustentando que "a exigência da demonstração da repercussão geral acaba implicando na redefinição do próprio perfil do Supremo Tribunal Federal, agora não mais competente, em sede de recurso extraordinário, para analisar causas que, embora constitucionais, não envolvam discussões de relevância social, quantitativa e qualitativamente aferida", VENTURI, Elton, Anotações sobre a repercussão geral como pressuposto de admissibilidade no recurso extraordinário, in Direito processual civil, 2007, p. 308. A alteração do perfil do Supremo é compatível com os propósitos do recurso extraordinário, o qual, ao lado recurso especial, visa "precipuamente à assecuração da segurança jurídica, resguardando a inteireza positiva, a validade, a autoridade e a uniformidade de interpretação da Constituição e das leis federais; apenas remota e indiretamente prestam-se à tutela do direito subjetivo do litigante" (in CRUZ E TUCCI, José Rogério, Precedente judicial como fonte de direito, 2004, p. 266). 
Nas palavras de MARINONI e MITIDIERO, “insere-se a repercussão geral como uma técnica processual que conspira para realização do direito fundamental à tutela jurisdicional efetiva (que é necessariamente prestada em prazo razoável), estimulando ainda a compatibilização vertical das decisões judiciais, prestando homenagem ao valor da igualdade e perseguindo a racionalização da atividade judiciária"442.

\subsubsection{Regulamentação}

O requisito da repercussão geral do recurso extraordinário está previsto no art. $102, \S 3^{\circ}$, da $\mathrm{CF}$, cuja redação é a seguinte: "no recurso extraordinário o recorrente deverá demonstrar a repercussão geral das questões constitucionais discutidas no caso, nos termos da lei, a fim de que o Tribunal examine a admissão do recurso, somente podendo recusá-lo pela manifestação de dois terços de seus membros".

Embora a inovação constitucional tenha ocorrido em 2004, somente em 2006 é que foi sancionada lei regulamentando o dispositivo. Com efeito, a Lei $\mathrm{n}^{\mathrm{o}}$ 11.418/2006 inseriu no Código de Processo Civil ${ }^{443}$ os arts. 543-A e 543-B, conforme redação abaixo:

“Art. 543-A. O Supremo Tribunal Federal, em decisão irrecorrivel, não conhecerá do recurso extraordinário, quando a questão constitucional nele versada não oferecer repercussão geral, nos termos deste artigo.

$\S 1^{\circ}$ Para efeito da repercussão geral, será considerada a existência, ou não, de questões relevantes do ponto de vista econômico, político, social ou jurídico, que ultrapassem os interesses subjetivos da causa.

\footnotetext{
${ }^{442}$ In MARINONI, Luiz Guilherme e MiTIDIERO, Daniel, Repercussão geral no recurso extraordinário, 2008, p. 5.

${ }^{443}$ Nem por isso a repercussão geral é requisito somente dos recursos cíveis: "Apesar de a Lei 11.418 ter regulamentado o $\$ 3 .^{\circ}$ do art. 102 da CF por intermédio do Código de Processo Civil, o recurso extraordinário é instituto de natureza constitucional, como bem revela o inc. III do art. 102 da CF. Por conseguinte, a ampla repercussão é necessária para o conhecimento dos recursos extraordinários em geral, interpostos nos processos cíveis, criminais, trabalhistas ou eleitorais, independentemente da alínea (a, b, c ou d) na qual reside a fundamentação do inconformismo." (in SouZA, Bernardo Pimentel, Apontamentos sobre a repercussão geral no recurso extraordinário, in Direito civil e processo - Estudos em homenagem ao Professor Arruda Alvim, 2007, p. 1.232). V., no mesmo sentido, CoUTO, Mônica Bonetti, Repercussão geral da questão constitucional: algumas notas reflexivas, in Direito civil e processo - Estudos em homenagem ao Professor Arruda Alvim, 2007, p. 1.375, nota de rodapé nº 1.
} 
$\S 2^{\circ}$ O recorrente deverá demonstrar, em preliminar do recurso, para apreciação exclusiva do Supremo Tribunal Federal, a existência da repercussão geral.

$\S 3^{\circ}$ Haverá repercussão geral sempre que o recurso impugnar decisão contrária a súmula ou jurisprudência dominante do Tribunal.

$\S 4^{o}$ Se a Turma decidir pela existência da repercussão geral por, no mínimo, 4 (quatro) votos, ficará dispensada a remessa do recurso ao Plenário.

$\S 5^{\circ}$ Negada a existência da repercussão geral, a decisão valerá para todos os recursos sobre matéria idêntica, que serão indeferidos liminarmente, salvo revisão da tese, tudo nos termos do Regimento Interno do Supremo Tribunal Federal.

$\S 6^{\circ} O$ Relator poderá admitir, na análise da repercussão geral, a manifestação de terceiros, subscrita por procurador habilitado, nos termos do Regimento Interno do Supremo Tribunal Federal.

$\S 7^{o}$ A Súmula da decisão sobre a repercussão geral constará de ata, que será publicada no Diário Oficial e valerá como acórdão."

"Art. 543-B. Quando houver multiplicidade de recursos com fundamento em idêntica controvérsia, a análise da repercussão geral será processada nos termos do Regimento Interno do Supremo Tribunal Federal, observado o disposto neste artigo.

$\S 1^{\circ}$ Caberá ao Tribunal de origem selecionar um ou mais recursos representativos da controvérsia e encaminhá-los ao Supremo Tribunal Federal, sobrestando os demais até o pronunciamento definitivo da Corte.

$\S 2^{\circ}$ Negada a existência de repercussão geral, os recursos sobrestados considerar-se-ão automaticamente não admitidos.

$\S 3^{\circ}$ Julgado o mérito do recurso extraordinário, os recursos sobrestados serão apreciados pelos Tribunais, Turmas de Uniformização ou Turmas Recursais, que poderão declará-los prejudicados ou retratar-se.

$\S 4^{o}$ Mantida a decisão e admitido o recurso, poderá o Supremo Tribunal Federal, nos termos do Regimento Interno, cassar ou reformar, liminarmente, o acórdão contrário à orientação firmada. 
$\S 5^{\circ}$ O Regimento Interno do Supremo Tribunal Federal disporá sobre as atribuições dos Ministros, das Turmas e de outros órgãos, na análise da repercussão geral."

O regimento interno do STF, por sua vez, regulamenta o assunto nos arts. 322 a 329.

\subsubsection{Conceito, presunção legal e demonstração da repercussão geral}

$\mathrm{O}$ art. 543-A, $\S 1^{\circ}$, do CPC, e o art. 322, par. único, do RISTF, consideram de repercussão geral as questões relevantes do ponto de vista econômico, político, social ou jurídico ${ }^{444}$, que ultrapassem os interesses subjetivos da causa ou das partes ${ }^{445}$. O art. $102, \S 3^{\circ}$, da $\mathrm{CF}$, por sua vez, fala na demonstração da repercussão geral das "questões constitucionais discutidas no caso". Logo, não basta que as questões sejam relevantes sob um, alguns ou todos os aspectos previstos nos dispositivos acima, transcendendo o interesse das partes; a questão deve necessariamente ser de índole constitucional. Uma vez que a repercussão geral diz respeito a requisito de admissibilidade de recurso de

\footnotetext{
${ }^{444} \mathrm{~V}$., esmiuçando cada um desses conceitos, THEODORO JUNIOR, Humberto, Repercussão geral do Recurso Extraordinário (Lei no 11.418) e Súmula Vinculante do Supremo Tribunal Federal (Lei $n^{\circ} 11.417$ ), in Revista IOB de Direito Civil e Processual Civil, nº 48, 2007, pp. 108/110.

${ }^{445}$ Conforme informações extraídas do site do STF (<http://www.stf.jus.br/portal/cms/verTexto.asp?servico= jurisprudenciaRepercussaoGeral\&pagina=numeroRepercussao $>$, acesso em 18/10/2011), atualizadas em 13/10/2011, os processos recursais distribuídos com preliminar de repercussão geral, entre 2007 (segundo semestre) e 2011, dizem respeito aos seguintes ramos do direito, num total de 94.901 processos: direito administrativo e outras matérias de direito público (29.798 processos); direito tributário (16.239 processos); direito processual civil e do trabalho (14.993 processos); direito do trabalho (9.430 processos); direito civil (9.080 processos); direito do consumidor (5.753 processos); direito previdenciário (4.205 processos); direito processual penal (2.823 processos); direito penal (1.819 processos); direito eleitoral e processo eleitoral (396 processos); não informado (262 processos); direito da criança e do adolescente (71 processos); direito internacional (22 processos); direito marítimo ( 9 processos); aposentadoria (1 processo). Em termos de assunto, os mais incidentes são: direito administrativo e outras matérias de direito público - servidor público civil - reajustes de remuneração, proventos ou pensão (1.315 processos); direito processual civil e do trabalho - atos processuais - nulidade (789 processos); direito civil - obrigações - inadimplemento - juros de mora, legais/contratuais - capitalização, anatocismo (725 processos); direito civil - responsabilidade civil indenização por dano moral (610 processos); direito processual civil e do trabalho - recurso - cabimento (560 processos); direito civil - empresas - espécies de sociedades - anônima, direito civil - obrigações espécies de contratos - compra e venda, direito do consumidor - contratos de consumo - telefonia (512 processos); direito administrativo e outras matérias de direito público - intervenção no domínio econômico expurgos inflacionários, planos econômicos - poupança (511 processos); direito administrativo e outras matérias de direito público - servidor público civil - sistema remuneratório e benefícios - gratificação incorporada, quintos e décimos, VPNI (467 processos); direito do consumidor - contratos de consumo bancários - expurgos inflacionários, planos econômicos (439 processos); direito administrativo e outras matérias de direito público - militar - sistema remuneratório e benefícios - gratificações e adicionais (435 processos).
} 
competência do STF, não poderia ser diferente, já que o art. 102, caput, da CF, estabelece que cabe a esse tribunal, precipuamente, a guarda da Constituição.

O fato de hoje se considerarem determinadas questões constitucionais destituídas de repercussão geral não significa que elas serão "menos importantes" para o fim do recurso extraordinário para sempre. Por exemplo, sem recurso para o STF, o julgamento de tais questões ficará restrito ao âmbito dos tribunais de origem; nada impedirá assim que em tais casos os tribunais diferentes abracem teses também diferentes para as mesmas questões, dando origem a relevante divergência jurisprudencial que poderá no futuro dar lugar ao acolhimento da prejudicial de repercussão geral ${ }^{446}$.

Na mesma medida, em se alterando o contexto econômico, político, social e até mesmo jurídico, é possível que o STF passe a enxergar determinada matéria com outros olhos, atribuindo-lhe repercussão geral a despeito de decisão anterior que antes não a reconhecia, ou vice-versa. Evidentemente, essa mudança de percepção jamais atingirá aqueles que foram desfavorecidos pelo entendimento superado.

Embora à primeira vista não pareça, esse ponto é especialmente relevante se considerarmos que a repercussão geral não exige, para ser decidida, que a questão tenha sido exaustivamente discutida e tenha sido suficientemente amadurecida pelo tribunal. A situação é exatamente a inversa: ainda que a matéria seja inédita no STF e venha a ser julgada pela primeira vez, a decisão preliminar sobre a existência ou não da repercussão geral surtirá efeitos erga omnes.

É fundamental, nessa toada, que o tribunal tenha a possibilidade de mudar o entendimento, se for o caso, na medida em que a questão for amadurecendo. Para tanto, os próprios julgadores devem estar atentos ao eventual surgimento da necessidade de revisitar posicionamento anterior; não devem jamais se acomodar e aplicar reiteradamente a mesma decisão somente porque já foi apreciada uma vez, como se estivesse inscrita em pedra e fosse eternamente imutável.

${ }^{446}$ In Botelho De Mesquita, José Ignacio, Amadeo, Rodolfo da Costa Manso Real, Dellore, Luiz Guilherme Pennacchi, RiBEIRo, Débora, TeIXEIRA, Guilherme Silveira e ZveIBIL, Daniel Guimarães, A repercussão geral e os recursos repetitivos. Economia, Direito e Política, artigo no prelo, 2009, p. 7. 
Retornando ao assunto objeto deste tópico, como bem observa CRUZ E TUCCI, andou bem o legislador ao, em vez de enumerar exaustivamente as causas que possam ter a expressiva dimensão da repercussão geral, optar por estabelecer conceito jurídico indeterminado, a depender da aplicação pelo julgador à luz dos aspectos particulares do caso sub judice $e^{447}$, até porque tal descrição exaustiva seria tarefa humanamente impossível ${ }^{448}$.

É interessante notar que tanto o art. 543-A, $\S 3^{\circ}$, do CPC, quanto o art. 323, $\S 2^{\circ}$, do RISTF, presumem ser revestido de repercussão geral o recurso extraordinário que impugna decisão contrária a súmula ou jurisprudência dominante do tribunal. A presunção é corretíssima, pois o simples fato de haver súmula ou jurisprudência dominante (o que quer que isso signifique, como já exposto) sobre determinada matéria já demonstra que ela se reveste de amplo interesse ${ }^{449}$. Além do mais, é importante que decisões nessas condições sejam reexaminadas pelo STF, para que ele ratifique seu entendimento e reforme a decisão recorrida, ou retifique seu entendimento e mantenha a decisão recorrida $^{450}$. Mais uma vez exsurge nítido o propósito de prestigiar o precedente judicial emanado do STF e de uniformizar, verticalmente, a jurisprudência ${ }^{451}$.

447 In CRUZ E TUCCI, José Rogério, Anotações sobre a repercussão geral como pressuposto de admissibilidade do Recurso Extraordinário (Lei $n^{\circ} 11.418 / 2006$ ), in Revista do Advogado, no 92, 2007, p. 26. V., afirmando que o fato de se estar diante de conceito jurídico indeterminado permite "um controle social, pelas partes e demais interessados, da atividade do Supremo Tribunal Federal mediante um cotejo de casos já decididos pela própria Corte", MARINONI, Luiz Guilherme e MITIDIERO, Daniel, Repercussão geral no recurso extraordinário, 2008, pp. 35/36. V., abordando o assunto, Couto, Mônica Bonetti, Repercussão geral da questão constitucional: algumas notas reflexivas, in Direito civil e processo - Estudos em homenagem ao Professor Arruda Alvim, 2007, pp. 1.376/1.377.

${ }^{448}$ Nem por isso se deve entender que a atividade do juiz envolve um poder discricionário, pois há parâmetros e valores que se impõem ao julgador de forma cogente (in THEODORO JUNIOR, Humberto, Repercussão geral do Recurso Extraordinário (Lei $n^{\circ}$ 11.418) e Súmula Vinculante do Supremo Tribunal Federal (Lei $n^{\circ}$ 11.417), in Revista IOB de Direito Civil e Processual Civil, $\mathrm{n}^{\circ} 48,2007$, p. 105).

${ }^{449}$ In CRUZ E TUCCI, José Rogério, Anotações sobre a repercussão geral como pressuposto de admissibilidade do Recurso Extraordinário (Lei $n^{o}$ 11.418/2006), in Revista do Advogado, no 92, 2007, p. 26.

${ }^{450}$ V., no mesmo sentido, VENTURI, Elton, Anotações sobre a repercussão geral como pressuposto de admissibilidade no recurso extraordinário, in Direito processual civil, 2007, p. 312.

${ }^{451}$ Em sentido semelhante ao nosso, MARINONI e MITIDIERO afirmam, a propósito do art. 543-A, § $3^{\circ}$, do CPC, que: "O desiderato evidente aí está em prestigiar-se a força normativa da Constituição, encarnada que está, nessa senda, na observância das decisões do Supremo Tribunal Federal a respeito da mais adequada interpretação constitucional. O fito de perseguir a unidade do Direito via compatibilização vertical das decisões faz-se aqui evidente." (in MARINONI, Luiz Guilherme e MITIDIERO, Daniel, Repercussão geral no recurso extraordinário, 2008, p. 40). 
Ainda nos termos do art. $323, \S 2^{\circ}$, do RISTF, presume-se a existência de repercussão geral quando o recurso versar sobre questão cuja repercussão já houver sido reconhecida pelo tribunal. $\mathrm{O}$ entendimento é intuitivo e sequer necessitava vir disciplinado expressamente, embora seja preferível pecar por excesso que por omissão.

Consoante o art. 543-A, $\S 2^{\circ}$, do $\mathrm{CPC}$, a repercussão geral deve ser demonstrada como matéria preliminar nas razões de recurso extraordinário. Trata-se de ônus do recorrente, a quem cabe desenvolver argumentação que comprove o preenchimento das hipóteses do art. 543-A, $\S \S 1^{\circ}$ ou $3^{\circ}$, do CPC. Pelo art. $327,1^{\mathrm{a}}$ parte, do RISTF, inclusive, a presidência do tribunal recusará recursos que não apresentem preliminar formal e fundamentada de repercussão geral.

Vale ressaltar que, em se tratando o recurso extraordinário de mecanismo de controle de constitucionalidade ${ }^{452}$, o Supremo Tribunal Federal pode admitir o recurso por entender que há repercussão geral com fundamento diverso daquele suscitado pelo recorrente. Em outras palavras, a argumentação da parte no sentido de que a questão constitucional debatida é relevante e transcende os interesses subjetivos da causa, embora seja necessária e constitua requisito de admissibilidade recursal, não vincula o STF, que é livre para reconhecer a repercussão geral por outros motivos, ainda que não suscitados pelo recorrente ${ }^{453}$.

\subsubsection{Competência para a apreciação da repercussão geral}

$\mathrm{O}$ art. 543-A, $\S 2^{\circ}$, do CPC, deixa claro que a apreciação da repercussão geral é tarefa que compete exclusivamente ao Supremo Tribunal Federal. O dispositivo é coerente com o art. 102, $\S 3^{\circ}$, da $\mathrm{CF}$, que prevê que a repercussão geral só pode ser recusada pela manifestação de dois terços dos membros do tribunal. Da conjugação desses dois artigos extrai-se que o tribunal a quo não pode, em nenhuma hipótese, negar seguimento a recurso extraordinário por suposta ausência de repercussão geral. Caso o

\footnotetext{
${ }^{452}$ No controle abstrato de normas, a causa de pedir é aberta, de modo que, embora o autor não esteja dispensado de motivar o pedido, o Supremo Tribunal Federal pode realizar o julgamento por fundamentos não invocados, à semelhança do que ocorre no controle de normas na Alemanha e na Espanha (in CAZETTA JÚNIOR, José Jesus, A ineficácia do precedente no sistema brasileiro de jurisdição constitucional (18911993): contribuição ao estudo do efeito vinculante, Tese (Doutorado), 2004, pp. 162/163).

${ }^{453}$ In MARINONI, Luiz Guilherme e MITIDIERO, Daniel, Repercussão geral no recurso extraordinário, 2008, p. 44.
} 
faça, é cabível o ajuizamento de reclamação para a preservação da competência do Supremo Tribunal Federal (art. 102, I, "l”, da CF), pois o exame e o julgamento de tal requisito implicam, sempre, em ato colegiado, da turma ou do plenário do $\mathrm{STF}^{454}$.

Para o fim de evitar a sobrecarga desnecessária do pleno, o art. 543-A, § $4^{\circ}$, do CPC, estabelece que, se a turma decidir pela existência da repercussão geral por, no mínimo, quatro votos, ficará dispensada a remessa do recurso ao plenário. A razão para isso é puramente aritmética: em sendo o STF composto por onze ministros, já tendo sido obtidos quatro votos favoráveis ao reconhecimento da repercussão geral, impossível será alcançar o quórum mínimo exigido pela Constituição - de dois terços, ou oito ministros para que seja negada a existência da repercussão geral ${ }^{455}$.

Embora o quórum qualificado para o reconhecimento da inexistência da repercussão geral represente uma garantia para a parte, teria sido mais dinâmico se tal prerrogativa dependesse do voto da maioria absoluta dos integrantes das próprias turmas $^{456}$. Afinal, se a eles compete a apreciação dos demais requisitos de admissibilidade do recurso extraordinário, assim como o julgamento do próprio mérito do recurso, parece conservador demais retirar de sua competência o exame de matéria preliminar, atinente ao reconhecimento ou não da existência da repercussão geral.

Muito provavelmente o legislador constituinte quis imputar regra rígida, equivalente à da edição, revisão ou cancelamento de súmula vinculante, para que a comunidade jurídica não se insurgisse contra a repercussão geral sob o argumento de que a mesma cercearia o direito de acesso à instância extraordinária. Com isso, porém, acabou por criar um entrave procedimental.

454 In CRUZ E TUCCI, José Rogério, Anotações sobre a repercussão geral como pressuposto de admissibilidade do Recurso Extraordinário (Lei $n^{\circ}$ 11.418/2006), in Revista do Advogado, n 92, 2007, p. 27.

455 In CoUTO, Mônica Bonetti, Repercussão geral da questão constitucional: algumas notas reflexivas, in Direito civil e processo - Estudos em homenagem ao Professor Arruda Alvim, 2007, p. 1.378 e PORTO, Sérgio Gilberto e UstáRROZ, Daniel, A repercussão geral das questões constitucionais no recurso extraordinário (inovações procedimentais da Lei 11.418 e na Emenda Regimental 21 do STF), in Direito civil e processo - Estudos em homenagem ao Professor Arruda Alvim, 2007, p. 1.496.

${ }^{456} \mathrm{~V}$., nesse sentido, mencionando o idêntico posicionamento de ANDRÉ RAMOS TAVARES, CRUZ E TUCCI, José Rogério, Anotações sobre a repercussão geral como pressuposto de admissibilidade do Recurso Extraordinário (Lei no 11.418/2006), in Revista do Advogado, nº 92, 2007, p. 27. 
Além da dificuldade de reunir os ministros em plenário ${ }^{457}$, sempre que se mantiverem aquém do quórum qualificado os votos no sentido de não se conhecer do recurso extraordinário por ausência do requisito da repercussão geral, a tramitação poderá compreender dois julgamentos: um no plenário, para apreciação da preliminar de repercussão geral; e, uma vez positivo o juízo feito pelo plenário, outro na turma, para apreciação do restante da matéria. Aumentará, portanto, a carga de trabalho do tribunal ${ }^{458}$.

Como se vê, embora o objetivo da norma seja irretocável em todos os aspectos, o procedimento que se escolheu para implementá-la talvez não seja o mais eficiente.

\subsubsection{Momento e procedimento para a apreciação da repercussão geral}

A Lei n ${ }^{\circ} 11.418 / 2006$ silenciou a respeito do momento para a apreciação da repercussão geral, cabendo ao regimento interno do STF a disciplina de tal questão.

Com efeito, o art. 323, caput, do RISTF, prevê que, "quando não for caso de inadmissibilidade do recurso por outra razão, o(a) Relator(a) ou o Presidente submeterá, por meio eletrônico, aos demais Ministros, cópia de sua manifestação sobre a existência, ou não, de repercussão geral'. Da redação do artigo, fica subentendido que a apreciação dos demais requisitos de admissibilidade do recurso extraordinário deve ser feita previamente à apreciação da existência da repercussão geral. A regra parece lógica e mesmo antes da edição da norma regimental já havia quem defendesse posicionamento idêntico $^{459}$.

\footnotetext{
${ }^{457}$ Assim como PORTO e USTÁRrOZ, entendemos que "a interpretação do Regimento conforme a Constituição conduz à realização de uma sessão pública para o debate e decisão quanto à repercussão geral, e não se limita à troca de e-mails com a posterior publicização desses" (in PORTO, Sérgio Gilberto e USTÁRROZ, Daniel, A repercussão geral das questões constitucionais no recurso extraordinário (inovaçães procedimentais da Lei 11.418 e na Emenda Regimental 21 do STF), in Direito civil e processo - Estudos em homenagem ao Professor Arruda Alvim, 2007, p. 1.497).

${ }^{458}$ In BARBosa MOREIRA, José Carlos, A emenda constitucional n $n^{\circ} 45$ e o processo, in Revista Forense, vol. 383,2006 , pp. 188/189.

${ }^{459} \mathrm{~V}$., nesse sentido, referindo-se ainda ao posicionamento semelhante de ElVIO FERREIRA SARTORIO e FLÁVIO CHEIM JORGE, CRUZ E TUCCI, José Rogério, Anotações sobre a repercussão geral como pressuposto de admissibilidade do Recurso Extraordinário (Lei n $n^{\circ} 11.418 / 2006$ ), in Revista do Advogado, $\mathrm{n}^{\circ}$ 92, 2007, p. 28.
} 
Uma vez preenchidos os demais requisitos de admissibilidade do recurso, o relator então apreciará a existência ou não de repercussão geral.

Após a sua manifestação, os demais ministros serão instados a se manifestar, se quiserem, no prazo de vinte dias (art. 324, caput, do RISTF). Decorrido o prazo de vinte dias sem manifestações suficientes para recusa do recurso, reputar-se-á existente a repercussão geral (em caso de dúvida, a presunção milita em favor do recorrente) e os autos devem em seguida retornar ao relator para a apreciação e julgamento do mérito do recurso - exceto se o relator em sua manifestação declarar que a matéria é infraconstitucional, caso em que a ausência de pronunciamento no prazo será considerada como manifestação de inexistência de repercussão geral (art. 324, $\S \S 1^{\circ}$ e $2^{\circ}$, do RISTF), autorizando a aplicação do art. 543-A, $\S 5^{\circ}$, do CPC, de que trataremos adiante.

Da mesma forma, se na própria turma forem proferidos quatro votos no sentido de que há repercussão geral, os autos devem em seguida retornar ao relator (art. 543-A, $\S 4^{\circ}$, do CPC), que julgará o mérito do recurso, podendo aplicar-se inclusive a regra do art. 557, do CPC, ou pedirá dia para julgamento, após vista ao Procurador-Geral, se necessária (art. 325, caput, do RISTF). Por outro lado, se, pelo mínimo de três votos a dois, os integrantes da turma entenderem que não há repercussão geral, o recurso deve ser submetido ao pleno (art. 102, $\S 3^{\circ}$, da CF).

No pleno, se menos de oito ministros votarem pela inexistência de repercussão geral, deve ser admitido o recurso (art. 102, $\S 3^{\circ}$, da $\mathrm{CF}$ ), com o envio dos autos ao relator para o julgamento do mérito. Por outro lado, caso oito ministros manifestem-se no sentido de que não há repercussão geral, o recurso não será conhecido (art. 102, $\S 3^{\circ}$, da $\mathrm{CF}$ ), cabendo ao relator formalizar e subscrever a decisão de recusa do recurso (art. 325, caput, do RISTF).

Finda essa fase, tem-se a “decisão preliminar”, cuja súmula constará de ata e valerá como acórdão, qualquer que seja a sua conclusão (art. 543-A, $\S 7^{\circ}$, do CPC); se afirmar a existência da repercussão geral, o seu teor será publicado no Diário Oficial, com menção clara à matéria do recurso (art. 325, par. único, do RISTF). 


\subsubsection{6 \\ Irrecorribilidade da decisão preliminar e efeitos para o futuro}

De acordo com o art. 543-A, caput, do CPC, e com o art. 326, do RISTF, a decisão que não conhecer do recurso extraordinário quando a questão constitucional nele versada não oferecer repercussão geral é irrecorrível ${ }^{460}$, devendo ser comunicada pelo relator à presidência do tribunal.

Nessa linha, prestigiando-se novamente o precedente do STF e a uniformização vertical da jurisprudência, "negada a existência da repercussão geral, a decisão valerá para todos os recursos sobre matéria idêntica, que serão indeferidos liminarmente, salvo revisão da tese, tudo nos termos do Regimento Interno do Supremo Tribunal Federal", conforme o art. 543-A, $§ 5^{\circ}$, do CPC. No STF, o indeferimento liminar competirá ao presidente (arts. 13, V, “c”, e 327, caput, do RISTF), e ao relator, quando o recurso não tiver sido liminarmente recusado por aquele (art. $327, \S 1^{\circ}$, do RISTF). De certa forma, pode-se dizer que a regra do art. $323, \S 2^{\circ}$, do RISTF, segundo a qual se presume a existência de repercussão geral quando o recurso versar questão cuja repercussão já houver sido reconhecida pelo tribunal, é o contraponto dessa regra aqui.

Ambas as fórmulas parecem adequadas na medida em que prezam pela economia e pela celeridade processual. Em já tendo o STF reconhecido, em abstrato, a existência ou a inexistência de repercussão geral sobre determinada matéria, não há por que submeter a mesma questão à apreciação da turma ou do pleno repetidas vezes, exceto, evidentemente, no caso de a tese ter sido revista, ou estar em procedimento de revisão. A decisão deve então surtir efeitos para o futuro, erga omnes, sobre todos os casos que versarem sobre a mesma matéria. Novamente prestigia-se precedente oriundo do STF, como meio de uniformizar a jurisprudência; mas abre-se uma brecha para impedir o engessamento do entendimento jurisprudencial - reiteramos, por oportuno, o que dissemos sobre o assunto no item "4.3.6.3" acima.

\footnotetext{
${ }^{460} \mathrm{~V}$., sustentando o cabimento de embargos de declaração e, eventualmente, de mandado de segurança, este último com fundamento no art. $5^{\circ}$, II, da Lei $\mathrm{n}^{\mathrm{o}}$ 1.533/1951 (posteriormente revogada pela Lei $\mathrm{n}^{\mathrm{o}}$ 12.016/2009), a contrario sensu, e no art. 102, I, "d”, da CF, MARINONI, Luiz Guilherme e MiTIDIERO, Daniel, Repercussão geral no recurso extraordinário, 2008, pp. 58/60. V., também sustentando o cabimento de embargos de declaração, SoUZA, Bernardo Pimentel, Apontamentos sobre a repercussão geral no recurso extraordinário, in Direito civil e processo - Estudos em homenagem ao Professor Arruda Alvim, 2007, p. 1.231 .
} 
Ressalte-se que essa eficácia para o futuro não fica limitada à declaração da existência ou da inexistência da repercussão geral. Na hipótese de multiplicidade de recursos sobre a mesma controvérsia constitucional, determinará a extinção do sobrestamento (suspensão), com a retomada do curso dos demais recursos pendentes, ou a rejeição automática destes, conforme o caso. $\mathrm{O}$ assunto será tratado com atenção no tópico seguinte.

\subsubsection{Multiplicidade de recursos sobre a mesma controvérsia}

Embora a repercussão geral tenha o intuito primordial de filtrar os recursos extraordinários que serão julgados pelo STF, fazendo com que o tribunal deixe de se ocupar de questões menores, de interesse somente das partes da demanda, o grande mérito desse novo requisito de admissibilidade recursal é a capacidade que tem de uniformizar a jurisprudência sobre a questão constitucional em exame. Além disso, na existência de múltiplos recursos sobre a mesma controvérsia, ao apreciar a repercussão geral daquele eleito como paradigma, o STF decide numa enxurrada a repercussão geral das outras centenas ou milhares de recursos lastreados na mesma questão constitucional, contribuindo para a celeridade e para o desafogamento do tribunal supremo.

$\mathrm{O}$ art. 543-B, $\S 1^{\circ}$, do CPC, dispõe que, quando houver multiplicidade de recursos com fundamento em idêntica controvérsia, caberá ao tribunal de origem selecionar um ou mais recursos representativos e encaminhá-los ao Supremo Tribunal Federal, sobrestando os demais até o pronunciamento definitivo da corte. Em sentido semelhante, o art. 328, caput, do RISTF, determina que, protocolado ou distribuído recurso cuja questão for suscetível de reproduzir-se em múltiplos feitos, a presidência do tribunal ou o relator, de ofício ou a requerimento da parte interessada, comunicará o fato aos tribunais ou turmas de Juizado Especial, a fim de que observem o quanto disposto acima, podendo pedir-lhes informações, que deverão ser prestadas em cinco dias, e sobrestar "todas as demais causas com questão idêntica" - a despeito da redação, pelo que se infere do disposto no art. 543-B, $\S \S 1^{\circ}$ e $2^{\circ}$, do CPC, só se suspenderá o andamento dos recursos extraordinários $^{461}$. Ainda, de acordo com o respectivo par. único, quando se verificar

461 In Botelho de Mesquita, José Ignacio, Amadeo, Rodolfo da Costa Manso Real, Dellore, Luiz Guilherme Pennacchi, RIBEIRO, Débora, TEIXEIRA, Guilherme Silveira e ZVEIBIL, Daniel Guimarães, $A$ repercussão geral e os recursos repetitivos. Economia, Direito e Política, artigo no prelo, 2009, pp. 4/5. 
subida ou distribuição de múltiplos recursos com fundamento em idêntica controvérsia, a presidência do tribunal ou o relator selecionará um ou mais representativos da questão e determinará a devolução dos demais aos tribunais ou turmas de Juizado Especial de origem.

A respeito do critério de seleção dos paradigmas ${ }^{462}$, reiteramos o que dissemos no item "4.2.3.4" acima, quando tratamos do tema da súmula vinculante, no sentido de que, quanto mais diversificados forem os órgãos prolatores das decisões recorridas, do ponto de vista regional, melhor. Embora o requisito também não se encontre disposto em lugar nenhum, tampouco sua ausência seja impedimento para o julgamento da preliminar de repercussão geral, trata-se de meio de garantir que a controvérsia represente discussão nacional, e não regional, e que serão abordados todos os aspectos relevantes acerca da questão. Outrossim, analogicamente, pode ser empregado o critério previsto no art. $1^{\circ}, \S 1^{\circ}$, da Resol.-STJ $n^{\circ} 8 / 2008$, segundo o qual, no caso de recursos especiais repetitivos, "serão selecionados pelo menos um processo de cada Relator e, dentre esses, os que contiverem maior diversidade de fundamentos no acórdão e de argumentos no recurso especial", como sugerem BotELHO DE MESQUITA et. al. ${ }^{463}$.

O tribunal de origem não emitirá juízo de admissibilidade sobre os recursos extraordinários já sobrestados, nem sobre os que venham a ser interpostos, até que o Supremo Tribunal Federal decida os que tenham sido selecionados como representativos da controvérsia (art. 328-A, caput, do RISTF). Nos casos anteriores, o tribunal de origem sobrestará os agravos de instrumento contra decisões que não tenham admitido os recursos extraordinários (art. 328-A, $\S 1^{\circ}$, do RISTF).

Negada a existência de repercussão geral, os recursos sobrestados considerar-se-ão automaticamente não admitidos (art. 543-B, § $2^{\circ}$, do CPC), sendo os agravos de instrumento contra decisões que não tenham admitido os recursos extraordinários julgados prejudicados (art. 328-A, § 1º, do RISTF). Afinal, como já se disse no tópico anterior, a decisão preliminar que julga a existência ou não de repercussão

\footnotetext{
${ }^{462}$ Referimo-nos aos "paradigmas", no plural, pois é mais comum que sejam eleitos vários recursos para esse fim, e não apenas um.

463 In Botelho de Mesquita, José Ignacio, Amadeo, Rodolfo da Costa Manso Real, Dellore, Luiz Guilherme Pennacchi, RIBEIRO, Débora, TEIXEIRA, Guilherme Silveira e ZVEIBIL, Daniel Guimarães, $A$ repercussão geral e os recursos repetitivos. Economia, Direito e Política, artigo no prelo, 2009, p. 17.
} 
geral, além de ser irrecorrível, deve surtir efeitos erga omnes e, portanto, qualquer que seja o seu sentido, aplica-se sobre todos os recursos, pendentes ou futuros, que tratem de idêntica controvérsia constitucional.

Por outro turno, conhecido o recurso extraordinário, pela presença de todos os seus requisitos de admissibilidade (inclusive da repercussão geral) e julgado o seu mérito, os recursos sobrestados retomarão seu curso. Porém, se a decisão preliminar surte efeitos erga omnes, o mesmo não ocorre com a decisão que, após admitir a existência da repercussão geral, julga o mérito dos paradigmas. Essa decisão surte efeitos um pouco mais restritos, na medida em que é dotada do que convencionamos chamar neste trabalho de eficácia quase vinculante.

Com efeito, a partir do julgamento do mérito dos recursos paradigma, o tribunal poderá declarar prejudicados os recursos até então sobrestados, porque a decisão recorrida teria sido dada no mesmo sentido da tese vencedora no STF, ou retratar-se, na hipótese contrária (art. 543-B, § $3^{\circ}$, do CPC) ${ }^{464}$. Essa retratação - anômala, pois faz com que o processo dê um passo para trás ${ }^{465}$ - não é obrigatória, o que por si só demonstra que a decisão de mérito do STF no julgamento dos recursos paradigma não surte efeitos vinculantes. Por outro lado, surte ela efeitos quase vinculantes, pois, de acordo com o art. 543-B, $\S 4^{\circ}$, do CPC ("mantida a decisão e admitido o recurso, poderá o Supremo Tribunal Federal, nos termos do Regimento Interno, cassar ou reformar, liminarmente, o acórdão contrário à orientação firmada"), e o art. 21, § 1", do RISTF ("poderá o(a) Relator(a) negar seguimento a pedido ou recurso manifestamente inadmissível, improcedente ou contrário à jurisprudência dominante ou a Súmula do Tribunal, deles não conhecer em caso de incompetência manifesta, encaminhando os autos ao órgão que

\footnotetext{
${ }^{464}$ Como bem ponderado por PORTO e USTÁRROZ: "A efetividade da norma dependerá da responsabilidade de os tribunais inferiores acatarem as orientações da Suprema Corte, colaborando a seu modo com a efetividade processual. De nada adiantará às Câmaras, ou Turmas, permanecerem rebeldes, afinal o recurso será admitido e provido liminarmente pelo Ministro, após os trâmites burocráticos de estilo." (in PORTO, Sérgio Gilberto e USTÁRROZ, Daniel, A repercussão geral das questões constitucionais no recurso extraordinário (inovações procedimentais da Lei 11.418 e na Emenda Regimental 21 do STF), in Direito civil e processo - Estudos em homenagem ao Professor Arruda Alvim, 2007, p. 1.498).

${ }^{465} \mathrm{~V}$., sustentando que essa eficácia contraria a lógica do sistema, porque põe a causa adiante do efeito, de maneira que, "na vigência do princípio da intangibilidade do direito adquirido, do ato jurídico perfeito e da coisa julgada, é inadmissível a declaração da nulidade ou rescisão de um ato com fundamento em causa que lhe seja posterior", Botelho DE MESQuitA, José Ignacio, AMADEO, Rodolfo da Costa Manso Real, Dellore, Luiz Guilherme Pennacchi, RIBEIRO, Débora, TeIXEIRA, Guilherme Silveira e ZveIBIL, Daniel Guimarães, A repercussão geral e os recursos repetitivos. Economia, Direito e Política, artigo no prelo, 2009 , p. 30.
} 
repute competente, bem como cassar ou reformar, liminarmente, acórdão contrário à orientação firmada nos termos do art. 543-B do Código de Processo Civil'), não havendo retratação, poderá o STF, e o próprio relator por decisão monocrática, cassar ou reformar, liminarmente, o acórdão contrário à conclusão da corte no julgamento dos paradigmas. Nas palavras de BotelHO DE Mesquita et. al., "feita a opção por uma das teses, não ficam os Tribunais inferiores obrigados a curvar-se diante dela, mas monta-se o cerco contra a possibilidade de decisões divergentes" 466 .

Aqui novamente discordamos da opção empregada pelo legislador. Se a intenção é fazer com que a decisão de mérito tomada pelo Supremo no julgamento dos recursos paradigma prevaleça em relação a todos os casos que versem sobre a mesma controvérsia constitucional - e parece ser essa a intenção, tanto que o próprio relator mediante decisão monocrática poderá cassar ou reformar o acórdão contrário à decisão da corte -, melhor seria se desde já se estabelecesse a obrigatoriedade de retratação pelo tribunal de segundo grau. De que adianta conferir ao órgão a quo a liberdade de não se retratar se ela já nasce fadada ao destino quase certeiro de não prosperar? Trata-se de liberdade muito mais formal do que substancial, que não tem razão de ser. Aliás, o mais correto mesmo seria submeter imediatamente o caso à apreciação do relator, sem a possibilidade (ou sequer obrigatoriedade) de retratação pelo tribunal de segundo grau, já que a própria retratação em si parece descabida, pois, de maneira bastante "peculiar", faz com que o processo volte para trás.

Mais do que isso, pensamos que a decisão contrária à conclusão da corte no julgamento dos recursos paradigma deveria ser obrigatoriamente reformada, pelo relator ou pelo colegiado - substituindo-se o verbo "poderá" por "deverá", no art. 543-B, $\S 4^{\circ}$, do CPC, e no art. $21, \S 1^{\circ}$, do RISTF -, surtindo efeitos efetivamente vinculantes, sem prejuízo da possibilidade de ser oportunamente revisto o entendimento (por procedimento que poderia, por exemplo, obedecer, em linhas gerais, àquele de revisão ou cancelamento de súmula vinculante).

466 In Botelho De Mesquita, José Ignacio, Amadeo, Rodolfo da Costa Manso Real, Dellore, Luiz Guilherme Pennacchi, RiBeIRo, Débora, TeIXeIRA, Guilherme Silveira e ZveIBIL, Daniel Guimarães, $A$ repercussão geral e os recursos repetitivos. Economia, Direito e Política, artigo no prelo, 2009, p. 29. 
Para nós seria essa a solução correta, mas com uma importante ressalva. Como já dissemos alhures, entendemos que as decisões apenas deveriam surtir efeitos "extra-autos" após estarem devidamente amadurecidas no seio do tribunal. Para compatibilizar essa regra (que é mais uma premissa do nosso pensamento, do que propriamente uma regra) com a técnica da repercussão geral, a opção seria atribuir eficácia vinculante à decisão de mérito do STF, tomada no julgamento dos recursos paradigma após o reconhecimento da existência da repercussão geral, apenas se dotada de maturidade comprovada. Votação a esse respeito, inclusive, poderia ocorrer na mesma oportunidade da votação da repercussão geral, exigindo-se, por exemplo, manifestação favorável de no mínimo dois terços do tribunal; ou seja, em sendo a repercussão geral reconhecida, partirse-ia para uma segunda votação, acerca dos efeitos do subsequente julgamento do mérito do recurso (efeitos inter partes ou efeitos erga omnes?). Enfim, como está longe disso o sentido da lei em vigor, fica aqui uma sugestão - ou um início de sugestão, a ser aprimorado - de lege ferenda.

Por fim, vale dizer que a presidência do tribunal promoverá ampla e específica divulgação do teor das decisões sobre repercussão geral, bem como formação e atualização de banco eletrônico de dados a respeito (art. 329, do RISTF) ${ }^{467}$. Como bem pontuam PORTO e USTÁRROZ, “importante, nessa linha, preservar a publicidade e a motivação adequada nos julgamentos, para que a sociedade civil acompanhe, fiscalize e consiga aplicar as orientações do Pretório Excelso" ${ }^{468}$.

\subsubsection{Intervenção de terceiros}

Assim como ocorre no controle de constitucionalidade concentrado e no procedimento de edição, revisão ou cancelamento de súmula vinculante, o art. 543-A, § 6º, do CPC, autoriza o relator a admitir, na análise da repercussão geral, a manifestação de terceiros, subscrita por procurador habilitado. Segundo o art. $323, \S 3^{\circ}$, do RISTF, a decisão do relator admitindo a intervenção de amicus curiae pode ser tomada de ofício ou a requerimento e é irrecorrível.

\footnotetext{
467 As informações encontram-se disponíveis no site do STF (<http://www.stf.jus.br/portal/cms/verTexto. asp?servico=jurisprudenciaRepercussaoGeralInicial\&pagina=telainicial $>$ ), acesso em 18/10/2011.

${ }^{468}$ In PORTO, Sérgio Gilberto e USTÁRROZ, Daniel, A repercussão geral das questões constitucionais no recurso extraordinário (inovações procedimentais da Lei 11.418 e na Emenda Regimental 21 do STF), in Direito civil e processo - Estudos em homenagem ao Professor Arruda Alvim, 2007, p. 1.500.
} 
Além do fato de ser sempre positiva a coleta de opiniões de pessoas ou entidades representativas da sociedade civil, no caso da repercussão geral a autorização para a manifestação de terceiros é de extrema importância porque, como visto, a escolha dos recursos paradigma faz com que todos os demais recursos extraordinários sobre a mesma controvérsia constitucional fiquem sobrestados. A intervenção no processo alheio (inclusive para, com fundamento no critério da representatividade, requerer que o seu recurso seja incluído entre os que serão simultaneamente julgados ${ }^{469}$ ), portanto, é o único meio de os sujeitos que tiveram seus recursos sobrestados influírem no julgamento de matéria que terá repercussão direta sobre seus próprios recursos.

Justamente por isso, nos parece que, na análise da repercussão geral, a intervenção de terceiros deveria ser franqueada a todos os interessados, sempre, ao invés de depender de autorização do relator em tal sentido. O texto do Código de Processo Civil não deixa dúvidas de que, no atual sistema, o relator "poderá admitir manifestação de pessoas, órgãos ou entidades com interesse na controvérsia" (destaque nosso), “considerando a relevância da matéria”. A postura parece autoritária se for considerado o grau de influência que o julgamento da repercussão geral terá sobre todos os demais processos que tratem da mesma controvérsia constitucional em apreço nos recursos representativos.

Nessa medida, é até contraditório que a lei exija ser a matéria relevante para autorizar a intervenção do amicus curiae; afinal, o simples fato de a decisão preliminar sobre a existência ou não de repercussão geral surtir efeitos sobre todos os demais recursos versando a respeito da mesma controvérsia constitucional já a torna naturalmente relevante, independentemente da matéria tratada.

Ainda que não se admita a intervenção de todo e qualquer sujeito, devendo no mínimo restar preenchido o requisito da pertinência temática pois caso contrário a situação poderia realmente fugir do controle, pensamos que a todos os titulares de ações ou recursos que discutam a controvérsia constitucional sujeita à averiguação de repercussão

${ }^{469}$ Embora inexista propriamente direito da parte à escolha de seu recurso para aferição, a partir dele, da existência ou da inexistência da repercussão geral (in MARINONI, Luiz Guilherme e MiTIDIERO, Daniel, Repercussão geral no recurso extraordinário, 2008, p. 62). 
geral, e que tragam dados e argumentos novos, inéditos nos recursos eleitos como representativos $^{470}$, deveria ser estendida tal prerrogativa, já que tais sujeitos serão necessariamente atingidos pela apreciação da repercussão geral e, eventualmente, caso positivo o juízo feito a seu respeito, pelo subsequente julgamento do mérito dos $\operatorname{recursos}^{471}$.

Como muito bem lembrado por BotelHo De MESQuita et. al., "para boa compreensão dos temas vinculados à autoridade e à eficácia das sentenças, tem-se revelado útil o entendimento de que os efeitos de toda e qualquer sentença que julgue procedente uma ação se produzem sempre erga omnes, bastando para tanto que o processo se tenha desenvolvido entre legítimos contraditores. Esses efeitos se produzem diretamente para as partes e indiretamente, ou por via reflexa, para terceiros. A eficácia indireta ou reflexa é proporcionada pela existência de algum nexo jurídico entre a res in judicio deducta $e$ as relações com ela conexas, por meio do qual o efeito da sentença pronunciada entre as partes se comunica à esfera jurídica de terceiros, a despeito de a relação do terceiro com qualquer das partes não ser objeto da sentença. Condição dessa eficácia erga omnes, como ficou dito, é que o processo se tenha conduzido entre legítimos contraditores, o que assegura a observância do princípio do contraditório." ${ }^{472}$. A situação aqui é exatamente a mesma: para que a decisão da repercussão geral possa surtir efeitos erga omnes, necessário que o seu julgamento tenha se dado perante legítimos contraditores, entendidos aqueles que possuem interesse direto na matéria - não apenas as partes dos recursos paradigma, mas também as partes dos recursos sobrestados. Ainda que estes prefiram não se manifestar no julgamento da repercussão geral dos recursos

\footnotetext{
${ }^{470}$ In PORTO, Sérgio Gilberto e USTÁRROZ, Daniel, A repercussão geral das questões constitucionais no recurso extraordinário (inovações procedimentais da Lei 11.418 e na Emenda Regimental 21 do STF), in Direito civil e processo - Estudos em homenagem ao Professor Arruda Alvim, 2007, p. 1.498.

471 Conforme ressalta VENTURI, “diante da determinação do sobrestamento de recursos extraordinários repetitivos nas instâncias inferiores, em virtude da remessa ao STF de alguns recursos 'representativos da controvérsia' comum a todos eles (\$ $1^{o}$ do art. 543-B do CPC), é notório o particular interesse jurídico ostentado por todos aqueles recorrentes cujos recursos foram sobrestados em intervir no julgamento dos recursos que subiram ao STF uma vez que, na hipótese de negar o Tribunal a existência da repercussão geral, por conseqüência, todos os demais deverão ser inadmitidos já na origem ( $\$ 2^{\circ}$ do art. 543-B do CPC). Neste caso, a intervenção se justificará pelo interesse jurídico próprio (individual) do interveniente, que acaba tendo a apreciação de sua pretensão já judicializada condicionada ao julgamento do recurso extraordinário em que busca intervir." (in VENTURI, Elton, Anotações sobre a repercussão geral como pressuposto de admissibilidade no recurso extraordinário, in Direito processual civil, 2007, p. 316).

472 In Botelho De Mesquita, José Ignacio, Amadeo, Rodolfo da Costa Manso Real, Dellore, Luiz Guilherme Pennacchi, RIBEIRO, Débora, TEIXEIRA, Guilherme Silveira e ZveIBIL, Daniel Guimarães, $A$ repercussão geral e os recursos repetitivos. Economia, Direito e Política, artigo no prelo, 2009, pp. 10/11.
} 
paradigma, que assim se omitam por opção própria, e não por um óbice criado pelo relator sob o argumento de que a matéria tratada é "irrelevante".

É forçoso reconhecer que, na prática, essa regra poderia fazer cair por terra a celeridade que se almeja com a instituição da repercussão geral, pois em tese poderiam vir a ser apresentadas tantas manifestações quantos fossem as ações e os recursos sobre a mesma controvérsia constitucional. Contudo, não sobrará muito espaço para a manifestação de terceiros caso o tribunal: se esmere em eleger como paradigmas os recursos efetivamente representativos da controvérsia, que examinem a fundo todos os argumentos pertinentes; e torne pública essa seleção, para que todos os interessados possam analisar previamente as peças recursais escolhidas como modelo.

Destarte, para que o mecanismo funcione bem, é necessário um esforço conjunto dos magistrados e dos advogados; afinal, como sói ocorrer, "a mera base legal do instituto não é suficiente para garantir o êxito idealizado na reforma" ${ }^{473}$. O tribunal deve cumprir seu papel em bem selecionar os paradigmas; os causídicos, ao representarem as pessoas, órgãos ou entidades com interesse na controvérsia, devem se abster de requerer a intervenção em processo alheio a não ser que efetivamente possuam algum dado ou argumento relevante, capaz de influenciar no resultado do julgamento, a acrescentar.

Além do quanto exposto, pensamos que, uma vez reconhecida a repercussão geral dos recursos paradigma, antes de se passar ao julgamento do mérito dos recursos, deveria ser franqueada nova oportunidade para a intervenção de terceiros, dessa vez para que se manifestem não sobre a existência de repercussão geral, mas sobre o mérito em si. A lei é omissa sobre esse ponto, mas o reputamos essencial, em razão dos efeitos que o julgamento de mérito deve surtir sobre os casos fundados em discussões análogas.

A necessidade de ser franqueada a manifestação daqueles que tiveram seus recursos suspensos é ainda mais evidente se se considerar que o tribunal poderá negar provimento ao recurso com fundamento em questões ventiladas em outro acórdão, que não o acórdão recorrido, de que, exatamente por isto, não tenham cuidado as razões do recurso,

${ }^{473}$ In PORTO, Sérgio Gilberto e USTÁRROZ, Daniel, A repercussão geral das questões constitucionais no recurso extraordinário (inovações procedimentais da Lei 11.418 e na Emenda Regimental 21 do STF), in Direito civil e processo - Estudos em homenagem ao Professor Arruda Alvim, 2007, p. 1.490. 
mas que comportariam solução diversa e em sentido oposto, desde que se tivesse propiciado ao recorrente oportunidade para debatê-las. O mesmo ocorrerá, em prejuízo do recorrido, se o tribunal der provimento ao recurso com fundamento em razões sustentadas por um dos recursos agrupados, mas não pelo recurso sob julgamento, e que, por isto, não foram respondidas pelas contrarrazões, quando poderiam tê-lo sido e vitoriosamente ${ }^{474}$.

Para facilitar o trabalho das partes e dos próprios julgadores, evitando manifestações desnecessárias que apenas repisam argumentos já constantes dos recursos paradigma ou das respectivas contrarrazões, interessante seria que o relator formulasse uma espécie de "relatório preliminar", identificando pontualmente todos os argumentos para a manutenção ou reforma das decisões recorridas nos recursos paradigmáticos. Isso já é feito, de certa forma, pelo relator antes do julgamento da preliminar de repercussão geral e tais informações ficam disponíveis para o público e para os magistrados no site do Supremo Tribunal Federal, em seção voltada ao "plenário virtual" "475. Bastaria, portanto, que o relator redigisse o relatório não apenas à luz da preliminar de repercussão geral, mas à luz também do mérito do recurso; ou que o redigisse somente à luz da preliminar de repercussão geral e depois, se positivo o juízo feito a seu respeito, o complementasse com os argumentos atinentes ao mérito. A intervenção das partes, nessa medida, somente seria permitida para acrescentar algum dado ou argumento novo, não incluído no relatório preliminar, que então seria aditado para contemplar as novas informações. Finda essa fase, aí sim os recursos paradigma seriam incluídos em pauta de julgamento, com a elaboração, pelo relator, do relatório (do acórdão) propriamente dito. Está aí mais uma sugestão - ou princípio de sugestão - para o aperfeiçoamento do sistema.

Caso não se entenda por franquear às partes que tiveram seus recursos suspensos a possibilidade de se manifestarem sobre o mérito dos recursos paradigma antes de seu julgamento, que ao menos se conceda a oportunidade de se manifestarem em seus próprios processos, antes do julgamento, com conhecimento dos recursos agrupados e informações prestadas por outros tribunais. Assim, ainda que não consigam influenciar a decisão a ser tomada nos recursos paradigma, que tenham a oportunidade de convencer o

\footnotetext{
${ }^{474}$ In Botelho De Mesquita, José Ignacio, Amadeo, Rodolfo da Costa Manso Real, Dellore, Luiz Guilherme Pennacchi, RIBEIRO, Débora, TEIXEIRA, Guilherme Silveira e ZVEIBIL, Daniel Guimarães, $A$ repercussão geral e os recursos repetitivos. Economia, Direito e Política, artigo no prelo, 2009, p. 28.

${ }^{475}$ O plenário virtual encontra-se disponível no seguinte endereço eletrônico: <http://www.stf.jus.br/portal/ jurisprudenciaRepercussao/listarProcesso.asp?situacao=EJ>, acesso em 11/11/2011.
} 
tribunal a não aplicar, em seus próprios casos, a decisão que naturalmente lhe serviria de modelo - como demonstrado, a decisão tomada nos paradigmas surte efeitos quase vinculantes, e não vinculantes; e ainda que surtisse efeitos vinculantes (conforme nossa proposta), poderia ser revista a qualquer tempo, mediante procedimento próprio.

\subsubsection{Outras questões relevantes}

Há mais alguns pontos relevantes no trato da repercussão geral a respeito dos quais a lei silencia, mas que a prática recomenda o exame. O primeiro diz com a possibilidade de as partes que tiveram os seus recursos eleitos como paradigma poderem deles desistir, ou requerer a sua "desafetação" como paradigmas. O segundo diz com a possibilidade de as partes dos recursos sobrestados recorrerem da decisão de mérito que julgar os recursos paradigma, após reconhecida a existência de repercussão geral ${ }^{476}$.

Quanto ao primeiro ponto, entendemos que, dadas as peculiaridades trazidas ao recurso extraordinário pelo instituto da repercussão geral, não se aplica aos recursos eleitos como paradigma a regra geral, prevista no art. 501, do CPC, de que "o recorrente poderá, a qualquer tempo, sem a anuência do recorrido ou dos litisconsortes, desistir do recurso". Isso porque os recursos extraordinários paradigmáticos se prestam a um fim muito maior do que a simples tutela dos direitos subjetivos das partes, no caso concreto. Nessa medida, parece aplicável aos recursos extraordinários selecionados como paradigma, por analogia, a regra de que, "proposta a ação direta, não se admitirá desistência" (art. 5, da Lei $\left.n^{\circ} 9.868 / 1999\right)^{477}$.

Aparentemente (e, por que não dizer, surpreendentemente), não é essa a diretriz que vem sendo seguida no Supremo Tribunal Federal. Embora não exista muita informação disponível sobre o tema, há notícia de que a corte havia admitido a repercussão geral da questão relativa à constitucionalidade da incidência do IPI sobre o açúcar, sob o ângulo da violação do princípio da seletividade, no RE $n^{\circ} 567.948-9 / \mathrm{RS}$. Antes do

\footnotetext{
${ }^{476}$ Naturalmente, há outras questões relevantes sobre as quais a lei silencia, mas a nossa intenção não é esgotar o tema por meio do presente estudo.

477 V., no mesmo sentido, Botelho De Mesquita, José Ignacio, AmAdeo, Rodolfo da Costa Manso Real, Dellore, Luiz Guilherme Pennacchi, Ribeiro, Débora, TeIXeIRA, Guilherme Silveira e ZveIBIL, Daniel Guimarães, A repercussão geral e os recursos repetitivos. Economia, Direito e Política, artigo no prelo, 2009, p. 12.
} 
julgamento do mérito do recurso, porém, o recorrente pleiteou a sua desistência, o que foi devidamente homologado, por simples despacho do relator, que acabou por selecionar outro de matéria idêntica - no caso em análise, o RE no 591.145/PR - para exame da matéria de fundo.

Também no "Relatório da Repercussão", disponível no site do tribunal ${ }^{478} \mathrm{e}$ atualizado em 19/04/2010, consta menção alusiva ao caso em referência que dá a entender que a desistência do recurso eleito como paradigma deve ser admitida, com a sua consequente substituição: “III - Possibilidade de se trocar o leading case: É possível que o processo em que a repercussão geral foi reconhecida não possa ser levado a julgamento de mérito (em razão de homologação de desistência, por exemplo). Nesse caso, o Ministro relator poderá selecionar outro de matéria idêntica que lhe tenha sido distribuído para que nele encaminhe no exame da matéria de fundo (despacho de 21/6/2008 no AI 716.509, Min. Marco Aurélio, substituindo o RE 567.948 pelo RE 591.145).”.

Quanto à desafetação do recurso, para que outro, ou outros, sejam eleitos como paradigma em seu lugar, entendemos que será permitido ao recorrente - assim como às partes de processos que versem sobre idêntica controvérsia, porquanto serão atingidas pela decisão a ser tomada pelo STF - pleitear providências nesse sentido. O pedido deverá ser feito mediante petição e deverá ser fundamentado. Se o recorrente apontar outro recurso, ou outros recursos, mais representativos da controvérsia, ainda melhor, embora possa simplesmente alegar que o seu apelo não possui a representatividade necessária, sem realizar qualquer sorte de comparação. O pedido será acolhido ou não, a depender dos argumentos formulados.

Quanto ao segundo ponto aventado acima, entendemos não ser cabível contra a decisão que julgar os recursos extraordinários paradigma o manejo de recurso, nem mesmo de recurso de terceiro prejudicado, pelas partes que tiveram os seus recursos sobrestados. Isso porque, como visto acima, tal precedente surtirá efeitos quase vinculantes, e não vinculantes, não possuindo tais sujeitos, tecnicamente, interesse recursal.

478 O "Relatório da Repercussão" encontra-se disponível no seguinte endereço eletrônico: <http://www.stf.jus.br/arquivo/cms/jurisprudenciaRepercussaoGeralRelatorio/anexo/RelatorioRG_Mar2010. pdf>, acesso em 11/11/2011. 
Ainda que assim não fosse, guardadas as devidas proporções, parece aplicável, por analogia, o raciocínio concernente à uniformização de jurisprudência e ao incidente de inconstitucionalidade. Com efeito, na hipótese de instauração de incidente de uniformização de jurisprudência, a parte poderá recorrer não da decisão do incidente, que firmará em abstrato a orientação a ser seguida no caso concreto, mas da decisão que aplicar no caso concreto a orientação fixada em abstrato. Da mesma forma, no incidente de inconstitucionalidade, a parte poderá recorrer não da decisão do plenário, que resolverá o incidente, mas da decisão do órgão fracionário que aplicar, em concreto, a orientação firmada no incidente. Há inclusive súmula nesse sentido: "a decisão que enseja a interposição de recurso ordinário ou extraordinário não é a do plenário, que resolve o incidente de inconstitucionalidade, mas a do órgão (câmaras, grupos ou turmas) que completa o julgamento do feito" (Súmula-STF n 513).

Assim, aqueles que tiveram seus recursos suspensos poderão recorrer das decisões do tribunal que, após o julgamento do mérito dos paradigmas, julgarem os próprios recursos até então sobrestados, aplicando a decisão dos paradigmas ou não; mas jamais poderão desafiar diretamente a decisão tomada nos paradigmas.

Essa solução parece até intuitiva se levarmos em consideração razões de ordem prática: seria inviável direcionar ao mesmo órgão, ao mesmo processo, aos mesmos autos, no mesmo momento, todos os recursos de todos aqueles que tiveram os seus recursos extraordinários (ou agravos de instrumento) sobrestados, que potencialmente podem chegar a centenas, ou a milhares.

\subsubsection{Recurso especial e recursos repetitivos}

\subsubsection{Considerações introdutórias}

Em 1988, a Constituição Federal criou o Superior Tribunal de Justiça e, com ele, o recurso especial. São impugnáveis por essa via as decisões proferidas, em única ou última instância, pelos Tribunais Regionais Federais ou pelos tribunais dos Estados, do Distrito Federal e Territórios, quando: contrariarem tratado ou lei federal, ou negarem-lhes vigência; julgarem válido ato de governo local contestado em face de lei federal; ou derem 
a lei federal interpretação divergente da que lhe haja atribuído outro tribunal (art. 105, III, "a", "b" e "c", da CF, respectivamente).

À semelhança do que ocorreu com o recurso extraordinário, em que se estabeleceu, no caso de múltiplos recursos versando sobre idêntica controvérsia constitucional, a necessidade de selecionar o mais ou os mais representativos para exame da repercussão geral e depois, se o caso, julgamento do mérito, com o sobrestamento dos demais, o legislador introduziu alterações no ordenamento com o fim de regular o julgamento dos chamados recursos especiais repetitivos. As novas figuras processuais não se confundem ${ }^{479}$, mas nesse ponto específico possuem inegável similaridade ${ }^{480}$.

Desde a sua previsão no ordenamento, sempre sobressaiu o propósito uniformizador do recurso especial, especialmente em função da previsão da alínea "c" do permissivo constitucional. A inovação processual que estabeleceu novo método para o julgamento dos recursos repetitivos reforçou ainda mais esse aspecto, reafirmando a nossa tese de que a valorização do precedente judicial e dos mecanismos de uniformização de jurisprudência tem granjeado posição de destaque nas mais recentes reformas processuais.

\subsubsection{Regulamentação}

A Lei $n^{\circ}$ 11.672/2008 houve por bem incluir no Código de Processo Civil o art. 543-C, que regulamenta os recursos especiais repetitivos, nos seguintes termos:

\footnotetext{
${ }^{479}$ Dentre as diferenças, "chama a atenção a inexistência no STJ de uma 'prejudicial de repetição recursal', análoga à que denominamos 'prejudicial de repercussão geral' no STF, e bem assim a inexistência de identidade entre os efeitos resultantes da adoção de cada um desses institutos" (in BOTELHO DE MESQUITA, José Ignacio, AmADEO, Rodolfo da Costa Manso Real, Dellore, Luiz Guilherme Pennacchi, RIBEIRO, Débora, TEIXEIRA, Guilherme Silveira e ZveIBIL, Daniel Guimarães, A repercussão geral e os recursos repetitivos. Economia, Direito e Política, artigo no prelo, 2009, p. 17).

${ }^{480} \mathrm{~V}$., nesse sentido, afirmando que "do julgamento do RE com repercussão geral, do mesmo modo que do julgamento do REsp com recursos repetitivos, decorrerá a aprovação de uma tese, que terá duplo alcance: (a) será aplicada na decisão do mérito do recurso interposto no caso concreto e (b) passará a influir na decisão das demais causas em que se controverta a respeito da mesma questão de direito", BOTELHO DE Mesquita, José Ignacio, Amadeo, Rodolfo da Costa Manso Real, Dellore, Luiz Guilherme Pennacchi, RIBEIRO, Débora, TeIXEIRA, Guilherme Silveira e ZveIBIL, Daniel Guimarães, A repercussão geral e os recursos repetitivos. Economia, Direito e Política, artigo no prelo, 2009, p. 27.
} 
"Art. 543-C. Quando houver multiplicidade de recursos com fundamento em idêntica questão de direito, o recurso especial será processado nos termos deste artigo.

$\S 1^{o}$ Caberá ao presidente do tribunal de origem admitir um ou mais recursos representativos da controvérsia, os quais serão encaminhados ao Superior Tribunal de Justiça, ficando suspensos os demais recursos especiais até o pronunciamento definitivo do Superior Tribunal de Justiça. $\S 2^{\circ}$ Não adotada a providência descrita no $\S 1^{\circ}$ deste artigo, o relator no Superior Tribunal de Justiça, ao identificar que sobre a controvérsia já existe jurisprudência dominante ou que a matéria já está afeta ao colegiado, poderá determinar a suspensão, nos tribunais de segunda instância, dos recursos nos quais a controvérsia esteja estabelecida.

$\S 3^{\circ} \mathrm{O}$ relator poderá solicitar informações, a serem prestadas no prazo de quinze dias, aos tribunais federais ou estaduais a respeito da controvérsia. $\S 4^{\circ} O$ relator, conforme dispuser o regimento interno do Superior Tribunal de Justiça e considerando a relevância da matéria, poderá admitir manifestação de pessoas, órgãos ou entidades com interesse na controvérsia.

$\S 5^{\circ}$ Recebidas as informações e, se for o caso, após cumprido o disposto no $\S 4^{o}$ deste artigo, terá vista o Ministério Público pelo prazo de quinze dias. $\S 6^{o}$ Transcorrido o prazo para o Ministério Público e remetida cópia do relatório aos demais Ministros, o processo será incluído em pauta na seção ou na Corte Especial, devendo ser julgado com preferência sobre os demais feitos, ressalvados os que envolvam réu preso e os pedidos de habeas corpus.

$\S 7^{o}$ Publicado o acórdão do Superior Tribunal de Justiça, os recursos especiais sobrestados na origem:

I - terão seguimento denegado na hipótese de o acórdão recorrido coincidir com a orientação do Superior Tribunal de Justiça; ou

II - serão novamente examinados pelo tribunal de origem na hipótese de o acórdão recorrido divergir da orientação do Superior Tribunal de Justiça.

$\S 8^{\circ} \mathrm{Na}$ hipótese prevista no inciso II do $\S 7^{o}$ deste artigo, mantida a decisão divergente pelo tribunal de origem, far-se-á o exame de admissibilidade do recurso especial. 
$\S 9^{\circ}$ O Superior Tribunal de Justiça e os tribunais de segunda instância regulamentarão, no âmbito de suas competências, os procedimentos relativos ao processamento e julgamento do recurso especial nos casos previstos neste artigo."

Embora disponha a propósito do processamento dos recursos especiais entre os arts. 255 e 257, o RISTJ é omisso sobre os recursos especiais repetitivos, tendo, no âmbito interno do tribunal, a regulamentação sobre o assunto ficado a cargo da Resol.-STJ $n^{\circ}$ 8/2008. O art. 543-C, $\S 9^{\circ}$, do CPC, informa expressamente que "o Superior Tribunal de Justiça e os tribunais de segunda instância regulamentarão, no âmbito de suas competências, os procedimentos relativos ao processamento e julgamento do recurso especial nos casos previstos neste artigo".

\subsubsection{Conceito}

Recursos especiais repetitivos são considerados os múltiplos recursos especiais com fundamento em idêntica questão de direito (art. 543-C, caput, do CPC, e art. $1^{\circ}$, caput, da Resol.-STJ nº 8/2008). Nessa condição, ficam todos sujeitos ao procedimento previsto nos instrumentos normativos acima identificados.

Estão sujeitos a tal procedimento não apenas os recursos novos, mas também os recursos especiais já distribuídos que, a critério do relator, forem considerados representativos de questão jurídica objeto de recursos repetitivos (art. $2^{\circ}, \S 1^{\circ}$, da Resol.STJ $n^{\circ}$ 8/2008). Caso assim seja, a decisão do relator será comunicada aos demais ministros e ao presidente dos Tribunais de Justiça e dos Tribunais Regionais Federais, conforme o caso, para suspender os recursos que versem sobre a mesma controvérsia (art. $2^{\circ}, \S 2^{\circ}$, da Resol.-STJ no 8/2008).

Ainda, o procedimento estabelecido na Resol.-STJ nº 8/2008 aplica-se, no que couber, aos agravos de instrumento interpostos contra decisão que não admitir recurso especial (art. $7^{\circ}$, da Resol.-STJ no 8/2008). 
$\mathrm{Na}$ existência de recursos especiais repetitivos, caberá ao presidente do tribunal de origem, ou ao vice-presidente (art. $1^{\circ}$, caput, da Resol.-STJ n 8/2008), admitir um ou mais recursos representativos da controvérsia, os quais serão encaminhados ao Superior Tribunal de Justiça, onde serão distribuídos por dependência ao mesmo relator (art. $1^{\circ}, \S 4^{\circ}$, da Resol.-STJ $n^{\circ} 8 / 2008$ ), ficando suspensos os demais recursos especiais até o pronunciamento definitivo do STJ (art. 543-C, $\S 1^{\circ}$, do CPC) ${ }^{481}$.

Não sendo adotada tal providência pelo presidente ou pelo vice-presidente do tribunal de origem, o relator no Superior Tribunal de Justiça, ao identificar que sobre a controvérsia já existe jurisprudência dominante ou que a matéria já está afeta ao colegiado, poderá determinar a suspensão, nos tribunais de segundo grau, dos recursos nos quais a controvérsia esteja estabelecida (art. 543-C, § $2^{\circ}$, do CPC). Conforme BOTELHO DE MESQUITA et. al., "o critério é meramente quantitativo e a decisão do relator, talvez por isto mesmo, ao contrário do que ocorre na repercussão geral, não é submetida ao juízo de seus pares; é simplesmente comunicada a eles (Resolução cit., art. $2^{o}$., $\$ 2^{o}$.)"482.

Será selecionado pelo menos um processo de cada relator e, dentre os escolhidos, os que contiverem maior diversidade de fundamentos no acórdão e de argumentos no recurso especial (art. $1^{\circ}, \S 1^{\circ}$, da Resol.-STJ $n^{\circ}$ 8/2008). Mais importante que a diversidade dos fundamentos é a qualidade dos mesmos, entendida como a aptidão para ensejar a reforma do acórdão recorrido ${ }^{483}$. O agrupamento de recursos repetitivos levará em consideração apenas a questão central discutida, sempre que o exame desta possa tornar prejudicada a análise de outras questões arguidas no mesmo recurso $\left(\operatorname{art} .1^{\circ}, \S\right.$ $2^{\circ}$, da Resol.-STJ no 8/2008).

\footnotetext{
${ }^{481}$ A suspensão será certificada nos autos, nos termos do art. $1^{\circ}$, § $3^{\circ}$, da Resol.-STJ n ${ }^{\circ} 8 / 2008$.

482 In Botelho De Mesquita, José Ignacio, Amadeo, Rodolfo da Costa Manso Real, Dellore, Luiz Guilherme Pennacchi, RIBEIRO, Débora, TEIXEIRA, Guilherme Silveira e ZVEIBIL, Daniel Guimarães, $A$ repercussão geral e os recursos repetitivos. Economia, Direito e Política, artigo no prelo, 2009, pp. 17/18.

483 In Botelho De Mesquita, José Ignacio, AmAdeO, Rodolfo da Costa Manso Real, Dellore, Luiz Guilherme Pennacchi, RIBEIRO, Débora, TEIXEIRA, Guilherme Silveira e ZVEIBIL, Daniel Guimarães, $A$ repercussão geral e os recursos repetitivos. Economia, Direito e Política, artigo no prelo, 2009, p. 25.
} 
Como com propriedade pontuam Botelho De MESQuita et. al., "do ponto de vista prático, parece difícil encontrar um recurso especial que se valha de todos os fundamentos úteis ao provimento do recurso, pelo que melhor fará o presidente do Tribunal recorrido se reservar sua iniciativa para o momento em que disponha da possibilidade de agrupar um número de recursos realmente representativos da controvérsia, tanto do ponto de vista quantitativo como qualitativo" 484.

Essa questão nos remete a outro ponto igualmente relevante, atinente à necessidade de maturidade da controvérsia. Com efeito, a lei não estabelece esse como requisito para o julgamento de recursos especiais repetitivos. Assim, pelo que consta do art. 543-C, do CPC, bem como da Resol.-STJ nº 8/2008, ainda que o STJ jamais tenha se debruçado sobre a matéria, na hipótese de múltiplos recursos versando sobre a mesma questão, deverá selecionar os mais representativos da controvérsia ${ }^{485}$, suspendendo os "menos representativos", sendo que a tese firmada no julgamento dos recursos paradigma surtirá efeitos amplos.

Por tudo o que já se expôs neste trabalho, não parece razoável a solução prevista pela legislação processual. Justamente em função dos efeitos amplos que surtirá o julgamento dos recursos paradigma, melhor seria se, para possibilitar o julgamento por esse novel mecanismo, fosse exigida a maturidade do debate no STJ. Apenas depois de examinados em casos sucessivos todos os argumentos favoráveis e contrários à tese jurídica posta em discussão e atingido um mínimo de consenso é que se deveria permitir que o julgamento surtisse efeitos para além do caso concreto.

Assim, ao invés de o procedimento previsto ser aplicado automaticamente sempre que houver multiplicidade de recursos especiais sobre a mesma controvérsia, o ideal seria que fosse ele reservado aos casos em que, além da multiplicidade de recursos, restasse constatada a maturidade da questão dentro do tribunal.

\footnotetext{
484 In Botelho De Mesquita, José Ignacio, Amadeo, Rodolfo da Costa Manso Real, Dellore, Luiz Guilherme Pennacchi, RIBEIRO, Débora, TEIXEIRA, Guilherme Silveira e ZVEIBIL, Daniel Guimarães, $A$ repercussão geral e os recursos repetitivos. Economia, Direito e Política, artigo no prelo, 2009, p. 25.

${ }^{485}$ Referimo-nos aos mais "representativos", no plural, pois é mais comum que sejam eleitos vários recursos para esse fim, e não apenas um.
} 
Ainda que não consista propriamente em método de uniformização de jurisprudência (tanto que não exige a existência de controvérsia, real ou potencial, para que tenha lugar), o mecanismo dos recursos repetitivos indiretamente atinge esse fim, ao proporcionar um meio para que os demais casos sobre a mesma controvérsia cheguem ao mesmo resultado dos recursos paradigma. Não seria nada conveniente que, após o julgamento dos recursos paradigma, com influência sobre outras centenas ou milhares de processos, o STJ na oportunidade seguinte retificasse seu entendimento, não por alteração das circunstâncias relevantes para a fixação da tese jurídica, mas por ter refletido melhor sobre o assunto, ou por ter se debruçado sobre argumentos até então não pensados.

Sob pena de criar imensa insegurança jurídica, deve-se esperar um mínimo de estabilidade das decisões que surtem efeitos para além do caso concreto. Certamente, no caso dos recursos repetitivos, essa estabilidade só será atingida após o devido amadurecimento do assunto dentro da corte. Como essa preocupação não se encontra refletida na lei em vigor, fica aqui mais uma sugestão de lege ferenda, ou mesmo de lege lata, caso a classe dos magistrados passe a acolher interpretação da lei em tal sentido.

\subsubsection{Competência e momento para o julgamento do recurso paradigma}

Após a seleção do recurso paradigma e a suspensão dos demais recursos, o relator poderá solicitar informações, a serem prestadas no prazo de quinze dias, aos tribunais federais ou estaduais a respeito da controvérsia (art. 543-C, § $3^{\circ}$, do CPC, e art. 3', I, da Resol.-STJ n 8/2008). Recebidas as informações e, se for o caso, admitida a intervenção de terceiros, será aberta vista ao Ministério Público pelo prazo de quinze dias (art. 543-C, § 5 ${ }^{\circ}$, do CPC, e art. $3^{\circ}$, II, da Resol.-STJ nº 8/2008).

Transcorrido esse prazo e remetida aos demais ministros cópia do relatório, do acórdão recorrido, do recurso especial, das contrarrazões, da decisão de admissibilidade, do parecer do Ministério Público e de outras peças indicadas pelo relator, com pelo menos cinco dias de antecedência em relação ao julgamento (art. $4^{\circ}$, par. único, da Resol.-STJ no 8/2008), o processo será incluído em pauta na seção ou, se houver questão de competência de mais de uma seção, na Corte Especial (art. $2^{\circ}$, caput, da Resol.STJ $n^{\circ} 8 / 2008$ ), devendo ser julgado com preferência sobre os demais feitos, ressalvados os 
que envolvam réu preso e os pedidos de habeas corpus (art. 543-C, $\S 6^{\circ}$, do CPC, e art. $4^{\circ}$, caput, da Resol.-STJ n ${ }^{\circ}$ 8/2008).

\subsubsection{Efeitos sobre os recursos sobrestados}

Publicado o acórdão do Superior Tribunal de Justiça, os recursos especiais sobrestados na origem: terão seguimento denegado na hipótese de o acórdão recorrido coincidir com a orientação do Superior Tribunal de Justiça (art. 543-C, § 7º I, do CPC); ou serão novamente examinados pelo tribunal de origem na hipótese de o acórdão recorrido divergir da orientação do Superior Tribunal de Justiça (art. 543-C, § 7º, II, do CPC). Nesse último caso, mantida a decisão divergente pelo tribunal de origem mediante decisão fundamentada $^{486}$, far-se-á o exame de admissibilidade do recurso especial (art. 543-C, $\S 8^{\circ}$, do CPC), para posterior processamento perante o STJ, se o caso.

Como se vê, essa solução lembra muito aquela prevista no art. 543-B, § $3^{\circ}$, do CPC, para o recurso extraordinário, consubstanciando mais uma hipótese de precedente de eficácia quase vinculante, pelos mesmos motivos. Aliás, nesse ponto, reiteramos tudo o que já dissemos no item "4.3.6.7” acima, no sentido de que a possibilidade de retratação pelo tribunal de segundo grau deveria ser abolida para, em vez disso, se determinar a imediata prolação de decisão pelo relator (ou eventualmente pelo colegiado) no sentido da tese firmada no julgamento dos recursos paradigma, reformando portanto a decisão recorrida.

Outrossim, se já distribuídos os recursos especiais sobrestados, serão julgados pelo relator, nos termos do art. 557, do CPC (art. 5 , I, da Resol.-STJ n ${ }^{\circ}$ 8/2008); e se ainda não distribuídos, serão julgados pela presidência, nos termos da Resol.-STJ n ${ }^{\circ}$ 3/2008 ${ }^{487}$ (art. 5º II, da Resol.-STJ no 8/2008).

\footnotetext{
${ }^{486}$ A Corte Especial do STJ, na sessão do dia 10/12/2009, no julgamento de Questão de Ordem alusiva aos REsps $n^{\circ} 1.148 .726 / \mathrm{RS}, 1.154 .288 / \mathrm{RS}, 1.155 .480 / \mathrm{RS}$ e 1.158.872/RS, decidiu que, para a manutenção de decisão divergente, necessário ao tribunal rebater cada argumento do STJ. Segundo LAZARI, "parece ter havido um 'recado' aos tribunais de origem para que a retratação ocorra: ou faz-se a retratação por mera adequação ao acórdão paradigmático, ou não se faz a retratação e fundamenta-se o porquê de não fazê-la" (in LAZARI, Rafael José Nadim de, Algumas questões jurisprudenciais sobre os "recursos representativos da controvérsia”, in Revista Dialética de Direito Processual, nº 104, 2011, p. 139).

${ }^{487}$ A Resol.-STJ no 3/2008 é composta de dois artigos, a saber: "Art. $1^{\circ}$ Compete ao Presidente, antes da distribuição: I - não conhecer de agravo de instrumento manifestamente inadmissível; II - negar seguimento a recurso especial manifestamente inadmissível, prejudicado ou em confronto com súmula ou jurisprudência
} 
Nesse ponto, o alcance do sistema dos recursos repetitivos não lembra o do recurso extraordinário; antes parece ser bem mais amplo. Explica-se: o art. 557, do CPC, como já visto ao longo desta tese, atribui ao relator competência para negar seguimento ou dar provimento a recurso contrário, ou favorável, conforme o caso, a súmula ou jurisprudência dominante de tribunal superior. A Resol.-STJ n ${ }^{\circ} 8 / 2008$, por seu art. $5^{\circ}$, I, ao determinar que, se já distribuídos, sejam os recursos especiais sobrestados julgados pelo relator nos termos do art. 557, do CPC, confere à tese vitoriosa o status oficial de jurisprudência dominante ${ }^{488}$ - não fosse assim, a Resol.-STJ no 8/2008 não faria referência ao art. 557, do CPC, prevendo simplesmente a possibilidade de julgamento monocrático pelo relator.

Na qualidade de jurisprudência dominante, a tese vencedora no STJ passa a ter um espectro de atuação muito maior, pois além de limitar o número de recursos especiais contrários a ela, passa a autorizar: a negativa de seguimento pelo relator a recursos que a desafiem (art. 557, caput, do CPC); o provimento pelo relator a recursos que impugnem decisões que a desafiem (art. 557, $\S 1^{\circ}$, do CPC); a negativa de seguimento pelo relator a AREsp e ARExt que a desafiem (art. 544, § 4, II, "b", do CPC); o provimento pelo relator a AREsp e ARExt que impugnem decisões que a desafiem (art. 544, $\S 4^{\circ}$, II, “c”, do CPC); e a decisão pelo relator de conflito de competência (art. 120, par. único, do CPC). Logo, não restam dúvidas acerca do alcance amplo do sistema de recursos repetitivos, em comparação com o sistema da repercussão geral do recurso extraordinário $^{489}$.

dominante no Tribunal; III - dar provimento a recurso especial, se o acórdão recorrido estiver em confronto com súmula ou jurisprudência dominante no Tribunal; IV - conhecer de agravo de instrumento para: a) negar seguimento a recurso especial, na hipótese prevista no inciso II; b) dar provimento a recurso especial, na hipótese prevista no inciso III. $\S 1^{\circ}$ O Presidente julgará embargos de declaração opostos contra as decisões que emitir. $\S 2^{\circ}$ Interposto agravo regimental contra decisão emitida pelo Presidente, os autos serão distribuídos, observando-se o art. $9^{\circ}$ do Regimento Interno. Art. $2^{\circ}$ Esta resolução entra em vigor na data de sua publicação no Diário da Justiça eletrônico.".

${ }^{488}$ In Botelho De Mesquita, José Ignacio, Amadeo, Rodolfo da Costa Manso Real, Dellore, Luiz Guilherme Pennacchi, Ribeiro, Débora, TeixeIRA, Guilherme Silveira e ZveIBIL, Daniel Guimarães, A repercussão geral e os recursos repetitivos. Economia, Direito e Política, artigo no prelo, 2009, p. 19.

${ }^{489}$ V., nesse sentido, In Botelho De Mesquita, José Ignacio, AmadeO, Rodolfo da Costa Manso Real, Dellore, Luiz Guilherme Pennacchi, RIBEIRO, Débora, TeIXEIRA, Guilherme Silveira e ZVEIBIL, Daniel Guimarães, A repercussão geral e os recursos repetitivos. Economia, Direito e Política, artigo no prelo, 2009, pp. 22/23. 
Por fim, para que seja dada a devida publicidade, a coordenadoria do órgão julgador expedirá ofício aos tribunais de origem com cópia do acórdão relativo ao recurso especial julgado na forma do art. 543-C, do CPC, e da mencionada Resolução do STJ (art. $6^{\circ}$, da Resol.-STJ nº 8/2008).

\subsubsection{Intervenção de terceiros}

Reza o art. 543-C, $\S 4^{\circ}$, do CPC, que "o relator, conforme dispuser o regimento interno do Superior Tribunal de Justiça e considerando a relevância da matéria, poderá admitir manifestação de pessoas, órgãos ou entidades com interesse na controvérsia". Como se vê, assim como no recurso extraordinário, o relator poderá (e não deverá, obrigatoriamente), admitir a intervenção de terceiros, considerando a relevância da matéria. A redação do respectivo $\S 5^{\circ}$ apenas reforça o caráter facultativo de tal providência.

O art. $3^{\circ}$, I, da Resol.-STJ n ${ }^{\circ}$ 8/2008, também dispõe sobre o assunto, estabelecendo que, antes do julgamento do recurso, o relator "poderá (...) autorizar, ante a relevância da matéria, a manifestação escrita de pessoas, órgãos ou entidades com interesse na controvérsia, a serem prestadas no prazo de quinze dias".

Como exposto no item anterior, a tese vitoriosa no STJ no julgamento do recurso repetitivo terá espectro de atuação amplíssimo, recomendando a intervenção de terceiros com interesse na causa. Nessa medida, nos parece que aqui também o legislador deveria ter sido menos conservador, tornando ao relator obrigatória a admissão de terceiros com interesse na controvérsia - entendidos aqueles com pertinência temática e, principalmente, as partes de processos que versam sobre idêntica tese de direito, ainda que seus processos ainda estejam em primeiro grau e não tenham tido recursos suspensos.

É no mínimo abusivo o requisito da "relevância da matéria" para que se admita a manifestação de terceiros no presente caso, já que, em razão dos extensos efeitos que serão atribuídos ao julgamento do recurso especial paradigma, independentemente do assunto tratado, toda e qualquer matéria torna-se naturalmente relevante. 
No mais, reitera-se tudo o quanto já exposto no item “4.3.6.8” quando tratamos da intervenção de terceiros no recurso extraordinário.

\subsubsection{Outras questões relevantes}

Assim como se disse em relação à repercussão geral, há mais alguns pontos relevantes no trato dos recursos repetitivos a respeito dos quais a lei silencia, mas que a prática recomenda o exame. O primeiro diz com a possibilidade de as partes que tiveram os seus recursos eleitos como paradigma poderem deles desistir, ou requerer a sua "desafetação" como paradigma. O segundo diz com a possibilidade de as partes dos recursos sobrestados recorrerem da decisão de mérito que julgar os recursos paradigma ${ }^{490}$.

No que tange ao primeiro ponto, entendemos que, diferentemente do que sustentamos quanto ao recurso extraordinário, aos recursos especiais repetitivos eleitos como paradigma deve se aplicar a regra geral, prevista no art. 501, do CPC, de que "o recorrente poderá, a qualquer tempo, sem a anuência do recorrido ou dos litisconsortes, desistir do recurso". É certo que o recurso especial também é voltado muito mais à tutela do ordenamento jurídico do que à tutela dos direitos subjetivos das partes; mas não se vislumbra nele qualquer resquício de controle de constitucionalidade, a autorizar, do nosso ponto de vista, a aplicação por analogia do art. $5^{\circ}$, da Lei $n^{\circ} 9.868 / 1999^{491}$.

Mas nem por isso, porém, deve ser obstado o julgamento da tese jurídica nele compreendida. Explica-se: considerando que a eleição do recurso paradigma gera a suspensão dos demais recursos versando sobre questão idêntica, a sua simples desistência às vésperas do julgamento ensejaria uma série de prejuízos para esses recursos suspensos, porquanto seria necessário selecionar novo recurso paradigma, com as consequências daí advindas. Tudo isso sem contar que o procedimento poderia vir a ser infinitamente frustrado, em face de sucessivos pedidos de desistência. Tendo isso em mente, o ideal é que, nesse caso, seja julgada a questão de direito posta no recurso especial eleito como

\footnotetext{
${ }^{490}$ Naturalmente, há outras questões relevantes sobre as quais a lei silencia, mas a nossa intenção não é esgotar o tema por meio do presente estudo.

${ }^{491}$ V., em sentido semelhante, Botelho DE MESQuita, José Ignacio, AMADEO, Rodolfo da Costa Manso Real, Dellore, Luiz Guilherme Pennacchi, RibeIRo, Débora, TeIXeIRA, Guilherme Silveira e ZveIBIL, Daniel Guimarães, A repercussão geral e os recursos repetitivos. Economia, Direito e Política, artigo no prelo, 2009, pp. 25/26.
} 
representativo da controvérsia e, após, seja deferido o pedido de desistência para o caso concreto.

É, aparentemente, o que propõe LAZARI, invocando o entendimento semelhante de Fredie Didier Junior, Leonardo José Carneiro da Cunha, Andrea Carla Barbosa e Diego Martinez Fervenza Cantoario: "A posição mais adequada, pois, é vincular à transcendência decisória a 'tese representativa da controvérsia', e não o 'recurso representativo da controvérsia'. O recurso é mero instrumento, e, como tal, dele se deve poder dispor. Já a tese, essa sim, é que deve ficar vinculada (...)"492.

O mesmo deve valer para os casos de perda do objeto do recurso, por desistência da ação ou acordo entre as partes, por exemplo.

Essa solução, embora "esquisita" à primeira vista, preserva, ao mesmo tempo, o interesse particular, já que a decisão tomada no julgamento do paradigma não surte efeitos sobre o caso concreto, e o interesse público, já que não afeta os demais recursos suspensos, que retomam normalmente o procedimento previsto no art. 543-C, do CPC, e na Resol.-STJ nº 8/2008.

Não obstante, em termos quantitativos, não tem sido esse o entendimento prevalecente em torno da matéria dentro do tribunal. No julgamento de Questão de Ordem levantada no REsp n ${ }^{\circ}$ 1.063.343/RS ${ }^{493}$, a Corte Especial, por maioria, considerou inviável o acolhimento de pedido de desistência recursal formulado quando já iniciado o procedimento de julgamento de recurso especial representativo da controvérsia na forma do art. 543-C, do CPC, e da Resol.-STJ nº 8/2008. O precedente, tal como um leading case, foi mencionado, e o seu entendimento reproduzido, no julgamento dos REsps $\mathrm{n}^{\circ}$ 1.111.148/SP $\mathrm{SP}^{494}$ e 1.129.971/BA ${ }^{495}$, em que também se levantou a questão.

\footnotetext{
492 In LAZARI, Rafael José Nadim de, Algumas questões jurisprudenciais sobre os "recursos representativos da controvérsia”, in Revista Dialética de Direito Processual, n 104, 2011, p. 135.

${ }^{493}$ STJ, Corte Especial, QO no REsp no 1.063.343/RS, rel. Min. NANCY ANDRIGHI, j. 17/12/2008.

${ }^{494}$ STJ, Primeira Seção, REsp no 1.111.148/SP, rel. Min. MAURo CAMPBELl MARQUES, j. 24/02/2010.

${ }^{495}$ STJ, Primeira Seção, REsp no 1.129.971/SP, rel. Min. MAURo CAMPBELl MARQUES, j. 24/02/2010.
} 
Com todo o respeito e acatamento, não podemos concordar com essa posição, pois ela trata de maneira desigual os recorrentes, conforme tenham tido seus recursos eleitos como paradigma ou não. Ou seja, ao recorrente que teve o seu recurso selecionado como representativo da controvérsia não é dado desistir; mas ao recorrente que teve o seu recurso suspenso em razão da seleção de outro como representativo da controvérsia é dado desistir. Ora, se na base do próprio instituto está a premissa de tratar os iguais de maneira igual, julgando-se os recursos repetitivos de maneira semelhante, também do ponto de vista processual o tratamento conferido deve ser o mesmo.

Por outro lado, no julgamento do REsp no 1.067.237/SP ${ }^{496}$, aderiu-se à opção por nós preconizada, tendo constado da certidão de julgamento que " $a$ Seção, por unanimidade, decidiu as duas teses afetadas pelo Sr. Ministro Relator na sistemática do art. 543-C do Código de Processo Civil, sem efeitos para o caso concreto, que foi julgado prejudicado, nos termos do voto do Sr. Ministro Relator" (destaque nosso). Para fins de ilustração, reproduzimos a ementa do julgado, separada em duas partes:

“RECURSO ESPECIAL REPETITIVO. JULGAMENTO NOS MOLDES DO ART. 543-C DO CPC. SISTEMA FINANCEIRO DA HABITAÇÃO. EXECUÇÃO EXTRAJUDICIAL DE QUE TRATA O DECRETO-LEI N ${ }^{o}$ 70/66. SUSPENSÃO. REQUISITOS. CADASTROS DE RESTRIÇÃO AO CRÉDITO. MANUTENÇÃO OU INSCRIÇÃO. REQUISITOS.

\section{Para efeitos do art. 543-C, do CPC:}

1.1. Em se tratando de contratos celebrados no âmbito do Sistema Financeiro da Habitação, a execução extrajudicial de que trata o Decretolei $n^{o} 70 / 66$, enquanto perdurar a demanda, poderá ser suspensa, uma vez preenchidos os requisitos para a concessão da tutela cautelar, independentemente de caução ou do depósito de valores incontroversos, desde que: a) exista discussão judicial contestando a existência integral ou parcial do débito; b) essa discussão esteja fundamentada em jurisprudência do Superior Tribunal de Justiça ou do Supremo Tribunal Federal (fumus boni iuris).

${ }^{496}$ STJ, Segunda Seção, REsp n ${ }^{\text {o }}$ 1.067.237/SP, rel. Min. LuIS FeLIPE SALOMão, j. 24/06/2009. 
1.2. Ainda que a controvérsia seja relativa a contratos celebrados no âmbito do Sistema Financeiro da Habitação, 'a proibição da inscrição/manutenção em cadastro de inadimplentes, requerida em antecipação de tutela elou medida cautelar, somente será deferida se, cumulativamente: i) houver ação fundada na existência integral ou parcial do débito; ii) ficar demonstrado que a alegação da cobrança indevida se funda na aparência do bom direito e em jurisprudência consolidada do STF ou STJ; iii) for depositada a parcela incontroversa ou prestada a caução fixada conforme o prudente arbítrio do juiz'.

\section{Aplicação ao caso concreto:}

2.1. Recurso especial prejudicado, diante da desistência do autor na ação principal." (destaque nosso)

Reconhecemos que essa declaração com efeitos retroativos, que após o julgamento do recurso considera-o prejudicado por desistência ou perda do objeto, é um tanto quanto estranha, e, do ponto de vista técnico-jurídico, talvez nem seja a mais correta. É no mínimo paradoxal que seja julgado no mérito um recurso que logo na sequência terá sua desistência homologada ou a perda de seu objeto reconhecida de modo a não lhe afetar a decisão recentemente proferida; também é no mínimo paradoxal que o julgamento tomado em um recurso surta efeitos sobre outros recursos, mas não sobre o próprio. Mas "abandonar alguns hábitos, para adquirir outros, não raras vezes adquire contornos dramáticos $" 497$... A previsão de novos institutos no ordenamento, assim, torna imperioso que passemos a pensar "fora da caixa", com vistas a atingir soluções que funcionem não só na teoria, mas, principalmente, na prática.

Com relação à possibilidade de requerer a desafetação de seu recurso, para que outro, ou outros, sejam eleitos como paradigma em seu lugar, nos mesmos moldes do que já dissemos em relação ao recurso extraordinário, entendemos que será permitido ao recorrente - assim como às partes de processos que versem sobre idêntica controvérsia, porquanto poderão ser atingidas pela decisão a ser tomada pelo STJ - pleitear providências nesse sentido.

\footnotetext{
${ }^{497}$ In SANTOS, Evaristo Aragão, Sobre a idéia de sistema de direito e sua contribuição para uma teoria do precedente judicial, Tese (Doutorado), 2011, p. 244.
} 
No que tange ao segundo ponto aventado no preâmbulo deste item, também entendemos não ser cabível contra a decisão que julgar os recursos especiais paradigma o manejo de recurso, nem mesmo de recurso de terceiro prejudicado, pelas partes que tiveram os seus recursos sobrestados. Isso porque, como visto acima, tal precedente surtirá efeitos quase vinculantes, e não vinculantes, não possuindo tais sujeitos, portanto, interesse recursal.

Ainda que assim não fosse, e também por analogia à regra da uniformização de jurisprudência e do incidente de inconstitucionalidade, aqueles que tiveram seus recursos sobrestados poderão recorrer das decisões que, após o julgamento do mérito dos paradigmas, julgarem os próprios recursos até então sobrestados, aplicando a decisão dos paradigmas ou não; mas jamais poderão desafiar diretamente a decisão tomada nos paradigmas.

\subsection{Eficácia persuasiva}

\subsubsection{Conceito e requisitos}

Conforme definição do dicionário Houaiss, persuasivo é adjetivo que significa "capaz de persuadir, convincente". Quando se fala em eficácia persuasiva da jurisprudência, então, está-se a fazer referência à capacidade que a jurisprudência possui de persuadir ou de convencer o juiz a acolher a tese jurídica em que se baseia, como se fosse um paradigma a ser seguido. Embora tenha essa capacidade, essa aptidão, nem sempre a jurisprudência persuade ou convence, o que denota que seus motivos determinantes não são de observância obrigatória, a não ser, é claro, para os próprios casos de que extraídos os precedentes.

No nosso sistema, qualquer decisão judicial pode surtir efeitos persuasivos e, portanto, servir de modelo para decisões posteriores em casos semelhantes. Basta que a parte a invoque para sustentar a sua tese jurídica, ou que o juiz a ela faça referência para fundamentar a sua decisão. Não há regras rígidas que determinem quando e como isso pode acontecer. 
Normalmente, porém, precedentes judiciais isolados não costumam dar azo a esse tipo de efeito; muito mais impactante e persuasiva é a citação de jurisprudência, representada por um conjunto uniforme e reiterado de decisões dos tribunais em determinado sentido. A situação é diferente no sistema de common law, em que um único julgado, mesmo que não reiterado, é considerado precedente obrigatório, porquanto declara a existência de uma norma jurídica para determinada situação de fato ${ }^{498}$.

LIMONGI FRANÇA estudou detidamente o assunto e concluiu que, preenchidos uns tantos requisitos, a jurisprudência pode, excepcionalmente, adquirir caráter de preceito geral, assumindo a feição de verdadeiro costume judiciário, em razão da necessidade natural de suprir a legislação para o fim de regular, de modo estável, situações não previstas ou não resolvidas expressamente pela lei.

Segundo o autor, em primeiro lugar, o entendimento não pode ser contrário a lei expressa em vigor. Além disso, deve ser intrinsecamente válido, de modo a atender aos reclamos de uma lacuna do sistema jurídico. Em terceiro lugar, deve ser de aceitação comum (geral, abrangendo o consenso daqueles que possuem a função de julgar), reiterada (repetida por lapso de tempo razoável) e pacífica (sem ressalvas que possam colocar em dúvida a sua procedência jurídica) ${ }^{499}$.

No nosso entender, embora não estejam escritos em lugar nenhum, a jurisprudência, para desempenhar papel persuasivo, ou então mais persuasivo, influenciando efetivamente decisões, deve obedecer a alguns outros requisitos. Sem sombra de dúvida, esses requisitos estão presentes na praxe forense e, automaticamente, no "inconsciente" dos advogados e magistrados, tais como máximas de experiência judiciária.

Em primeiro lugar, é importante que a jurisprudência seja dominante, ou, ainda melhor, pacífica. Esse critério leva em consideração essencialmente a quantidade de julgados proferidos em determinado sentido. É possível que em certa matéria existam dois ou mais posicionamentos conflitantes, cada qual com a adesão de parcela dos magistrados.

\footnotetext{
${ }^{498} \mathrm{~V}$., sobre o assunto, NOGUEIRA, Gustavo Santana, Jurisprudência vinculante no direito norte-americano e no direito brasileiro, in Revista de Processo, $\mathrm{n}^{\circ}$ 161, 2008, p. 104 e SOARES, Guido Fernando Silva, Common Law - Introdução ao direito dos EUA, 1999, p. 52.

499 In LimONGi FrançA, Rubens, Jurisprudência - Seu caráter de forma de expressão de Direito, in Repertório Enciclopédico do Direito Brasileiro, vol. 30, pp. 285/288.
} 
Nesse caso, há que se perquirir qual posicionamento conta com mais adesão: será essa a jurisprudência dominante. Por outro lado, se não houver posicionamento conflitante, e o entendimento for unânime, dir-se-á que a jurisprudência é pacífica.

Na doutrina é comum ver autores que equiparam os termos "jurisprudência dominante" e "jurisprudência pacífica", como se ambos estivessem a se referir ao mesmo fenômeno. Para nós, há uma ligeira diferença nas expressões, como exposto acima. Dominante é aquele que domina alguém ou algo, que prevalece sobre alguém ou algo; logo, pressupõe a existência de outrem ou de outra coisa, com quem ou com o que possa se comparar. Já pacífico é o incontestável, em relação ao qual ninguém ou nada se opõe ${ }^{500}$. Nessa perspectiva, é evidente que a jurisprudência pacífica é um tanto mais forte que a dominante $^{501}$. É como se houvesse uma escada e, quanto mais alto o degrau, maior a eficácia persuasiva:

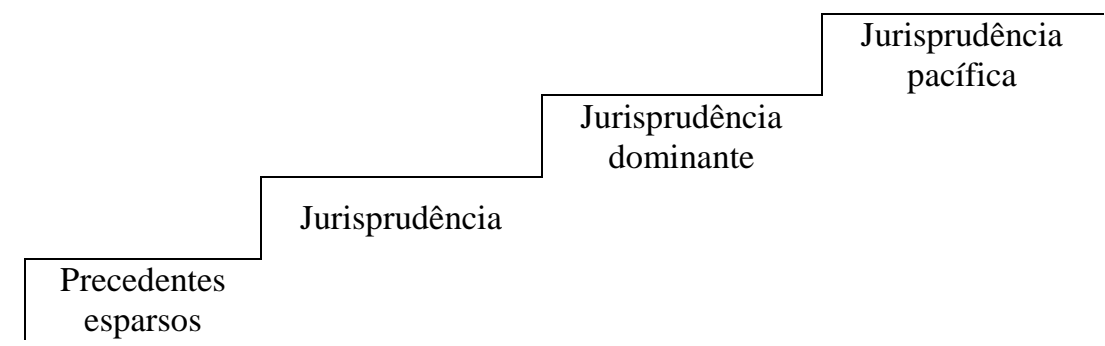

\footnotetext{
${ }^{500}$ V., em sentido semelhante ao nosso, afirmando que "pacífica será a jurisprudência quando não encontrar ela relevante oposição, ou seja, nos casos em que os tribunais não discutem a respeito de certo tema ou, ainda, a discussão que ele enseja não merece séria atenção" e que "dominante, ao contrário, é a jurisprudência que predomina na orientação dos tribunais, ainda que pesem, contra tal tese, correntes de julgados", ARENHART, Sérgio Cruz, A nova postura do relator no julgamento dos recursos, in Revista de Processo, $\mathrm{n}^{\circ} 103,2001$, p. 47. Para CARDOSO, não existe jurisprudência não pacífica, já que a expressão designa um conjunto de decisões no mesmo sentido, proferidas de modo estável e reiterado, acerca de um assunto determinado (in CARDOSO, Oscar Valente, Súmulas vinculantes e desvinculação da jurisprudência, in Revista Dialética de Direito Processual, $\mathrm{n}^{\circ}$ 77, 2009, p. 70). De fato, é esse o sentido da expressão "jurisprudência". Todavia, quando se fala em jurisprudência pacífica, não se está a fazer referência a entendimentos dissonantes dentro dela - realmente, isso seria de todo impossível -, mas a entendimentos dissonantes fora dela. Assim, é possível que a uma corrente jurisprudencial (formada por decisões no mesmo sentido, proferidas de modo estável e reiterado, acerca de um assunto determinado) contraponham-se precedentes em sentido contrário; nesse caso, a jurisprudência não será pacífica. Por outro lado, se o entendimento jurisprudencial permanecer único e isolado, sem qualquer posicionamento contrário que o desafie, dir-se-á que a jurisprudência é pacífica.

${ }^{501}$ Com fundamento no mesmo raciocínio, “o acórdão unânime sobreleva em prestígio aos que provocaram votos divergentes" (in PEREIRA DOS SANTOS, Carlos Maximiliano, Hermenêutica e aplicação do direito, 2007, p. 151). Em sentido semelhante, PARENTE registra que "precedente vinculativo bom é o que nasce com a nitidez de quem vem para ficar (ainda que seja alterado depois), que é fruto do pensamento totalmente dominante do Tribunal (de preferência, unânime) e de cujo processo de elaboração, pelo conteúdo dos debates e conclusões, depreenda-se que não houve vacilação ou dúvida séria entre os julgadores" (in PARENTE, Eduardo de Albuquerque, Jurisprudência: da divergência à uniformização, 2006, p. 61).
} 
Ainda que admitidas tais diferenças, é forçoso reconhecer que nenhum dos dois conceitos - jurisprudência dominante e jurisprudência pacífica - é preciso, na medida em que são variáveis no tempo. Assim, o que é dominante ou pacífico hoje nem sempre será dominante ou pacífico amanhã. Isso acontece porque as teses jurídicas são mutáveis e refletem a consciência jurídica da comunidade em determinado contexto histórico ${ }^{502}$.

Outra polêmica que surge em torno do termo "jurisprudência dominante" diz com o fato de a expressão referir-se a quantidade ou qualidade. CRUZ E TUCCI, por exemplo, lança a dúvida: "Em diversas ocasiões, criticando a infeliz expressão jurisprudência dominante, tivemos a oportunidade de questionar qual teria sido a verdadeira intenção do legislador: jurisprudência qualitativa ou quantitativamente dominante?..." 503 .

Como já ponderado, pensamos que a expressão está a se referir a jurisprudência quantitativamente dominante. Nem por isso descartamos o critério da qualidade $^{504}$. É esse, inclusive, o segundo requisito da nossa lista: quanto melhor fundamentado o entendimento, maior o seu grau de convencimento. Isso, aliás, se faz presente em todas as vertentes da nossa vida - quanto melhor a fundamentação do médico, mais inclinados ficamos a aderir àquele tratamento; quanto melhor a fundamentação do vendedor, mais tendentes nos tornamos a adquirir aquele produto etc.

Em terceiro lugar, deve-se considerar o nível hierárquico da autoridade prolatora da decisão: quanto mais alto, maior grau de influência terá o respectivo entendimento jurisprudencial. Isso porque autoridades hierarquicamente superiores tendem a ser mais sábias e experientes ${ }^{505} \mathrm{e}$, por isso, a errar menos ${ }^{506}$, o que aumenta o seu grau de

\footnotetext{
${ }^{502}$ In MARINHO FilHo, Luciano, Breves comentários aos embargos de divergência e aos incidentes de uniformização de jurisprudência no direito processual brasileiro, in Revista Dialética de Direito Processual, $\mathrm{n}^{\mathrm{o}} 74,2009$, p. 48.

${ }^{503}$ In CRUZ E TUCCI, José Rogério, Precedente judicial como fonte de direito, 2004, p. 18, nota de rodapé no 15 .

${ }^{504}$ V., afirmando que os precedentes se examinam "sob o aspecto da qualidade, e não da quantidade", MonteIRO, Washington de Barros, Da jurisprudência, in Revista Forense, vol. 202, 1963, p. 374.

${ }^{505}$ Nesse sentido, há mais de cinquenta anos, GuIMARÃES já afirmava que: "A jurisprudência é, nos tribunais, a sabedoria dos experientes. É o conselho precavido dos mais velhos. Quem conhece a lei e ignora a jurisprudência, diz, com exagêro embora, DUPLIANT, não conhece quase nada." (in GUIMARÃES, Mário, $O$ juiz e a função jurisdicional, 1958, p. 327). Tanto é assim que os arts. 101, caput, e 104, par. único, da CF, exigem que os ministros do STF e do STJ, respectivamente, sejam cidadãos com mais de trinta e cinco anos de idade e tenham "notável saber jurídico".
} 
credibilidade e confiabilidade. Mais do que isso, as decisões das autoridades hierarquicamente superiores são as que tendem a triunfar, já que são elas que, em grau de recurso, julgam por último ${ }^{507}$. Tornou-se célebre, nos Estados Unidos, frase do juiz ROBERT H. JACKSON, em voto proferido no caso Brown vs. Allen, em 1953, que expressa justamente esse aspecto: "we are not final because we are infallible, but we are infallible only because we are final" ${ }^{, 508}$. Assim, normalmente, a decisão de um tribunal estadual ou federal não será tão persuasiva quanto a decisão de um tribunal superior, justamente porque aquela dificilmente prevalecerá se em confronto com esta.

Em quarto lugar, o entendimento jurisprudencial deve ser atual ${ }^{509}$. Não precisa ser recente, basta que não se encontre superado por entendimento posterior - tanto que, com fundamento no mesmo raciocínio, "não se conhece do recurso especial pela divergência, quando a orientação do tribunal se firmou no mesmo sentido da decisão recorrida" (Súmula-STJ $n^{\circ}$ 83). Mudanças de orientação são comuns e saudáveis para a evolução do direito, de modo que o critério visa a assegurar que a decisão efetivamente reflete posicionamento ainda em vigor ${ }^{510}$.

\footnotetext{
${ }^{506}$ Embora o certo e o errado, ao menos no campo das ciências humanas, sejam conceitos relativos.

${ }^{507}$ Esse aspecto já era notado por SAVIGNY: "L'influenza di un tribunale superiore sui tribunali ad esso subordinati è di natura alquanto diversa: poichè qui non agisce soltanto l'autoritá, che impone rispetto, ma il potere, che compete al tribunale superiore di far trionfare le proprie convinzioni con sentenze riformative. Quando il tribunale inferiore si sottomette all'opinione contraria, esso non cede già ad una forza esterna, ma piuttosto opera nel senso e secondo lo spirito benefico della gerarchia dei tribunali o della graduzione delle istanze." (in SAVIGNY, Friedrich Carl von, Sistema del diritto romano attuale, vol. 1, 1896, p. 114). V., em sentido semelhante, o primeiro inclusive invocando as lições do mestre tedesco, BUZAID, Alfredo, Uniformização da jurisprudência, in Revista da Ajuris - Associação dos Juízes do Rio Grande do Sul, $\mathrm{n}^{\circ} 34$, 1985, p. 212 e CunHA, Sérgio Sérvulo da, Nota breve sobre o efeito vinculante, in Revista de Informação Legislativa, no 129, 1996, p. 6.

508 In CAZETTA JÚNIOR, José Jesus, A ineficácia do precedente no sistema brasileiro de jurisdição constitucional (1891-1993): contribuição ao estudo do efeito vinculante, Tese (Doutorado), 2004, p. 93.

${ }^{509} \mathrm{Na}$ common law, quanto mais antiga for a regra de direito, maior autoridade ela terá. V., nesse sentido, FERRO, Marcelo Roberto, A jurisprudência como forma de expressão de direito, in Revista de Direito Civil, Imobiliário, Agrário e Empresarial, no 51, 1990, pp. 94/95 e LIMONGI FRANÇA, Rubens, Jurisprudência Seu caráter de forma de expressão de Direito, in Repertório Enciclopédico do Direito Brasileiro, vol. 30, p. 281. V., sustentando que para a common law um precedente (sua ratio decidendi) nunca perde sua vigência, ainda que os anos o tenham tornado inaplicável às circunstâncias modernas, podendo ser invocado desde que demonstrada a sua utilidade para o caso, FERRAZ JUNIOR, Tércio Sampaio, Introdução ao estudo do direito técnica, decisão, dominação, 1994, pp. 243/244. Afinal, não se trata de estudar os casos do passado como simples curiosidades históricas, mas de enxergá-los como se tivessem sido decididos ontem (in POSNER, Richard A., The problems of jurisprudence, 1993, p. 3). Nem por isso ocorre o engessamento do sistema, pois os juízes anglo-saxões frequentemente desconsideram precedentes que não se coadunam mais com as circunstâncias modernas (in Ross, Alf, Direito e justiça, 2000, pp. 112/113).

${ }^{510}$ Vale a ressalva de que, decisões proferidas num mesmo sentido, num curto período, podem representar o início de uma nova orientação, ou simplesmente uma orientação efêmera, restrita àquele momento. V., sobre
} 
Tais elementos devem ser sempre avaliados em conjunto, sendo certo que o grau de persuasão do entendimento jurisprudencial será tanto maior se for dominante ou pacífico, bem fundamentado, defendido por autoridade hierárquica superior e atualíssimo. $\mathrm{Na}$ prática nem sempre todos esses elementos se colocam simultaneamente, o que não retira por completo da jurisprudência (ou eventualmente do precedente judicial, mesmo que isolado) a sua eficácia persuasiva.

É difícil dizer aqui qual critério prepondera sobre o outro - se de fato algum prepondera. Deve ser sempre examinado o caso concreto, à luz de suas peculiares características.

\subsubsection{Súmulas}

Como já exposto, as súmulas da jurisprudência predominante, desde que idealizadas pelo Min. Victor Nunes LEAL, sempre tiveram eficácia meramente persuasiva. Como, porém, sempre foram de aceitação geral por parte da magistratura, há quem diga que na prática assumem eficácia quase vinculante, apesar de não haver qualquer impedimento para que o julgador, singular ou colegiado, decida contrariamente à posição registrada nos enunciados ${ }^{511}$.

Basicamente, consistem em textos resumidos que sintetizam regras sobre a interpretação de determinadas normas, recebendo números convencionais para facilitar a busca e a referência. Justamente por essa natureza, o art. 102, § $4^{\circ}$, do RISTF, e o art. 124,

tal aspecto, LOPES, Raquel Cardoso, Uniformização da jurisprudência, in Revista Forense, vol. 390, 2007, p. 572.

511 V., referindo-se a essa eficácia prática quase vinculante, TOSTES, Natacha Nascimento Gomes, Uniformização de jurisprudência, in Revista de Processo, $\mathrm{n}^{\circ}$ 104, 2001, p. 209. V., em sentido semelhante, sustentando que "embora thes falte efeito vinculante, elas são geralmente adotadas pelos juizes e tribunais do país, seja pelo poder de convicção dos acórdãos de que se originaram, seja por motivos de ordem prática", GARCIA, Dínio de Santis, Efeito vinculante dos julgados da Corte Suprema e dos Tribunais Superiores, in Revista dos Tribunais, vol. 734, 1996, p. 44. V., ainda, afirmando que, "entre nós, ainda que não expressa essa obrigatoriedade, as Súmulas são de aplicação obrigatória quando ocorrem as hipóteses nelas previstas: nem se há de permitir que continuem as partes a litigar em juízo sobre questão na qual o Tribunal Superior, encarregado de julgá-la, em final decisão, tem orientação firmada a respeito", CORRÊA, Oscar Dias, Breves ponderações sobre a crise do Poder Judiciário, in Revista de Processo, $\mathrm{n}^{\circ}$ 98, 2000, $\mathrm{p}$. 157. 
do RISTJ, dispõem que a citação da súmula pelo número correspondente dispensará, perante o tribunal, a referência a outros julgados no mesmo sentido.

Em regra, as súmulas representam entendimento consolidado e reiterado do tribunal que a edita, mas, ao contrário do que muitos pensam, nem sempre isso acontece e por vezes súmulas se formam com base em um único precedente ${ }^{512}$. Embora fosse extremamente desejável que o requisito da existência de repetidas decisões anteriores se colocasse em relação a todas as súmulas, tal qual é posto em relação à súmula vinculante, a ausência de posicionamento constante e firme do tribunal não é óbice para a edição das súmulas da jurisprudência predominante - ou seja, paradoxalmente, nem sempre as súmulas da jurisprudência predominante refletem a jurisprudência predominante...

No Código de Processo Civil, a súmula é prevista no art. 479, caput, do CPC, que, ao tratar do incidente de uniformização de jurisprudência, o qual será abordado mais adiante, prevê que o "o julgamento, tomado pelo voto da maioria absoluta dos membros que integram o tribunal, será objeto de súmula e constituirá precedente na uniformização da jurisprudência”. De resto, a súmula é regulada pelos regimentos internos, e por resoluções, dos tribunais.

Devido aos limites deste trabalho, veremos a seguir o tratamento conferido às súmulas pelo STF e pelo STJ. Fica, contudo, a ressalva de que os demais tribunais do país preveem em seus regimentos internos outros regramentos a propósito das súmulas editadas no âmbito interno de cada tribunal, já que a súmula da jurisprudência predominante, desde há muito, não é mais prerrogativa exclusiva do STF.

\subsubsection{Súmulas do STF}

No Regimento Interno do STF, a súmula é tratada nos arts. 102 e 103 . Tais artigos esclarecem que a jurisprudência assentada pelo tribunal será compendiada na Súmula do Supremo Tribunal Federal ${ }^{513}$ (art. 102, caput, do RISTF) e, ao lado dos arts.

\footnotetext{
${ }^{512} \mathrm{~V}$., no mesmo sentido, ao tratar do incidente de uniformização de jurisprudência, que pode culminar na edição de súmula, CARDOSO, Oscar Valente, Súmulas vinculantes e desvinculação da jurisprudência, in Revista Dialética de Direito Processual, nº 77, 2009, pp. 73/74.

513 Conforme muito bem apontado por DALL'AGNOL, "a Súmula, em realidade, compreende o conjunto de enunciados; a prática, porém, tem ignorado a circunstância, denominando-se 'súmulas' os diferentes
} 
354-A a 354-G, do RISTF, os quais parecem ter substituído a Resol.-STJ no 388/2008 para todos os efeitos, regulamentam o procedimento para a edição, revisão ou cancelamento de enunciados na súmula.

Em suma, a inclusão de enunciados na súmula, bem como a sua alteração ou cancelamento, devem ser deliberados em plenário, por maioria absoluta (art. $7^{\circ}, \mathrm{VII}, \mathrm{e}$ 102 , $\S 1^{\circ}$, do RISTF), sendo que quaisquer ministros podem propor a revisão da jurisprudência assentada em matéria constitucional e da compendiada na súmula, procedendo-se ao sobrestamento do feito, se necessário (art. 103, do RISTF).

A propósito do procedimento previsto para a edição, revisão e cancelamento da súmula, chama-se a atenção para tudo o quanto já exposto acima quando tratamos da súmula vinculante, uma vez que o art. $2^{\circ}$ da Emenda Regimental no 46/2011, que incluiu os arts. 354-A a 354-G no Regimento Interno, previu expressamente que "esta emenda aplica-se, no que couber, ao procedimento de edição, revisão ou cancelamento de súmula não vinculante", dando a entender que o novel procedimento substituiu por completo, inclusive no que diz respeito às súmulas não vinculantes, aquele previsto na Resol.-STJ $n^{\circ}$ $388 / 2008$.

Os verbetes cancelados ou alterados guardarão a respectiva numeração com a nota correspondente, tomando novos números os que forem modificados (art. 102, § $2^{\circ}$, do RISTF). Os adendos e emendas à súmula, datados e numerados em séries separadas e sucessivas, serão publicados três vezes consecutivas no DJ (art. 102, § $3^{\circ}$, do RISTF).

De tudo o quanto exposto, percebe-se que a súmula do STF conta com um procedimento bastante rígido para a sua edição, exigindo o voto da maioria absoluta do plenário. Esse fato demonstra que, no âmbito desse tribunal supremo, não é qualquer decisão ou entendimento que é capaz de gerar súmula; é necessário que o voto seja tomado pelo mais alto órgão do tribunal, pela maioria dos membros que o compõem, em procedimento que em muito se assemelha com o da súmula vinculante. Não à toa, a súmula do STF tende a ser respeitada, ainda que formalmente desprovida de eficácia vinculante.

enunciados, todos caracterizados por um número determinado, na ordem crescente de sua publicação" (in DALl'Agnol Junior, Antonio Janyr, Admissão do recurso de apelação e súmulas (exegese do art. 518, $\$ 1^{\circ}$, do $(P C)$, in Revista do Advogado, n 85, 2006, p. 184, nota de rodapé no 8). 
Percebe-se, outrossim, que a súmula contém válvulas de escape que permitem a sua revisão ou cancelamento, afastando-se a temida estagnação de seus enunciados.

\subsubsection{Súmulas do STJ}

No âmbito do Superior Tribunal de Justiça, seu regimento interno reserva à súmula os arts. 122 a 127. Também aqui o assunto é de extrema importância, uma vez que, à semelhança do que ocorre no STF, a jurisprudência firmada pelo tribunal será compendiada na Súmula do Superior Tribunal de Justiça.

De acordo com o que consta no regimento, será objeto de súmula o julgamento tomado pelo voto da maioria absoluta dos membros que integram a Corte Especial ou cada uma das seções, em incidente de uniformização de jurisprudência; também poderão ser inscritos na súmula os enunciados correspondentes às decisões firmadas por unanimidade dos membros componentes da Corte Especial ou da seção, em um caso, ou por maioria absoluta em pelo menos dois julgamentos concordantes (art. 122, $\S 1^{\text {o }}$, do RISTJ).

As hipóteses não param por aí: qualquer ministro poderá propor, na turma, a remessa do feito à Corte Especial, ou à seção, para o fim de ser compendiada em súmula a jurisprudência do tribunal, quando verificar que as turmas não divergem na interpretação do direito (art. 126, caput, do RISTJ); igualmente, a Comissão de Jurisprudência poderá propor à Corte Especial ou à seção que seja compendiada em súmula a jurisprudência do tribunal, quando verificar que as turmas não divergem na interpretação do direito (art. 126, $\S 3^{\circ}$, do RISTJ).

Ainda, semelhantemente ao procedimento de uniformização de jurisprudência constante do art. 555, $\S 1^{\circ}$, do CPC, que será tratado adiante, o art. 127, caput, do RISTJ, prevê que, quando convier pronunciamento da Corte Especial ou da seção, em razão da relevância da questão jurídica, ou da necessidade de prevenir divergências entre as turmas, o relator, ou outro ministro, no julgamento de qualquer recurso, poderá propor a remessa do feito à apreciação da seção respectiva, ou da Corte 
Especial, se a matéria for comum às seções. Acolhida a proposta, a turma remeterá o feito ao julgamento da seção ou da Corte Especial, dispensada a lavratura do acórdão. Com as notas taquigráficas, os autos irão ao presidente do órgão do tribunal, para designar a sessão de julgamento. A Secretaria expedirá cópias autenticadas do relatório e das notas taquigráficas e fará sua distribuição aos ministros que compuserem o órgão competente para o julgamento (art. 127, § $1^{\circ}$, do RISTJ). Proferido o julgamento, cópia do acórdão será, no prazo da sua publicação, remetida à Comissão de Jurisprudência, para elaboração de projeto de súmula, se for o caso (art. 127, § 2º do RISTJ). Exsurge, portanto, mais uma possibilidade de edição de súmula no âmbito interno do STJ.

Daí se vê que a regra do RISTJ é bem mais ampla em comparação com a regra prevista no RISTF. Enquanto no STF, para a edição de súmula, é necessário o voto da maioria absoluta do plenário, convocado especialmente para esse fim, no STJ seis situações autorizam essa mesma providência, quais sejam: o julgamento tomado pelo voto da maioria absoluta dos membros da Corte Especial ou de cada uma das seções, em incidente de uniformização de jurisprudência (o que é bastante coerente com o art. 479, do CPC); o julgamento tomado pela unanimidade dos membros componentes da Corte Especial ou da seção, em um caso; o julgamento tomado pelo voto da maioria absoluta dos membros componentes da Corte Especial ou da seção, em pelo menos dois julgamentos concordantes; proposta nesse sentido por qualquer dos ministros, quando verificar que as turmas não divergem na interpretação do direito; proposta nesse sentido pela Comissão de Jurisprudência, quando verificar que as turmas não divergem na interpretação do direito; o julgamento de recurso pela Corte Especial ou pela seção, quando convier o seu pronunciamento, em razão da relevância da questão jurídica, ou da necessidade de prevenir divergência entre as turmas.

Esquematicamente, as situações que podem dar ensejo a edição de súmulas pela Corte Especial ou pelas seções do STJ são as seguintes, na medida em que obedecidos os requisitos adiante estabelecidos: 


\begin{tabular}{|c|c|}
\hline \multicolumn{2}{|c|}{ Súmulas - STJ } \\
\hline Situação & Requisito \\
\hline Incidente de uniformização de jurisprudência & \multirow{2}{*}{ Julgamento por maioria absoluta } \\
\hline Dois ou mais julgamentos concordantes & \\
\hline Um único caso & Julgamento por unanimidade \\
\hline Proposta de qualquer ministro & \multirow{2}{*}{$\begin{array}{l}\text { Não divergência entre turmas na interpretação do } \\
\text { direito }\end{array}$} \\
\hline Proposta da Comissão de Jurisprudência & \\
\hline Recurso em trâmite perante turma & $\begin{array}{l}\text { Julgamento proferido pela Corte Especial ou por uma } \\
\text { das seções, quando for conveniente }\end{array}$ \\
\hline
\end{tabular}

A bem da verdade, o texto utilizado no RISTJ dá a entender que o julgamento tomado pelo voto da maioria absoluta dos membros da Corte Especial ou de cada uma das seções em incidente de uniformização de jurisprudência deve culminar necessariamente na edição de súmula (“será objeto da súmula o julgamento (...)”, destaque nosso), seguindo a regra do art. 479, do CPC, enquanto que as demais hipóteses previstas poderão culminar na edição de súmula, mas não o farão obrigatoriamente ("também poderão ser inscritos na súmula os enunciados (...)", "qualquer Ministro poderá propor (...)”, “a Comissão de Jurisprudência poderá, também, propor (...)” e “(...) proferido o julgamento, cópia do acórdão será, no prazo da sua publicação, remetida à Comissão de Jurisprudência, para elaboração de projeto de súmula, se for o caso”, destaque nosso).

Em quaisquer casos acima, a inclusão da matéria objeto de julgamento na súmula da jurisprudência do tribunal será deliberada pela Corte Especial ou pela seção, por maioria absoluta de seus membros (art. 122, § $2^{\circ}$, do RISTJ), sendo que, se a seção entender que a matéria a ser sumulada é comum às seções, remeterá o feito à Corte Especial (art. 122, § $3^{\circ}$, do RISTJ). Afinal, compete às seções "sumular a jurisprudência uniforme das Turmas da respectiva área de especialização e deliberar sobre a alteração e o cancelamento de súmulas" (art. 12, par. único, III, do RISTJ); já dentre as atribuições da Corte Especial está a de "sumular a jurisprudência uniforme comum às Seções e deliberar sobre a alteração e o cancelamento de suas súmulas" (art. 11, par. único, VII, do RISTJ).

Com vistas a conferir a devida publicidade, os enunciados da súmula, seus adendos e emendas, datados e numerados, serão publicados três vezes no Diário da União, em datas próximas (art. 123, caput, do RISTJ). As edições ulteriores da súmula, por seu turno, incluirão os adendos e emendas (art. 123, par. único, do RISTJ). 
À semelhança do que ocorre no STF, quaisquer ministros poderão propor, em novos feitos, a revisão da jurisprudência compendiada na súmula, sobrestando-se o julgamento, se necessário (art. 125, $\S 1^{\circ}$, do RISTJ).

Assim, se algum dos ministros propuser revisão da jurisprudência compendiada na súmula, em julgamento perante a turma, esta, se acolher a proposta, remeterá o feito ao julgamento da Corte Especial, ou da seção, dispensada a lavratura do acórdão, juntando-se, entretanto, as notas taquigráficas e tomando-se o parecer do Ministério Público Federal (art. 125, § $2^{\circ}$, do RISTJ). A alteração ou o cancelamento do enunciado da súmula serão deliberados na Corte Especial ou nas seções, conforme o caso, por maioria absoluta de seus membros, com a presença de, no mínimo, dois terços de seus componentes (art. 125, $\S 3^{\circ}$, do RISTJ).

Ficarão vagos, com a nota correspondente, para efeito de eventual restabelecimento, os números dos enunciados que o tribunal cancelar ou alterar, tomando os que forem modificados novos números da série (art. 125, $§ 4^{\circ}$, do RISTJ) ${ }^{514}$.

À semelhança do quanto dito em relação à súmula do STF, percebe-se que a súmula do STJ conta também com um procedimento rígido para a sua edição, embora as hipóteses que a autorizam sejam mais amplas do que as previstas no STF. Ainda assim, dentro do superior tribunal, não é qualquer decisão ou entendimento que é capaz de gerar súmula; é necessário que o voto seja tomado pela Corte Especial ou pela seção, pela unanimidade ou pela maioria dos membros que as compõem, exigindo-se pelo menos duas decisões concordantes, dependendo da situação. O RISTJ prevê também duas hipóteses de edição de súmula com o nítido caráter de prevenir divergência, por iniciativa de qualquer ministro ou da Comissão de Jurisprudência, exigindo, para esse fim, uniformidade na interpretação do direito entre as turmas. Prevê, por fim, hipótese derradeira de edição de súmula, pela Corte Especial ou pela seção, a depender da relevância da questão jurídica, ou da necessidade de prevenir divergência entre as Turmas. Não à toa, a súmula do STJ também tende a ser respeitada, apesar de, formalmente, não possuir eficácia vinculante.

\footnotetext{
${ }^{514}$ Segundo LeAL, "por essa forma, a citação de um dos verbetes da Súmula corresponderá sempre a um texto único, evitando confusões no correr do tempo. Ainda que se lhe mude uma só palavra, o novo texto deverá ser identificado com numeração própria, de modo que, em qualquer tempo, sendo necessário, se possam confrontar o texto novo e o revogado." (in LEAL, Victor Nunes, Passado e futuro da súmula do STF, in Revista de Direito Administrativo, $\left.\mathrm{n}^{\circ} 145,1981, \mathrm{p} .12\right)$.
} 
Da mesma maneira, o RISTJ prevê válvulas de escape que permitem a revisão ou o cancelamento da súmula, impossibilitando a estagnação de seus enunciados.

\subsection{Adequada utilização dos precedentes judiciais e da jurisprudência: inspiração nas técnicas oriundas da common law}

Para a adequada utilização dos precedentes judiciais e da jurisprudência, sejam eles de eficácia vinculante, quase vinculante ou meramente persuasiva, é necessário que o intérprete aja com certa cautela.

Em primeiro lugar, deve-se considerar que casos dificilmente são idênticos entre si. Mas isso não impede que a decisão de um caso influencie na decisão de outro. Para tanto, tal qual é feito pelo juiz da common law, deve-se extrair do paradigma os motivos determinantes da decisão (ratio decidendi), descartando-se os elementos secundários, periféricos (obiter dicta). Se os motivos determinantes guardarem semelhança com o caso concreto e forem essenciais para a sua solução, o paradigma pode, e deve, ser utilizado. Se, ao contrário, somente os elementos secundários tiverem relação com o caso sub judice, deve-se descartar o paradigma, como feito na common law pelo procedimento de distinguishing ${ }^{515}$.

Para a realização desse exercício, que nem sempre é tarefa fácil, deve-se abandonar o vício de leitura apenas das ementas dos acórdãos e, principalmente, dos enunciados das súmulas de jurisprudência (predominante ou vinculante). Como já explicado, tanto um quanto outro são meros resumos. Nessa medida, mesmo que muito bem redigidos, não dispensam o exame da íntegra das decisões e dos debates de que se originaram, já que são eles que fornecerão o contexto fático em que proferidos e aprovados, assim como os demais elementos necessários para a exata compreensão do sentido do paradigma.

\footnotetext{
515 Como já exposto, pela teoria do stare decisis, "a força vinculativa de um caso anterior limita-se ao princípio ou regra indispensável à solução das questões de fato e de direito efetivamente suscitadas $e$ decididas. Todos os pronunciamentos que não são indispensáveis à decisão constituem dicta." (in RE, Edward D., Stare decisis, in Revista de Informação Legislativa, n 122, 1994, p. 284).
} 
Por mais que por força do hábito falemos em "eficácia vinculante da súmula", "eficácia vinculante da decisão", "eficácia persuasiva da jurisprudência” etc. (até mesmo nesta tese tomamos a liberdade de fazer uso de tais expressões), como já demonstrado, não é o dispositivo da decisão, ou seu extrato, que surtem efeitos vinculantes, quase vinculantes ou persuasivos para com outros casos, mas sim seus motivos determinantes. Assim, para que os motivos determinantes sejam corretamente identificados, imprescindível se faz a leitura atenta e integral das decisões.

Deve-se ter em mente que o precedente é sempre uma decisão relativa a um caso particular; assim, "il precedente non si comprende se l'interpretazione della norma che in esso è stata applicata non viene connessa direttamente con la fattispecie concreta che è stata decisa" ${ }^{\prime 516}$.

Nesse ponto, merece aplausos a iniciativa do STF de incluir em seu Regimento Interno o art. 354-F, no sentido de que "o teor da proposta de súmula aprovada, que deve constar do acórdão, conterá cópia dos debates que lhe deram origem, integrando-o, e constarão das publicações dos julgamentos no Diário da Justiça Eletrônico", e de disponibilizar em seu site ${ }^{517}$ o texto completo dos debates e das propostas para a aprovação das súmulas vinculantes.

Ainda sobre o assunto, muito interessantes são as ponderações de KEITH S. Rosenn, Professor da Faculdade de Direito da Universidade de Miami, que, em passagem pelo Brasil há alguns anos, quando indagado a respeito das diferenças entre a nossa súmula vinculante e o sistema de stare decisis, assim respondeu: “(...) Normalmente as súmulas do STF se baseiam em quatro ou cinco acórdãos onde foram estabelecidos [foi estabelecido] um mesmo procedimento que se transforma em súmula. Nós não temos a Súmula, nós temos somente a jurisprudência, e tem que se ver o caso inteiro e entender a norma jurídica como um resultado dos fatos específicos. E se houve um fato diferente que seja relevante, você pode, sem desobedecer essa força vinculatória, distinguir do precedente dizendo que os fatos de um determinado caso são diferentes. E essa é a maneira de argüir,

\footnotetext{
${ }^{516}$ In TARUfFo, Michele, Precedente e giurisprudenza, in Rivista Trimestrale di Diritto e Procedura Civile, ano $61, \mathrm{n}^{\circ} 3,2007$, p. 710.

517 Conforme o seguinte endereço eletrônico: <http://www.stf.jus.br/portal/cms/verTexto.asp?servico= jurisprudenciaSumulaVinculante>, acesso em 27/09/2011.
} 
em nosso sistema. Estamos sempre discutindo se os fatos são parecidos ou não. E, muitas vezes, o Supremo muda uma linha de jurisprudência dizendo que os fatos são um pouco diferentes e essas diferenças são significativas para os motivos jurídicos, que alteram uma decisão de maneira importante. Temos que comparar uma decisão com outra e ler os acórdãos inteiros para entender qual é o feito. Aqui todo mundo lê a Súmula e o acórdão permanece desconhecido. Essas são as diferenças importantes entre a súmula vinculante e o nosso sistema de stare decisis. Acho importante a adoção dessa emenda, adotada recentemente pelo senado brasileiro, de conceder a força vinculatória das súmulas. Mas espero que não esqueçam os fatos do sistema. As súmulas vinculantes diferem de maneira importante do nosso stare decisis." ${ }^{\circ 18}$.

Caso a leitura atenta da íntegra das decisões não seja observada, corre-se o risco de, em sendo o paradigma mal interpretado, serem decididos de forma igual casos desiguais, em grave afronta ao princípio da isonomia, semelhantemente ao que ocorre quando são decididos de forma diversa casos iguais. Isso porque, como demonstrado, as ementas e as súmulas não prescindem por completo da atividade hermenêutica do intérprete. Embora sejam menos abstratas que as leis, porquanto formuladas à luz de casos concretos, somente com a pesquisa acurada dos casos antecedentes é que é possível enxergar seus motivos determinantes e concluir efetivamente se devem ser aplicados ao caso sub judice ou não ${ }^{519}$.

Em segundo lugar, como já defendido reiteradas vezes nesta tese, a utilização do paradigma deve ser feita sempre de maneira crítica, e não de forma automática. É natural que em determinado momento os entendimentos se tornem ultrapassados ou inadequados, exigindo uma revisitação. Em casos tais, não se deve ter receio de propor atualizações, com vistas a proporcionar a evolução do direito.

\footnotetext{
${ }^{518}$ In RosEnN, Keith S., Direito comparado: Brasil x EUA, in Revista Consulex (entrevista), disponível em <http://campus.fortunecity.com/clemson/493/jus/m10-002.htm>, acesso em 21/09/2011.

${ }^{519}$ Concordamos com o modo com que TOSTES arremata a questão: "Não pensem, pois, os magistrados que, ao adotarem o entendimento sumulado, ou o pensamento traduzido na jurisprudência constante, estarão livres da completa e profunda investigação e apreciação de cada caso. A remissão ao entendimento anterior cristalizado, sumulado ou não, somente tem cabida quando efetivamente verifica o juiz tratar-se da mesma fattispecie, sendo, então, e somente então, de se aplicar o princípio da adequação, para garantia da segurança jurídica." (in TOSTES, Natacha Nascimento Gomes, Uniformização de jurisprudência, in Revista de Processo, $\mathrm{n}^{\mathrm{o}}$ 104, 2001, p. 211).
} 
Nessa seara, feitas as devidas adaptações para o ordenamento pátrio, também se mostra útil a prática do overruling, igualmente oriunda do direito da common law. Afinal, se até naquele sistema, de natureza eminentemente jurisprudencial, se admite a superação de paradigmas, não haveria por que no Brasil, em que o precedente judicial desempenha papel um pouco menos incisivo, adotar-se postura diferente.

Vale a ressalva de que a alteração de entendimentos não pode, ou ao menos não deve, na medida do possível, decorrer da simples mudança de opinião do julgador, mas de alterações jurídicas e/ou sociais relevantes, ou da percepção de pontos jurídicos consideráveis não apreciados por ocasião da formulação do precedente. Caso assim não fosse, a incerteza e a insegurança jurídica seriam até maiores do que as decorrentes da inexistência do precedente ${ }^{520}$.

Conforme já demonstrado, nas hipóteses de súmulas oriundas do STF e do STJ, sejam elas vinculantes ou não, existem procedimentos expressamente previstos nos respectivos regimentos internos para a revisão ou o cancelamento dos enunciados, sendo necessário, em qualquer caso, o voto da maioria absoluta de seus integrantes. Mesmo que não houvesse previsão expressa a tal respeito, a rigor, no caso de súmula não vinculante, bastaria o seu abandono pelo magistrado. Embora muitas vezes ocorra, não concordamos com essa prática. O mais correto, por assim dizer, é que o magistrado siga fielmente todas as súmulas em vigor e, uma vez ultrapassado ou superado o entendimento nelas estampado, provoque a revisão de seu texto ou o total cancelamento do enunciado, quando então a súmula perderá qualquer efeito persuasivo.

O mesmo se diga em relação à jurisprudência não sumulada. Uma vez entendendo que ela não mais reflete os anseios da sociedade por uma decisão justa, o magistrado pode simplesmente descartá-la, proferindo decisões em sentido diverso. Até mesmo na common law é frequente a prática de desconsiderar precedentes que não se coadunam mais com as atuais circunstâncias ${ }^{521}$. Em casos tais, contudo, o mais correto é que a jurisprudência que se pretende desconsiderar seja expressamente enfrentada, afirmando o magistrado que, embora ciente do entendimento até então prevalecente, opta

\footnotetext{
${ }^{520}$ In PARENTE, Eduardo de Albuquerque, Jurisprudência: da divergência à uniformização, 2006, p. 61.

${ }^{521}$ In Ross, Alf, Direito e justiça, 2000, pp. 112/113.
} 
conscientemente por julgar de maneira diferente, expondo os motivos para tanto ${ }^{522}$. De outra forma, poder-se-ia passar a equivocada impressão de que o magistrado decidiu em sentido diverso ao entendimento prevalecente por simples ignorância ou rebeldia, o que não contribuiria, em nenhuma medida, para a superação do entendimento atacado e para a consequente evolução do direito.

Por fim, há que se chamar a atenção acerca da necessidade de se manterem sempre atualizados os repertórios de jurisprudência. Como demonstrado no item "3.2" acima, o direito jurisprudencial da common law somente se desenvolveu a partir da catalogação das decisões judiciais em livros; nessa medida, como corretamente aponta TARUFFO, "the devices aimed at publishing judgements in order to make them known are essential to any system of precedent" ${ }^{, 523}$. Hoje em dia, com a informatização, essa tarefa tornou-se mais simples ${ }^{524}$. Aos servidores dos tribunais bastam apenas alguns minutos para incluírem nos respectivos sites de internet as íntegras das decisões proferidas. Aos usuários, igualmente, bastam apenas alguns minutos para se ter acesso a tais decisões ${ }^{525}$. As ferramentas de busca facilitam ainda mais o procedimento de consulta, tornando de conhecimento amplo e geral a interpretação conferida a leis e atos normativos por juízes, turmas, câmaras, tribunais etc.

Importante que fique claro que em nenhum momento defendemos a importação pura e simples de institutos do sistema inglês ou norte-americano para o sistema brasileiro. Como visto, são modelos de direito completamente diferentes, que

\footnotetext{
${ }^{522} \mathrm{~V}$., em sentido semelhante, sustentando que "os tribunais podem deixar de decidir de acordo com decisão já prolatada, ainda que diante de caso similar, quando têm justificativa para tanto e desde que procedendo à devida fundamentação do motivo pelo qual estão alterando a sua primitiva decisão", MARINONI, Luiz Guilherme, A transformação do civil law e a oportunidade de um sistema precedentalista para o Brasil, disponível em <http://marinoni.adv.br>, acesso em 16/09/2011, p. 4. V., explicando que no direito italiano a prática de motivar a recusa a seguir os precedentes da Corte de Cassação tem sido exigida desde a década de 1980, Galgano, Francesco, L'efficacia vincolante del precedente di Cassazione, in Contratto e Impresa, $\mathrm{n}^{\circ}$ 3, 1999, p. 890.

523 In TARUFFO, Michele, Institutional factors influencing precedents, in Interpreting precedents: a comparative study, 1997, p. 451.

${ }^{524} \mathrm{~V}$., no mesmo sentido, RosAS, Roberto, Da súmula à súmula vinculante, in Revista dos Tribunais, vol. 879, 2009, p. 43. V., tratando amplamente da informatização e de seu impacto no processo, LUCON, Paulo Henrique dos Santos, Duração razoável e informatização do processo nas recentes reformas, in Direito civil e processo - Estudos em homenagem ao Professor Arruda Alvim, 2007, pp. 1.397/1.413.

${ }^{525}$ Tanto que os dissídios atuais decorrem não mais do desconhecimento dos julgados superiores, mas de divergências doutrinárias (in RAmOS, Saulo, Reforma do Judiciário: efeito vinculante das decisões dos Tribunais Superiores, in Revista da Esmape - Escola Superior da Magistratura de Pernambuco, $\mathrm{n}^{\circ}$ 9, 1999, pp. 399/400).
} 
possuem suas bases em princípios totalmente diversos, de maneira que qualquer providência nesse sentido dificilmente seria bem-sucedida ${ }^{526}$. Porém, isso não significa que não podemos nos inspirar em técnicas que naqueles países funcionam muito bem - como é o caso da diferenciação entre a ratio decidendi e o obiter dictum, após exame pormenorizado do paradigma em cotejo com o caso atual, do procedimento de distinguishing, do procedimento de overruling etc. -, realizando as devidas adaptações para o ordenamento pátrio ${ }^{527}$.

Justamente por reconhecer a existência de um sistema de precedentes, o direito anglo-saxão desenvolveu, a partir de determinadas premissas, técnicas e mecanismos para torná-lo efetivo, sem comprometer a evolução do próprio direito. No Brasil, por outro lado, a influência dos precedentes, apesar de ser hoje uma realidade, é incipiente, havendo ainda muita relutância por parte da comunidade jurídica em reconhecer a existência de um sistema que verdadeiramente suporta o precedente como parte do processo criativo do direito.

Destarte, em não se enxergando, ainda, um conjunto orgânico de princípios a respeito do papel do precedente judicial na nossa jurisdição, interessante se faz a transposição, com as adaptações cabíveis, de experiências jurídicas estrangeiras.

\footnotetext{
${ }^{526} \mathrm{~V}$., destacando o cuidado que se deve ter na adoção de institutos estrangeiros, RAMOs, Saulo, Reforma do Judiciário: efeito vinculante das decisões dos Tribunais Superiores, in Revista da Esmape - Escola Superior da Magistratura de Pernambuco, $\mathrm{n}^{\circ}$ 9, 1999, pp. 382/383.

527 V., exatamente no mesmo sentido, DinAMARCO, Cândido Rangel, Decisóes vinculantes, in Revista de Processo, $\mathrm{n}^{\circ}$ 100, 2000, p. 170.
} 


\section{OUTROS MEIOS DE UNIFORMIZAÇÃO DE JURISPRUDÊNCIA}

SUMÁRIO. 5.1 Incidente de uniformização de jurisprudência. 5.2 Incidente de assunção de competência. 5.2.1 Confronto com o incidente de uniformização de jurisprudência. 5.3 Embargos de divergência. 5.4 Processos coletivos. 5.5 O problema dos Juizados Especiais Estaduais e Federais.

\subsection{Incidente de uniformização de jurisprudência}

O incidente de uniformização de jurisprudência, previsto nos arts. 476 a 479, do CPC, é uma das formas legais previstas no nosso ordenamento para a uniformização interna dos tribunais. Inspirado no prejulgado da lei processual anterior ${ }^{528}$, não é ação própria, tampouco recurso, mas incidente suscitado no decorrer deste (incluindo-se também os casos de remessa necessária), ou no decorrer de ação de competência originária do tribunal, cuja característica principal é o julgamento per saltum.

Apesar de ser pouco visto na praxe forense, trata-se de instituto de extrema importância para evitar desigualdades na interpretação do texto da lei, razão pela qual merece as nossas considerações.

De acordo com a regra processual, compete a qualquer juiz, ao dar o voto na turma, câmara, ou grupo de câmaras, solicitar o pronunciamento prévio do tribunal pleno, ou do órgão especial que lhe faça as vezes, acerca da interpretação do direito em tese quando: verificar que, a seu respeito, ocorre divergência (art. 476, I, do CPC); ou no julgamento recorrido a interpretação for diversa da que lhe haja dado outra turma, câmara, grupo de câmaras ou câmaras cíveis reunidas (art. 476, II, do CPC).

$\mathrm{Na}$ hipótese do inciso I, duas situações se colocam: pode ser que a divergência já exista no tribunal, antes do julgamento que a suscitou, de maneira que o

\footnotetext{
${ }^{528} \mathrm{~V}$., afirmando que o instituto também guarda semelhança com o instituto alemão, com o direito italiano e português, e com a técnica de uniformização de jurisprudência prevista no Código de Processo Civil e Comercial do Estado de São Paulo, de 1930, SANCHES, Sydney, Uniformização da jurisprudência, 1975, p. 15.
} 
incidente servirá para solucionar a divergência já existente; ou pode ser que a divergência se crie dentro do tribunal durante o julgamento em curso, ocasião em que o incidente servirá para obstar a divergência infundada, evitando a alteração da orientação até então dominante ou pacífica no tribunal pelo voto de um número reduzido de juízes. Nesse último caso, a divergência se verifica quando, antes da conclusão do julgamento, os votos já manifestados, que compõem a maioria, são contrários: à orientação da própria turma ou câmara, até então correspondente à orientação dos demais órgãos fracionários; ou, em não tendo a própria turma ou câmara ainda se pronunciado a propósito da tese jurídica posta em discussão, à orientação de outros órgãos fracionários do mesmo tribunal. Ao constatar qualquer dessas situações, o juiz que ainda não tiver votado deverá requerer a instauração do incidente ${ }^{529}$.

Já a hipótese do art. 476, II, do CPC, é diversa e tem dado espaço a controvérsias na doutrina. Referido dispositivo menciona o caso em que "no julgamento recorrido a interpretação for diversa da que lhe haja dado outra turma, câmara, grupo de câmaras ou câmaras cíveis reunidas" (destaque nosso). Nessa medida, pressupõe que não haja divergência entre o julgamento recorrido e a própria turma, câmara, grupo de câmaras ou câmaras cíveis reunidas que julgará o recurso; pelo contrário, a divergência deve ser em relação a outro órgão fracionário.

Isso só é possível em dois cenários: a própria turma ou câmara que julgará o recurso ainda não se pronunciou em julgados anteriores a propósito da tese jurídica posta em discussão, e por isso não tem como conflitar com o julgamento recorrido; ou a própria turma ou câmara que julgará o recurso já se pronunciou em julgados anteriores a propósito da tese jurídica posta em discussão, no mesmo sentido do julgamento recorrido, divergindo do julgamento de outros órgãos fracionários. Esse último caso é regido pelo art. 476, I, do CPC, haja vista tratar-se de hipótese de divergência preexistente ao julgamento que a suscitou. Logo, só poder ser a primeira situação acima que o art. 476, II, do CPC, visa a disciplinar.

Daí decorre que, enquanto o inciso I do art. 476, do CPC, pressupõe a existência de divergência no tribunal (ainda que surgida no curso do julgamento do recurso

$529 \mathrm{~V}$., nesse sentido, MARCATO, Antonio Carlos, Incidente de uniformização de jurisprudência, in Apontamentos de direito processual civil, 1996, pp. 24/25. 
ou da ação), o inciso II pressupõe a inexistência, ainda, de divergência. No caso do inciso II, assim, é necessário que os votos proferidos no julgamento do recurso, ainda insuficientes para compor a maioria (pois senão estaria efetivamente criada a divergência), ameacem criar a divergência, que até esse momento é potencial, e não real.

O objetivo de tal norma é o de prevenir a ocorrência da divergência antes do seu surgimento, remetendo-se a apreciação da tese jurídica para o pleno tão logo constatada a possibilidade de ela vir a existir. Desse modo, caso alguma alteração no entendimento até então dominante ou pacífico tenha de ser feita, que o seja pelo mais alto órgão da corte, e não pelo entendimento individual de dois integrantes de órgão fracionário $^{530}$.

Essa norma segue os mesmos caminhos do art. 861, do CPC/1939, que autorizava o prejulgado nas hipóteses de divergência real e potencial: "a requerimento de qualquer de seus juízes, a Câmara, ou turma julgadora, poderá promover o pronunciamento prévio das Câmaras reunidas sobre a interpretação de qualquer norma jurídica, se reconhecer que sobre ela ocorre, ou poderá ocorrer, divergência de interpretação entre Câmaras ou turmas" (destaque nosso).

Evidentemente, a decisão recorrida pode estar de acordo ou confrontar com a orientação de outro órgão fracionário. É apenas essa última hipótese que, por opção política do legislador, merece a proteção do incidente de uniformização de jurisprudência, com fundamento no inciso II do art. 476, do CPC. O instituto então será aplicável se um juiz já tiver votado no sentido de manter a decisão recorrida e outro juiz estiver propenso a fazer o mesmo; nesse caso, ao invés de emitir seu voto, deverá provocar a manifestação prévia do tribunal pleno.

Por outro lado, se a decisão recorrida estiver de acordo com o posicionamento de outro órgão fracionário, o incidente de uniformização só poderá ser invocado quando a divergência tornar-se real, isto é, quando forem proferidos dois votos, aptos a compor maioria, em sentido contrário ao da decisão recorrida. E isso só poderá

${ }^{530} \mathrm{O}$ entendimento não é unânime. V., sustentando que o incidente de uniformização não contempla a hipótese de prevenção de divergência, JULIANI, Cristiano Reis, A nova redação do artigo 555 do CPC e a uniformização de Jurisprudência, in Revista Síntese de Direito Civil e Processual Civil, no 23, 2003, p. 38. 
ocorrer se a maioria divergente formar-se em relação aos dois primeiros juízes votantes; se se formar em relação aos dois últimos, não restará mais qualquer juiz para, ao dar o voto, requerer a instauração do incidente.

A tese acima, defendida por BotelHo DE MESQuita ${ }^{531}$ e integralmente acatada por nós, não é unânime. Tratando do inciso II, do art. 476, do CPC, NEGRÃO 532 menciona duas correntes: de acordo com a primeira, por julgamento recorrido se há de entender tanto o de primeiro grau como o de apelação; de acordo com a segunda, a uniformização só é cabível, na hipótese do inciso II, no caso de embargos infringentes. SANCHES $^{533}$ é um dos autores que compartilham dessa segunda corrente. BARBOSA MOREIRA $^{534}$, por sua vez, aduz que a fórmula do inciso I é tão ampla que sob ela já cabe o próprio caso previsto no inciso II.

Embora a iniciativa do incidente de uniformização de jurisprudência seja do juiz, a parte poderá, ao arrazoar o recurso ou em petição avulsa, requerer fundamentadamente que o julgamento obedeça ao disposto acima (art. 476, par. único, do $\mathrm{CPC}$ ). Ainda que se trate de faculdade, e não de dever da parte, recomenda-se que o interessado faça sempre uso dessa prerrogativa, tendo em vista a possibilidade de nenhum outro juiz apontar a divergência - hipótese que dispensaria o procedimento do incidente, por não ter sido verificada a divergência. A mesma prerrogativa é franqueada ao Ministério

\footnotetext{
${ }^{531}$ In BotelHo DE MESQUITA, José Ignacio, Da uniformização da jurisprudência - uma contribuição para seu estudo, in Teses, estudos e pareceres de processo civil, vol. 2, 2005, pp. 231/233. V., sustentando posicionamento semelhante, MARCATO, Antonio Carlos, Incidente de uniformização de jurisprudência, in Apontamentos de direito processual civil, 1996, pp. 25/26.

532 In Negrão, Theotonio, Código de Processo Civil e legislação processual em vigor, 2011, p. 579, comentário ${ }^{\circ} 8$ ao art. 476, do CPC.

${ }^{533}$ De acordo com o autor: "Segundo o n. II do art. 476, cabe pronunciamento prévio do Tribunal quando, 'no julgamento recorrido, a interpretação for diversa da que lhe haja dado outra Turma, Câmara, Grupo de Câmaras ou Câmaras Cíveis Reunidas'. Isso parece ocorrer em caso de apelação, julgada com um voto vencido. É que, comportando embargos infringentes, nestes se examinaráo 'julgamento recorrido' (isto é, o da apelação), e, então, se verificará se entrou em divergência, em matéria de direito, com interpretação de outra Turma, Câmara, Grupo ou Câmaras Cíveis Reunidas. Nos embargos infringentes, reconhecida a divergência, se provocará o pronunciamento prévio." (in SANCHES, Sydney, Uniformização da jurisprudência, 1975, p. 35).

${ }^{534}$ In Barbosa MoreiRa, José Carlos, Comentários ao Código de Processo Civil, vol. 5, 2008, p. 12. V., em sentido semelhante, MARINHO FILHO, Luciano, Paralelo analítico entre mecanismos de uniformização de jurisprudência no direito processual pátrio, in Revista Dialética de Direito Processual, nº 90, 2010, p. 58.
} 
Público $^{535}$, por força do quanto previsto nos arts. 127 , caput, da CF, e 82 , III, e $499, \S 2^{\circ}$, do CPC.

Daí se vê que não basta a existência de decisões divergentes entre órgãos fracionários do mesmo tribunal para que se torne obrigatória a instauração do incidente; é necessário que alguém - os juízes, ou as partes, ou o Ministério Público - suscite efetivamente a divergência ou, então, que o entendimento modelo, em relação ao qual se coloca a divergência, esteja sumulado. Isso porque a publicação no órgão oficial faz com que a súmula presuma-se conhecida por todos, tornando prescindível que a divergência seja trazida expressamente ${ }^{536}$.

Para que o instituto cumpra com a função para o qual foi previsto, qual seja, harmonizar internamente o tribunal no que diz respeito à interpretação das leis, é necessário que a divergência jurisprudencial (ou a sua ameaça) não se encontre superada, isto é, seja atual. Já no que tange à matéria do incidente, deve esta ficar restrita a questão central, capaz de influir no resultado do julgamento, seja de mérito ou apenas processual.

Da redação do art. 476, caput, do CPC, no sentido de que "compete a qualquer juiz (...)" (destaque nosso), infere-se que a instauração do incidente não é faculdade, mas dever de ofício do sujeito judicante, sempre que se verificarem as hipóteses referidas nos incisos daquele artigo ${ }^{537}$. Além disso, tanto o Estado quanto a comunidade

\footnotetext{
${ }^{535}$ V., no mesmo sentido, VIGLIAR, José Marcelo Menezes, Uniformização de jurisprudência - Segurança jurídica e dever de uniformizar, 2003, p. 187.

${ }^{536}$ In Botelho DE MESQuiTA, José Ignacio, Da uniformização da jurisprudência - uma contribuição para seu estudo, in Teses, estudos e pareceres de processo civil, vol. 2, 2005, p. 235.

${ }^{537}$ V., nesse sentido, afirmando ser inadmissível qualquer juízo de conveniência ou oportunidade, VIGLIAR, José Marcelo Menezes, Uniformização de jurisprudência - Segurança jurídica e dever de uniformizar, 2003, p. 190. V., no mesmo sentido, reconhecendo porém que "essa obrigatoriedade não tem sido admitida com facilidade pelos nossos Tribunais", em conferência proferida em Santos em 5 de agosto de 1985, BOTELHO DE MESQUITA, José Ignacio, Da uniformização da jurisprudência - uma contribuição para seu estudo, in Teses, estudos e pareceres de processo civil, vol. 2, 2005, p. 228. V., também defendendo a dita obrigatoriedade, BRAGHITTONI, Rogério Ives, Uniformização de jurisprudência e art. $555, \S 1^{\circ}$, do Código de Processo Civil, in Revista do Instituto dos Advogados de São Paulo, no 15, 2005, p. 247, BuZAID, Alfredo, Uniformização da jurisprudência, in Revista da Ajuris - Associação dos Juízes do Rio Grande do Sul, $\mathrm{n}^{\circ} 34$, 1985, p. 213 e SANCHES, Sydney, Uniformização da jurisprudência, 1975, p. 18. V., em sentido oposto, asseverando que, "na prática dos tribunais, o entendimento vigorante é que não é toda divergência sobre a tese jurídica que deve levar à uniformização da jurisprudência, mas apenas aquela que, pela reiteração e repercussão, bem como prognóstico futuro de repetição, convenha se ver uniformizada e consagrada em Súmula", Greco FilHo, Vicente, Direito processual civil brasileiro, vol. 2, 2000, p. 361. V., por fim, sustentando que o incidente deve necessariamente ser provocado pela parte, em atenção ao princípio
} 
jurídica precisam de segurança na produção das decisões, sendo a uniformização especialmente a interna - dever do Judiciário e direito do jurisdicionado, como já tivemos a oportunidade de esclarecer. Nesse ponto, o instituto difere do prejulgado do CPC/1939, uma vez que o respectivo art. 861 previa que a câmara ou turma julgadora poderia promover o pronunciamento prévio das câmaras reunidas no caso de divergência na interpretação de norma jurídica.

Em sendo a instauração do incidente de uniformização de jurisprudência um dever, e não uma faculdade, na hipótese de sua não instauração a despeito do conhecimento pelo órgão judicante dos fatos previstos nos incisos I e II do art. 476, do CPC, prosseguindo-se consequentemente com o julgamento, é cabível a interposição de recurso especial ou extraordinário pela parte prejudicada, arguindo-se a nulidade do mesmo ${ }^{538}$. Caso o julgamento seja tomado por decisão monocrática, é cabível, antes, agravo regimental, possibilitando a manifestação do colegiado sobre o assunto. Após o trânsito em julgado, a decisão é impugnável ainda por ação rescisória ${ }^{539}$.

Mesmo que reconhecida a divergência pelo órgão fracionário, pode o pleno posicionar-se contra ela. Em verdade, o procedimento se processa em duas etapas: na primeira delas, o órgão fracionário, perante o qual tramita o recurso ou a ação de sua competência originária, delibera sobre a existência da divergência; reconhecendo-a, suspende o julgamento e lavra acórdão nesse sentido, indo os autos ao presidente do tribunal para designar a sessão de julgamento (art. 477, do CPC). Na segunda etapa,

dispositivo, TesheINer, José Maria Rosa, Uniformização de jurisprudência, in Revista da Ajuris Associação dos Juízes do Rio Grande do Sul, nº 50, 1990, p. 181.

${ }^{538}$ Tratando do tema, PARENTE constata, com pesar, que essa postura teria poucas chances de êxito, pois hoje os tribunais não têm reconhecido a característica obrigatória do incidente e, portanto, não têm aceitado a interposição de recurso contra a negativa de instauração. O autor sugere, tendo em vista a falta de opções recursais aptas, a impetração de mandado de segurança por violação ao art. 476, do CPC, admitindo que também nesse caso as chances de êxito seriam mínimas. V., sobre o assunto, PARENTE, Eduardo de Albuquerque, Jurisprudência: da divergência à uniformização, 2006, pp. 69/70. V., no mesmo sentido, Botelho De Mesquita, José Ignacio, Da uniformização da jurisprudência - uma contribuição para seu estudo, in Teses, estudos e pareceres de processo civil, vol. 2, 2005, p. 236. V., em sentido oposto, sustentando que o instituto configura objeto de padronização do colegiado/tribunal e que sua omissão ou denegação não exprime qualquer prejuízo imediato ao jurisdicionado, faltando-lhe portanto interesse recursal, MARINHO FILHO, Luciano, Paralelo analítico entre mecanismos de uniformização de jurisprudência no direito processual pátrio, in Revista Dialética de Direito Processual, nº 90, 2010, p. 57. V., em sentido semelhante a este último, tratando porém da uniformização pelo art. $555, \S 1^{\circ}$, do CPC, JULIANI, Cristiano Reis, A nova redação do artigo 555 do CPC e a uniformização de Jurisprudência, in Revista Síntese de Direito Civil e Processual Civil, no 23, 2003, p. 38.

${ }^{539}$ V., no mesmo sentido, SANCHES, Sydney, Uniformização da jurisprudência, 1975, p. 22. 
chegando os autos ao pleno, é como se fosse feito um segundo juízo de admissibilidade do incidente; o pleno pode, assim, reconhecer ou não a existência da divergência.

Em não se reconhecendo o incidente, retorna-se ao órgão fracionário para o prosseguimento do julgamento do recurso ou da ação. Por outro lado, em sendo instaurado e concluído o incidente, reconhecendo-se a divergência, será dada pelo tribunal a interpretação a ser observada, cabendo a cada juiz emitir o seu voto em exposição fundamentada (art. 478, caput, do CPC), ouvindo-se sempre o chefe do Ministério Público que funciona perante o tribunal (art. 478, par. único, do CPC).

Em sendo tomado pelo voto da maioria absoluta dos membros que integram o tribunal, o julgamento será objeto de súmula, constituindo precedente na uniformização da jurisprudência (art. 479, caput, do CPC), competindo aos regimentos internos de cada tribunal a disposição sobre a publicação no órgão oficial das súmulas de jurisprudência predominante (art. 479, par. único, do CPC).

Nas precisas palavras de BOTELHO DE MESQuitA, “isto significa que, a partir do julgado de uniformização, se tomado pelo voto da maioria absoluta, perdem o valor de precedente as decisões anteriores sobre a interpretação da mesma norma, ficando todas superadas pela que lhe foi dada pelo tribunal pleno, que passa a valer como precedente único" ${ }^{, 540}$. É lógico que as partes sempre poderão invocar precedentes passados, mas estes não terão valor algum, porquanto superados por precedente superior, sumulado.

Conclui-se do exposto que o entendimento fixado no julgamento do incidente tem eficácia vinculante para o caso concreto que deu ensejo ao incidente e eficácia persuasiva sobre todos os demais casos semelhantes. Ainda assim, resta nítida a sua importância para o sistema, haja vista que, mesmo com eficácia meramente persuasiva para os casos em geral, o precedente proferido nessas condições configura relevante instrumento de uniformização interna dos tribunais, especialmente se erigido ao status de súmula.

\footnotetext{
${ }^{540}$ In BotelHo DE MESQUITA, José Ignacio, Da uniformização da jurisprudência - uma contribuição para seu estudo, in Teses, estudos e pareceres de processo civil, vol. 2, 2005, p. 235.
} 
Como já visto, as leis possuem caráter abstrato e geral, cabendo aos tribunais conferirem o sentido exato da sua interpretação. A decisão proferida no incidente de uniformização serve justamente para esse fim e, ainda que não seja de observância obrigatória, desempenha importante papel no sentido de guiar e orientar decisões futuras, visando à coerência interna dos tribunais e, consequentemente, à harmonia geral do sistema.

Como aponta PARENTE: “O problema da divergência interna, mercê de, em tese, ser mais enxuto, é muito grave, pois gera enorme incerteza, que é o dissenso entre órgãos do mesmo tribunal. (...) Portanto, a manutenção da divergência injustificada perante o mesmo tribunal é a mais nefasta expressão da desigualdade na aplicação da lei (e perante ela). ${ }^{, 541}$. O instituto ora analisado presta-se justamente a combater esse mal, daí porque defendemos sua enorme importância.

Lamentavelmente, do incidente de uniformização de jurisprudência não se extrai toda a sua utilidade, já que o instrumento é pouco utilizado na prática: ao mesmo tempo em que os advogados receiam gerar precedentes desfavoráveis aos interesses de seus clientes, os magistrados evitam submeterem-se ao pensamento da maioria ${ }^{542}$. Com isso, e por mais paradoxal que possa parecer, optam por permanecer numa espécie de "limbo jurídico", onde impera a divergência.

Situação curiosa em relação ao incidente de uniformização de jurisprudência diz respeito ao fato de o Supremo Tribunal Federal não o admitir em seus julgamentos.

\footnotetext{
${ }^{541}$ In PARENTE, Eduardo de Albuquerque, Jurisprudência: da divergência à uniformização, 2006, p. 67.

${ }^{542}$ In CRUZ E TUCCI, José Rogério, Variações sobre precedentes judiciais vinculantes e persuasivos, in Revista Magister de Direito Civil e Processual Civil, ano 1, ${ }^{\circ}$ 5, 2005, p. 18. BRAGHITTONI aponta outros três possíveis motivos para a rara ocorrência dos incidentes de uniformização de jurisprudência nos tribunais: complexidade dos julgamentos realizados por órgãos plenários; sobrecarga notória dos tribunais; e desprestígio dos precedentes judiciais em nossa cultura (in BRAGHITTONI, Rogério Ives, Uniformização de jurisprudência e art. 555, $\$ 1^{\circ}$, do Código de Processo Civil, in Revista do Instituto dos Advogados de São Paulo, $\mathrm{n}^{\circ} 15,2005$, p. 241). Até podemos concordar com os dois primeiros motivos, mas não com o terceiro: o precedente judicial nunca foi tão prestigiado no ordenamento pátrio como nos dias de hoje. Vale ressaltar que a pouca utilização do instituto já era notada no início de sua vigência. Cuidando do assunto, SANCHES o aborda nos seguintes termos: "Além do desamor à iniciativa, por arraigados hábitos profissionais ou por excesso de serviço, outros fatores, ainda de ordem subjetiva, podem ser anotados: a modéstia ou a vaidade do magistrado, que teme submeter seus pontos-de-vista à aprovação ou desaprovação de seus pares; o desapego ao debate, à polêmica, à controvérsia, que os anos de exercício funcional vão trazendo, a cada dia de grande cansaço mental." (in SANCHES, Sydney, Uniformização da jurisprudência, 1975, p. 24).
} 
Argumenta-se que a razão para isso é o fato de serem cabíveis embargos de divergência contra a decisão da turma que divergir do julgamento da outra turma ou do plenário. Não podemos concordar com esse argumento pois, como será visto adiante, o STJ prevê o cabimento de incidente de uniformização de jurisprudência (arts. 118 a 120, do RISTJ) $e$ de embargos de divergência (arts. 546, I do CPC, e 266 e 267, do RISTJ). Ademais, ainda que voltados também à uniformização da jurisprudência, os embargos de divergência não suprem por completo o dito incidente, já que, além de agirem a posteriori, no STF são cabíveis apenas de decisão que julga recurso extraordinário (ou, quando muito, agravo de instrumento, por força da disposição do art. 330, do RISTF). Todos os demais recursos e ações de competência originária do STF ficam, portanto, descobertos pelos embargos de divergência, restando possível em relação a eles somente a utilização da afetação, nos termos do art. 22, par. único, "a" e "b", do RISTF.

Ademais, apesar de não possuir previsão regimental (ao contrário do que ocorre no TJSP, por exemplo, em que o incidente de uniformização é expressamente regulado pelos arts. 187 a 189, do RITJSP), não há óbice algum para que se aplique o instituto no âmbito do tribunal supremo, tendo em vista que o Código de Processo Civil não contempla qualquer restrição nesse sentido.

Nessa toada, fica difícil reprimir a pouca exploração do instituto pelos tribunais em geral se nem mesmo a mais alta corte do país o utiliza ou, no mínimo, o estimula. O exemplo, sem dúvida, deveria partir de cima para baixo. Se os advogados são parciais e visam ao interesse exclusivo de seus clientes, o mesmo não se pode dizer dos magistrados, que em prol da unicidade do sistema, deveriam, com todas as ressalvas já feitas no decorrer deste trabalho, abrir mão de suas convicções particulares, ainda que isso implique em submissão ao pensamento da maioria.

\subsection{Incidente de assunção de competência}

O incidente de uniformização de jurisprudência convive no sistema processual com outros mecanismos de uniformização interna dos tribunais, dentre os quais o denominado "incidente de assunção de competência", implementado pela Lei $\mathrm{n}^{\circ}$ 10.352, de 26 de dezembro de 2001. Referida lei incluiu no art. 555, do CPC, o $\S 1^{\text {o }}$, que prevê que, 
"ocorrendo relevante questão de direito, que faça conveniente prevenir ou compor divergência entre câmaras ou turmas do tribunal, poderá o relator propor seja o recurso julgado pelo órgão colegiado que o regimento indicar; reconhecendo o interesse público na assunção de competência, esse órgão colegiado julgará o recurso".

Apesar de ter o mesmo propósito do incidente de uniformização de jurisprudência, esse novo instituto diferencia-se dele em diversos aspectos ${ }^{543}$.

Em primeiro lugar, o incidente de uniformização pode ser instaurado por ocasião do julgamento de todo e qualquer recurso ou de ação de competência originária do tribunal, já que o Código de Processo Civil não faz qualquer limitação a esse respeito; já a uniformização pelo art. $555, \S 1^{\circ}$, do CPC, é restrita às hipóteses de agravo e apelação (e remessa necessária, por analogia ${ }^{544}$ ), uma vez que são essas as únicas duas espécies de recurso mencionadas no caput do artigo, cuja redação também foi alterada pela Lei $\mathrm{n}^{\circ}$ $10.352 / 2001$ para contemplar tal restrição ${ }^{545}$.

Em segundo lugar, o incidente de uniformização, por sua própria natureza jurídica, instaura-se incidentalmente ao recurso ou à ação, suspendendo o curso destes até julgamento definitivo daquele; a uniformização pelo art. 555, § $1^{\circ}$, do CPC, pelo contrário, determina que o recurso em si seja julgado pelo órgão colegiado indicado pelo regimento do tribunal, gerando verdadeiro deslocamento de competência para a apreciação do recurso.

Em terceiro lugar, enquanto o incidente de uniformização aparece como um dever do julgador, a uniformização pelo art. 555, $\S 1^{\circ}$, do CPC, assume a forma de faculdade, porquanto o artigo diz que, "ocorrendo relevante questão de direito, que faça conveniente prevenir ou compor divergência entre câmaras ou turmas do tribunal, poderá

\footnotetext{
${ }^{543}$ V., em sentido contrário, afirmando que as diferenças são ínfimas ou inexistentes, MARINHO FILHO, Luciano, Paralelo analítico entre mecanismos de uniformização de jurisprudência no direito processual pátrio, in Revista Dialética de Direito Processual, $\mathrm{n}^{\circ}$ 90, 2010, p. 61.

544 V., no mesmo sentido, PARENTE, Eduardo de Albuquerque, Jurisprudência: da divergência à uniformização, 2006, p. 72.

${ }^{545}$ A redação original do art. 555, caput, do CPC, era: "O julgamento da turma ou câmara será tomado pelo voto de três juízes, seguindo-se ao do relator o do revisor e o do terceiro juiz". Após a Lei no 10.352/2001, o art. 555, caput, do CPC, assumiu a seguinte redação: "No julgamento de apelação ou de agravo, a decisão será tomada, na câmara ou turma, pelo voto de 3 (três) juízes".
} 
o relator propor (...)" (destaque nosso). Além disso, para que o relator possa propor o deslocamento da competência, são necessários dois outros requisitos, quais sejam, a relevância da questão de direito e a conveniência em fazê-lo.

Em quarto lugar, a instauração do incidente de uniformização pode ser feita por qualquer dos julgadores, ao proferirem seu voto, havendo ainda autorização para que a parte (e também o Ministério Público) requeira a sua instauração; ao passo que a uniformização pelo art. $555, \S 1^{\circ}$, do CPC, é de iniciativa exclusiva do relator, em função novamente do que consta da redação do texto legal.

Em último lugar, para a instauração e julgamento do incidente de uniformização, basta a existência ou a iminência da divergência; para que a uniformização pelo art. 555, $\S 1^{\circ}$, do CPC, ocorra, porém, é necessário outro elemento, além da divergência real ou potencial, que é a existência de interesse público. Assim, mesmo que o órgão de origem entenda estarem presentes relevante questão de direito e conveniência em compor ou prevenir divergência, o órgão destinatário pode recusar a assunção da competência, por entender não haver interesse público a autorizá-la. Tal decisão será irrecorrível, já que aqui não há a obrigatoriedade do art. 476 e ss., do CPC; todavia, uma vez que nesse momento o julgamento não terá sido concluído ainda, a parte interessada na uniformização poderá propor a instauração do respectivo incidente, cujo processamento, aí sim, será obrigatório se presentes os requisitos legais.

Da mesma forma que o incidente, o meio de uniformização que ora se discute tem a aptidão de gerar precedente orientador de decisões, com eficácia persuasiva para casos semelhantes e eficácia vinculante para o caso concreto. Diferente do que ocorre com aquele, entretanto, o julgamento proferido neste pela maioria absoluta dos membros que integram o tribunal não deve ser objeto de súmula - até porque na hipótese do art. 555, $\S 1^{\circ}$, do CPC, o voto é tomado à luz de um caso concreto, e não em abstrato, como ocorre no incidente de uniformização ${ }^{546}$.

A inclusão do $\S 1^{\circ}$ no art. 555, do CPC, cuidou de positivar, e de ampliar para os demais tribunais do país, regra denominada de "afetação", que já era aplicada na

\footnotetext{
${ }^{546}$ V., no mesmo sentido, VIGLIAR, José Marcelo Menezes, Uniformização de jurisprudência - Segurança
} jurídica e dever de uniformizar, 2003, p. 195. 
prática pelo STF e pelo STJ, com fundamento em previsão regimental. Com efeito, naquele, o relator submeterá o feito ao julgamento do plenário quando houver matérias em que divirjam as turmas entre si ou alguma delas em relação ao plenário, assim como quando, em razão da relevância da questão jurídica ou da necessidade de prevenir divergência entre as turmas, convier pronunciamento do plenário (art. 22, par. único, "a" e "b", do RISTF). Neste, as turmas remeterão os feitos de sua competência à seção de que são integrantes quando convier pronunciamento da seção, em razão da relevância da questão, e para prevenir divergência entre as turmas da mesma seção (art. 14, II, do RISTJ); da mesma forma, as seções e as turmas remeterão os feitos de sua competência à corte especial quando convier pronunciamento da corte especial em razão da relevância da questão jurídica, ou da necessidade de prevenir divergência entre as seções (art. 16, IV, do RISTJ) $)^{547}$.

\subsubsection{Confronto com o incidente de uniformização de jurisprudência}

Do exame dos dois institutos acima, fica evidente a preocupação do legislador em uniformizar a jurisprudência dos tribunais. Embora o objetivo seja louvável e defendido de maneira enfática por nós, porém, fica a impressão de que a inclusão do $\S 1^{\circ}$ ao art. 555, do CPC, foi feita de forma pouca meditada, atabalhoada, fazendo emergir pontos de conflito do novo mecanismo com o incidente de uniformização de jurisprudência.

Muito melhor seria que o legislador tivesse promovido alterações pontuais nesse instituto, se fosse o caso, com o intuito de aprimorá-lo, ao invés de criar mecanismo novo, como fez. A própria Exposição de Motivos da Lei $\mathrm{n}^{\circ}$ 10.352/2001, ao tratar do novo (nem tão novo) mecanismo de uniformização, enfatiza que "esta sistemática supera, com grande vantagem operacional, a do instituto de uniformização de jurisprudência, de limitadíssimo emprego em nossa prática forense", deixando claro o objetivo do legislador de competir com o incidente de uniformização - e, de certa forma, de esvaziá-lo.

A propósito das diferenças entre eles, quanto ao primeiro ponto, é óbvio que o incidente de uniformização supera em muito o mecanismo do art. 555, $\S 1^{\circ}$, do CPC, já

${ }^{547}$ V., abordando o fenômeno, NoGUEIRA, Gustavo Santana, Jurisprudência vinculante no direito norteamericano e no direito brasileiro, in Revista de Processo, $\mathrm{n}^{\circ}$ 161, 2008, p. 110. 
que este fica restrito a agravos e apelações. Se o objetivo é preservar a harmonia entre as decisões, é indiferente de que recurso ou ação sejam elas provenientes, não havendo por que limitar o mecanismo a uma ou outra espécie recursal como fez a Lei $n^{\circ}$ 10.352/2001, ao alterar a redação do caput do $\operatorname{artigo~}^{548}$.

Em relação ao segundo aspecto, reconhecemos que o procedimento do art. $555, \S 1^{\circ}$, do CPC, é mais enxuto que o procedimento do incidente, já que naquele a uniformização da divergência e o julgamento do recurso desenvolvem-se de uma só vez, em uma fase única. Mas nem por isso o procedimento é melhor. Pelo contrário, entendemos que o procedimento bipartido, subjetivamente complexo, é muito mais adequado para a uniformização da jurisprudência, pois permite ao pleno ou órgão especial do tribunal concentrar-se na fixação da tese jurídica, sem se perder nas particularidades do caso concreto, reservadas à análise do órgão fracionário ${ }^{549}$.

Defendendo posicionamento semelhante, CRUZ E TUCCI assevera que “enquanto o incidente processual regrado nos arts. 476 a 479 conduz à pacificação do entendimento sobre tese jurídica que integra a competência material de determinado

\footnotetext{
${ }^{548}$ V., em sentido contrário, sustentando que, apesar da redação do dispositivo, o novo instituto encontra-se previsto no capítulo "da ordem dos processos no tribunal" e, por esse motivo, deve ser aplicado em todas as matérias de competência do colegiado, como mandados de segurança, habeas corpus, conflitos de competência etc., BraghitTONI, Rogério Ives, Uniformização de jurisprudência e art. 555, $\$ 1^{\circ}$, do Código de Processo Civil, in Revista do Instituto dos Advogados de São Paulo, $\mathrm{n}^{\circ}$ 15, 2005, p. 251 e Juliani, Cristiano Reis, A nova redação do artigo 555 do CPC e a uniformização de Jurisprudência, in Revista Sintese de Direito Civil e Processual Civil, $\mathrm{n}^{\circ}$ 23, 2003, pp. 35/36. V., em sentido semelhante, defendendo a utilização desse mecanismo de uniformização para outros recursos e ações de competência originária dos tribunais, BARBOSA MoReIRA, José Carlos, $O$ novo processo civil brasileiro (exposição sistemática do procedimento), 2008, p. 181.

${ }^{549} \mathrm{~V}$., em sentido contrário, sustentando que "o novo dispositivo poderá trazer mais celeridade para situações antes sujeitas ao sistema do incidente", PARENTE, Eduardo de Albuquerque, Jurisprudência: da divergência à uniformização, 2006, p. 73. V., defendendo posicionamento semelhante, sob a justificativa de que com o novo procedimento "evita-se assim o vaivém, causa de maior demora", BARBOSA MOREIRA, José Carlos, O novo processo civil brasileiro (exposição sistemática do procedimento), 2008, p. 181. Nesse sentido é também o posicionamento de DINAMARCO, que afirma que "o novo sistema evita os males da duplicidade de pronunciamentos do tribunal, um pelo órgão competente para uniformizar e outro por aquele que decide sobre o recurso - agilizando os serviços jurisdicionais a mandar que em uma só sessão e mediante um só acórdão o recurso já fique julgado" (in DinAMARCo, Cândido Rangel, A reforma da reforma, 2003, p. 140).
} 
pretório, o novo mecanismo preocupa-se apenas com a solução de um caso isolado" ${ }^{550}$. Exatamente no mesmo sentido é a percepção de VIGLIAR ${ }^{551}$.

Independentemente de qual procedimento seja o melhor, o único ou o bipartido, o fato é que a Lei $\mathrm{n}^{\mathrm{o}} 10.352 / 2001$, ao criar o novo mecanismo ao lado do incidente de uniformização, acabou por gerar (mais) uma incoerência interna no sistema. Fere a lógica das coisas que sejam percorridos dois caminhos distintos para se atingir o mesmo objetivo. Na nossa concepção, ou bem o legislador deveria ter optado pelo procedimento único, e alterado a sistemática do incidente de uniformização; ou deveria ter optado pelo procedimento bipartido, adaptando o procedimento do novel mecanismo - a nosso ver, completamente desnecessário, como já dito. Não se deveria admitir essa indecisão, como se o legislador, sem saber qual procedimento seria o melhor, houvesse tomado decisão salomônica...

No que diz respeito ao terceiro aspecto, novamente sobressai a superioridade do incidente de uniformização, na medida em que este constitui dever do sujeito judicante, enquanto que a uniformização pelo art. 555, $\S 1^{\circ}$, do CPC, aparece como faculdade do relator, a ser instaurada a depender da relevância da questão de direito envolvida e da conveniência da situação. Poderíamos supor que a opção do legislador foi motivada por ingenuidade, mas ingênuo o legislador não é, porquanto na própria Exposição de Motivos da Lei $\mathrm{n}^{\mathrm{o}}$ 10.352/2001 reconhece que o incidente é de "limitadíssimo emprego em nossa prática forense". Ora, se mesmo sendo (ao menos aparentemente) obrigatório o incidente de uniformização é pouco utilizado, o que levaria o legislador a crer que o novo mecanismo, facultativo, seria amplamente acolhido?

O resultado era mais do que esperado: em 2005, “à luz da experiência de alguns anos", BARBOSA MOREIRA afirmou que o mecanismo jamais alcançou a eficiência desejada, assim como o correlato expediente da uniformização de jurisprudência regulado nos arts. 476 e ss., do $\mathrm{CPC}^{552}$.

\footnotetext{
${ }^{550}$ In CRUZ E TUCCI, José Rogério, Variações sobre precedentes judiciais vinculantes e persuasivos, in Revista Magister de Direito Civil e Processual Civil, ano 1, nº 5, 2005, p. 22.

${ }^{551}$ In VIGLIAR, José Marcelo Menezes, Uniformização de jurisprudência - Segurança jurídica e dever de uniformizar, 2003, pp. 194/195.

552 In BARBosA MOREIRA, José Carlos, Súmula, jurisprudência, precedente: uma escalada e seus riscos, in Revista Síntese de Direito Civil e Processual Civil, no 35, 2005, p. 7.
} 
Além do mais, o que se quer dizer com "relevante questão de direito, que faça conveniente prevenir ou compor divergência (...)"? Parece-nos que toda questão de direito é relevante e que prevenir ou compor divergência é sempre conveniente, como forma de garantir aplicação isonômica do direito. Tais requisitos são inócuos, porquanto redundantes, além de colocarem nas mãos do magistrado enorme discricionariedade, que facilmente pode se transmutar em subjetivismo e arbitrariedade.

Há quem sustente, como é o caso de DinAMARCO, que relevante é a questão jurídica que transcende "os interesses dos sujeitos em litígio, projetando influência sobre a sociedade como um todo ou sobre os valores inerentes à vida social, notadamente aqueles que a Constituição Federal abriga e resguarda" ${ }^{, 553}$. Se de fato foi essa a intenção do legislador, andou ele muito mal, pois ainda que o assunto seja particular e de interesse de poucos, na existência de divergência, real ou iminente, a uniformização de entendimentos parece sempre recomendável.

Sobre o quarto aspecto, que limita a instauração da uniformização pelo art. $555, \S 1^{\circ}$, do CPC, à iniciativa do relator, mais uma vez ressaltamos a nossa perplexidade. Se o mecanismo visa a um bem maior, que extrapola o interesse das partes e do próprio caso concreto, que é a uniformização da jurisprudência no âmbito interno do tribunal, não há por que limitar a sua iniciativa ao relator do recurso. Qualquer outro magistrado votante, ao julgar o caso concreto, poderia notar uma divergência que tenha passado despercebida pelo relator e, nessa condição, deveria estar apto a tomar a iniciativa da uniformização. Pela redação do Código de Processo Civil, porém, tal só é possível na hipótese do incidente de uniformização; no caso do art. 555, $\S 1^{\circ}$, do CPC, a iniciativa fica restrita ao relator, sempre.

Nem se diga que o referido dispositivo legal deve ser interpretado de maneira extensiva, a permitir a iniciativa do mecanismo de uniformização por qualquer dos julgadores. Embora haja quem defenda essa interpretação ${ }^{554}$, partindo do princípio de que a

\footnotetext{
${ }^{553}$ In DiNAMARCO, Cândido Rangel, A reforma da reforma, 2003, p. 136.

${ }^{554}$ V., nesse sentido, JULIANI, Cristiano Reis, A nova redação do artigo 555 do CPC e a uniformização de Jurisprudência, in Revista Síntese de Direito Civil e Processual Civil, n 23, 2003, p. 38, MARINHO FILHO, Luciano, Paralelo analítico entre mecanismos de uniformização de jurisprudência no direito processual pátrio, in Revista Dialética de Direito Processual, nº 90, 2010, p. 61 e PARENTE, Eduardo de Albuquerque,
} 
lei não deve conter palavras inúteis, caso assim fosse, o legislador teria utilizado a mesma terminologia do art. 476, caput, do CPC, ao invés de se referir exclusivamente ao relator. Agora por que ele optou por essa restrição, é mais uma incógnita que não conseguimos decifrar; a bem da verdade, tudo indica que a alteração insere-se no movimento iniciado no limiar da década de 1990, de aparelhar o relator com maiores poderes. No nosso entender, tal característica revela, por mais uma vertente, a total impropriedade do novo mecanismo de uniformização.

Quanto ao fato de esse instituto não prever a possibilidade de manifestação da parte quanto à necessidade de uniformização da jurisprudência, julgamos que dos males esse é o menor de todos. Afinal, mesmo que não haja dispositivo equivalente ao art. 476, par. único, do CPC, nada impede que, fundamentadamente e com supedâneo no art. $555, \S$ $1^{\circ}$, do CPC, a parte interessada peticione nos autos chamando a atenção do relator para a necessidade de provocar a uniformização. Dificilmente o relator determinará o desentranhamento da petição por ausência de previsão legal; antes, será obrigado a abrir vista à parte contrária, em respeito ao princípio do contraditório, e a se manifestar, também fundamentadamente, sobre o pleito.

Por fim, no que tange à última questão suscitada, parece irrelevante que para que tenha lugar o procedimento de uniformização de jurisprudência preencha-se o requisito da existência de interesse público, tal como determina o novo instituto. $\mathrm{Na}$ realidade, sempre que houver divergência interna nos tribunais estará presente o interesse público em uniformizá-la, por todos os motivos de que já tratamos acima.

Ainda que se entenda que o legislador está a se referir a outra espécie de interesse público ${ }^{555}$ (senão a lei seria redundante, pois - repise-se - dispersar a divergência

Jurisprudência: da divergência à uniformização, 2006, p. 72. De forma um pouco diferente, BARBOSA MOREIRA comenta que a sugestão de instaurar o procedimento de uniformização pode partir de outro membro e ser encampada pelo relator (in BARBOSA MOREIRA, José Carlos, O novo processo civil brasileiro (exposição sistemática do procedimento), 2008, p. 181).

555 DinAMARCO, por exemplo, enumera cinco critérios para aferição do interesse público de que trata o art. $555, \S 1^{\circ}$, do CPC: “ $\left.a\right)$ quando pender no tribunal ou nos órgãos inferiores subordinados a ele uma quantidade significativa de causas envolvendo a mesma tese jurídica, como aquelas de interesses de funcionários públicos ou de contribuintes; b) quando a causa envolver direitos ou interesses transindividuais de particular relevância ou de pertinência a grupos bastante numerosos, ainda mais quando se tratar de ação coletiva ou civil pública com esse conteúdo; c) quando estiver em causa um direito ou um preceito fundamental, especialmente se para o julgamento da causa for necessário o pronunciamento do tribunal sobre um texto constitucional, seu significado, sua dimensão; d) quando for previsível a repercussão 
é sempre de interesse público), voltado a questões de alto interesse social, que transcendem os interesses individuais das partes etc., não nos parece que o raciocínio prospera. A uniformização torna-se medida de rigor (ou pelo menos deveria se tornar) sempre que houver divergência, ainda que a matéria de fundo diga respeito a um número restrito de sujeitos ou relações jurídicas. Tanto é assim que a própria Constituição Federal admite recurso especial com fundamento na alínea "c" do permissivo constitucional tão-somente diante da existência de dissídio jurisprudencial, sendo indiferente, para esse fim, a demonstração de interesse público ou, também, de repercussão geral. Tal fato demonstra que a divergência por si só deveria bastar para justificar a uniformização.

Diante de todo o exposto, pensamos que o novo mecanismo era absolutamente desnecessário para o sistema e que o incidente de uniformização de jurisprudência contém em si todos os elementos para atingir satisfatoriamente os objetivos para os quais foi criado. Melhor seria se o legislador houvesse envidado seus esforços em encontrar soluções para contribuir com o prestígio do incidente e incentivar o seu uso (inclusive, e principalmente, pelos tribunais superiores), ao invés de criar mecanismo que, ao competir com ele, o enfraquece ainda mais. As intenções foram boas; os resultados, nem tanto ${ }^{556}$.

\subsection{Embargos de divergência}

A redação original do Código de Processo de 1973 previa, no par. único do art. 546, que, "além dos casos admitidos em lei, é embargável, no Supremo Tribunal Federal, a decisão da turma que, em recurso extraordinário, ou agravo de instrumento, divergir do julgamento de outra turma ou do plenário". Com redação semelhante à que constava do par. único do art. 833, do CPC/1939, conforme alteração introduzida pela Lei $n^{\circ} 623 / 1949$, o texto foi revogado pelo art. 44, da Lei $n^{\circ} 8.038 / 1990$. Constou ainda da referida lei, em seu art. 29, ainda em vigor, que "é embargável, no prazo de quinze dias, a decisão da turma que, em recurso especial, divergir do julgamento de outra turma, da

macroeconômica do acatamento de uma tese jurídica em discussão na causa; e) quando se tratar de tema processual bastante repetitivo, como a admissibilidade de agravos internos ou regimentais em certos casos polêmicos etc." (in DinAMARCO, Cândido Rangel, A reforma da reforma, 2003, pp. 136/137).

${ }^{556}$ Como quase tudo em direito, o entendimento sofre oposição. V., sustentando que a nova regra é mais rica que o tradicional incidente de uniformização, por supostamente conter abertura para utilização em casos mais frequentes e numerosos e por conferir maior eficácia aos julgamentos, DinAmARCO, Cândido Rangel, $A$ reforma da reforma, 2003, p. 138. 
seção ou do órgão especial, observando-se o procedimento estabelecido no regimento interno".

A Lei $\mathrm{n}^{\circ}$ 8.950, de 13 de dezembro de 1994, cuidou de reintroduzir no Código de Processo Civil os embargos de divergência, ao incluir o inciso VIII no art. 496, para prever, dentre os recursos cabíveis, "embargos de divergência em recurso especial e em recurso extraordinário". A mesma lei também revigorou e alterou o art. 546, do CPC, para dispor acerca das duas hipóteses de cabimento do recurso.

A primeira é da decisão da turma que, em recurso especial, divergir do julgamento de outra turma, da seção ou do órgão especial (art. 546, I, do CPC); a segunda é da decisão da turma que, em recurso extraordinário (ou em agravo de instrumento, de acordo com o art. 330, do RISTF), divergir do julgamento da outra turma ou do plenário (art. 546, II, do CPC). Os procedimentos respectivos encontram-se previstos nos Regimentos Internos do STJ (arts. 266 e 267) e do STF (arts. 330 a 336), conforme dispõe o art. 546, par. único, do CPC.

Para a exata compreensão da norma, deve-se ter em mente que o STJ é dividido em três seções, cuja competência é fixada em razão da natureza da relação jurídica litigiosa ${ }^{557}$, a que se subordinam seis turmas ${ }^{558}$; além disso, possui um órgão

\footnotetext{
${ }^{557}$ Nos termos do art. $9^{\circ}$, do RISTJ, à Primeira Seção cabe processar e julgar os feitos relativos a: licitações e contratos administrativos; nulidade ou anulabilidade de atos administrativos; ensino superior; inscrição e exercício profissionais; direito sindical; nacionalidade; desapropriação, inclusive a indireta; responsabilidade civil do Estado; tributos de modo geral, impostos, taxas, contribuições e empréstimos compulsórios; preços públicos e multas de qualquer natureza; servidores públicos civis e militares; habeas corpus referentes às matérias de sua competência; direito público em geral, exceto benefícios previdenciários; à Segunda Seção cabe processar e julgar os feitos relativos a: domínio, posse e direitos reais sobre coisa alheia, salvo quando se tratar de desapropriação; obrigações em geral de direito privado, mesmo quando o Estado participar do contrato; responsabilidade civil, salvo quando se tratar de responsabilidade civil do Estado; direito de família e sucessões; direito do trabalho; propriedade industrial, mesmo quando envolverem arguição de nulidade do registro; constituição, dissolução e liquidação de sociedade; comércio em geral, inclusive o marítimo e o aéreo, bolsas de valores, instituições financeiras e mercado de capitais; falências e concordatas; títulos de crédito; registros públicos, mesmo quando o Estado participar da demanda; locação predial urbana; habeas corpus referentes às matérias de sua competência; direito privado em geral; à Terceira Seção cabe processar e julgar os feitos relativos a: matéria penal em geral, salvo os casos de competência originária da Corte Especial e os habeas corpus de competência das Turmas que compõem a Primeira e a Segunda Seções; benefícios previdenciários, inclusive os decorrentes de acidentes de trabalho. Em dezembro de 2011 foi aprovada alteração no RISTJ, com validade a partir de $1^{\circ}$ de janeiro de 2012, deslocando a competência para o processamento e julgamento dos feitos relativos a benefícios previdenciários, inclusive os decorrentes de acidentes de trabalho, da Terceira para a Primeira Seção.
}

558 A Primeira e a Segunda Turmas são integrantes da Primeira Seção; a Terceira e a Quarta Turmas são integrantes da Segunda Seção; a Quinta e a Sexta Turmas são integrantes da Terceira Seção. 
especial, denominado de "Corte Especial", e o Plenário, este último com atribuições meramente administrativas (art. 10, do RISTJ). O STF, por sua vez, é dividido em duas turmas, que têm competência para julgar as mesmas matérias; acima das duas turmas, situa-se o Plenário.

Tendo em vista a forma como é dividido o STJ, nos parece que o art. 546, I, do CPC, deveria ter ido mais além, ampliando o espectro de atuação dos embargos de divergência, para abranger também as decisões proferidas pela seção que divergirem do entendimento de outra seção ou do órgão especial - esse raciocínio não se aplica ao STF, naturalmente, pois lá existem apenas duas turmas, submetidas diretamente ao Plenário.

Nas palavras de ARRUDA ALVIM, "o recurso de embargos de divergência reveste-se de um caráter acentuadamente público e de interesse geral, dado que do seu julgamento - contrário ou favorável ao recorrente - resultará sempre o benefício socialmente prezável do estabelecimento da certeza e da uniformidade do direito" ${ }^{559}$. Nessa medida, justamente para evitar a persistência de divergência dentro dos órgãos responsáveis por uniformizar a jurisprudência em matéria federal de todo o país, razoável seria que no âmbito do STJ fossem cabíveis embargos de divergência também contra decisão proferida pela seção.

Ainda que atingida a harmonia entre as turmas entre si, ou entre as turmas e o órgão especial, a uniformização não estará completa se permanecer divergência entre as próprias seções, ou entre as seções e o órgão especial. Mesmo que em tais situações seja possível suscitar incidente de uniformização de jurisprudência (arts. 118 a 120, do RISTJ), ou pleitear a afetação do recurso (art. 16, IV, do RISTJ), seria importante o cabimento dos embargos de divergência, pois estes agem a posteriori e, portanto, não se confundem com os demais mecanismos de uniformização interna.

\footnotetext{
${ }^{559}$ In ARRUdA AlviM, José Manoel de, Cabimento de embargos de divergência contra acórdão (de mérito) de Turma, proferido em agravo regimental, tirado de decisão de relator de recurso extraordinário Imprescindibilidade de uma releitura da súmula $n^{\circ}$ 599/STF, in Revista do Advogado, no 88, 2006, p. 23. V., em sentido semelhante, afirmando que, em comparação com as demais vias de uniformização de jurisprudência, o interesse público nos embargos de divergência é ainda maior, "pois seu objetivo é a uniformização interna do STJ e do STF, a partir do julgamento do recurso especial ou do recurso extraordinário, que são instrumentos de preservação do sistema federativo nacional", FREIRE, Rodrigo da Cunha Lima, Reflexões sobre o cabimento dos embargos de divergência em recurso especial, in Direito civil e processo - Estudos em homenagem ao Professor Arruda Alvim, 2007, p. 1.213.
} 
Nessa linha de pensamento, interessante seria que os embargos de divergência fossem cabíveis em todos os recursos e ações originárias em trâmite perante o STJ e o STF. Se o foco é a uniformização e divergências podem surgir independentemente do tipo de recurso ou do tipo de ação, não há por que limitar o cabimento dos embargos de divergência a uma ou outra figura processual. É verdade que ampliação nesse sentido aumentaria, em tese, a sobrecarga de trabalho do STF e do STJ, pois teria o condão de multiplicar o número de recursos nesses tribunais. Mas se o aumento for grande demais é porque algo está errado e as turmas estão julgando a torto e a direito, sem se darem conta de que integram uma estrutura única, que deve prezar, acima de tudo, pela harmonia interna. Não bastasse isto, deve-se considerar que os embargos de divergência são, mais do que qualquer outro, recurso previsto para não ser usado. Explica-se: o ordenamento processual disponibiliza meios de uniformização de jurisprudência que agem a priori; os embargos de divergência agem a posteriori; logo, possuem aplicação residual e só devem ser usados quando "falharem" os meios de uniformização a priori. Assim, uma vez ampliado o cabimento dos embargos de divergência para outros recursos e ações de competência originária do STF e do STJ, não deve - ao menos, não deveria - ser tão relevante o aumento no volume de recursos. E ainda assim, honestamente, pensamos que a busca seria por um bem maior e que o resultado atingido compensaria o preço pago.

Ainda a propósito da ampliação do cabimento dos embargos de divergência, cumpre mencionar que a Lei Complementar no 35, de 14 de março de 1979, conhecida como "Lei Orgânica da Magistratura", ao dispor no art. 101, § 3º "a", em capítulo reservado à disciplina dos Tribunais de Justiça, que a cada uma das seções caberá processar e julgar "os embargos infringentes ou de divergência das decisões das Turmas da respectiva área de especialização", abriu intenso debate a respeito do cabimento ou não de embargos de divergência nos tribunais de segundo grau. TERRA, em texto datado de vinte e cinco anos atrás, escreveu sobre o assunto, fazendo referência a um julgamento tomado pelo pleno do TJSP em que se decidiu, por maioria de votos, pela inadmissibilidade dos embargos de divergência contra decisão da câmara que, em apelação cível, destoe do julgado de outra câmara do Tribunal de Justiça ${ }^{560}$.

\footnotetext{
${ }^{560}$ In TERRA, Marcelo, Embargos de divergência no Tribunal de Justiça, in Revista dos Tribunais, vol. 606, 1986, pp. 271/273.
} 
No referido artigo, TERRA indica que os fundamentos do voto vencedor foram: o CPC não instituiu o recurso de embargos de divergência senão perante o $\mathrm{STF}^{561}$; a LOM não é lei processual; a LOM fez simples referência aos embargos de divergência, entre outros recursos, ações e incidentes que cada seção do Tribunal de Justiça deve julgar; há necessidade de lei processual disciplinando os embargos de divergência e os requisitos formais de interposição, para que se possa admiti-los; mais razoável é se admitir que a LOM se limitou a simples e pura previsão, a ser regulada depois por lei de processo.

Já os fundamentos dos votos vencidos - dos então Des. CÉSAR DE MORAES e AFFONSO ANDRÉ, este último ex-presidente do TJSP (1984/1985) - foram basicamente os seguintes: aos embargos de divergência aplica-se a mesma disciplina dos embargos infringentes; a LOM é lei de processo; não só as leis de processo dispõem sobre normas processuais; a LOM já é lei específica e, portanto, não está condicionada a outra lei; a LOM emanou de legislador competente; os embargos de divergência complementam o incidente de uniformização de jurisprudência ${ }^{562}$.

Embora o julgado acima seja deveras antigo, o entendimento que nele predominou foi também o que prevaleceu ao longo dos últimos anos, de maneira que hoje não se admite a utilização de embargos de divergência senão no âmbito do STF e do STJ.

De nossa parte, entendemos que seria sim adequada a extensão dos embargos de divergência aos tribunais de segundo grau, já que, em princípio, todo meio de uniformização de jurisprudência é bem-vindo. Ainda que com o incidente de uniformização previsto no art. 476 e ss., do CPC, e com o mecanismo de uniformização previsto no art. 555, $\S 1^{\circ}$, do CPC, os embargos de divergência venham a ter pouco valor prático (pois, por operarem a posteriori, serão utilizados apenas de forma residual, quando não suscitado o incidente de uniformização, ou a uniformização pelo art. $555, \S 1^{\circ}$, do

\footnotetext{
${ }^{561}$ Em sua redação original, o art. 546, do CPC, previa que "o processo e o julgamento do recurso extraordinário, no Supremo Tribunal Federal, obedecerão ao que dispuser o respectivo regimento interno", sendo que o par. único do artigo dispunha que, "além dos casos admitidos em lei, é embargável, no Supremo Tribunal Federal, a decisão da turma que, em recurso extraordinário, ou agravo de instrumento, divergir do julgamento de outra turma ou do plenário". Essa redação foi revogada somente em 1990, pela Lei no 8.038, de maneira que, quando TERRA escreveu o texto referido, os embargos de divergência eram cabíveis apenas perante o STF.

${ }^{562}$ In TERRA, Marcelo, Embargos de divergência no Tribunal de Justiça, in Revista dos Tribunais, vol. 606, 1986, pp. 272/273.
} 
CPC), seria benéfico para o ordenamento poder contar com mais esse instrumento de uniformização.

O fato é que, na linha inversa do que ocorreu com o sistema processual como um todo, que passou a privilegiar o precedente judicial e os mecanismos de uniformização de jurisprudência em geral, ao longo do tempo a jurisprudência firmou entendimento no sentido de restringir o cabimento de embargos de divergência, ao invés de ampliá-lo. Na contramão dessa tendência veio só o cancelamento da Súmula-STF no 599 ("são incabíveis embargos de divergência de decisão de turma, em agravo regimental"), em 2007, após enorme pressão da comunidade jurídica ${ }^{563}$.

Como já exposto, diferentemente do incidente de uniformização de jurisprudência, em que se extrai um pronunciamento prévio do tribunal acerca da interpretação a ser conferida a determinada norma, os embargos de divergência têm natureza repressiva, já que posteriores à prolação da decisão divergente, que o recurso pretende modificar. Nessa medida, sob a óptica do recorrente, contemplam uma dupla finalidade: a imediata, que é a reforma da decisão recorrida; e a mediata, que é a uniformização da jurisprudência, intramuros.

Tendo esses dois aspectos em mente, uma interessante e intrigante questão se apresenta: em que sentido devem ser julgados os embargos de divergência quando a jurisprudência do STF ou do STJ, após a interposição do recurso mas antes do seu

\footnotetext{
${ }^{563}$ Nem poderia ser diferente, já que, como visto, alterações legislativas inseridas no CPC aumentaram os poderes do relator ao ponto de permitir o julgamento de recursos via decisão monocrática, cabendo contra essa decisão agravo interno ou regimental para o restante do colegiado. Não seria correto que contra essa decisão colegiada, proferida em sede de agravo interno ou regimental, não pudessem ser manejados embargos de divergência - tanto que em 2005 foi editada a Súmula-STJ n ${ }^{\circ}$ 316, no sentido de que "cabem embargos de divergência contra acórdão que, em agravo regimental, decide recurso especial". V., examinando o tema, antes ainda do cancelamento da referida súmula, ALVES, Eliana Calmon, Embargos de divergência e a Súmula 599/STF, in Direito processual: inovações e perspectivas - estudos em homenagem ao Ministro Sálvio de Figueiredo Teixeira, 2003, pp. 213/223, ARRUDA ALVIM, José Manoel de, Cabimento de embargos de divergência contra acórdão (de mérito) de Turma, proferido em agravo regimental, tirado de decisão de relator de recurso extraordinário - Imprescindibilidade de uma releitura da súmula $n^{o}$ 599/STF, in Revista do Advogado, ${ }^{\circ}$ 88, 2006, pp. 20/31, PEREIRA, Milton Luiz, Embargos de divergência contra decisão lavrada por relator, in Revista dos Tribunais, vol. 778, 2000, pp. 11/16, RosAs, Roberto, Direito sumular - comentários às súmulas do Supremo Tribunal Federal e do Superior Tribunal de Justiça, 2006, p. 307 e VIVEIROS, Estefânia, Agravo interno no Superior Tribunal de Justiça e ampliação dos poderes do relator, in Universitas/Jus - Revista do Instituto de Ciências Jurídicas e Sociais do Centro Universitário de Brasília, no 7, 2001, pp. 81/86.
} 
julgamento, se consolida em sentido conflitante com o acórdão impugnado e com o acórdão paradigma, em favor de uma terceira corrente?

Analisando especificamente esse tema, MONTEIRO NETO afirma que a Primeira Seção do STJ, em algumas oportunidades, especialmente ao lidar com matérias tributárias, entendeu por julgar inadmissíveis embargos de divergência em tais situações por não mais existir qualquer divergência acerca da matéria, faltando ao recurso, supostamente, requisito de admissibilidade ${ }^{564}$. Assim como o autor, não podemos concordar com essa solução: para a admissibilidade dos embargos de divergência, basta a ocorrência da divergência ao tempo da interposição dos embargos; positivo o juízo de admissibilidade, a decisão será prolatada de acordo com a tese prevalecente no momento do julgamento.

Assim, ainda que antes do julgamento, mas após a interposição do recurso, essa divergência tenha sido superada em favor da tese defendida no acórdão recorrido, o caso é de improcedência, e não de inadmissibilidade do recurso; em sentido contrário, caso a divergência tenha sido superada em favor da tese defendida no acórdão paradigma, o caso é de procedência do recurso. É essa a exegese que se extrai da Súmula-STJ $n^{\circ} 168$ ("não cabem embargos de divergência quando a jurisprudência do Tribunal se firmou no mesmo sentido do acórdão embargado") e do art. 332, do RISTF ("não cabem embargos, se a jurisprudência do Plenário ou de ambas as Turmas estiver firmada no sentido da decisão embargada, salvo o disposto no art. $\left.103^{565, "}\right)$.

Assim sendo, na hipótese de após a interposição do recurso, mas antes do seu julgamento, se consolidar entendimento em favor de uma terceira corrente, diverso do entendimento defendido pelo acórdão recorrido e pelo acórdão paradigma, não será o caso de inadmissibilidade dos embargos de divergência, já que a divergência efetivamente existia quando da sua interposição, mas de provimento ou improvimento do recurso. Será de provimento, caso a nova tese jurídica coloque o embargante em posição mais vantajosa que a do acórdão recorrido; será de improvimento, caso a nova tese jurídica coloque o

\footnotetext{
${ }^{564}$ In MONTEIRO NETO, Nelson, Embargos de divergência em recurso especial: fixação de tese jurídica não coincidente com as confrontadas na petição de interposição, in Revista Forense, vol. 381, 2005, pp. 507/508.

$565 \mathrm{O}$ art. 103, do RISTF, prevê que "qualquer dos Ministros pode propor a revisão da jurisprudência assentada em matéria constitucional e da compendiada na Súmula, procedendo-se ao sobrestamento do feito, se necessário".
} 
embargante em posição menos vantajosa que a do acórdão recorrido. E a razão para isso é simples: não se admite, no nosso ordenamento, a reforma para pior (reformatio in pejus) ${ }^{566}$.

Somente dessa maneira restarão atendidos os dois aspectos dos embargos de divergência, que são o julgamento do caso concreto e a uniformização da jurisprudência. Por outro lado, caso prevalecesse o entendimento esposado pela Primeira Seção do STJ mencionado por MONTEIRO NETO, como explicado acima, estaria atendido o requisito da uniformização, porquanto - independentemente do recurso - superada a divergência no âmbito interno do tribunal, mas o caso concreto ficaria relegado, na medida em que não seria atingido por essa subsequente uniformização.

A solução proposta é bastante razoável, tanto que o próprio STJ já chegou a resultado semelhante, tendo consignado em ementa de acórdão que, "nos embargos de divergência, uma vez comprovado o dissídio, cabe à Seção aplicar o direito à espécie, podendo chegar a uma solução diversa da encontrada nos acórdãos em confronto" ${ }^{\text {"567. } \mathrm{O}}$ importante é a aplicação do direito à espécie, tal qual ocorre no recurso especial (art. 257, do RISTJ).

Como se vê, não basta a simples previsão dos embargos de divergência no Código de Processo Civil e nos regimentos internos do STF e do STJ. É necessário que o recurso seja processado e julgado corretamente, de acordo com os fins para os quais previsto, sob pena de tornar inoperante a letra da lei. Por vezes, em razão das incessantes alterações sociais, políticas, econômicas etc., a realidade é muito mais complexa do que aquela vislumbrada pelo legislador. Mesmo quando isso acontece, não se pode jamais perder de vista o objetivo primordial da norma.

\footnotetext{
${ }^{566}$ MONTEIRO NETO defende posição idêntica à nossa: "Se a tese que a $1^{a}$ Seção consagrou, logo após demonstrado o dissídio, ainda que não coincidente com as confrontadas na petição de recurso, é menos vantajosa para o embargante, cumpre negar-lhe provimento, pois o nosso ordenamento repele a reforma para pior. Agora: se a tese jurídica que o STJ assentou, aplicada à espécie, não configura reformatio in peius, mas, ao contrário, melhora a situação do embargante (...), a nosso ver a verdadeira solução é conhecer do recurso (já que constatado o dissídio), e dar-lhe provimento, uma vez que o órgão julgador assentou tese jurídica, pouco importando que não coincida com as confrontadas, e por isso deve aplicá-la, sim, à espécie sob exame." (in MONTEIRO NETO, Nelson, Embargos de divergência em recurso especial: fixação de tese jurídica não coincidente com as confrontadas na petição de interposição, in Revista Forense, vol. 381, 2005, p. 508).

${ }^{567}$ STJ, Segunda Seção, EREsp no 130.605/DF, rel. Min. Ruy RosAdO DE AGUiAR, j. 13/10/1999.
} 
Nas últimas décadas, especialmente após a edição da Lei da Ação Civil Pública (Lei no 7.347, de 24 de julho de 1985) e do Código de Defesa do Consumidor (Lei $\mathrm{n}^{\mathrm{o}}$ 8.078, de 11 de setembro de 1990), no âmbito infraconstitucional, e a promulgação da Constituição Federal de 1988, no âmbito constitucional, ganharam lugar de destaque os interesses ou direitos transindividuais, situados numa posição intermediária entre os interesses públicos e os interesses privados ${ }^{568}$. A bem da verdade, tais interesses e direitos sempre existiram; nos últimos anos, porém, acentuou-se a preocupação em protegê-los de forma diferenciada, ampla, tendo em vista a massificação das relações humanas e, consequentemente, a massificação dos conflitos.

São considerados transindividuais os interesses ou direitos: difusos, entendidos os de natureza indivisível, de que sejam titulares pessoas indeterminadas e ligadas por circunstâncias de fato (art. 81, par. único, I, do CDC), como por exemplo os que assistem pela televisão à mesma propaganda enganosa; coletivos, entendidos os de natureza indivisível de que seja titular grupo, categoria ou classe de pessoas ligadas entre si ou com a parte contrária por uma relação jurídica base (art. 81, par. único, II, do CDC), como por exemplo os consumidores que assinam contratos de adesão contendo a mesma cláusula abusiva; e individuais homogêneos, entendidos os decorrentes de origem comum (art. 81, par. único, III, do CDC), como por exemplo os consumidores que adquirem produtos fabricados em série com o mesmo defeito ${ }^{569}$.

Sem prejuízo das ações individuais que competem a cada um dos titulares de tais interesses ou direitos, o ordenamento jurídico coloca à disposição de determinados entes legitimados os processos coletivos, cujo objetivo é tutelar por meio de uma única demanda - e portanto de uma só vez - todos os titulares desses interesses ou direitos transindividuais.

\footnotetext{
568 In MAzZILli, Hugo Nigro, A defesa dos interesses difusos em juízo - Meio ambiente, consumidor, patrimônio cultural, patrimônio público e outros interesses, 2004, p. 48.

${ }^{569}$ V., mencionando os exemplos citados, MAZzILli, Hugo Nigro, A defesa dos interesses difusos em juízo Meio ambiente, consumidor, patrimônio cultural, patrimônio público e outros interesses, 2004, pp. 48/49.
} 
As modificações sociais, políticas, econômicas e culturais operadas desde a Revolução Industrial ganharam força no pós-guerra, ensejando a multiplicação dos conflitos levados ao Judiciário em velocidade muito superior à melhoria da estrutura destinada a recepcioná-los. O desenvolvimento do processo coletivo tem demonstrado que a molecularização desses conflitos é a resposta mais adequada às pretensões desses "novos" sujeitos de direito e ao combate dos efeitos nocivos gerados pela sua atomização $^{570}$.

A análise científica dos problemas de acesso à justiça foi objeto do denominado "Projeto de Florença para o Acesso à Justiça". Conduzido por CAPPELLETTI e GARTH, o projeto identificou, nos países do mundo ocidental, três momentos distintos, conhecidos como ondas renovatórias ${ }^{571}$. A primeira onda renovatória diz respeito à assistência judiciária para os pobres; a segunda onda renovatória refere-se justamente à representação dos interesses difusos, assim chamados os interesses coletivos ou grupais; e a terceira onda renovatória concentra sua atenção numa concepção mais ampla de acesso à justiça, com a adoção de procedimentos simplificados (como os Juizados Especiais Cíveis e Criminais, por exemplo) e com a utilização de meios alternativos de solução de controvérsias (como a arbitragem, a conciliação e a mediação, por exemplo).

Segundo os autores do referido projeto, em relação à defesa dos direitos que pertençam a um grupo, ao público em geral ou a um segmento do público, “(...) para ser efetiva, a decisão deve obrigar a todos os membros do grupo, ainda que nem todos tenham tido a oportunidade de ser ouvidos. Dessa maneira, outra noção tradicional, a da coisa julgada, precisa ser modificada, de modo a permitir a proteção judicial efetiva dos interesses difusos." $" 572$.

De modo geral, entendemos que a extensão do resultado da sentença aos titulares dos interesses ou direitos transindividuais resolver-se-ia no plano da eficácia da

\footnotetext{
${ }^{570}$ In AlmeIDA, Gustavo Milaré, Poderes investigatórios do Ministério Público nas ações coletivas, $2010, \mathrm{p}$. 4.

571 V., amplamente sobre o assunto, CAPPELLETTI, Mauro e GARTH, Bryant, Acesso à justiça, 1988, pp. $31 / 73$.

572 In CAPPElletti, Mauro e GARTH, Bryant, Acesso à justiça, 1988, p. 50. V., em sentido semelhante, MANCUSO, Rodolfo de Camargo, Ação civil pública em defesa do meio ambiente, patrimônio cultural e dos consumidores (Lei 7.347/85 e legislação complementar), 1994, pp. 163/164 e VIGLIAR, José Marcelo Menezes, Interesses difusos e coletivos, 2004, pp. 157/158.
} 
sentença, porquanto as ações coletivas nada mais são do que simples ações concorrentes. Mais ainda, pensamos que a LACP (art. 16) e o CDC (art. 103), ao estabelecerem que a coisa julgada nos processos coletivos opera-se erga omnes ou ultra partes, conforme o caso, segundo o resultado da demanda (secundum eventum litis), disseram muito e criaram pouco, sendo que o pouco que criaram "restringiu o sistema vigente em prejuízo dos titulares de direitos difusos ou coletivos" $" 573$. Todavia, para que seja mantido o foco do presente trabalho, não cabe aqui discorrer sobre os efeitos da sentença e os limites da coisa julgada oriunda de processo coletivo ${ }^{574}$. O que nos interessa nesta sede é que, por reunir potenciais múltiplas demandas individuais, a decisão tomada no processo coletivo atinge invariavelmente os titulares de tais potenciais múltiplas demandas individuais ${ }^{575}$.

A despeito disso, "a ação coletiva não induz litispendência ou coisa julgada em relação a ações individuais, salvo se versar interesses individuais homogêneos, quanto aos lesados que intervieram na ação; nem prejudicará direitos individuais diferenciados ${ }^{\prime 576}$, conforme preceitua o art. $103, \S \S 1^{\circ}$ a $3^{\circ}$, do CDC, pelo simples fato de serem distintas as partes e os objetos de tais demandas ${ }^{577}$.

Nessa medida, embora a uniformização da jurisprudência não seja propriamente a finalidade dos processos coletivos, acaba sendo ela uma consequência ${ }^{578}$, pois por meio da prolação de uma única sentença, que abrange os sujeitos ligados por circunstâncias de fato (difusos), por uma relação jurídica base (coletivos) ou por uma

\footnotetext{
${ }^{573}$ In Botelho De Mesquita, José Ignacio, A coisa julgada no Código do Consumidor, in Coisa julgada, 2004, p. 42.

${ }^{574} \mathrm{~V}$., examinando o assunto de modo irretocável, BOTELHO DE MESQUITA, José Ignacio, A coisa julgada no Código do Consumidor, in Coisa julgada, 2004, pp. 21/42. V., de nossa autoria, examinando a disciplina da coisa julgada nas ações concorrentes, LOMBARDI, Mariana Capela, Da coisa julgada civil - limites subjetivos e extensão a terceiros, Dissertação (Mestrado), 2008, pp. 115/122.

575 V., afirmando que, com exceção da ação direta de inconstitucionalidade, da ação declaratória de constitucionalidade e das ações coletivas, no sistema jurídico brasileiro as decisões judiciais não possuem força obrigatória (ou efeito vinculante) a não ser com relação às partes do processo, CUNHA, Sérgio Sérvulo da, Nota breve sobre o efeito vinculante, in Revista de Informação Legislativa, $\mathrm{n}^{\circ} 129,1996$, p. 6, nota de rodapé $\mathrm{n}^{\circ} 1$.

${ }^{576}$ In MAZZILLI, Hugo Nigro, A defesa dos interesses difusos em juízo - Meio ambiente, consumidor, patrimônio cultural, patrimônio público e outros interesses, 2004, p. 480.

${ }^{577}$ In Botelho De Mesquita, José Ignacio, A coisa julgada no Código do Consumidor, in Coisa julgada, 2004, p. 39

${ }^{578}$ V., em sentido semelhante, sustentando a aproximação entre os temas "uniformização da jurisprudência" e "tutelas jurisdicionais coletivas", VIGLIAR, José Marcelo Menezes, Uniformização de jurisprudência Segurança jurídica e dever de uniformizar, 2003, p. 33.
} 
origem comum (individuais homogêneos), cuida de tratá-los de forma isonômica, prevenindo a divergência. Justamente nesse sentido, afirma-se que "criações legislativas como as ações coletivas têm grande potencial para fazer com que pessoas que estejam em situação idêntica recebam tratamento idêntico no Judiciário, que deverá disciplinar da mesma forma a situação de todos" ${ }^{, 579}$.

A Lei $n^{\circ}$ 9.099, de 26 de setembro de 1995, ao revogar a Lei $n^{\circ} 7.244$, de 7 de novembro de 1984 (que implantou os Juizados Especiais de Pequenas Causas), introduziu no sistema processual brasileiro os Juizados Especiais Cíveis e Criminais, com o intuito de oferecer aos jurisdicionados alternativa mais simples e célere para a resolução de seus conflitos. Tanto é assim que o art. $2^{\circ}$ da lei esclarece que "o processo orientar-se-á pelos critérios da oralidade, simplicidade, informalidade, economia processual $e$ celeridade, buscando, sempre que possível, a conciliação ou a transação".

Não são todos os casos que podem ser processados perante os Juizados Especiais, mas somente as causas cíveis de menor complexidade ${ }^{580}$ e as infrações penais de menor potencial ofensivo ${ }^{581}$. De acordo com o art. 98 , I, da CF, o procedimento deve ser oral e sumaríssimo, permitidos, nas hipóteses previstas em lei, a transação e o julgamento de recursos por turmas de juízes de primeiro grau. Com relação ao sistema recursal, o art. 41, caput e $\S 1^{\circ}$, da Lei $n^{\circ} 9.099 / 1995$, prevê que, da sentença, excetuada a homologatória

\footnotetext{
${ }^{579}$ In MedinA, José Miguel Garcia, WAMBIER, Luiz Rodrigues e WAMBIER, Teresa Arruda Alvim, A súmula vinculante, vista como meio legítimo para diminuir a sobrecarga de trabalho dos tribunais brasileiros, in Revista do Advogado, no 92, 2007, p. 8. V., no mesmo sentido, MANCUSO, Rodolfo de Camargo, Divergência jurisprudencial e súmula vinculante, 2007, p. 429 e PARENTE, Eduardo de Albuquerque, Jurisprudência: da divergência à uniformização, 2006, p. 82.

${ }^{580}$ Assim consideradas as causas cujo valor não exceda a quarenta vezes o salário mínimo; as enumeradas no art. 275, II, do CPC (a saber, as causas, qualquer que seja o valor, de arrendamento rural e de parceria agrícola; de cobrança ao condômino de quaisquer quantias devidas ao condomínio; de ressarcimento por danos em prédio urbano ou rústico; de ressarcimento por danos causados em acidente de veículo de via terrestre; de cobrança de seguro, relativamente aos danos causados em acidente de veículo, ressalvados os casos de processo de execução; de cobrança de honorários dos profissionais liberais, ressalvado o disposto em legislação especial; e que versem sobre revogação de doação); a ação de despejo para uso próprio; e as ações possessórias sobre bens imóveis de valor não excedente a quarenta vezes o salário mínimo (art. $3^{\circ}$, da Lei $n^{\circ}$ 9.099/1995). Ficam excluídas da competência do Juizado Especial as causas de natureza alimentar, falimentar, fiscal e de interesse da Fazenda Pública, e também as relativas a acidentes de trabalho, a resíduos e ao estado e capacidade das pessoas, ainda que de cunho patrimonial (art. $3^{\circ}, \S 2^{\circ}$, da Lei $\left.n^{\circ} 9.099 / 1995\right)$.

${ }^{581}$ Assim consideradas as contravenções penais e os crimes a que a lei comine pena máxima não superior a dois anos, cumulada ou não com multa (art. 61, da Lei nº 9.099/1995).
} 
de conciliação ou laudo arbitral, caberá recurso para o próprio Juizado, que será julgado por uma turma composta por três juízes togados, em exercício no primeiro grau de jurisdição, reunidos na sede do Juizado.

Esse aspecto demonstra que o legislador quis separar por completo, inclusive no que toca ao sistema recursal, a esfera de atuação dos Juizados Especiais da esfera de atuação da justiça comum, formando uma espécie de microssistema, o mais autossuficiente possível, com regras e princípios próprios, autônomos, do ponto de vista procedimental, em relação ao Código de Processo Civil ${ }^{582}$.

Embora o objetivo do legislador tenha sido louvável, não se pode deixar de notar que, nessa onda de dissociar por completo os Juizados Especiais da justiça comum, suprimiu-se por veto do Presidente da República o art. 47, da Lei n 9.099/1995, o qual previa o denominado "recurso de divergência", nos seguintes termos: "a lei local poderá instituir recurso de divergência desse julgamento ao Tribunal de Alçada, onde houver, ou ao Tribunal de Justiça, sem efeito suspensivo, cabível quando houver divergência com a jurisprudência do próprio Tribunal ou de outra turma de Juízes, ou quando o valor do pedido julgado improcedente ou da condenação for superior a vinte salários mínimos".

O Ministério da Justiça assim se manifestou quanto ao referido art. 47, tendo sido essa a razão do veto: "O art. 47 do projeto de lei deve ser vetado, com fundamento no interesse público, porque a intenção que norteou a iniciativa parlamentar foi propiciar maior agilidade processual, o que não aconteceria com a sanção deste dispositivo, visto que ele ensejaria o aumento de recursos nos tribunais locais, em vez de sua diminuição. Daí, não mais haveria brevidade na conclusão das causas, contrariando todo o espírito que moveu a proposição e que traduz o anseio de toda a sociedade brasileira." ${ }^{583}$. Realmente, não houvesse sido vetado o art. 47, teria sido criado mais um grau de jurisdição no âmbito dos Juizados Especiais, remetendo-se causas para a justiça

\footnotetext{
${ }^{582} \mathrm{~V}$., no mesmo sentido, CAMBI, Eduardo, Uniformização das questões de direito nos juizados especiais cíveis e federais: a criação do recurso de divergência, in Aspectos polêmicos e atuais dos recursos de acordo com a Lei 10.352/2001, 2002, p. 170 e CARNEIRO, João Geraldo Piquet, Estratégia de aperfeiçoamento e consolidação dos Juizados Especiais Cíveis, in Revista do Advogado, nº 75, 2004, p. 34.

583 O veto está disponível em <http://www.planalto.gov.br/ccivil_03/Leis/Mensagem_Veto/anterior_98/VEPLEI-9095-1995.pdf $>$, acesso em 30/09/2011.
} 
comum, assoberbando ainda mais os tribunais. Não era motivo, porém, para suprimir esse importante instrumento de uniformização de jurisprudência.

Não se está aqui a discutir os méritos ou deméritos do método de uniformização idealizado originalmente pela Lei $n^{\circ}$ 9.099/1995 - a esse respeito, há quem diga que essa fórmula não era mesmo a melhor, pois com a redação proposta teria uma amplitude muito maior que a necessária para dirimir a divergência jurisprudencial ${ }^{584}$, mas essa análise foge dos objetivos deste estudo. O fato é que era esse o único mecanismo de que a Lei dos Juizados Especiais dispunha para resolver o problema da dissidência jurisprudencial.

Concorda-se que a celeridade deve ser sempre visada, não só nos Juizados Especiais, como também na justiça comum. Mas nunca à custa da isonomia e da segurança jurídica - como lembra CARVALHO, "o aforismo 'justiça que tarda não é justiça' é eivado de relativismo, pois é preferível que o jurisdicionado obtenha o proveito desejado, ainda que demorado" $" 585$. Caso aquele fosse o objetivo primordial, bastaria eliminar os recursos do Código de Processo Civil e suprimir o segundo grau de jurisdição do ordenamento brasileiro $^{586}$. Inegavelmente os processos teriam trâmite muito mais célere. Os resultados atingidos, porém, nem sempre seriam os melhores.

Conforme WAMBIER, "privilegiar a celeridade pode redundar em desprestígio para a segurança jurídica" ${ }^{, 587}$. Aparentemente, foi essa a opção do legislador: sacrificou-se a segurança jurídica em troca da celeridade do procedimento. A nosso ver o preço foi altíssimo e nada compensador. Em texto que trata da EC no 45/2004, BARBOSA MOREIRA, com habitual sensatez, alertou para o fato de que: “(...) é hora de aceitarmos, com suas inevitáveis conseqüências, uma verdade fundamental: a de que jamais se logrará

${ }^{584}$ V., nesse sentido, CAMBI, Eduardo, Jurisprudência lotérica, in Revista dos Tribunais, vol. 786, 2001, p. 123.

585 In CARVAlHo, Ivan Lira de, Decisões vinculantes, in Revista Forense, vol. 343, 1998, p. 525. V., em sentido semelhante, sustentando que "a celeridade não é o único nem o maior valor a ser considerado, em matéria processual” (in TESHEINER, José Maria Rosa, Uniformização de jurisprudência, in Revista da Ajuris - Associação dos Juízes do Rio Grande do Sul, nº 50, 1990, p. 182).

586 Curiosamente, houve quem defendesse a dispensa do duplo grau de jurisdição nos Juizados. V., comentando o assunto, CARNEIRO, João Geraldo Piquet, Estratégia de aperfeiçoamento e consolidação dos Juizados Especiais Cíveis, in Revista do Advogado, no 75, 2004, p. 35.

587 In WAMBIER, Luiz Rodrigues, Uma proposta em torno do conceito de jurisprudência dominante, in Revista de Processo, $\mathrm{n}^{\mathrm{o}}$ 100, 2000, p. 84. 
construir um sistema de Justiça que concilie de maneira perfeita a rapidez do funcionamento com a preservação de garantias de que, no presente momento histórico, dificilmente se poderia abrir mão. Alguma concessão sempre se terá de fazer, e é mister boa dose de prudência para buscar o necessário equilíbrio entre valores não raro contrapostos. ${ }^{, 588}$. O alerta, ainda que voltado a outra situação, se encaixa com perfeição na hipótese de que tratamos aqui.

Para agravar a situação, deve-se considerar que no âmbito dos Juizados Especiais não é cabível a interposição de recurso especial, que é o instrumento constitucional por excelência voltado à uniformização da exegese das leis federais (art. 105, III, “c”, da CF). Isso porque o art. 105, III, da CF, diz que devem ser julgadas em recurso especial "as causas decididas, em única ou última instância, pelos Tribunais Regionais Federais ou pelos tribunais dos Estados, do Distrito Federal e Territórios". Evidentemente, as turmas recursais dos Juizados Especiais não integram os tribunais regionais federais ou os tribunais estaduais. A Súmula-STJ nº 203 reafirmou essa posição, ao deliberar que "não cabe recurso especial contra decisão proferida, nos limites de sua competência, por órgão de segundo grau dos Juizados Especiais".

É certo que é cabível a interposição de recurso extraordinário, conforme autoriza expressamente a Súmula-STF nº 640, já que o art. 102, III, da CF, não estabelece os mesmos requisitos do art. 105 , III, da $\mathrm{CF}^{589}$, mas isso não refresca a situação, pois esse instrumento processual não é adequado a dirimir divergência na interpretação de lei federal, voltado que é para resguardar texto exclusivamente de ordem constitucional.

\footnotetext{
${ }^{588}$ In BARBOSA MOREIRA, José Carlos, A emenda constitucional $n^{\circ} 45$ e o processo, in Revista Forense, vol. 383, 2006, p. 187. V., em sentido parecido, afirmando que "os atos processuais devem desenrolar-se em várias etapas, uma vez que, conforme advertia Carnelutti, a semente da verdade exige um lapso temporal adequado para tornar-se espiga ("veritas filia temporis')", CRUZ E TUCCI, José Rogério, Ineficiência da administração da justiça e dano moral, in Questões práticas de processo civil, 1998, p. 103. BotTALlo também constata que “(...) no mundo civilizado em geral, o andamento do processo tende a ser lento, o que se explica pela necessidade de evitar-se superficialismos, erros e injustiças e de assegurar-se a efetividade das garantias do contraditório e da ampla defesa" (in BotTAllo, Eduardo Domingos, Súmula vinculante e República, in Revista do Advogado, n" 81, 2005, p. 29). V., em sentido oposto, sustentando que "não é difícil construir um argumento de que a morosidade da Justiça está longe de aumentar a segurança jurídica das suas decisões", PINHEIRO, Armando Castelar, Reforma do Judiciário: observações de um economista, in Revista do Advogado, $\mathrm{n}^{\circ}$ 75, 2004, p. 19.

${ }^{589}$ V., comparando a redação dos arts. 102, III e 105, III, ambos da CF, NEGRÃo, Theotonio, O novo recurso extraordinário: perspectivas na Constituição de 1988, in Revista do Advogado, nº 81, 2005, p. 9.
} 
Para suprir essa falha, o STF e o STJ têm admitido nos últimos tempos o recurso à via da reclamação, para fazer prevalecer na interpretação da legislação infraconstitucional a jurisprudência do STJ $^{590}$. O STJ inclusive editou a Resolução $n^{\circ} 12$, de 14 de dezembro de 2009, disciplinando "o processamento, no Superior Tribunal de Justiça, das reclamações destinadas a dirimir divergência entre acórdão prolatado por turma recursal estadual e a jurisprudência desta Corte" ${ }^{\text {"591 }}$. A solução, a nosso ver, é meramente paliativa, pois, além de muito restritiva ${ }^{592}$, não ataca o problema em seu âmago.

${ }^{590}$ Confira-se a seguinte ementa: "EMBARGOS DE DECLARAÇÃO. RECURSO EXTRAORDINÁRIO. AUSÊNCIA DE OMISSÃO NO ACÓRDÃO EMBARGADO. JURISPRUDÊNCIA DO SUPERIOR TRIBUNAL DE JUSTIÇA. APLICAÇÃO ÀS CONTROVÉRSIAS SUBMETIDAS AOS JUIZADOS ESPECIAIS ESTADUAIS. RECLAMAÇÃO PARA O SUPERIOR TRIBUNAL DE JUSTIÇA. CABIMENTO EXCEPCIONAL ENQUANTO NÃO CRIADO, POR LEI FEDERAL, O ÓRGÃO UNIFORMIZADOR. 1. No julgamento do recurso extraordinário interposto pela embargante, o Plenário desta Suprema Corte apreciou satisfatoriamente os pontos por ela questionados, tendo concluído: que constitui questão infraconstitucional a discriminação dos pulsos telefônicos excedentes nas contas telefônicas; que compete à Justiça Estadual a sua apreciação; e que é possível o julgamento da referida matéria no âmbito dos juizados em virtude da ausência de complexidade probatória. Não há, assim, qualquer omissão a ser sanada. 2. Quanto ao pedido de aplicação da jurisprudência do Superior Tribunal de Justiça, observe-se que aquela egrégia Corte foi incumbida pela Carta Magna da missão de uniformizar a interpretação da legislação infraconstitucional, embora seja inadmissível a interposição de recurso especial contra as decisões proferidas pelas turmas recursais dos juizados especiais. 3. No âmbito federal, a Lei 10.259/2001 criou a Turma de Uniformização da Jurisprudência, que pode ser acionada quando a decisão da turma recursal contrariar a jurisprudência do STJ. É possível, ainda, a provocação dessa Corte Superior após o julgamento da matéria pela citada Turma de Uniformização. 4. Inexistência de órgão uniformizador no âmbito dos juizados estaduais, circunstância que inviabiliza a aplicação da jurisprudência do STJ. Risco de manutenção de decisões divergentes quanto à interpretação da legislação federal, gerando insegurança jurídica e uma prestação jurisdicional incompleta, em decorrência da inexistência de outro meio eficaz para resolvê-la. 5. Embargos declaratórios acolhidos apenas para declarar o cabimento, em caráter excepcional, da reclamação prevista no art. 105, I, $f$, da Constituição Federal, para fazer prevalecer, até a criação da turma de uniformização dos juizados especiais estaduais, a jurisprudência do Superior Tribunal de Justiça na interpretação da legislação infraconstitucional." (STF, Pleno, EDcl no RE no 571.572/BA, rel. Min. ELLEN GRACIE, j. 26/08/2009).

${ }^{591}$ V., examinando o tema de forma ampla, LuCON, Paulo Henrique dos Santos, Evolução da reclamação constitucional e seu emprego para assegurar a autoridade dos precedentes, artigo no prelo, 2011.

${ }^{592}$ Com efeito, "apenas questões de direito material podem ser discutidas nessa sede e, além disso, somente será cabivel a reclamação quando houver julgamento de recurso repetitivo, enunciado de súmula ou uma multiplicidade de precedentes sedimentando posição pacífica do Tribunal acerca do tema" (in LUCON, Paulo Henrique dos Santos, Evolução da reclamação constitucional e seu emprego para assegurar a autoridade dos precedentes, artigo no prelo, 2011 , p. 14). Confira-se, restringindo ainda mais o cabimento do instituto, ementa de decisão recentemente prolatada pela Segunda Seção do STJ: "RECLAMAÇÃO. RESOLUÇÃO/STJ $N^{\circ}$ 12/2009. JUIZADOS ESPECIAIS. REQUISITOS. JURISPRUDÊNCIA CONSOLIDADA. DEFINIÇÃO. 1. Para que seja admissível o manejo da Reclamação disciplinada pela Res/STJ $n^{\circ}$ 12/2009 é necessário que se demonstre a contrariedade a jurisprudência consolidada desta Corte quanto a matéria, entendendo-se por jurisprudência consolidada: (i) precedentes exarados no julgamento de Recursos Especiais em Controvérsias Repetitivas (art. 543-C do CPC); ou (ii) enunciados de Súmula da jurisprudência desta Corte. 2. Não se admite, com isso, a propositura de reclamações com base apenas em precedentes exarados no julgamento de recursos especiais. 3. Para que seja admissível a reclamação é necessário também que a divergência se dê quanto a regras de direito material, não se admitindo a reclamação que discuta regras de processo civil, à medida que o processo, nos juizados especiais, orienta-se pelos peculiares critérios da Lei 9.099/95. 4. As hipóteses de teratologia deverão ser apreciadas em cada situação concreta. 5. Reclamação não conhecida." (STJ, Segunda Seção, Rcl no 4858/RS, rel. Min. Paulo De Tarso Sanseverino, j. 23/11/2011). Registre-se, ainda, que "o relator decidirá de plano reclamação manifestamente inadmissível, improcedente ou prejudicada, em conformidade ou dissonância com decisão proferida em reclamação 
Destarte, para que se estimule a busca pelo sistema alternativo dos Juizados Especiais - que é opcional para o autor da ação ${ }^{593}$, embora obrigatório para o réu -, assim como para que o mesmo não caia em total descrédito por não proporcionar isonomia e segurança jurídica, necessário que se introduza instrumento capaz de uniformizar as divergências entre os diversos Juizados Especiais ${ }^{594}$, e entre esses e os tribunais que lhes são superiores, ainda que com isso se perca um pouco em celeridade. O processo jamais será instantâneo, porque é em si uma relação continuada, composta por atos sucessivos, que necessariamente se desenvolve no tempo ${ }^{595}$.

Ressalte-se que atualmente se encontra em trâmite perante a Câmara dos Deputados o PL no 4.723/2004, apresentado pelo Poder Executivo, o qual inclui na Lei dos Juizados Especiais a Seção XIII-A ao Capítulo II, para disciplinar a uniformização da jurisprudência. O projeto, que inclusive já foi submetido à apreciação do Senado Federal,

anterior de conteúdo equivalente" (art. $1^{\circ}, \S 2^{\circ}$, da Resol.-STJ $\mathrm{n}^{\circ}$ 12/2009) e que "as decisões proferidas pelo relator são irrecorríveis" (art. $6^{\circ}$, da Resol.-STJ $\mathrm{n}^{\circ}$ 12/2009). Diante disso, segundo LUCON, é clara a "intenção de reduzir a utilização da reclamação" (in idem, ibidem, p. 16).

${ }^{593}$ Tendo em vista que o sistema alternativo dos Juizados Especiais é opcional para o autor da ação, " $a$ ausência de um mecanismo de uniformização da jurisprudência deve ser um fator a ser levado em consideração pelo reclamante ou por seu advogado, que terá de escolher entre o sistema tradicional, mais lento, mas mais seguro, ou assumir os riscos de optar pelo sistema dos Juizados Especiais, podendo vir a ser derrotado, caso a questão de direito seja divergente e a turma recursal, competente ou para onde a causa tenha sido distribuída, tenha entendimento que não lhe seja favorável" (in CAMBI, Eduardo, Uniformização das questões de direito nos juizados especiais cíveis e federais: a criação do recurso de divergência, in Aspectos polêmicos e atuais dos recursos de acordo com a Lei 10.352/2001, 2002, p. 172).

${ }^{594}$ A carência dos Juizados Especiais Estaduais é tão evidente nesse aspecto que de janeiro a setembro de 2011 deram entrada no STJ 1.350 reclamações contra decisões de turmas recursais dos Juizados Especiais Estaduais (notícia disponível em <http://www.valor.com.br/brasil/1090206/stj-limita-recursos-de-juizadosespeciais-estaduais>, acesso em 10/11/2011).

${ }^{595}$ In COUTURE, Eduardo Juan, Fundamentos do direito processual civil, 1946, p. 109. Segundo esse mesmo autor: "El proceso civil es, en su forma, un conjunto de actos jurídicos. Como su nombre lo indica, estos actos se hallan ordenados en forma sucesiva. Colocados unos tras otros con arreglo a un orden ya determinado, adquieren en su continuidad un sentido de desarrollo y desenvolvimiento. De la misma manera que los procesos físicos, químicos y biológicos, el proceso civil es un fenómeno continuativo, dinámico." (in idem, Fundamentos de derecho procesal, 1951, p. 3). Nessa mesma linha, de acordo com LuCON, "o processo, como método de solução de conflitos, é dinâmico e, como conseqüência, encontra no fator tempo um de seus elementos característicos e naturais" (in LuCON, Paulo Henrique dos Santos, Duração razoável e informatização do processo nas recentes reformas, in Direito civil e processo - Estudos em homenagem ao Professor Arruda Alvim, 2007, p. 1.397). V., em sentido semelhante, discorrendo sobre a estrutura procedimental rígida herdada do processo romano-canônico, CINTRA, Antonio Carlos de Araújo, Sobre os limites objetivos da apelação civil, Tese (Livre Docência), 1986, p. 10. 
recebeu pareceres favoráveis e, desde 17/08/2011, se encontra com o seu relator, o Dep. ARNALDO FARIA DE SÁ ${ }^{596}$.

No que diz respeito aos Juizados Especiais Federais, criados com a Lei $n^{\circ}$ 10.259, de 12 de julho de 2001, voltados aos feitos de valor que não ultrapasse sessenta salários mínimos (art. $3^{\circ}$, caput, da Lei $\left.\mathrm{n}^{\mathrm{o}} 10.259 / 2001\right)^{597}$ e às infrações de menor potencial ofensivo (art. $2^{\circ}$, caput, da Lei $\mathrm{n}^{\circ} 10.259 / 2001$ ), todos de competência da Justiça Federal, a situação não é muito diferente. Embora contem com regulamentação própria, que prevê certo mecanismo de uniformização de jurisprudência - o qual possui a natureza jurídica de recurso e muito mais se assemelha aos embargos de divergência do que ao incidente de uniformização do Código de Processo Civil ${ }^{598}$-, aqui também o sistema não está livre de críticas. Confira-se, a propósito, a redação do art. 14, caput, da lei citada acima: "caberá pedido de uniformização de interpretação de lei federal quando houver divergência entre decisões sobre questões de direito material proferidas por Turmas Recursais na interpretação da lei”.

Finalizado o julgamento, para suscitar o pedido de uniformização, o vencido deve alegar a existência de divergência: entre turmas da mesma região, caso em que o pedido será julgado em reunião conjunta das turmas conflitantes, sob a presidência do juiz coordenador (art. 14, $\S 1^{\circ}$, da Lei $n^{\circ} 10.259 / 2001$ ); entre turmas de diferentes regiões, ou

\footnotetext{
${ }^{596}$ Andamento disponível em <http://www.camara.gov.br/proposicoesWeb/fichadetramitacao?idProposicao= 274425>, acesso em 02/11/2011. Vale informar que o PL n ${ }^{\circ} 3.994 / 2000$, de autoria do Dep. CHIQUiNHO Feitosa, que resgatava o recurso de divergência, foi (definitivamente) arquivado em 02/04/2007, após receber parecer desfavorável, no mérito, da Comissão de Constituição e Justiça e de Cidadania, uma vez que "atribuiria ao procedimento dos Juizados Especiais o duplo grau de jurisdição, desvirtuando-o em um de seus aspectos essenciais" (andamento disponível em <http://www.camara.gov.br/proposicoesWeb/ fichadetramitacao?idProposicao=20580>, acesso em 02/11/2011).

${ }^{597}$ Não se incluem na competência dos Juizados Especiais Federais as causas: referidas no art. 109, II, III e XI, da CF (a saber, as causas entre Estado estrangeiro ou organismo internacional e Município ou pessoa domiciliada ou residente no País, as causas fundadas em tratado ou contrato da União com Estado estrangeiro ou organismo internacional e a disputa sobre direitos indígenas), as ações de mandado de segurança, de desapropriação, de divisão e demarcação, populares, execuções fiscais e por improbidade administrativa e as demandas sobre direitos ou interesses difusos, coletivos ou individuais homogêneos; sobre bens imóveis da União, autarquias e fundações públicas federais; para a anulação ou cancelamento de ato administrativo federal, salvo o de natureza previdenciária e o de lançamento fiscal; que tenham como objeto a impugnação da pena de demissão imposta a servidores públicos civis ou de sanções disciplinares aplicadas a militares (art. $3^{\circ}$, § $1^{\circ}$, da Lei $\mathrm{n}^{\circ} 10.259 / 2001$ ). Quando a pretensão versar sobre obrigações vincendas, para fins de competência do Juizado Especial, a soma de doze parcelas não poderá exceder o valor de sessenta salários mínimos (art. $3^{\circ}$, § $2^{\circ}$, da Lei no $\left.10.259 / 2001\right)$.

${ }^{598}$ In MARINHO FILHO, Luciano, Paralelo analítico entre mecanismos de uniformização de jurisprudência no direito processual pátrio, in Revista Dialética de Direito Processual, nº 90, 2010, p. 62.
} 
entre turma e súmula ou jurisprudência dominante do STJ, casos em que o pedido será julgado por turma de uniformização, integrada por juízes de turmas recursais ${ }^{599}$, sob a presidência do coordenador da Justiça Federal (art. 14, § 2º ${ }^{\circ}$ da Lei n ${ }^{\circ} 10.259 / 2001$ ).

Quando a orientação acolhida pela turma de uniformização contrariar súmula ou jurisprudência dominante no Superior Tribunal de Justiça, a parte interessada poderá provocar a manifestação deste, que dirimirá a divergência (art. $14, \S 4^{\circ}$, da Lei no 10.259/2001). Em outras palavras, é o mesmo que dizer que, se a parte interessada provocar a manifestação do STJ, deverá prevalecer o entendimento deste, já que o tribunal superior dificilmente dirimirá a divergência julgando contra súmula por ele próprio emitida. Ainda nesse caso, presente a plausibilidade do direito invocado e havendo fundado receio de dano de difícil reparação, poderá o relator conceder, de ofício ou a requerimento do interessado, medida liminar determinando a suspensão dos processos nos quais a controvérsia esteja estabelecida (art. 14, § 5º da Lei no 10.259/2001).

Eventuais pedidos de uniformização idênticos, recebidos subsequentemente em quaisquer turmas recursais, ficarão retidos nos autos, aguardando-se pronunciamento do Superior Tribunal de Justiça (art. 14, $\S 6^{\circ}$, da Lei $\mathrm{n}^{\circ}$ 10.259/2001). A medida é interessante mas na prática só será efetiva se as turmas recursais possuírem sistema informatizado altamente integrado, capaz de identificar eventual coincidência entre pedidos. De todo modo, de acordo com a lei, uma vez julgado o pedido de uniformização e publicado o acórdão respectivo, os pedidos retidos serão apreciados pelas turmas recursais, que poderão exercer juízo de retratação ou declará-los prejudicados, se veicularem tese não acolhida pelo STJ (art. 14, § $9^{\circ}$, da Lei $n^{\circ} 10.259 / 2001$ ).

Se necessário, o relator pedirá informações ao presidente da turma recursal ou ao Coordenador da Turma de Uniformização e ouvirá o Ministério Público, no prazo de cinco dias. Eventuais interessados, ainda que não sejam partes no processo, poderão se manifestar, no prazo de trinta dias (art. 14 , $\S 7^{\circ}$, da Lei $n^{\circ} 10.259 / 2001$ ). Decorridos tais prazos, o relator incluirá o pedido em pauta na seção, com preferência sobre todos os demais feitos, ressalvados os processos com réus presos, os habeas corpus e os mandados de segurança (art. 14, § $8^{\circ}$, da Lei $\left.n^{\circ} 10.259 / 2001\right)$.

599 A reunião de juízes domiciliados em cidades diversas será feita pela via eletrônica, nos termos do art. 14 , $\S 3^{\text {o }}$, da Lei no $10.259 / 2001$. 
De tudo o quanto exposto, é interessante notar que o pedido só tem cabimento quando envolver questão de direito material. Chama a atenção também o fato de não haver previsão para o caso de divergência entre turma e juízos ou tribunais federais, e entre turma e súmula ou jurisprudência dominante do STF, ou de outro tribunal superior. Com certeza, além de um detalhe ou outro que deveriam se adequar ao incidente de uniformização de jurisprudência previsto no Código de Processo Civil, são esses dois importantes aspectos que mereceriam ser revisitados pelo legislador.

Não há por que limitar o pedido de uniformização a questões materiais, quando questões processuais também podem suscitar divergência e são igualmente relevantes $^{600}$. Tanto é verdade que se diz que análises realizadas nos tribunais superiores resultaram na percepção de que a maioria das questões dizia respeito a questões de cunho processual e que a restrição foi promovida justamente com o intuito de diminuir a incidência recursal ${ }^{601}$. Nada mais ilógico; para tornar efetivo o mecanismo de uniformização, o raciocínio deveria ser, no mínimo, em sentido contrário, de modo a contemplar, se não todas, pelos menos as hipóteses mais frequentes...

Da mesma forma, não tem por que se permitir a uniformização entre turmas recursais, mas não entre turmas recursais e juízos federais ou tribunais federais; no mesmo sentido, não tem por que se permitir a uniformização perante o STJ, mas não perante o STF, se hierarquicamente este é o tribunal que ocupa o cume da estrutura judiciária ${ }^{602}-$ ainda que se admita o cabimento de recurso extraordinário, essa solução não parece ser suficiente, já que esse recurso não tem a função imediata de uniformizar a jurisprudência.

Outra questão curiosa é que, para que a divergência se dê em relação ao STJ, exige-se o confronto com súmula ou jurisprudência dominante deste; já para que a divergência se dê em relação a outras turmas recursais não há qualquer requisito especial, o

\footnotetext{
${ }^{600}$ V., no mesmo sentido, CAMBI, Eduardo, Uniformização das questões de direito nos juizados especiais cíveis e federais: a criação do recurso de divergência, in Aspectos polêmicos e atuais dos recursos de acordo com a Lei 10.352/2001, 2002, p. 177.

${ }^{601}$ In MARINHO FILHO, Luciano, Paralelo analítico entre mecanismos de uniformização de jurisprudência no direito processual pátrio, in Revista Dialética de Direito Processual, nº 90, 2010, p. 62.

${ }^{602}$ V., em sentido semelhante ao nosso, CAMBI, Eduardo, Uniformização das questões de direito nos juizados especiais cíveis e federais: a criação do recurso de divergência, in Aspectos polêmicos e atuais dos recursos de acordo com a Lei 10.352/2001, 2002, p. 176.
} 
que leva a crer que um mero precedente em sentido contrário seria suficiente para configurar a sua ocorrência. A rigor, um precedente do STJ vale mais que um precedente de turma recursal. O certo, assim, seria inverter os parâmetros, ou no mínimo equipará-los.

Realmente, em matéria de divergência jurisprudencial, a Lei no 10.259/2001 é superior à Lei $n^{o}$ 9.099/1995, uma vez que ao menos prevê algum mecanismo de uniformização. Ainda assim nos parece que o método deveria ser melhor trabalhado, o que demanda, nesse aspecto, uma reorganização em relação a todos os Juizados Especiais, sejam eles estaduais ou federais. 


\section{CONCLUSÕES}

O precedente judicial é de importância fundamental na experiência jurídica, qualquer que seja o sistema em foco.

Tradicionalmente, nos sistemas de common law, provenientes do direito inglês, em que prevalece o direito casuístico, o precedente judicial assume função diferente daquela que exerce nos sistemas de civil law, provenientes da Europa continental, de tradição romano-germânica, em que predomina o direito codificado. Na common law, o precedente judicial tem, em regra, papel vinculante, coercitivo (binding authority); na civil law, pelo contrário, o precedente judicial interpreta em geral papel de cunho persuasivo, de valor moral (persuasive authority).

Apesar das diferenças entre os sistemas de common law e de civil law, cada vez maior tem sido a interação entre eles: ao mesmo tempo em que os países de common law têm feito uso, em certos casos, do papel persuasivo da jurisprudência, e adotado textos codificados, os países de civil law têm, em algumas situações, atribuído ao precedente judicial eficácia vinculante, ou quase vinculante. As influências mútuas demonstram que o momento é de desconstrução de paradigmas, o que torna, no Brasil, o ambiente propício para a criação de soluções inspiradas em técnicas estrangeiras - como é o caso, em matéria de precedente, da diferenciação entre a ratio decidendi e o obiter dictum, do procedimento de distinguishing, do procedimento de overruling etc.

O Brasil, sob a influência dos assentos e estilos da corte portuguesa, nunca ignorou a importância dos precedentes. Apesar de os seus efeitos terem variado no tempo, de acordo com o contexto histórico, os precedentes judiciais sempre estiveram na alça de

mira dos juristas. É possível dizer o mesmo a propósito dos mecanismos de uniformização de jurisprudência: sempre se teve a noção da insegurança e do desconforto que a oscilação de entendimentos gera na sociedade.

Reconhecemos hoje duas importantes funções na jurisprudência, que praticamente se confundem, já que a segunda decorre da primeira: a primeira é a de interpretar a lei, delimitando o alcance do texto legal; a segunda é a de adequar a lei no 
tempo, de acordo com as necessidades da realidade social presentes no momento de aplicação da lei.

Tendo esses dois aspectos em mente, conclui-se que aquilo que os tribunais aplicam no dia-a-dia não é exatamente a lei em si, mas a particular interpretação que conferem à lei. Para tanto, devem estar atentos aos fatos e ao tempo em que vivem, não bastando o conhecimento puramente técnico do direito para que se resolvam os conflitos.

Nesse contexto, para o advogado, mais importante do que conhecer o texto seco da lei é conhecer o que os tribunais, especialmente os superiores, dizem que ela diz. A uma, porque somente tendo esse panorama completo é que o advogado consegue aconselhar bem seu cliente; a duas, porque o precedente, mesmo quando não dotado de eficácia vinculante, ou quase vinculante, possui poderoso papel persuasivo quando mencionado nas peças processuais, sendo capaz de influenciar julgamentos. Também pelos magistrados é importante o conhecimento da interpretação conferida à lei pelos tribunais, especialmente pelos superiores, permitindo-se a aplicação uniforme da norma e garantindo-se isonomia entre os jurisdicionados.

Esse último ponto é extremamente relevante. Da forma como constituído, o nosso sistema jurídico admite que situações jurídicas análogas sejam julgadas de maneiras diferentes, a depender da interpretação conferida à lei aplicável pelo sujeito ou órgão prolator da decisão. A lei, por sua própria natureza, é geral, abstrata e impessoal; muitas vezes, é integrada ainda por conceitos juridicamente indeterminados e por cláusulas gerais. Natural, portanto, que dê ensejo a interpretações diversas e a leituras até mesmo contraditórias.

Não bastasse isto, o magistrado carrega seus valores pessoais, suas ideologias, seus pontos de vista, sua história, suas máximas de experiência, de maneira que isso tudo também influencia as decisões judiciais. Vale lembrar: o juiz é imparcial, mas jamais neutro, porquanto, pela própria natureza da condição humana, é absolutamente impossível dissociar por completo o homem do profissional.

Ocorre que, com isso, a situação que se forma beira o insuportável, na medida em que provoca nos jurisdicionados insegurança jurídica. Não é crível que, apesar 
de a lei ser igual para todos, para o mesmo conflito jurídico uns possam obter tutela jurisdicional e outros não, a depender da sorte (ou do azar) da parte na distribuição dos respectivos processos. Toda essa incerteza gera desconfiança em relação ao Poder Judiciário e à administração da justiça em geral, culminando em séria perda de autoridade.

Para remediar o problema, nos parece que, ao mesmo tempo em que aos juízes deve ser garantida a liberdade de interpretarem os textos legais, tal liberdade não deve ser absoluta, porque isso daria ensejo a arbitrariedades e, consequentemente, à proliferação da jurisprudência lotérica, de todo indesejável e nociva ao sistema. Acima de tudo, a ordem jurídica deve ser coerente.

A uniformização é não só um direito do jurisdicionado, mas acima de tudo um dever do Estado, que serve essencialmente ao seu próprio interesse em manter o império de suas leis e o respeito às suas instituições. Embora formado por inúmeros sujeitos, o Poder Judiciário compõe uma estrutura única, que deve ter visão uniforme sobre determinados temas.

Sob a (pretensa) justificativa de garantir maior isonomia e segurança jurídica aos jurisdicionados, nos últimos anos têm sido introduzidas reformas na legislação constitucional e processual com o duplo objetivo de conferir maior valor ao precedente e de uniformizar a jurisprudência. Até tentamos separar os dois fenômenos, mas concluímos que são duas faces de uma mesma moeda, pois, ao dotar o precedente de maior valor, atinge-se a uniformização, e vice-versa.

A técnica de coletivização de demandas insere-se dentro desse contexto e, em geral, tem se mostrado adequada para a tutela de interesses ou direitos transindividuais. Embora a uniformização da jurisprudência não seja a finalidade dos processos coletivos, acaba sendo ela uma consequência, pois por meio da prolação de uma única sentença, que abrange os sujeitos ligados por circunstâncias de fato (difusos), por uma relação jurídica base (coletivos) ou por uma origem comum (individuais homogêneos), cuida de tratá-los de forma isonômica, prevenindo a divergência.

Vale mencionar também a atribuição de eficácia vinculante a determinados precedentes. Ao lado das sentenças proferidas em sede de controle de constitucionalidade 
concentrado, conhecidas há tempos, merece destaque a recente inclusão no ordenamento jurídico brasileiro do sistema de súmulas vinculantes, após treze anos de tramitação da proposta que a concebeu.

Pensamos que o sistema é tão positivo - desde que observadas fielmente as regras que o permeiam, evidentemente - que todos os tribunais superiores deveriam ter a prerrogativa de editar suas próprias súmulas vinculantes. Na nossa concepção, aliás, todos os entendimentos de tribunais superiores, uma vez maturados e consolidados, deveriam ser registrados em súmula, a qual deveria surtir efeitos vinculantes. Infelizmente não foi esse o posicionamento adotado pelo legislador. Inclusive, se só a previsão da súmula vinculante do STF já gerou polêmica e intensos debates, imagina-se o estardalhaço que seria causado se o instituto fosse estendido para os demais tribunais superiores! Tal fato, por si só, nos faz indagar se a comunidade jurídica brasileira estaria pronta para tamanha "revolução"...

Não podemos deixar de citar, ainda, a atribuição de eficácia quase vinculante a outros tantos precedentes. Dentro dessa categoria inserem-se as modificações implementadas nas duas últimas décadas com o intuito de: alargar os poderes do relator (art. 38, da Lei n 8.038/1990, art. 557, caput e $\S 1^{\circ}$, do CPC, art. 544, § $4^{\circ}$, II, "b" e “c”, do CPC, e art. 120, par. único, do CPC) e do juiz de primeiro grau (art. 518, § $1^{\circ}$, do CPC, e art. 285-A, do CPC); restringir as hipóteses de cabimento de remessa necessária (art. 475, § $3^{\circ}$, do $\mathrm{CPC}$ ); alargar os efeitos da decisão proferida em sede de controle de constitucionalidade incidental pelo plenário ou órgão especial dos tribunais, ou pelo plenário do Supremo Tribunal Federal; criar o requisito da repercussão geral no recurso extraordinário; e prever procedimento específico para o processamento e julgamento de recursos especiais repetitivos.

Quanto à ampliação dos poderes do relator e do juiz de primeiro grau, nosso descontentamento é aparente. Não porque somos contrários a tal tendência (embora pensemos que medidas nesse sentido devam ser adotadas com parcimônia), mas porque discordamos da forma atabalhoada com a qual foi incluída no ordenamento. Acima de tudo, chama atenção o tratamento nada harmônico conferido às diversas hipóteses previstas, gerador de relevante incoerência interna no sistema. Ora, qualquer que fosse a escolha do legislador, pensamos que os critérios utilizados nos arts. 38, da Lei $\mathrm{n}^{\circ}$ 
8.038/1990, 557, caput e $\S 1^{\circ}$, do CPC, 544, $\S 4^{\circ}$, II, “b” e “c”, do CPC, 120, par. único, do CPC, 518, $\S 1^{\circ}$, do CPC, e 285-A, do CPC, deveriam ser os mesmos em todos os casos.

Não faz sentido, por exemplo, que o juiz de primeiro grau possa obstar o seguimento de recurso de apelação cuja tese jurídica seja contrária a paradigma do STF e do STJ quando o relator, no tribunal, pode fazê-lo tomando em consideração paradigma de qualquer tribunal superior, e não apenas do STF e do STJ. Pelo fato de as normas estarem diretamente ligadas, deveria haver uma relação de continuidade entre elas. $\mathrm{O}$ mesmo se diga com relação às normas do art. 557, caput, do CPC, e do $\S 1^{\circ}$ do mesmo artigo. Enquanto a primeira determina (rectius: permite) que o relator negue seguimento a recurso cuja tese jurídica viole súmula ou jurisprudência dominante "do respectivo tribunal, do Supremo Tribunal Federal, ou de Tribunal Superior", a segunda permite que o relator dê provimento a recurso cuja tese jurídica esteja em consonância com súmula ou jurisprudência dominante "do Supremo Tribunal Federal, ou de Tribunal Superior", excluindo-se a menção ao "respectivo tribunal". A diferenciação implementada pelo legislador não tem a menor razão de ser e acaba gerando perplexidade, por regulamentar questões análogas de forma díspar. Como se vê, também no âmbito procedimental se coloca a problemática socrática: “um peso, duas medidas”...

A propósito dos critérios em si, chama atenção o fato de, em alguns casos, se prestigiar a jurisprudência dominante, o que quer que isso signifique, e não só a súmula. Ora, se o entendimento não se encontra maturado e consolidado a ponto de ser erigido ao status de súmula, não deve, ou ao menos não deveria, surtir mais do que efeitos persuasivos. Também chama atenção o fato de a lei processual prestigiar, em determinadas situações, precedentes oriundos de juízos de primeiro grau e de tribunais de segundo grau, e não só precedentes de tribunais superiores, quando na verdade a uniformização deve, ou ao menos deveria, partir sempre de cima para baixo.

A expressão máxima do nosso inconformismo reside no art. 285-A, do CPC, que além de muitos outros defeitos, que não cabe aqui enunciar, atribui eficácia quase vinculante a precedente de primeiro grau, oriundo do próprio juízo, ainda que não tenha sido confirmado por tribunal que lhe seja funcionalmente superior, ou que divirja de entendimento prevalecente nele. Sequer era o caso de se admitir o julgamento 
antecipadíssimo da lide, sem a citação do réu; mas se era para ser assim, que no mínimo se utilizasse como paradigma entendimento sumulado de tribunal superior.

Conjugados os fatos expostos acima, chegamos à conclusão de que a preocupação primeira do legislador tem sido a de desafogar os tribunais, mormente os superiores, e não a de conferir aos jurisdicionados maior segurança jurídica, mediante tratamento isonômico. A uniformização de entendimentos até tem sido visada, mas de maneira reflexa, e somente na medida em que contribua para o descongestionamento da carga de trabalho dos tribunais.

Concordamos que isso é importante e que o alívio na agenda dos juízes auxilia o incremento de qualidade das decisões. Reconhecemos também que a prestação jurisdicional deve ser tempestiva e que, para tanto, devem ser introduzidos mecanismos para a busca da tão almejada duração razoável do processo. Acreditamos, porém, que a preocupação primordial deve ser sempre com a isonomia e com a segurança jurídica, as quais só serão atingidas a partir da efetiva uniformização da jurisprudência.

Assim, caso de fato o nosso ordenamento ainda não esteja pronto para atribuir eficácia vinculante a todas as súmulas de tribunais superiores - registre-se novamente que nós pensamos que essa seria a solução mais adequada -, que atribua a tais súmulas eficácia quase vinculante, para permitir que o juiz de primeiro grau e que o relator de tribunal de segundo grau e de tribunal superior neguem seguimento a recursos que contemplem teses jurídicas contrárias a elas; que atribua a tais súmulas eficácia quase vinculante também para permitir que o relator de tribunal de segundo grau e de tribunal superior dê provimento a recursos que contemplem teses jurídicas concordantes com elas; mas que não atribua essa mesma eficácia a mera "jurisprudência dominante”, ou a súmulas ou precedentes provenientes de juízos de primeiro grau ou de tribunais de segundo grau.

Essa última situação deve ser evitada a todo custo, pois ainda que gere certa uniformização, faz isso da maneira errada, na medida em que erige ao posto de paradigma entendimentos ainda não consolidados (tanto que ainda não sumulados), e que não necessariamente estão em conformidade com os entendimentos dos tribunais superiores, aos quais, cada qual no seu âmbito de atuação, cabe a última palavra. 
Embora essa mudança de concepção possa ser feita de lege lata, bastando a conscientização em tal sentido por parte dos magistrados e dos operadores do direito em geral, o ideal é que, para que se torne efetivamente operante, seja refletida em alterações de lege ferenda. Apesar de sermos geralmente contrários às constantes e sucessivas reformas introduzidas no Código de Processo Civil, que por vezes o desfiguram a ponto de nos remeter à Criatura de MARY SHELLEY, pensamos que as modificações aqui sugeridas seriam para o bem, porque teriam por finalidade o resgate da coerência interna do ordenamento processual, e também a uniformização da jurisprudência, da forma mais correta e precisa, que é aquela que é guiada de cima para baixo.

O tratamento conferido à repercussão geral no recurso extraordinário e aos recursos especiais repetitivos também é merecedor de nossas considerações. Em primeiro lugar, pensamos que, tendo sido devidamente maturada e consolidada a matéria dentro do tribunal, a decisão de mérito tomada no recurso extraordinário paradigma, depois de reconhecida a repercussão geral, deveria surtir efeitos vinculantes, para todos os casos, ou recursos, que versem sobre a mesma controvérsia constitucional. No mesmo sentido, a decisão de mérito tomada no recurso especial paradigma, no caso de recursos repetitivos, deveria dar ensejo a esse mesmo tipo de efeito, desde que, novamente, suficientemente maturada e consolidada a matéria dentro do tribunal.

Não se trata, obviamente, de dotar de eficácia vinculante todas as decisões proferidas em recurso extraordinário ou especial, mas somente aquelas cujas matérias já foram exaustivamente discutidas dentro do tribunal e que contam com ampla adesão dos ministros; e que podem ser replicadas sucessivamente, na hipótese de existirem múltiplos recursos, ou recursos repetitivos, sobre a mesma controvérsia. Aí sim o recurso extraordinário e o recurso especial proporcionariam efetiva uniformização de jurisprudência.

Independentemente desse aspecto, é fato que muitas outras questões relevantes atinentes à repercussão geral e aos recursos repetitivos deixaram de ser regulamentadas (como a possibilidade de desistência e de desafetação do recurso paradigma, e o cabimento de recurso por terceiros contra a decisão que julgar no mérito o paradigma), merecendo, portanto, solução de lege ferenda. Isso sem contar algumas outras 
relevantes questões que merecem ser objeto de maior reflexão (como a possibilidade vs. obrigatoriedade de o juiz admitir a intervenção de amicus curiae), mesmo que de lege lata.

No que diz respeito aos instrumentos propriamente ditos de uniformização de jurisprudência, temos basicamente três comentários a fazer.

O primeiro é que o incidente de uniformização deveria ser mais prestigiado, não só pelos advogados, mas também (e principalmente) pelos magistrados. Se aqueles defendem interesses particulares de seus clientes, a quem nem sempre convém suscitar posição orientadora pelo tribunal a respeito de determinado assunto, estes devem sempre zelar pela uniformização do ordenamento. Ainda que com isso tenham que abrir mão de suas convicções pessoais para se sujeitar ao pensamento da maioria, trata-se de contingência inerente ao exercício da função. Assim, não só os tribunais deveriam estimular o seu uso, como o exemplo deveria partir de cima, dos tribunais superiores.

Justamente para prestigiar o incidente - e aí reside o nosso segundo comentário - nos parece que o instituto da assunção de competência, previsto no art. $555, \S$ $1^{\circ}$, do CPC, deveria ser abolido do ordenamento. Isso porque, como demonstrado no decorrer do trabalho, a técnica do incidente de uniformização, em todos os aspectos, é muito superior, tornando a previsão mais recente absolutamente dispensável. No máximo se deveria cogitar da extensão dos embargos de divergência aos tribunais de segundo grau, e só.

Quanto ao terceiro ponto, chamamos a atenção para a necessidade de serem criados meios efetivos de uniformização de jurisprudência no âmbito dos Juizados Especiais Estaduais e Federais. Não é porque perante tais órgãos são processadas causas cíveis de menor complexidade e infrações penais de menor potencial ofensivo que as regras processuais que os regulam devem ser tratadas com menos rigor e cuidado. Até mesmo para o prestígio desse sistema, o tratamento conferido aos jurisdicionados deve ser tão isonômico e seguro quanto aquele dispensado na justiça comum.

Como se vê, de uma forma geral, a preocupação com a uniformização da jurisprudência tem sempre estado em evidência no Brasil, desde a época da dominação portuguesa. Apesar de ser esse o alegado mote de algumas das reformas implementadas na 
Constituição Federal e na legislação processual nas últimas décadas, nem sempre os cuidados devidos têm sido observados, o que novamente nos leva a crer que o verdadeiro intento do legislador tem sido desafogar o Judiciário, submerso num oceano de demandas, por vezes à custa de garantias caras ao processo.

É imperioso que o legislador, e os operadores do direito em geral, tenham em mente que a diversidade de entendimentos nem sempre é maléfica para o sistema. No caso de direito novo, por exemplo, é natural e saudável que surjam correntes em um sentido e em outro que lhe seja contrário. A uniformização deve ser buscada, sem dúvida, mas somente depois de exaustivamente ponderados todos os argumentos favoráveis e contrários à tese jurídica prevalecente. Assim, apenas depois de maturado e consolidado o entendimento - e portanto fixado em súmula - é que se deve cogitar da uniformização, a partir dele.

E não é qualquer entendimento maturado e consolidado que deve dar ensejo a uniformização da jurisprudência, mas apenas aquele oriundo de tribunal superior. Não pretendemos sustentar que, no caso de divergência entre órgãos fracionários do mesmo tribunal, a solução seja atribuída ao tribunal superior. Tal possibilidade, apesar de não ser ruim, é completamente inviável na prática, pelo que dela sequer cogitamos. O que queremos evitar é que, por exemplo, o relator de tribunal de segundo grau negue seguimento a uma apelação com fundamento exclusivamente em súmula oriunda do próprio tribunal, ainda mais se divergente de súmula oriunda de tribunal superior. Infelizmente, da forma como está configurado o ordenamento, é possível ocorrer essa situação absurda.

A razão pela qual defendemos a súmula vinculante editada pelo STF é que ela parece reunir todos esses requisitos: para atingir esse status, além de ser oriundo de tribunal superior (rectius: do tribunal supremo, localizado no ápice do ordenamento), o entendimento deve ter sido suficientemente debatido (o art. 103-A, caput, da CF, fala que a súmula será aprovada "após reiteradas decisões sobre matéria constitucional”, como já dito), bem como contar com a aprovação de dois terços dos ministros. Além de tudo, a súmula vinculante é composta de válvula de escape, que permite a sua revisão ou o seu cancelamento, sempre que se mostrar ultrapassado ou, por algum outro motivo, inadequado o entendimento nela esposado. 
Aliás, quanto a esse aspecto, é importante que fique claro que, ao defender a fixação em súmula dos entendimentos maturados e consolidados, não pretendemos engessá-los. O sistema prevê, tanto com relação às súmulas vinculantes, quanto com relação às súmulas da jurisprudência predominante, de eficácia meramente persuasiva, procedimentos para a revisão e o cancelamento dos enunciados. Essa feição é fundamental para assegurar aos entendimentos uma relativa estabilidade, sem, contudo, torná-los imunes à evolução natural das coisas.

Pretendemos evitar que, mantido o contexto histórico, cultural, político, social e econômico, os jurisdicionados fiquem à mercê de entendimentos diversos, muitas vezes antagônicos, fundados em razões de ordem meramente subjetiva do julgador, comprometendo a unidade do ordenamento. Mas nem por isso desestimulamos o debate e a busca de novas interpretações com o fim de fazer evoluir o direito e de tornar adequada a percepção de seus institutos. Até por isso, entendemos que, por mais remansosa que seja a jurisprudência, é necessário que o intérprete faça o cotejo entre a tese jurídica por ela sugerida e o caso concreto, à luz da melhor doutrina e dos princípios gerais de direito. $\mathrm{O}$ pior erro é o daqueles que, por incompetência ou comodismo, lidam com a jurisprudência de forma não criteriosa.

Destarte, na linha da lição de TARUFFO, para quem é necessário "reinterpretar a realidade mutável dos vários sistemas processuais por meio de esquemas cognitivamente mais atualizados e heuristicamente mais eficazes" ${ }^{\circ 03}$, é chegada a hora de assumir o relevante papel desempenhado pelo precedente judicial e pela jurisprudência em nosso ordenamento, independentemente da tradição de nossas raízes históricas, e de tracejar as premissas principais de um sistema misto, em que a lei reina, mas a jurisprudência governa ${ }^{604}$. Ficam, a título de sugestão, tanto de lege lata quanto de lege ferenda, as humildes considerações expendidas neste estudo.

\footnotetext{
${ }^{603}$ In TARUFFO, Michele, Observações sobre os modelos processuais de civil law e de common law, in Revista de Processo, no 110, 2003, p. 158.

${ }^{604}$ V., nesse sentido, invocando a lição de CARLOS COSSIO, FERRO, Marcelo Roberto, Da jurisprudência, in Revista de Direito Civil, Imobiliário, Agrário e Empresarial, ${ }^{\circ}$ 62, 1992, p. 95. V., citando frase de José ANTOLIN DEL CUETO em sentido idêntico, CRUZ, José Raimundo Gomes da, A jurisprudência ante a Constituição de 1988, in Revista de Direito Civil, Imobiliário, Agrário e Empresarial, nº 54, 1990, p. 83.
} 


\section{Bibliografia}

AlmeIDA, Cynthia Rach de, Do impedimento do juiz julgar contra a lei, in Revista Forense, vol. 308, Rio de Janeiro, Forense, out./dez. 1989, pp. 287/288.

AlmeidA, Gustavo Milaré, Poderes investigatórios do Ministério Público nas ações coletivas, São Paulo, Atlas, 2010.

Alves, Eliana Calmon, Embargos de divergência e a Súmula 599/STF, in Direito processual: inovações e perspectivas - estudos em homenagem ao Ministro Sálvio de Figueiredo Teixeira (obra coletiva), coord. Eliana Calmon Alves e Uadi Lammêgo Bulos, São Paulo, Saraiva, 2003, pp. 213/223.

AmadeO, Rodolfo da Costa Manso Real, Botelho DE MesquitA, José Ignacio, LOMBARDI, Mariana Capela, Dellore, Luiz Guilherme Pennacchi, RiBEIRO, Débora, TEIXEIRA, Guilherme Silveira, ZveIBIL, Daniel Guimarães, Balanço de uma polêmica: a Súmula-STF 343, in Direito processual civil (obra coletiva), coord. Milton Paulo de Carvalho e Daniel Penteado de Castro, vol. 2, São Paulo, Quartier Latin, 2011, pp. $343 / 368$.

Botelho de Mesquita, José Ignacio, Dellore, Luiz Guilherme Pennacchi, RibeIRo, Débora, TeIXeIRA, Guilherme Silveira e ZveIBIL, Daniel Guimarães, $A$ repercussão geral e os recursos repetitivos. Economia, Direito e Política, artigo no prelo, 2009.

ANDRADE, Dárcio Guimarães de, Uniformização de jurisprudência, in Revista Trimestral de Jurisprudência dos Estados, n 179, São Paulo, EJV, nov./dez. 2000, pp. 59/64.

ANDRADE, Fábio Martins de, $O$ conseqüencialismo, a modulação temporal dos efeitos e o ativismo judicial nas decisões do Supremo Tribunal Federal e o Estado de Direito, in Revista Dialética de Direito Tributário, nº 172, São Paulo, jan. 2010, pp. 34/43.

Antokoletz, Daniel, Tratado de derecho romano, Buenos Aires, El Ateneo, 1930.

AraúJo, Justino Magno, A renovação do processo civil brasileiro e os desafios do Judiciário no século XXI, in Revista da Escola Paulista da Magistratura, vol. 3, $\mathrm{n}^{\circ} 2$, São Paulo, jul./dez. 2002, pp. 105/128. 
ARENHART, Sérgio Cruz, A nova postura do relator no julgamento dos recursos, in Revista de Processo, $\mathrm{n}^{\circ}$ 103, São Paulo, RT, jul./set. 2001, pp. 37/58.

e Marinoni, Luiz Guilherme, Curso de processo civil: processo de conhecimento, vol. 2, $7^{\mathrm{a}}$ ed., São Paulo, RT, 2007.

ARriBAS, Bruno Felipe da Silva Martin de, Decisão monocrática relatorial: análise do artigo 557 do Código de Processo Civil, in Revista da Esmape - Escola Superior da Magistratura de Pernambuco, no 20, Recife, jul./dez. 2004, pp. 97/127.

ArRuda Alvim, José Manoel de, As normas processuais civis, in A norma jurídica (obra coletiva), coord. Sérgio Ferraz, Rio de Janeiro, Freitas Bastos, 1980, pp. 49/72.

, Cabimento de embargos de divergência contra acórdão (de mérito) de Turma, proferido em agravo regimental, tirado de decisão de relator de recurso extraordinário - Imprescindibilidade de uma releitura da súmula $n^{o}$ 599/STF, in Revista do Advogado, no 88, São Paulo, AASP, nov. 2006, pp. 20/31.

ASCARELl, Tullio, Problemas das sociedades anônimas e direito comparado, São Paulo, Saraiva, 1945.

Assis, Araken de, Eficácia da coisa julgada inconstitucional, in Revista Dialética de Direito Processual, no 4, São Paulo, jul. 2003, pp. 9/28.

AzEVEDo, Álvaro Villaça, Os assentos no direito processual civil, in Justitia - Órgão do Ministério Público de São Paulo, nº 74, São Paulo, jul./set. 1971, pp. 115/143.

Azevedo, Luiz Carlos de, Função da jurisprudência nos conflitos entre a lei natural e a lei positiva, in Revista Trimestral de Jurisprudência dos Estados, $\mathrm{n}^{\circ}$ 34, São Paulo, EJV, set./out. 1985, pp. 41/46.

e CRUZ E TUCCI, José Rogério, Lições de história do processo civil romano, São Paulo, RT, 2001.

e CRUZ E TUCCI, José Rogério, Lições de história do processo civil canônico (história e direito vigente), São Paulo, RT, 2001. 
e CRUZ E TUCCI, José Rogério, Lições de história do processo civil lusitano, São Paulo, RT e Coimbra, 2009.

BAPTISTA DA SILVA, Ovídio Araújo, A jurisdictio romana e a jurisdição moderna, in Revista Jurídica, $\mathrm{n}^{\circ}$ 355, Porto Alegre, Notadez, mai. 2007, pp. 11/28.

Barbosa Moreira, José Carlos, El control judicial de la constitucionalidad de las leyes en el Brasil: un bosquejo, in Temas de direito processual, $6^{\mathrm{a}}$ série, São Paulo, Saraiva, 1997, pp. 183/193.

Algumas inovações da Lei 9.756 em matéria de recursos civis, in Aspectos polêmicos e atuais dos recursos cíveis de acordo com a Lei $n^{\circ}$ 9.756/98 (obra coletiva), coord. Teresa Arruda Alvim Wambier e Nelson Nery Junior, São Paulo, RT, 1999, pp. $320 / 329$.

, O juiz e a cultura da transgressão, in Temas de direito processual, $7^{\mathrm{a}}$ série, São Paulo, Saraiva, 2001, pp. 251/261.

, Súmula, jurisprudência, precedente: uma escalada e seus riscos, in Revista Síntese de Direito Civil e Processual Civil, no 35, Porto Alegre, mai./jun. 2005, pp. $5 / 16$.

, A emenda constitucional $n^{\circ} 45$ e o processo, in Revista Forense, vol. 383, Rio de Janeiro, Forense, jan./fev. 2006, pp. 181/191.

, Comentários ao Código de Processo Civil, vol. 5, 14ª ed., Rio de Janeiro, Forense, 2008.

, O novo processo civil brasileiro (exposição sistemática do procedimento), $27^{\mathrm{a}}$ ed., Rio de Janeiro, Forense, 2008.

BARtoletto, Luiz Carlos, Analogia, jurisprudência e princípios gerais do direito, in Revista de Direito Civil, Imobiliário, Agrário e Empresarial, nº 72, São Paulo, abr./jun. 1995, pp. 26/31.

BertocchI, Aido Faustino, O juiz e seu poder criador, in Revista da Ajuris - Associação dos Juízes do Rio Grande do Sul, nº 48, Porto Alegre, mar. 1990, pp. 202/211. 
Bevilaqua, Clovis, Theoria geral do direito civil, $2^{\mathrm{a}}$ ed., Rio de Janeiro, Francisco Alves, 1929.

BonDIOLI, Luis Guilherme Aidar, O julgamento liminar de improcedência da demanda da ótica do réu (art. 285-A), in Direito civil e processo - Estudos em homenagem ao Professor Arruda Alvim (obra coletiva), coord. Araken de Assis, Eduardo Arruda Alvim, Nelson Nery Jr., Rodrigo Mazzei, Teresa Arruda Alvim Wambier e Thereza Alvim, São Paulo, RT, 2007, pp. 1.323/1.332.

Botelho de Mesquita, José Ignacio, A coisa julgada no Código do Consumidor, in Coisa julgada, Rio de Janeiro, Forense, 2004, pp. 21/42.

, Conflito entre a intangibilidade da coisa julgada e outro princípio constitucional. Um falso problema, in Coisa julgada, Rio de Janeiro, Forense, 2004, pp. 89/123.

, A revisão do Código de Processo Civil, in Revista do Advogado, $\mathrm{n}^{\circ} 75$, São Paulo, AASP, abr. 2004, pp. 61/66.

, Da ação civil, in Teses, estudos e pareceres de processo civil, vol. 1, São Paulo, RT, 2005, pp. 33/128.

, A crise do Judiciário e o processo, in Teses, estudos e pareceres de processo civil, vol. 1, São Paulo, RT, 2005, pp. 255/262.

As novas tendências do direito processual: uma contribuição para o seu reexame, in Teses, estudos e pareceres de processo civil, vol. 1, São Paulo, RT, 2005, pp. $263 / 307$.

Apresentação: Teoria e prática do processo civil e comercial, in Teses, estudos e pareceres de processo civil, vol. 1, São Paulo, RT, 2005, pp. 308/314.

O princípio da liberdade na prestação jurisdicional, in Teses, estudos $e$ pareceres de processo civil, vol. 2, São Paulo, RT, 2005, pp. 33/50.

A nova lei de recursos (Lei 8.038/90), in Teses, estudos e pareceres de processo civil, vol. 2, São Paulo, RT, 2005, pp. 187/197. 
, A súmula da jurisprudência predominante no Supremo Tribunal Federal, in Teses, estudos e pareceres de processo civil, vol. 2, São Paulo, RT, 2005, pp. 215/226.

, Da uniformização da jurisprudência - uma contribuição para seu estudo, in Teses, estudos e pareceres de processo civil, vol. 2, São Paulo, RT, 2005, pp. 227/236.

, Uniformização da jurisprudência (esboço de substitutivo ao Projeto de Lei 3.804/93), in Teses, estudos e pareceres de processo civil, vol. 2, São Paulo, RT, 2005, pp. $237 / 242$.

, O desmantelamento do sistema brasileiro de controle de constitucionalidade, in Teses, estudos e pareceres de processo civil, vol. 2, São Paulo, RT, 2005, pp. $258 / 272$.

, Mudança e mesmice em matéria constitucional, in Teses, estudos e pareceres de processo civil, vol. 3, São Paulo, RT, 2007, pp. 250/254.

De Getúlio Vargas a Lula. A cubanização do direito brasileiro, artigo no prelo, 2009.

LombARd, Mariana Capela, AmadeO, Rodolfo da Costa Manso Real, Dellore, Luiz Guilherme Pennacchi, RIBEIRO, Débora, TEIXEIRA, Guilherme Silveira e ZVEIBIL, Daniel Guimarães, Balanço de uma polêmica: a Súmula-STF 343, in Direito processual civil (obra coletiva), coord. Milton Paulo de Carvalho e Daniel Penteado de Castro, vol. 2, São Paulo, Quartier Latin, 2011, pp. 343/368.

AmadeO, Rodolfo da Costa Manso Real, Dellore, Luiz Guilherme Pennacchi, RIBEIRO, Débora, TEIXEIRA, Guilherme Silveira e ZveIBIL, Daniel Guimarães, A repercussão geral e os recursos repetitivos. Economia, Direito $e$ Política, artigo no prelo, 2009.

Bottallo, Eduardo Domingos, Súmula vinculante e República, in Revista do Advogado, nº 81, São Paulo, AASP, abr. 2005, pp. 29/33.

BraghitTONI, Rogério Ives, Uniformização de jurisprudência e art. 555, $\$ 1^{o}$, do Código de Processo Civil, in Revista do Instituto dos Advogados de São Paulo, $\mathrm{n}^{\circ}$ 15, São Paulo, RT, jan./jun. 2005, pp. 241/256. 
Brasil JUNIOR, Samuel Meira, Precedentes vinculantes e jurisprudência dominante na solução das controvérsias, Tese (Doutorado), Universidade de São Paulo, São Paulo, 2010.

Bueno, Cássio Scarpinella, A nova etapa da reforma do Código de Processo Civil, vol. 2, $2^{a}$ ed., São Paulo, Saraiva, 2007.

BuEno FILHO, Edgard Silveira, Os precedentes no direito brasileiro, in Revista dos Tribunais, vol. 716, São Paulo, RT, jun. 1995, pp. 24/26.

Burini, Bruno, O artigo 285-A do Código de Processo Civil, in Direito processual civil (obra coletiva), coord. Milton Paulo de Carvalho, São Paulo, Quartier Latin, 2007, pp. $181 / 214$.

BuZAID, Alfredo, Uniformização da jurisprudência, in Revista da Ajuris - Associação dos Juízes do Rio Grande do Sul, no 34, Porto Alegre, jul. 1985, pp. 189/217.

CAlamandrei, Piero, La cassazione civile, vols. 1 e 2, Torino, Fratelli Boca, 1920. , Eles, os juízes, vistos por um advogado, trad. port. Ary dos Santos, $4^{\mathrm{a}}$ ed., LCE, Lisboa, 1971.

CAMBI, Eduardo, Jurisprudência lotérica, in Revista dos Tribunais, vol. 786, São Paulo, RT, abr. 2001, pp. 108/128.

, Uniformização das questões de direito nos Juizados Especiais Cíveis e Federais: a criação do recurso de divergência, in Aspectos polêmicos e atuais dos recursos de acordo com a Lei 10.352/2001 (obra coletiva), coord. Nelson Nery Junior e Teresa Arruda Alvim Wambier, São Paulo, RT, 2002, pp. 169/178.

CAnotilho, José Joaquim Gomes, A principalização da jurisprudência através da Constituição, in Revista de Processo, n 98, São Paulo, RT, abr./jun. 2000, pp. 83/89. , Direito constitucional e teoria da Constituição, $7^{\mathrm{a}}$ ed., Coimbra, Almedina, 2003.

CAPPelletti, Mauro, O controle de constitucionalidade das leis no direito comparado, trad. port. Aroldo Plínio Gonçalves, Porto Alegre, Sérgio Fabris, 1984. 
, The judicial process in comparative perspective, Oxford, Clarendon Press, 1989.

, Constitucionalismo moderno e o papel do Poder Judiciário na sociedade contemporânea, in Revista de Processo, nº 60, São Paulo, RT, out./dez. 1990, pp. 110/117.

Algunas reflexiones sobre el rol de los estudios procesales en la actualidad, in Revista de Processo, nº 64, São Paulo, RT, out./dez. 1991, pp. 145/157.

, Problemas de reforma do processo civil nas sociedades contemporâneas, in Revista Forense, vol. 88, trad. port. José Carlos Barbosa Moreira, Rio de Janeiro, Forense, abr./jun. 1992, pp. 119/128.

, Juízes legisladores?, trad. port. Carlos Alberto Alvaro de Oliveira, Porto Alegre, Sérgio Fabris, 1993.

, Repudiando Montesquieu? A expansão e a legitimidade da "Justiça Constitucional”, in Revista Forense, vol. 99, trad. port. Fernando Sá, rev. Carlos Alberto Alvaro de Oliveira, Rio de Janeiro, Forense, mar./abr. 2003, pp. 127/150.

e GARTH, Bryant, Acesso à justiça, Porto Alegre, Sérgio Fabris, 1988.

CARdoso, Oscar Valente, Súmulas vinculantes e desvinculação da jurisprudência, in Revista Dialética de Direito Processual, no 77, São Paulo, ago. 2009, pp. 70/84.

CARLIn, Volnei Ivo, O papel do juiz, na sociedade moderna, in Revista de Processo, $\mathrm{n}^{\circ} 45$, São Paulo, RT, jan./mar. 1987, pp. 243/258.

, Jurisprudência como função substitutiva do legislador, in Seqüência: estudos jurídicos e políticos, no 16, Florianópolis, jun. 1988, pp. 31/37.

CARmona, Carlos Alberto, Apresentação, in PAREnTE, Eduardo de Albuquerque, Jurisprudência: da divergência à uniformização, São Paulo, Atlas, 2006, pp. ix/x.

CARneIro, Athos Gusmão, Poderes do relator e agravo interno - artigos 557, 544 e 545 do CPC, in Revista Síntese de Direito Civil e Processo Civil, no 6, jul./ago. 2000, pp. $5 / 26$. 
CARneIRo, João Geraldo Piquet, Estratégia de aperfeiçoamento e consolidação dos Juizados Especiais Cíveis, in Revista do Advogado, no 75, São Paulo, AASP, abr. 2004, pp. $34 / 37$.

Carnelutti, Francesco, Sistema di diritto processuale civile, vol. 1, Padova, Cedam, 1936.

_, Sistema di diritto processuale civile, vol. 2, Padova, Cedam, 1936.

, Derecho y proceso, Buenos Aires, EJEA, 1971.

Carvalho, Amílton Bueno de, A lei, o juiz, o justo, in Revista da Ajuris - Associação dos Juizes do Rio Grande do Sul, nº 39, Porto Alegre, mar. 1987, pp. 132/152.

Carvalho, Ivan Lira de, Decisões vinculantes, in Revista Forense, vol. 343, Rio de Janeiro, Forense, jul./set. 1998, pp. 519/527.

CAZETTA JÚNIOR, José Jesus, A ineficácia do precedente no sistema brasileiro de jurisdição constitucional (1891-1993): contribuição ao estudo do efeito vinculante, Tese (Doutorado), Universidade de São Paulo, São Paulo, 2004.

, Assentos da Casa da Suplicação, in Revista do Advogado, nº 84, São Paulo, AASP, dez. 2005, pp. 73/89.

, Os precedentes judiciais nos Estados Unidos: apontamentos para uma comparação, in Revista de Direito Administrativo, $\mathrm{n}^{\circ}$ 244, Rio de Janeiro, FGV/Atlas, jan./abr. 2007, pp. 186/207.

CernicChiaro, Luiz Vicente, Jurisprudência, in Revista da Procuradoria Geral do INSS, vol. 6, nº 3, Brasília, MPAS/INSS, out./dez. 1999, pp. 23/24.

CHIARLONI, Sergio, Un mito rivisitato: note comparative sull'autorità del precedente giurisprudenziale, in Rivista di Diritto Processuale, ano 56, $\mathrm{n}^{\circ} 3$, Padova, jul./set. 2001, pp. 614/632.

ChIOvenda, Giuseppe, Istituzioni di diritto processuale civile, vol. 1, $2^{\mathrm{a}}$ ed., Napoli, Dott. Eugenio Jovene, 1935. 
Cianci, Mirna, Súmula vinculante. Os meios processuais de controle da vinculação (Lei 11.417/2006, art. $7^{\circ}$ ), in Direito civil e processo - Estudos em homenagem ao Professor Arruda Alvim (obra coletiva), coord. Araken de Assis, Eduardo Arruda Alvim, Nelson Nery Jr., Rodrigo Mazzei, Teresa Arruda Alvim Wambier e Thereza Alvim, São Paulo, RT, 2007, pp. 1.357/1.374.

Cintra, Antonio Carlos de Araújo, Sobre os limites objetivos da apelação civil, Tese (Livre Docência), Universidade de São Paulo, São Paulo, 1986.

ClÈve, Clèmerson Merlin, A fiscalização abstrata da constitucionalidade no direito brasileiro, 2a ed., São Paulo, RT, 2000.

Coelho, Luiz Carlos Galvão, A função supletiva do juiz em casos de omissão da lei, in Revista de Processo, n 45, São Paulo, RT, jan./mar. 1987, pp. 236/239.

Cole, Charles D., Stare decisis na cultura jurídica dos Estados Unidos. O sistema de precedente vinculante do Common Law, in Revista dos Tribunais, vol. 87, São Paulo, RT, jun. 1998, pp. 11/21.

Precedente judicial: a experiência americana, in Revista de Processo, $\mathrm{n}^{\mathrm{o}}$ 92, São Paulo, RT, out./dez. 1998, pp. 71/86.

CORRÊA, Oscar Dias, Breves ponderações sobre a crise do Poder Judiciário, in Revista de Processo, no 98, São Paulo, RT, abr./jun. 2000, pp. 153/160.

CôRTES, Osmar Mendes Paixão, A experiência brasileira com a vinculação das decisões judiciais e a atual súmula vinculante introduzida pela EC 45/2004, in Direito civil e processo - Estudos em homenagem ao Professor Arruda Alvim (obra coletiva), coord. Araken de Assis, Eduardo Arruda Alvim, Nelson Nery Jr., Rodrigo Mazzei, Teresa Arruda Alvim Wambier e Thereza Alvim, São Paulo, RT, 2007, pp. 1.383/1.396.

Couto, Mônica Bonetti, Repercussão geral da questão constitucional: algumas notas reflexivas, in Direito civil e processo - Estudos em homenagem ao Professor Arruda Alvim (obra coletiva), coord. Araken de Assis, Eduardo Arruda Alvim, Nelson Nery Jr., Rodrigo Mazzei, Teresa Arruda Alvim Wambier e Thereza Alvim, São Paulo, RT, 2007, pp. 1.375/1.382. 
COUTURE, Eduardo Juan, Fundamentos do direito processual civil, trad. port. Rubens Gomes de Sousa, São Paulo, Saraiva, 1946.

, Fundamentos de derecho procesal, $2^{\mathrm{a}}$ ed., Buenos Aires, Depalma, 1951.

, Interpretação das leis processuais, trad. port. Gilda Maciel Corrêa Meyer Russomano, São Paulo, Max Limonad, 1956.

, La justicia inglesa, in Estudios de derecho procesal civil, tomo I, $2^{\mathrm{a}}$ ed., Depalma, Buenos Aires, 1978, pp. 143/175.

, Trayectoria y destino del derecho procesal civil hispanoamericano, in Estudios de derecho procesal civil, tomo I, $2^{\text {a }}$ ed., Depalma, Buenos Aires, 1978, pp. 291/342.

CRetella Júnior, José, Curso de direito romano - o direito romano e o direito civil brasileiro, $6^{\mathrm{a}}$ ed., Rio de Janeiro, Forense, 1978.

CRUZ, José Raimundo Gomes da, A jurisprudência ante a Constituição de 1988, in Revista de Direito Civil, Imobiliário, Agrário e Empresarial, nº 54, São Paulo, out./dez. 1990, pp. 83/98.

CRUZ E TUCCI, José Rogério, Tempo e processo: uma análise empírica das repercussões do tempo na fenomenologia processual (civil e penal), São Paulo, RT, 1997.

, Ineficiência da administração da justiça e dano moral, in Questões práticas de processo civil, São Paulo, Atlas, 1998, pp. 103/107.

, Precedente judicial como fonte de direito, São Paulo, RT, 2004.

, O problema da lentidão da justiça e a questão da súmula vinculante, in Revista do Advogado, no 75, São Paulo, AASP, abr. 2004, pp. 73/77.

, Eficácia do precedente judicial na história do direito brasileiro, in Revista do Advogado, nº 78, São Paulo, AASP, set. 2004, pp. 43/48.

, Variações sobre precedentes judiciais vinculantes e persuasivos, in Revista Magister de Direito Civil e Processual Civil, ano 1, nº 5, Porto Alegre, mar./abr. 2005, pp. 13/23. 
, O diálogo do Dr. Theotonio com a jurisprudência, in Revista do Advogado, nº 81, São Paulo, AASP, abr. 2005, pp. 71/73.

, Limites subjetivos da eficácia da sentença e da coisa julgada civil, São Paulo, RT, 2006.

, Duração razoável do processo (art. $5^{\circ}$, LXXVIII, da CF), in Direito civil e processo - Estudos em homenagem ao Professor Arruda Alvim (obra coletiva), coord. Araken de Assis, Eduardo Arruda Alvim, Nelson Nery Jr., Rodrigo Mazzei, Teresa Arruda Alvim Wambier e Thereza Alvim, São Paulo, RT, 2007, pp. 1.076/1.086.

, Anotações sobre a repercussão geral como pressuposto de admissibilidade do Recurso Extraordinário (Lei no 11.418/2006), in Revista do Advogado, no 92, São Paulo, AASP, jul. 2007, pp. 23/31.

e AzEvedo, Luiz Carlos de, Lições de história do processo civil romano, São Paulo, RT, 2001.

e Azevedo, Luiz Carlos de, Lições de história do processo civil canônico (história e direito vigente), São Paulo, RT, 2001.

e AzEVEDo, Luiz Carlos de, Lições de história do processo civil lusitano, São Paulo, RT e Coimbra, 2009.

CunHA, Sérgio Sérvulo da, Nota breve sobre o efeito vinculante, in Revista de Informação Legislativa, n 129, Brasília, jan./mar. 1996, pp. 5/16.

, O efeito vinculante e os poderes do juiz, São Paulo, Saraiva, 1999.

DAll'Agnol Junior, Antonio Janyr, Admissão do recurso de apelação e súmulas (exegese do art. 518, $\S 1^{\circ}$, do CPC), in Revista do Advogado, $\mathrm{n}^{\circ}$ 85, São Paulo, AASP, mai. 2006, pp. 181/187.

DAVID, René, O direito inglês, São Paulo, Martins Fontes, 1997.

Delgado, José Augusto, Poderes, deveres e responsabilidade do Juiz, in Revista de Processo, no 42, São Paulo, RT, abr./jun. 1986, pp. 37/57. 
Dellore, Luiz Guilherme Pennacchi, Evolução do controle de constitucionalidade das leis: rumo ao controle concentrado?, Dissertação (Mestrado), Pontifícia Universidade Católica de São Paulo, São Paulo, 2007.

, Botelho de Mesquita, José Ignacio, Lombardi, Mariana Capela, AmAdeO, Rodolfo da Costa Manso Real, RIBEIRO, Débora, TEIXEIRA, Guilherme Silveira e ZveIBIL, Daniel Guimarães, Balanço de uma polêmica: a Súmula-STF 343, in Direito processual civil (obra coletiva), coord. Milton Paulo de Carvalho e Daniel Penteado de Castro, vol. 2, São Paulo, Quartier Latin, 2011, pp. 343/368.

Botelho de Mesquita, José Ignacio, Amadeo, Rodolfo da Costa Manso Real, RibeIRo, Débora, TeIXeIRA, Guilherme Silveira e ZveIBIL, Daniel Guimarães, $A$ repercussão geral e os recursos repetitivos. Economia, Direito e Política, artigo no prelo, 2009.

DERZI, Misabel, Modulação de efeitos das decisões judiciais, in Revista de Direito Tributário, nº 111, São Paulo, Malheiros, 2010, pp. 60/64.

DIAS, Luiz Claudio Portinho, Recurso contra decisão em consonância com jurisprudência assente das Cortes Superiores: litigância de má-fé?, in Revista da Procuradoria Geral do INSS, vol. 5, n 4, Brasília, MPAS/INSS, jan./mar. 1999, pp. 44/46.

DinAmarco, Cândido Rangel, O relator, a jurisprudência e os recursos, in Aspectos polêmicos e atuais dos recursos cíveis de acordo com a Lei $n^{\circ}$ 9.756/98 (obra coletiva), coord. Teresa Arruda Alvim Wambier e Nelson Nery Junior, São Paulo, RT, 1999, pp. $127 / 144$.

, Súmulas vinculantes, in Revista Forense, vol. 347, Rio de Janeiro, Forense, jul./set. 1999, pp. 51/65.

, Decisões vinculantes, in Revista de Processo, $\mathrm{n}^{\mathrm{o}}$ 100, São Paulo, RT, out./dez. 2000, pp. 166/185.

, A reforma da reforma, $6^{\text {a }}$ ed., São Paulo, Malheiros, 2003.

, A reclamação no processo civil brasileiro, in Nova era do processo civil, São Paulo, Malheiros, 2003, pp. 195/206. 
Instituições de direito processual civil, vol. 1, 4ª ed., São Paulo, Malheiros, 2004.

, Vocabulário do processo civil, São Paulo, Malheiros, 2009.

DINIZ, Antonio Carlos de Almeida, A recepção do instituto de efeito vinculante pelo direito brasileiro, in Revista de Direito Constitucional e Internacional, $\mathrm{n}^{\circ} 39$, São Paulo, RT, abr./jun. 2002, pp. 209/224.

Donoso, Denis, Um novo princípio contraditório. Análise da constitucionalidade das técnicas de massificação de soluções e da escalada da importância do precedente judicial, in Revista Dialética de Direito Processual, no 73, São Paulo, abr. 2009, pp. $22 / 35$.

DUARTE, Ricardo Quass, O tempo inimigo no processo civil brasileiro, São Paulo, LTr, 2009.

FAgundes, Miguel Seabra, Contribuição da jurisprudência à evolução do direito brasileiro, in Revista Forense, vol. 126, Rio de Janeiro, Forense, nov. 1949, pp. 18/24.

FERnANDES, Sérgio Ricardo de Arruda, A influência da jurisprudência dos tribunais no julgamento realizado na instância revisora, in Revista de Direito do Tribunal de Justiça do Estado do Rio de Janeiro, nº 67, Rio de Janeiro, abr./mai. 2006, pp. 60/69.

FERnANDEZ, Alberto Vicente, Funcion creadora del juez, Buenos Aires, Abeledo-Perrot, 1980.

FERraz Junior, Tércio Sampaio, Introdução ao estudo do direito: técnica, decisão, dominação, 2a ed., São Paulo, Atlas, 1994.

FERreIRA, Maria Elizabeth Malaquias, Modulação dos efeitos temporais no controle jurisdicional de constitucionalidade e reflexos sobre a norma do art. 52, X, da Constituição Federal, in Revista de Informação Legislativa, nº 173, Brasília, jan./mar. 2007, pp. 193/207.

FERREIRA DA Silva, Luis Renato, A regra do precedente no direito inglês, in Revista de Direito Civil, Imobiliário, Agrário e Empresarial, no 75, São Paulo, jan./mar. 1996, pp. 48/56. 
FerreIRA FILHO, Manoel Gonçalves, Curso de direito constitucional, 26 a ed., São Paulo, Saraiva, 1999.

FERRO, Marcelo Roberto, A jurisprudência como forma de expressão de direito, in Revista de Direito Civil, Imobiliário, Agrário e Empresarial, nº 51, São Paulo, jan./mar. 1990, pp. 89/103.

, Da jurisprudência, in Revista de Direito Civil, Imobiliário, Agrário e Empresarial, nº 62, São Paulo, out./dez. 1992, pp. 83/96.

Figueiredo, Samuel Mac Dowell de, A defesa do processo, in Revista do Advogado, $\mathrm{n}^{\circ} 84$, São Paulo, AASP, dez. 2005, pp. 215/218.

FINE, Toni M., O uso do precedente e o papel do princípio do stare decisis no sistema legal norte-americano, in Revista dos Tribunais, vol. 89, São Paulo, RT, dez. 2000, pp. 90/96.

FreIRE, Rodrigo da Cunha Lima, Reflexões sobre o cabimento dos embargos de divergência em recurso especial, in Direito civil e processo - Estudos em homenagem ao Professor Arruda Alvim (obra coletiva), coord. Araken de Assis, Eduardo Arruda Alvim, Nelson Nery Jr., Rodrigo Mazzei, Teresa Arruda Alvim Wambier e Thereza Alvim, São Paulo, RT, 2007, pp. 1.211/1.229.

FREITAS, Juarez, Hermenêutica jurídica: o juiz só aplica a lei injusta se quiser, in Revista da Ajuris - Associação dos Juízes do Rio Grande do Sul, n 40, Porto Alegre, jul. 1987, pp. $39 / 52$.

Gajardoni, Fernando da Fonseca, O princípio constitucional da tutela jurisdicional sem dilações indevidas e o julgamento antecipadíssimo da lide (artigo 285-A do CPC), in As grandes transformações do processo civil brasileiro - Homenagem ao Professor Kazuo Watanabe (obra coletiva), coord. Carlos Alberto de Salles, Quartier Latin, São Paulo, 2009, pp. 995/1.030.

Galgano, Francesco, L'efficacia vincolante del precedente di Cassazione, in Contratto e Impresa, nº 3, Padova, Cedam, set./dez. 1999, pp. 889/896. 
Garcez Neto, Martinho, Função criadora da Jurisprudência, in Revista da EMERJ, ${ }^{\circ}$ 19, Rio de Janeiro, 2002, pp. 46/52.

GARCIA, Dínio de Santis, Efeito vinculante dos julgados da Corte Suprema e dos Tribunais Superiores, in Revista dos Tribunais, vol. 734, São Paulo, RT, dez. 1996, pp. 40/47.

Garth, Bryant e Cappelletti, Mauro, Acesso à justiça, Porto Alegre, Sérgio Fabris, 1988.

Goron, Lívio Goellner, A jurisprudência como fonte de direito: a experiência angloamericana, in Revista de Direito Constitucional e Internacional, $\mathrm{n}^{\circ}$ 47, São Paulo, RT, abr./jun. 2004, pp. 284/295.

GRAU, Eros Roberto, Sobre a produção legislativa e a normativa do direito oficial: o chamado 'efeito vinculante', in Revista da Escola Paulista da Magistratura, vol. 1, $\mathrm{n}^{\circ}$ 3, São Paulo, mai./out. 1997, pp. 67/80.

Eqüidade, razoabilidade e proporcionalidade, in Revista do Advogado, $\mathrm{n}^{\circ}$ 78, São Paulo, AASP, set. 2004, pp. 27/30.

GRECO, Leonardo, Eficácia da declaração erga omnes de constitucionalidade ou inconstitucionalidade em relação à coisa julgada anterior, disponível em <http://www. mundojuridico.adv.br>, acesso em 06/10/2011.

Greco Filho, Vicente, O juiz e a lei, in EDP: Estudos de Direito Público, no 1, São Paulo, jan./jun. 1987, pp. 45/50.

, Direito processual civil brasileiro, vol. 1, 15ª ed., São Paulo, Saraiva, 2000.

, Direito processual civil brasileiro, vol. 2, 14ª ed., São Paulo, Saraiva, 2000.

GrINOVER, Ada Pellegrini, O controle do raciocínio judicial pelos tribunais superiores brasileiros, in Revista da Ajuris - Associação dos Juízes do Rio Grande do Sul, $\mathrm{n}^{\circ}$ 50, Porto Alegre, nov. 1990, pp. 5/20.

, Mudanças estruturais no processo civil brasileiro, in Revista IOB de Direito Civil e Processual Civil, nº 44, Porto Alegre, nov./dez. 2006, pp. 35/55. 
, O controle difuso da constitucionalidade e a coisa julgada erga omnes das ações coletivas, in Revista do Advogado, nº 89, São Paulo, AASP, dez. 2006, pp. 7/11.

GuASQUe, Luiz Fabião, A inconstitucionalidade das leis, in Revista dos Tribunais, vol. 689, São Paulo, RT, mar. 1993, pp. 93/99.

GUIMARÃES, Mário, O juiz e a função jurisdicional, Rio de Janeiro, Forense, 1958.

Gustin, Moacyr Barbosa de Sousa, Da Jurisprudência como ciência compreensiva: a dialética do compreender mediante o interpretar, in Revista de Informação Legislativa, no 125, Brasília, jan./mar. 1995, pp. 205/212.

HAZARD JR., Geoffrey C. e TARUfFO, Michele, Normas transnacionais de processo civil, in Revista de Processo, n ${ }^{\circ}$ 102, trad. port. Antonio Gidi, São Paulo, RT, abr./jun. 2001, pp. 197/218.

IbBETSOn, David e LEWIS, Andrew, The Roman law tradition, in The Roman law tradition (obra coletiva), coord. Andrew Lewis e David Ibbetson, Cambridge, Cambridge University Press, 1994, pp. 1/14.

JULIANI, Cristiano Reis, A nova redação do artigo 555 do CPC e a uniformização de Jurisprudência, in Revista Síntese de Direito Civil e Processual Civil, $\mathrm{n}^{\circ}$ 23, Porto Alegre, mai./jun. 2003, pp. 35/41.

KARAn, Munir, A função judicial, in Revista de Processo, n ${ }^{\circ}$ 42, São Paulo, RT, abr.jun. 1986, pp. 169/186.

KELSEN, Hans, Teoria pura do direito, 6ª ed., São Paulo, Martins Fontes, 1999.

LAZARI, Rafael José Nadim de, Algumas questões jurisprudenciais sobre os "recursos representativos da controvérsia”, in Revista Dialética de Direito Processual, $\mathrm{n}^{\circ} 104$, São Paulo, nov. 2011, pp. 132/143.

LAZZARINI, Alvaro, Magistratura: deontologia, função e poderes do juiz, in Revista de Processo, n 48, São Paulo, RT, out./dez. 1987, pp. 206/216. 
LEAL, Pastora do Socorro Teixeira, A vinculação da interpretação judicial: aspectos constitucionais, in Revista de Direito Constitucional e Internacional, $\mathrm{n}^{\circ}$ 43, São Paulo, RT, abr./jun. 2003, pp. 209/278.

LEAL, Victor Nunes, Atualidade do Supremo Tribunal, in Revista de Direito Administrativo, $\mathrm{n}^{\mathrm{o}} 78$, Rio de Janeiro, FGV, out./dez. 1964, pp. 453/459.

Passado e futuro da súmula do STF, in Revista de Direito Administrativo, $\mathrm{n}^{\circ}$ 145, Rio de Janeiro, FGV, jul./set. 1981, pp. 1/20.

LEwIS, Andrew e IBbETSOn, David, The Roman law tradition, in The Roman law tradition (obra coletiva), coord. Andrew Lewis e David Ibbetson, Cambridge, Cambridge University Press, 1994, pp. 1/14.

LiebMan, Enrico Tullio, A força criativa da jurisprudência e os limites impostos pelo texto da lei, in Revista de Processo, $\mathrm{n}^{\mathbf{0}}$ 43, trad. port. Teresa Celina de Arruda Alvim Pinto, São Paulo, RT, jul./set. 1986, pp. 57/60.

LIMA, Ronaldo Cunha, Harmonizar a jurisprudência, in Revista da Procuradoria Geral do INSS, vol. 4, nº 3, Brasília, MPAS/INSS, jan. 1998, pp. 10/12.

LimONGI FRANÇA, Rubens, Jurisprudência - Seu caráter de forma de expressão de Direito, in Repertório Enciclopédico do Direito Brasileiro (obra coletiva), org. J. M. de Carvalho Santos e José de Aguiar Dias, vol. 30, Rio de Janeiro, Borsoi, 1947-1955, pp. $272 / 295$.

,O direito, a lei e a jurisprudência, São Paulo, RT, 1974.

, Hermenêutica jurídica, 10ª ed., São Paulo, RT, 2010.

LOMBARDI, Mariana Capela, Da coisa julgada civil - limites subjetivos e extensão a terceiros, Dissertação (Mestrado), Universidade de São Paulo, São Paulo, 2008.

Botelho de Mesquita, José Ignacio, Amadeo, Rodolfo da Costa Manso Real, Dellore, Luiz Guilherme Pennacchi, RiBeIro, Débora, TeiXeIRA, Guilherme Silveira e ZveIBIL, Daniel Guimarães, Balanço de uma polêmica: a Súmula-STF 343, in Direito processual civil (obra coletiva), coord. Milton Paulo de Carvalho e Daniel Penteado de Castro, vol. 2, São Paulo, Quartier Latin, 2011, pp. 343/368. 
LOPES, José Reinaldo de Lima, O Oráculo de Delfos - O Conselho de Estado no BrasilImpério, São Paulo, Saraiva, 2010.

LOPES, Raquel Cardoso, Uniformização da jurisprudência, in Revista Forense, vol. 390, Rio de Janeiro, Forense, mar./abr. 2007, pp. 567/581.

LOR, Encarnacion Alfonso, Súmula vinculante e repercussão geral: novos institutos de direito processual constitucional, São Paulo, RT, 2009.

LuCON, Paulo Henrique dos Santos, Novas tendências na estrutura fundamental do processo civil, in Revista do Advogado, nº 88, São Paulo, nov. 2006, pp. 145/172.

, Duração razoável e informatização do processo nas recentes reformas, in Direito civil e processo - Estudos em homenagem ao Professor Arruda Alvim (obra coletiva), coord. Araken de Assis, Eduardo Arruda Alvim, Nelson Nery Jr., Rodrigo Mazzei, Teresa Arruda Alvim Wambier e Thereza Alvim, São Paulo, RT, 2007, pp. $1.397 / 1.413$.

, Evolução da reclamação constitucional e seu emprego para assegurar a autoridade dos precedentes, artigo no prelo, 2011.

LuIZ, Elton, O nascimento da jurisprudência, in Revista da Faculdade de Direito Cândido Mendes, $\mathrm{n}^{\circ}$ 9, Rio de Janeiro, 2004, pp. 35/43.

MACHADO, Fábio Cardoso, Da uniformização jurídico-decisória por vinculação às súmulas de jurisprudência: objeções de ordem metodológica, sócio-cultural e políticojurídica, in Revista da Ajuris - Associação dos Juízes do Rio Grande do Sul, no 99, Porto Alegre, set. 2005, pp. 107/132.

MaCHADO, Hugo de Brito, Ação declaratória de constitucionalidade, in Revista dos Tribunais, vol. 697, São Paulo, RT, nov. 1993, pp. 34/40.

MAINE, Henry Sumner, Ancient Law - Its connection with the early history of society and its relation to modern ideas, London, John Murray, 1920.

MALLET, Estevão, A jurisprudência sempre deve ser aplicada retroativamente?, in Revista do Advogado, no 86, São Paulo, AASP, jul. 2006, pp. 23/35. 
Mancuso, Rodolfo de Camargo, Ação civil pública em defesa do meio ambiente, patrimônio cultural e dos consumidores (Lei 7.347/85 e legislação complementar), $3^{\mathrm{a}}$ ed., São Paulo, RT, 1994.

, A jurisprudência, dominante ou sumulada, e sua eficácia contemporânea, in Aspectos polêmicos e atuais dos recursos cíveis de acordo com a Lei no 9.756/98 (obra coletiva), coord. Teresa Arruda Alvim Wambier e Nelson Nery Junior, São Paulo, RT, 1999, pp. 518/532.

, Divergência jurisprudencial e súmula vinculante, $3^{\mathrm{a}}$ ed., São Paulo, RT, 2007.

Súmula vinculante: perguntas e respostas, in Direito civil e processo Estudos em homenagem ao Professor Arruda Alvim (obra coletiva), coord. Araken de Assis, Eduardo Arruda Alvim, Nelson Nery Jr., Rodrigo Mazzei, Teresa Arruda Alvim Wambier e Thereza Alvim, São Paulo, RT, 2007, pp. 1.462/1.470.

MARCATO, Antonio Carlos, Incidente de uniformização de jurisprudência, in Apontamentos de direito processual civil, São Paulo, CPC, 1996, pp. 19/30.

MARINHO FILHO, Luciano, Breves comentários aos embargos de divergência e aos incidentes de uniformização de jurisprudência no direito processual brasileiro, in Revista Dialética de Direito Processual, no 74, São Paulo, mai. 2009, pp. 48/56.

Paralelo analítico entre mecanismos de uniformização de jurisprudência no direito processual pátrio, in Revista Dialética de Direito Processual, nº 90, São Paulo, set. 2010 , pp. 54/65.

MARINONI, Luiz Guilherme, Tutela antecipatória, julgamento antecipado e execução imediata da sentença, $5^{\text {a }}$ ed., São Paulo, RT, 2002.

, Precedentes obrigatórios, 2a ed., São Paulo, RT, 2011.

A transformação do civil law e a oportunidade de um sistema precedentalista para o Brasil, disponível em <http://marinoni.adv.br>, acesso em 16/09/2011. 
, Coisa julgada erga omnes e eficácia vinculante, disponível em <http://marinoni.adv.br>, acesso em 16/09/2011.

, O custo e o tempo do processo civil brasileiro, disponível em $<$ http://marinoni.adv.br>, acesso em 16/09/2011.

, O precedente na dimensão da igualdade, disponível em <http://marinoni. adv.br>, acesso em 16/09/2011.

, Os precedentes na dimensão da segurança jurídica, disponível em <http:// marinoni.adv.br>, acesso em 16/09/2011.

, Precedentes obrigatórios, disponível em <http://marinoni.adv.br >, acesso em $16 / 09 / 2011$.

, Princípio da segurança dos atos jurisdicionais, disponível em $<$ http://marinoni.adv.br>, acesso em 16/09/2011.

, Proposta de regulamentação da eficácia obrigatória dos precedentes, disponível em <http://marinoni.adv.br>, acesso em 16/09/2011.

e AREnhart, Sérgio Cruz, Curso de processo civil: processo de conhecimento, vol. 2, $7^{\mathrm{a}}$ ed., São Paulo, RT, 2007.

e MITIDIERO, Daniel, Repercussão geral no recurso extraordinário, $2^{\mathrm{a}}$ ed., São Paulo, RT, 2008.

MARTINS, Ives Gandra da Silva, Eficácia de decisões em controle concentrado de constitucionalidade, in Direito processual: inovações e perspectivas - estudos em homenagem ao Ministro Sálvio de Figueiredo Teixeira (obra coletiva), coord. Eliana Calmon Alves e Uadi Lammêgo Bulos, São Paulo, Saraiva, 2003, pp. 285/295.

, Reflexões sobre o controle concentrado de constitucionalidade, in Revista do Advogado, no 99, São Paulo, AASP, set. 2008, pp. 54/61.

Duas hipóteses para súmulas vinculantes, in Revista Jus Vigilantibus, disponível em <http://jusvi.com/artigos/36441>, out. 2008, acesso em 02/11/2011. 
Mazzilli, Hugo Nigro, A defesa dos interesses difusos em juizo - Meio ambiente, consumidor, patrimônio cultural, patrimônio público e outros interesses, $17^{\mathrm{a}}$ ed., São Paulo, Saraiva, 2004.

MedinA, José Miguel Garcia, WAmbier, Luiz Rodrigues e WAMbIER, Teresa Arruda Alvim, A súmula vinculante, vista como meio legítimo para diminuir a sobrecarga de trabalho dos tribunais brasileiros, in Revista do Advogado, $\mathrm{n}^{\circ}$ 92, São Paulo, AASP, jul. 2007, pp. 7/22.

MedinA, Paulo Roberto de Gouvêa, Sentença emprestada - uma nova figura processual..., in Revista de Processo, $\mathrm{n}^{\circ}$ 135, São Paulo, RT, mai. 2006, pp. 152/160.

Mello, Pedro Thaumaturgo Soriano de, Um estudo sobre a eqüidade e o poder criador do juiz, in Revista do Tribunal Regional do Trabalho da $8^{a}$ Região, $n^{\circ}$ 50, Belém, jan./jul. 1993, pp. 91/102.

MENDES, Gilmar Ferreira, Jurisdição constitucional: o controle abstrato de normas no Brasil e na Alemanha, $3^{\text {a }}$ ed., São Paulo, Saraiva, 1999.

, O efeito vinculante das decisões do Supremo Tribunal Federal nos processos de controle abstrato de normas, disponível em <http://jus.com.br/revista/texto/108/oefeito-vinculante-das-decisoes-do-supremo-tribunal-federal-nos-processos-de-controleabstrato-de-normas>, ago. 1999, acesso em 08/10/2011.

Argüição de descumprimento de preceito fundamental (art. 102, § $1^{\circ}, C F$ ), disponível em <http://jus.com.br/revista/texto/235/arguicao-de-descumprimento-depreceito-fundamental-art-102-1o-cf>, dez. 1999, acesso em 08/10/2011.

Direitos fundamentais e controle de constitucionalidade (estudos de direito constitucional), $3^{\mathrm{a}}$ ed., São Paulo, Saraiva, 2004.

MitidIERO, Daniel e MARINONI, Luiz Guilherme, Repercussão geral no recurso extraordinário, $2^{\mathrm{a}}$ ed., São Paulo, RT, 2008.

MonTEIRo, Washington de Barros, Da jurisprudência, in Revista Forense, vol. 202, Rio de Janeiro, Forense, abr./jun. 1963, pp. 373/374. 
MonteIRo NeTO, Nelson, Embargos de divergência em recurso especial: fixação de tese jurídica não coincidente com as confrontadas na petição de interposição, in Revista Forense, vol. 381, Rio de Janeiro, Forense, set./out. 2005, pp. 505/510.

Montenegro Filho, Misael, Primeiras impressões a respeito do artigo 285-A. A criação do processo entre o autor e o magistrado, in Revista do Advogado, $\mathrm{n}^{\circ}$ 85, São Paulo, AASP, mai. 2006, pp. 188/196.

MORAES, Alexandre de, Consumidor e direito à prestação jurisdicional eficiente e célere, in Revista do Advogado, nº 89, São Paulo, AASP, dez. 2006, pp. 12/20.

MORBIDELLI, Janice Helena Ferreri, $O$ efeito vinculante nas decisões em ação direta de inconstitucionalidade e ação declaratória de constitucionalidade, in Revista de Processo, no 129, São Paulo, RT, nov. 2005, pp. 81/91.

Moreira Alves, José Carlos, A evolução do controle da constitucionalidade no Brasil, in As garantias do cidadão na justiça (obra coletiva), coord. Sálvio de Figueiredo Teixeira, São Paulo, Saraiva, 1993, pp. 1/14.

, Direito romano, 14ª ed., Rio de Janeiro, Forense, 2007.

MUSCARI, Marco Antonio Botto, Súmula vinculante, São Paulo, Juarez de Oliveira, 1999.

Negrão, Theotonio, $O$ novo recurso extraordinário: perspectivas na Constituição de 1988, in Revista do Advogado, nº 81, São Paulo, AASP, abr. 2005, pp. 7/18.

, Código de Processo Civil e legislação processual em vigor, $43^{\mathrm{a}}$ ed., São Paulo, Saraiva, 2011.

NEVES, António Castanheira, O instituto dos “assentos” e a função jurídica dos supremos tribunais, Coimbra, Coimbra, 1983.

O problema da constitucionalidade dos assentos: comentário ao Acórdão $n^{o}$ 810/93 do Tribunal Constitucional, Coimbra, Coimbra, 1994.

NÉRI Da SilveIRA, José, A função do juiz, in Revista da Ajuris - Associação dos Juízes do Rio Grande do Sul, n 54, Porto Alegre, mai. 1992, pp. 40/52. 
Nery, Rosa Maria de Andrade e Nery Junior, Nelson, Código de Processo Civil comentado, $6^{\mathrm{a}}$ ed., São Paulo, RT, 2002.

Nery Junior, Nelson e Nery, Rosa Maria de Andrade, Código de Processo Civil comentado, $6^{\mathrm{a}}$ ed., São Paulo, RT, 2002.

NoBre JÚNIOR, Edilson Pereira, $O$ direito processual brasileiro e o efeito vinculante das decisões dos tribunais superiores, in Revista de Processo, $\mathrm{n}^{\circ}$ 105, São Paulo, RT, jan./mar. 2002, pp. 64/95.

NogueIRA, Gustavo Santana, Jurisprudência vinculante no direito norte-americano e no direito brasileiro, in Revista de Processo, n 161, São Paulo, RT, jul. 2008, pp. $101 / 114$.

OliveIRA, Carlos Alberto Alvaro de, Embargos de divergência perante o Superior Tribunal de Justiça. Conceito de semelhança. O que interessa é o fato jurídico nuclear, desimportando diferenças irrelevantes do ponto de vista jurídico. Exame lógico do problema. Admissibilidade do recurso interposto à luz dos princípios que regem a matéria, in Revista de Processo, no 131, São Paulo, RT, jan. 2006, pp. 165/172.

PACHÚ, Cláudia Oliveira, Aspectos gerais dos efeitos da declaração de (in) constitucionalidade das leis no controle abstrato de normas, in Revista de Direito Constitucional e Internacional, nº 59, São Paulo, RT, abr./jun. 2007, pp. 56/69.

PARENTE, Eduardo de Albuquerque, Jurisprudência: da divergência à uniformização, São Paulo, Atlas, 2006.

PASTORE, Délton Esteves, Aspectos processuais da ação direta de inconstitucionalidade, Dissertação (Mestrado), Universidade de São Paulo, São Paulo, 2007.

PEREIRA, Milton Luiz, Embargos de divergência contra decisão lavrada por relator, in Revista dos Tribunais, vol. 778, São Paulo, RT, ago. 2000, pp. 11/16.

Pereira dos Santos, Carlos Maximiliano, Hermenêutica e aplicação do direito, $19^{\mathrm{a}}$ ed., Rio de Janeiro, Forense, 2007. 
PEREIRA JUNIOR, Ricardo, O desafio moderno e o Judiciário: ordem jurídica, tempo, espaço e atuação da justiça, Dissertação (Doutorado), Universidade de São Paulo, São Paulo, 2010.

PERNÍA, Hermann Petzold, El juez y la interpretación de la ley, in Revista de la Facultad de Ciencias Juridicas y Politicas, $\mathrm{n}^{\circ}$ 69, Caracas, 1988, pp. 59/76.

, El problema de la subsunción y la argumentación jurídica, disponível em <http://www.grupologosula.org/dikaiosyne/art/dik017.pdf>, acesso em 25/08/2011.

, Subsunción, hermenéutica y argumentación em derecho, disponível em $<$ http://carloscolmenares.com/userfiles/SUBSUNCION\%20\%20HERMENEUTICA\%2 0Y\%20ARGUMENTACION\%20EN\%20DERECHO.pdf>, acesso em 25/08/2011.

PIMENTA, Paulo Roberto Lyrio, Limites subjetivos e objetivos da coisa julgada no controle abstrato de constitucionalidade, in Revista Dialética de Direito Processual, ${ }^{\circ} 4$, São Paulo, jul. 2003, pp. 122/129.

Algumas considerações sobre a postulação inicial na ação direta de inconstitucionalidade, in Revista Dialética de Direito Processual, $n^{\circ}$ 24, São Paulo, mar. 2005, pp. 112/119.

PINHEIRO, Armando Castelar, Reforma do Judiciário: observações de um economista, in Revista do Advogado, no 75, São Paulo, AASP, abr. 2004, pp. 17/22.

PINTO, José Augusto Rodrigues, Constitucionalidade e supletividade do artigo 285-A do CPC, in LTr: suplemento trabalhista, $\mathrm{n}^{\circ} 88$, São Paulo, 2006, pp. 371/375.

PINTO, Nelson Luiz, Manual dos recursos cíveis, $3^{\mathrm{a}}$ ed., São Paulo, Malheiros, 2003.

PISANI, Andrea Proto, Principio d'eguaglianza e ricorso per cassazione, in Revista de Processo, no 191, São Paulo, RT, jan. 2011, pp. 201/210.

Pombo, Rodrigo Goulart de Freitas, A desistência de recurso especial repetitivo representativo da controvérsia: o entendimento do STJ, disponível em <http://www. migalhas.com.br/mostra_noticia_articuladas.aspx?cod=119320>, out. 2010, acesso em $11 / 11 / 2011$. 
Porto, Sérgio Gilberto, Coisa julgada civil, 3ª ed., São Paulo, RT, 2006.

e UstárRoz, Daniel, A repercussão geral das questões constitucionais no recurso extraordinário (inovações procedimentais da Lei 11.418 e na Emenda Regimental 21 do STF), in Direito civil e processo - Estudos em homenagem ao Professor Arruda Alvim (obra coletiva), coord. Araken de Assis, Eduardo Arruda Alvim, Nelson Nery Jr., Rodrigo Mazzei, Teresa Arruda Alvim Wambier e Thereza Alvim, São Paulo, RT, 2007, pp. 1.489/1.500.

POSNER, Richard A., The problems of jurisprudence, Harvard University Press, 1993.

RAMOS, Elival da Silva, O controle de constitucionalidade, in Estudos em homenagem à Professora Ada Pellegrini Grinover (obra coletiva), org. Flávio Luiz Yarshell e Maurício Zanoide de Moraes, São Paulo, DPJ, 2005, pp. 205/216.

Ramos, Saulo, Reforma do Judiciário: efeito vinculante das decisões dos Tribunais Superiores, in Revista da Esmape - Escola Superior da Magistratura de Pernambuco, no 9, Recife, jan./jun. 1999, pp. 367/403.

RE, Edward D., Stare decisis, in Revista de Informação Legislativa, $\mathrm{n}^{\mathrm{o}}$ 122, trad. port. Ellen Gracie Northfleet, Brasília, abr./jun. 1994, pp. 281/287.

REICHELT, Luis Alberto, A duração do processo, o julgamento do recurso extraordinário dotado de repercussão geral e a modulação de inconstitucionalidade, in Revista de Processo, no 193, São Paulo, RT, mar. 2011, pp. 131/150.

RIBAS, Antonio Joaquim, Consolidação das leis do processo civil, $3^{\mathrm{a}}$ ed., Rio de Janeiro, Jacintho Ribeiro dos Santos, 1915.

Ribeiro, Débora, Botelho de Mesquita, José Ignacio, Lombardi, Mariana Capela, Amadeo, Rodolfo da Costa Manso Real, Dellore, Luiz Guilherme Pennacchi, TEIXEIRA, Guilherme Silveira e ZveIBIL, Daniel Guimarães, Balanço de uma polêmica: a Súmula-STF 343, in Direito processual civil (obra coletiva), coord. Milton Paulo de Carvalho e Daniel Penteado de Castro, vol. 2, São Paulo, Quartier Latin, 2011, pp. 343/368. 
Botelho De Mesquita, José Ignacio, Amadeo, Rodolfo da Costa Manso Real, Dellore, Luiz Guilherme Pennacchi, TeiXeIRA, Guilherme Silveira e ZveibiL, Daniel Guimarães, A repercussão geral e os recursos repetitivos. Economia, Direito e Política, artigo no prelo, 2009.

RodRIGUes, Walter Piva, O direito de ser citado, in IOB - Repertório de Jurisprudência: civil, processual, penal e comercial, $\mathrm{n}^{\circ}$ 1, São Paulo, jan. 1994, pp. 16/19.

Súmula vinculante em matéria processual, in Revista do Tribunal Regional do Trabalho da $15^{a}$ Região, nº 16, Campinas, mar. 2002, pp. 181/186.

, O princípio da colegialidade das decisões nos tribunais, in Revista Dialética de Direito Processual, no 1, São Paulo, abr. 2003, pp. 176/178.

Abolir a correição parcial?, in Revista do Advogado, $\mathrm{n}^{\circ}$ 81, São Paulo, AASP, abr. 2005, pp. 117/119.

Romani, Dagoberto, O juiz, entre a lei e o direito, in Revista dos Tribunais, vol. 633, São Paulo, RT, jul. 1988, pp. 234/236.

RosA, Fábio Bittencourt da, Juiz: poder criador, in LEX: Jurisprudência do Superior Tribunal de Justiça e Tribunais Regionais Federais, n 33, São Paulo, mai. 1992, pp. $60 / 63$.

RosAS, Roberto, Do assento e do prejulgado à Súmula do STF, in Revista dos Tribunais, vol. 404, São Paulo, RT, jun. 1969, pp. 19/21.

Direito processual constitucional (princípios constitucionais do processo civil), São Paulo, RT, 1983.

Jurisprudência. Uniformização. Súmula, in Direito processual: inovações e perspectivas - estudos em homenagem ao Ministro Sálvio de Figueiredo Teixeira (obra coletiva), coord. Eliana Calmon Alves e Uadi Lammêgo Bulos, São Paulo, Saraiva, 2003, pp. 383/397.

Direito sumular - comentários às súmulas do Supremo Tribunal Federal e do Superior Tribunal de Justiça, 13ª ed., São Paulo, Malheiros, 2006. 
, Da súmula à súmula vinculante, in Revista dos Tribunais, vol. 879, São Paulo, RT, jan. 2009, pp. 41/47.

Rosenn, Keith S., Direito comparado: Brasil x EUA, in Revista Consulex (entrevista), disponível em <http://campus.fortunecity.com/clemson/493/jus/m10-002.htm>, acesso em 21/09/2011.

Ross, Alf, Direito e justiça, trad. port. Edson Bini, São Paulo, Edipro, 2000.

SANCHES, Sydney, Uniformização da jurisprudência, São Paulo, RT, 1975.

, O juiz e os valores dominantes: o desempenho da função jurisdicional em face dos anseios sociais por justiça, in Revista dos Tribunais, vol. 669, São Paulo, RT, jul. 1991, pp. 238/243.

Aspectos processuais do controle de constitucionalidade, in Revista de Processo, no 79, São Paulo, RT, jul./set. 1995, pp. 134/141.

SAntos, Alberto Senna, Coisa julgada e o controle de constitucionalidade da norma, in Revista de Processo, n 141, São Paulo, RT, nov. 2006, pp. 94/115.

SANTOS, Evaristo Aragão, Sobre a idéia de sistema de direito e sua contribuição para uma teoria do precedente judicial, Tese (Doutorado), Pontifícia Universidade Católica de São Paulo, São Paulo, 2011.

SANTOS, Francisco Cláudio de Almeida, Atividade jurisdicional: princípios gerais aplicáveis, in Revista de Processo, n 58, São Paulo, RT, abr./jun. 1990, pp. 135/149.

SARLET, Ingo Wolfgang, Efeito vinculante e reforma do Judiciário, in Revista da Academia Brasileira de Direito Constitucional, vol. 2, Curitiba, 2002, pp. 15/23.

Savigny, Friedrich Carl von, Sistema del diritto romano attuale, trad. ital. Vittorio Scialoja, vol. 1, Torino, Unione Tipografico, 1896.

SCIASCIA, Gaetano, Sinopse de direito romano, $2^{\mathrm{a}}$ ed., São Paulo, Saraiva, 1959.

SHIMURA, Sérgio, A súmula vinculante como mecanismo de tutela coletiva, in Direito civil e processo - Estudos em homenagem ao Professor Arruda Alvim (obra coletiva), 
coord. Araken de Assis, Eduardo Arruda Alvim, Nelson Nery Jr., Rodrigo Mazzei, Teresa Arruda Alvim Wambier e Thereza Alvim, São Paulo, RT, 2007, pp. 900/910.

Silva, Wilma Nogueira de Araújo Vaz da, O papel do juiz na criação do direito, in Revista do Tribunal Superior do Trabalho, Brasília, LTr, 1987, pp. 131/162.

Silva Neto, Francisco da Cunha e, O controle difuso: uma forma de humanização do controle de constitucionalidade das leis, in Revista de Direito Constitucional e Internacional, $\mathrm{n}^{\circ}$ 59, São Paulo, RT, abr./jun. 2007, pp. 131/145.

Slaibi FILHo, Nagib, Ação declaratória de constitucionalidade, Rio de Janeiro, Forense, 1994.

SoARES, Guido Fernando Silva, Common Law - Introdução ao direito dos EUA, São Paulo, RT, 1999.

SOBRINHO, Elício de Cresci, O juiz e as máximas da experiência, in Revista do Tribunal de Justiça do Estado do Pará, no 46, Belém, 1988, pp. 82/96.

O juiz criador do direito e a interpretação razoável, in Revista da Ajuris Associação dos Juízes do Rio Grande do Sul, n 50, Porto Alegre, nov. 1990, pp. 21/32.

SouZA, Bernardo Pimentel, Apontamentos sobre a repercussão geral no recurso extraordinário, in Direito civil e processo - Estudos em homenagem ao Professor Arruda Alvim (obra coletiva), coord. Araken de Assis, Eduardo Arruda Alvim, Nelson Nery Jr., Rodrigo Mazzei, Teresa Arruda Alvim Wambier e Thereza Alvim, São Paulo, RT, 2007, pp. 1.230/1.233.

STRECK, Lenio Luiz, O efeito vinculante das súmulas e o mito da efetividade: uma crítica hermenêutica, in Revista do Instituto de Hermenêutica Jurídica, vol. 1, $\mathrm{n}^{\mathrm{o}} 3$, Porto Alegre, 2005, pp. 83/128.

, Crise de paradigmas - Devemos nos importar, sim, com o que a doutrina diz, disponível em <http://www.leniostreck.com.br/site/wp-content/uploads/2011/10/ 10.pdf>, out. 2011, acesso em 03/12/2011.

, Regra ou princípio - Ministro equivoca-se ao definir presunção da inocência, in Consultor Jurídico, disponível em <http://www.conjur.com.br/2011-nov- 
17/ministro-fux-presuncao-inocencia-regra-nao-principio>, nov. 2011, acesso em 03/12/2011.

TAlAMINI, Eduardo, Coisa julgada e sua revisão, São Paulo, RT, 2005.

TARUFFO, Michele, Institutional factors influencing precedents, in Interpreting precedents: a comparative study (obra coletiva), org. D. Neil MacCormick e Robert S. Summers, Aldershot e Vermont, Dartmouth e Ashgate, 1997, pp. 437/460.

, Giudizio: processo, decisione, in Rivista Trimestrale di Diritto e Procedura Civile, ano 52, nº 3, Milano, Giuffrè, set. 1998, pp. 787/804.

, Il giudice e la "Rule of Law", in Rivista Trimestrale di Diritto e Procedura Civile, ano 53, nº 3, Milano, Giuffrè, set. 1999, pp. 931/943.

, Senso comum, experiência e ciência no raciocínio do juiz, in Revista Forense, vol. 355, trad. port. Cândido Rangel Dinamarco, rev. Luiz Felipe Duarte Martins Costa, Rio de Janeiro, Forense, mai./jun. 2001, pp. 101/118.

Legalidade e justificativa da criação judiciária do direito, in Revista da Esmape - Escola Superior da Magistratura de Pernambuco, $\mathrm{n}^{\circ}$ 14, trad. port. Pierino Sani, Recife, jul./dez. 2001, pp. 431/456.

, Observações sobre os modelos processuais de civil law e de common law, in Revista de Processo, $\mathrm{n}^{\circ}$ 110, trad. port. José Carlos Barbosa Moreira, São Paulo, RT, abr./jun. 2003, pp. 141/158.

, Precedente e giurisprudenza, in Rivista Trimestrale di Diritto e Procedura Civile, ano 61, nº 3, Milano, Giuffrè, set. 2007, pp. 709/725.

, Cultura e processo, in Rivista Trimestrale di Diritto e Procedura Civile, ano 63, nº 1, Milano, Giuffrè, mar. 2009, pp. 63/92.

, Icebergs do common law $e$ civil law? Macrocomparação $e$ microcomparação processual e o problema da verificação da verdade, in Revista de Processo, $\mathrm{n}^{\mathrm{o}}$ 181, trad. port. Hermes Zanetti Junior, São Paulo, RT, mar. 2010, pp. $167 / 172$. 
e HAZARD JR., Geoffrey C., Normas transnacionais de processo civil, in Revista de Processo, $\mathrm{n}^{\circ}$ 102, trad. port. Antonio Gidi, São Paulo, RT, abr./jun. 2001, pp. 197/218.

TARZIA, Giuseppe, La durata del processo civile e la tutela dei deboli, in Rivista di Diritto Processuale, ano 60, n 2, Padova, abr./jun. 2005, pp. 317/328.

TEIXEIRA, Guilherme Silveira, A ampliação dos poderes do juiz nas recentes reformas processuais e a necessidade de equilíbrio entre segurança e efetividade do processo, Dissertação (Mestrado), Universidade de São Paulo, São Paulo, 2006.

Botelho de Mesquita, José Ignacio, Lombardi, Mariana Capela, Amadeo, Rodolfo da Costa Manso Real, Dellore, Luiz Guilherme Pennacchi, RIBEIRO, Débora e ZveIBIL, Daniel Guimarães, Balanço de uma polêmica: a Súmula-STF 343, in Direito processual civil (obra coletiva), coord. Milton Paulo de Carvalho e Daniel Penteado de Castro, vol. 2, São Paulo, Quartier Latin, 2011, pp. 343/368.

, Botelho de Mesquita, José Ignacio, Amadeo, Rodolfo da Costa Manso Real, Dellore, Luiz Guilherme Pennacchi, RIBEIRO, Débora e ZveIBIL, Daniel Guimarães, A repercussão geral e os recursos repetitivos. Economia, Direito e Política, artigo no prelo, 2009.

TEIXEIRA, Sálvio de Figueiredo, As tendências brasileiras rumo à jurisprudência vinculante, in Revista do Instituto dos Advogados de São Paulo, $\mathrm{n}^{\circ}$ 2, São Paulo, RT, jul./dez. 1998, pp. 145/157.

TERRA, Marcelo, Embargos de divergência no Tribunal de Justiça, in Revista dos Tribunais, vol. 606, São Paulo, RT, abr. 1986, pp. 271/274.

TESheINer, José Maria Rosa, Uniformização de jurisprudência, in Revista da Ajuris Associação dos Juízes do Rio Grande do Sul, n 50, Porto Alegre, nov. 1990, pp. 178/183.

THEODORO JUNIOR, Humberto, Repercussão geral do Recurso Extraordinário (Lei $n^{o}$ 11.418) e Súmula Vinculante do Supremo Tribunal Federal (Lei $\left.n^{\circ} 11.417\right)$, in Revista IOB de Direito Civil e Processual Civil, no 48, Porto Alegre, jul./ago. 2007, pp. 100/127. 
Tostes, Natacha Nascimento Gomes, Uniformização de jurisprudência, in Revista de Processo, no 104, São Paulo, RT, out./dez. 2001, pp. 194/218.

Ustárroz, Daniel e PORTO, Sérgio Gilberto, A repercussão geral das questões constitucionais no recurso extraordinário (inovações procedimentais da Lei 11.418 e na Emenda Regimental 21 do STF), in Direito civil e processo - Estudos em homenagem ao Professor Arruda Alvim (obra coletiva), coord. Araken de Assis, Eduardo Arruda Alvim, Nelson Nery Jr., Rodrigo Mazzei, Teresa Arruda Alvim Wambier e Thereza Alvim, São Paulo, RT, 2007, pp. 1.489/1.500.

VAsConcelos, Arnaldo, Sobre a jurisprudência, in Revista da Faculdade de Direito de Fortaleza, n 29, Fortaleza, Universidade Federal do Ceará, jul./dez. 1988, pp. 143/153.

Velasco, Ignacio Maria Poveda, Direito, jurisprudência e justiça no pensamento clássico (greco-romano), in Revista da Faculdade de Direito da Universidade de São Paulo, $\mathrm{n}^{\circ}$ 101, São Paulo, jan./dez. 2006, pp. 21/32.

Velloso, Carlos Mário da Silva, Poder Judiciário: controle externo e súmula vinculante, in Revista do Advogado, no 75, São Paulo, AASP, abr. 2004, pp. 23/27.

VENDRAME, Antonio Carlos, O reiterado erro que pode se tornar jurisprudência, in Revista de Previdência Social, no 292, São Paulo, mar. 2005, pp. 192/193.

VENTURI, Elton, Anotações sobre a repercussão geral como pressuposto de admissibilidade no recurso extraordinário, in Direito processual civil (obra coletiva), coord. Milton Paulo de Carvalho, São Paulo, Quartier Latin, 2007, pp. 307/318.

Vigliar, José Marcelo Menezes, Uniformização de jurisprudência - Segurança jurídica e dever de uniformizar, São Paulo, Atlas, 2003. , Interesses difusos e coletivos, São Paulo, CPC, 2004.

VIGORITI, Vincenzo, Notas sobre o custo e a duração do processo civil na Itália, in Revista de Processo, $\mathrm{n}^{\circ}$ 43, trad. port. Teresa Celina de Arruda Alvim Pinto, São Paulo, RT, jul./set. 1986, pp. 142/148. 
VILARDI, Iara Ferfoglia Gomes Dias, Súmula vinculante: razões e conseqüências de sua implementação no sistema de direito brasileiro, Dissertação (Mestrado), Universidade de São Paulo, São Paulo, 2008.

VIVEIRos, Estefânia, Agravo interno no Superior Tribunal de Justiça e ampliação dos poderes do relator, in Universitas/Jus - Revista do Instituto de Ciências Jurídicas e Sociais do Centro Universitário de Brasília, no 7, Brasília, jul./dez. 2001, pp. 59/88.

WAMBIER, Luiz Rodrigues, Uma proposta em torno do conceito de jurisprudência dominante, in Revista de Processo, $\mathrm{n}^{\circ}$ 100, São Paulo, RT, out./dez. 2000, pp. 81/87.

, WAMBIER, Teresa Arruda Alvim e MedinA, José Miguel Garcia, A súmula vinculante, vista como meio legítimo para diminuir a sobrecarga de trabalho dos tribunais brasileiros, in Revista do Advogado, n 92, São Paulo, AASP, jul. 2007, pp. $7 / 22$.

WAMBIER, Teresa Arruda Alvim, Os princípios constitucionais da legalidade e da isonomia, como inspiradores da compreensão de algumas recentes alterações do direito positivo - Constituição Federal e CPC, in Revista do Advogado, $\mathrm{n}^{\circ}$ 88, São Paulo, AASP, nov. 2006, pp. 187/192.

Anotações sobre princípio do contraditório como um dos fundamentos do processo civil contemporâneo, in Direito processual civil (obra coletiva), coord. Milton Paulo de Carvalho, São Paulo, Quartier Latin, 2007, pp. 71/80.

, MedinA, José Miguel Garcia e WAmbIER, Luiz Rodrigues, A súmula vinculante, vista como meio legítimo para diminuir a sobrecarga de trabalho dos tribunais brasileiros, in Revista do Advogado, n 92, São Paulo, AASP, jul. 2007, pp. $7 / 22$.

YARSHELl, Flávio Luiz, A Reforma do Judiciário e a promessa de "duração razoável do processo”, in Revista do Advogado, no 75, São Paulo, AASP, abr. 2004, pp. 28/33. , Ação rescisória: juízos rescindente e rescisório, São Paulo, Malheiros, 2005. 
YoshIKAwA, Eduardo Henrique de Oliveira, Origem e evolução do devido processo legal substantivo: o controle da razoabilidade das leis do século XVII ao século XXI, São Paulo, Letras Jurídicas, 2007.

Zavascki, Teori Albino, Eficácia das sentenças na jurisdição constitucional, São Paulo, RT, 2001.

Zveibil, Daniel Guimarães, Botelho De Mesquita, José Ignacio, LombARdi, Mariana Capela, Amadeo, Rodolfo da Costa Manso Real, Dellore, Luiz Guilherme Pennacchi, RiBeIRO, Débora e TeIXEIRA, Guilherme Silveira, Balanço de uma polêmica: a Súmula-STF 343, in Direito processual civil (obra coletiva), coord. Milton Paulo de Carvalho e Daniel Penteado de Castro, vol. 2, São Paulo, Quartier Latin, 2011, pp. 343/368.

Botelho de Mesquita, José Ignacio, Amadeo, Rodolfo da Costa Manso Real, Dellore, Luiz Guilherme Pennacchi, RibeIRo, Débora e TeIXEIRA, Guilherme Silveira, A repercussão geral e os recursos repetitivos. Economia, Direito e Política, artigo no prelo, 2009. 


\section{Resumo}

A presente tese examina o papel do precedente judicial no sistema processual brasileiro, à luz das recentes reformas introduzidas na legislação, constitucional e infraconstitucional, com o duplo objetivo de dotar o precedente de maior valor e de uniformizar a jurisprudência, as quais demonstram que o momento é de desconstrução de paradigmas.

Após delimitar o tema e discorrer sobre a sua importância, traçamos as premissas essenciais do estudo, definindo o que seja precedente judicial e jurisprudência, identificando as funções da jurisprudência e analisando a importância de uniformizá-la, para o fim de garantir maior isonomia e segurança jurídica aos jurisdicionados e de diminuir o tempo do litígio (CAPÍTULO 1).

Em seguida, fazemos uma breve abordagem do assunto do ponto de vista histórico (CAPÍTULO 2) e sob a perspectiva da common law (CAPÍTULO 3).

Passamos então para os dois capítulos centrais da tese. Analisamos o papel do precedente judicial no atual ordenamento, de acordo com a sua carga de eficácia, a saber, vinculante, quase vinculante e persuasiva (CAPÍTULO 4); e examinamos os demais meios de uniformização da jurisprudência, focando inclusive no problema dos Juizados Especiais Estaduais e Federais (CAPÍTULO 5).

Finalmente, discorremos acerca de nossas conclusões, demonstrando que, apesar de o precedente judicial e a jurisprudência desempenharem papel relevante no nosso ordenamento (que configura um verdadeiro sistema misto, em que a lei reina, mas a jurisprudência governa), não há ainda premissas muito bem definidas, sendo necessárias alterações, de lege lata e de lege ferenda, para que seja conferido tratamento sistemático e harmônico ao assunto.

Palavras-chave: $\quad$ precedente judicial; jurisprudência; súmula; uniformização de jurisprudência; stare decisis. 


\begin{abstract}
The present thesis analyzes the judicial precedent role within the Brazilian procedural system, in light of the recent reforms introduced in the legislation, either constitutional or infraconstitutional, with an aim at adding value to the precedent and standardizing jurisprudence, both of which make it evident that this is the moment for unbuilding of paradigms.
\end{abstract}

After delimitating the matter and discussing its importance, we have outlined the assumptions which are essential for the study, defining what judicial precedent and jurisprudence are, identifying the functions of jurisprudence and analyzing the importance of standardizing it, so as to ensure greater isonomy and judicial assurance to those who are granted a jurisdiction and to reduce the litigation time (CHAPTER 1).

Following, we have briefly approached the matter under a historical point of view (CHAPTER 2) and under the perspective of the common law (CHAPTER 3).

And then we went to the two core chapters of the thesis. We have analyzed the role that the judicial precedent plays in the existing legal system, in accordance with its effectiveness, that is, binding, almost binding and persuasive (CHAPTER 4); and examined the other means for standardization of jurisprudence, with focus including on the issue of State and Federal Special Courts (CHAPTER 5).

Finally, we have explained our conclusions, showing that, despite the judicial precedent and jurisprudence playing a relevant role in our legal system (which constitutes a real mixed system, where the law reigns, but the jurisprudence governs), there are no well-defined assumptions, yet, a few adjustments being necessary, lege lata and lege ferenda, so that a systematic and harmonic treatment can be given to the matter.

Keywords: $\quad$ judicial precedent; jurisprudence; standardization of jurisprudence; stare decisis. 


\section{Riassunto}

La presente tesi esamina il ruolo del precedente giudiziale nel sistema processuale brasiliano, alla luce delle recenti riforme introdotte nella legislazione, costituzionale e infracostituzionale, con il doppio obiettivo di dotare il precedente di maggior valore e di uniformare la giurisprudenza, dimostrando che il momento è di decostruzione di paradigmi.

Dopo aver delimitato il tema e aver discusso sulla sua importanza, abbiamo tracciato le premesse essenziali dello studio, definendo cosa sia precedente giudiziale e giurisprudenza, identificando le funzioni della giurisprudenza e analizzando l'importanza di uniformarla, con la finalità di garantire maggior isonomia e sicurezza giuridica a chi è sottomesso alla giurisdizione dello Stato e di diminuire il tempo del litigio (CAPITOLO 1).

In seguito, facciamo un breve esame dell'argomento dal punto di vista storico (CAPITOLO 2) e sotto la prospettiva della common law (CAPITOLO 3).

Dopo di ciò passiamo ai due capitoli centrali della tesi. Analizziamo il ruolo del precedente giudiziale nell'attuale ordinamento, secondo il suo carico di efficacia, ossia, vincolante, quasi vincolante e persuasiva (CAPITOLO 4); e esaminiamo gli altri mezzi di uniformazione della giurisprudenza, focalizzando anche nel problema dei Tribunali Speciali Statali e Federali (CAPITOLO 5).

Finalmente, discorriamo sulle nostre conclusioni, dimostrando che, malgrado il precedente giudiziale e la giurisprudenza svolgano un ruolo di rilievo nel nostro ordinamento (che configura un vero sistema misto, in cui la legge regna, ma la giurisprudenza governa), non ci sono ancora premesse molto ben definite, essendo necessarie le alterazioni, di lege lata e di lege ferenda, affinché sia conferito trattamento sistematico e armonico all'argomento.

Parole chiave: $\quad$ precedente giudiziale; giurisprudenza; massima di giurisprudenza; uniformazione della giurisprudenza; stare decisis. 